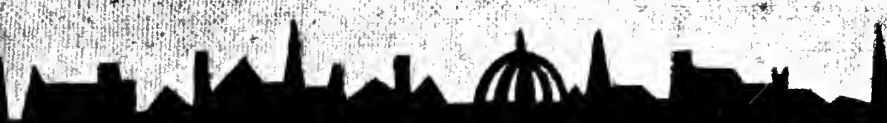

HISTORIC TOWNS

IS:

OF $\quad$ isi

NEW

ENGLAND

\section{ain}




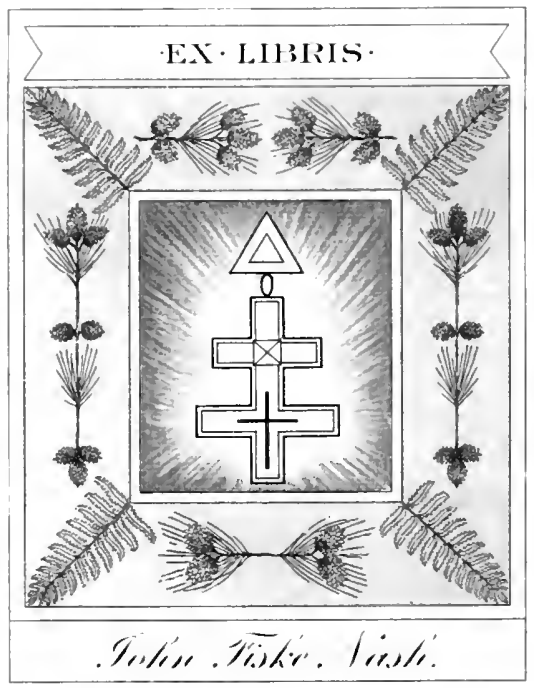


1

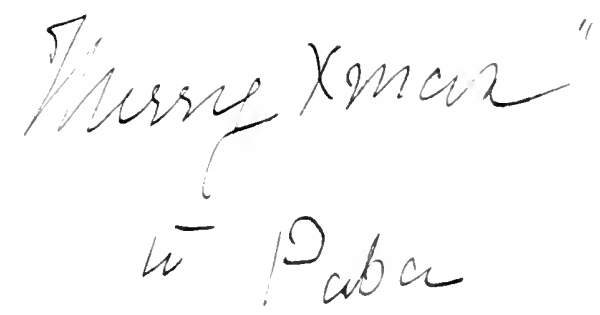

gro. Face rover.

1900

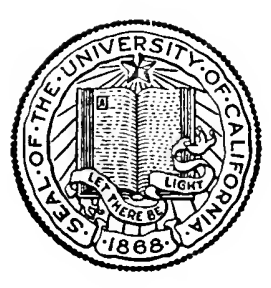

LIBRARY

THE UNIVERSITY

OF CALIFORNIA

SANTA BARBARA

PRESENTED BY

ERIC SCHMIDT 
.

.

$$
4
$$




$$
\text { . }
$$




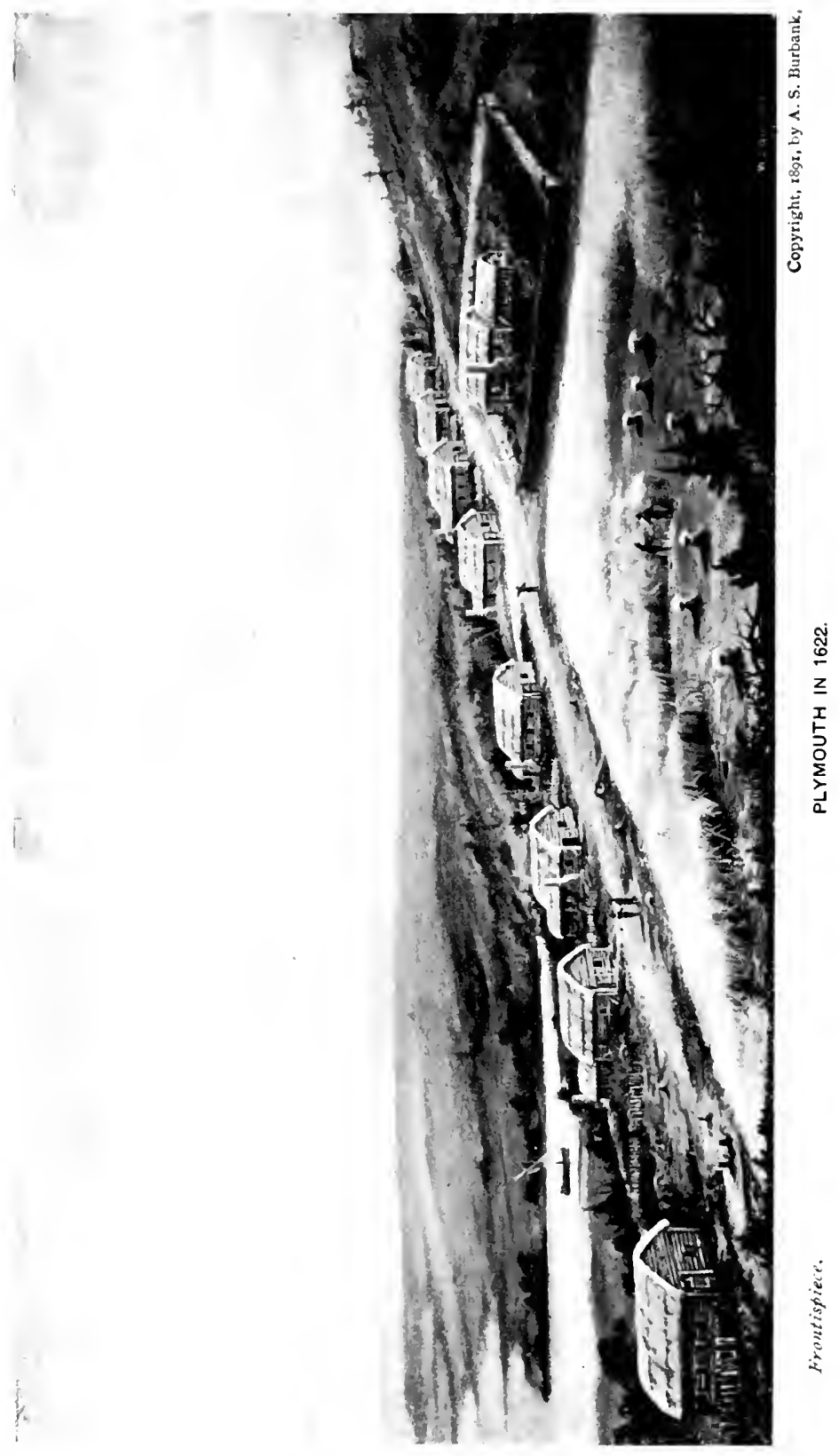




\section{HISTORIC TOWNS \\ OF}

NEW ENGLAND

Edited by

Illustrated

Second Edition-Third Impression

NEW YORK \& LONDON Tbe Kllickerbocker Dresg 1899 
Coryright, 1898

$\mathrm{By}$

G. P. PUTNAM'S SONS

Entered at Stationers' Hall, Londor.

Tbe Wnickerbocker prese, Aew york 


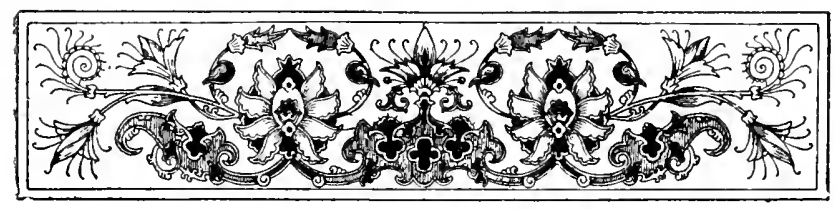

\section{PREFACE}

IN July, I893, while the first Summer Meeting of the American Society for the Extension of University Teaching was in session at the University of Pennsylvania, I conducted the students, in trips taken from week to week, to historic spots in Philadelphia, the battle-fields of the Brandywine and of Germantown, and to the site of the winter camp at Valley Forge. The experiment was brought to the attention of Dr. Albert Shaw, and at his instance I made a plea through the pages of The American Monthly Review of Reviews, October, 1893 , for the revival of the mediæval pilgrimage, and for its adaptation to educational and patriotic uses. After pointing out some of the advantages of visits paid under competent guidance and with reverent spirit to spots made sacred by high thinking and self-forgetful living, I suggested a ten days' pilgrimage in the footsteps of George Washington. 
The suggestion took root in the public mind. Leading journals commended the idea. New England people, already acquainted with the thought of local historical excursions, hailed the proposed pilgrimage with enthusiasm. Men and women from a score of States avowed their eagerness to make the experiment; and at the close of the University Extension Summer Meeting of July, I 894 , in which I had lectured on American history, I found myself conducting for the University Extension Society a pilgrimage, starting from Philadelphia, to Hartford, Boston, Cambridge, Lexington, Concord, Salem, Plymouth, Newburg, West Point, Tarrytown, Tappan, New York, Princeton, and Trenton.

The press contributed with discrimination the publicity essential to success. Every community visited rendered intelligent and generous co-operation. And surely no pilgrims, mediæval or modern, ever had such leadership; for among our cicerones and patriotic orators were: Col. T. W. Higginson, Drs. Edward Everett Hale and Talcott IVilliams, Hon. Hampton L. Carson, Messrs. Charles Dudley Warner, Richard Watson Gilder, Charles Carlton Coffin, Frank B. Sanborn, Edwin D. Mead, 
Hezekiah Butterworth, George P. Morris, Professors W. P. Trent, William M. Sloane, W. W. Goodwin, E. S. Morse, Brig.-Gen. O. B. Ernst, Major Marshall H. Bright, and Rev. William E. Barton.

I had planned in the months that followed to publish a souvenir volume containing the more important addresses made by distinguished men on the historic significance of the places visited; but as the happy experience receded into the past a larger thought laid hold of me. Why not sometime in the infrequent leisure of a busy minister's life edit a series of volumes on American Historic Towns? Kingsley's novels were written amid parish duties, and Dr. McCook has found time, amid exacting ministerial duties, to make perhaps the most searching study ever made by an American of the habits of spiders. Medical experts agree concerning the value of a wholesome avocation to the man who takes his vocation seriously; and congregations are quick to give ear to the earnest preacher whose sermons betray a large outlook on life.

A series of illustrated volumes on American Historic Towns, edited with intelligence, would prove a unique and important contribution to 
historical literature. To the pious pilgrim to historic shrines the series would, perhaps, give the perspective that every pilgrim needs, and furnish information that no guide-book ever offers. To those who have to stay at home the illustrated volumes would present some compensation for the sacrifice, and would help to satisfy a recognized need. The volumes would probably quicken public interest in our historic past, and contribute to the making of another kind of patriotism than that Dr. Johnson had in mind when he defined it as the "last refuge of a scoundrel."

I foresaw some at least of the serious difficulties that await the editor of such a series. If all the towns for which antiquarians and local enthusiasts would fain find room should be included, the series would be too long. A staff of contributors must be secured, possessing literary skill, historical insight, the antiquarian's patience, and enough confidence in the highest success of the series to be prepared to waive any requirement of adequate pecuniary compensation. Space must be apportioned with impartial but not unsympathetic hand, and the illustrations selected with due discrimination. And, finally, publishers were 
to be found willing to assume the expense required for the production in suitable form of a series for which no one could with accuracy forecast the sale.

The last and perhaps most serious difficulty was removed almost a year ago when Messrs. G. P. Putnam's Sons expressed a willingness to take the commercial risk involved in publishing the present volume, which will, it is hoped, be the first of a series. Contributors were then found whose work has, I trust, secured for the undertaking an auspicious beginning. Critics inclined at first glance to speak harshly of the differences among the contributors in style and in literary method are advised to withhold judgment till a closer reading has made clear, as it will, the fundamental differences there are among the towns themselves in history and in spirit. Adequate reasons which need not be stated here have made it advisable to omit Lexington, Groton, Portsmouth, the Mystic towns, and other towns which would naturally be included in a later volume on New England Towns, in case the publication should be continued.

So many have co-operated in the making of this book that I will not undertake to name 
them all. But I cannot forbear to acknowledge the valuable assistance I have received at every stage of the work from Mr. G. H. Putnam, Mr. George P. Morris, associate editor of The Congregationalist, and Miss Gertrude Wilson, instructor in history at the historic Emma Willard School. The Century Company has, in the preparation of the first chapter on Boston and the chapter on Newport, kindly allowed the use of certain illustrations and portions of articles on Boston and Newport, which have appeared in St. Nicholas and old Scribner's respectively. Some of the illustrations for the Portland chapter have been furnished by Lamson, the Portland photographer.

The Essex Institute, with characteristic generosity, has loaned most of the cuts for the Salem chapter. The Ohio State Archæological and Historical Society has allowed the reproduction from The Ohio Quarterly of some of the designs in the Rutland chapter, while certain of the illustrations in the Cape Cod Towns chapter appeared first in Falmouth Illustrated.

Conscious of the editorial shortcomings of the volume, I still dare to hope that it may have such a cordial reception as will justify the 


\section{Preface}

publication at some time of a volume on Historic Towns of the Middle States.

Lyman P. Powell

Ambler, Pennsyluania

September 21, 1898 .

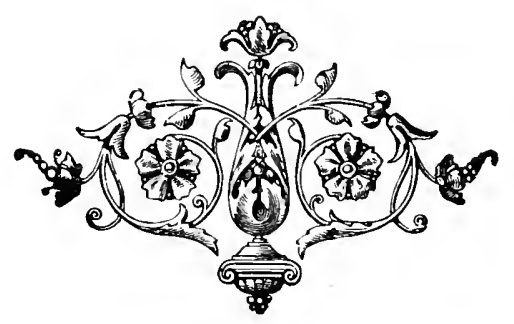





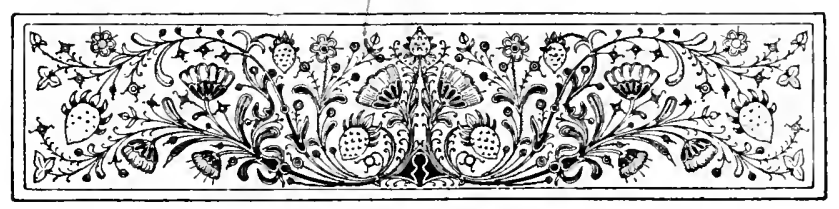

\section{CONTENTS}

Introduction . George Perry Morris . I

Portland . . Samuel T. Pickard . 53

Rutland, Mass. . Edwin D. Mead . $8 \mathbf{I}$

Salem . . . George Dimmick Latimer . I 2 I

Boston.. . . . ${ }_{167}$

(Edward Everett Hale . 187

Cambridge . . Samuel A. Eliot . . 2 II

Concord . . Frank B. Sanborn . . 243

Plymouth . . Ellen Watson · . 299

Cape Cod Towns . Katharine Lee Bates . 345

Deerfield . . George Sheldon . . 403

Newport . . Susan Coolidge . . 443

Providence . . William B. Weeden . . 475

HARTFORD . . Mary K. Talcott . 507

New Haven . . Frederick H. Cogswell · 553 


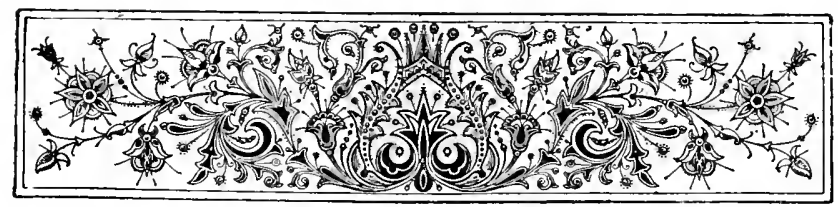

\section{ILLUSTRATIONS}

\section{PORTLAND}

White Head, Cushing Islani . . . . . . . 55

DEERING'S WOODS . . . . . . . . 59

Showing brook which the soldiers had to ford in the fight with the Indians in I689.

First Parish Church .

Containing the Mowatt cannon-ball.

The Birthplace of Loxgfellow

HENRY.W. LONGFELLOW

N. P. Willis .

\section{RUTLAND}

Dr. Cutler's Church and Taksonage at Ipswich HamLET, $1787^{\circ}$. . . . . . . . $s_{3}$

View of Rutland Street *. . . . . . . . . 85

MANASSEH CUTler $^{2}$. . . . . . . . 9 I

1 Reproduced by permission of A. S. Burbank, Plymouth, Mass.

2 Reproduced by permission of the Ohio State Archæological and Historical Society, Columbus, Ohio.

${ }^{3}$ Reproduced by permission of C. K. Bartlett, Rutland, Mass. xiii 
PAGE

NATHAN $\mathrm{DANE}^{\mathrm{I}} \cdot$. . . . . . . . . . . 92

RUFUS PUTNAM" . . . . . . . . . . . . . . . . 95

Site OF MARIETta ANI HaRMAR, I $755^{2}$. . . . IOJ

The "Central Tree" ". . . . . . . . 103

THE Old RUThAND INx ${ }^{4}$. . . . . . . . 104

View of Rutland Centre gron Meschopalie Hill ${ }^{3}$. 107

BrITISH BARRACKS ${ }^{4}$. . . . . . . 112

The Rufes Putsan House ${ }^{3}$. . . . . . Iit

\section{SALEM}

GOVERNOR ENDICOTT'S SUN-DIAL AND SWORD ${ }^{1}$. . . 122

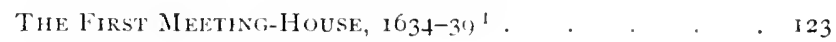

GOVERNOR ShMON Bradstreet ${ }^{1}$. . . . . . 125

GOVERNOK JUHN ENDiCutT ${ }^{1}$. . . . . . 126

The PICKERING FirfBACK ${ }^{1}$. . . . . . I2S

OLD CRADLE ${ }^{1}$. . . . . . . . . . I3I

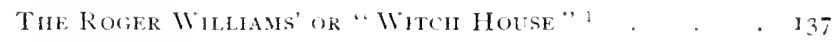

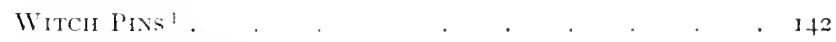

Timothy Pickering; . . . . . . . . . 153

SOME OLI THOORWAS' . . . . . . . I55

BOWDITCH DesK ANH) () UADRANT ${ }^{1}$. . . $15^{8}$

Willian H. Prfascott. . . . . . . I60

Natianiel Iílthorne . . . . . . . . . . . 63

From an engraving from a painting by C. G. Thompson.

Nathaniel HawthorNe-BiRthplace of HaWthorNe-

HOUSE OF THE SEVEX ( ABDLE-GRHAHAWE IlOLSE-

TIE OLD TOWX PUMP ${ }^{1}$. . . . . . 165

SHAL OF THE CITY OF SALIM ${ }^{1}$. . . . . . 166

${ }^{1}$ Reproduced by permission of the Essex Institute, Salem, Mass.

2 Reproduced by permission of the Ohio State Archaological and Historical Society, Columbus, Ohio.

${ }^{3}$ Reproduced by permission of C. R. Bartlett, Rutland, Mass.

* Reproduced by permission of the . V'ru England Magasine, Bustun, Mass. 


\section{Illustrations}

\section{BOSTON}

PACE

SUCCORY OR "BOSTON WEED" . . . . . . I67

Trinity Church ${ }^{\mathrm{i}}$. . . . . . . . .

Boston IN $\mathbf{I 7 5 7}$. . . . . . . . . I

From a drawing by Governor Puwnall.

"Old Corner Bookstore". . . . . . . I75

Oliver Wendell Holmes . . . . . . I7t

PUblic Library . . . . . . . . . . 179

MAP OF BOSTON IN I T22 . . . . . . 180

Charles SUMNER . . . . . . . . . 182

Phillips Brooks. . . . . . . . Ist

Faneuil Hall in the isth Century . . . . . i 89

Governor Thomas Hutchinson . . . . . . igo

From a portrait in possession of the Massachusetts Historical Society, once the property of Jonathan Mayhew.

The Old South Church in its Present Condition. Bult IN 1729 . . . . . . . 193

Old State Holse. . . . . . . . . . 197

IANES OTJS . . . . . . . . . . . . . 999

Sanuel Adams . . . . . . . . . 201

Bostox MASSACRE . . . . . . . . . 203

From a painting by $\mathrm{A}$. Chappel.

Landing of British Troops at boston, i 768 . . . 205

MAP OF BOSTON IN I775 . . . . . . 206

The Frog POND on the Common as It Notr APPEARs - 209

SEAL OF THE City OF Boston . . . . . . 2 IO

CAMBRIIUFE

Hartard College Gate . . . 213

IIONF OF LONGFELLW . . . . . . 2 I5

${ }^{1}$ Reproduced by permission of Daniel W. Colbath \& Co., Boston, Mass. 
"The MUSes' Factories."-Lowell.

STATUE OF JOHN HARVARD AND MEMORIAL HaLl, HARVARD

Colitece

Holworthy Hall, Harvard Colleg: . . . 229

HOME OF LOWELL. . . . . . . . . $23 \mathrm{I}$

Washington ElM . . . . . . . . . . 233

James Russell Loweli. . . . . . . . 235

Gymasium, Harvard College . . . . . . 237

William E. Russell . . . . . . 240

\section{CONCORD}

Concord River, by Thoreau's Landing . . . . 245

Ralph Waldo EMerson (1858) . . . . . . 252

From a sketch by Rowse.

'The Fight at the Brivge' ' . . . . . . 255

Redrawn from Ralph Earle's sketch of 1775 .

The Battle of Lexingtox, April 19, 1775 . . . 263.

From an old print.

Muskets of Captain John Parker . . . . 266

The Minute-Man ${ }^{2}$. . . . . . . . 269,

French's first statue.

Hawthorne's Oli MaNise . . . . . . 274

REVOLLTIONARY INN ${ }^{1}$. . . . . . . . . . 277

HeNry Thoreau $(1857)^{1}$. . . . . . . 250

Grayes of the Emerson Family . . . . . . $28_{3}$

HOME OF EMERSON . . . . . . . . 287

A. Bronson Alcott $(1575)^{1}$. . . . . . . 292

LOUISE M. AlCOTT . . . . . . . . . 295

SEAL OF THE City OF CONCORD . . . . . . . 297

${ }^{1}$ Reproduced by permission of the $N$ is England Magazine, Boston, Mass.

${ }^{2}$ Reproduced by permission of the W. H. Brett Engraving Co., Boston, Mass. 


\section{Illustrations}

\section{PLYMOUTH}

PAGE:

Facsimile of a Page from Governor Bradford's Manu-

SCript, "Plimoth Plantation" . . . . 3OI

The original is now in the Boston State House.

PUlPIT Rock, Clarke's ISLAND ${ }^{1}$. . . . . 302

The Early Norman Doorway at Austerfield Church . 305

The Old Fort and First Meeting-House, on Burial

HILl, I62I ${ }^{1}$. . . . . . . . 307

GOVERnOR EDWARd WinsluW' ${ }^{1}$. . . . . . 3 I 3

THE HARBOR ${ }^{1}$. . . . . . . . . . . $32 \mathrm{I}$

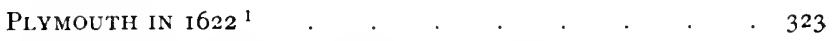

The "Mayflower" in Plymouth Harbor ${ }^{1}$. . . 333

From the painting by W. F. Halsall, in Pilgrim Hall.

The Old Colony Seal.

The landing of the Fathers, Plymouth, December 22, I620

Copied from an old painting on glass.

The Fuller Cradle . . . . . . . . . . 337

An Old English Spinning-Wheel . . . . . 338

The Doten House, I660 ${ }^{1}$. . . . . . . . . 339

The oldest house in Plymouth.

The Grave of Dr. Francis le Barran, the Nameless NOBLEMAN ${ }^{1}$. . . . . . . . . 342

Seal of the City of Plymouth . . . . . . . 343

\section{CAPE COD TOWNS}

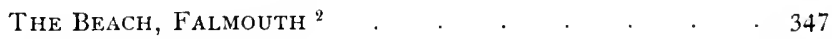

Map of Cape Cod Section ${ }^{3}$. . . . . . . . . 349

Provincetown . . . . . . . . . . . . . 355

${ }^{1}$ Reproduced by permission of A. S. Burbank, Plymouth, Mass.

2 Reproduced by permission of the Falmouth Board of Industry, Falmouth, Mass.

S Reproduced by permission of Geo. H. Walker \& Co., Boston, Mass. 
WhARVES AT PRONINCTOWN PAGM

Provincetown in is $39 . \quad$. . . . . . . . . 363

From an old drawing.

Highland Light . . . . . . . . . $37 \mathrm{I}$

Oyster Point, Wellflekt . . . . . . . 373

Bishop and Clekt Light, Hyanis . . . . 376

Old Windmll, Eastham . . . . . . . . $37 \mathrm{~S}$

Ruins of the Chatham light . . . . . . 383

Life-Saring Station at Wellfleet . . . . . 356

Bass River Bridge, Soutil Yarmouth . . . . 387

BARNSTABLE INN . . . . . . . . . . . 399

BIRD'S-EYE VIEW OF FALMOUTH ${ }^{1}$. . . . . . . . 395

The Village Greex ${ }^{2}$. . . . . . . . . 397

SHIRICK's POND, FAlioutiI ${ }^{1}$. . . . . . . 399

The Whale-Ship "Conhovore Morris" and the FalMOUTH CAPTAINS Who SAILED IN HeR ${ }^{1}$. . fOI

DEERFIELI)

Old DeErField StTreet, I67I-189S . . . . 405

FRARY House, jogs . . . . . . . . . . . . OS

Oldest in the county.

Thirb Meetixg-House, i695-I729 . . . . . . + fig

(Old Indian house on the right.)

Pakson Willians's llouse. . . . . . . $42 I$

Built by the town, I 707 -stankling I S9S.

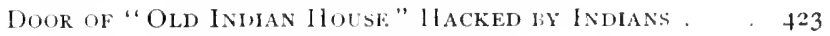

Now in Nemorial Hall.

Tombstunes of Rev. Join Williams and his Wife • • 425

STEPHEN WILLIAMS, I693-1782 . . . . $\$ 28$

A captive of February $29,1703-4$.

${ }^{1}$ Reproduced by permission of the Fulmouth Board if Industry, Falmouth, Mass.

2 Reproduced by permission of $\mathbf{W}$. H. Hewins, Falmouth, Mass. 


\section{Illustrations}

xix

FAGE

George Fuller, I822-I884 . . . . . . . . 437

Buffet from " Parson Williams's" House . . . . 439

Now in Memorial Hall.

\section{NEIVPORT}

The Old Stone Mill . . . . . . . . . 445

NEWPORT IN I795 ${ }^{1}$. $\quad . \quad . \quad . \quad . \quad . \quad . \quad 447$

George Berkeley, Dean of Derry ${ }^{2}$. . . . . . $45 \mathrm{I}$

Whitehall, the Berkeley Residence, Bullt i729 · · 453.

"Purgatory" . . . . . . . . . . 457

Rochambeau's Headquarters ${ }^{1}$. . . . . . . 459

Life Mask of Washington ${ }^{4}$. . . . . . 463

Made by Houdon in 1785 .

The Parsonage of Mrs. Stowe's "Minister's Woolng" 1460

Doorway of Old House on Thanes Street ${ }^{3}$. . . 468

General Nathanael Greene ${ }^{1}$. . . . . $47 \mathrm{I}$

From one of Malbone's best miniatures.

SEAL of The City of Newport . . . . . . . 473

\section{PROVIDENCE}

View of Providence . . . . . . . . . . 477

From the south.

Roger Williams Received by the INdians . . . 479

From a design by A. H. Wray.

The Roger Williams Monument . . . . . 483

STEPHEN HOPKINS ${ }^{5}$. . . . . . . . . 490

1 Reproduced by permission of Simon Hart, Newport, R. I.

${ }^{2}$ Reproduced, with permission, from Porter's Two Hundredth Birthday of Bishop George Berkeley, published by Messrs. Charles Scribner's Sons.

${ }^{3}$ Reproduced by permission of The Century Co.

- Reproduced, with permission, from the American llonthly Reziezi of Reviews, from the editor's article on the Renaissance of the Mediaz'al Pilgrimage. published in October, 1893

${ }^{5}$ Reproduced by permission of Messrs. D. Appleton \& Co., 
PAGE

BROWN UNIVERSITY . . . . . . . . . 493

Francis Wayland . . . . . . . . . . . 499

The Capitol . . . . . . . . . . 503

Seal of the City of Providence . . . . . . 506

HARTHORD

MAIN STKEET . . . . . . . . . . 509

Old Center Burying-Ground . . . . . . . 513

The Charter OAK . . . . . . . . . . 520

Old State House, now City Hall . . . . . 529

Built in 1794.

Statue of Israel Putsidn . . . . . . . . . 539

J. Q. A. Ward, sculptor.

Kenhy Memorial Tower ${ }^{1}$. . . . . . . 541

The CAPitol . . . . . . . . . . $5+3$

Soldiers' Memorial Arch . . . . . . . . 545

HARRiet Beecher Stowe . . . . . . . . $5+6$

Dr. Horace Bushiell. . . . . . . . 547

From a crayon drawing by S. IV. Rowse.

J. Hammond Trumbull, Ll. D. . . . . . . 549

ARMS OF THE City of HaRTFORi). . . . . . 551

NEW HAVEN

TEMPLE STREeT . . . . . . . . . . 555

JOHN DAVENPORT . . . . . . . . . . . 557

From a portrait in possession of Yale College.

Roger Sherman ${ }^{2}$. . . . . . . . . $56 \mathrm{r}$

Photographed from statue on the east front of the Capitol at Hartford.

1 Reproduced from Trips by Trolley and A wheel around Hartford.

"Reproduced, with permission, from Boutell's Life of Roger Sherman, published by A. C. McClurg \& Co., Chicago, Ill. 


\section{Illustrations}

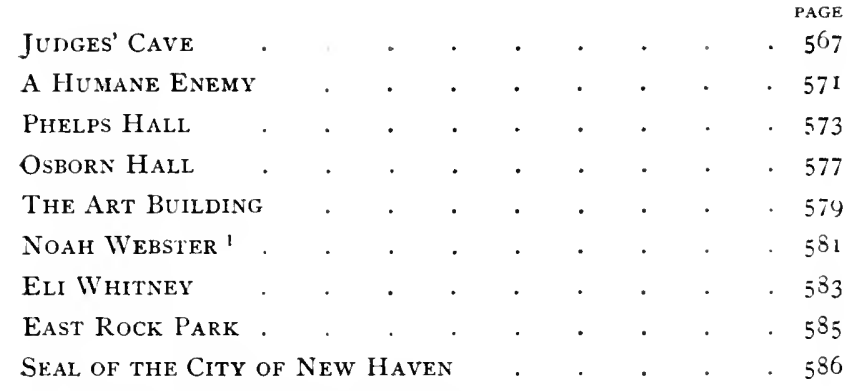

${ }^{1}$ Reproduced, with permission, from Webster's Dictionary, published by G. $\&$ C. Merriam Co., Springfield, Mass.

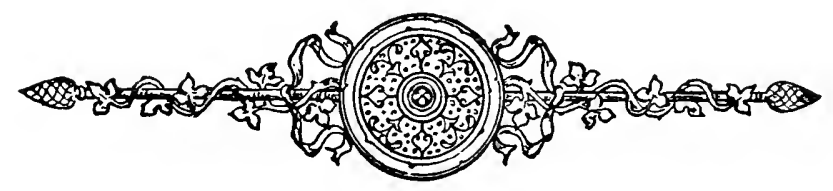





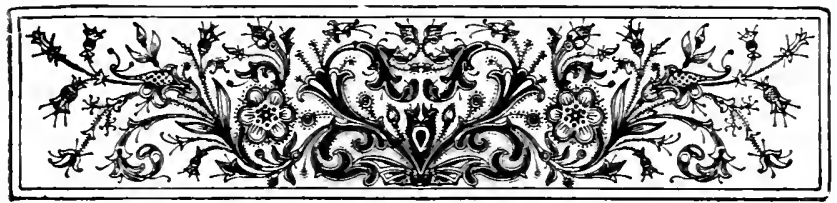

\section{INTRODUCTION}

BY GEORGE PERRY MORRIS

FROM the earliest days of the New England Colonies down to the present time, those European analysts of our national life, whose opinions have been based on personal observation, have usually conceded that in New England towns and villages one might, at almost any period of their history, find a higher average degree of physical comfort, intelligence and mental attainment, and political liberty and power than was or is to be found in any other communities of Christendom. Thus Alexis de Tocqueville, in 1835 , wrote:

"The existence of the townships of New England is, in general, a happy one. Their government is suited to their tastes, and chosen by themselves. . . . The conduct of local business is easy. . . . No tradition exists of a distinction of ranks; no portion of the community is tempted to oppress the remainder; and the 
abuses which may injure isolated individuals are for. gotten in the general contentment which prevails. . . 'The native of New England is attached to his township because it is independent and free; his co-operation in its affairs ensures his attachment to its interest; the well-being it affords him secures his affection, and its welfare is the aim of his ambition and of his future exertions. He takes a part in every occurrence in the place; he practises the art of government in the small sphere within his reach; he accustoms himself to those forms which can alone ensure the steady progress of liberty; he imbibes their spirit; he acquires a taste for order, comprehends the union of the balance of powers, and collects clear practical notions on the nature of his duties and the extent of his rights." "

If this be true, the question inevitably arises, how has it come to pass? New England, as a whole, is far from fertile. Its winters are long and severe. Of mineral wealth it has little. The raw materials for its countless factories and mills, the fuel for its factories, homes, and railroads, must be obtained in the territory south and west of the Hudson River. The cereals which furnish the staple diet of its peo-

${ }^{1}$ De Tocqueville's Democracy' in America, chapter v. Mr. F. J. Lippitt, who assisted M. de Tocqueville in the preparation of this work, says that once when they "had been talking about townmeetings, de Tocqueville exclaimed with a kindling eye (usually quite expressionless), 'Mais, c'est la commune !'"-Cf. The Century Magazine, September, ISos, p. 7о . 
ple come from Western plains. Its best blood and brawn have gone to found commonwealths ranging from the Alleghany to the Sierra Nevada mountains, and, into towns once populated and dominated by the purest of English stock, there have come Irish from Ireland and Canada, French by way of Canada, Portuguese, Italians, and Jews from Russia, so that, in I 890, the alien male adult population of the several States was found by the Federal census takers to be, in Maine, 5 r.43 per cent. ; New Hampshire, 50.5 per cent.; Vermont, 41.25 per cent.; Massachusetts, 46. Io per cent.; Rhode Island, 49.78 per cent. ; Connecticut, 36.52 per cent.

And yet, notwithstanding these economic disadvantages, this depletion of a population inheriting noble ideals, and the infusion of a class of settlers holding, in many instances, political and religious convictions quite at variance with those of the founders of the colonies, the "type" persists. The New England towns are still unlike, and in some respects superior to, those of other sections of the country. The New England States still lead in reformatory legislation. New England's approval or disapproval of ideas affecting na- 
tional destiny still has weight with Congress and Presidents altogether disproportionate to the number of her representatives in Congress or her votes in the Electoral College.

If one will walk about New England towns one will find in each a church, a town-house, and a school, and in most of them a railroad station and a factory. In the majority of them there will also be a public library, small perhaps and usually housed in the town-house, but open to all, and supported from the public funds. In the larger towns, especially in those where manufacturing is a prominent factor in the communal prosperity, a hospital, supported by public taxation, is open to all. In almost every town there is a grass-covered, tree-shaded "common," which serves as a village or town park, and on it usually stand memorial tablets or statues testifying to the valor of the dead who went forth to fight in the War of the Revolution or in the Civil War.

The church symbolizes that belief in God and that disposition to obey His will and law which the noblest and wisest men of all ages and climes have agreed upon as the sine qua non of civic as well as of individual prosperity, and in this instance it also stands for that 
separation of Church and State which our national experience-and that of Canada and the Australian Colonies as well-shows to be the ideal relation. That for a time, in the early days of Massachusetts and Connecticut, there was an unsuccessful attempt to preserve a union of State and Church, an attempt which had for some of its least commendable incidents the wholesale hanging of men and women for witchcraft, the expulsion of Quakers, and the ostracism or exclusion of Roman Catholics and Anglicans, is not to be denied.

That the people of New England have been duly conscientious is apparent by the multiplication of churches at home, and by their neverceasing, overflowing gifts to establish churches, colleges, schools, and Christian missions in the South and West and in foreign lands. It is from the thrifty, prosperous, philanthropic New Englander that the treasuries of the great Protestant missionary and educational societies receive their largest average per-capita gifts, and it is to New England that the steps of the Western and Southern educator still turn for endowments which his State may not, or the people cannot, or do not, give.

Peopled by inhabitants given over to intro- 
spection, and as fond of theology as the Scotch, the early New England communities were intensely religions and sectarian. God to them was a Personal Sovereign, intimately concerned with their daily life. They were His chosen people, and, as such, pledged to obedience to His service. The Church was His Bride; the clergyman was $H$ is spokesman, and received the deference-social as well as official-which was due to one so augustly commissioned. The social as well as the intellectual life of the community centred almost exclusively in the life of the church and the sermons of its clergy. Sectarian animosities were the inevitable product of a mistaken emphasis put upon the form or utterance of truth, rather than upon truth itself ; or, to put it differently, of a provincialism and narrowness of vision that made it impossible for the many to understand that truth is many-sided, that men are different temperamentally, that revelation is continuous and progressive, and that religion is not theology. Communities exist in New England where the old view still obtains, where sectarianism is as rampant as ever, where the clergyman is the social autocrat as well as the shepherd of souls. But such towns are becoming fewer and fewer 
as the years go by, and of towns of the newer type, where the church is recognized as only one of the many agents which God has for ushering in His Kingdom on earth, New England now has quite as many, probably, as are to be found elsewhere.

To those interested in the theological and religious history of English-speaking peoples, certain New England towns have a peculiar fascination and value as environments which have affected character. Northampton, Nassachusetts, will ever be a Mecca because of the identification of Jonathan Edwards with the town. Concord, in the same commonwealth, has not only the unique glory that belongs to a town where national history has been made and the best American literature of its class written by Hawthorne and Thoreau, but also it is the town where Emerson's ministerial ancestors lived, where he flowered out and became

that grey-eyed seer

Who in pastoral Concord ways

With Plato and Hafiz walked.

Newport, Rhode Island, with all its present pre-eminence as a place where "Fashion is a potency . . . making it hard to judge be- 
tween the temporary and the lasting," will ever remain most worthy of resort because it was the birthplace of William Ellery Channing, and, for thirty years, was the home of the Rev. Dr. Samuel Hopkins, both eminent as theologians and as brave pioneer antagonists of human slavery. Dr. Hopkins was the model for the New England pastor described by Harriet Beecher Stowe in The Minister's Hooing. Northfield, Massachusetts, is known to thousands of Christians the world over, who have never seen its rare beauty of river and landscape, because a boy, one Dwight L. Moody, was born and bred there, and has become the greatest evangelist of modern times. Litchfield, Connecticut, is famous as the birthplace of Henry Ward Beecher, and if one wishes flash-light pictures of New England ecclesiastical and social life at the beginning of this century, let one read the autobiographic records of Lyman, Henry IVard, Harriet, and Catherine E. Beecher.

Portland, Maine, is known to thousands throughout the English-speaking world, who are ignorant of every other fact in its long and honorable history, because Francis E. Clark there conceived and began that movement to 
enlist young people in active Christian service, which is now known as the International Young People's Society of Christian Endeavor, with 54, I9 I local societies, and more than three and one quarter million adherents enrolled, Russia alone, of the nations of the earth, being without a society now. Hartford, Connecticut, with a discernment and gratitude not always displayed by municipalities, has named its beautiful municipal park after Horace Bushnell, for many years its most eminent divine and "first citizen."

Salem, fascinating as it is because of its connection with the witchcraft delision and the early Puritan theocracy; because of its being for a time the home of Hawthorne, who has preserved its ancient local color and atmosphere in his fiction; and because of its ancient glory as a seaport town, whence departed a fleet of sailing craft that made Salem known throughout the world, in places where Boston and New York were then unknown, nevertheless derives its chief glory from the fact that it was the town where Roger Williams, the Welsh statesman and prophet, found a church willing to sit at his feet. The church's loyalty, however, gave way at last to the resistless pres- 
sure of the civil authorities and the zealous ecclesiastical tyrants of the Puritan commonwealth, and it permitted him to depart, to es. tablish in Rhode Island a community based upon the principle of entire liberty of conscience, and majority rule in secular affairs. Massachusetts' loss and the world's gain are thus summed up by Gervinus the German historian :

"The theories of freedom in Church and State, taught in the schools of philosophy in Europe, were here [Rhode Island] brought into practice in the government of a small community. It was prophesied that the democratic attempts to obtain universal suffrage, a general elective franchise, annual parliaments, entire religious freedom, and the Miltonian right of schism would be of short duration. But these institutions have not only maintained themselves here, but have spread over the whole Union. They have superseded the aristocratic commencements of Carolina and of New York, the High-Church party in Virginia, the theocracy in Massachusetts, and the monarchy throughout America: they have given laws to one quarter of the globe, and, dreaded for their moral influence, they stand in the background of every democratic struggle in Europe."

Boston, with all her glories, has none of which she is more proud, than the fact that within her borders Phillips Brooks was born 
and labored most of his life. Those who came within his range of influence said of him, as Father Taylor said of Emerson, "He might think this or that, but he was more like Jesus Christ than any one he had ever known."

To mention Roger Williams, Jonathan Edwards, William Ellery Channing, Ralph Waldo Emerson, Horace Bushnell, Henry Ward Beecher, Phillips Brooks, Francis E. Clark, and Dwight L. Moody, is to name the greatest spiritual forces which New England has known, and towns fed with manna by such prophets have not failed to indicate the influence of personality in transforming environment.

The "town-house," or town-hall, of the New England town or village, in its architecture, is a modern structure, often as simple, unpretentious, and unornamented as the "meetinghouse" near which it usually stands on the village green or "town common." It is the arena wherein rich and poor, educated and illiterate, wise and foolish, meet, at least annually, and as much oftener as occasion demands, to decide those questions of Home Rule which are most vital to all concerned. Education, wealth, moral worth, shrewd native sense, oratory, 
gifts of persuasion, the stirrings of ambition, civic pride, thrift, foresight, all have their due weight in this forum, this "school as well as source of democracy"-as Mr. Bryce aptly phrases it. But when the vote is taken, the blacksmith and the bank president, the master and the servant, the principal of the high school and the loafer around the village bar stand on precisely the same footing. The vote of one is as decisive as that of the other,- - no less, no more.

Debate and procedure which have the qualitative character are followed by voting of the quantitative character, and the result represents average intelligence and capacity for self-government. But that result, because it is the product of the expressed will of all, has an authority more enduring and inspiring than any that the autocracies, oligarchies, or constitutional monarchies of Europe have ever displayed or now possess.

Using the town-meeting as a rapier, Samuel Adams

"fenced with the British ministry ; it was the claymore with which he smote their counsels; it was the harp of a thousand strings that he swept into a burst of passionate defiance, or an electric call to arms, or a proud pæan of 
exulting triumph, defiance, challenge, and exultationall lifting the continent to independence. His indomitable will and command of the popular confidence played Boston against London, the provincial town-meeting against the royal Parliament, Faneuil Hall against St. Stephen's."

This popular government not only enabled the New England Colonies to lead all the others in the War of the Revolution, it also furnished men and ideas for the formidable task of constitution-making after the Revolution was over and independence won. As early as I 773, the rustic Solons of the town of Mendon, Massachusetts, had resolved in town-meeting:

"That all men have an equal right to life, liberty, and property.

"Therefore all just and lawful government must originate in the free consent of the people.

"That a right to liberty and property, which are natural means of self-preservation, is absolutely inalienable, and can never lawfully be given up by ourselves or taken from us by others."

Naturally, a section of the country where such sentiments were held by village Hampdens had a preponderant influence, when the time came to draft the Declaration of Independence and

${ }^{1}$ Geo. Wm. Curtis, Orations and Addresses, vol. iii. 
the Constitution, and the readiness of the towns to submit to taxation and to give their sons when the call to arms came is a matter of unimpeachable record. In the army of $231,79 \mathrm{I}$ soldiers, furnished by the Thirteen Colonies to combat the forces of Great Britain in the Revolution, the four New England Colonies sent i 8,25 I men, Massachusetts contributing 67,907, Connecticut 31,939, New Hampshire I 2,497, and Rhode Island 5,908.

In the War of i8 12, New England, as a section, was not very enthusiastic, but her quota of troops was, nevertheless, forthcoming. In the Civil War, I861-65, her troops were the first to respond to the call of President Lincoln, and, out of 2,778,304 men who enlisted, 363, I61 came from New England. Of these, Massachusetts furnished 146,730 , Maine 70,107, Connecticut 55,864, New Hampshire 33,937 , Vermont 33,288 , and Rhode Island 23,236 . In fact, surveying the history of New England towns from the time when they contributed their quota of men and money to the aid of the Mother Country in her fight with France to decide who should be supreme on the North American continent, down to the recent contest between the United States and 
Spain, it can truthfully be said of their democratic form of government that it "is the most powerful and flexible in history. It has proved to be neither violent, cruel, nor impatient, but fixed in purpose, faithful to its own officers, tolerant of vast expense, of enormous losses, of torturing delays, and strongest at the very points where fatal weakness was most suspected." And this, be it remembered, where " the poorest and most ignorant of every race. . . are the equal voters with the richest and most intelligent." This, too, where the newly landed, propertyless immigrant from Italy or Russia, if able to comply with the generous provisions governing naturalization and the exercise of the franchise, has the same potentiality at the polls as the thrifty, well-to-do, heavily taxed citizen whose ancestors, perchance, may have come over with the Pilgrims on The Mayflower.

Considered either in its origin or its development, the New England town-meeting merits the study of all who are interested in the extension of principles of democracy. The English settlers of New England were, as Mr. Bryce says, "largely townsfolk, accustomed to municipal life and to vestry meetings." They 
brought with them, as an inheritance from their Teutonic ancestors, a habit of self-rule which the peculiar isolation of the colonies and the separate communities in the colonies strengthened; hence a form of government in which the town was the unit evolved inevitably.

The more mixed composition of the population in the Middle Atlantic Colonies, for the same reason, inevitably caused a mixed type of government to be created there, in which the county or shire divided the authority with the town; while in the Southern Colonies the immigrants were of such a character, and the economic conditions so different from those in New England, that a more aristocratic form of government evolved, semi-feudal in its type, and the county, rather than the town, became the important minor political unit within the State, never, however, having a vigorous independent life, the colony and afterward the State becoming the source of authority and the end of government. Long years afterward, in the Civil War, the two types of government clashed, and the type prevailed which Thomas Jefferson praised and wished transferred to Virginia, for, said he: 
"Those wards called townships in New England are the vital principle of their governments, and have proved themselves the wisest invention ever devised by the wit of man for the perfect exercise of self-government and for its preservation."

It is well, however, to note, that Mr. Charles Borgeaud, the eminent Genevan historian, in his work on the Rise of Modern Democracy, disputes the Teutonic origin of the town-meeting, and contends that it must be credited to the democratic principles of the New Testament as interpreted and accepted, first by the Brownists of England, and held later by the Pilgrim Fathers and those of the Puritans who accepted the Independent form of church government, rather than to any principle of communal government first evolved by Teutons. He says :

"At the moment when the colonists of New England quitted the Mother Country, whatever was left of that old self-government which had been exercised by their forefathers was under the influence of the general movement, and was undergoing aristocratic transformation. The vestries, or meetings of the inhabitants of the parish, were being replaced by committees known as select vestries, which were originally elected, and then, before long, recruited by co-optation. Had the American colo- 
nists purely and simply imitated in their new country the system which they had seen at work in England, they certainly would not have founded the democratic government of the town-meeting. In order to explain their political activity, we must take into account, and that largely, their religious ideas. And we shall be naturally led to do this if we remember that, in the beginning, each settlement or town was, before all things, a congregation, and that the town-meeting was in most cases the same thing as the assembly of the congregation. In Virginia, where the colonists remained members of the Anglican Church, there was no town-meeting, but only select vestries as in England, and these had certainly lost all family likeness, if they really were related to the Thing and the Tungemot."

In due time, when pioneers from New England found their way to the then virgin lands of Central New York, the valley of the Ohio, and the northern half of the vast valley of the Mississippi, they carried with them the political and religious ideals of New England. Where they were a large majority of the settlers within a given territory, or where at the time when its organic structure was forming they dominated it, the town was established as the political unit in the territory. Such was the case in Michigan, Illinois, MVisconsin, and Minnesota. Where New England settlers joined with those from the Middle States, or 
the border States of Kentucky and Virginia, they often found it necessary to compromise on a system in which the county and the town were peers, as in Ohio, Indiana, and Iowa. But, as experience has proved, the modified township system, as it is found in Illinois and Michigan, is more advantageous than the system of divided authority, and many of the Western States are gradually adopting it, California, Nebraska, and the Dakotas having recently made it either permissible or mandatory.

Nor are signs lacking that in the South, as its white population increases by immigrants from the North, as the patriarchal and pastoral type of civilization gives way to the modern industrial and corporate type, as cities and towns multiply, and local as well as State pride has free chance to develop, there will be an adoption of the modified township system and a gradual abolition of the county system.

Among the changes of the last half-century in New England, one notable one has been the tendency of the larger towns to adopt the city form of government as soon as it was deemed that the increase of population warranted the step and made it necessary. This fact, as well as the marked increase of urban 
population in New England, ${ }^{1}$ is counted by some students of her social development as indicative of retrogression, however inevitable. Certain it is, that if the town of Brookline, with its population of $\mathrm{I} 6, \mathrm{I} 64$, and its property valuation of $\$ 64,169,200,{ }^{2}$ and annual appropriations of more than $\$ 900,000$, can still work the ancient machinery of the town-meeting without the slightest loss either of a pecuniary or a civic sort, other towns, with a smaller population and much smaller valuation of property, cannot reasonably claim that mere physical growth is any warrant for the change from a system so purely democratic to one less so and much more readily adapted to serve the ends of partisan bosses and those who batten at the public crib.

The third of the indispensable and everpresent institutions found in every New England town or village is the public school, open

1 In 1810 , less than 15 per cent. of the population of Rhode Island was found in towns of 8000 or more inhabitants ; in 1890 , nearly 80 per cent. In Massachusetts, in 1790 , five per cent. were urban dwellers; in 1890 , 70 per cent. In Connecticut, in 1830,3 per cent. lived in cities; in 1890 , more than 50 per cent. In 1840,3 per cent. in New Hampshire lived in cities; in 1890 , more than 25 per cent. In 1820 , in Maine, 4 per cent. lived in cities; in 1890 , 20 per cent.

${ }^{2}$ Cf. Town Records of Brookline, $1897-98$. 
to all and supported by all. Roman Catholic, Protestant and Jew, Caucasian and African, French Canadian and Irish, Italian and Portuguese, English and German, mingle in the school-room and learn the essential likeness of each to the other, their common and peculiar gifts, and their common duties to God and the State. No man in the community is so rich or aristocratic as to escape taxation for support of the school, even though his children may never darken the doors. No man in the community is so humble or so poor as to be debarred from sending his children to the highest as well as to the lowest grades. Unsectarian in the sense that they derive support from taxpayers of all sects and inculcate the dogmas of none, secular in the sense that religion is not a part of the curriculum, they ever have been a bulwark to the cause of religion, partly by reason of the example of the teaching force, who usually are men and women with religious faith as well as mental attainment, and partly because they have developed the rational powers of men, and thus enabled them to discriminate between superstition and truth. Beginning, in the more favored and advanced communities, with kin- 
dergarten instruction for young children, and not ceasing until the youth or maiden is prepared to enter the college or university, the State and the town, co-operating together, make it possible for every parent to give to his children, or for every ambitious or friendless boy or girl to secure for himself or herself, at the public expense, a thorough preparatory education. Nor is there any item of his vearly tax bill which the typical New Englander pays with greater alacrity and more certainty of belief as to its equity or economy than his annual contribution for popular education. For it is ingrained in his very being. wover into the texture of his life, to believe, as Garfield said, that "next in importance to freedom and justice is popular education, without which neither freedom nor justice can be permanently maintained." Moreover, being shrewd as well as a man of high principles and a lover of learning for its own sake, the New Englander is convinced that it pays to be educated, and to have educated neighbors and children. His reasoning takes this form: The more children in the schools, the fewer youths and adults in the jails and poorhouses. The better informed the mill operatives, the 
larger the output of the mills. The higher the standard of living, the larger the demand for the product of the soil and the loom, and the better the home market. The more intelligent the voter, the less the seductive power of the demagogue and the "political boss." In short, the New England people have always believed, and still believe, what the inscription on the Public Library in Boston declares :

THE COMMONWEALTH REQUIRES THE EDUCATION OF THE PEOPLE AS THE SAFEGUARD OF ORDER AND LIBERTY.

That the policy has been a wise one, is indicated by New England's share in the various struggles for liberty which the country has seen, the stability of all her institutions, her exemption from disorder and industrial disputes which culminate in violence, her inhospitality to "boss rule" in politics, and the thrift and prosperity of her citizens.

Historically speaking, the "public school" is a very ancient New England institution. Boston had one as early as 1635 , and, in 1647 . the General Court of Massachusetts enacted: 
"That to the end that learning may not be buried in the graves of our forefathers, it was ordered in all the Puritan colonies that every township, after the Lord hath increased them to the number of fifty households, shall appoint one to teach all children to write and read; and when any town shall increase to the number of one hundred families, they shall set up a Grammar School, the master thereof to be able to instruct youth so far as they may be fitted for the University."

Nine years earlier, in $6_{3} 8$, the same body had founded a college (Harvard) at Cambridge, in order, as they said, that " the light of learning might not go out, nor the study of God's word perish." These two acts of the General Court may be reckoned as the germs from which has developed that system of secondary and higher education which has given Massachusetts the place of leader in the history of education in America.

In I645, Connecticut passed a law similar to the earlier Massachusetts statute of 1642 , but not until I 7or was Yale University founded at New Haven. Rhode Island did not have a system of popular education until just as the eighteenth century was closing. New Hampshire, Maine, and Vermont accepted the Massachusetts methods and ideals, with some minor variations. 


\section{Introduction}

Devout as were the founders of New England, it followed inevitably that they should establish institutions where their children might obtain a distinctly religious training as well as a general education. Thus, for a long period of New England history, the Christian academy, under denominational control, flourished just as it does now in the West, and for much the same reason. As the public-school system has expanded, as town after town has added the high school to the primary and grammar school, as sectarian fences have toppled over or ceased to be restrictive, the academy of the old type has ceased to play the part it once did in New England life. But, in any survey of the history of education in New England, it should not be overlooked. Many excellent institutions of this type still survive to meet the demands of those persons who either distrust the public high school, or else are unable to send their children to one, owing to residence in towns where the school system has not developed to that extent. But, as a rule, the New England boy and girl, no matter what the social station or wealth of his or her parent, still " derives his or her preparation for college or life from the community in 
which he or she lives." And, as Phillips Brooks said in his address at the two hundred and fiftieth anniversary of the Boston Latin School:

"That is the real heart of the whole matter. . . . It constitutes the greatest claim of the public-school system. It represents the fundamental idea of the town undertaking the education of her children. . . . It educates the thought of law and obedience, the sense of mingled love and fear, which is the true citizen's true emotion to his city. It educates this in the very lessons of the school-room, and makes the person of the State the familiar master of the grateful subject from his boyhood. . . . It is in the dignity and breadth and seriousness which the sense that their town is training them gives to their training, that the advantage of the publicschool boys over the boys of the best private schools alway's consists."

Emigrating westward, the pioneers from New England carried with them the public school, the academy, and the college. Connecticut's settlers in the Western Reserve, Ohio, took with them conceptions of duty in this respect, which profoundly affected the future history of the commonwealth. Ohio has come to be, in this later day, what Virginia was in the early history of the country- " The Mother of Presidents"-and has more col- 
leges within its borders than any State in the Union. It was a Massachusetts soldier, Gen. Rufus Putnam of Rutland, a Congregational clergyman, Rev. Nanasseh Cutler of Hamilton, Massachusetts, and an Ipswich, Massachusetts, lawyer, Nathan Dane, who founded Marietta, Ohio, and induced Congress to put into the epoch-marking Ordinance of 1787 governing the Northwest Territory, this remarkable declaration and article:

"Religion, and morality, and knowledge, being necessary to good government and the happiness of mankind, schools and means of education shall forever be encouraged."

As early as I797, Muskingum Academy was founded in the territory conceded, and in due time came Marietta, Oberlin, Wabash, Illinois, Knox, Beloit, Olivet, and Ripon Colleges, all Christian institutions within the territory originally governed by the Ordinance of 1787 .

Precisely similar has been the record of New England emigrants beyond the Mississippi. Wherever they have settled and shaped the civic ideals, whether in the Dakotas, Iowa, Minnesota, Nebraska, Kansas, Colorado, or in California, there they have laid the foundations of a free public-school system, and of academies 
and colleges controlled by Christian educators and trustees. Nor do they cease to believe in the academy and the college now that the competition of the State university in the States of the interior and the West is so intense, and the reliance of the treasuries of these Western Christian institutions upon the gifts of their friends in New England increases rather than abates.

Impressed with the need, in all sections of the country, of a well-instructed and intelligent electorate, and convinced that the South was too poor to provide for itself the schools that its unfortunate illiterate whites and blacks needed, New Englanders early began to contribute to the support of academies and colleges in the South. Not always welcomed by the ruling class, the pioneers in this work persevered, and many of them have lived long enough to receive the thanks of those who at first despised and scorned them. Millions of dollars have gone from New England for the founding and support of such institutions as Berea College, Kentucky; Atlanta University, Georgia; Hampton Institute, Virginia ; Fisk University, Tennessee; and Tuskeegee Institute, Alabama. Three New Englanders, 
George Peabody of Danvers, Mass., John F. Slater of Norwich, Conn., and Daniel Hand of Guilford, Conn., have given between them $\$ 5,100,000$ in bequests or donations for the establishment or assistance of schools, colleges, and training schools for teachers in the South. The Peabody Education Fund, from is 868 to I 897 , distributed in the South, from its income alone, a sum amounting to $\$ 2,478,527$.

Nor is New England's influence, educationally speaking, limited to the United States. The educational system of Honolulu is based on New England models. Robert College, near Constantinople, has spread the principles of Christian democracy in Church and State, as they are held by New Englanders, throughout Bulgaria and the Balkan states, and given ideals to the Young Turkey party in the land where the Sultan is dominant. The Huguenot Seminary in South Africa was distinctly modelled after Mt. Holyoke Seminary, and its first teaching staff was made up of New England women educated at Mt. Holyoke. Wherever American Protestant missionaries have gone and established schools and colleges in Asia, Africa, or Europe, almost invariably the master spirits, the men and women who 
have given character to, and established the ideals of, the institutions, have been graduates of the New England colleges and academies, even if not New-England-born.

Subtract from the history of education in the United States, during the latter half of the century just closing, the influence of four men, Horace Mann, Henry Barnard, Charles William Eliot, and William Torrey Harris, and you take from it the best that it stands for to-day. All of these men were born in New England. All were reformers. All showed great administrative ability. All lived to see their radical views find general acceptance. Horace Mann did his greatest work in remodelling the public-school system of Massachusetts. Barnard did a similar work in Connecticut, Rhode Island, and Wisconsin, but his greatest service to the cause of education was his masterly editing of the American Fournal of Education, from $\mathrm{I} 855$ to $\mathrm{I} 88 \mathrm{I}$. Eliot has transformed the curriculum of Harvard, the oldest university of the North, has resolutely contended for the largest measure of election by the student in his selection of studies, his personal conduct, and his personal attitude toward God, and he has 
made "Veritas" in very truth the appropriate motto of the leading American institution of learning. Harris, as an interpreter of the philosophy of education, both in his many writings and more numerous addresses, has lifted the popular conception of the profession of teaching to a loftier and more rational plane, while his control of the United States Bureau of Education since 1889 has given it a standing abroad, and a measure of utility at home, which it is gratifying to contemplate.

Few towns in New England possess more charm, whether of nature or society, than the towns in which her long-established institutions of learning have taken root, flourished, and dominated the life of the community. New Haven, Cambridge, and Providence are all cities now with a heterogeneous population and large manufacturing interests, and they each contain thousands of inhabitants to whom Harvard, Yale, and Brown are of as little practical benefit or concern as if they were situated in remote Hawaii or Porto Rico. Nevertheless, the chief glory of each of these large towns is its institution of learning, and to each there come added beauty of life and elevation of tone because of the presence 
within its borders of so many thirsty and hungry students and highly educated and apt instructors. It would be idle, however, to claim, for instance, that Cambridge to-day is quite as unique and charming in its simplicity and purity of life, or quite as classic in its atmosphere, as it was in the days when the town was a village, when the university was a college, and when thought and manners were as ideal as James Russell Lowell in his essay, Cambridge Thirty Years Ago, and Thomas Wentworth Higginson in his latest book, Cheerful Yesterdays, picture them.

To study the American college town at its best, unsullied by the grime of industrialism and the temptations and conventionalities of city life, one must go to hill-towns like Amherst and Williamstown, Massachusetts, or Hanover, New Hampshire. But even there, standards of living and conduct among students and instructors have been changed and influenced by the habits and ideals of the universities and the cities. Hence, to see the American college town in all its pristine simplicity and beauty, one now has to go to the new New England, and visit such institutions as Oberlin, Beloit, Knox, Iowa, and Colorado 
colleges, concerning which, and others of their type, Mr. Bryce writes :

"They get hold of a multitude of poor men who might never resort to a distant place for education. They set learning in a visible form, plain indeed and humble, but dignified even in her humility, before the eyes of a rustic people, in whom the love of knowledge, naturally strong, might never break from the bud into the flower, but for the care of some zealous gardener. They give the chance of rising in some intellectual walk of life to many a strong and earnest nature who might otherwise have remained an artisan or storekeeper, and perhaps failed in those avocations."

New England has a railroad mileage greater in proportion to its population and area than any section of the United States. Indeed, it is greater than that of any European country. In 1895 , there were I I. 77 miles of railroad for each one hundred square miles of territory, and r. I I miles for each ten thousand inhabitants, the proportion in Massachusetts rising to 26.35 miles for each one hundred square miles. The same year, the number of em-

${ }^{1}$ Chapter cii., Bryce's American Commonwealth. For an interesting and significant account of the impression made by one of the Western Christian colleges upon a friendly and thoroughly trained French observer, see the translation of an article by Th. Bentzon (Madame Blanc) in the Revue des Deux Mondes, printed in McClure's Magazine, May, I895. 
ployés engaged in railway traffic in New England was 60,593. On January I, i 840 , New England had only 426 miles of railway. January 1,1895 , it had 7,398 miles of road, which reported gross earnings of $\$ 82,845,40 \mathrm{I}$, and I 6,069, i 78 passengers transported during the previous year.

The significance of these facts is apparent to the casual traveller through New England as well as to the economist. Nerves of steel and iron have bound urban and rural populations together, made the cities and towns accessible to the inland trader, farmer, and producer, and the country districts accessible to the wares of the merchant and manufacturer, and to the lover of nature. Suburban residence for the urban toiler has been made possible and cheap, while New England, as a whole, has been transformed from an agricultural and seafaring section to one with great and most varied manufacturing interests. Boston has come to be next to the largest centre for exports in the country, and the commercial and industrial as well as the intellectual capital of New England.

From the standpoint of resthetics, the railroad station in the average New England 
town is a monstrosity, although in all fairness it should be said that within a decade there has been a notable improvement in this respect. But from the standpoint of economics and social science, the railway station is subordinate only to the church and the school in its service to society; and the degree of civilization in any community may be accurately computed by the volume and variety of the traffic done with its station agents. If one is desirous of studying the New England town, let him frequent the platforms of the railroad station and the freight-house, ascertain how large a proportion of its inhabitants leave town daily to do business in the adjacent city, how many travel even farther in pursuit of pleasure or on business, how many depart on outings that imply thrift and a desire for recreation and rest. Let him study the bulk of the raw material as it comes from the woolmarkets of Europe and America, from the cotton fields of the South, and from the mines of Alabama, Pennsylvania, and Minnesota, and then inspect it as it goes forth again, converted into manifold forms of useful tools, machinery, fabrics, etc., and he will not lack for data respecting the status of the community. If he 
finds that pianos, organs, books, pictures, the latest devices of sanitary science, bicycles, etc., are arriving, he may justly infer that the inhabitants are in touch with the outer world and eager to take advantage of the latest discoveries of men of science. Nor is it imprudent to assert that such a study made in the average New England town will indicate economic wants, and their satisfaction, such as no communities elsewhere can display.

Compared with other sections of the country, New England has railroads which are better supervised by the States, more honestly constructed, capitalized and administered, and more responsive to public needs. Concentration of power and responsibility in the hands of the few goes on apace in New England, as well as elsewhere, so that now there are only four railway corporations of much importance in New England. But, through such governmental agents as the Massachusetts Board of Railroad Commissioners (organized in I 869, and the model for similar bodies elsewhere in the nation), the people still retain the whip-hand, still protect the rights of individuals, communities, and investors, and bring about those reductions in fare and freight charges, 
and those improvements in service, which public welfare and safety demand.

No attempt-however brief or superficialto describe the life of the New England town of the last decade of the nineteenth century, especially in the States of Massachusetts, Connecticut, and Rhode Island, could justifiably fail to note the transformation-economic, physical, and social-which the bicycle and trolley electric railroad have wrought in the life of the towns of those States.

New England capitalists and New England inventors were the first to put on the market safety bicycles that were well constructed, adapted for daily use or pleasure, and reasonably cheap, and New England still retains the lead in the domestic and export trade in bicycles. Naturally, then, New England people were the first to purchase the product of their own factories. Space does not suffice to indicate here how general now is the use of the bicycle even in the remotest hamlets, and how it has changed modes of living. Farmers' boys and girls among the lakes and hills of Maine and Vermont, fishermen's children on the sand-dunes of Cape Cod, run their errands, visit their neighbors, and get their daily 
sport with the bicycle. Artisans and professional men in all the towns and cities go to and from their shops, offices, and homes on steeds that require no fodder, and while doing it gain physical exercise and mental exhilaration that transportation in the old ways never furnished. Horses still are in demand for sport and draught work, and the few who love horses continue to breed and own them. But for the multitude a far cheaper and more tractable kind of steed has come, one which rivals the locomotive as well as the horse and forces steam-railway managers to face serious problems, mechanical and fiscal.

As to the electric street railway, perhaps a few facts relative to Massachusetts may indicate a state of affairs that to some extent is typical now of the section, and will become more so as population in New Hampshire, Maine, and Vermont drifts townward.

From i 860 to I 889 , the number of street-railway companies in Massachusetts increased only from twenty to forty-six, and the mileage from eighty-eight to 574, the motor force of course being horse-power. From i 889 to 1897 , the number of companies increased from forty-six to ninety-three, and the mileage from 547 to 


\section{Introduction}

I4I3, the motor power being almost exclusively electric. During the same period, the number of passengers carried on the ten main lines increased from $148,189,403$ in 1889 , to $308,684,224$ in 1897 . The total capital invested in these street railways now amounts to $\$ 63$, i 12,800 , and, in I 897 , earned 7.78 per cent. on the average.

So much for statistics which are impressive in themselves. But if one would appreciate the magnitude of this traffic, and the radical transformation which the new power and improved service have wrought in the life of the people who patronize these railroads, he must do more than compare statistics. He must note the result of making the residence in the suburb and the workshop in the city accessible to a degree that the steam railway cannot expect to duplicate, of giving city dwellers opportunities to journey seaward and hillward at a trifling expense, of providing residents of the villages with inexpensive transportation to the towns and residents of the towns with transportation to the cities, of cultivating the knowledge of and love for open-air life and nature among city dwellers and of enlarging the social horizon and area of observation of the villager, 
of giving a poor man a vehicle that transports him with a speed and a sense of pleasure that vies with that of the high-priced trotter of the wealthy horseman, of giving to society a centripetal force that tends to take city workers countryward at a time when other social forces, centrifugal in their tendency, are drawing him cityward.

Naught would occasion more bewilderment to the ancient residents of Marblehead, Hingham, or Plymouth, could they return to their former places of abode, than the "Broomstick Trains" which Oliver Wendell Holmes's fancy pictured thus :

" On every stick there 's a witch astride,The string you see to her leg is tied. She will do a mischief if she can, But the string is held by a careful man, And whenever the evil-minded witch Would cut some caper, he gives a twitch. As for the hag, you can't see her, But hark! you can hear her black cat's purr, And now and then, as a car goes by, You may catch a gleam from her wicked eye."

These trains whirl through the crooked streets with a mysterious, awe-compelling power, that would suggest witchery were it not for the 
clang of their alarm bells, and the knowledge that fares must be paid. They disturb the quiet and solemnity of many an ancient village, and have brought knowledge of evil as well as of good to many a youth. What railways and steamship lines have done in bringing peoples of all climes and continents nearer together, and thus at once widened men's area of knowledge and sympathy, and contracted the physical area of the earth, this the electrically propelled motor is doing on a smaller scale for the people of the towns of the ancient commonwealths of New England.

In ante-bellum days, New England and the South were, perhaps, most unlike in their attitude toward manufacturing, and the difference was one that meant far more than a mere incident of difference of climate or a difference of opinion as to sectional or federal fiscal policy. The art of manufacturing, as New Englanders had practised it for generations before what is now known as the "factory system" developed, had been based on a universal recognition of the nobility of labor, the necessity for personal initiative, and the duty of thrift. Toil was considered honorable for men and women alike. Every hillside stream was 
set at work turning the wheels of countless mills. Yankee ingenuity was given free play in the invention of appliances, and Yankee initiative saw to it that after the raw material was converted into the finished product, markets were found in the newer settlements of the Interior and IVest, or in Europe and Asia. Many a farmer was a manufacturer as well. Home industries flourished, and no month in the year was too inclement for toil and its reward.

With the application of steam power to the transportation of freight and passengers, with the invention of the spinning-jenny and the perfecting of the cotton loom and the development of the "factory system" of specialized and divided labor, New England, quick to perceive wherein her future prosperity lay, at once leaped forward to seize the opportunity, and the relative superiority thus early gained she has not lost, even though other sections more favorably situated as to accessible supplies of fuel and raw materials have, in the meantime, awakened and developed.

Whether judged by the legislation governing their operation, their structural adaptability to the work to be done, their equipment of 


\section{Introduction}

machinery, the variety and quality of their product, or the intelligence and earning capacity of their operatives, the New England factories can safely challenge comparison with those of any in the world, and the typical factory towns of New England, whether along her largest rivers, such as Lowell and Hartford, or at tide-water, as Fall River and Bridgeport, or nestled among the hills, as North Adams or St. Johnsbury, are the frequent subject of study by the deputed agents of European governments or manufacturers, anxious to ascertain what it is that makes the American manufacturer so dangerous a competitor in the markets of Europe, Asia, and Africa.

Few more interesting movements in the history of man's upward struggle have been chronicled than the successive waves of immigration which have swept into the factories of towns like Lowell, Massachusetts, and Manchester, New Hampshire. First came from the hill towns and farms the daughters of the original English, Irish, and Scotch settlers-women like Lucy Larcom,- then the Irish, specially imported from Ireland, and then the French from Canada. The Irish came when the original stock became, in its own estimation, too 
select for daily toil in the factory. The French came at an opportune time for the employers, when the Irish were also stirred by loftier ambitions. And it is already apparent that, whereas the French came, at first, only to win money to take back to Canada, now they are settling down to become citizens as well as residents, aspiring to higher and other realms of activity - in short, getting ready to give way in turn to some other nationality. Of course, nothing just stated should be interpreted to imply that the ideals of New England respecting the honorable nature of toil have changed, or that her factory operatives have ceased to be men of all races including the English. She has, however, witnessed or rather been the scene of a remarkable process of assimilation and transformation of races such as none of the manufacturing towns of England have seen.

Thus far, consideration has been given to those factors in the life of the community which it may truthfully be said are to be found in a large majority of the towns and villages of New England. It would be necessary, for a complete study of the New England town at its best, to include other factors, such as the 
savings-bank, the local lodges of the fraternal, secret orders, the co-operative bank-known in the Middle States as the building loan association,- - the daily or weekly local newspaper, and the gossip and wisdom retailed by the habitués of the "village store," which, in many of the smaller towns, serves as the clearing-house of ideas, local and national. Nor could any thorough study of the New England town as an institution fail to note at least the beneficent effect which the exclusion of shops where intoxicating liquors are retailed has had upon all of the States, thanks to that measure of prohibition which has been made possible through statutory or legislative enactment. So that, in the towns of the agricultural districts of New England, the legalized dram-shop is unknown, as are all the attendant moral and economic evils that follow in its train when the traffic is tolerated. Nor is the possibility of excluding the saloon from larger towns-manufacturing and residential-to be gainsaid in view of the record established by such cities as Cambridge, Somerville, Chelsea, Brookline, and Newton, Massachusetts. In fact, Cambridge, with its more than eighty thousand inhabitants, for nearly twelve years now has enforced local 
prohibition in a way to make its method of doing so a model for the country; the secret of the method by which it secures an annual "No-license vote" and a non-partisan administration of all city affairs being, in short, the union of temperance men of all degrees of abstinence, Jews and Christians of all sects, and citizens of all national parties on the simple platform-" No saloons, and no tests for local officials other than fitness, and soundness on questions of local policy."

But there is one factor in the life of very many of the New England towns to-day that cannot be passed by without some allusion. It is the town or city library. In many instances the gift of some private donor, who was either born in the town, and making a home and fortune elsewhere desired to testify that he was not unmindful of ancestral environment and of youthful privileges, or else accumulated a fortune in the town and desired both to perpetuate his memory and to render a public service, the library building usually stands as a token of that marked interest in public education and public welfare which Americans of wealth reveal by gifts, generous to a degree unknown elsewhere in 
Christendom, competent European judges being witnesses. Appleton's Annual Encyclopedia records a total of $\$ 27,000,000$ given to religious, educational, and philanthropic institutions in the United States, in sums of $\$ 5000$ or more, by individuals, as donations or bequests during the year I 896 . In this list are recorded gifts, amounting to $\$ 195,000$, to establish or to endow town libraries in New England.

Sometimes the major portion of the contents of the library building is also the gift of the generous donor of the edifice, but, usually, the town assumes responsibility for the equipment and maintenance of the library, deriving the necessary income from appropriations voted by the citizens in town-meetings or by aldermen and councilmen, members of the local legislature, and assessed and collected pro rata according to the valuation of property, just as all other town or city taxes are collected. But, whether the gift of some private individual or the creation and property of the town, the fact remains that the handsomest public buildings in New England to-day are the public-library buildings, and in no department of civic life are the New England States and towns so far in advance of those of other 
sections of the country as in their generous annual appropriations for the maintenance of this form of individual and civic betterment. New Hampshire is to be credited with the first law permitting towns to establish and to maintain libraries by general taxation. This she did in 1849 . Massachusetts followed in 1854 , Vermont in 1865 , Connecticut in $188 \mathrm{I}$. Boston, however, deserves credit for being the pioneer in public taxation for a municipal library, and to the Hon. Josiah Quincy, grandfather of its present mayor, who, in I 847 , proposed to the City Council that they request the Legislature for authority to lay a tax to establish a free library, belongs the honor of having founded in America a form of municipal and town activity, than which, as Stanley Jevons says, in his book Methods of Social Reform, "there is probably no mode of expending public money which gives a more extraordinary and immediate return in utility and enjoyment."

Already, library administrators and farsighted educators and publicists foresee a time when it will be as compulsory for towns to establish and support free public libraries as it now is compulsory for them to establish and 
support free public schools. Massachusetts, perhaps, approaches nearer that ideal now than any other State, only ten of its 353 cities and towns being without public libraries.

Fortunately for the sociologist, the historian, the economist, and the lover of literature, the inhabitants of New England have not failed to chronicle in various forms and ways the deeds and thoughts of their contemporaries. Thus there is a large class of historic documents of which Bradford's history of Plimoth Plantation is the magnum opus. Then there are innumerable town histories, - of which the four-volume history of Hingham, Massachusetts, is a model, -family genealogies, sermons, diaries, volumes of correspondence, such as that which passed between John Adams and his wife, memorial addresses, such as Emerson and G. W. Curtis delivered at Concord, and Webster and Robert C. Winthrop at Plymouth, which inform and often inspire all who patiently explore their contents. Last, but not least, there are the products of New England's representative authors, who in prose or poetry have recorded indelibly the higher life of their own or of passing generations. In short, a literatureloving people has given birth to literature, and 
the New England town of the past can never totally fade out of the memory of future generations so long as men and women are left to read the poetry of Longfellow, Whittier, Holmes, and Aldrich, Lowell's Biglow Papers, Harriet Beecher Stowe's Oldtown Folks and $A$ Minister's Wooing, the short stories of Sarah Orne Jewett, Mary E. Wilkins, Rose Terry Cooke, Alice Brown, Maria L. Pool, and Jane G. Austin, the prose romances of Hawthorne and F. J. Stimson, and the histories of Palfrey, Bancroft, Parkman, and Fiske.

That New Englanders in the past have been and even now are provincial, is the indictment of Europeans and of some Americans. That they have developed reason at the expense of imagination, utility at the expense of beauty, is also affirmed. Their Puritan ancestors are the butt of the ridicule of the caricaturist, of ultra-Liberal preachers and devotees of materialistic science, and of those who have never read history, European or American. No less an authority than Matthew Arnold has described the life of New England as "uninteresting." To all such critics, the New Englander can and will reply with dignity and force when proper occasion offers, but this is not the place 
even to summarize his argument. Suffice it to say that the children of New England are ever returning to her. They sojourn for a time in Europe, the valley of the Mississippi, in Southern California, and in Hawaii. They find more salubrious climes, more beautiful works of ecclesiastical and municipal art, better municipal government, and sometimes greater opportunities for investment of capital and ability and choicer circles of society than those which exist in the towns in which they were born or reared. But in due time the yearning for the hills, valleys and seacoast of rocky and rigorous New England, for the established institutions, the generally diffused intelligence, the equality of opportunity, the sane standards of worth, and the inspiring historical traditions of the early home becomes too strong to be resisted longer, and back to the homestead they come-some on annual visits, some as often as the exchequer permits, some never to depart. New England has thousands of citizens to-day who, having either made, or failed to make, their fortunes in the West, have returned to New England to dwell. Once a New Englander, always a New Englander, in spirit if not in residence. Travel abroad, or 
residence elsewhere, may modify the austerity, broaden the sympathy, polish the manners, and stimulate the imagination of the New Englander, but it never radically alters his views on the great issues of life and death, or makes him less of a democrat or less of a devotee of Wisdom.

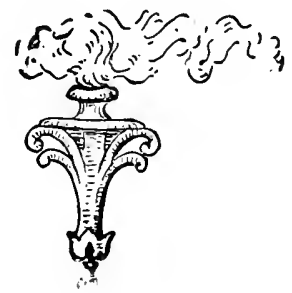




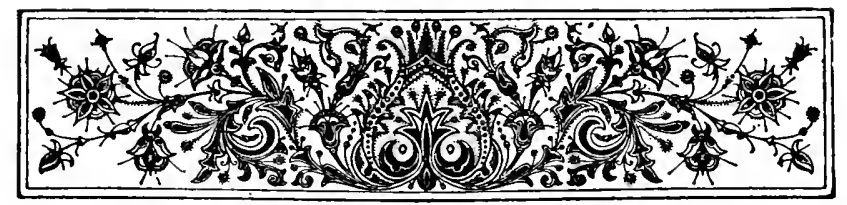

\title{
HISTORIC TOWNS OF NEW ENGLAND
}

\author{
PORTLAND \\ "THE GEM OF CASCO BAY" \\ BY SAMUEL T. PICKARD
} PORTLAND enjoys a peculiar distinction
among New England cities, not only by reason of the natural advantages of her location, but because of the historical events of which she has been the theatre, and the men of mark in literature, art, and statesmanship whom she has produced. Among the indentations of the Atlantic coast there is no bay which presents a greater wealth and variety of charming scenery, in combination with the advantages of a safe and capacious harbor, than that on which Portland is situated. It is 
thickly studded with islands which are of most picturesque forms, presenting beetling cliffs, sheltered coves, pebbly beaches, wooded heights, and wide, green lawns dotted with summer cottages. It is of the beauty of this bay that Whittier, who was familiar with its scenery, sings in The Ranger:

"Nowhere fairer, sweeter, rarer,

Does the golden-locked fruit-bearer

Through his painted woodlands stray ;

Than where hillside oaks and beeches

Overlook the long blue reaches,

Silver coves and pebbled beaches,

And green isles of Casco Bay ;

Nowhere day, for delay,

With a tenderer look beseeches,

'Let me with my charmed earth stay !'"

The peninsula upon which Portland is located is almost an island. It is nearly three miles long, and has an average width of three quarters of a mile-making it in area the smallest city in the United States, and the most compactly settled, for its forty thousand inhabitants occupy almost every available building spot. At each extremity of the peninsula is a hill on the summit of which is a wide public promenade, affording charming 


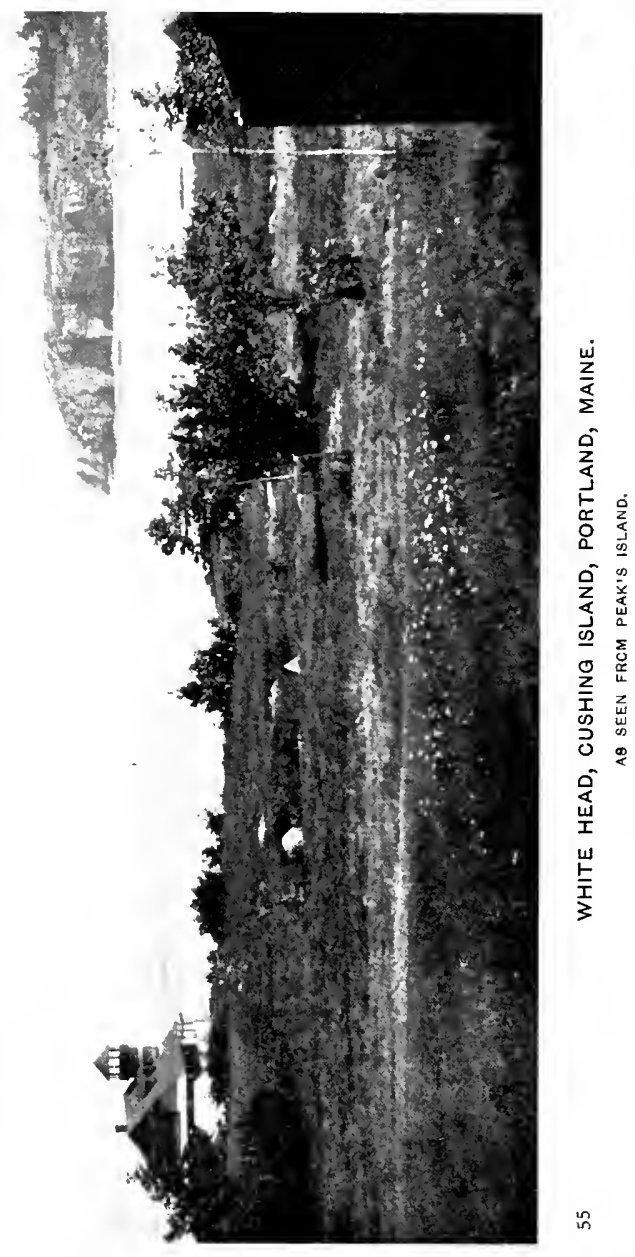


views - to the east, of the bay, the islands, and the blue sea beyond; to the west and northwest, of the White Mountain range, all the peaks of which are visible, the intervening distance being about eighty miles. The IVestern Promenade is the favorite resort at sunset; the Eastern has charms for all hours of the day. Both can be reached by electric railways.

In I6I4, Captain John Smith, of Pocahontas fame, came prospecting along this coast, and gave the name to Cape Elizabeth, which it still bears, in honor of the Virgin Queen, then recently deceased. The first settlers, George Cleeves and Richard Tucker, came hither in I632, and the settlement was known as Casco until the name was changed to Falmouth in 1658 ; it was incorporated as Portland in 1785. There were but few settlers in the first forty years, and these lived in amity with the Indians until the time of King Philip's War.

In 1676 , the settlement was utterly destroyed by the savages, and all who were not killed were carried into captivity. One of the killed was Thomas Brackett, an ancestor of the statesman who in these later days has made the name famous-Thomas Brackett Reed. Mrs. Brackett was carried by the In- 
dians to Canada, where she died in captivity. Two of her grandchildren came back to Falmouth when the place was rebuilt after the second destruction by the French and Indians, in May, I690. In I689, a large body of French and Indians threatened the town. They were routed in Deering's Woods by troops from Plymouth Colony, commanded by Major Church. Eleven settlers were killed and a large number wounded. It is a curious fact that Speaker Reed is also a descendant of the first settler, Cleeves. There is something remarkable in the persistency with which the descendants of the pioneers returned to the spot where there had been complete and repeated massacres of their ancestors. There are many families in Portland beside the one mentioned above who are descended from the pioneers who were killed or driven off by the savages.

The first minister of Falmouth was the Reverend George Burroughs, who escaped the massacre of 1676 by fleeing to one of the islands in the bay. Unfortunately for him, before the place was rebuilt he removed to Salem; he was too independent, however, to suit the dominant clergy, and was hanged as a wizard in 1692 , on charges incredibly ridicu- 
lous. The speech made by this worthy man on the scaffold brought the people to their senses and ended the witchcraft craze. His descendants also went back to Falmouth and are represented in many families of the present city of Portland, who take no shame from the hanging of their ancestor.

So thorough was the second destruction of the place in $\mathrm{I} 690$, that no one was left to bury the victims of the slaughter. Their bleached bones were gathered and buried more than two years after by Sir IVilliam Phips, while on his way from Boston to build a fort at Pemaquid. The settlement of the peninsula was resumed after the treaty of peace concluded at Utrecht in 1713 , and for sixty years thereafter the growth of the place was rapid. When the town was bombarded and burned by a British squadron in October, I 775, there were nearly three hundred families made homeless-about three quarters of the entire population. For nine hours, four ships anchored in the harbor threw an incessant shower of grape-shot, redhot cannon-balls, and bombs upon the defenceless town, which had shown its sympathy with the patriot cause in a practical way after the battles of Lexington and Bunker Hill. The 


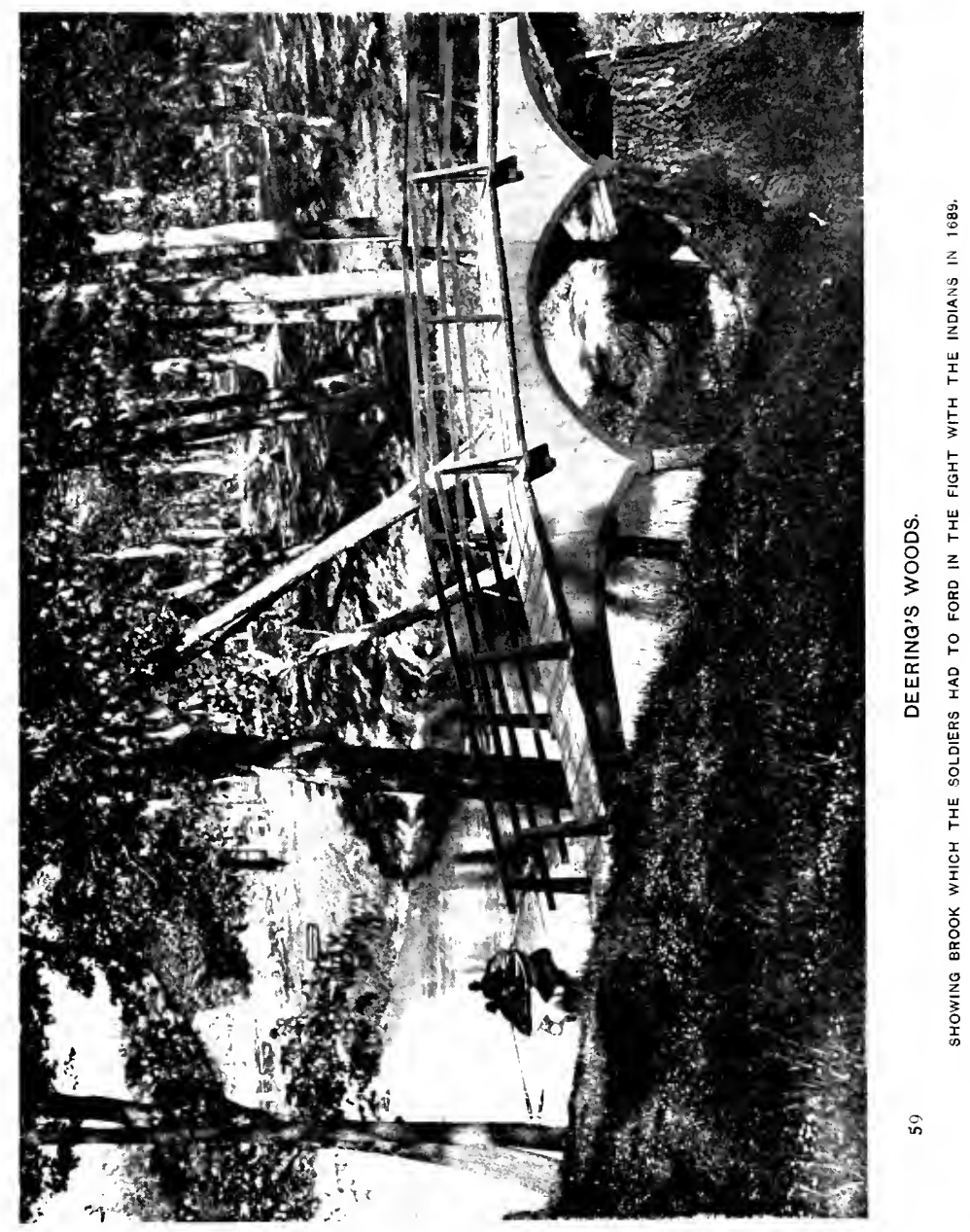


spirited citizens of Falmouth might have avoided the bombardment by giving up a few cannon and small-arms ; but this, in town meeting, they refused to do, even when they saw the loaded guns and mortars trained upon them at short range, and knew that Captain Mowatt had a special grudge against the place because of an insult put upon him by some of the citizens a few months earlier. The spirit of the town was not broken by the terrible punishment it received. A few days after Mowatt sailed away, while the ruins were still smoking, a British man-of-war came into the harbor to forbid the erection of batteries, and the demand was met by the throwing up of earthworks and the placing of guns, which forced the immediate departure of the ship. The lines of these earthworks are still to be traced at Fort Allen Park, a beautiful pleasure ground on Munjoy overlooking the harbor, and they are preserved with care as a relic of Revolutionary times. Another relic is a cannon-ball thrown from Mowatt's fleet, which lodged in the First Parish meeting-house, and is now to be seen in the ceiling of the church which occupies the same site. From this ball depends the large central chandelier. There 
was an incident of the bombardment which illustrates the simplicity and coolness of a heroine whose name deserves a place beside that of Barbara Frietchie. The fashionable tavern of the town was kept by Dame Alice Greele, and here, during the whole Revolutionary period, the committee of public safety met, the judges held their courts, and political conventions had their sessions. It was here that the citizens in town meeting heroically voted to stand the bombardment rather than give up the guns demanded by Mowatt. But after making this brave decision they hastily packed up all their portable possessions and removed their families to places of safety, some not stopping short of inland towns, and others finding shelter under the lee of a high cliff that used to be at the corner of Casco and Cumberland Streets, at no great distance from their homes. Braver than the bravest of the men of Falmouth, Dame Alice would not desert her tavern, although its position was so dangerously exposed that every house in its vicinity was destroyed by bursting bombs and heated cannon-balls. Throughout that terrible day she stood at her post, and with buckets of water extinguished the fires on her 
premises as fast as kindled. When Mowatt began to throw red-hot cannon-balls, one of them fell into the dame's back yard among some chips, which were set on fire. She picked up the ball in a pan, and as she tossed it into the street, she said to a neighbor who was passing: "They will have to stop firing soon, for they have got out of bombs and are making new balls, and can't wait for them to cool!" Portland ought to mark with a bronze tablet the site of Alice Greele's tavern. The building stood until i $\$ 46$ at the corner of Congress and Hampshire Streets. It was then removed to Washington Street.

Portland had a rapid growth of population and increase in wealth during the European disturbances caused by the ambition of Napoleon. The carrying-trade of the world was almost monopolized by neutral American bottoms, and ship-building became then, as it continued to be for a long time afterward, a leading industry along the Maine coast. Great fortunes were made by Portland ship-owners. Many fine old-fashioned mansions that now ornament Congress, High, State, Spring, and Danforth Streets, were built by merchants in the first years of the present century, and are 


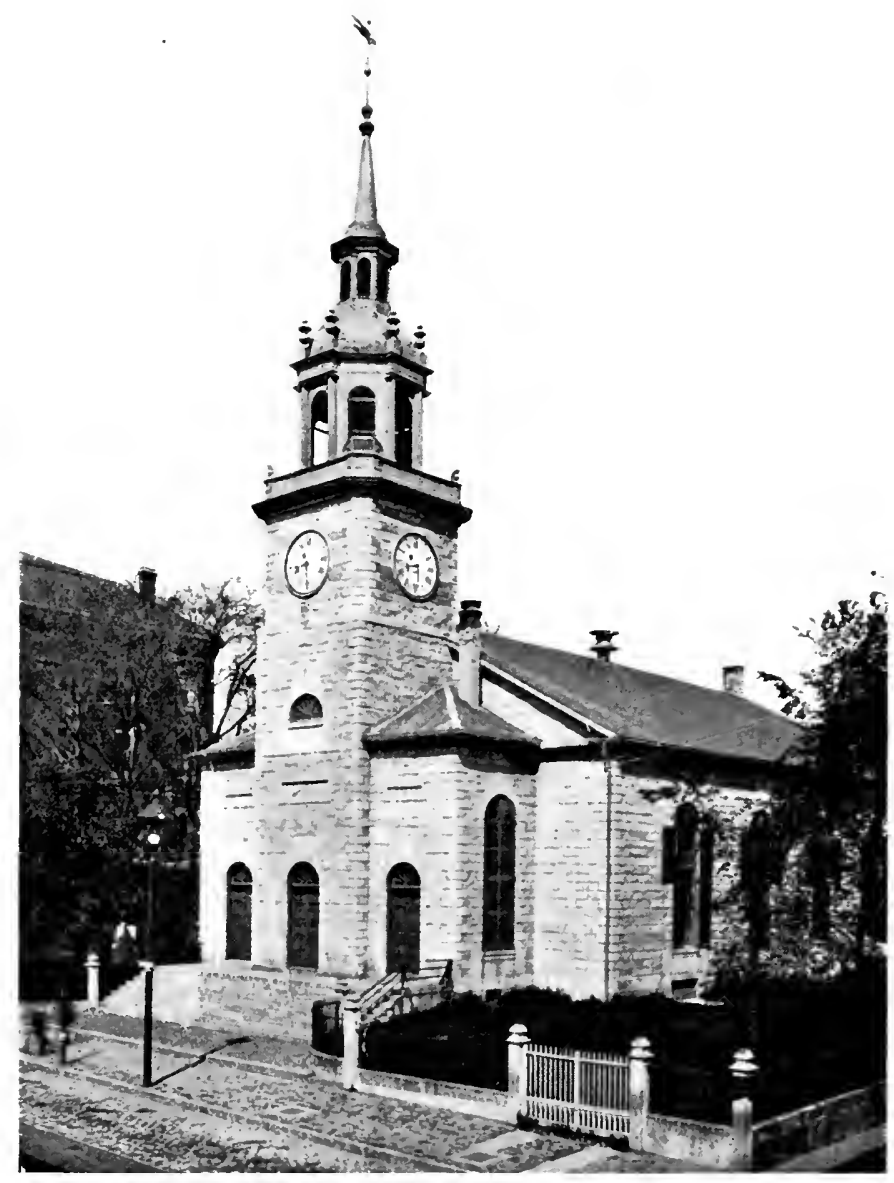

63

FIRST PARISH CHURCH.

CONTAINING THE MOWATT CANNON-BALL. 
reminders of the peculiar conditions of that time. A sharp check to the rising tide of prosperity was given by the embargo act of I 807 . After the peace of 1815 , the trade with the West Indies grew into great importance, and for fifty years was a leading factor in the commerce of Portland. Lumber and fish were the chief exports, and return cargoes of sugar and molasses made this the principal market for those commodities-the imports in these lines for many years exceeding those at New York and Boston. West India molasses was distilled in large quantities into New England rum, until the temperance reform, under the lead of the Portland philanthropist, Neal Dow, closed up the distilleries; in their place came sugar factories and refineries which turned out a more wholesome product. But about thirty years ago, changes in the methods of making sugar caused the loss of this industry to Portland.

The development of the canning business has of late years been an important feature of the industrial prosperity of Maine, owing partly to the fact that the climate and soil of this State produce a quality of sweet corn that cannot be matched in other States, and also to the fact that the system of canning now in use 
was a Portland invention. All over the interior of Maine may be found corn factories owned by Portland merchants, and, on the coast, canneries of lobsters and other products of the fields and fisheries of Maine.

Portland is the winter seaport of the Canadas, and several lines of steamships find cargoes of Western produce at this port. For this business the port has excellent facilities, as it is the terminus of the Grand Trunk Railway system, which has its other terminus at Chicago. There is another line to Montreal, through the White Mountain Notch, which, like the Grand Trunk, owes its existence to Portland enterprise. Of late years the lakes and forests and sea-coast of Maine have, to a marked degree, become the pleasure-ground of the Union, and, naturally, Portland is the distributing point for the rapidly increasing summer travel in this direction. Its lines of railway stretch northward and eastward to regions abounding in fish and game; the White Hills of New Hampshire and the Green Mountains of Vermont are within easy reach. Steamers from this port ply along the whole picturesque coast to New Brunswick and Nova Scotia. During the summer 
months, eight or ten pleasure steamers make trips between the city and the islands of Casco Bay, furnishing a great variety of pleasurable excursions. These islands, except the smallest of them, are the summer homes of a multitude of families-many of them from Canada and from the IVestern States.

The ancient Eastern Cemetery, on the southern slope of Munjoy, is the buryingplace of the pioneers, including the victims of the French and Indian massacres of two centuries ago. The graves most frequently visited are those of the captains of the U. S. brig Entcrprisc and His Majesty's brig Boxcr, both of whom were killed in the naval engagement off this coast, September 5, I \& I3. By their side lies Lieutenant Waters, mortally wounded in the same action. The poet Longfellow was in his seventh year at the time of this fight, and his memory of it is enshrined in My Lost Youth:

"I remember the sea-fight far away, How it thundered o'er the tide! And the dead captains as they lay In their graves, o'erlooking the tranquil bay, Where they in battle died."

Commodore Edward Preble, of Tripoli fame, and Rear-Admiral Alden, who fought at Vera 


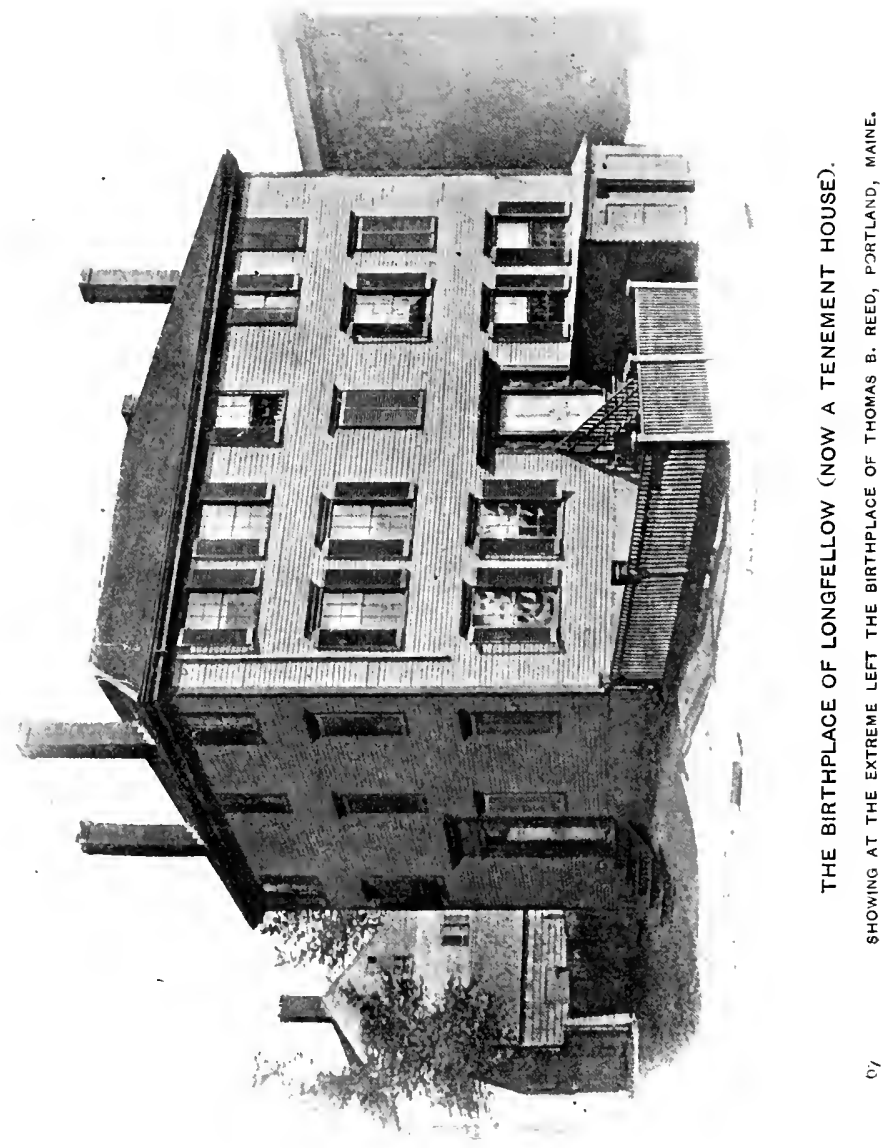


Cruz, New Orleans, and Mobile, both Portlanders, are buried here. There is also a monument commemorating the gallant Lieutenant Henry Wadsworth, who fell before Tripoli in ISO4,- - a volunteer in a desperate and tragic enterprise. He was a brother of Longfellow's mother, and a new lustre has been added to his name by the nephew who bore it. In this ground also, but unmarked, are the graves of the victims of the French and Indian siege and massacre of 1690 , and of the eleven men killed in the more fortunate battle of the previous year.

The first house in Portland built entirely of brick was erected in 1785 , by General Peleg Wadsworth, who was Adjutant-General of Massachusetts during the Revolution; it is now known as the Longfellow house, and stands next above the Preble House, on Congress Street. The poet was not born in this house, but was brought to it as an infant, and it was his home until his marriage, in $183 \mathrm{I}$. It is now owned and occupied by his sister, Mrs. Pierce, who has provided that eventually it shall become the property of the Maine Historical Society, which ensures its preservation as a reminder that Maine gave our country its most 
widely known and best-loved poet. The house in which Longfellow was born is the threestory frame building at the corner of Fore and Hancock Streets. Around the corner, on Hancock Street, is the house in which Speaker Reed was born.

For his services in the Revolutionary War, Massachusetts gave General Wadsworth a large tract of land in Oxford County, to improve which he removed to Hiram, and the family of his son-in-law, Stephen Longfellow, thereafter occupied his residence in Portland. To the end of his life, the poet made this house his home whenever he visited the scenes of his youth, and many of his best poems were written there. The central part of the hotel adjoining was the mansion of Commodore Edward Preble, built just before his death in I 807 , and some of the best rooms in this hotel have still the wood-carving and other ornamentation given them by the hero of Tripoli. A grandson of the Commodore was one of the officers of the Kearsarge when that ship sunk the rebel cruiser Alabama, in the most picturesque naval engagement of modern times.

We have seen that Portland has a history connecting it with the French and Indian 
Wars, the Revolution, and the War of I8r2. It was also the scene of a curious episode in the late Civil War-the cutting out of the United States revenue cutter Calcb Cushing, in June, $186_{3}$. The cutter had been preparing for an encounter with the rebel privateer $T a$ cony, which had been capturing and burning many vessels on the coast of New England. A delay in fitting her out had been occasioned by the illness and death of her captain. In the meantime, the Tacony had captured the schooner Archor, and transferred her armament to the prize, which, after burning the Tacony, boldly sailed into Portland harbor in the guise of an innocent fisherman, with Lieutenant Reade in command. His purpose was to burn two gunboats then being fitted out in the harbor, but he found them too well guarded. He then turned his attention to the cutter, which was preparing for a fight with him with no suspicion that he was lying almost alongside. Captain Clarke had died the day before Reade's arrival, and Lieutenant Davenport, a Georgian by birth, was in command of the cutter. At night, when only one watchman was on deck, a surprise was quietly effected, and the crew put in irons. With a good wind 


\section{Portland}

the cutter might easily have gotten away from the sleeping town and slipped by the unsuspicious forts; but she was becalmed just after passing the forts, and in the morning three steamers were armed and sent in pursuit. At the time it was supposed that the Southern lieutenant had turned traitor, but the event proved his loyalty; for he refused to inform his captors where the ammunition was kept, and they had only a dozen balls for the guns, which were all spent without injury to the pursuers. The affair was watched by thousands on the hills and house-tops, and on yachts which in the dead calm were rowed to the scene. At length the town was startled by the blowing up and utter demolition of the cutter; the Confederates had set fire to the vessel and tried to escape in the boats, but were at once captured by the steamers which had been circling around them. The Archer was also captured, with all the chronometers and other valuables of the vessels bonded or destroyed by the Tacony. It proved an important check to the operations of the Confederacy on the sea, and it came just one week before the battle of Gettysburg and the capture of Vicksburg. 
The first British squadron to enter the harbor of Portland after the bombardment by Mowatt in 1775 , came just eighty-five years afterward to a day. It was sent to give dignity to the embarkation of the Prince of Wales in I860. It was in Portland, at what are now called the Victoria wharves, that the Prince, then a young man of nineteen, took his last step on American soil. His embarkation on a bright October day was one of the finest pageants ever witnessed in this country. Five of the most powerful men-of-war in the British navy, in gala trim, with yards manned, saluted the royal standard, gorgeous in crimson and gold, then for the first and only time displayed in this country. The deafening broadsides when the Prince reached the deck of the Hero were answered from the American forts and men-of-war.

Another pageant, this time grand and solemn, was enacted in this harbor, in February, is 80. A British squadron, convoyed by American battle-ships, brought the remains of the philanthropist, George Peabody, in the most powerful ironclad the world had then seen. The funeral procession of boats from the English and American ships was an impressive spectacle. 


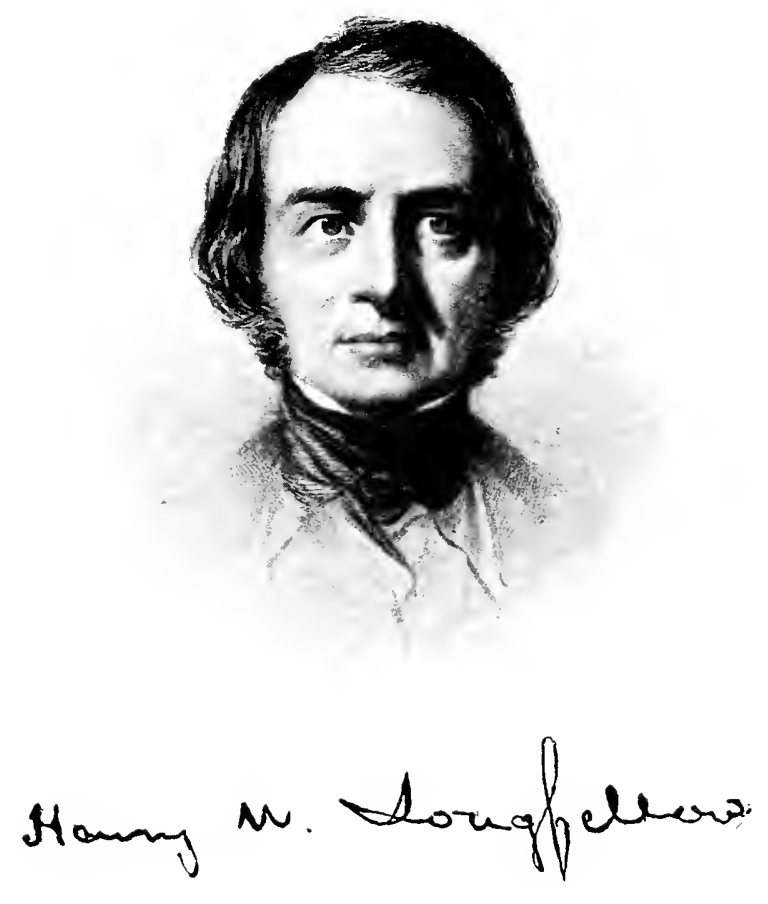


It was a bright winter day, immediately succeeding a remarkable ice-storm, and the trees of the islands, the cape, and the city sparkled in the sun as if every bough were encrusted with diamonds-a wonderful frame for a memorable picture. Nature had put on her choicest finery to relieve the sombre effect of the draped flags, the muffled oars, the long, slow lines of boats, and the minute guns from ships and forts.

The great fire of July 4, 1866, which burned fifteen hundred buildings in the centre of the city, also destroyed an immense number of shade trees, mostly large elms, the abundance of which had given to Portland the title of "Forest City." In a few years the buildings were replaced by greatly improved structures; but the trees could not be improvised so readily, and the scar of the fire is still noticeable from the absence of aged trees in the district swept by it. Advantage was taken of the clearing of the ground in the most thickly settled part of the city, to lay out Lincoln Park in the centre of the ruins. This is now a charming spot, with its fountain and flowers, its lawns and shaded walks.

The city is fortunate in the abundance and 
purity of its water supply, which is drawn from Lake Sebago, sixteen miles distant. The natural outlet of this lake is the Presumpscot River, which has several valuable water-powers along its short course to its mouth in Casco Bay, near Portland harbor.

It will be remembered that Nathaniel Hawthorne received his collegiate education, in the same class with Longfellow, at Brunswick, which is in the same county with Portland, but it is not so generally known that during his teens his home was at Raymond, on the shore of Sebago Lake, and in the same county. Part of each year he spent in school at Salem; but his mother's home was in the little hamlet in the picturesque wilderness a few miles from Portland, and here he spent the happiest months of his youth, as he has testified in many letters. His biographers have generally failed to take account of this, and, indeed, have asserted that he was at Raymond only a part of one year. A little volume recently published, entitled Hawthorne's First Diary, brings out the facts in this neglected but important episode in the career of this great master in our literature. While fitting for college, Hawthorne became, for a single term, the pupil 
of the Reverend Caleb Bradley, of Stroudwater, a suburb of Portland. The building in which he studied is still to be seen at Stroudwater. The house of his mother at Raymond is converted into a church, but as to exterior remains very much as when his boy life was spent in it. It was in this same county of Cumberland that Mrs. Stowe wrote the whole of Uncle Ton's Cabin, while her husband was a professor in Bowdoin College. Thus, three of the greatest names in American literature are linked to Portland and its immediate vicinity.

Portland can count to her credit many jurists, lawyers, and orators of national repute, among them Theophilus Parsons, Simon Greenleaf, Ashur Ware, Sargent S. Prentiss, Nathan Clifford, and George Evans. William Pitt Fessenden lived and died in the house on State Street now occupied by Judge W. L. Putnam. Like Fessenden eminent as Senator and Secretary of the Treasury, Lot M. Morrill spent the last years of his life in Portland. Still another great Senator and Secretary of the Treasury, who was also Chief-Justice, honored this city by bearing its name-Salmon Portland Chase. He was actually named for 

the town, his uncle, Salmon Chase, being a Portland lawyer, and his parents were determined that there should be no mistake as to the person for whom he was named!

At an early period in his career, James $\mathrm{G}$. Blaine edited the Portland Daily Adrertiser. Among writers of celebrity, we may name N. P. Willis and his sister, "Fanny Fern"; John Neal, poet and novelist; Henry IV. and Samuel Longfellow; J. H. Ingraham, whose many novels had a great sale fifty or sixty years ago; Elijah Kellogg; Mrs. Ann S. Stephens; Seba Smith, author of the Fack Downing Letters, and his more famous wife, Elizabeth Oakes Smith; Thomas Hill, for a time President of Harvard University; and the divines, Edward Payson and Cyrus Bartol. The home of Charles Farrar Brown, "Artemus Ward," was in an adjoining county, but like the ChiefJustice just mentioned, he came to Portland for his baptismal name, his uncle, Charles Farrar, being a Portland physician. Two sculptors of national fame have gone out from Portland-Paul Akers and Franklin Simmons, and some of the best works of both these artists adorn public places in the city. The Dead Pearl Diver, by Akers, may be found in the reading- 
room of the Public Library; and Simmons has two bronze statues in the city, one a seated figure of Longfellow, at the head of State Street, overlooking "Deering's Woods," and the other a noble statue of America, in Monument Square, commemorating the sons of Portland who died for the Union; no finer soldiers' monument than this has ever been erected. Of other artists who have attained distinction, we may name $\mathrm{H}$. B. Brown, now residing in London, whose landscapes and marine views have given him a recognized position among the best American artists; Charles O. Cole, portrait painter; and Charles Codman, J. R. Tilton, and J. B. Hudson, landscape painters.

Immense sums are being expended on the defences of the city by the United States government, as it is realized that in case of war with Great Britain this would be the point of attack, because Portland is the natural seaport of the Canadas, and Maine is thrust, in a provoking way, between the Maritime Provinces and the Province of Quebec. Portland can indulge in no dream of great commercial importance so long as the country which its position especially dominates is under a for- 
eign flag; but if ever Maine should be annexed to Canada, or the annexation takes the alternative form, a great future is assured for a town so farorably located. In the meantime, the beautiful city must be content to be the centre of distribution for the pleasure travel of the summer, and for the other half of the year, by means of its capacious harbor, it can continue to furnish an outlet for that part of the business of the Great Lakes which in summer is handled at Montreal.

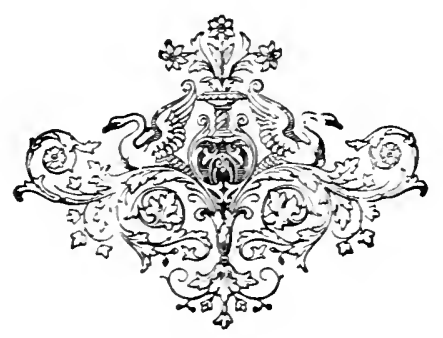




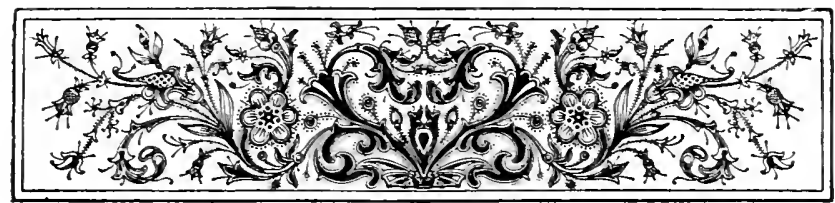

OLD RUTLAND, MASSACHUSETTS

THE CRADLE OF OHIO

\author{
BY EDWIN D. MEAD
} $\mathrm{HE}$ Old South Historical Society in Boston
inaugurated in I 896 the custom of annual historical pilgrimages. It had learned from Parkman and Motley and Irring how vital and vivid history is made by visits to the scenes of history. Its pilgrimages must be short to places near home; but the good places to visit in New England are many. Great numbers of people, young and old, join in the pilgrimages. Six hundred went to the beautiful Ihittier places beside the Merrimac, the second year; and as many the third year to the King Philip country, on Narragansett Bay.

The first year's pilgrimage was to old Rutland, Massachusetts, "the cradle of Ohio." A hundred of the young people went on the train 
from Boston, on that bright July day; and when they had climbed to the little village on the hill, and swept their eyes over the great expanse of country round about Wachusett and away to Monadnock, and strolled down to the old Rufus Putnam house, by whose fireside the settlement of Marietta was planned, a hundred more people had come from the surrounding villages; and a memorable little celebration was that under the maples after the luncheon, with the dozen energetic speeches from the young men and the older ones. It was a fine inauguration of the Old South pilgrimages, and woke many people to the great possibilities of the historical pilgrimage as an educational factor. ${ }^{1}$

Ten years before, there was hardly a man in Massachusetts who ever thought of Rutland as a historical town. The people of Princeton and Paxton and Hubbardston and Oakham looked across to the little village on the hill from their villages on the hills, and they did not think of it; the people of Worcester drove up of a Sunday to get a dinner at the old village tavern, and they did not think of it; the Amherst College boy's and the Smith College 


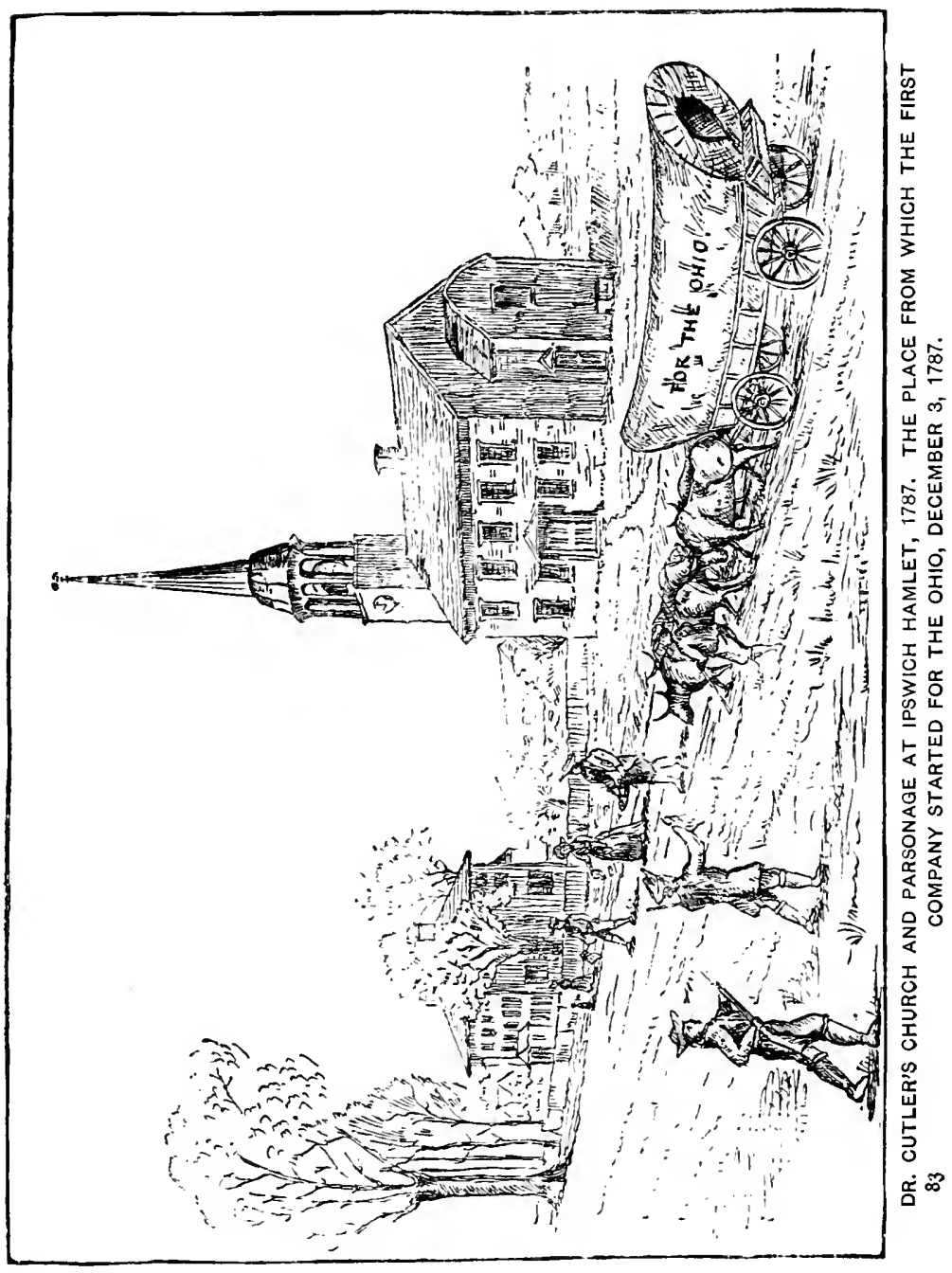


girls rode past on the Central Massachusetts road, at the foot of the hill, on their way to Boston, and heard "Rutland!" called, but they thought nothing of history; and in Boston the last place to which people would have thought of arranging a historical pilgrimage was this same Rutland.

Yet when the Old South young people went there on their first pilgrimage, Rutland had already become a name almost as familiar in our homes as Salem or Sudbury or Deerfield. The Old South young people themselves had been led to think very much about it. In I S93, the year of the World's Fair at Chicago, the great capital of the great West, a place undreamed of a hundred years before, when Rutland was witnessing its one world-historical event, the Old South lectures were devoted to "The Opening of the West." Two of the eight lectures were upon "The Northwest Territory and the Ordinance of 1787 " and "Marietta and the Western Reserve"; two of the leaflets issued in connection were Manasseh Cutler's Description of Ohio in ${ }_{17} 87$ and Garfield's address on The Northwest Territory and the II'estern Reserve; and one of the subjects set for the Old South es- 


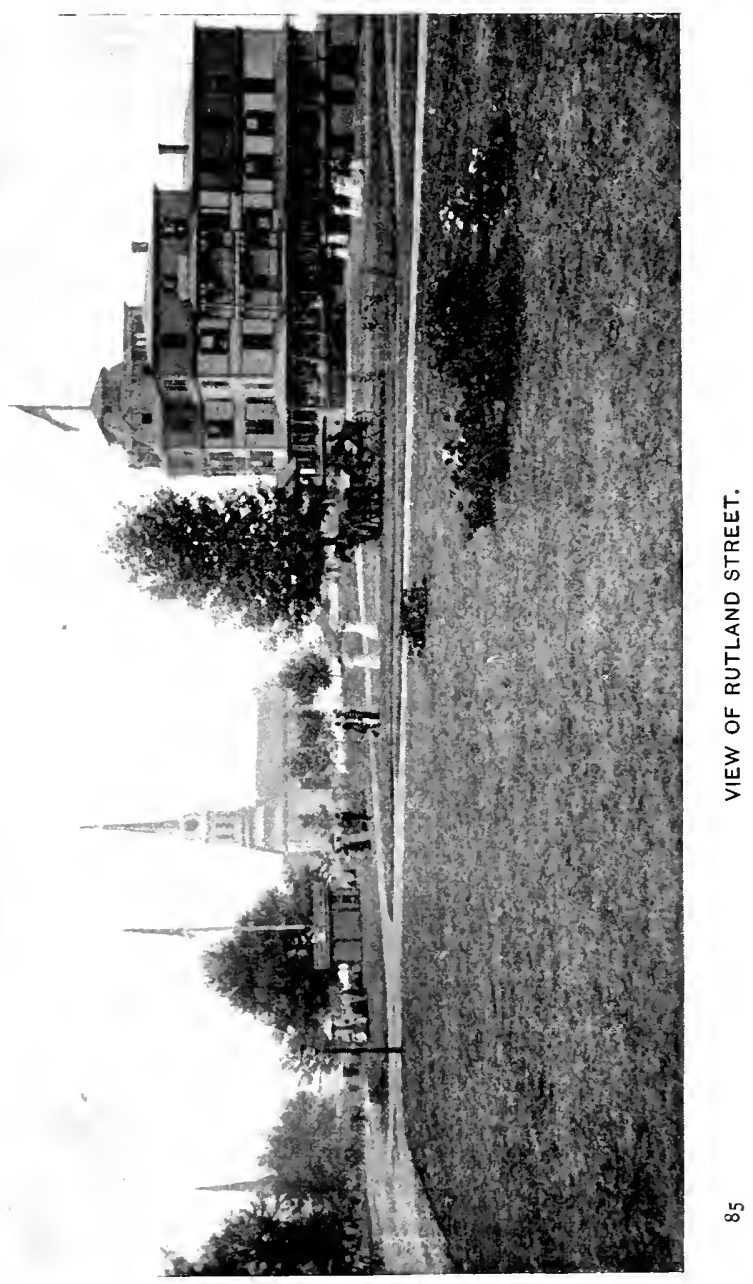


says was "The Part Taken by Massachusetts Men in Connection with the Ordinance of I $787 . " \quad$ These studies first kindled the imaginations of hundreds of young people and first roused them to the consciousness that westward expansion had been the great fact in our history from the time of the Revolution to the time of the Civil War; that New England had had a controlling part in this great movement, which, by successive waves, has reached Ohio, Illinois, Kansas, Colorado, Oregon, so that there is more good New England blood today west of the Hudson than there is east of it ; and that this movement, which has transformed the United States from the little strip along the Atlantic coast which fought for independence to the great nation which stretches now from sea to sea, began at the old town of Rutland, Massachusetts. This Rutland on the hill is the cradle of Ohio, the cradle of the West.

It was not, by any means, these Boston lectures on "The Opening of the West" which reawakened Massachusetts and the country to the forgotten historical significance of old Rutland. That awakening was done by Senator Hoar, in his great oration at the Marietta centennial, in 1888 . Senator Hoar's oration did not in- 
deed awaken Massachusetts to the great part taken by Massachusetts men in connection with the Ordinance of 1787 , or the part of New England in the settlement and shaping of the West. No awakening to these things was necessary. There is no New England household which has not kindred households in the West, ever in close communication with the old home; and the momentous significance of the Ordinance of 1787 , and the decisive part taken by Massachusetts statesmen in securing it, the Massachusetts historian and orator were never likely to let the people forget.

"At the foundation of the constitution of these new Northwestern States," said Daniel Webster in his great reply to Hayne, "lies the celebrated Ordinance of 1787 . We are accustomed to praise the lawgivers of antiquity ; we help to perpetuate the fame of Solon and Lycurgus; but I doubt whether one single law of any lawgiver, ancient or modern, has produced effects of more distinct, marked and lasting character than the Ordinance of 1787. That instrument was drawn by Nathan Dane, a citizen of Massachusetts; and certainly it has happened to few men to be the authors of a political measure of more large and enduring consequence. It fixed forever the character of the population in the vast regions northwest of the Ohio, by excluding from them involuntary servitude. It impressed on the soil itself, while it was yet a wilderness, an incapacity to sustain 
any other than free men. It laid the interdict against personal servitude, in original compact, not only deeper than all local law, but deeper also than all local constitutions. We see its consequences at this moment, and we shall never cease to see them, perhaps, while the Ohio shall flow."

Mr. Hoar spoke as strongly of the Ordinance, in his Marietta oration. "The Ordinance of I 78 ; belongs with the Declaration of Independence and the Constitution; it is one of the three title-deeds of American constitutional liberty:" But the chief merit of his oration was not the new emphasis with which he said what Webster had said, but the picturesqueness and the power with which he brought the men and the events of that great period of the opening of the West home to the imagination. The oration was especially memorable for the manner in which it set Rufus Putnam, the man of action, the head of the Ohio Company, the leader of the Marietta colony, in the centre of the story, and made us see old Rutland as the cradle of the movement.

Complete religious liberty, the public support of schools, and the prohibition forever of slavery, - these were what the Ordinance 
of 1787 secured for the Northwest. "When older States or nations," said Mr. Hoar, "where the chains of human bondage have been broken, shall utter the proud boast, "With a great sum obtained I this freedom,' each sister of this imperial group-Ohio, Michigan, Indiana, Illinois, Wisconsin-may lift her queenly head with the yet prouder answer, "But I was free-born.' " The moment of this antislavery article of the Ordinance, in view of the course of our national history during the century that has followed, it would not be possible to overstate. When the great test of civil war came, to settle of what sort this republic should be, who dare contemplate the result had these five States been slave States and not free!

Massachusetts makes no false or exclusive claims of credit for the Ordinance of 1787 . She does not forget the services of William Grayson, nor those of Richard Henry Lee. She does not forget Thomas Jefferson. ${ }^{1}$

${ }^{1}$ The Ordinance of 1784 , the original of the Ordinance of 1787 , was drawn up by Jefferson himself, as chairman of the committee appointed by Congress to prepare a plan for the government of the territory. The draft of the committee's report, in Jefferson's own handwriting, is still preserved in the archives of the State Department at Washington. "It is as completely Jefferson's own work," says Bancroft, " as the Declaration of Independence." Jefferson worked with the greatest earnestness to secure the insertion of 
The names of Nathan Dane, Rufus Putnam, Rufus King, Timothy Pickering and Manasseh Cutler are names of the greatest moment in the history of the West. No other group of men did so much as these Massachusetts men to determine what the great IVest should be, by securing the right organization and institutions for the Northwest Territory and by securing at the beginning the right kind of settlers for Ohio.

It was really Manasseh Cutler who did most at the final decisive moment to secure the adop-

a clause in the Ordinance of $17 s_{4}$ prohibiting slavery in the Northwest; and the clause was lost by only a single vote. "The voice of a single individual," said Jefferson, who foresaw more clearly than any other what the conflict with slavery was to mean to the republic, "would have prevented this abominable crime. Heaven will not always be silent. The friends of the rights of human nature will in the end prevail." They prevailed for the Northwest Territory with the achievement of Manasseh Cutler, Rufus Putnam and Nathan Dane.

Was it from Jefferson that Putnam and his men at Marietta caught their classical jargon? There was a great deal of pretentious classicism in America at that time, new towns everywhere being freighted with high-sounding Greek and Roman names. The founders of Marietta-so named in honor of Marie Antoinette-named one of their squares Cafitolium; the road which led up from the river was the Sacra Via; and the new garrison, with blockhouses at the corners, was the Campus Martizs. Jefferson had proposed dividing the Northwest into ten States, instead of five as was finally done, and for these States he proposed the names of Sylvania, Michigania, Assenisipia, Illinoia, Polypotamia, Cherronesus, Metropotamia, Saratoga, Pelisipia and Washington. 


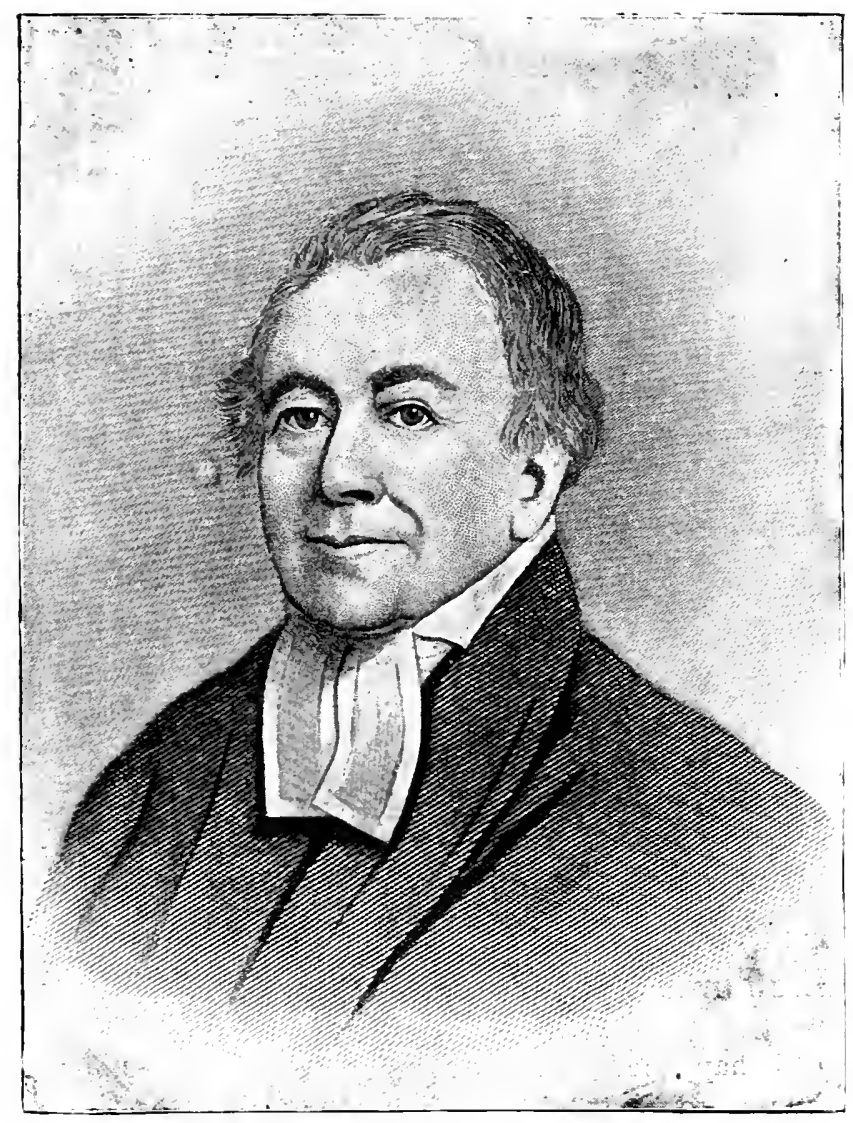

MANASSEH CUTLER. 
tion of the clause in the great Ordinance which forever dedicated the Northwest to freedom. Of all these Massachusetts men he was by far the most interesting personality; and of all revelations of the inner character of that criti-

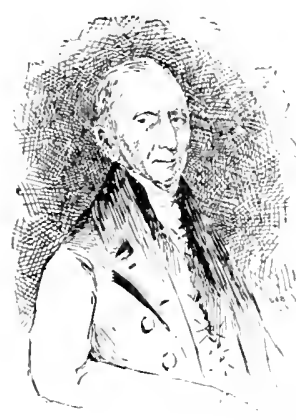

NATHAN DANE. cal period, none is more interesting or valuable than that given by his Life and Letters. It is to be remembered too that the first company of men for MariettaCutler urged Adelphia as the right name for the town -started from Manasseh Cutler's own home in Ipswich, joining others at Danvers, December 3 , I 787 , almost a month before the Rutland farmers left to join Putnam at Hartford. For the shrine of Manasseh Cutler is not at Rutland, but at Hamilton, which was a part of Ipswich. The home of Nathan Dane was Beverly.

“ It happened," said Edward Everett Hale, at the Marietta centennial, "that it was Manasseh Cutler who was to be the one who should call upon that Continental Congress to do the duty which they had pushed aside for five or six years. It happened that this diplomatist suc- I 


\section{Old Rutland}

ceeded in doing in four days what had not been done in four years before. What was the weight which Manasseh Cutler threw in-to the scale? It was not wealth; it was not the armor of the old time; it was simply the fact, known to all men, that the men of New England would not emigrate in to any region where labor and its honest recompense is dishonorable. The New England men will not go where it is not honorable to do an honest day's work, and for that honest day's work to claim an honest recompense. They never have done it, and they never will do it; and it was that potent fact, known to all men, that Manasseh Cutler had to urge in his private conversation and in his diplomatic work. When he said, 'I am going away from New York, and my constituents are not going to do this thing,' he meant exactly what he said. They were not going to any place where labor was dishonorable, and where workmen were not recognized as freemen. If they had not taken his promises, they would not have come here; they would have gone to the Holland Company's lands in New York, or where Massachusetts was begging them to go-into the valley of the Penobscot or the Kennebec."

Senator Hoar, in his oration, said of Manasseh Cutler :

"He was probably the fittest man on the continent, except Franklin, for a mission of delicate diplomacy. It was said just now that Putnam was a man after Washington's pattern and after Washington's own heart. Cutler was a man after Franklin's pattern and after Franklin's own heart. He was the most learned naturalist in America, as Franklin was the greatest master in 
physical science. He was a man of consummate prudence in speech and conduct; of courtly manners; a favorite in the drawing-room and in the camp; with a wide circle of friends and correspondents among the most famous men of his time. During his brief service in Congress, he made a speech on the judicial system, in 1803 , which shows his profound mastery of constitutional principles. It now fell to his lot to conduct a negotiation second only in importance to that which Franklin conducted with France in 1778 . Never was ambassador crowned with success more rapid or more complete."

But here, in old Rutland, it is not with Manasseh Cutler that we are concerned, but with Rufus Putnam. Rufus Putnam was the head of the Ohio Company, and the leader in the actual settlement of the new Territory. It was with Putnam that Manasseh Cutler chiefly conferred concerning the proposed Ohio colony. He left Boston for New York, on his important mission, on the evening of June 25 , I 787 , and on that day he records in his diary: "I conversed with General Putnam, and settled the principles on which I am to contract with Congress for lands on account of the Ohio Company." Of Rufus Putnam, Senator Hoar said in his oration, after his tributes to Varnum, Meigs, Parsons, Tupper and the rest : 


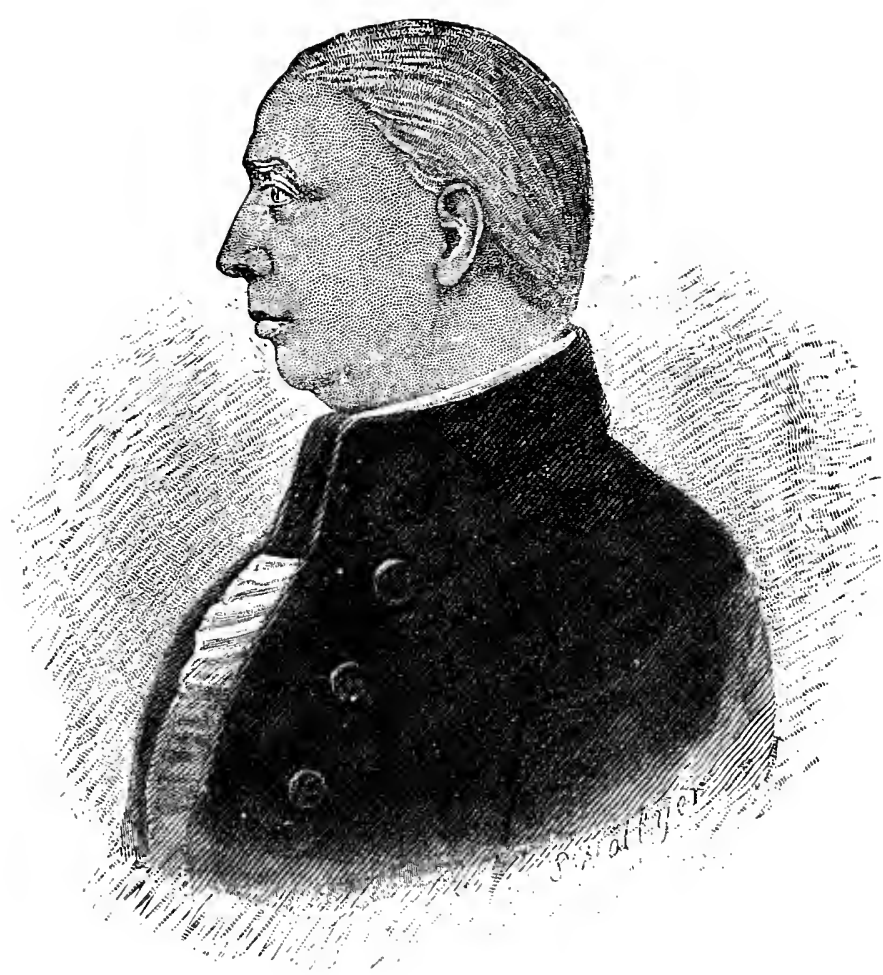

Sinfus Dutnam

95 
"But what can be said which shall be adequate to the worth of him who was the originator, inspirer, leader, and guide of the Ohio settlement from the time when he first conceived it, in the closing days of the Rerolution, until Ohio took her place in the Union as a free State in the summer of i 803 ? Erery one of that honorable body would have felt it as a personal wrong had he been told that the foremost honors of this occasion would not be given to Rufus Putnam. Lossing calls him 'the father of Ohio.' Burnet says, "He was regarded as their principal chief and leader.' He was chosen the superintendent at the meeting of the Ohio Company in Boston, November $2 \mathbf{I}$, I 787 , 'to be obeyed and respected accordingly.' The agents of the company, when they roted in 1789 "that the 7 th of April be forever observed as a public festival,' speak of it as 'the day when General Putnam commenced the settlement in this country.' Harris dedicates the documents collected in his appendix to Rufus Putnam, 'the founder and father of the State.' He was a man after Washington's own pattern and after Washington's own heart; of the blood and near kindred of Israel Putnam, the man who "dared to lead where any man dared to follow." "'

Mr. Hoar recounts the great services of Putnam during the Revolution, beginning with his brilliant success in the fortification of Dorchester Heights :

"We take no leaf from the pure chaplet of Washington's fame when we say that the success of the first great 
military operation of the Revolution was due to Rufus Putnam."

\section{But it was not Senator Hoar's task to nar- rate the military services of General Putnam. ${ }^{1}$}

"We have to do," he said, "only with the entrenchments constructed under the command of this great engineer for the constitutional fortress of American liberty. Putnam removed his family to Rutland, Worcester County, Mass., early in 1780 . His house is yet standing, about ten miles from the birthplace of the grandfather of President Garfield. He himself returned to Rutland when the war was over. $\mathrm{He}$ had the noble public spirit of his day, to which no duty seemed trifling or obscure. For five years he tilled his farm and accepted and performed the public offices to which his neighbors called him. He was representative to the General Court, selectman, constable, tax collector and committee to lay out school lots for the town; State surveyor, commissioner to treat with the Penobscot Indians and volunteer in putting down Shays's Rebellion. $\mathrm{He}$ was one of the founders and first trustees of Leices-

${ }^{1}$ Rufus Putnam was born in Sutton, Massachusetts, April 9, 1738 , just fifty years before he founded Marietta, where he died May 1, 1824. He was a cousin of General Putnam. Early in life he was a millwright and a farmer; but he studied mathematics, surveying and engineering - after distinguished service in the old French war-and became our leading engineer during the Revolution, and an able officer in many campaigns. He first planned the Ohio settlement. and at the outset made it a distinct condition that there should be no slavery in the territory. Five years after the founding of Marietta, Putnam was made Surveyor-General of the United Slates; and his services in Ohio until the time of his death were of high importance. 
ter Academy, and, with his family of eight children, gave from his modest means a hundred pounds toward its endowment. But he had larger plans in mind. The town constable of Rutland was planning an empire."

Putnam's chief counsellor in his design at the first was Washington, whose part altogether in the opening of the West was so noteworthy. $\mathrm{Mr}$ Hoar tells of the correspondence between Putnam and Washington, and follows the interesting history to the organization of the Ohio Company, at the Bunch of Grapes Tavern in Boston, in 1786 , and the departure of the Massachusetts emigrants at the end of the next year.

"Putnam went out from his simple house in Rutland to dwell no more in his native Massachusetts. It is a plain, wooden dwelling, perhaps a little better than the average of the farmers' houses of New England of that day; yet about which of Europe's palaces do holier memories cling! Honor and fame, and freedom and empire, and the faith of America went with him as he crossed the threshold."

To Rutland, as one who loved the old town and its history has well said, "belongs the honor of having carried into action the Ordinance of 1787 . Standing on Rutland hill, and looking around the immense basin of which it 
forms the centre, it is with conscious pride that one looks upon the old landmarks and calls up to the imagination the strong and brave and true men whose traditions have permeated the soil and left their marks in the civilization which has been the type for the development of the whole of the great Northwest." For this old town on the hilltop was veritably "the cradle of Ohio." Here was first effectually heard that potent invitation and command, so significant in the history of this country in these hundred years, "Go West!" This town incarnates and represents as no other the spirit of the mighty movement which during the century has extended New England all through the great West.

As early as $178_{3}$, about the time of the breaking up of the army at Newburgh on the Hudson, General Putnam and nearly three hundred army officers had proposed to form a new State beyond the Ohio, and Washington warmly endorsed their memorial to Congress asking for a grant of land; but the plan miscarried. As soon as the Ordinance was passed, the Ohio Company, of which Putnam was the president, bought from the government five or six million acres, and the first great movement 
of emigration west of the Ohio at once began. Within a year following the organization of the territory, twenty thousand people became settlers upon the banks of the Ohio. But the Pilgrim Fathers of the thousands and the millions, the pioneers to whom belongs the praise, were the forty or fifty farmers who from old Rutland pushed on with Putnam through the snows of Connecticut and Pennsylvania, coming to Pittsburgh just as the spring of 1788 came, and dropping down the river to Marietta in the little boat which they had named, by a beautiful fatality, the Mayflower. "Forever honored be Marietta as another Plymouth!"

The men who first settled the Northwest Territory, - as President Hayes, following Mr. Hoar at Marietta, well called it, "the most fortunate colonization that ever occurred on earth,"-and who set the seal of their character and institutions upon it, were of the best blood of New England.

"Look for a moment," said Mr. Hoar, "at the fortyeight men who came here a hundred years ago to found the first American civil government whose jurisdiction did not touch tide-water. See what manner of men they were; in what school they had been trained; what traditions they had inherited. I think that you must agree 


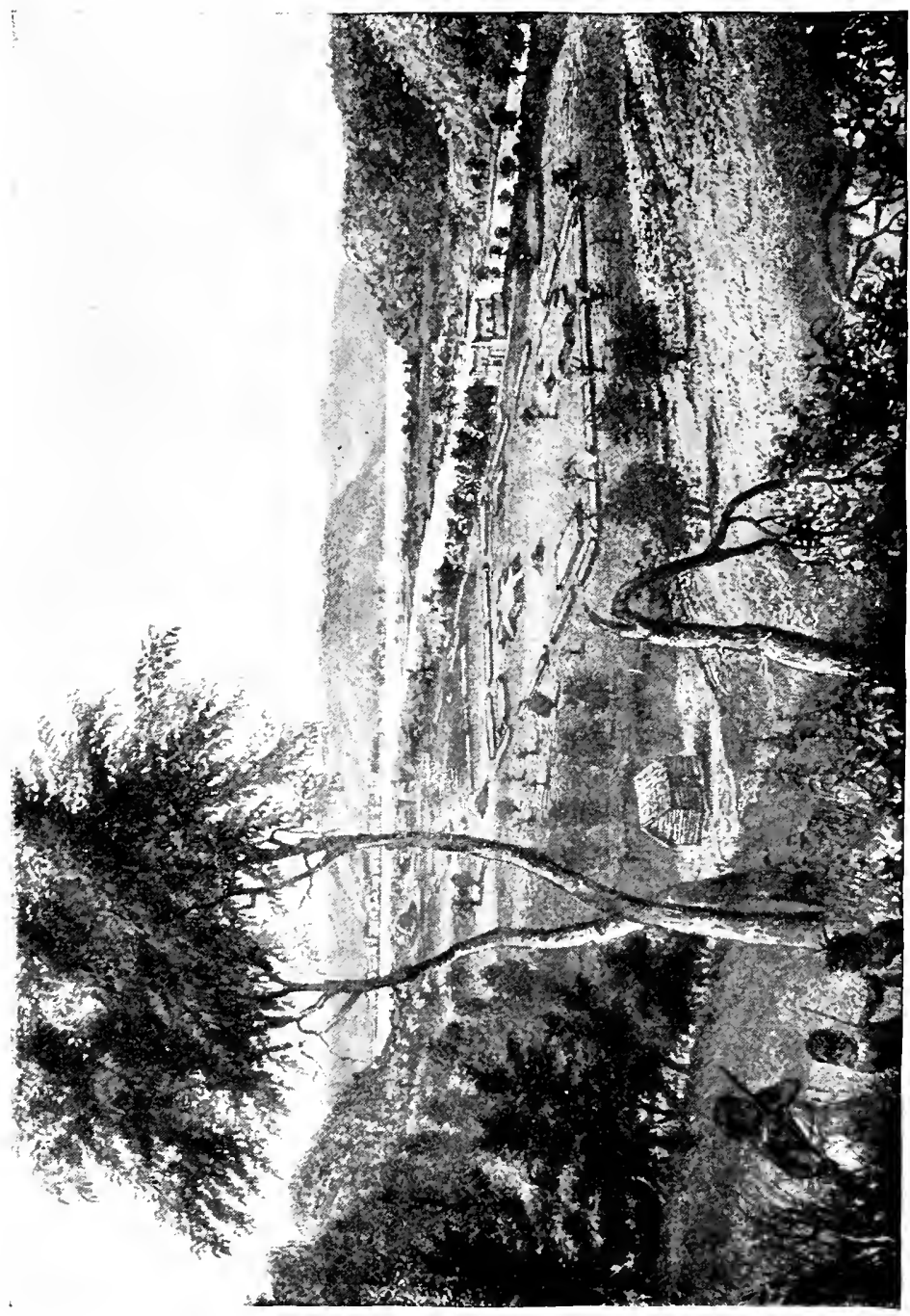

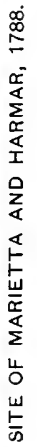


that of all the men who ever lived on earth fit to perform 'that ancient, primitive and heroical work,' the founding of a State, they were the fittest."

Here we remember too the words of Washington.

"No colony in America," said Washington, the warm friend of Putnam, who was deeply concerned that the development of the West should begin in the right way, in the hands of the right men, "was ever settled under such favorable auspices as that which has just commenced at the Muskingum. Information, property and strength will be its characteristics. I know many of the settlers personally, and there never were men better calculated to promote the welfare of such a community."

We honor old Rutland not only because she sent men to open the IVest, but because she sent her best, because she pitched the tone for the great West high.

But Rutland is not only "the cradle of Ohio," pre-eminent as that distinction is in her history. She also-like the other towns on the hills round about her, and like every good old New England town-has her long line of simple local annals, well worthy the attention of the summer visitor from Boston or Chicago. Happy are you if you hear them all from the lips of one or another of the local antiquarians, as you ride with him through the fields 
to Muschopauge Pond, or along the Princeton road to Wachusett, or over Paxton way to see the lot which Senator Hoar has bought on the top of Asnebumskit Hill,- - perhaps finding the Senator himself on the hill, as we did, where he could see Worcester in one direction, and in the other, Rutland.

I remember well the crisp September night when I first saw Rutland, with the new moon in the clear sky, and the evening star. I remember that the man who drove me up from the little station to the big hotel on the hill, while I filled my lungs with Rutland air, proved to be the hotel proprietor himself, and, which was much better, proved-and proved it much more the next day-to be the very prince of local antiquarians. He had himself writ-

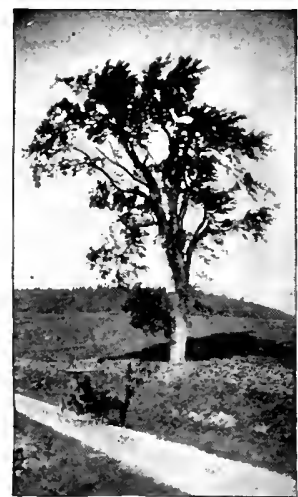

the "central tree."

ten a history of Rutland for a history of Worcester County, and there was nothing that he did not know. If there was anything, then the good village minister-he has been to Marietta since, and is president of the Rutland His- 
torical Society-had read it in some book; or the town clerk knew it; or Mr. Miles remembered it-who was to Rutland born, and whose memory was good. So in the dozen pleasant visits which I have made to Rutland since, I have not only taken mine ease with the benevolent boniface, but have taken many history lessons on the broad piazzas and the hills.

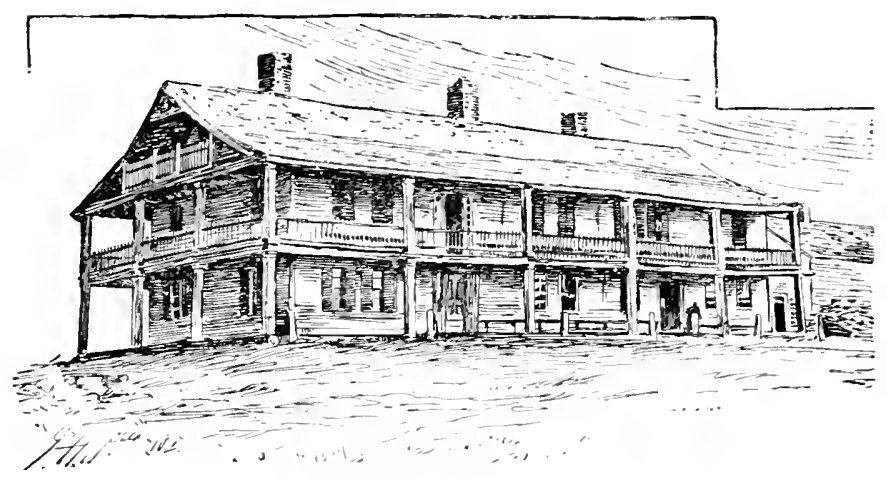

THE OLD RUTLAND INN.

The boniface will tell you, sitting in the corner looking toward W $\mathrm{W}$ achusett, how, in 1686, Joseph Trask, alias Pugastion, of Pennicook; Job, alias Pompamamay, of Natick; Simon Pitican, alias IVananapan, of Wramassick; Sassawannow, of Natick, and another-Indians who claimed to be lords of the soil-gave a 


\section{Old Rutland}

deed to Henry Willard and Joseph Rowlandson and Benjamin Willard and others, for $£ 23$ of the then currency, of a certain tract of land twelve miles square, the name in general being Naquag, the south corner butting upon Muschopauge Pond, and running north to Quanitick and to Wauchatopick, and so running upon great Wachusett, etc. Upon the petition, he will tell you, of the sons and grandsons of Major Simon Willard, of Lancaster, deceased-that famous Major Willard who went to relieve Brookfield when beset by the Indians-and others; the General Court in I 7 I 3 confirmed these lands to these petitioners, "provided that within seven years there be sixty families settled thereon, and sufficient lands reserved for the use of a gospel ministry and schools, except what part thereof the Hon. Samuel Sewall, Esq., hath already purchased, - the town to be called Rutland, and to lye to the county of Middlesex." The grant was about one eighth of the present Worcester County, comprising almost all the towns round about. When the new Worcester County was incorporated, Rutland failed of becoming the shire town, instead of Worcester, by only one vote-and that vote, they say in Rutland, was 
bought by a base bribe. The antiquarian taverner will point his spy-glass toward Barre for you, and tell you it was named after our good friend in the House of Commons in the Stamp Act days ; toward Petersham hill, back of it, where John Fiske spends his summers, and tell you about Shay's' Rebellion; toward Hubbardston, and tell you it was named for an old speaker of the Massachusetts House of Representatives; toward Princeton, and tell you it perpetuates the memory of Thomas Prince, the famous old pastor of the Old South Church in Boston, founder of the Prince Library; toward Paxton, and tell you about Charles Paxton, who was something or other; toward Oakham, and tell you something else. He will tell you that Holden is so called after that same family whose name is also honored in Holden Chapel at Harvard College; and he will probably point to Shrewsbury, on the hill away beyond Holden, and talk about General Artemas WVard, whose old home and grave are there.

He will tell about the first settlers of Rutland, respectable folk from Boston and Concord and other places, and how many immigrants from Ireland there were, with their church-mem- 


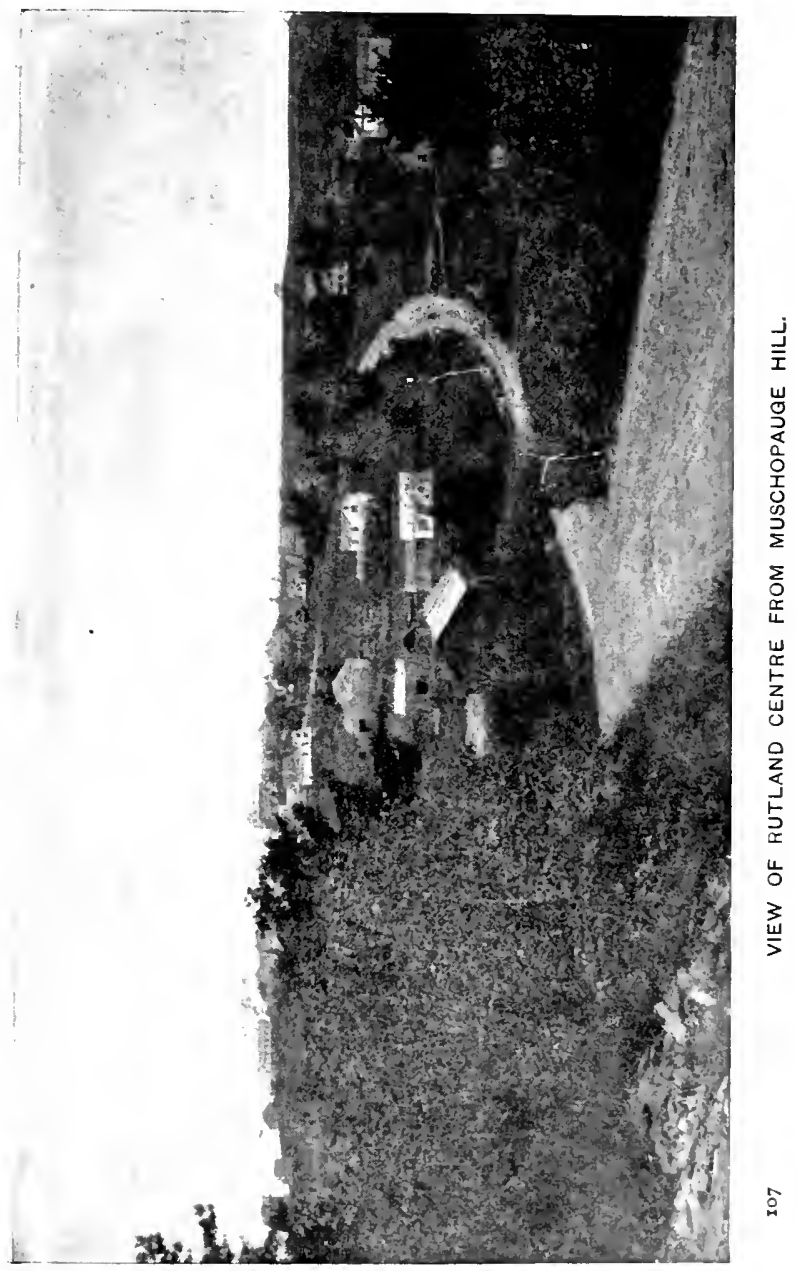


bership papers in their pockets. He will tell you of Judge Sewall's farm of a thousand acres in the north part of the town, and of his gift of the sacramental vessels to the church; of the five hundred acres granted to the Ancient and Honorable Artillery Company; of how the road through the village was laid out ten rods wide, and so remains unto this day; of the call to the "able, learned, orthodox minister," Joseph Willard, in I $72 \mathrm{I}$, and how he was "cut off by the Indians "- shot in the field north of the meeting-house-just before the installation day, so that Thomas Frink, "an able and learned, orthodox and pious person," was called instead. Presently there was "a coolness in affection in some of the brethren " towards Mr. Frink, because two fifths of the churchmembers were Presbyterians, over against the three fifths Congregationalists, and " contrary" to his advice and admonition communed with the Presbyterians in other towns." The upshot was a split, and a Presbyterian church in the west part of the town. These Rutland Presbyterians seem to have come from Ireland-they were of the same sort as those who founded Londonderry, New Hampshire just before; and some of them were so tenacious of their 
own ordinances that they carried their infants in their arms on horseback as far as Pelham to have them baptized in good Presbyterian form.

Rutland had her minute-men, and fifty of them were at Bunker Hill. She had some hot town-meetings between the Stamp Act time and Lexington, and passed ringing resolutions and some stiff instructions to Colonel Murray, her representative to the General Court, whom more and more she distrusted, and who, when the final pinch came, declared himself a Tory out-and-out, and fled to Nova Scotia, leaving Rutland "by a back road," to avoid a committee of the whole, which was on its way to visit him.

To tell the truth, this Tory Colonel, John Murray, must have been the most interesting figure ever associated with old Rutland, save General Rufus Putnam himself ; and, curiously enough, the Putnam place had belonged first to Murray, - the house being built by him for one of his married daughters, all of Murray's lands and goods being confiscated, and this house falling into Putnam's hands in 1780 or I 782 , probably at a very low figure.

He was not John Murray when he came to Rutland, but John McMorrah. He came 
from Ireland with John and Elizabeth McClanathan, Martha Shaw and others, his mother dying on the passage. He was not only penniless when he set his foot on the American shore, but in debt for his passage. "For a short time," says the chronicle, "he tried manual labor; but he was too lazy to work, and to beg ashamed." He found a friend in Andrew Hendery, and began peddling; then he kept a small store, and later bought cattle for the army. Everything seemed to favor him, and he became the richest man that ever lived in Rutland. "He did not forget Elizabeth McClanathan, whom he sailed to America with, but made her his wife." She lies, along with Lucretia Chandler, his second wife, and Deborah Brindley, the third, in the old Rutland graveyard. "He placed horizontaily over their graves large handsome stones underpinned with brick, whereon were engraved appropriate inscriptions." He had a large family, seven sons and five daughters; and the oldest son, Alexander, remained loyal to America and to Rutland when his father fled-entering the army and being wounded in the service. Murray became a large landholder and had many tenants ; he was the "Squire" of the region. He grew 


\section{Old Rutland}

arbitrary and haughty as he grew wealthy, but was popular, until the stormy politics came. "On Representative day," we read, "all his. friends that could ride, walk, creep or hobble were at the polls; and it was. not his fault if they returned dry." He held every office the people could give him, and represented them twenty years in the General Court. He was a large, fleshy man, and, "when dressed in his. regimentals, with his gold-bound hat, etc., he made a superb appearance." He lived in style, with black servants and white. "His high company from Boston, Worcester, etc., his office and parade, added to the popularity and splendor of the town. He promoted schools, and for several years gave twenty dollars. yearly towards supporting a Latin grammar school." He also gave a clock to the church, which was placed in front of the gallery, and proved himself a thoroughly modern man by inscribing on the clock the words, "A Gift of John Murray, Esq."

All these things your loyal Rutland host will tell you, or read to you out of the old books, where you can read them, and many other things. And he will take you to drive, down past the Putnam place, to the field where a 
large detachment of Burgoyne's army was quartered after the surrender at Saratoga. The prisoners' barracks stood for half a century, converted to new uses; and the well dug by the soldiers is still shown-as, until a few years ago, were the mounds which marked the

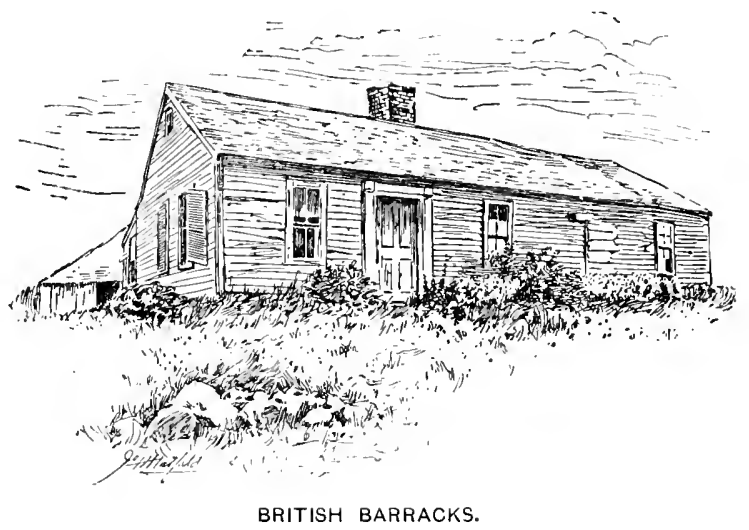

graves of those who died. Three of the officers fell in love with Rutland girls, and took them back to England as their wives. Yet none of their stories is so romantic as the story of that vagrant Betsy, whose girlhood was passed in a Rutland shanty, and who, after she married in New York the wealthy Frenchman, Stephen Jumel, and was left a widow, then married Aaron Burr. 
St. Edmundsbury, in old Suffolk, where Robert Browne first preached independency, has an air so bracing and salubrious that it has been called the Montpellier of England. Old Rutland might well be called the Montpellier of Massachusetts. Indeed, when a few years ago the State of Massachusetts decided to establish a special hospital for consumptives, the authorities asked the opinions of hundreds of physicians and scientific men in all parts of the State as to where was the best place for it, the most healthful and favorable point; and a vast preponderance of opinion was in behalf of Rutland. On the southern slope, therefore, of Rutland's highest hill the fine hospital now stands; and until people outgrow the foolish notion that a State must have all its State institutions within its own borders,- - until Massachusetts knows that North Carolina is a better place for consumptives than any town of her own,--there could not be a wiser choice. The town is so near to Worcester, and even to Boston, that its fine air, broad outlook and big hotel draw to it hundreds of summer visitors ; and latterly it has grown enterprising,--for which one is a little sorry,- -and has waterworks and coaching parades. 
The central town in Massachusetts, Rutland is also the highest village in the State east of the Connecticut. From the belfry of the village church, from the dooryards of the village people, the eye sweeps an almost boundless horizon, from the Blue Hills to Berkshire and from Monadnock to Connecticut, and the breezes on the summer day whisper of the White Hills and the Atlantic. It is not hard for the imagination to extend the view far beyond New England, to the town on the Muskingum which the prophetic eye of Putnam saw from here, and to the great States beyond, which rose obedient to the effort which began with him;

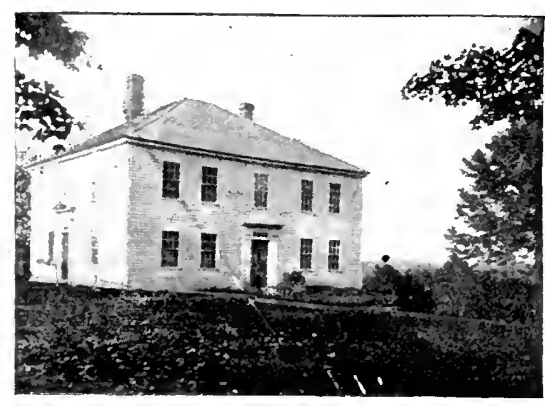

THE RUFUS PUTNAM HOUSE. it is not hard to catch messages borne on winds from the Rocky Mountains and the Pacific.

Just at the foot of the hill, -to the west. as is fitting,- - stands the old Rufus Putnam house, the church clock telling the hour above. Wachusett looming beyond the valley, the 
maples rustling before the door, to the west the sough of the pines. Its oaken timbers are still as sound as when Murray put them in place before the Revolution, each clapboard still intact, the doors the same, the rooms but little altered. Could Putnam return to earth again and to Rutland, he would surely feel himself at home as he passed through the gate.

In I893, when the enthusiasm re-inforced by our Old South lectures on "The Opening of the West" was strong, I wrote these words about the Rufus Putnam house:

" This historic house should belong to the people. It should be insured against every mischance. It should be carefully restored and preserved, and stand through the years, a memorial of Rufus Putnam and the farmers who went out with him to found Ohio, a monument to New England influence and effort in the opening and building of the great West. This room should be a Rufus Putnam room, in which there should be gathered every book and picture and document illustrating Putnam's career; this should be the Ordinance room, sacred to memorials of Manasseh Cutler and all who worked with him to secure the great charter of liberty ; this the Marietta room, illustrating the Marietta of the first days and the last, binding mother and daughter together, and becoming the pleasant ground for the interchange of many edifying courtesies. There should be, too, a Rutland room, with its hundred objects illustrat- 
ing the long history of the town,-almost every important chapter of which has been witnessed by this venerable building,-with memorials also of the old English Rutland and of the many American Rutlands which look back reverently to the historic Massachusetts town; and a Great West library, on whose shelves should stand the books telling the story of the great oak which has grown from the little acorn planted by Rufus Putnam a hundred years ago. We can think of few memorials which could be established in New England more interesting than this would be. We can think of few which could be established so easily. It is a pleasure to look forward to the day when this shall be accomplished. It is not hard to hear already the voice of Senator Hoar, at the dedication of this Rufus Putnam memorial, delivering the oration in the old Rutland church. Men from the West should be there with men from the East, men from Marietta, from the Western Reserve, from Chicago, from Puget Sound. A score of members of the Antiquarian Society at Worcester should be there. That score could easily make this vision a reality. We commend the thought to these men of Worcester. We commend it to the people of Rutland, who, however the memorial is secured, must be its custodians."

Just a year from the time these words were written, the pleasing plan and prophecy - more fortunate than most such prophecies-began to be fulfilled. It was a memorable meeting in old Rutland on that brilliant October day in I 894. Senator Hoar and seventy-five good 
men and women came from Worcester; and Edward Everett Hale led a zealous company from Boston; and General Walker drove over with his friends from Brookfield, his boyhood home near by, - the home, too, of Rufus Putnam before he came to Rutland; and when everybody had roamed over the old Putnam place, and crowded the big hotel dining-room for dinner, and then adjourned to the village church, so many people from the town and the country round about had joined that the church never saw many larger gatherings. The address which Senator Hoar gave was full of echoes of his great Marietta oration; and when the other speeches had been made, it was very easy in the enthusiasm to secure pledges for a third of the four thousand dollars necessary to buy the old house and the hundred and fifty acres around it. The rest has since then been almost entirely raised; the house has been put into good condition, and is visited each year by hundreds of pilgrims from the East and the IVest; and a noteworthy collection of historical memorials has already been made,--all under the control of the Rutland Historical Society, which grew out of that historic day, and which is doing a noble 
work for the intellectual and social life of the town, strengthening in the minds of the people the proud consciousness of their rich inheritance, and prompting them to meet the new occasion and new duty of to-day as worthily as Rufus Putnam and the Rutland farmers met the duty and opportunity of 1787 . In the autumn of 1898 , there was another noteworthy celebration at Rutland. This time it was the Sons of the Revolution who came; and they placed upon the Putnam house a bronze tablet with the following inscription, written by Senator Hoar, who was himself present and the chief speaker, as on the earlier occasion :

"Here, from i 78 I to 788 , dwelt General Rufus Putnam, Soldier of the Old French War, Engineer of the works which compelled the British Army to evacuate Boston and of the fortifications of West Point, Founder and Father of Ohio. In this house he planned and matured the scheme of the Ohio Company, and from it issued the call for the Convention which led to its organization. Over this threshold he went to lead the Company which settled Marietta, April 7, i 788 . To him, under God, it is owing that the great Northwest Territory was dedicated forever to Freedom, Education, and Religion, and that the United States of America is not now a great slaveholding Empire."

Many such celebrations will there be at the 
home of Rufus Putnam, and at the little village on the hill. Ever more highly will New England estimate the place of old Rutland in her history; ever more sacred and significant will it become as a point of contact for the East and West; and in the far-off years the sons and daughters of Ohio, Indiana, Illinois, Michigan and Wisconsin will make pilgrimages to it, as the children of New England pilgrimage to Scrooby.

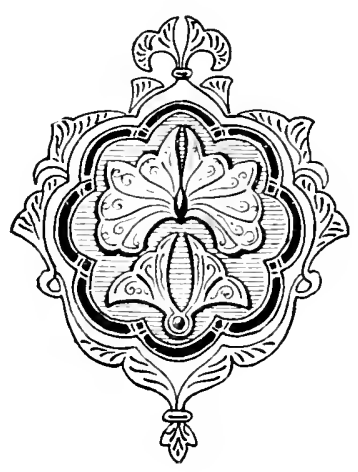


: 


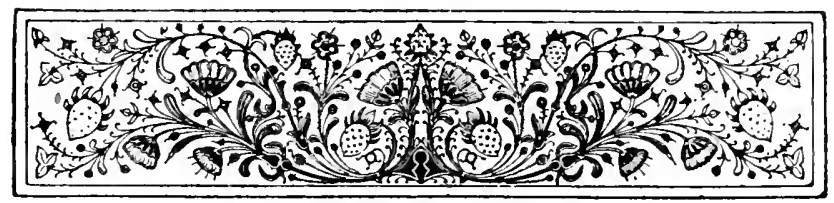

\section{SALEM}

\section{THE PURITAN TOWN}

BY GEORGE DIMMICK LATIMER

$S_{\text {a palimpsest, an ancient manuscript that has }}^{\text {ALEM is what historical students would call }}$ been scraped and then rewritten with another and later text. By careful study of the almost illegible characters and sometimes by chemical treatment, great treasures of the ancient learning, such as Orations of Cicero, the Institutes of Gaius and versions of the New Testament, have been discovered under monkish rules and medieval chronicles. Such a charm of research and discovery awaits the historical student in this modern, progressive city. The stranger within our gates is at first impressed by the many good business blocks, the elegant residences amid beautiful lawns on the broad, well-shaded streets, the handsome public buildings, many of them once stately mansions of 
the old sea-captains, and a very convenient electric-car service that makes the city a famous shopping-place for the eastern half of the county. But here and there the visitor comes upon some memorial tablet or commemorative stone, some ancient cemetery or venerable building-faded characters of an earlier text-

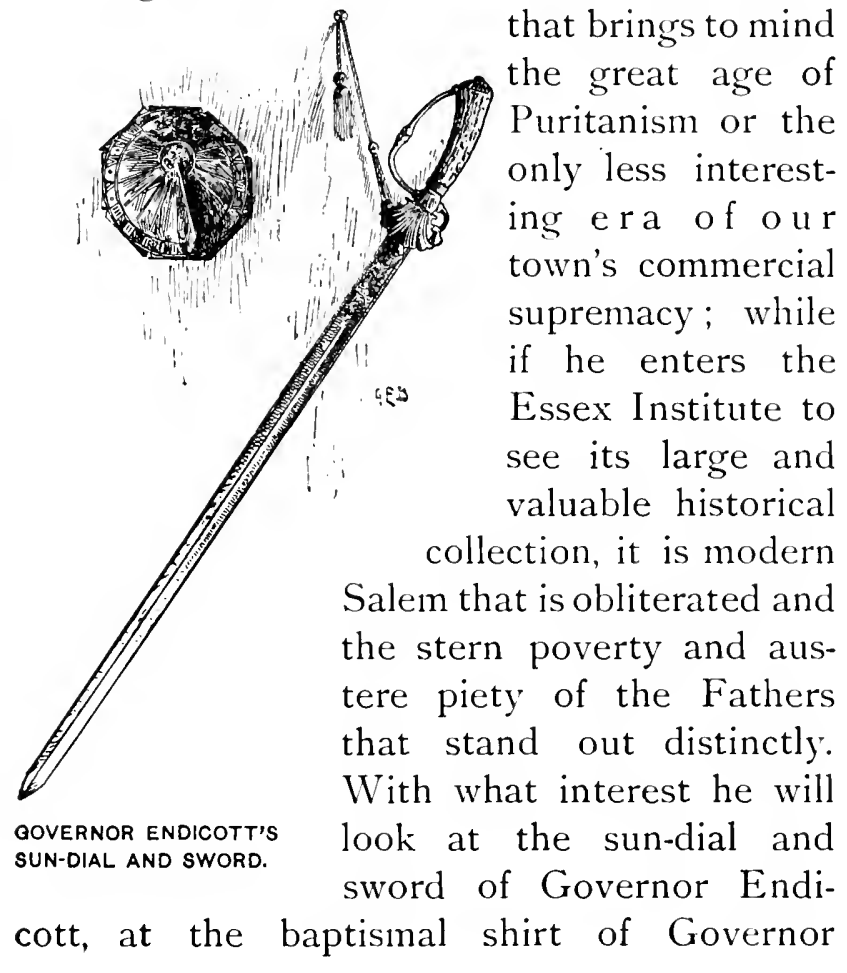




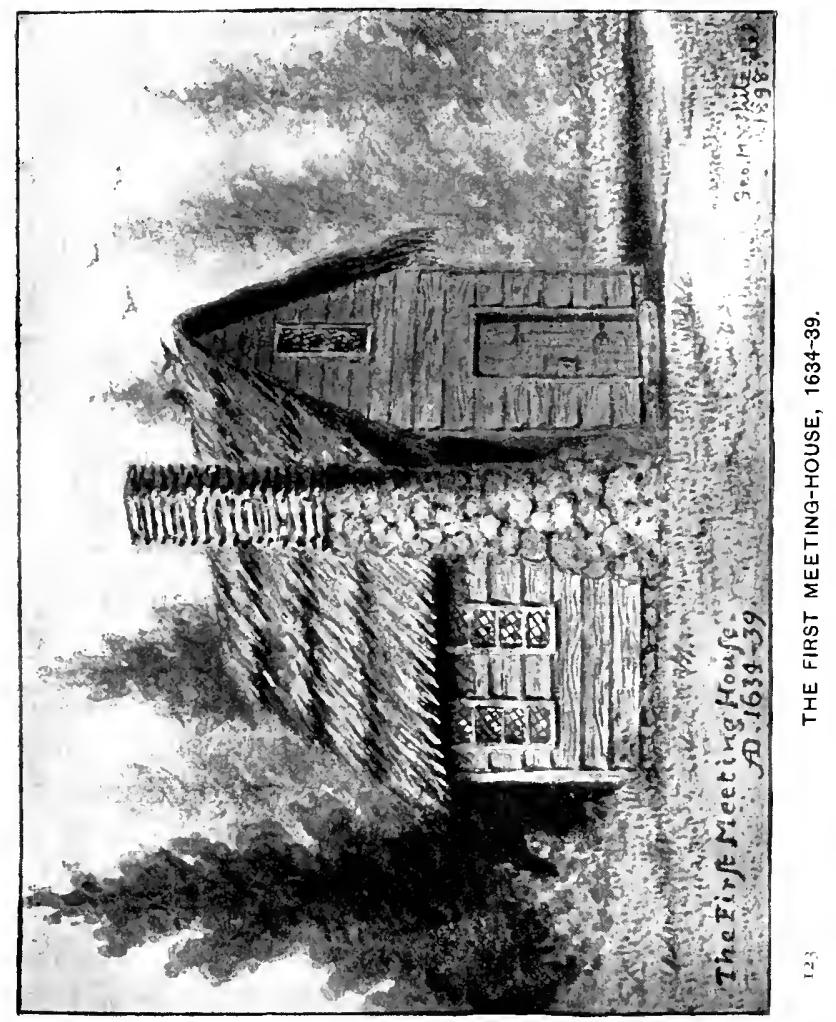


Bradford, and at the stout walking-stick of George Jacobs, one of the victims of the Witchcraft Delusion! The ancient pottery, the old pewter and iron vessels, the antique fowling-pieces and firebacks, the valuable autographs of charters and military commissions and title-deeds-all these survivals of the seventeenth century help to reconstruct that Puritan settlement under the direction of Endicott and Bradstreet, of Higginson and Roger Williams. Or if the visitor has entered the Peabody Academy of Science, rich in natural history and ethnological collections, it is the proud record of commercial supremacy at the beginning of this century which the old palimpsest reveals. As he studies the models of famous privateers and trading-vessels, the oil portraits of the old sea-captains and merchant princes, the implements and idols, the vestments and pottery, they brought

\footnotetext{
"From Greenland's icy mountains, From India's coral strand,"
}

he can easily imagine himself back in the days when Derby Street was the fashionable thoroughfare and its fine mansions overlooked the beautiful harbor, the long black wharves with 
their capacious warehouses and, moored alongside, the restless barks and brigantines for the moment quiet under the eyes of their hardy and successful owners.

Thanks to the historic spirit and the painstaking, loving labors of her citizens, Old Salem is easily deciphered under the handsome, modern, progressive city of thirty-four thousand inhabitants with factories, electric plants and Queen Anne cottages. Thanks to the genius of her distinguished son Nathaniel Hawthorne, the interpreter of the Puritan spirit, an in-

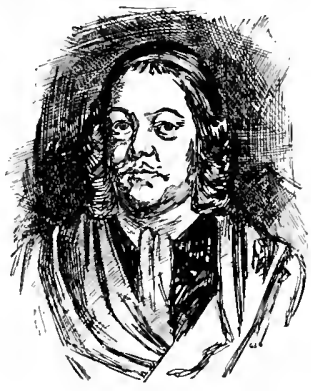
GOVERNOR SIMUN BRADSTREET. visible multitude of figures in steeple-hats and black cloaks and trunk-breeches, with here and there some gallant whose curling locks and gay attire are strangely out of place in the sober company, may always be suspected on the sleepy back-streets with their small, wooden, gambrel-roofed houses, or musing under the ancient willows in the venerable cemetery since I637 known as "The Burying Point," where were laid the bodies of Governor Bradstreet and many another Puritan. There are few Ameri- 
can cities in which it is so easy to feel the influence of a great past and to call up the images of Puritan minister and magistrate, for in Salem we are surrounded by their memorials, the houses they built, the church in which they first worshipped, their charter and

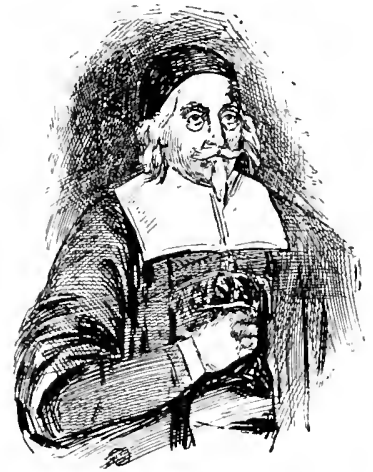

GOVERNOR JOHN ENDICOTT. title-deeds, their muskets and firebacks, even the garments they wore.

Salem really dates from 1626, when Roger Conant and a little band of English farmers and fishe rm en, in discouraged mood, left the bleak shore of Cape Ann and came to this region, then called by the Indians Naumkeag, a large tract of land, heavily wooded to the westward, and at the east running in irregular, picturesque manner out into Massachusetts Bay. Hither came in September, 1628, Captain John Endicott and a hundred adventurers, bringing with them a charter from the English company that claimed ownership of this territory, and many articles of English manufacture to exchange with the Indians for 
fish and furs. Endicott had been appointed Governor by the company, and immediately began to display the strength of character and readiness in resource that justified the wisdom of the directors and made him during his lifetime one of the commanding figures of the Bay Colony.

It was a busy time for these serious immigrants, who came in the fall and had to make hurried preparation for the winter. Behind them extended the vast, unknown forest, tenanted by savages and wild beasts, while in front stretched the three thousand miles of salt water they had just traversed. They built houses, they felled trees, they made treaties with the Indians, they hunted, fished, and ploughed the land they cleared. Apparently little had been done by Conant and his discouraged friends, but they had left a "faire house" at Cape Ann which was now brought to Naumkeag for the Governor's use.

Some of the colonists were actuated by love of religious freedom and some by hopes of gain. A strong hand was needed to enforce order and to give the settlement that religious character which its founders desired. It was found in Endicott, then in the prime of life, 
sternest of Puritans, quick of temper, imperious of will, and fortunately of intense religious convictions.

Hawthorne is the poet of the Puritan age. After reading the events of that memorable century in Felt's Annals of Salem and Upham's Salem Witchoraft, the student should

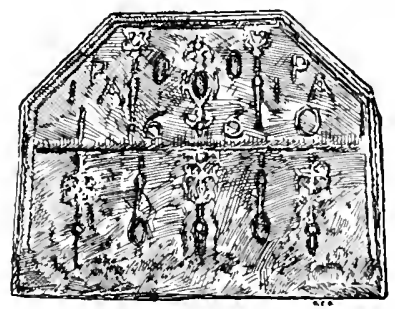

THE PICKERING FIREBACK. turn to the pages of the romancer for vivid pictures of the Puritan in his greatness of spirit and severity of rule. In The Maypole of Merry Mount Hawthorne has shown us, as only this Wizard of New England could, the dramatic moment when Endicott, accompanied by his mail-clad soldiers, presented himself at Mount Wollaston, near Quincy, and abruptly ended the festivities of the young and thoughtless members of the colony whom the lawless Morton had gathered around him. Nor would the portrait of Endicott be complete without the touch that shows him, in fierce anti-prelatial mood, cutting out the blood-red cross from the English flag, for which daring deed the General Court, fearing trouble with the home 


\section{Salem}

government, condemned him, then ex-Governor, to the loss of his office as assistant, or councillor, for one year.

The beginning of the severe, repressive rule of the Puritan over domestic and social life, so repellent to modern thought, is found in the instructions sent to Endicott by the directors of the English company.

"To the end the Sabbath may be celebrated in a religious manner, we appoint that all that inhabit the Plantation, both for the general and the particular employments, may surcease their labour every Saturday throughout the year at $3 \mathrm{o}^{\prime} \mathrm{c}$ in the afternoon, and that they spend the rest of that day in catechizing and preparing for the Sabbath as the ministers shall direct."

He was also to see that at least some members of each family were well grounded in religion,

"whereby morning and evening family duties may be well performed, and a watchful eye held over all in each family . . . that so disorders may be prevented and ill weeds nipt before they take too great a head."

For this purpose the company furnished him with blank books to record the daily employments of each family and expected these records to be sent over to England twice a year. 
In our natural dislike and distrust of such a Puritan Inquisition we should remember that the exigencies of the time and place go far towards justifying such stern precautions. The English company wanted a successful settlement, one to which they could themselves retreat if political and ecclesiastical oppression in the old country should prove too great for their endurance; and they well knew that prosperity depended upon order, sobriety, thrift, and piety. The splendid history and the moral leadership of New England in these three centuries have justified this painstaking, minute, even exasperating watch over the welfare of a colony far from the restraints of an old civilization, in peril from hostile savages and lawless adventurers on an inhospitable soil.

As a contrast to this gloomy picture of social life, their intentions towards the Indians shine in a bright light. The company wrote to Endicott in reference to the land questions certain to arise :

"If any of the savages pretend right of inheritance to all or any part of the lands granted in our Patent, we pray you endeavour to purchase their title, that we may avoid the least scruple of intrusion." 
Great pains were taken to establish just and humane relations with the red man. One of the objects of the company was the conversion of the Indians to the Gospel of Christ. Among the wise measures of the day it was forbidden to sell them muskets, ammunition or liquor, and they were permitted to enter the settlement at certain stated times only, for purposes of trade or treaty. As a nation, our treatment of the Indian has been so barbarous that this sagacious and Christian policy of the first Puritans calls for the highest praise and reveals another valuable trait in the heroic character of the Fathers.

That first winter at Naumkeag was a severe

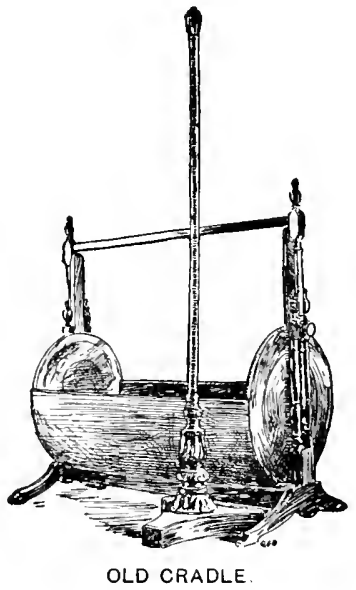
test of the fortitude of the Puritans. They suffered from lack of sufficient food and adequate shelter, and many died from disease. In their great need Governor Endicott wrote to Governor Bradford and asked that a physician be sent to them from the Plymouth set- 
tlement. Soon Dr. Fuller came and not only ministered to the sick, but in many conversations with Endicott and his companions doubtless prepared the way for their adoption of the Congregational or Independent form of church. The Pilgrims had withdrawn from the Church of England, averse to its ritual and discipline, and were known as Separatists. Even before their arrival at Plymouth they instituted the Congregational form of worship and discipline which they had already practised in England and Holland. But the Puritans at Naumkeag had intended to reform and not to give up the Anglican liturgy to which they were attached by tradition and sentiment. The Episcopal or the Congregational order of service was a momentous issue in these formative months and it is significant that on Dr. Fuller's return to Plymouth Endicott wrote to Bradford: "I am by him satisfied, touching your judgement of the outward form of God's worship; it is, as far as I can yet gather, no other than is warranted by the evidence of truth."

In the following spring four hundred immigrants and four Non-conformist clergymen, among them Francis Higginson and Samuel 
Skelton, arrived and steps were then taken for the formal organization of the church. In the contract the English company made with the Rev. Francis Higginson there is another evidence of its generous and enlightened policy. He was to receive $£ 30$ for his outfit, $£$ io for books and $£ 30$ per annum for three years. In addition, the company was to find him a house, food, and wood for that period, to transport himself and family, and to bring them back to England at the expiration of the time if it should then be his wish. He was also to have one hundred acres of land, and if he died his wife and children were to be maintained while on the plantation.

At this time the Indian name Naumkeag was given up and the settlement took its present name of Salem, an abbreviation of Jerusalem and meaning, as every one knows, Peace. The important event was the organization of the church. Services had been held during the winter, perhaps in that "faire house" of the Governor's, and doubtless the whole or parts of the Anglican liturgy had been used. A radical change now occurred. After suitable preparation by prayer and fasting the ministers were examined to test their fitness for the 
office, and then by a written ballot, the first use of the ballot in this country, Samuel Skelton was elected pastor and Francis Higginson teacher or assistant pastor. Then Mr. Higginson and "three or four of the gravest members of the church" laid their hands upon the head of Mr. Skelton, and with appropriate prayer installed him as minister of this first Puritan (as distinguished from the Pilgrim) church in America. Afterwards, by a similar imposition of hands and prayer by Mr. Skelton, Mr. Higginson was installed as teacher. The Plymouth church had been invited to send delegates, and as one of them Governor Bradford came, delayed by a storm, but in time to offer the right hand of fellowship. Thirty names were signed to the following covenant and the First Church of Salem was organized: "We covenant with the Lord and with one another, and do bind ourselves in the presence of God, to walk together in all $\mathrm{His}$ ways, according as He is pleased to reveal Himself unto us in His blessed word of truth." The deed was done. The Congregational creed and polity were adopted and the church that for more than two centuries dominated New England thought and life was established in Salem. 


\section{Salem}

For several years the youthful church met in a private house. But in ${ }^{1} 634$ the colonists were ready to build the "meeting-house" and the small, bare edifice, built of logs and boasting a thatched roof and stone chimney, was soon erected. "A poor thing, but mine own," the Puritan might have said as he recalled the venerable and beautiful cathedrals of the mother-country. But the Puritan doubtless never quoted Shakespeare. It is more probable that he thought of the tabernacle with which the chosen people journeyed in the wilderness, long before Solomon's temple crowned Mount Moriah, and rejoiced that the House of the Lord was at last set up in their midst. The sinewy oak timbers of this ancient building, within modern roof and walls, still remain, one of the most impressive monuments of this ancient town. Its size, $20 \times$ I 7 feet, makes one somewhat skeptical of the familiar statement that everybody went to church in the good old times. But I doubt not that both floor and gallery were well filled Sundays and at the great Thursday lecture, although on both days the preacher had the privilege, to modern divines denied, of reversing his hourglass after the sand had run out and, secure of 
his congregation, deliberately proceeding to his "Finally, Brethren." On one side sat the men, on the other the women and small children, each in his proper place, determined by wealth or public office. Even in that religious age four men, it appears, were appointed to prevent the boys from running downstairs before the Benediction was pronounced, while the constable, armed with a long pole tipped with a fox's tail, was always at hand to rouse the drowsy or inattentive. There was at each service a collection. Only church-members could vote at the town-meetings, held at first in the new meeting-house, but every householder was taxed for the support of the church. In I630, John Winthrop, the newly appointed Governor of the Colony, accompanied by several hundred persons, came to Salem. Disappointed in the place, they soon moved to Charlestown, and there established the seat of government. From that date Salem took the second place in the Colony, but always maintained, then as now, an independent, public-spirited life.

Hither came, in 1634 , Roger Williams, after the vicissitudes in those days experienced by an original and outspoken man. After the 


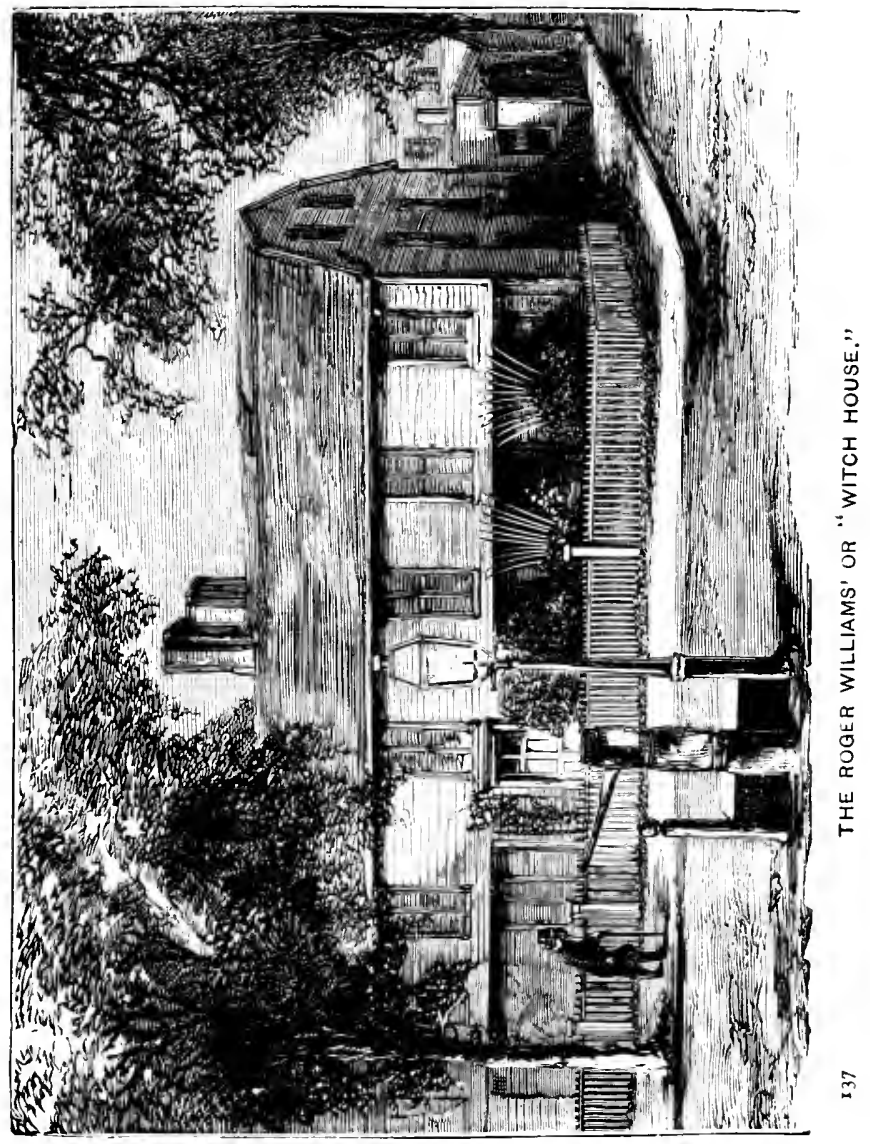


death of Mr. Higginson, he became the minister of the First Church. The original timbers of his dwelling-house, dating from 1635 , are still to be seen, more ancient than the ancient roof and walls that cover them, and reveal faded characters of the Puritan palimpsest. A double interest attaches to this venerable building, since as the residence of Judge Corwin tradition has made it the scene of some of the preliminary examinations in the witch trials. But the wanderings of Roger Williams were not yet ended. His attacks upon the authority of the magistrates as well as his controversies with the ministers brought him under the condemnation of the General Court. Though the Salem church resisted, it was obliged to part with its minister who quitted Massachusetts under sentence of banishment, to become the Founder of Rhode Island. A remarkable man was Roger Williams, of great gifts and singular purity of conscience, but his inflexible spirit, opposed to the theocratic rule of ministers and magistrates, was wisely set at constructive work in another colony.

This was the eventful age of Puritanism in the mother-country and in the colonies. All 
that we read of the austere piety and social restraints of the Puritan theocracy is found in this period from i629 to I 700 . Much might be said of the growth of Salem in population and wealth and influence in this century, but there is no time to tell the story in a single chapter. IVe come at once to the close of the century when the old town earned an unenviable notoriety by the tragic affair known as the Witchcraft Delusion.

We must think of Salem in 1692 as a town of 7 70o inhabitants, in a delightful situation on Massachusetts Bay, almost encircled by seawater, while at the west stretched away the vast forest, broken here and there by large plantations or farms which it was the policy of the Governor to grant to those who would undertake the pioneer work of cultivation. These farms, widely scattered, were known as Salem Village, and at a place a few miles from Salem, now known as Danvers Centre, there was a little group of farmhouses surrounding a church, of which the Rev. Samuel Parris was minister. In this family were two slaves, John and Tituba, whom he had brought from the West Indies, and two children, his daughter Elizabeth, nine years old, and his niece Abi- 
gail Williams, eleven years of age. In the winter of I69I-92 these children startled the neighborhood by their unaccountable performances, creeping under tables, assuming strange and painful attitudes, and uttering inarticulate cries. At times they fell into convulsions and uttered piercing shrieks. Dr. Griggs, the local physician, declared the children bewitched, and this explanation was soon after confirmed by a council of the ministers held at Mr. Parris's house.

Absurd as such an explanation seems to us, it must be remembered that, with rare exceptions, every one at that time believed in witchcraft. It found an apparent confirmation in the Bible, from the text, "Thou shalt not suffer a witch to live" (Exodus xxii., I $\$$ ), and the great legal authorities of England, Coke, Selden, and Matthew Hale, had given decisions implying the fact of witchcraft and indicating the various degrees of guilt. It was easier to accept this explanation since executions for this crime had already taken place at Charlestown, Dorchester, Cambridge, Hartford and Springfield. Governor Winthrop, Governor Bradstreet and Governor Endicott had each sentenced a witch to death. Gover- 
nor Endicott had pronounced judgment upon a person so important as Mistress Ann Hibbins, widow of a rich merchant and the sister of Governor Bellingham, familiar to us all in the pages of The Scarlet Letter. A few years before, Cotton Mather, the distinguished young divine of Boston, had published a work affirming his belief in witcheraft and detailing his study of some bewitched children in Charlestown, one of whom he had taken into his own family the better to observe.

It is not surprising, therefore, that these young girls, instead of being punished for mischievous conduct or treated for nervous derangement, were pitied as the victims of some malevolent persons and urged to name their tormentors. Encouraged by the verdict of physician and ministers, countenanced by Mr. Parris and the church-members, these "afflicted children," as they and some other girls and women similarly affected in the village were now called, began their accusations. The first persons mentioned were Tituba, the Indian slave, Goody Osborn, a bedridden woman whose mind was affected by many troubles, physical and mental, and Sarah Good, a friendless, forlorn creature, looked upon as a vagrant. 
In March, I692, the first examinations were held in the meeting-house in Salem Village, John Hawthorne, ancestor of the novelist, and Jonathan Corwin acting as magistrates. The accused did not receive fair treatment-their guilt was assumed from the first, no counsel was allowed, the judges even bullied them to force a confession. The eridence

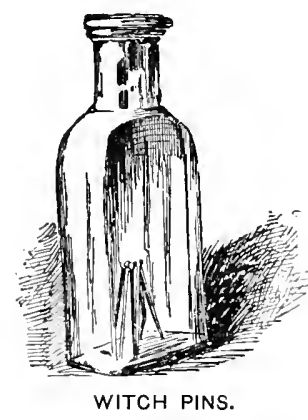

pins which they produced from their mouths or clothing, and in one instance, at least, stabbed by a knife the broken blade of which was shown by the "afflicted child." In one or two cases the children were convicted of deception, as in the case of the broken knife-blade. A young man present testified that he had broken the knife himself and had thrown away the useless blade in the presence of the accusing girl. But with merely 
a reprimand from the judge and the injunction not to tell lies, the girls were permitted to make their monstrous charges against the men and women who stood amazed, indignant, helpless, before accusations they could only deny, not refute.

In this first trial Tituba confessed that under threats from Satan, who had most often appeared to her as a man in black accompanied by a yellow bird, she had tortured the girls, and named as her accomplices the two women, Good and Osborn. After the trial, which took place a little later in Salem, Tituba was sent to the Boston jail, where she remained until the delusion was over. She was then sold to pay the expenses of her imprisonment, and is lost to history. The other women also were sent to jail, where they remained for many months, until the delusion was over.

The community felt a sense of relief after the confession of Tituba and the imprisonment of the other women. It was hoped Satan's power was checked. But on the contrary the power of the devil was to be shown in a far more impressive manner. The "afflicted children" continued to suffer and soon began to accuse men and women of unimpeachable 
lives. Within a few months several hundred people in Salem, Andover and Boston were arrested and thrown into the jails at Salem, Ipswich, Cambridge and Boston. As Governor Hutchinson, an historian of the time, stated, the only way to prevent an accusation was to become an accuser. The state of affairs resembled the Reign of Terror in France a century later, when men of property and position lived in fear of being regarded as "a suspect."

For the thrilling story of these trials and their wretched victims the student should turn to Mr. Upham's authoritative and popular volumes upon Salcm Witchcraft. The reader can never forget the tragic fate of the venerable Rebecca Nurse, George Burroughs, a former clergyman of the church in Salem Village, and the other victims. Here we can review only the trial of the Corey family, a fitting climax to this scene of horror.

Two weeks after the trial of Tituba and her companions, a warrant was issued for the arrest of Martha Corey, aged sixty, the third wife of Giles Corey, a well-known citizen. She was a woman of unusual strength of character and from the first denounced the witchcraft excite- 


\section{Salem}

ment, trying to persuade her husband who believed all the monstrous stories, not to attend the hearings or in any way countenance the proceedings. Perhaps it was her wellknown opinion that directed suspicion to her. At her trial the usual performance was enacted. The girls fell on the floor, uttered piercing shrieks, cried out upon their victim. "There is a man whispering in her ear!" one of them suddenly called out. "What does he say to you?" the judge demanded of Martha Corey, accepting without any demur this "spectral evidence." "We must not believe all these distracted children say," was her sensible answer. But good sense did not preside at the witch trials. She was convicted and not long afterward executed. Her husband's evidence went against her and is worth noting as fairly representative of much of the testimony that convicted the nineteen victims of this delusion :

"One evening I was sitting by the fire when my wife asked me to go to bed. I told her I would go to prayer, and when I went to prayer I could not utter my desires with any sense, not open my mouth to speak. After a little space I did according to my measure attend the duty. Some time last week I fetched an ox well out of the woods about noon, and he laying down in the yard, I went to raise him to yoke him, but he could not rise, 
but dragged his hinder parts as if he had been hip shot, but after did rise. I had a cat some time last week strongly taken on the sudden, and did make me think she would have died presently. My wife bid me knock her in the head, but I did not and since she is well. My wife hath been wont to sit up after I went to bed, and I have perceived her to kneel down as if she were at prayer, but heard nothing."

It is hard to believe that such statements, most probable events interpreted in the least probable manner, should have had any judicial value whatever. Yet it is precisely such a mixture of superstition and stupid speculation about unusual or even daily incidents that was regularly brought forward and made to tell against the accused.

Soon after his wife's arrest Giles Corey himself was arrested, taken from his mill and brought before the judges of the special court, appointed by Governor Phipps but held in Salem, to hear the witch trials. Again the accusing girls went through their performance, again the judges assumed the guilt of the accused, and tried to browbeat a confession from him. But in the interval between his arrest and trial this old man of eighty had had abundant leisure for reflection. He was sure 


\section{Salem}

not only of his own innocence but of his wife's as well, and it must have been a bitter thought that his own testimony had helped convict her. Partly as an atonement for this offense and partly to save his property for his children, which he could not have done if he had been convicted of witchcraft, after pleading " not guilty" he remained mute, refusing to add the necessary technical words that he would be tried "by God and his country." Deaf alike to the entreaties of his friends and the threats of the Court, he was condemned to the torture of peine forte ct dure, the one instance when this old English penalty for contumacy was enforced in New England. According to the law the aged man was laid on his back, a board was placed on his body with as great a weight upon it as he could endure, while his sole diet consisted of a few morsels of bread one day and a draught of water the alternate day, until death put an end to his sufferings.

The execution of eight persons on Gallows Hill three days later, September 22, were the last to occur in the Colony. Accusations were still made, trials were held, more people were thrown into jail. But there were no more executions, and the next spring there was, ac- 
cording to Hutchinson, such a jail delivery as was never seen before.

\section{"The smith filed off the chains he forged, The jail bolts backward fell ; And youth and hoary age came forth Like souls escaped from hell."}

The tragedy was at an end. It lasted about six months, from the first accusations in March until the last executions in September. Nineteen persons had been hanged, and one man pressed to death. There is no foundation for the statement that the witches were bumed. This is a mistake constantly made, and one that should always be corrected. But hundreds of innocent men and women were thrown into jail or obliged to flee to some place of concealment, their homes were broken up, their property injured, while they suffered great anxiety for themselves and friends.

It was an epidemic of mad, superstitious fear, bitterly to be regretted, and a stain upon the high civilization of the Bay Colony. It is associated with Salem, but several circumstances are to be taken into consideration. First of all, note the fact that while the victims were residents of Essex County, of Salem and 
vicinity, and the trials were held in Salem, yet the special court that tried them was appointed by the Governor ; the Lieutenant-Governor of the Colony, Stoughton, presided; and Boston ministers, notably Cotton Mather, the influential minister of the North Church, were interested observers. Boston as well as Salem is responsible for the tragedy. In the second place, remember that this dramatic event with all its frightful consequences led to a more rational understanding of the phenomena of witchcraft. By a natural revulsion of feeling future charges of witchcraft were regarded with suspicion, "spectral evidence" was disallowed, and there were no more executions for this crime in New England.

Various explanations of the conduct of the "afflicted children" have been offered. One writer has suggested that they began their proceedings in jest but, partly from fear of punishment if they confessed, partly from an exaggerated sense of their own importance, they continued to make charges against men and women whom they heard their elders mention as probable witches. In that little settlement there were property disputes, a church quarrel, jealousies, rivalries, and much 
misunderstanding, which had their influence. Another writer lays stress upon "hypnotic influence" and believes these young girls and nervous women were improperly influenced by malevolent persons, probably John and Tituba the Indian slaves. But a more natural explanation is that they were the victims of hystero-epilepsy, a nervous disease not so well understood in the past as to-day, which has at times convulsed the orderly life of a school or convent, and even a whole community. Then, too, the belief in witchcraft was general. Striking coincidences, personal eccentricities, unusual events and mysterious diseases seemed to find an easy explanation in an unholy compact with the devil. A witticism attributed to Judge Sewall, one of the judges in these trials, may help us to understand the common panic: "We know who's who but not which is witch." That was the difficulty. At a time when every one believed in witchcraft it was easy to suspect one's neighbor. It was a characteristic superstition of the century and should be classed with the barbarous punishments and religious intolerance of the age.

Eventually, justice, so far as possible, was 
done to the survivors. The Legislature voted pecuniary compensations and the church excommunications were rescinded. Ann Putnam, one of the more prominent of the "afflicted children," confessed her error and prayed for divine forgiveness. Rev. Samuel Parris offered an explanation that might be considered an apology. Judge Sewall, noblest of all the civil and ecclesiastical authorities implicated in this tragedy, stood up in the great congregation, Fast Day, in the South Church, Boston, and acknowledged his error in accepting "spectral evidence."

"Spell and charm had power no more,

The spectres ceased to roam, And scattered households knelt again Around the hearths of home."

Salem grew in wealth and population slowly but substantially. In 1765 there were only 4469 inhabitants. With the rest of the Colony she was putting forth her strength in the FrenchIndian wars and also resisting what she termed the usurpations of the Royalist governors or English Parliament. It was a public-spirited as well as high-spirited life. Soldiers and bounties and supplies were generously fur- 
nished for the wars. Pirates were captured or driven from the coast. A valuable commerce was developed, churches were built and schools increased. In I 768 the Essex Gazette was founded, with the motto, "Omne tulit punctum qui miscuit utile dulci,"-a motto that measures the social changes from the time of Endicott and Williams.

The citizens of Salem were not wanting in patriotism or courage in the years immediately preceding the Revolution. They met in the old town-house to protest against the Stamp Act, to denounce the tax on tea and the closing of Boston port, and in 1774 , in defiance of General Gage, to elect delegates to the First Continental Congress about to meet in Concord. As early as i 767 a committee had been appointed "to draft a subscription paper for promoting industry, economy and manufactures in Salem, and thereby prevent the unnecessary importation of European commodities which threaten the country with poverty and ruin." The report of the committee was not accepted but the movement was characteristic of the attitude of Salem.

A just claim is made that the first armed resistance to the British government was made 


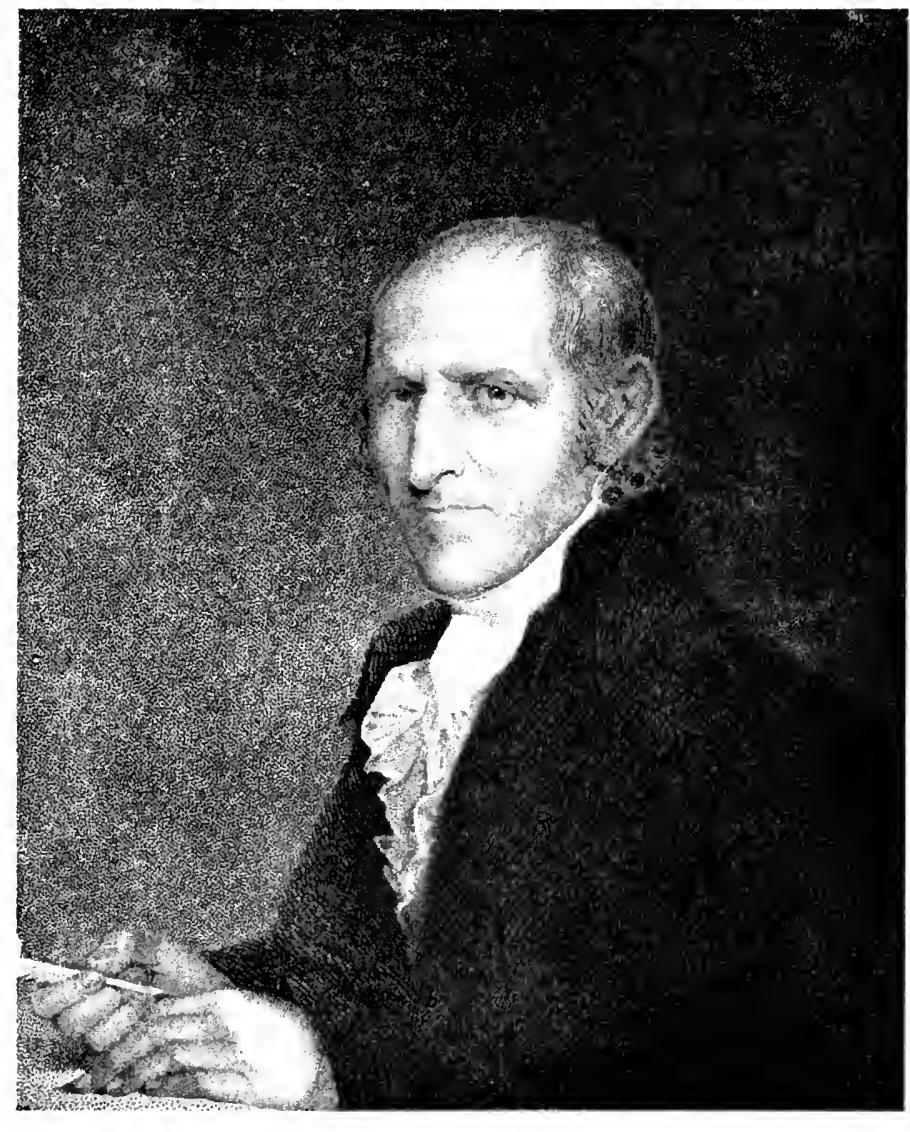

\section{Sichering.}


in Salem at the North Bridge, Sunday, February 26, I 775 , when the citizens assembled and took their stand on the north bank of the river to prevent Colonel Leslie and his three hundred soldiers from marching into North Fields in search of cannon supposed to be concealed there. The British officer thought of firing upon the citizens who, after crossing the bridge, had raised the draw and now stood massed on the opposite bank. But a townsman, Captain John Felt, said to the irate officer who had looked for an unimpeded march, "If you do fire you will all be dead men." His prompt utterance appears to have restrained the firing. Tradition says that there was a struggle to capture some boats, one of which at least was scuttled. After an hour and a half of delay, in which time Rev. Mr. Barnard of the North Church was conspicuous for his moderate counsels, the vexed and defeated Colonel Leslie promised that if the draw were lowered and he were permitted to march his men over it a distance of thirty rods, he would then wheel about and leave the town, an agreement fairly carried out. A commemorative stone marks this place and significant event at the beginning of the Revolution. 

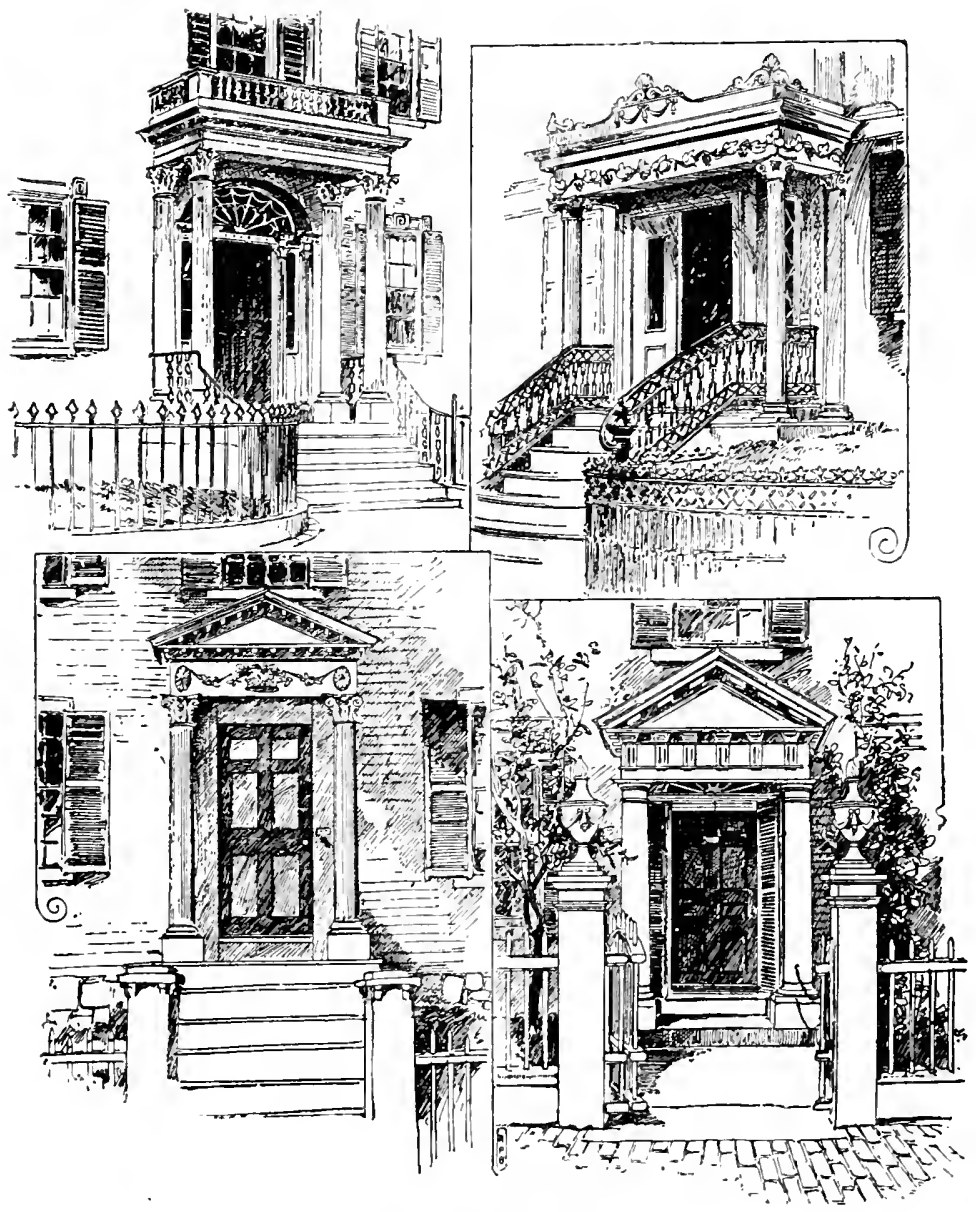

SOME OLD DOORWAYS. 
The years from i 760 to the War of is i 2 were the period of commercial prestige. At the beginning of the Revolution Washington turned to the coast towns for a navy, and Salem answered by furnishing at least i 58 privateers. Many were the prizes brought into the harbor as the war continued, and, as a result of this seamanship, an immense impetus was given to ship-building and the development of foreign commerce. This may be called the romantic era in the life of the venerable town. At the close of the war the town could boast of its great merchants and adventurous captains whose vessels were found in every port. Where did they not go, these vessels owned by Derby, Gray, Forrester, Crowninshield, and many another well-known merchant!

Under the stern rule of Endicott the old Puritan town had banished Quakers and Baptists and Episcopalians, but in the early years of this century her sons were intimate with Buddhist and Mohammedan and Parsee merchants. In $178_{5}$ "Lord" Derby, as Hawthorne called him, sent out the Grand Turk which, nearly two years later, brought back the first cargo direct from Canton to New 
England. At this time it is with peculiar interest we read that in 1796 this same "Lord" Derby sent the Astrea to Manila, which returned the following year with a cargo of sugar, pepper and indigo upon which duties of over $\$ 24,000$ were paid. That was the time when a sailing-vessel after a long voyage might enter the harbor any day, and therefore the boys of the town lay on the rocks at the Neck, eager to sight the incoming ship, and earn some pocket-money for their welcome news. Significant is the motto on the present city seal: Divitis Indice usque ad ultimum sinum. They were a hardy racethese Vikings of New England-bold, selfreliant, shrewd, prosperous, equally ready to fight or trade, as occasion might demand. The sailors of that day were the native sons of Salem, sturdy citizens, often well-to-do, who might have an "adventure" of several hundred dollars aboard to invest in tea or sugar or indigo. At fourteen or fifteen the Salem boy went out in the cabin of his father's vessel, at twenty he was captain, at forty he had retired and in his stately mansion enjoyed the wealth and leisure he had bravely and quickly earned. In i816 Cleopatra's Barge, a vessel 
of 190 tons burden, was launched in the harbor, and George Crowninshield went yachting in the Mediterranean in this luxurious vessel,-perhaps the first American pleasure yacht, as much admired in Europe as in New England. Many are the traditions of this romantic and prosperous era. Many are the famous names of merchants and sailors-men of great wealth and public spirit, mighty in time of war and influential in affairs of state, as Colonel Timothy Pickering, and Benjamin WV. Crowninshield, esteemed at home and abroad for their enlightened, progressive, humane, public-spirited services to town and State.

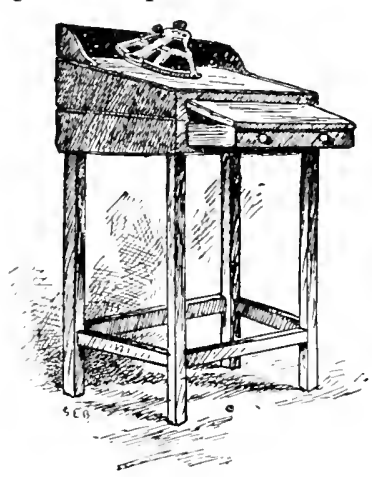

BOWDITCH DESK AND QUADRANT.

Many of their stately mansions still remain to attest the wealth and fashion and gracious hospitality of that period. The spacious rooms, rich in mahogany furniture, carved wainscoting, French mirrors, and Canton china, were the scenes of elegant and memorable entertainments when Washington, Lafayette, and many other celebrated men of Europe 
and America visited the old town. As regards the beautiful objects of interior decoration,now so eagerly sought, and often purchased at high prices,- Salem is one vast museum, almost every home boasting its inherited treasures, while a few houses are so richly dowered that the envy of less fortunate housekeepers can be easily pardoned.

The commerce in time went to Boston, and many of the sons of Salem followed it to help build up the wealth and character of the larger city. In fact where have not the sons, like the vessels, of Salem gone? Their memory is green in the old town and the citizen points with pride to the former residence-site of many a distinguished man she calls her son; of Bowditch, mathematician and author of the famous Navigator, of Judge Story and his no less eminent son, the poet and sculptor, of $\mathrm{IV}$. $\mathrm{H}$. Prescott, the heroic historian of Spain, of Jones Very, poet and mystic, and of many another man of mark in law and literature.

But of all the distinguished sons of Salem no one makes so eloquent an appeal to the popular heart as Nathaniel Hawthorne. Visitors are particularly interested in the places associated with his life and romances. Of these 
there are many, for the novelist lived at one time or another in half a dozen Salem houses, while several are identified with his stories. To
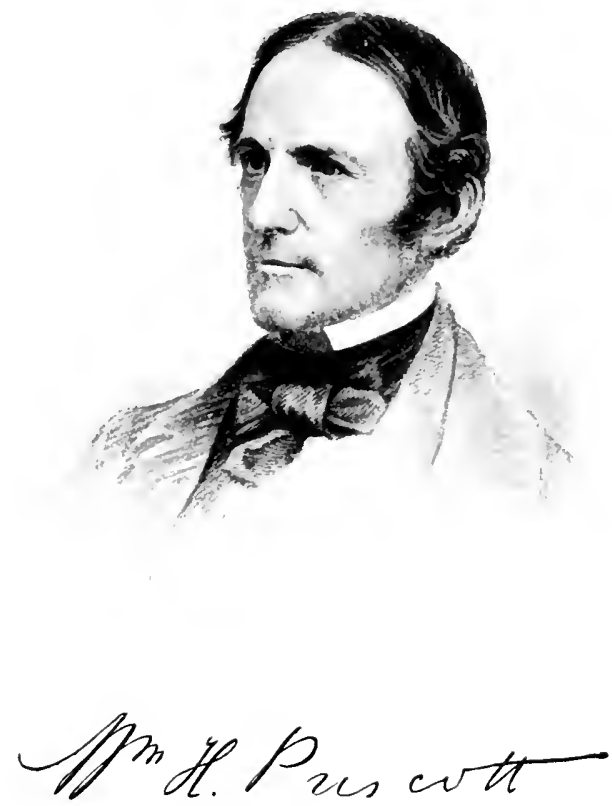

appreciate Hawthorne one should read him here, in the old Puritan town with its ancient houses, several of which date from the seventeenth century, its commemorative tablets, ancient tombstones, family names, and the collections of the Essex Institute. With magic 
pen he traced the greatness and the littleness of the Puritan age, its austere piety, its intolerance, its stern repression of the lighter side of human nature, its moral grandeur and its gloomy splendor. He did for our past what Walter Scott did for the past of the mother-country. Another "Wizard of the North," he breathed the breath of life into the dry and dusty materials of history; he summoned the great dead again to live and move among us.

The visitor will be interested in all the houses associated with his name,- - the modest birthplace on Union Street, the old residence on Turner Street popularly but erroneously called the House of the Seven Gables, the Peabody homestead, beside the Old Burying Point, where he found his wife and also Dr. Grimshawe's Secret. The visitor will be most interested, however, in the three-story, wooden building with the front door opening into the little garden at the side, after the fashion of many Salem houses, where he lived when Surveyor of the Port and wrote the immortal romance of Puritan New England. Here his wife wept over the woe of Hester Prynne and Arthur Dimmesdale, and hither came James T. 
Fields to hear the story which he so eagerly accepted. After one has read the facts of history in Felt and Upham and the diaries and chronicles of the seventeenth century, it is well to turn to Hawthorne for the realistic touch that makes the Puritan characters live once more for us. His sombre genius was at home in the Puritan atmosphere. How clearly its influence over him is acknowledged in the Introduction to The Scarlet Letter! He had the literary taste and the literary ambition, and he found his material in the musty records of the Customhouse, in the town pump so long a feature of Salem streets, in the church steeple, the ancient burying-ground, the old gabled houses, even the Main Street that had witnessed the varied pageants of more than two centuries. He was always leaving Salem and always returning, drawn by the "sensuous sympathy of dust for dust." Here his ancestors lay buried, and here, although he has said he was happiest elsewhere, lay his inspiration. The strange group of Pyncheons, Clifford, Hepzibah and the Judge, the Gentle Child, the Minister with the Black Veil, Lady Eleanore in her rich mantle, and the tragic group of The Scarlet Letter-these are not simply the crea- 


$$
\text { \& }
$$


tions of a delicate and somewhat morbid imagination, even more are they the marvellous resurrection of a life long dead.

The old town has a genuine pride in her great son whose fame, assured in England as in America, has added to her attractions. But owing to his invincible reserve and long absences he had only a limited acquaintance in Salem, and there is comparatively little of reminiscence and anecdote among those who remember him. He chose his companions here, perhaps in reaction from the intellectual society he had had in Concord, perhaps in search of literary material, from a jovial set with many a capital tale to tell of the old commercial days when the Custom-house with its militant eagle aloft was the centre of a bustling, cosmopolitan life that surged up and down its steps and over the long black wharves of Derby Street. Like many men of genius his character had more than one side and can now be studied in the abundance of material which the unwearied industry of his children has given us.

The novelist has gone, as the merchant and sailor went, as the Puritan magistrate and minister went. Another set of priceless as- 


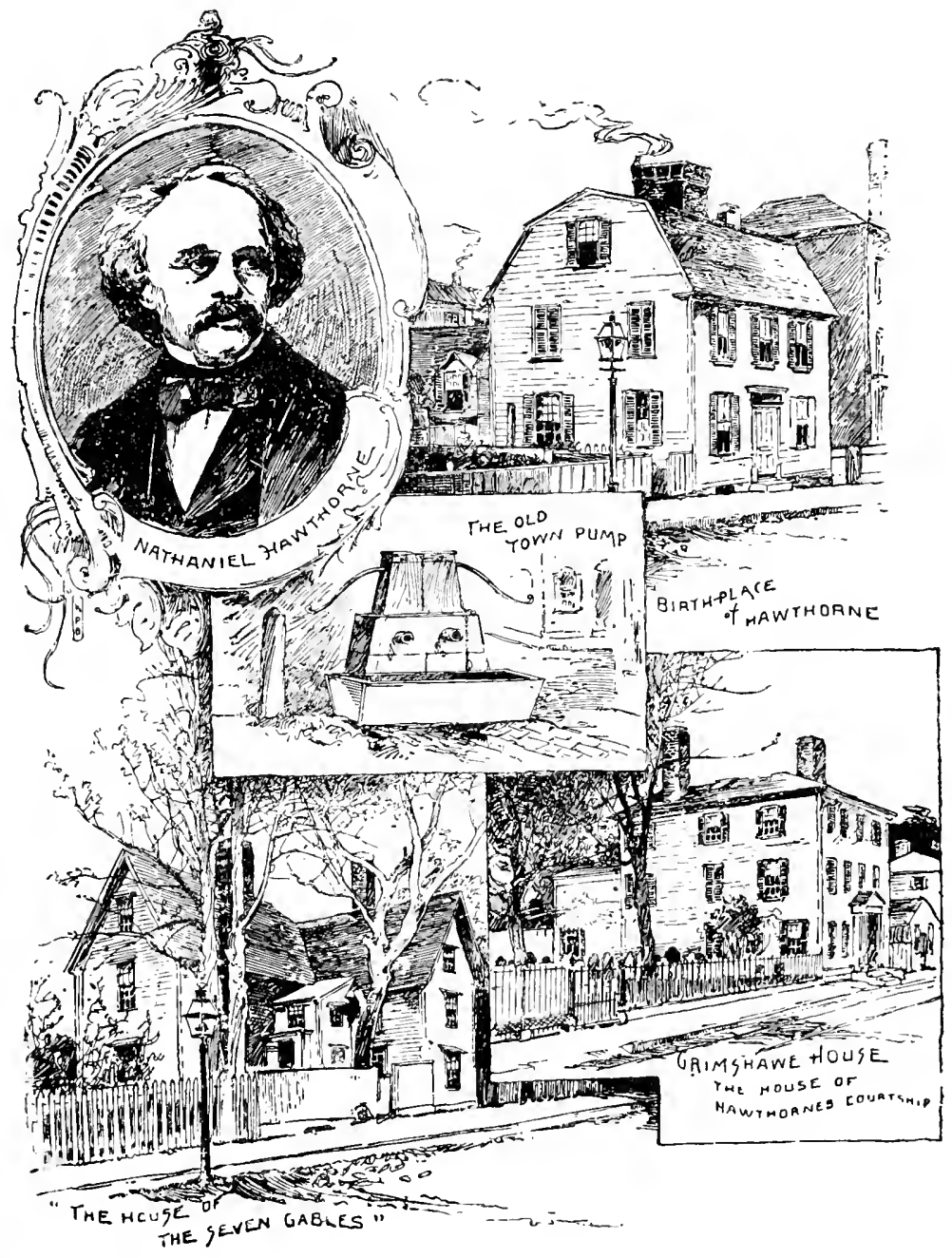

I 65 
sociations is added to the old town which now must confess to factories and a foreign population like many another New England seaport. The resident of Salem lives in a modern, progressive, handsome city, made the more attractive by eccentric roofs, "Mackintire" doorways, carved wooden mantels and wainscoting, ever suggestive of the venerable and impressive past, a past that may well serve as a challenge to the children of Viking and Puritan, inviting them to a fine self-control and a broad public spirit.

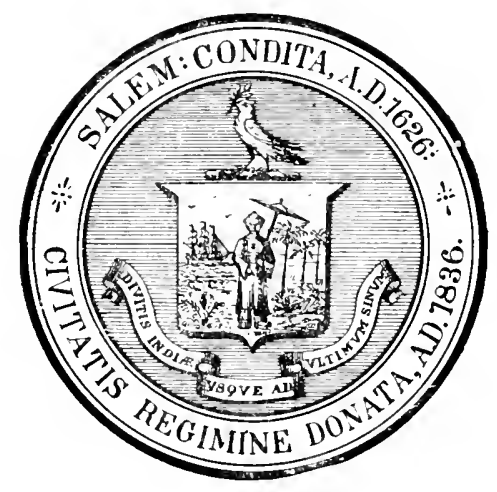




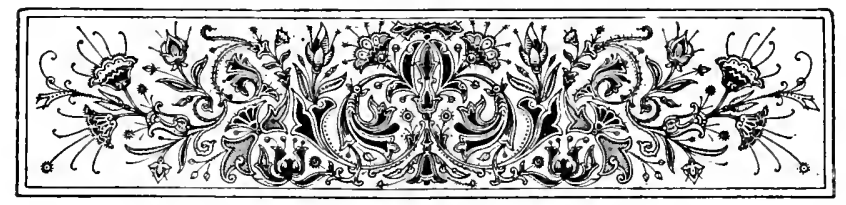

\section{BOSTON}

\section{THE TRIMOUNTAIN CITY}

BY THOMAS WENTWORTH HIGGINSON

THE summer traveller who approaches Bos1 ton from the landward side is apt to notice a tall and abundant wayside plant, having a rather stiff and ungainly stem, surmounted by a flower with soft and delicate petals and of a lovely shade of blue. This is the succory (Cichorium Intybus of the botanists), described by Emerson as "succory to match the sky." But it is not commonly known in rural New England by this brief name, being of tener called "Boston weed," simply because it

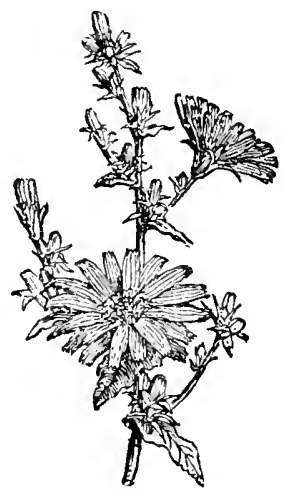

SUCCORY OR "BOSTON WEED." grows more and more abundant as one comes 
nearer to ihat city. When the experienced Boston traveller, returning to his home in late summer, sees this fair blossom on an ungainly stem assembled profusely by the roadside, he begins to collect his parcels and hand-bags, knowing that he approaches his journey's end.

The original Boston, as founded by Governor John Winthrop in 1639 , was established on a rocky, three-hilled peninsula, in whose thickets wolves and bears were yet harbored, and which was known variously as Shawmut and Trimountain. The settlement itself was a sort of afterthought, being taken as a substitute for Charlestown, where a temporary abocle had been founded by Winthrop's party. There had been much illness there, and so Mr. Blackstone, or Blaxtone, who had for seven years been settled on the peninsula, urged the transfer of the little colony. The whole tongue of land then comprised but 783 acres-an area a little less than that originally allotted to Central Park in New York. Boston now includes 23,66 I acres-about thirty times the original extent of the peninsula. It has a population of about 500,000-the State Census of I 895 showing 496,920 inhabitants. By the United States Census of 1890 


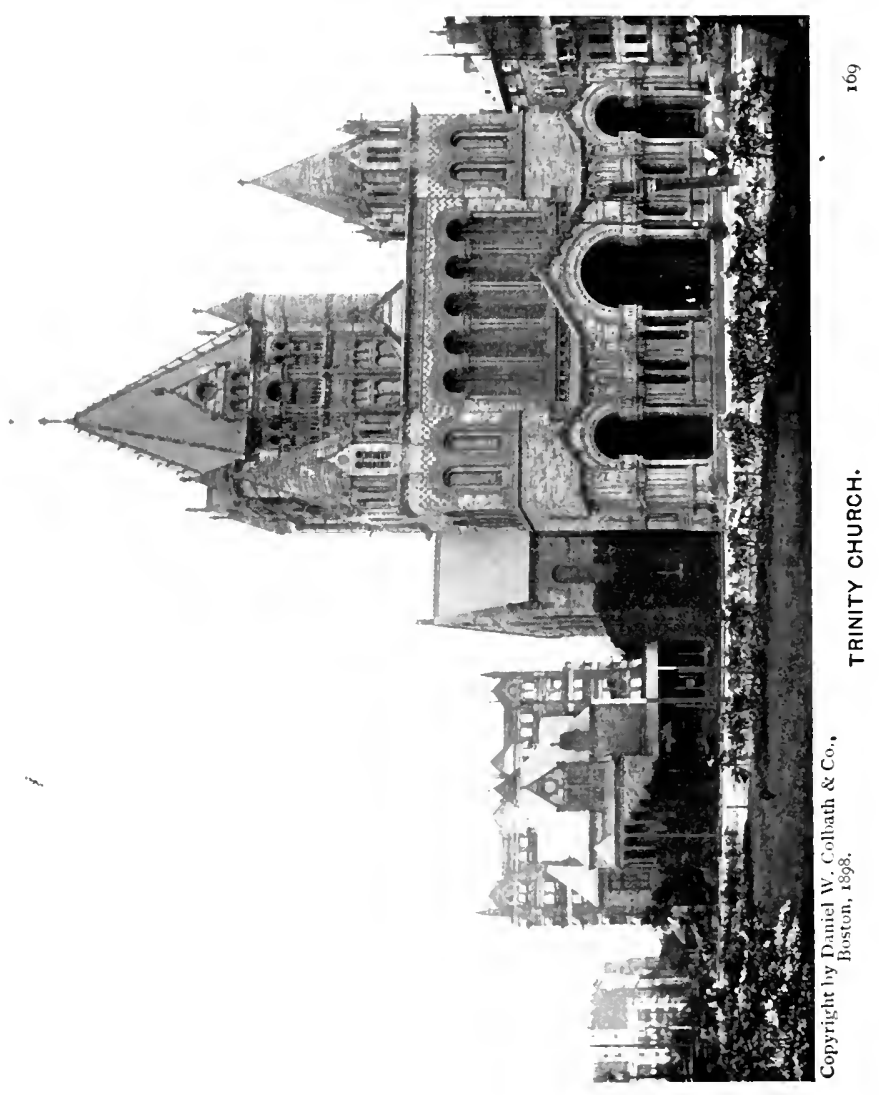


it had 448,477 , and was then the sixth in population among American cities, being surpassed by New York, Chicago, Philadelphia, Brooklyn, and St. Louis; and the union of New York and Brooklyn probably making it now the fifth. In 1880 it ranked fifth, St. Louis having since outstripped it. In 1870 it was only seventh, both St. Louis and Baltimore then preceding it. As with most American cities, this growth has been partly due to the annexing of suburbs; but during the last fifteen years there has been no such annexation, showing the increase to be genuine and intrinsic. The transformation in other ways has, however, been more astonishing than the growth. Of the original three hills, one only is now noticeable by the stranger. I myself can remember Boston, in my college days, as a pear-shaped peninsula, two miles by one, attached to the mainland by a neck a mile long and only a few yards wide, sometimes actually covered by the meeting of the tide-waters from both sides. The water also almost touched Charles Street, where the Public Garden now is, and it rolled over the flats and inlets called the Back Bay, where the costliest houses of the city now stand. 
The changes of population and occupation have been almost as great as of surface. The blue-jacketed sailor was then a figure as familiar in the streets as is now the Italian or the Chinese ; and the long wharves, then lined with great vessels, two or three deep, and fragrant with spicy Oriental odors, are now shortened, reduced, and given over to tugs and coasters. Boston is still the second commercial port in the country ; but its commerce is mainly coastwise or European only, and the picturesque fascination of the India trade has passed away. Even on our Northwest Pacific coast the early white traders, no matter whence they came, were known by the natives as "Boston men." The wealth of the city, now vastly greater than in those days, flows into other channelsrailways, factories, and vast land investments in the far West-enterprises as useful, perhaps more lucrative, but less picturesque. It is a proof of the vigor and vitality of Boston, and partly, also, of its favorable situation, that it has held its own through such transformations. Smaller cities, once powerful, such as Salem, Newburyport, and Portsmouth, have been ruined as to business by the withdrawal of foreign trade. 
Boston has certainly, in the history of the country, represented from an early time a certain quality of combined thrift and ardor which has made it to some extent an individual city. Its very cows, during its rural period, shared this attribute, from the time when they laid out its streets by their devious wanderings, to the time when "Lady Hancock"-as she was called-helped herself to milk from

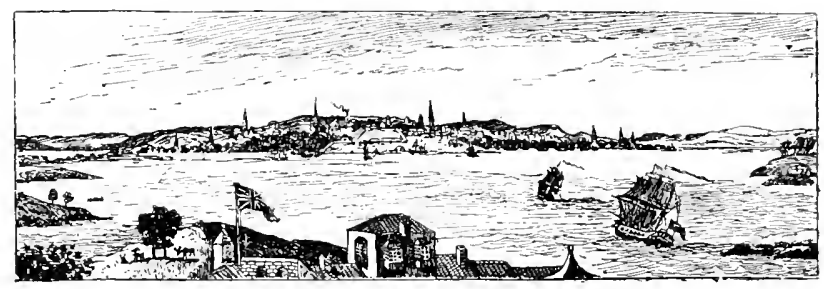

BOSTON IN 1757.

FROM A DRAWING BY GOVERNOR POWNALL.

the herd of her fellow-citizens in order to meet a sudden descent of official visitors upon her husband, the Governor. From the time when Boston was a busy little colonial martthe epoch best described in Hawthorne's Province House Legends and My' Kinsman Major Molincux-through the period when, as described in Mrs. Quincy's reminiscences, the gentlemen went to King's Chapel in scarlet 
cloaks, - down to the modern period of transcontinental railways and great manufacturing enterprises, the city has at least aroused a peculiar loyalty on the part of its citizens. Behind all the thunders of Wendell Phillips's eloquence there lay always this strong local pride. "I love inexpressibly," he said, " these streets of Boston, over which my mother held up my baby footsteps; and if God grants me time enough, I will make them too pure to be trodden by the footsteps of a slave." He survived to see his dream fulfilled. Instead of the surrendered slave, Anthony Burns, marching in a hollow square, formed by the files of the militia, Phillips lived to see the fair-haired boy, Robert Shaw, riding at the head of his black regiment, to aid in securing the freedom of a race.

During the Revolution, Boston was the centre of those early struggles on which it is now needless to dwell. Faneuil Hall still stands - the place from which, in 1774 , a letter as to grievances was ordered to be sent to the other towns in the State; the old State House is standing, where the plans suggested by the Virginia House of Burgesses were adopted; the old South Church remains, whence the disguised Indians of the Boston Tea-Party 
went forth, and where Dr. Warren, on March 5 , I775, defied the British officers, and when one of them held up warningly some pistolbullets, dropped his handkerchief over them and went on. The Old North or Christ Church also remains, where the two lights were hung out as the signal for Paul Revere's famous ride, on the eve of the battle of Lexington.

So prominent was Boston during this period that it even awakened the jealousy of other colonies ; and Mr. Thomas Shirley, of Charleston, South Carolina, said to Josiah Quincy, Jr., in March, I 773: "Boston aims at nothing less than the sovereignty of this whole continent. . . Take away the power and superintendence of Britain, and the colonies must submit to the next power. Boston would soon have that."

One of the attractions of Boston has long been, that in this city, as in Edinburgh, might be found a circle of literary men, better organized and more concentrated than if lost in the confusion of a larger metropolis. From the point of view of New York, this circle might be held provincial, as Edinburgh no doubt seemed from London; and the resident of the larger 


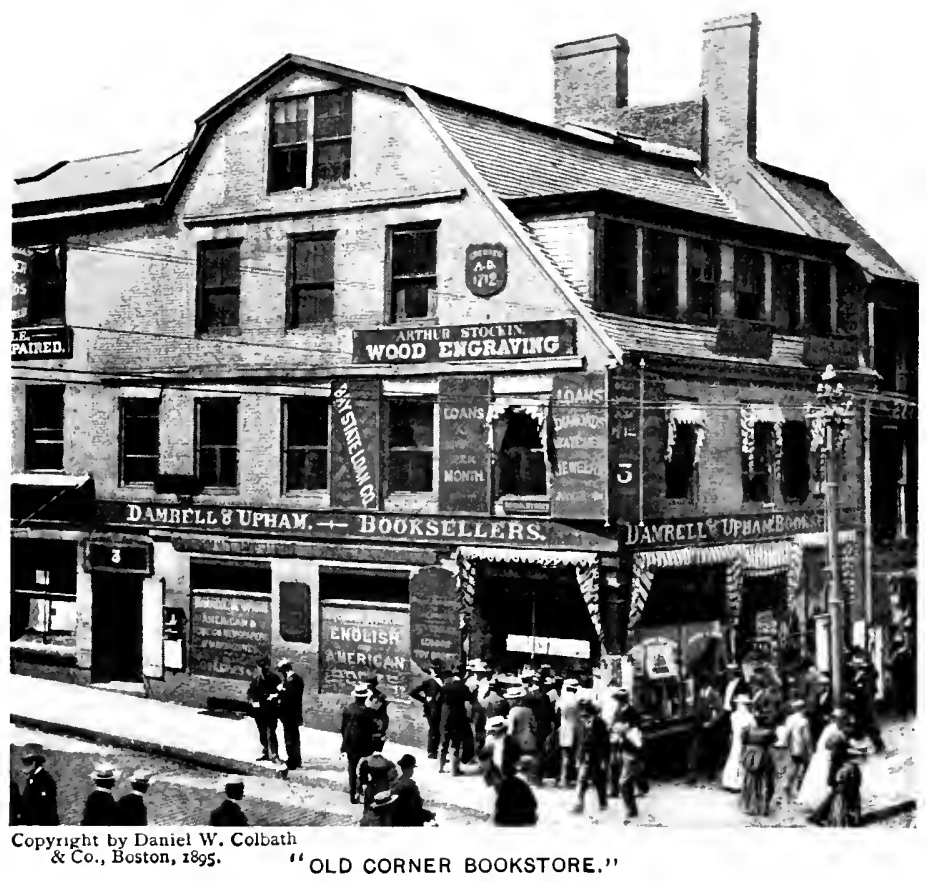


community might scornfully use about the Bostonian the saying attributed to Dr. Johnson about the Scotchman, that "much might be made of him if caught young." Indeed, much of New York's best literary material came always from New England; just as Scotland still holds its own in London literature. No doubt each place has its advantages, but there was a time when one might easily meet in a day, in one Boston bookstore-as, for instance, in the "Old Corner Bookstore," built in I 7 I 2, and still used for the same trade-such men as Emerson, Parker, Longfellow, Lowell, Holmes, Whittier, Sumner, Agassiz, Parkman, Whipple, Hale, Aldrich, and Howells; such women as Lydia Maria Child and Julia WVard Howe. Now, if we consider how much of American literature is represented by these few names, it is evident that if Boston was never metropolitan, it at least had a combination of literary ability such as no larger American city has yet rivalled.

I remember vividly an occasion when I was required to select a high-school assistant for the city where I then lived (Newport, Rhode Island), and I had appointed meetings with several candidates at the bookstore of Fields \& Osgood at Boston. While I was talking 


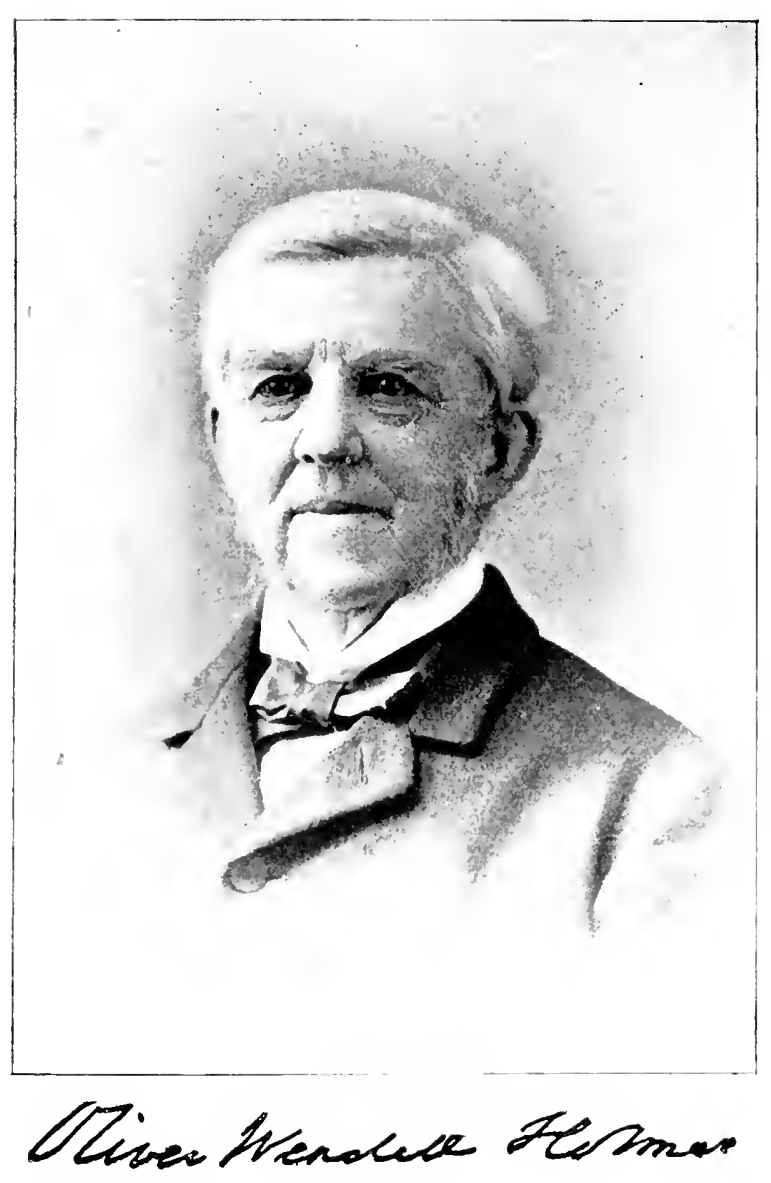

177 
with the most promising of these-the daughter of a clergyman in northern Vermont-I saw Dr. O. IV. Holmes pass through the shop, and pointed him out to her. She gazed eagerly after him until he was out of sight, and then said, drawing a long breath, "I must write to my father and sister about this! $U_{p}$ in Peacham we think a great deal of authors!"

Certainly a procession of foreign princes or American millionaires would have impressed her and her correspondents far less. It was like the feeling that Americans are apt to have when they first visit London or Paris and see -in Willis's phrase-_."whole shelves of their library walking about in coats and gowns"; and, strange as it may seem, every winter brings to Boston a multitude of young people whose expressed sensations are very much like those felt by Americans when they first cross the ocean.

The very irregularity of the city adds to its attraction, since most of our newer cities are apt to look too regular and too monotonous. Foreign dialects have greatly increased within a few years; for although the German element has never been large, the Italian population is constantly increasing, and makes itself very appar- 


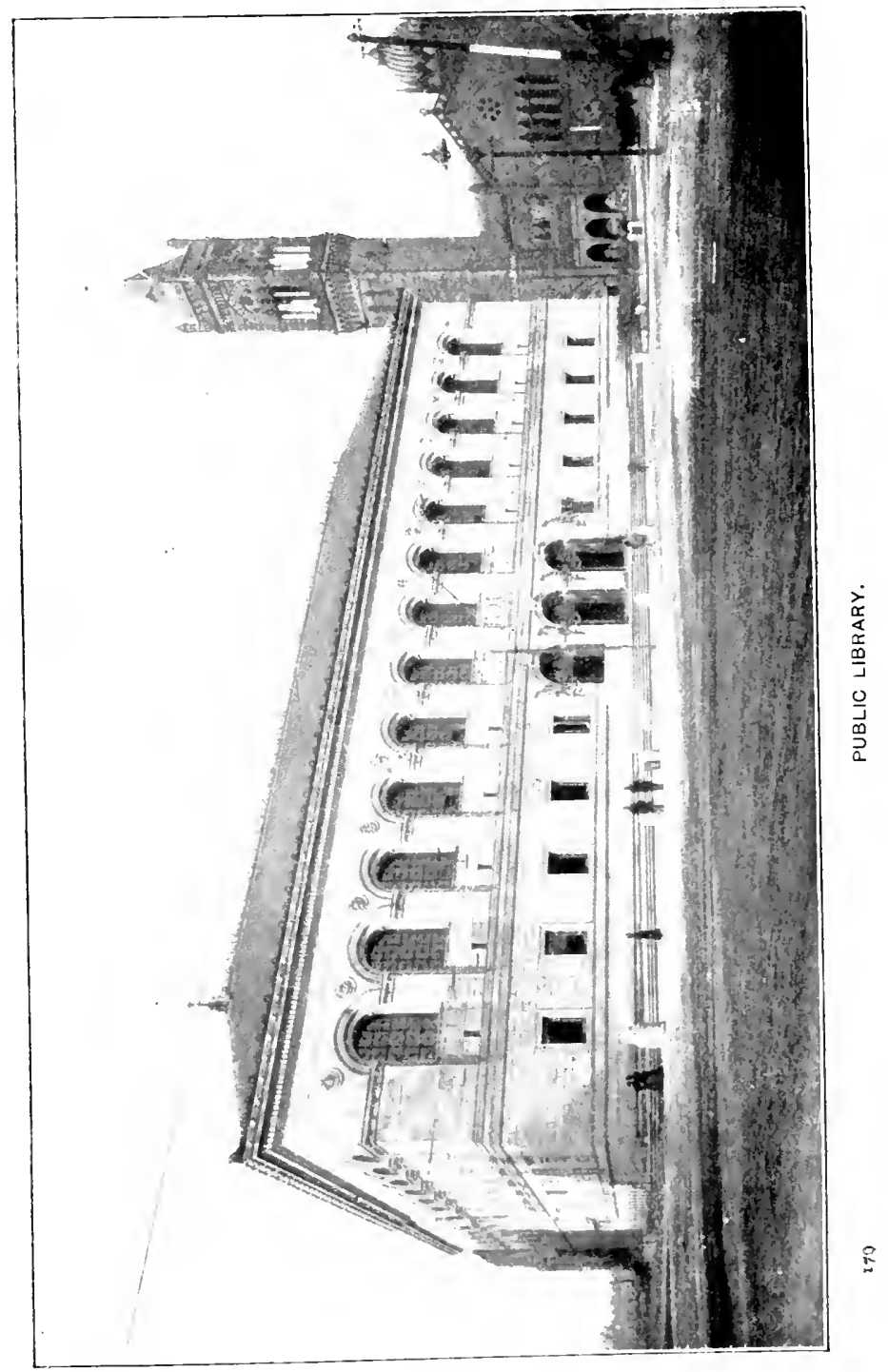


ent to the ear, as does also latterly the Russian. Books and newspapers in this last tongue are always in demand. Statues of eminent Bostonians-IVinthrop, Franklin, Samuel Adams, Webster, Garrison, Everett, Horace Mann, and others-are distributed about the city, and though not always beautiful as examples of art, are suggestive of dignified memories. Institutions of importance are on all sides, and though these are not different in kind from those now numerous in all vigorous American cities, yet in Boston they often claim a longer date or more historic associations. The great Public Library still leads American institutions of its class; and the Art Museum had a similar leadership until the rapid expansion of the Metropolitan Museum of New York City. The Massachusetts Institute of Technology and the New England Conservatory of Music educate large numbers of pupils from all parts of the Union; while Boston University and Boston College hold an honored place among their respective constituencies. Harvard University, Tufts College, and Wellesley College are not far distant. The Boston Athenæum is an admirable model of a society library. The public-school system of Boston has in 
times past had a great reputation, and still retains it; though it is claimed that the newer systems of the Western States are in some degree surpassing it. The Normal Art School of the State is in Boston; and the city has its own Normal School for common-school teachers. The free lectures of the Lowell Institute are a source of instruction to large numbers every season ; and there are schools and classes in various directions, maintained from the same foundation. The great collections of the Boston Society of Natural History are open to the public; and the Bostonian Society has been unwearied in its efforts to preserve and exhibit all memorials of local history. The Massachusetts Historical Society includes among its possessions the remarkable private library of Thomas Dowse, which was regarded as one of the wonders of Cambridge fifty years ago, and it possesses also the invaluable manuscript collections brought together by Francis Parkman when preparing his great series of histories. The New England Historic-Genealogical Society has a vast and varied store of materials in the way of local and genealogical annals; and the Loyal Legion has a library and museum of war memorials. 
For many years there has been in Boston a strong interest in physical education-an interest which has passed through various phases, but is now manifested in such strong institutions as the Athletic

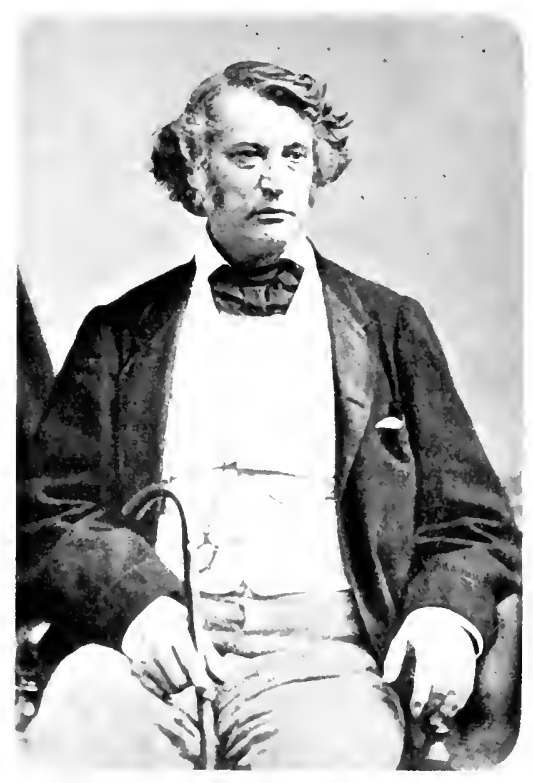

CHARLES SUMNER.

Club and the Country Clubthe latter for rural recreation. There is at Charlesbank, besicle the Charles River, a public open-air gym nasi um which attracts a large constituency : and there is, what is especially desirable, a class for women and children, with private grounds and buildings. It is under most efficient supervision, and is accomplishing great good. There are some ten playgrounds kept open at unused schoolhouses during the 
summer vacations, these being fitted up with swings, sand-pens, and sometimes flower-beds, and properly superintended. A great system of parks has now been planned, and partly established, around Boston, the largest of these being Franklin Park, near Egleston Square; while the system includes also the Arnold Arboretum, the grounds around Chestnut Hill Reservoir and Jamaica Pond, with a Marine Park at South Boston. Most of these are easily accessible by steam or electric cars, which are now reached from the heart of the city, in many cases through subways, and will soon be supplemented or superseded, on the more important routes, by elevated roads. The steam railways of the city are also to have their stations combined into a Northern and a Southern Union Station, of which the former is already in use and the latter in process of construction.

This paper is not designed to be a catalogue of the public institutions and philanthropies of Boston, but aims merely to suggest a few of the characteristic forms which such activities have taken. Nor is it written with the desire to praise Boston above her sisters among American cities ; for it is a characteristic of American 
society that, in spite of the outward uniformity attributed to the nation, each city has never-

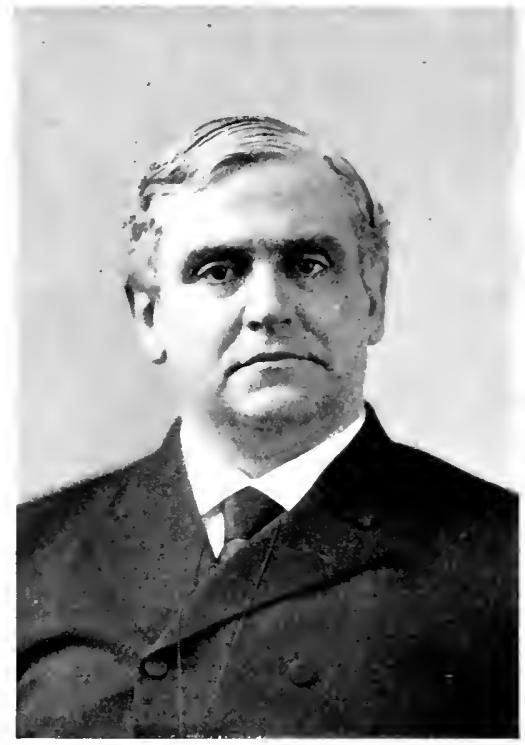

Copyright by H. G. Smith, Boston, 1893 .

PHILLIPS BROOKS. theless its own characteristics; and each may often learn from the others. This is simply one of a series of papers, each with a specific subject and each confined to its own theme. The inns, the theatres, the club-houses of a city, strangers are likely to discover for themselves; but there are further objects of interest not always so accessible. For want of a friendly guide, they may miss what would most interest them. It is now nearly two hundred years since an English traveller named Edward Ward thus described the Boston of I699: 


\section{Boston}

"On the southwest side of Massachusetts Bay is Boston, whose name is taken from a town in Lincolnshire, and is the metropolis of all New England. The houses in some parts joyn, as in London. The buildings, like their women, being neat and handsome. And their streets, like the hearts of the male inhabitants, being paved with pebble."

The leadership of Boston in a thousand works of charity and kindness, during these two centuries, has completely refuted the hasty censure of this roving Englishman; and it is to be hoped that the Boston of the future, like the Boston of the past, will do its fair share in the development of that ampler American civilization of which all present achievements suggest only the promise and the dawn.

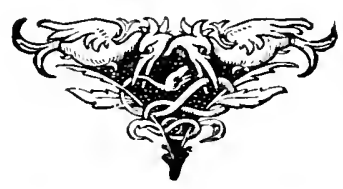


- 


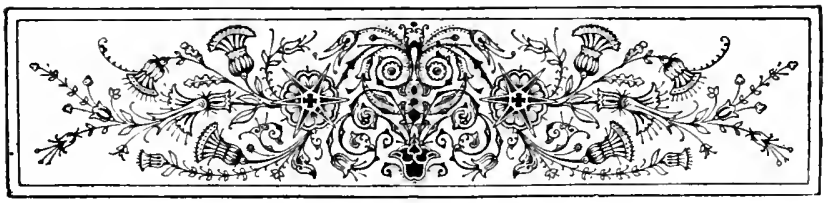

\section{REVOLUTIONARY BOSTON}

"Then and there American Independence was born."

\section{BY EDWARD EVERETT HALE}

THE American Revolution began in Boston. ning. John Adams says of Otis's speech in I76I in the Council Chamber of the Old State House, "Then and there American Independence was born." The visitor to Boston should go, very early in his visit, into the Old State House; and when he stands in the Council Chamber he will remember that as distinguished a person as John Adams fixed that place as the birthplace of independence.

But one does not understand the history of the opening of the great struggle without going back a whole generation. It was in I 745 that Governor William Shirley addressed the Massachusetts General Court in a secret session. He brought before them a plan 
which he had for the conquest of Louisburg in the next spring, before it could be reinforced from France. The General Court (which means the general assembly of Massachusetts) at first doubted the possibility of success of so bold an attempt; but eventually Shirley persuaded them to undertake it. The Province of New Hampshire and that of Connecticut co-operated, and their army of provincials, with some assistance from Warren of the English navy, took Louisbourg, which capitulated on the I 7 th of June, I745. Observe that the $I 7$ th of June is St. Botolph's day; and that he is the godfather of Boston.

When Louis XV. was told that this handful of provincials had taken the Gibraltar of America, he was very angry. In the next spring, the spring of 1746 , with a promptness and secrecy which make us respect the administration of the French navy, a squadron of more than forty ships of war, and transports sufficient to bring an army of three thousand men, was fitted out in France and despatched to America, with the definite and acknowledged purpose of wiping Boston from the face of the earth: 


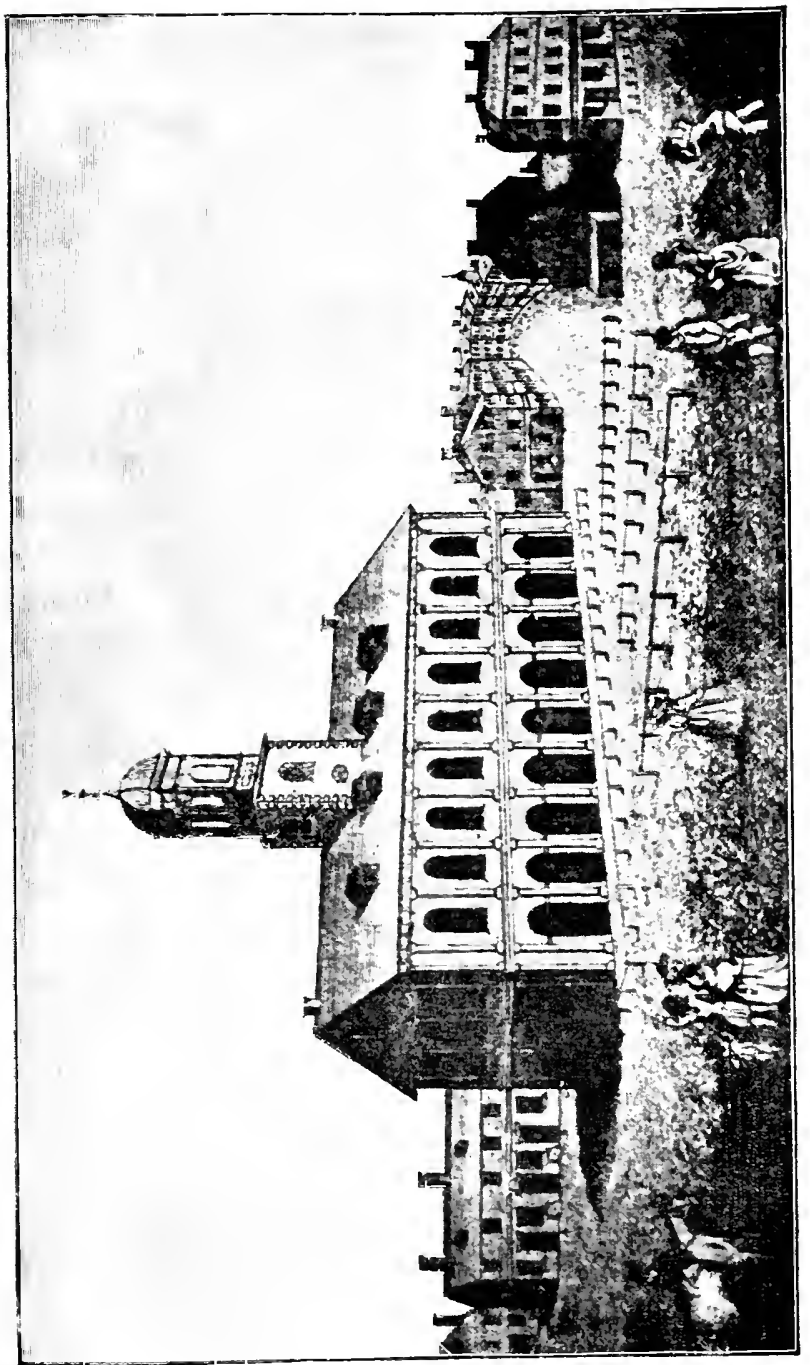

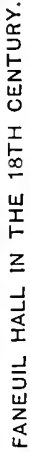


"For this Admiral D'Anville

Had sworn by cross and crown

To ravage with fire and steel

Our helpless Boston town."

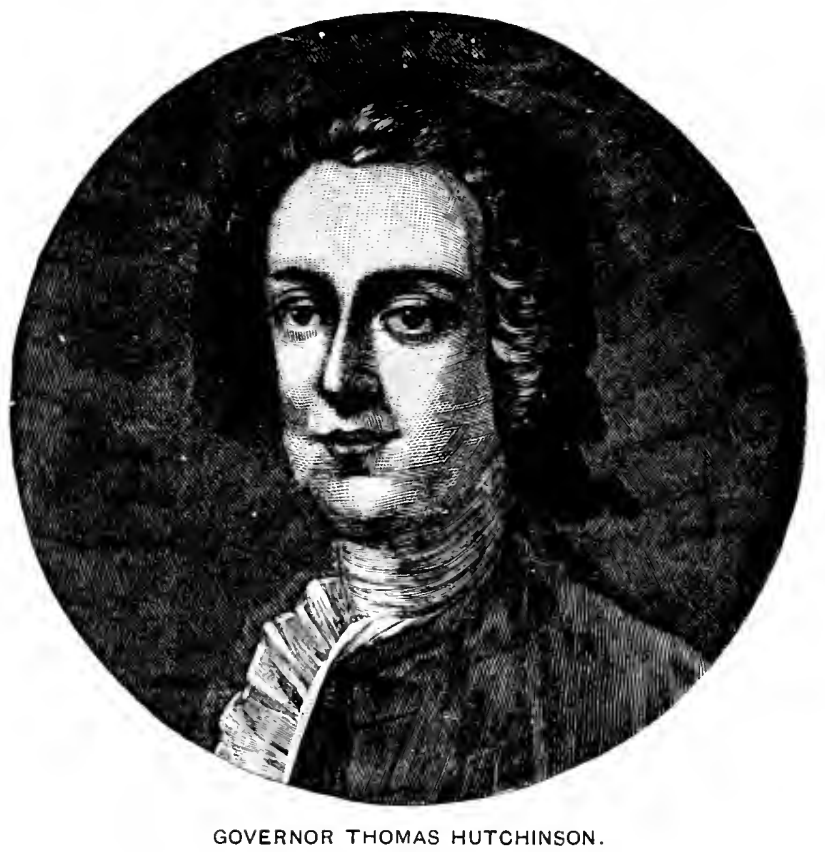

AFTER A PORTRAIT IN POSSESSION OF THE MASSACHUSETTS HISTORICAL SOCIETY, ONCE THE PROPERTY OF JONATHAN MAYHEW.

It was a disgrace to the military and naval organizations of England at the same time, that they had so little information there on the subject. 
They found out at last that this immense French fleet had sailed or was sailing. I think that it was the strongest expedition ever sent from Europe to America between Columbus's time and our own. Some blundering attempts to meet it were made by the English Admiralty. But their admiral had to make the lame excuse that seven times he tried to go to sea and seven times he was driven back by gales. Whatever the gales were, they did not stop D'Anville and his Armada, and poor Boston, which was to be destroyed, our clear little "town of hen-coops," clustering around the mill-pond, knew as little of the fate prepared for it as the British Admiralty. It was not until the month of September, I 746, that a fishing-boat from the Banks, crowding all sail, came into Boston and reported to Governor Shirley that her men had seen the largest fleet of the largest vessels which they had ever seen in their lives, and that these were French vessels. Shirley at once called his Council together and "summoned the train bands of the Province." The Council sank ships laden with stones in the channels of the harbor. Hasty fortifications were built upon the islands, and Shirley mounted upon them such guns as he 
could bring together. The "train bands" of the Province promptly obeyed the call, and for the next two months near seven thousand soldiers were encamped on Boston Common, ready for any movement which the descent of D'Anville might require. Cautious, wise, and strong beyond any of his successors in his office, Shirley put his hand upon the throttle of the newspapers. D'Anville should not learn, nor should anybody learn, that he had an army in Boston or that he knew his danger. And so you may read the modest files of the Boston papers of that day and you shall find no reference to these military movements of which every man and woman and child in Boston was thinking. It is not till his young wife dies that, by some accident in an editorial room, the confession slips into print that the train bands of the Province accompanied her body to its grave.

It was the only military duty which was required of that army of six thousand four hundred. The people of the times would have told you, every man and woman of them, that the Lord of Hosts had other methods for defending Boston.

What happened, or, if you please, what tran- 


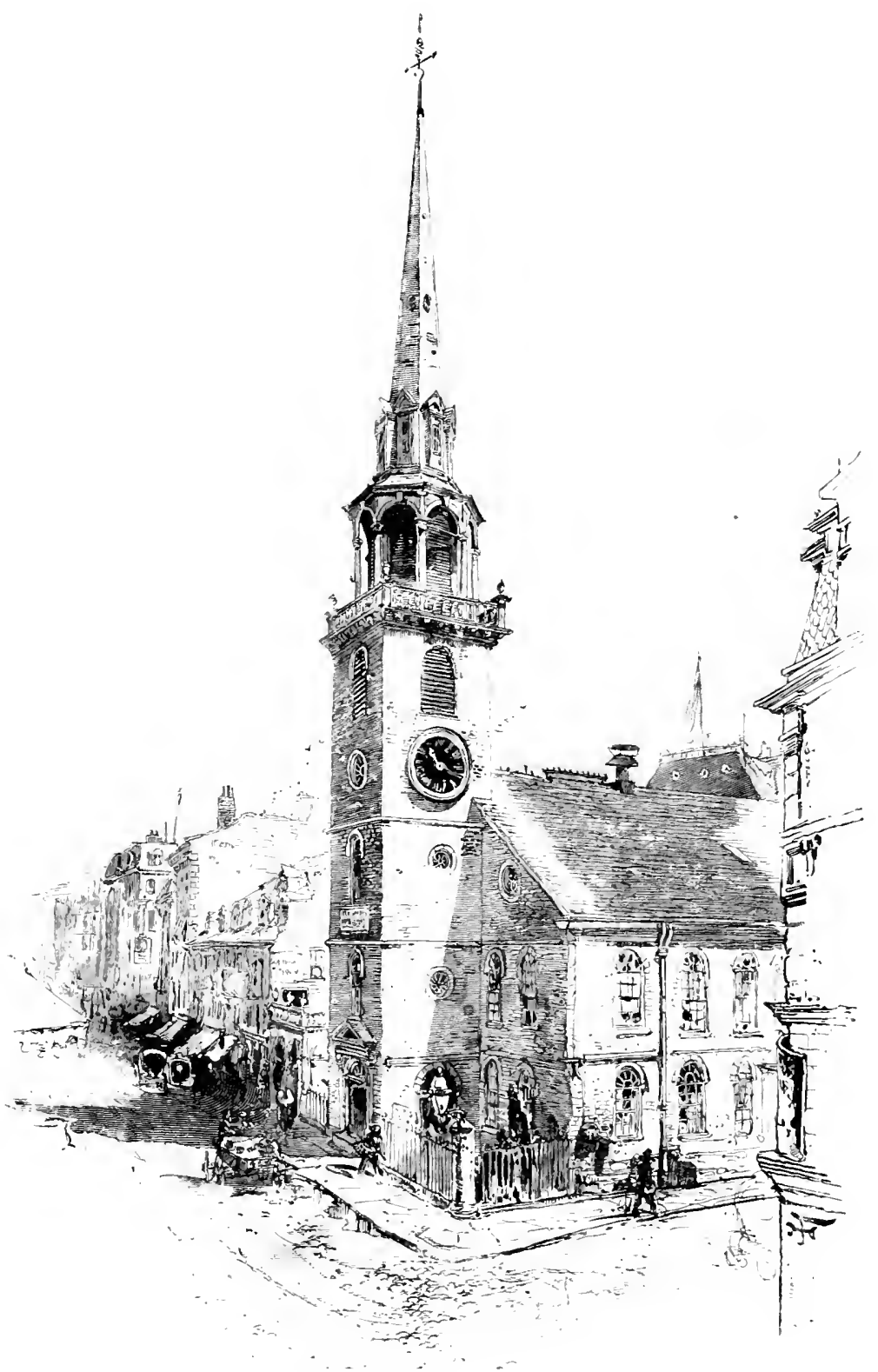

THE OLD SOUTH CHURCH IN ITS PRESENT CONDITION. 
spired, was this: Among his other preparations for his enemy, Shirley proclaimed a solemn Fast Day, in which the people should meet in all their meeting-houses and seek the help of the Almighty, and they did so. Thomas Prince, of the Old South Meetinghouse, tells us what happened there. In the morning, a crowded congregation joined in prayer, and Prince told them of their danger and exhorted them to their duty. In the afternoon the assembly met again. As Prince led them in their prayer, what seemed a hurricane from the southwest struck the meeting-house. A generation after, men remembered how the steeple above them shook in the gale, and Prince went on, calmly, in his address to the God who rides on the whirlwind:

"We do not presume to advise, O Lord, but if Thy Providence requires that this tempest shall sweep the invaders from the sea, we shall be content."

And this was precisely what happened: This southwest gale tore down the Bay. This side Cape Sable, just off Grand Manan, it found D'Anville's squadron in its magnificent array. It drove ship against ship. It capsized and sank some of the noblest vessels. 
It tore the masts out of others. It discouraged their crews and their officers. All that was left of this gallant squadron (which was to burn our "hen-coops" here) took refuge in Halifax Bay or crept back under jury-masts to France. In the harbor of Chebucto, as they called Halifax, the wrecks of the fleet were repaired as best they might be. D'Anville and his first officer both died, one as a suicide, and the other from the disgrace of the discomfiture. It is said in Nova Scotia that you may see some of the ships now, if you will look down at the right place in the clear sea, off Cape Sable. A miserable handful of the vessels straggled back to France at the opening of the winter.

The colonists of New England had thus learned two lessons, one in I745, and one in I 746. In I 745 they had learned that without any assistance from their own king they could storm and take the strongest fortress in America. In I 746 they learned that the anger of the strongest prince in Europe was powerless against them. Those who believed in the immediate providence of God thought that $\mathrm{He}$ stretched out $\mathrm{His}$ arm in their defense. Those who did not, thought that in the general 
providence of God, a people who were three thousand miles away from the greatest sovereign of the world might safely defy his wrath. Curiously enough, in the next year, I 747 , the people of Boston had an opportunity to learn a third lesson by measuring strength with their own sovereign.

In that year Admiral Knowles, in command of the English squadron,-rather a favorite till then, I fancy, with the people here,- -happened to want seamen. He availed himself of that bit of unwritten law which held in England till within my own memory, by impressing seamen from the docks. A memorial of the General Court says that the English government had carried this matter so far that, as they believed, three thousand Americans were at that time in the service of the British navy, having been unwillingly impressed there. But Knowles carried it farther yet. He took on board his fleet some hundreds of shipcarpenters, mechanics, and laboring men; and Boston broke out into a blaze of excitement and fury. There followed the first of the series of proceedings which, with various modifications, lasted for thirty years, until General Howe withdrew the British fleet and army from 


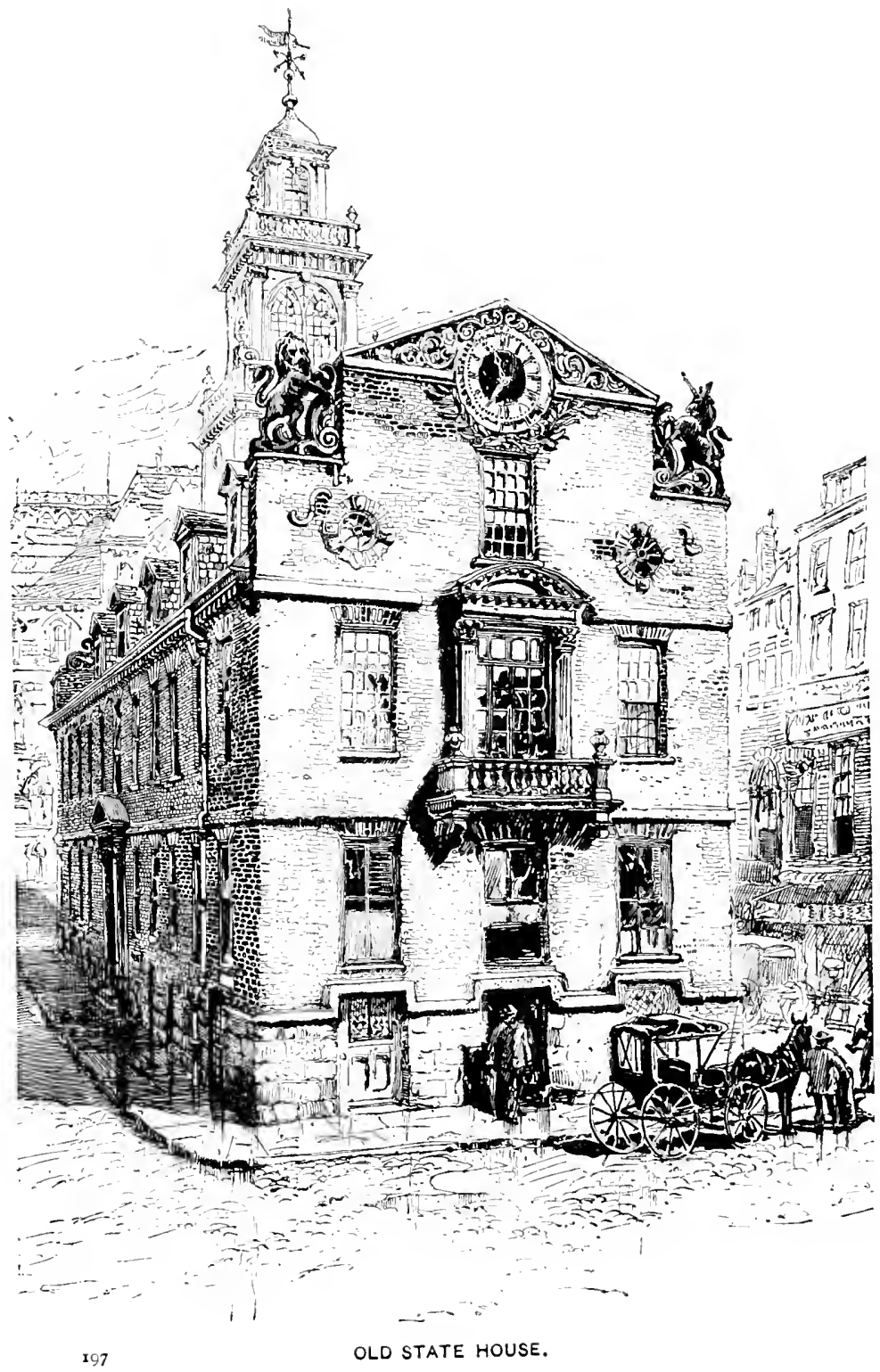


Boston. It was a combination of riots and town-meetings, the town-meetings expressing seriously what the rioters did not express so well, the rioters giving a certain emphasis, such as was understood in England, as to the intention of the town-meetings of Boston. We have the most amusing details of this affair in a very valuable and interesting history just published by Mr. John Noble. The rioters seized Knowles's officers whom they found in the town, and shut them up for hostages. Knowles declared that he would bombard the town. But what with the General Court and the town-meetings and the magistrates and the rest, he was soothed down, the people gave up their hostages, and he gave up the men whom he had seized. Boston had measured forces in this affair with King George. Both were satisfied with the result; and, if I may so speak, this first tussle ended in a tie.

Here were three trials of strength in three years. And the Boston people learned in each of them the elements of their real power. When, nearly twenty years after, Otis made his eloquent protest against the Writs of Assistance, he did not succeed. The Court 


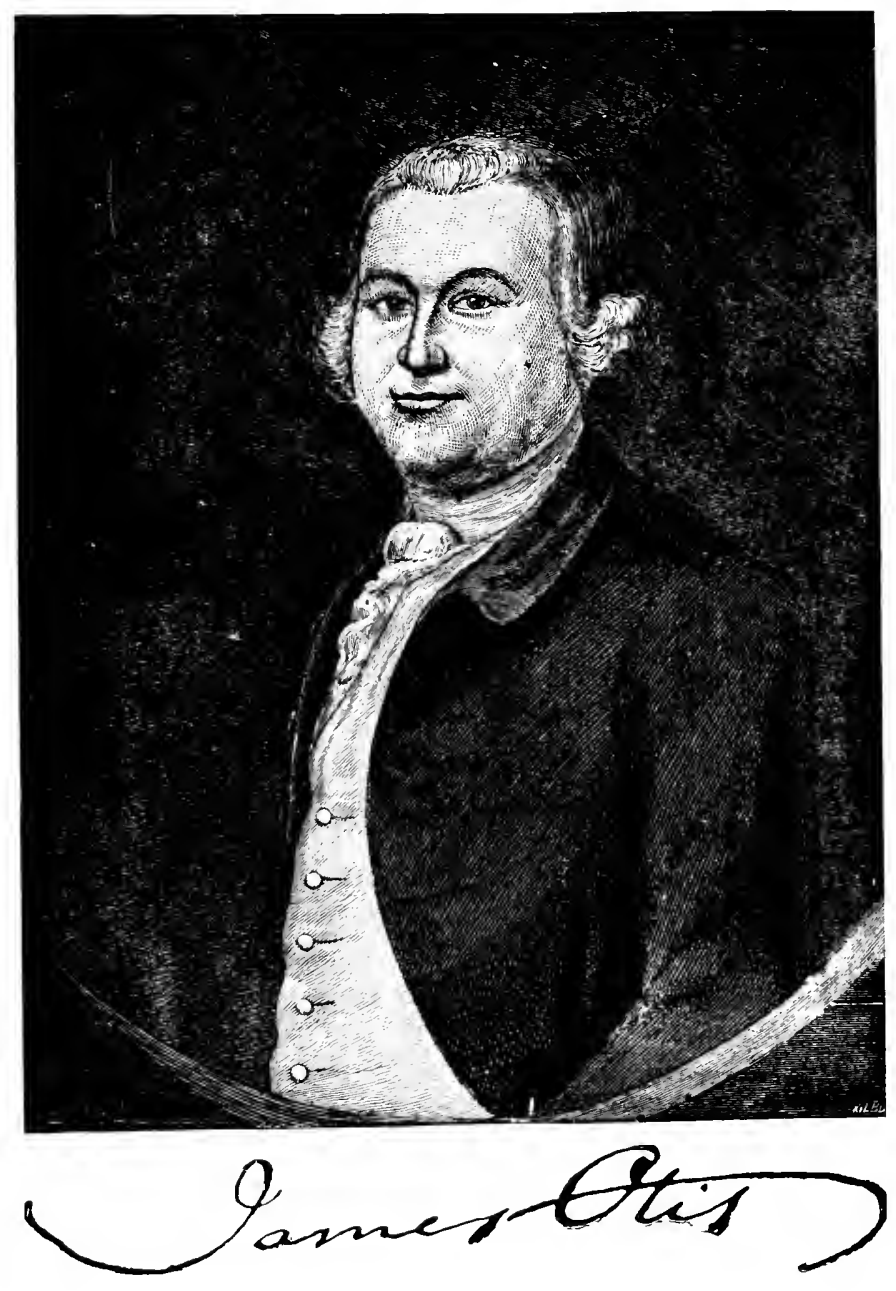


decided that the Province must permit the officers to make the searches in private houses which the Crown asked. But there was a point gained, in the confession that the Crown must ask, and thinking men took note of that confession.

"Sam" Adams, as he was always affectionately called, had graduated at Harvard College in I 740. There is no direct evidence known to me, but without it I believe that almost from that time Sam Adams was the inspiring genius of one or more private clubs in which the young men of Boston were trained in the fundamental principles of independence. On the other side it may be said that from the moment when Quebec fell the home government of England did everything that can be conceived of to disgust and alienate the people of Boston. The disgust showed itself now in grumbling, now in physical violence. In the midst of it all there was one quiet leader behind the scenes. Sam Adams had the confidence of the gentry and of the people both. When he wanted a grave and dignified expression of opinion he had a town-meeting called, and then this town-meeting heard speeches and passed resolutions of such dignity and 


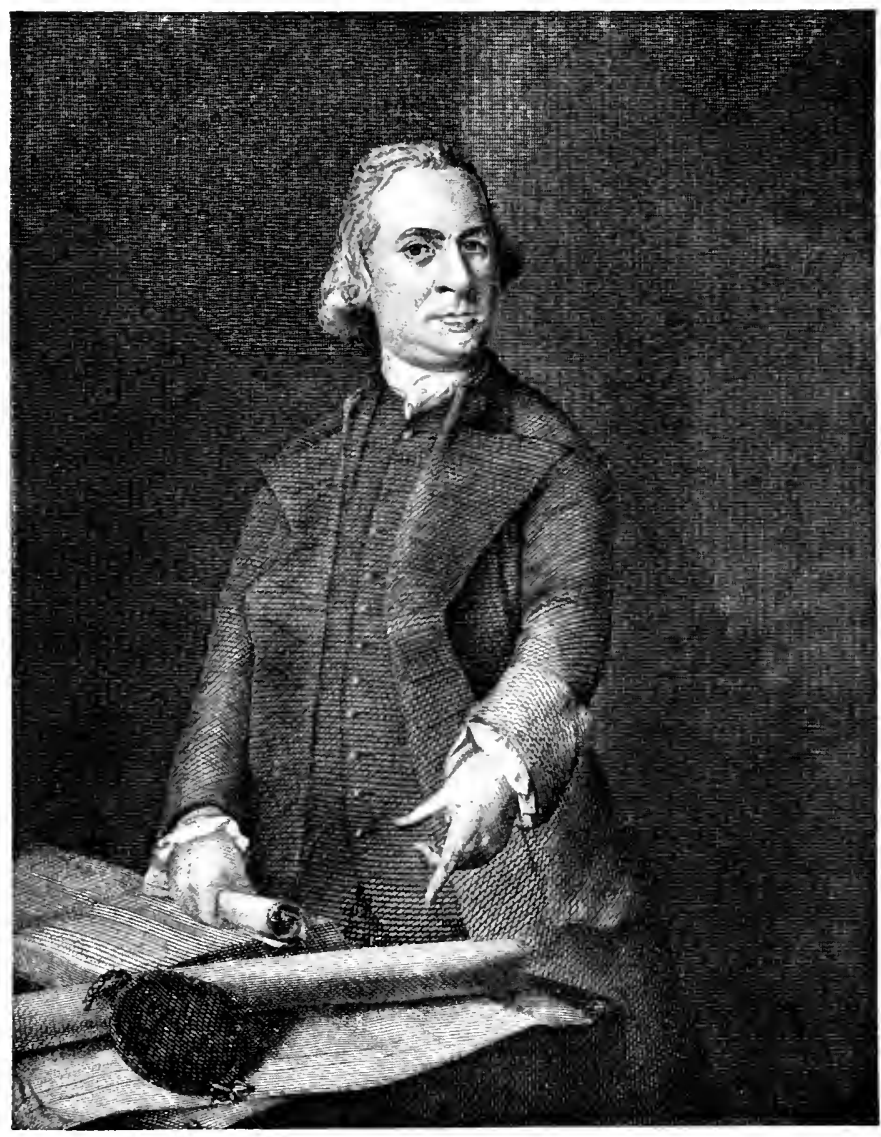

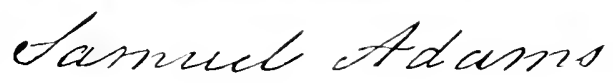


gravity as were worthy of any senate in the world. On the other hand, if Sam Adams needed to give emphasis to such resolution, the mob of Boston appeared in her streets, did what he wanted it to do, and stopped when he wanted it to stop. It is fair to say that George III.'s ministers lost their heads in their rage against the riots of Boston. The Boston Port Bill, the maddest and most useless act of vengeance, was aimed at the Boston mob; and yet in the thirty years between Louisbourg and Lexington this riotous mob of Boston never drew a drop of human blood in all its excesses. And this, though once and again the soldiers and sailors of England killed one and another of the people.

Now to follow along step by step the visible memorials of the war, I advise you to go to Roxbury through Washington Street by one of the Belt-line cars. The very name, Washington Street, should remind you that Washington rode in in triumph by this highway on the $17^{\text {th }}$ of March, I 776, the day when General Howe and the English troops evacuated the town. Let the car drop you at the Providence railway crossing in Roxbury and take another car to 


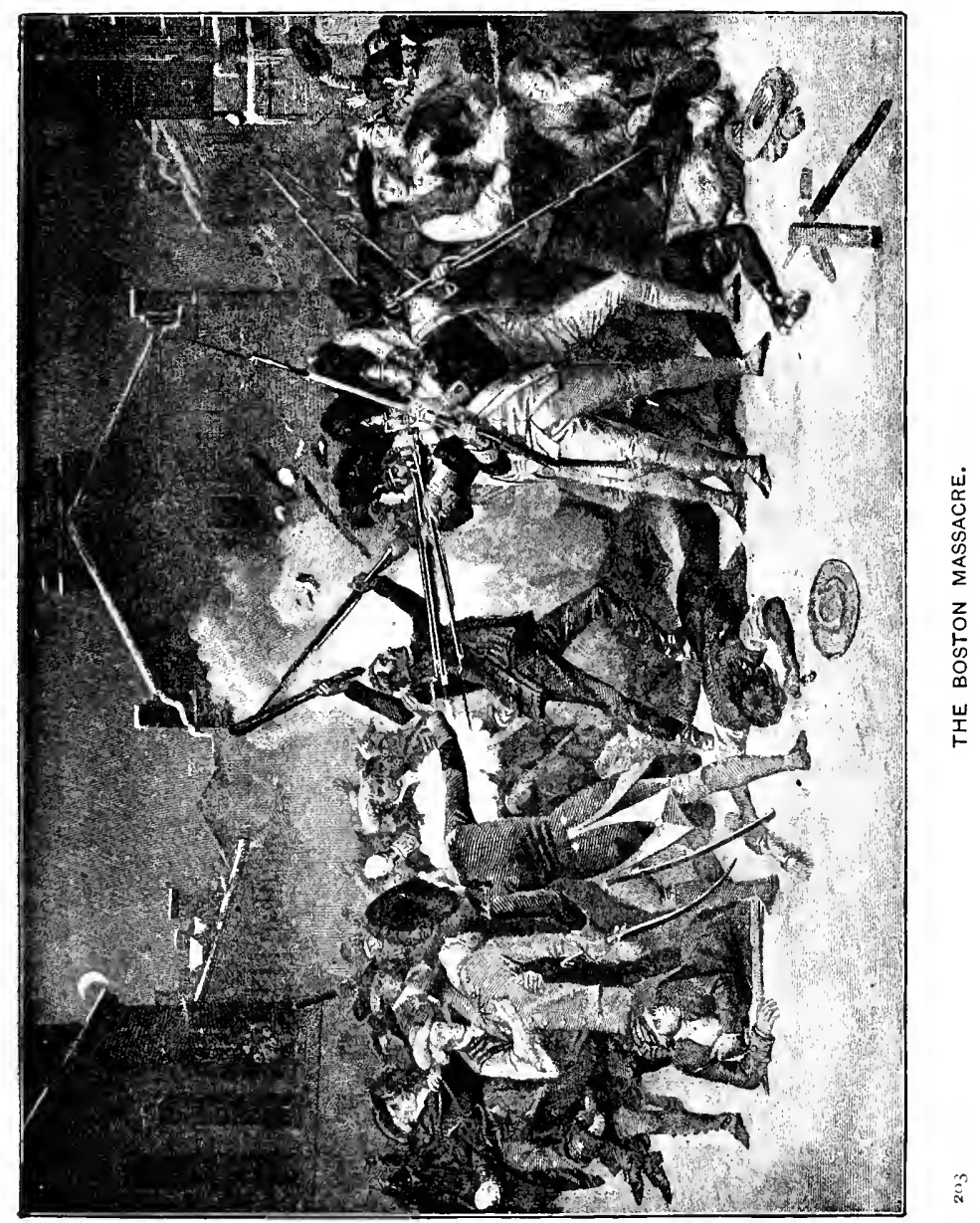


Brookline; or go on foot. All this time you have been on the track of the English general, Lord Percy, who was sent out with his column to reinforce Colonel Smith, who had charge of the earlier column sent against Concord, on the day of the battle of Lexington. You can, if you choose, on your wheel or on your feet, go into Cambridge with this column; but take care not to cross Charles River by the first bridge, but by that where the students' boathouses are, on the road which becomes Boylston Street as you enter Cambridge. You may then go on to Lexington and Concord.

On another day, start from Cambridge at the Law School. This stands on the very site of the old parsonage-Generai Ward's headquarters. The evening before the battle of Bunker Hill, Prescott's division was formed in parade here and joined in prayer with the minister of Cambridge before they marched to Bunker Hill. Anybody will show you Kirkland Street, which is the name now given to the beginning of "Milk Row," the road over which they crossed to Charlestown. If you are afraid to walk, take your wheel. Two miles, more or less, will bring you eastward to Charlestown Neck. Then turn to your right 


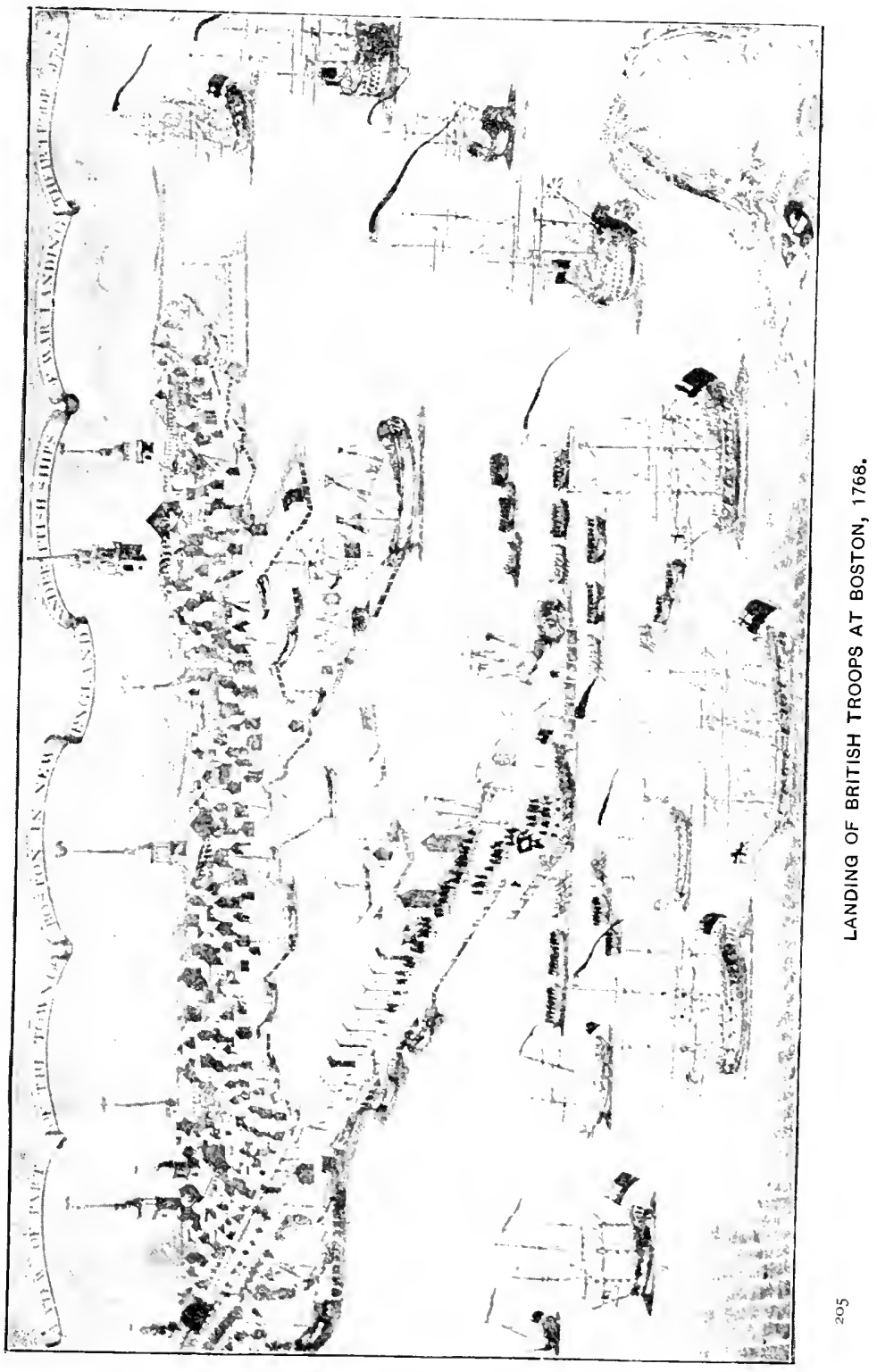


and walk to Bunker Hill Monument, which you can hardly fail to see.

It is quite worth while to ascend the monument. It gives you an excellent chance to obey Dr. Arnold's rule and study the topography on the spot. You cannot fail to see the United States Navy Yard just at your feet. Here Howe's forces gathered for the attack on Prescott's works on the day of the battle. And to the shore they retired after they were flung back in the first two unsuccessful attacks.

In the mad attack on Prescott's works, General Gage lost, in killed and wounded, one quarter of his little army. What was left became the half-starved garrison of Boston. I say " mad attack," because Gage had only to order a gunboat to close the retreat of the American force, and he could have starved it into surrender. But such delay was unworthy of the dignity of English generals, or, as they then called themselves, "British" generals. It is to be remembered that this use of the word "British," now much laughed at, was the fashionable habit of those times.

The date of the battle was June 17,1775 . Oddly enough, this had long been the saint's day of St. Botolph, the East Anglian saint 
for whom Boston in England was named. It seems probable, however, that this odd coincidence was never noticed for a hundred years. Since the majority of the people of Boston and Charlestown have been Catholics, it has attracted attention.

From that date to March I 7 , I 776, the date just now alluded to, Boston and the English army were blockaded by the American troops. They had gathered on the day after Lexington, commanded at first by Artemas Ward, the commander of the militia of Massachusetts, and afterwards by Washington, with Ward as his first major-general. The English retained their hold on Charlestown, but once and again the Americans attacked their forces there. They never marched out beyond Boston Neck or Charlestown Neck.

On the south, their most advanced works were where are now two little parks, Blackstone Square and Franklin Square, on the west and east sides of Washington Street, respectively. They had a square redoubt on the Common, where is now a monument to the heroes of the Civil War. A little eastward of this was a hill called Fox Hill, which was dug away to make the Charles Street of to-day. 
Farther west, where the ground is now covered with buildings, were two or three redoubts, generally called forts, by which they meant to prevent the landing of the Americans.

At that time Beacon Hill was much higher than it is now. Exactly on the point now marked by a monument, a monument was erected after the Revolution, in commemoration of the events of the year when it began. The present monument-completed lately-is an exact imitation of the first, but that this is of stone, and that was of brick. This has the old inscriptions.

Washington drove out the English by erecting the strong works on what was then called Dorchester Heights, which we now call South Boston. The places where most of these works existed are marked by inscriptions. Independence Square is on the site of one of them.

The careful traveller may go out to Roxbury, follow up Highland Street and turn to the right, and he will find an interesting memorial of one of the strong works built by General Ward. From this point, north and east, each of the towns preserves some relic of the same kind. In Cambridge one is marked 


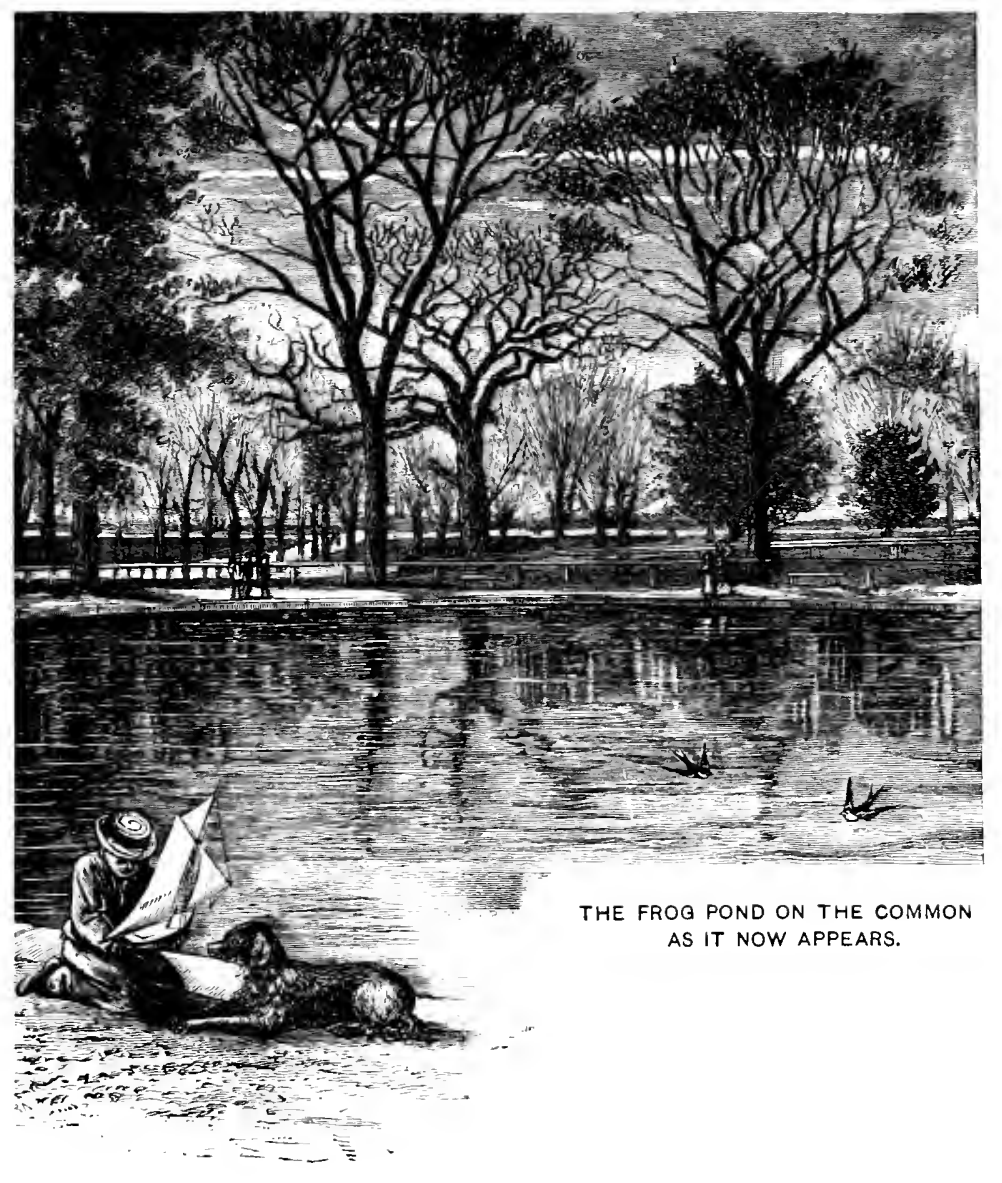




\section{0 Revolutionary Boston}

by a public square, on which the national flag is generally floating.

At the North End of Boston, where is now, and was then, the graveyard of Copp's Hill, the English threw up some batteries. These are now obliterated, but the point is interesting in Revolutionary history; because it was from this height that Gage and Burgoyne saw their men flung back by the withering fire of Bunker Hill.

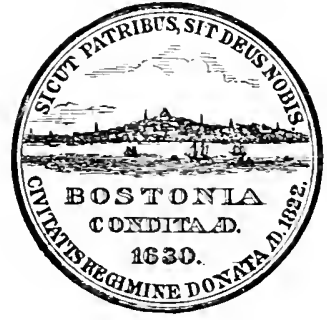




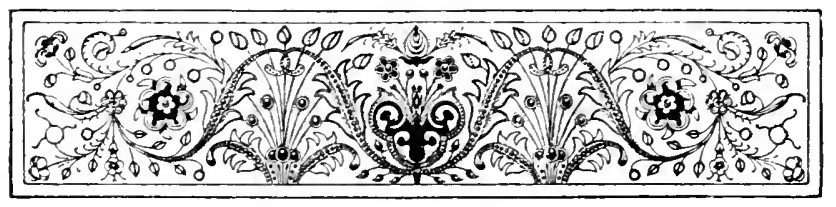

\title{
CAMBRIDGE
}

\author{
BY SAMUEL A. ELIOT
}

There is no place like it, no, not even for taxes."

Lowell's Letters, ii., ro2.

$\mathrm{HE}$ early history of New England seems
to many minds dry and unromantic. No mist of distance softens the harsh outlines, no mirage of tradition lifts events or characters into picturesque beauty, and there seems a poverty of sentiment. The transplanting of a people breaks the successions and associations of history. No memories of Crusader and Conqueror stir the imagination. Instead of the glitter of chivalry we have but the sombre homespun of Puritan peasants. Instead of the castles and cathedrals on which time has laid a hand of benediction we have but the rude log meeting-house and schoolhouse. Instead of Christmas merriment the voice of our past brings to us only the noise of axe and 
hammer, or the dreary droning of Psalms. It seems bleak, and destitute of poetic inspiration ; at once plebeian and prosaic.

But I cannot help feeling that if we look beneath the uncouth exterior we shall find in New England history much idealism, much that can inspire noble daring and feed the springs of romance. Out of the hard soil of the Puritan thought, out of the sterile rocks of the New England conscience, spring flowers of poetry. This story of the planting of Cambridge has-if I might linger on it-a wealth of dramatic interest, not indeed in its antiquity, - it is but a story of yesterday, - but in the human associations that belong to it and the patriotic memories it stirs. The Cambridge dust is eloquent of the long procession of saints and sages, scholars and poets, whose works and words have made the renown of the place. First the Puritan chiefs of Massachusetts; then the early scholars of the budding commonwealth; then the Tory gentry who made the town in the days before the Revolution the centre of a lavish hospitality, and who maintained a happy social life of which the memories still linger in the beautiful homes which they left behind them; then the patriot 


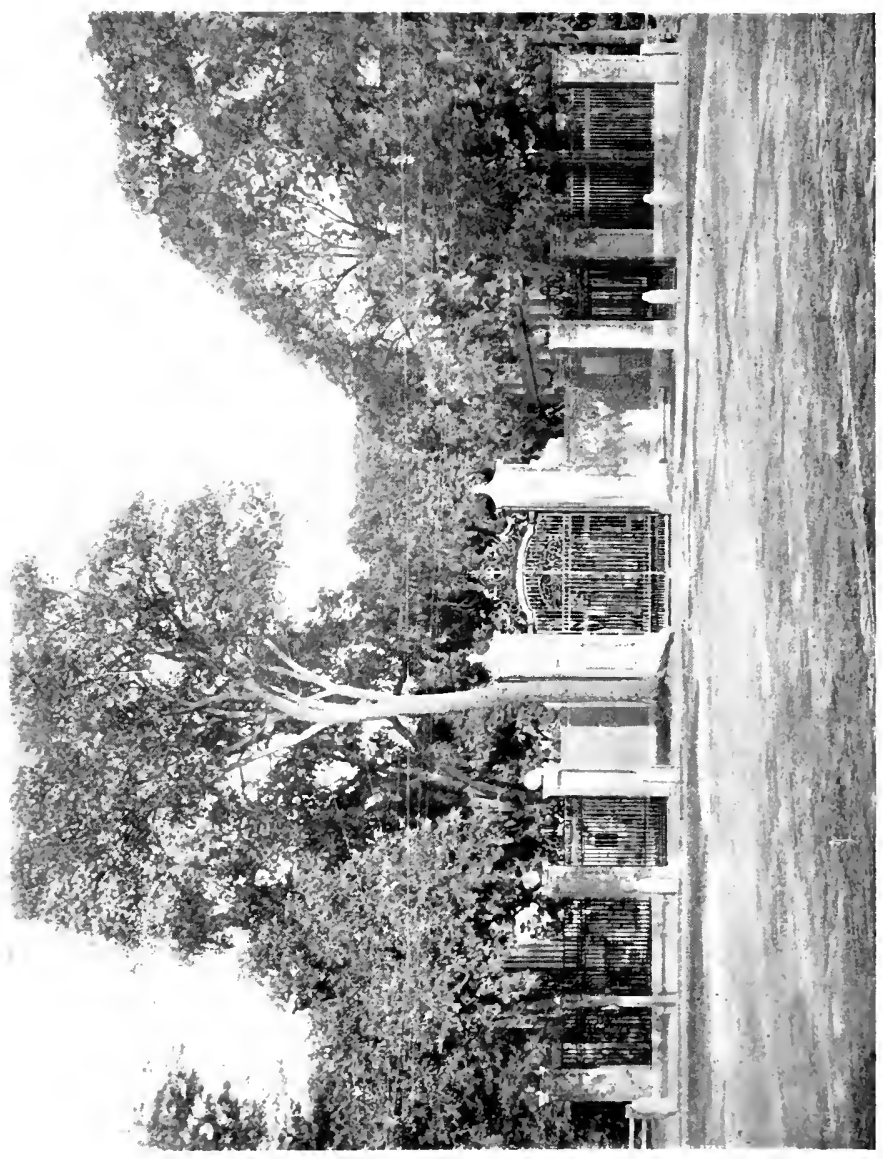

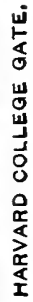


army surging about Boston in the exciting year of the siege, with the inspiring traditions of what Washington and Warren and Knox and Greene and the rest did and said; and finally the later associations of our great scholars and men of letters, chief of whom we rank Lowell and Holmes and Longfellow, whose lives were rooted deep in the Cambridge soil and whose dust there endears the sod.

The first figures on our Cambridge stage are those of the leaders of the Massachusetts colony. While Boston was clearly marked for prominence in the colony because of its geographical position, there was not at first the intention to make it the seat of government. It was too open to attack from the sea ; a position farther inland could be more easily defended, not indeed from the Indians, but from the enemy most to be dreaded,-the warships of an irate and hostile motherland. Accordingly Governor John Winthrop and his assistants, shortly after the planting of Boston. journeyed in the shallop of the ship in which they had come from England, four miles up the Charles River behind Boston until they came to a meadow gently sloping to the riverside, backed by rounded hills and protected 


\section{Cambridge}

by wide-spreading salt marshes. There on the 28 th of December, 1630 , they landed and fixed

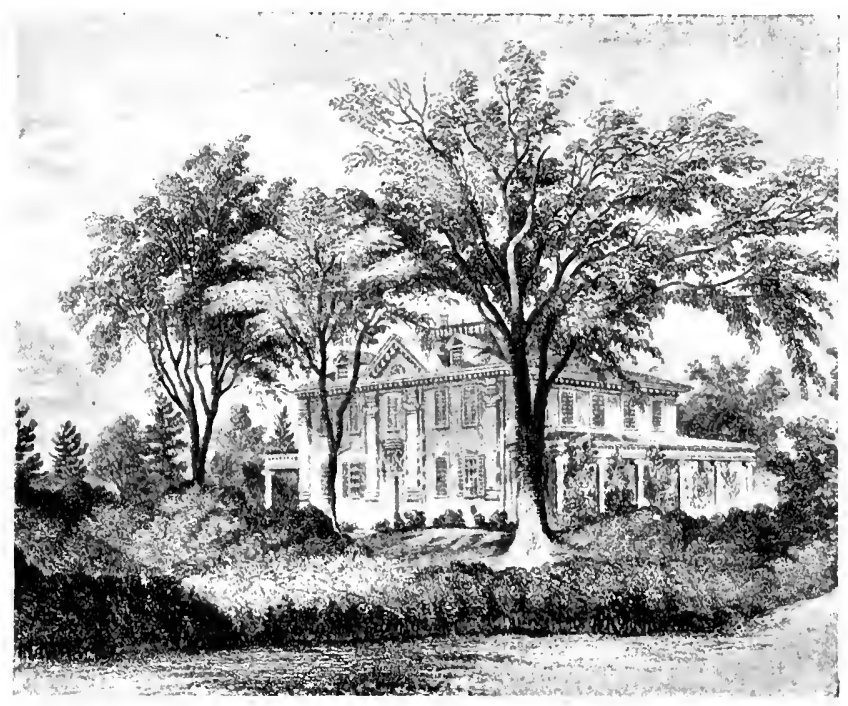

HOME OF LONGFELLOW.

the seat of their government. To quote the old chronicle :

"They rather made choice to enter further among the Indians than to hazard the fury of malignant adversaries who might pursue them, and therefore chose a place situated upon Charles River, between Charlestown and Watertown, where they erected a towne called Newtowne, and where they gathered the 8th Church of Christ." 
It was agreed that the Governor, John Winthrop, the Deputy Governor, Thomas Dudley, and all the councillors, except John Endicott, who had already settled at Salem, should build and occupy houses at Newtowne, but this agreement was never carried out. Winthrop, Dudley and Bradstreet built houses, and the General Court of the colony met alternately at Newtowne and at Boston until $1_{3} 8$, when it finally settled in Boston. Yet in spite of the superior advantages of Boston the new settlement evidently flourished, for in 1633 a traveller-the writer of New England's Prospect-describes the village as "one of the neatest and best compacted towns in New England, having many fair structures, with many handsome contrived streets. The inhabitants, most of them, are rich and well stored with cattle of all sorts."

This is doubtless an extravagant picture and true only in comparison with some of the neighboring plantations which were not so favorably situated. Newtowne was really a crude and straggling settlement made up of some sixty or seventy log cabins or poor frame houses stretching along a road which skirted the river marshes and of which the wanderings 


\section{Cambridge}

were prescribed more by the devious channel of the Charles than by mathematical exactness. The meeting-house, built of rough-hewn boards with the crevices sealed with mud, stood at the crossing of the road with the path that led down to the river, where there was a ladder for the convenience of landing. So primitive was the place that Thomas Dudley, the chief man of the town, writing home, could say, "I have no table nor any place to write in than by the fireside on my knee." Such was the splendor of the whilom capital of New England.

Like most of the Massachusetts towns, Cambridge began as a church. Though Dudley and Bradstreet and Haynes were high in the councils of the infant commonwealth, holding successively or simultaneously the offices of governor and military chief, yet the leading personality of the village was the minister. The roll of Cambridge ministers begins with the great name of Thomas Hooker, the founder of Connecticut, and the man who first visioned and did much to make possible our American democracy. Hooker, with his congregation from Braintree, in Essex, England, came to Massachusetts in $1_{6} 6_{2}$, and after a short stay 
at Mount Wollaston, settled at Newtowne, raising the population to nearly five hundred souls. But the stay of the Braintree church was short. Some adventurous spirits had penetrated the wilderness of the interior until they discovered the charm and fertility of the valley of the Connecticut, and soon Hooker and his company were impelled by " the strong bent of their spirits" to remove thither. They alleged, in petitioning the General Court for permission to remove, that their cattle were cramped for room in Newtowne, and that it behooved the English colonists to keep the Dutch out of Connecticut; but the real motive of the exodus was doubtless ecclesiastical. Hooker did not find himself altogether in accord with the Boston teacher, John Cotton. "Two such eminent stars," says Hubbard, writing in 1682 , "both of the first magnitude, though of different influence, could not well continue in one and the same orb." Hooker took the more liberal side in the antinomian controversy which had already begun to make trouble, and his subsequent conduct of affairs in Connecticut shows that he did not approve the Massachusetts policy of restricting the suffrage to church members. In the spring of 
1636 , therefore, Hooker and most of his congregation sold their possessions, and driving one hundred and sixty cattle before them, went on their way to the planting of Hartford and the founding of a new commonwealth.

This was the first of many separations by which Cambridge has become the mother of many sturdy children. The original boundaries of the town stretched from Dedham on the south all the way to the Merrimac River on the north. Gradually, by the gathering of new churches and peaceable partition, this territory has been divided, and out of the original Newtowne have been formed, besides the present Cambridge, Billerica, Bedford, Lexington, Arlington, Brighton and Newton. Governors Dudley and Bradstreet removed to Ipswich, and Simon Willard went to be the chief layman of Concord and a famous builder and defender of towns.

The rude houses of Hooker's congregation were bought by a newly arrived company, the flock of the Rev. Thomas Shepard. This firm but gentle leader, who left a deep impress on the habit of the town, was a youth of thirty-one, and a graduate, like many of the Massachusetts leaders, of Emanuel College, at 
Cambridge. He came to New England with a company of earnest followers, actuated, as he wrote, by desire for "the fruition of God's ordinances. Though my motives were mixed, and I looked much to my own quiet, yet the Lord let me see the glory of liberty in New England, and made me purpose to live among God's people as one come from the dead to His praise." His brave young wife died " in unspeakable joy" only a fortnight after his settlement at Cambridge, and was soon followed by the chief man of his flock and his closest friend, Roger Harlakenden, another godly youth of the manly type of English pioneers. At once, too, Shepard was plunged into the stormy debates of the antinomian controversy which nearly caused a permanent division in the Congregational churches. The general election of 1637 , which was held on the Common at Newtowne, was a tumultuous gathering, and discussion over the merits of "grace" and "works" ran high till John Wilson, minister of the Boston church, climbed up into a big oak tree, and made a speech which carried the day for John Winthrop to the confusion of the heretical disciples of Anne Hutchinson. Through these stormy waters Shepard 


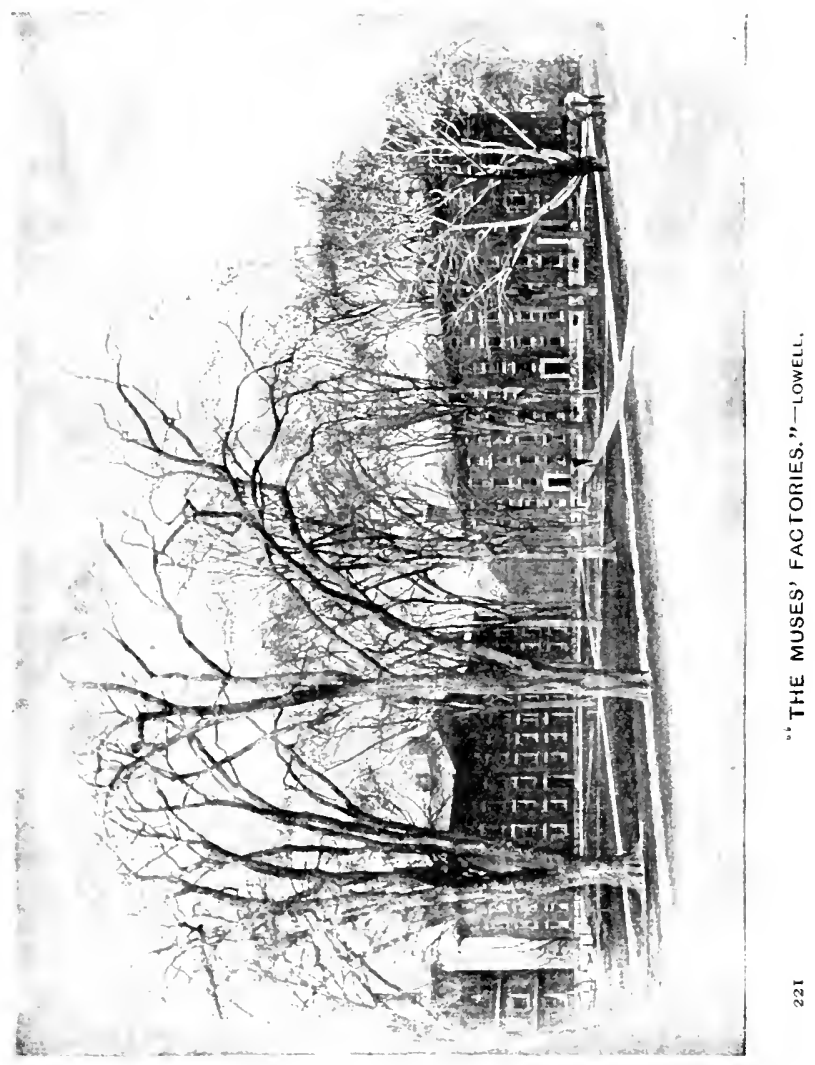


steered his course so discreetly that he came into high favor among all people as a sound and vigilant minister, and Cotton Mather tells us that "it was with a respect unto this rigilancy and the enlightening and powerful minis. try of Mr. Shepard, that, when the foundation of a college was to be laid, Cambridge, rather than any other place, was pitched upon to be the seat of that happy seminary."

The founding of Harvard College by the little colony was surely one of the most heroic, devout and fruitful events of American history. Upon the main entrance to the college grounds is written to-day an inscription taken from one of the earliest chronicles, entitled Now England's First Fruits. We read that:

"After God had carried us safe to New England and wee had builded our houses and provided necessaries for our livelihood, reared convenient places for God's worship and settled the Civil Government, one of the next things we longed for and looked after was to advance learning and perpetuate it to posterity, dreading to leave an illiterate ministry to the churches when our present ministers shall lie in the dust."

Accordingly, on the 28th day of October, I636, Sir Harry Vane-Milton's "Vane, young in years, but in sage counsel old"-being the 


\section{Cambridge}

Governor, the General Court of the colony passed the following memorable vote: "The Court agrees to give $£ 400$ towards a school or college-whereof $£ 200$ shall be paid the next year and $£ 200$ when the work is finished." In the following year this vote was supplemented by a further order that the college " is ordered to be at Newtowne, and that Newtowne shall henceforth be called Cambridge." This is the significant act that marks the distinction between the Puritan colony and all pioneer settlements based on material foundations. For a like spirit under like circumstances history will be searched in vain. Never were the bases of such a structure laid by a community of men so poor, and under such sullen and averted stars. The colony was nothing but a handful of settlers barely clinging to the wind-swept coast; it was feeble and insignificant, in danger from Indians on the one hand and foreign foes on the other ; it was in throes of dissension on the matter of heresy which threatened to divide it permanently, yet so resolved were the people that "the Commonwealth be furnished with knowing and understanding men and the churches with an able ministry," that they voted the entire 
annual income of the colony to establish a place of learning. Said Lowell :

"This act is second in real import to none that has happened in the Western hemisphere. The material growth of the colonies would have brought about their political separation from the mother country in the fulness of time, but the founding of the first college here saved New England from becoming a mere geographical expression. It did more, it insured our intellectual independence of the old world. That independence has been long in coming, but the chief names of those who have hastened its coming are written on the roll of Harvard College."

But even the self-sacrificing zeal of the colonists would have been almosi unavailing had it not been for the coming to Massachusetts at this time of a young Puritan minister, another graduate of Emanuel, upon whom death had already set his seal. Says the chronicler :

"As we were thinking and consulting how to effect this great work, it pleased God to stir up the heart of one Mr. John Harvard, a godly gentleman and a lover of learning then living amongst us, to bequeath the one half of his estate, in all about $\mathcal{E}_{1700 \text {, toward the erection }}$ of the college, and all his library."

Was ever a gift so marvellously multiplied as the bequest of this obscure young scholar? 


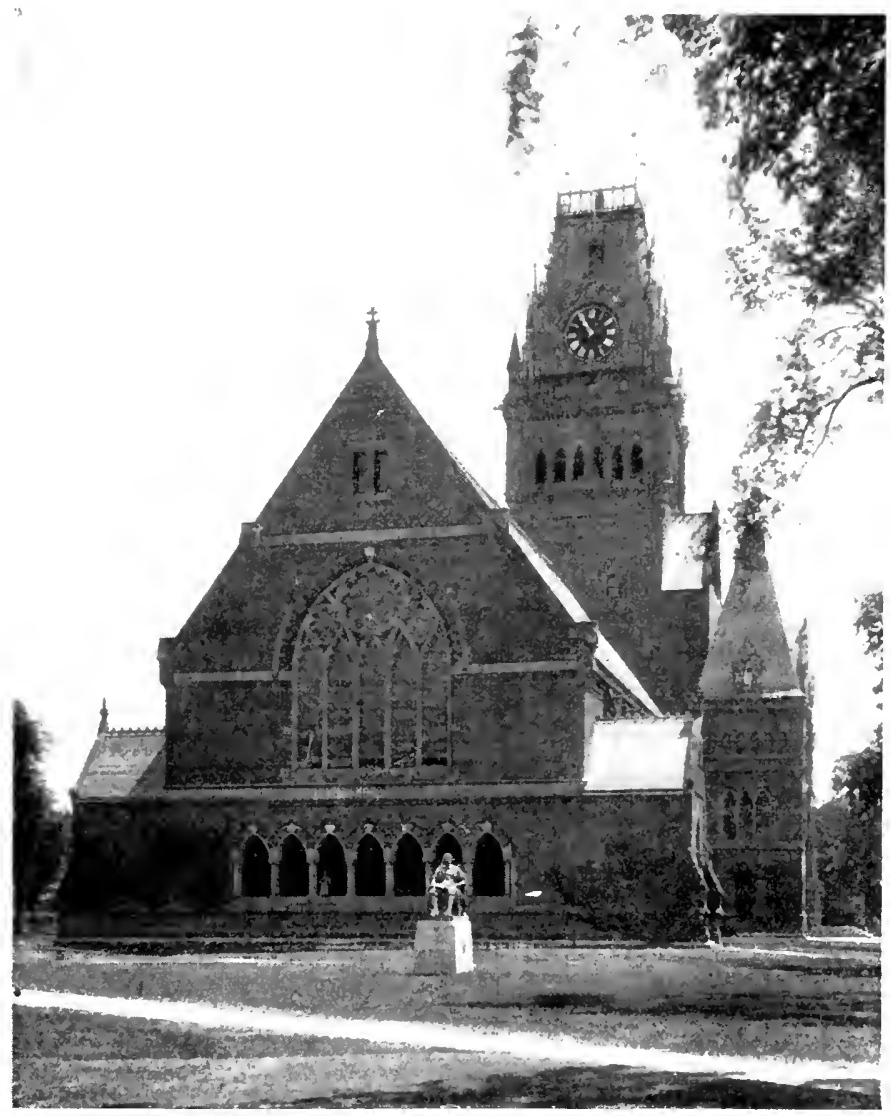

STATUE OF JOHN HARVARD AND MEMORIAL HALL, HARVARD COLLEGE. 
By this one decisive act of public-spirited and well-directed munificence this youth made for himself an imperishable name and enrolled limself among the foremost of the benefactors of humanity. In acknowledgment of Harvard's bequest the General Court voted in ${ }_{1} 6_{3} 8$ " that the College at Cambridge be called Harvard College."

It is the presence of the college that has given distinctive atmosphere to Cambridge. The character of the place has been determined by the fact that for more than two centuries and a half it has been the home of succeeding generations of men devoted not to trade and manufacture, but to the cultivation of the intellectual and spiritual elements in human life. Over the college gate stands an iron cross and upon the gate-post is the seal of the college with "Veritas" written across its open books. The Harvard life and spirit and teaching are all adapted to lead young men to the love and service of truth and to send them out to a ministry as wide and varied as the needs of humanity. The influence of the scholars and teachers and administrators that have been drawn into the service of the college is paramount, even if it is unconsciously 


\section{Cambridge}

exercised and felt, in the community about the college. Here have always been-inevitable in a town which is the resort of the chosen youth of the country - a healthy, wholesome independence of spirit and a high-minded earnestness. Here has always been the refined simplicity of life natural to a community composed of, or influenced by, men of quiet tastes and modest incomes. Here is that touch of sentiment which binds men to the place of their education and to the memories and friendships of youth. Here are the associations with great events and names which inspire patriotism and ambition of worthy service. Then, too, it has been said:

"Cambridge is an interesting place to live in because the poetry of Holmes, Longfellow and Lowell has touched with the light of genius some of its streets, houses, churches and graveyards, and made familiar to the imaginations of thousands of persons who never saw them, its rivers, marshes and bridges. It adds to the interest of living in any place that famous authors have walked in its streets, and loved its highways and byways, and written of its elms, willows and 'spreading chestnut tree,' of its robins and herons. 'The very names of Cambridge streets remind the dwellers in it of the biographies of Sparks, the sermons of Walker, the law-books of Story, the orations of Everett, and the presidencies of Dunster, Chauncy, Willard, Kirkland and Quincy." 
The place is not unworthy of the wealth of affection and poetic tribute that has been lavished upon it. The old Puritan church records, with their quaint entries about heresies and witchcraft, about ordinations where "four gallons of wine" and bushels of wheat and malt and hundredweights of beef and mutton were consumed, and about funerals conducted with solemn pomp; and the town records with notes about the "Palisadoe" and the Common rights and "the Cowyard" and the building of "The Great Bridge,"-a vast undertaking, - have more than merely antiquarian interest, for they reveal the intelligent and sturdy democracy and broad principles of government upon which the American republic rests.

But if these ancient records seem uninviting, let the visitor turn to the annals of the stirring time of the Revolution. General Gage called Harvard College "that nest of sedition." In that nest were hatched John Hancock, James Otis, Samuel Adams, John Adams, Joseph Warren and many another of the patriot leaders. The town was the abode of many of the leading Tory families, but as early as 1765 the town-meeting voted "that (with all humility) it is the opinion of the town that 


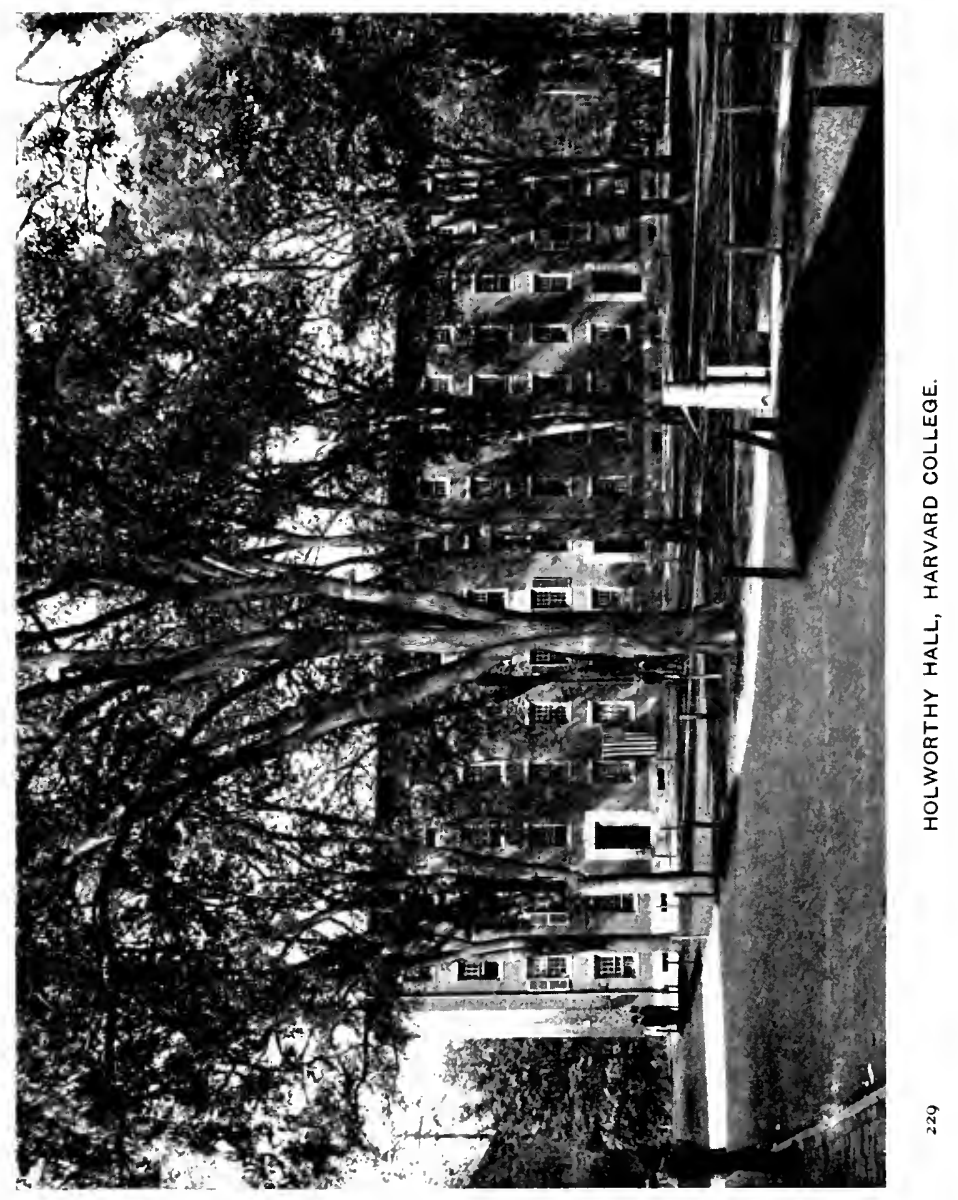


the inhabitants of this Province have a legal claim to all the natural, inherent, constitutional rights of Englishmen and-that the Stamp Act is an infraction upon these rights." And after an argument on the merits of the question it was further ordered "that this vote be recorded in the Town Book, that the children yet unborn may see the desire their ancestors had for their freedom and happiness." For the next ten years there is scarcely a proceeding in the preliminary debates and contests that led up to open revolution that is not illustrated in the resolutions recorded by the Cambridge town clerk. Vote followed vote, as the restrictive measures of Parliament irritated the townsmen, till at the town-meeting of 1773 it was resolved "that this town-is ready on the shortest notice, to join with the town of Boston and other towns, in any measures that may be thought proper, to deliver ourselves and posterity from slavery." The $2 \mathrm{~d}$ of September, 1774 , just escaped the historic importance of April igth in the next year. On that day several thousand men gathered on Cambridge Common and proceeded in orderly fashion to force the resignation of two of His Majesty's privy councillors, 
and then, marching up Brattle Street to the house of the Lieutenant-Governor of the Province, Thomas Oliver-the house that was afterwards the home in succession of Elbridge

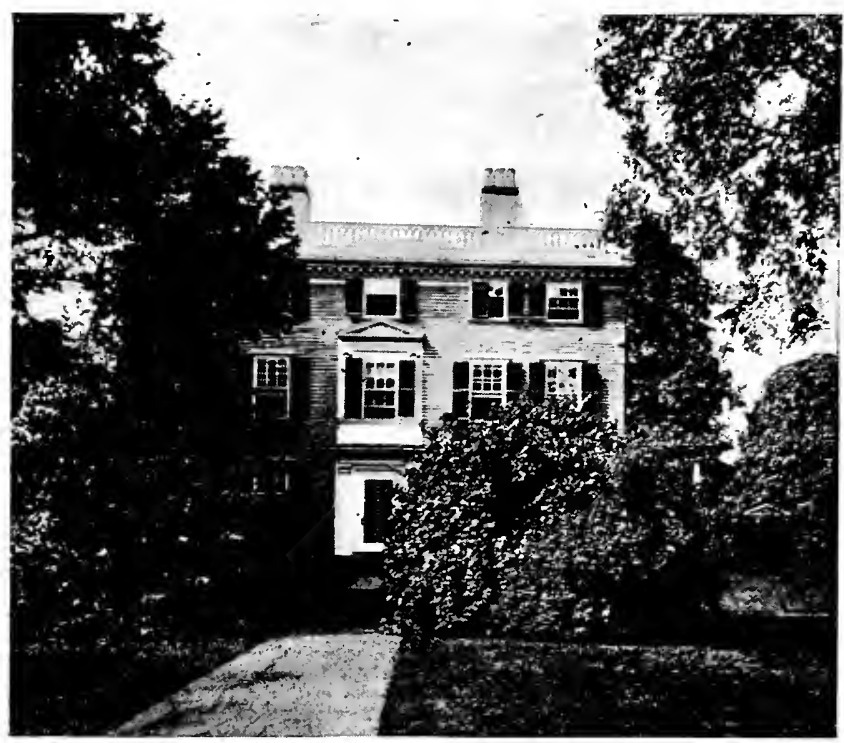

HOME OF LOWELL.

Gerry, Rev. Charles Lowell and his son James Russell Lowell - they extorted from him, too, a pledge to resign. "My house in Cambridge," he wrote, "being surrounded by about four thousand men, I sign my name- 
Thomas Oliver." Both the first and second of the Provincial Congresses met in Cambridge, and at last the running battle of April 19, 1775. swept through the borders of the town. Twenty-six Americans were killed within the boundaries of Cambridge, six of them citizens of the place, and the American militia who followed the British retreat from Concord on that momentous evening lay on their arms at last on Cambridge Common.

For eleven months after Concord fight, Cambridge was a fortified camp. The college buildings, the Episcopal church and the larger houses were occupied as barracks. General Ward established his headquarters in the gambrelroofed house which was afterwards the birthplace of Oliver Wendell Holmes. On the lawn before the house, in the hush of the June evening, Prescott's men were drawn up, while President Langdon of the college, in cap and gown, prayed for the success of their arms ere they marched to Bunker Hill. Two weeks later Washington reached the camp, and on July $3 \mathrm{~d}$, under the spreading elm at the western end of the Common, unsheathed his sword and, as the inscription reads, "took command of the American Army." Washington lived 


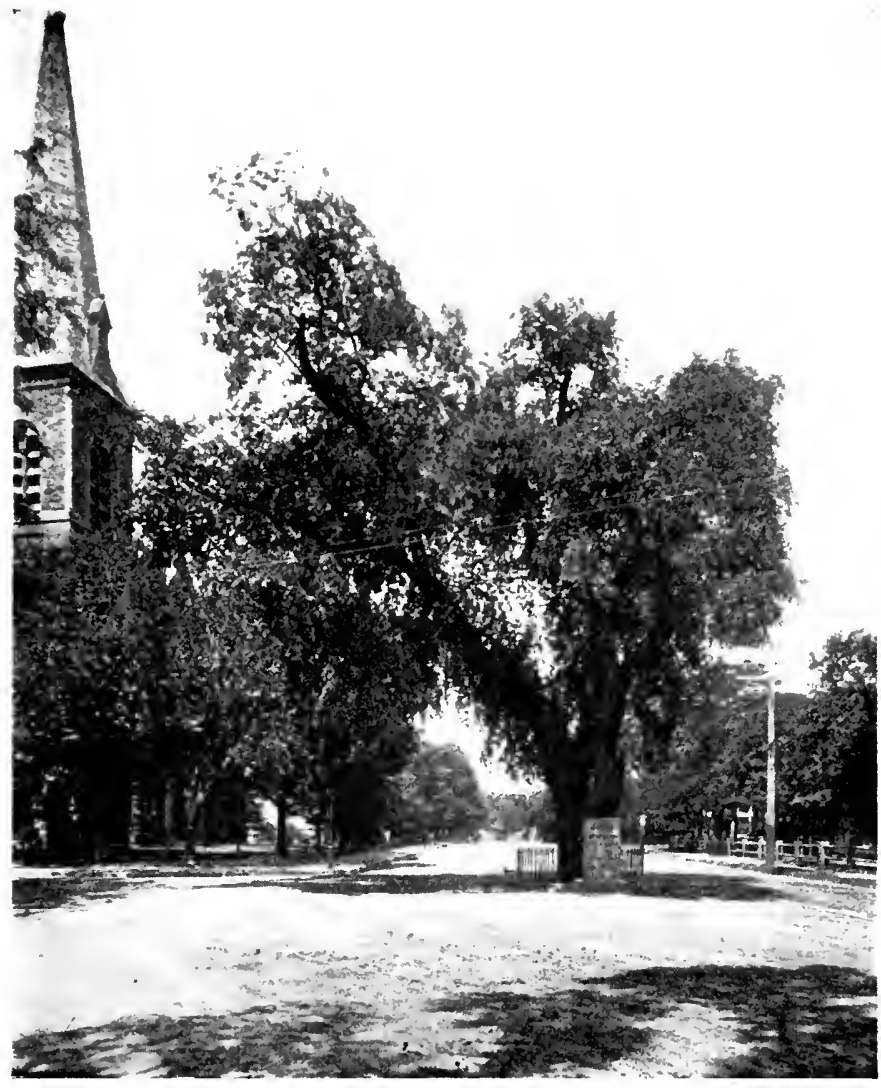

WASHINGTON ELM. 
for a while in the president's house, but soon made his headquarters in the fine old mansion of the Vassalls which was later the home of Longfellow.

After March, I 776, when Boston was finally evacuated by the British, Cambridge ceased to be involved in the military events of the Revolution, but in 1777 the captured troops of Burgoyne were quartered in the town, the soldiers swinging their hammocks in the college buildings and the officers occupying the deserted mansions of "Tory Row." Burgoyne lived in the house sometimes called, in derision of its first clerical occupant, "The Bishop's Palace," and Riedesel and his accomplished wife in the Lechmere house. "Never have I chanced," wrote Madame Riedesel, "upon such a charming situation," and never has our colonial life been more charmingly described than by this brave and vivacious German lady in the letters written from her pleasant prison to her distant home.

For fifty years after the Revolutionary epoch, Cambridge was a country town of quiet habits, its only distinguishing characteristic being the scholastic and literary atmosphere that hung about the college. It was a good 

place to be born in, and it was surely good to live in the place where Everett and Quincy ruled the academic world; where Longfellow wrote his poetry, and Palfrey his history, and Sparks his biographies; where IVashington Allston painted and Margaret Fuller dreamed; where IVilliam Story and Richard Dana and Lowell and Holmes and the rest walked to church and stopped to gossip with the neighbors at the post-office.

"No town in this country," says Thomas Wentworth Higginson, "has been the occasion of two literary descriptions more likely to become classic than two which bear reference to the Cambridge of fifty years ago. One of these is Lowell's well-known Fireside Trazels and the other is the scarcely less racy chapter in the Harvard $B o o k$, contributed by John Holmes, younger brother of the "Autocrat.",

To these happy descriptions we may now add the accounts of Colonel Higginson's boyhood in his Cheerful Yesterdays, and Dr. Holmes's loving story of his birthplace in the Poet at the Breakfast Table.

“Cambridge," wrote Lowell, "was still a country village with its own habits and traditions, not yet feeling too strongly the force of suburban gravitation. Approaching it from the west, by what was then called the New Road, you would pause on the brow of Symond's Hill to 


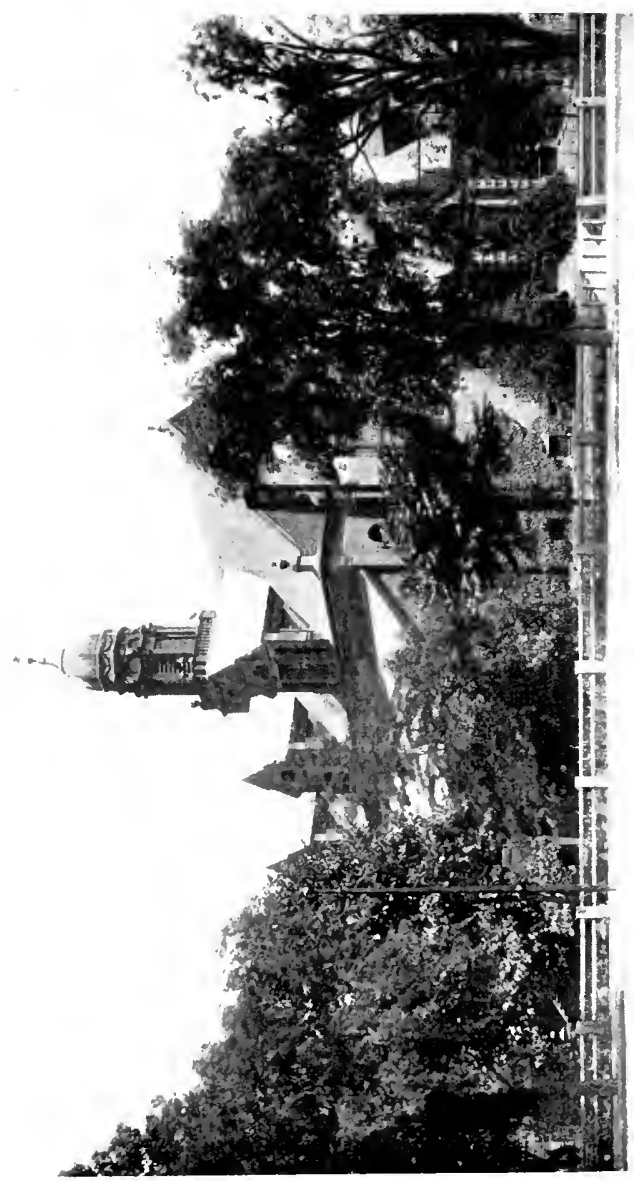

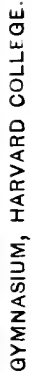

ขิ 
enjoy a view singularly soothing and placid. In front of you lay the town, tufted with elms, lindens, and horsechestnuts, which had seen Massachusetts a colony, and were fortunately unable to emigrate with the Tories, by whom, or by whose fathers, they were planted. Over it rose the noisy belfry of the College, the square, brown tower of the Episcopal Church, and the slim, yellow spire of the parish meeting-house. On your right the Charles slipped smoothly through green and purple salt meadows, darkened here and there with the blossoming black grass as with a stranded cloud-shadow. To your left upon the Old Road you saw some half-dozen dignified old houses of the colonial time, all comfortably fronting southward. We called it 'the Village' then, and it was essentially an English village-quiet, unspeculative, without enterprise, sufficing to itself, and only showing such differences from the original type as the public school and the system of town government might superinduce. A few houses, chiefly old, stood around the bare common, with ample elbow-room, and old women, capped and spectacled, still peered through the same windows from which they had watched Lord Percy's artillery rumble by to Lexington, or caught a glimpse of the handsome Virginia general who had come to wield our homespun Saxon chivalry. The hooks were to be seen from which had swung the hammocks of Burgoyne's captive red-coats. If memory does not deceive me, women still washed clothes in the town spring, clear as that of Bandusia. One coach sufficed for all the travel to the metropolis."

Cambridge is no longer the idyllic village of 


\section{Cambridge}

Lowell's boyhood, but a great suburban city bustling with many activities. So rapid has been the growth that Lowell on his return from Europe in I 889 wrote:

"I feel somehow as if Charon had ferried me the wrong way, and yet it is into a world of ghosts that he has brought me. I hardly know the old road, a street now, that I have paced so many years, for the new houses. My old homestead seems to have a puzzled look in its eyes as it looks down-a trifle superciliously methinkson these upstarts.

“The old English elms in front of my house have n't changed. A trifle thicker in the waist, perhaps, as is the wont of prosperous elders, but looking just as I first saw them seventy years ago, and it is balm to my eyes. I am by no means sure that it is wise to love the accustomed and familiar as much as I do, but it is pleasant and gives a unity to life which trying can't accomplish."

Cambridge is to-day the abode of as happy, comfortable and progressive a people as the world contains. It presents a unique example in this country of a city thoroughly well governed. It is now a quarter-century since partisanship has been tolerated in city affairs. In the City Hall, erected under the administration of Mayor William E. Russell, who here got his training for the splendid service he afterward rendered to the State, and might, had his 
life been spared, have rendered to the nation, no liquor license has ever been signed. So excellent has been the record of successive nonpartisan administrations in the city that the very phrase, "The Cambridge Idea," has become well known

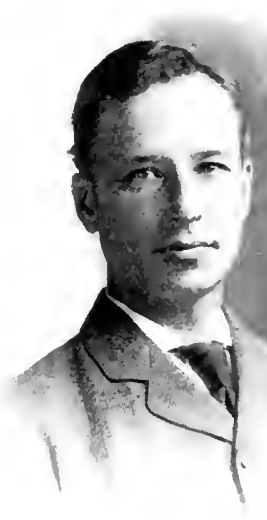

WILLIAM E. RUSSELL. even outside the limits of Massachusetts as signifying the conception of public office as a public trust and the conduct of municipal affairs on purely business principles. Yet in spite of its municipal expansion and business enterprises, Cambridge is still pre-eminently the place where the lamp of learning is kept lighted. Though the college waxes great in numbers and its buildings multiply, and the jar of business invades the academic quiet, yet the purposes and habits of the scholar's life still distinguish the community. It is said that when Cambridge people are at a 
loss for conversation one asks the other, "How is your new book coming on ?" and the question rarely fails to bring a voluble reply. There is an entire alcove in the City Library devoted to the works of Cambridge writers. "Brigadier-Generals," said Howells, himself once a resident of the town, "were no more common in Washington during the Civil War than authors in Cambridge." It is an interesting illustration of the persistence of good tradition that the place where was established the first printing-press in America, set up by Stephen Daye in 1639 , should still be a centre of book-production. Not only do John Fiske and Charles Eliot Norton and Thomas Wentworth Higginson and a score of others maintain the literary reputation of the place, but the great establishments of the Riverside Press, the University Press and the Athenæum Press put forth a constant stream of high-standard publications, and send a most characteristic Cambridge product all over the world. Still is Cambridge one of the shrines of pilgrimage. The antiquarians ponder over the mossy gravestones in the little "God's Acre" between the "Sentinel and Nun," as Dr. Holmes called the two church towers which front the college gate, and there 
they read the long inscriptions that tell the virtues of the first ministers of the parish and the early presidents of the college. The patriots come and stand under the Washington elm, or linger by the gates of the Craigie house or Elmwood, or pace the noble Memorial Hall, which declares how Harvard's sons died for their country, while visitors flock to the great museum which the genius and energy of Louis Agassiz upbuilt, and to the garden where Asa Gray taught and botanized. Thousands of men all over the country think of Cambridge with grateful love as they remember the years of their happy youth; and the citizens of the place, while they look backward with just pride, look forward with confidence that there is to be more of inspiring history and true poetry in the city's future than in its fortunate past. 


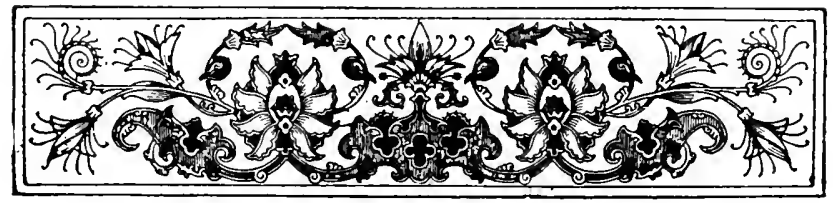

\section{CONCORD}

\section{FIRST IN MANY FIELDS}

BY FRANK B. SANBORN

LD this New World is,-geologically more ancient, perhaps, than that hemisphere from whose western edge Columbus set sail, four centuries ago, and found our continent lying across his way, as he plodded to Cathay. Yet, uncounted as our barbarous centuries and antediluvian æons are, real history begins only with the opening of the seventeenth century, when the English Puritan and the French Jesuit transferred to these shores the unfolding civilization and the rival religions of Western Europe. When we see at Plymouth the wooded glacial hillsides, under which the Pilgrims landed and established democracy in their wilderness, we may remember that their venture, though bolder, because earlier, than that of Bulkeley and Willard, who planted 
the Concord colony, was yet but fifteen years in advance, and was made beside a friendly ocean, bearing succor and trade, and feeding them from its abundance. But the Concord colonists sat down in the gloomy shadow of the forest, amid trails of the savage and the wolf. Still more heroic was the crusade of the Jesuit in New France; but while romance and martyrdom were his lot, our Puritans planted here the germs of a grand republic.

" God said, 'I am tired of kings,

I suffer them no more;

$\mathrm{U}_{\mathrm{p}}$ to my ear the morning brings

The outrage of the poor.

I will divide my goods,

Call in the wretch and slave;

None shall rule but the humble,

And none but 'Toil shall have.'"

The first event in the history of Massachusetts was this planting of a territorial democracy. The colony of Concord was granted by Winthrop and his legislature in September, 1635, to Peter Bulkeley, a Puritan minister, from the little parish of Odell or Woodhill (colloquially called "Wuddle") in English Bedfordshire, and to Simon Willard, a merchant, from Hawkshurst in Kent. Twelve other fam- 


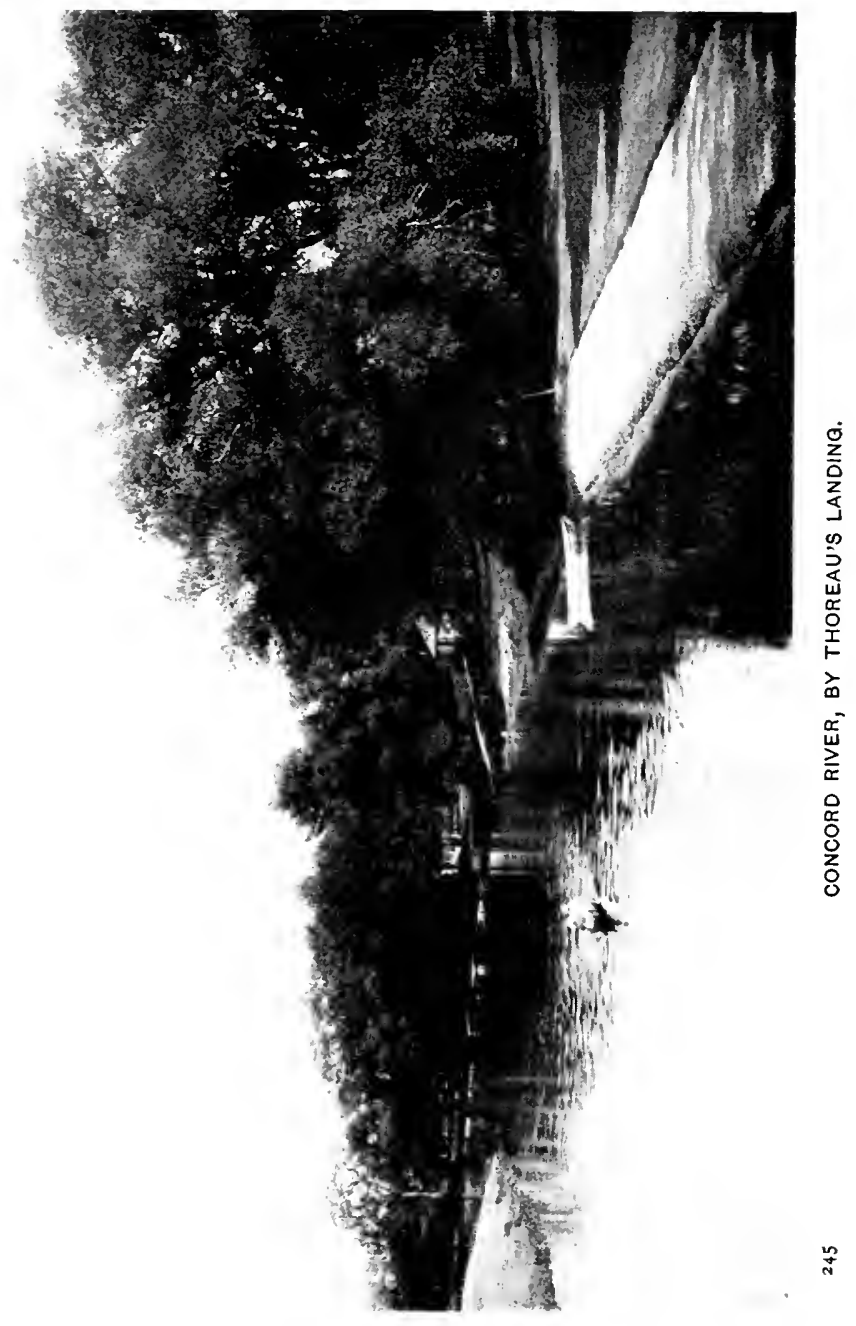


ilies were joined with them in the grant, and another minister, Rev. John Jones, brought other families from England, aiming towards Concord, in October, 1635 . The situation was doubtless chosen by Major Willard, an Indian trader and in after years a fighter of the Indians ; who also selected and partly colonized two other towns, farther in the wilderness,-Groton and Lancaster. But the true father of this Concord, and probably the giver of its name (altering it from the Indian Musketaquit), was Rev. Peter Bulkeley, ancestor of its most celebrated citizen, Waldo Emerson. Of this worthy, whose grave, like that of Moses, is unknown to this day, something should be said, before we come to later heroes. Peter Bulkeley was the son of Rev. Edward Bulkeley, a doctor of divinity in English Cambridge,-a scholar and man of wealth, who was rector of the Bedfordshire parish just named, where his son was born in $1_{5} 8_{3}$. He succeeded his father there in 1620 .

It is in the country of John Bunyan and Cowper the poet, this little parish of Odell. Like Concord River, the Ouse, on which it stands, is unmatched for winding, even in England. Below the old castle of Odell, and 
the church, still standing, where the Bulkeleys preached, runs this crooked stream, murmuring as it meanders through its fringe of meadowland, green as the richest strip of English pasture can be, which lies between such a river and the low hills that come down towards its edge. This Ouse (there is another in Yorkshire) flows from Bucks, the county of John Hampden, through Bedford, the county of the Russells, and Huntingdon, where Cromwell lived, and finally into the North Sea at Lynn. On the north bank lies the hill upon which Odell stands, - the highway from Sharnbrook to Harrold and Olney (long the home of Cowper) running from east to west along the breast of the hill. The old church standing amid trees-conspicuous is a chestnut of surpassing size and beauty-is directly opposite the ancient castle, now a comfortable and handsome mansion, built some two hundred years ago,--or about the time the oldest houses in Concord were built.

It was no love of adventure, we may be sure, that brought Peter Bulkeley, at the age of fiftytwo, from this lovely country into a land of forests and of poverty; but a desire to escape the ecclesiastical tyranny of Laud and his bish- 
ops, and to establish a true church in the wilderness. Some difficulties attended even this, for when, in July, I6 36 , Mr. Bulkeley was about to organize his church at Cambridge, in order to have Sir Henry Vane and John Winthrop (Governor and Deputy Governor that year) present at the ceremony, lo and behold! these great men "took it in ill part, and thought not fit to go, because they had not come to them before, as they ought to have done, and as others had done before them, to acquaint them with their purpose." Again, in April, 1637 , when Mr. Bulkeley was to be ordained (also in Cambridge), Winthrop says that Vane and John Cotton and John Wheelwright, and the two ruling elders of Boston "and the rest of that church which were of any note, did none of them come to this meeting." "The reason was conceived to be," adds Winthrop, "because they counted the Concord ministers as legal preachers," - that is, believers in a covenant of works (of the Law) instead of a covenant of grace. This was the issue upon which Wheelwright and Mrs. Hutchinson were banished, soon after.

Indeed, the ordination of Mr. Bulkeley took place in the very height of that fierce contro- 
versy between John Cotton and his former supporters, Wheelwright and Vane, which came near breaking up the little colony; and the Concord minister was one of the synod which, the next August, or perhaps later, specified some eighty doctrinal opinions as erroneous or heretical,- - about one error for every two white persons in Concord. The covenant of the village church, however, breathes a more liberal spirit ; for in it we find these words, evidently from the hand of Bulkeley:

"Whereas the Lord hath of $\mathrm{His}$ great goodness brought us from under the yoke and burdening of men's traditions, to the precious liberty of $\mathrm{His}$ ordinances, which we now do enjoy, -we will, according to our places and callings, stand for the maintenance of this liberty, to our utmost endeavor, and not return to any human ordinances from which we have escaped."

And the spirit of his oft-quoted sermon is also a witness to his true piety, whatever his doctrinal narrowness :

"There is no people but will strive to excel in something; what can we (in Concord) excel in, if not in holiness? If we look to number, we are the fewest; if to strength, we are the weakest; if to wealth and riches, we are the poorest of all the people of God through the whole world. We cannot excel nor so much as equal other people in these things; and if we come short in 
grace and holiness too, we are the most despicable people under Heaven."

Let us hope that the wish of the good pastor was granted, and that he lived to see the fruit of his labors. Yet there is a letter of his, written in 1650 to John Cotton, in which Bulkeley seems to regret the democratic liberty which Emerson, his descendant, never ceased to approve. The Concord minister writes:

"The Lord hath a number of holy and humble ones here amongst us, for whose sakes He doth spare, and will spare long; but, were it not for such a remnant, we should see the Lord would make quick work amongst us. Shall I tell you what I think to be the ground of all this insolency which discovers itself in the speech of men? Truly, I cannot ascribe it so much to any outward thing, as to the putting of too much liberty and power into the hands of the multitude, which they are too weak to manage; many growing conceited, proud, arrogant, self-sufficient. . . . Remember the former days which you had in old Boston; yet the number of professors is far more here than there. But tell me, which place was better governed? When matters were swayed there by your wisdom and counsel, they went on with strength and power for good. But here, where the heady or headless multitude have gotten the power into their hands, there is insolency and confusion; and I know not how it can be avoided, unless we should make the doors of the church narrower." 
This was the caution and reversion of age, -for the doubting Peter was then sixty-seven. But Emerson, at the age of sixty, could say, with unabated faith in Freedom :

"Call the people together!

The young men and the sires, The digger in the harvest field,

Hireling and him that hires;

Lo now, if these poor men

Can govern the land and sea, And make just laws below the sun,

As planets faithful be."

The experience of the ages has shown that the Puritans were right in making the doors of the church wider, not narrower; though we still hear the complaint of aged men, or young men born with a call to be old, that the former times were better than ours, and the "headless multitude" must be deprived of a voice in their own destiny.

When Emerson in 1835 , at the two hundredth anniversary of Concord, proposed to requite England's gift of her printed Doomsday Book by presenting her and the other European nations with our yet unpublished town records, he said: "Tell them the Union has 24 States, and Massachusetts is one; that in Massachusetts are 300 towns, and Concord is one; 
that in Concord are 500 rateable polls, and cary one has an equal sote." To-day there

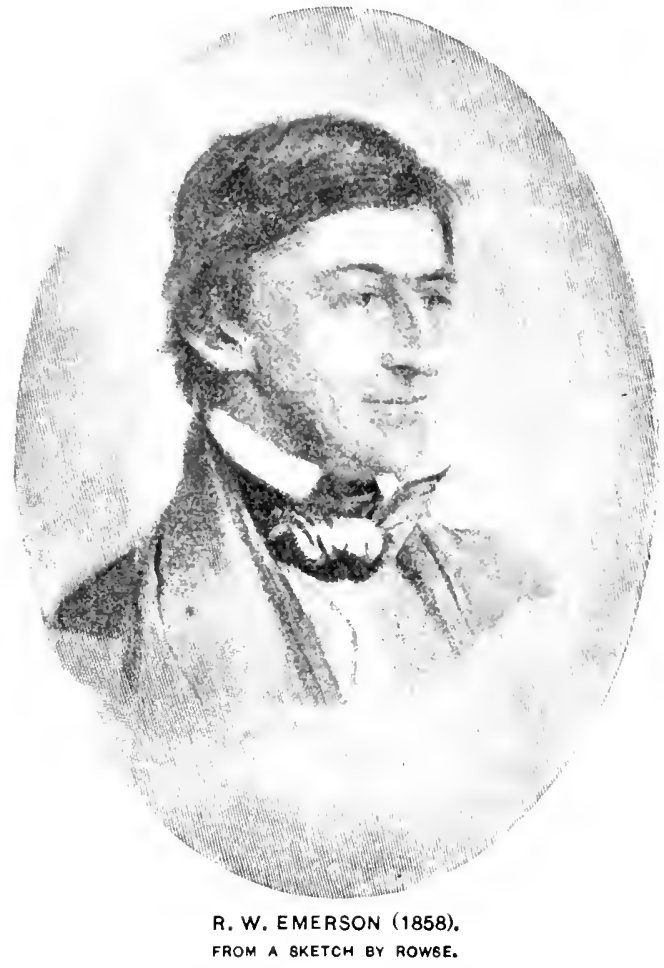

are 45 States; Massachusetts has 322 towns, besides nearly 30 cities; and instead of 500 ratable polls, Concord has now I 200 ; but each one still has an equal vote. 
Men are carried along, in spite of themselves, by the doctrine or system which they embrace; their life principle, once adopted, has more force than their temporary wish or will. So Calvinism, of which Peter Bulkeley was a fervent disciple, with its constant stress laid on the worth of the individual man, led inevitably to democracy, no matter how much the innate aristocratic feeling of the English gentleman-the class to which Bulkeley belonged-might revolt thereat. It was the same in both countries, the mother and the daughter; Old England and New England found John Calvin leading them along towards the Commonwealth of equal rights and abolished privileges,- - towards Sidney and Locke, Franklin and Jefferson, Lincoln and Gladstone.

This, then, is the first historic lesson of Concord, as of all New England,-Democracy through Calvinism, in spite of recalcitrant gentry and reactionary ministers. Philanthropy, too, that modern invention, which may almost be said to have come in with the eighteenth century, and to have had Franklin for its first missionary, began to show itself in our meadowy town, whose very name prefigured it. The epitaph of Rev. John Whit- 
ing, parish minister here for twenty-six years (dying in $175^{2}$ ), records that he was "a gentleman of singular hospitality and generosity, who never detracted from the character of any man, and was a universal lover of mankind." This would have been no compliment in Bulkeley's time, when the saints were entitled to be loved, and sinners were excluded; but the eighteenth century set up a higher standard, which has been maintained till now, when the votaries of evolution and the survival of the fittest are teaching a return to the old doctrine, -only reversing it; for now it is the sinners whom we are expected to admire, and to hate the saints.

The second historic lesson of Concord is like unto the first,- - but more startling and brilliant. It was the lesson of Revolution, which has been thoroughly learned since I 775 . The embattled farmers who, at yonder bridge,

"Fired the shot heard round the world,"

were conservative revolutionists, and as far from anarchy as from atheism. In the instructions given by this town to its representative in 1774 ,- - or rather, in a report made in townmeeting, January 20 th of that year, in view of 


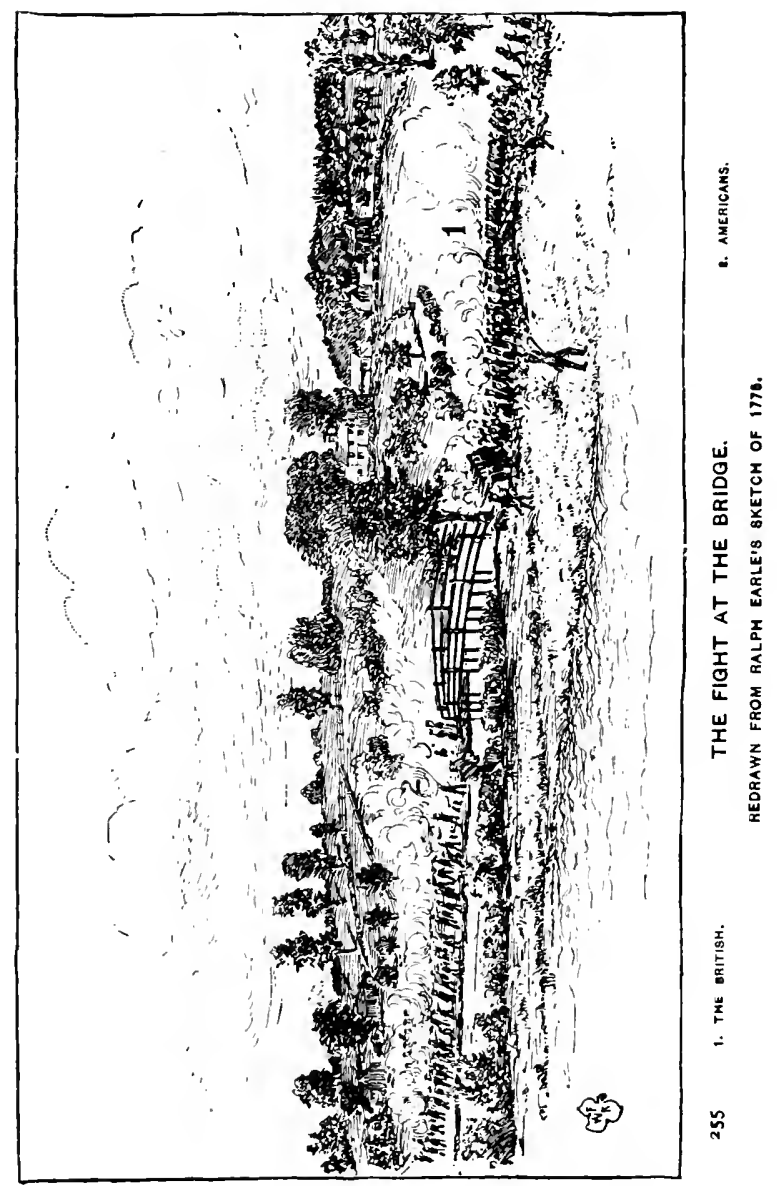


the Boston Tea-Party,-it was declared as the voice of the town :

"That we will, in conjunction with our brethren in America, risk our fortunes, and even our lives, in defence of his Majesty King George the Third, his person, crown, and dignity; and will also, with the same resolution, as his freeborn subjects in this country, to the utmost of our power and ability, defend all our charter-rights, that they may be transmitted inviolate to the latest posterity."

Three months after this, when the Boston Port Bill was in agitation, and two months later, when it had passed Parliament, the farmers of Concord took a bolder tone,"conscious," as they said in town-meeting, "of no alternative between the horrors of slavery, and the carnage and desolation of a civil war," except non-importation of British goods, to which the good citizens bound themselves. Still later, in a county convention which met in Concord, August 3I, I774, it was resolved:

"That we by no means intend to withdraw our allegiance from our gracious Sovereign; that when our ancestors emigrated from Great Britain, charters and solemm stipulations expressed the conditions, and what particular rights they yielded; what each party had to 
do and perform, and what each of the contracting parties were equally bound by. Therefore a debtor may as justly refuse to pay his debts, because it is inexpedient for him, as the Parliament deprive us of our charter privileges, because it is inexpedient to a corrupt administration for us to enjoy them. . . . And a sense of our duty as men, as freemen, as Christian freemen, united in the firmest bonds, obliges us to resolve that every civil officer in this Province, now in commission, and acting in conformity to the late act of Parliament, is not an officer agreeable to our charter-therefore unconstitutional, and ought to be opposed. . . . As we are resolved never to submit one iota to the Act, we will not submit to courts thus constituted, and acting in conformity to said Act. . . . In consequence of this resolve, all business at the Inferior Court of Common Pleas, and Court of General Sessions of the Peace, next to be holden in Concord, must cease."

This was peaceful revolution, proceeding, not upon any vague notion of a general "Social Contract," but on formal violations of a written contract, the Colony Charter, as explicitly stated. I ask attention to this, because it has been a favorite fancy of some modern writers, who praise the Puritans and disparage Jefferson and Franklin, that our Revolutionary fathers had gained through those two latitudinarians a glimpse of the levelling French doctrines, and gave themselves up to be guided 
by Rousseau and Voltaire, in dereliction of their Puritan ancestry. Precisely the opposite is true; the French author whom Jefferson may have had in mind, when he was not thinking of Pym and Hampden, Sergeant Maynard, Locke, and Algernon Sidney,-I mean Montesquieu,-having derived his theories more from the English constitutionalists than they from him. Probably not one of the men of Middlesex, who thus led the way to revolution in this law-abiding town of Concord (the seat of county justice), ever heard of Rousseau ; but they were lawyers, deacons, country justices and farmers, accustomed to sit on juries; and they understood the law of contract and the obligations of fair trade as well as any English lord could tell them.

They voted further, on this eventful summer day, that "a Provincial Congress is absolutely necessary, in our present unhappy situation,"-and they named October, and Concord, as a suitable time and place for its assembling. This first Provincial Congress did meet, October 7 th, at Salem, but adjourned to Concord that day ; it first met here, October I I, I 774, and, finding the county court-house too small for its three hundred members and clerks, 
and the people who gathered to support them, it moved over to the parish meeting-house (built in 1712 ), and remained in session there five days, when it removed to Cambridge, for the sake of being nearer Boston, then held as a garrison by British troops. The second Provincial Congress, of $\mathrm{I} 775$, also met in Concord for four weeks of March and April; and it had only been adjourned four days when the British grenadiers made their midnight march from Boston to Lexington, hoping to catch there the arch-rebels Hancock and Sam Adams, who had gone to Lexington as members of the Committee of Public Safety (of which Dr. Warren was chairman), then the executive of Massachusetts under the new revolutionary government. The Provincial Congress, the legislature of the Province, met again for the last time in Concord, April 22, I 775, to consider the results of the eventful i 9 th. It finally dissolved May 3 ist, after hearing a sermon from Dr. Langdon, the President of Harvard College ; and Concord ceased forever to be the legislative capital of Massachusetts. It became temporarily, however, the seat of Dr. Langdon's College, which in October, 1775 , began its recitations in the 
court-house and meeting-house, and so continued till June, I 776 .

Even Harvard College was at that time revolutionary; it gave up its few buildings in Cambridge to the army of Washington, and its president, a cousin of the wealthy New Hampshire patriot, John Langdon, made the prayer for Bunker Hill battle, as the troops marched out of Cambridge to give a feeble support to Prescott and his Middlesex farmers, entrenched on the hill. Washington had not yet reached Cambridge, to take command; had his strategic eye taken in the situation that morning, the result at Bunker Hill would have been different.

Lexington, the town which gave its name to the battle of April, I 775, more decidedly than Concord,- - though both names occur from the first,-was an offshoot from the older towns of Cambridge, Watertown and Woburn, rather than an original church seat, and was not established as a town until izi2. A range of hills separates it from the valley of the Musketaquit, and Paul Revere, in his night ride of April i 8th, celebrated by Longfellow, could not cross those hills, but left his message of war to be borne on to Concord vil- 
lage by young Prescott, distantly related to Prescott of Bunker Hill. But Lexington, though little more than half so populous as Concord at that time, had a warlike people, many of them descended from the fighting Monros of Scotland, captured by Cromwell, and exiled for their loyalty to the Stuarts. In Lexington they again turned out against the house of Hanover, and they were commanded that April morning by the grandfather of Lexington's most famous son, Theodore Parker. Captain John Parker, though ill on the igth of April, did his soldier's duty from two in the morning till midnight; and some of his men returned the British fire in early morning, against hopeless odds. Their turn came in the afternoon, when the retreating British were only saved from total defeat by the cannon of Lord Percy. Those first heroes of the Revolution, John Hancock and Samuel Adams, who had been at the Provincial Congress in Concord, at Lexington were in the early morning in the parsonage of Rev. Mr. Clark, a kinsman of Hancock, and narrowly escaped capture by the British soldiers, who had special orders to seize them.

John Pierpont, a poet whose Pegasus balked 
now and then, in his verses at Acton, April 19, I $\$_{5} \mathrm{I}$, anticipated Longfellow by this Wordsworthian version of Revere's ride to Lexington :

\section{"The foremost, Paul Revere,}

At Warren's bidding has the gauntlet run

Unscathed, and, dashing into Lexington, While midnight wraps him in her mantle dark, Halts at the house of Reverend Mister Clark."

As compared with Concord, though both were rural towns, Lexington was then, and long remained, more rustic than its westward neighbor; with less trade, less culture and fewer of the tendencies toward literature which early showed themselves in the parish of the Bulkeleys and Emersons. When Theodore Parker, in his career of scholarship and reform, began to look outward from his father's Lexington farm, it was towards Concord, as well as towards Boston, that he turned his eyes; he taught a district school in Concord, and preached in its pulpit as a candidate to stand beside Dr. Ripley, the pastor of the Old Manse. In after years he thus described the event which gave Lexington its chief title to fame, before Parker's own birth there: 


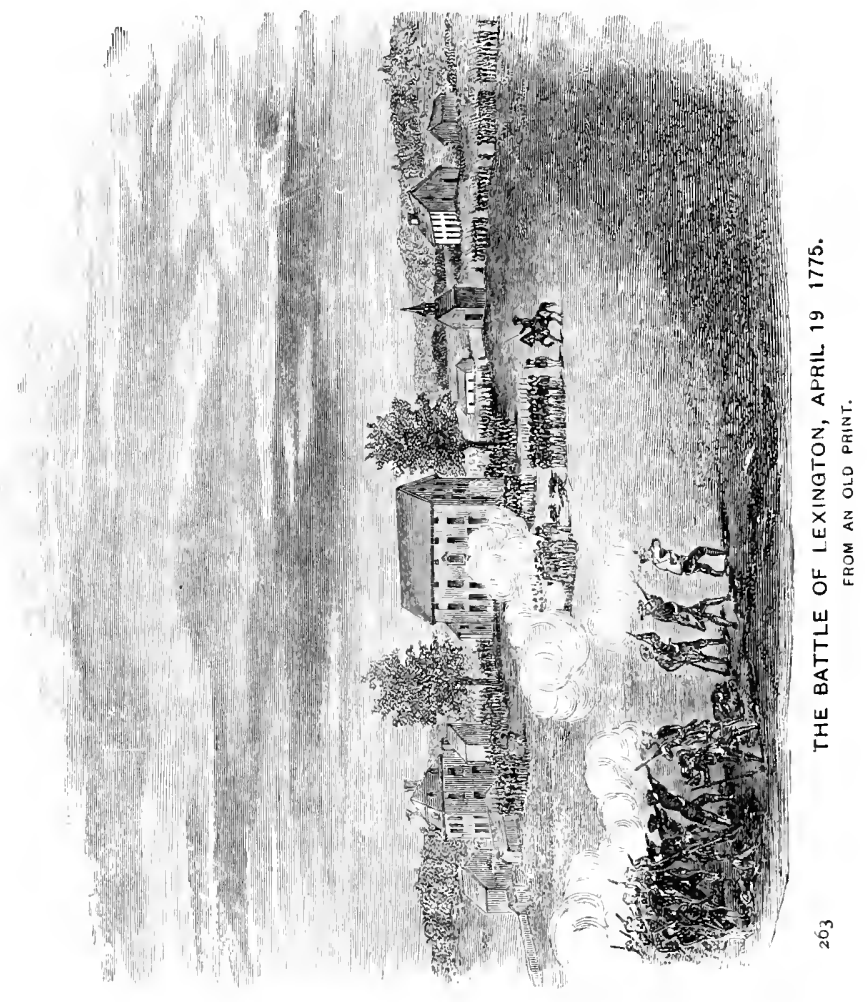


" The war of Revolution began at Lexington, to end at Yorktown. Its first battle was on the Nineteenth of April. Hancock and Adams lodged at Lexington with the minister. In the raw morning, a little after daybreak, a tall man, with a large forehead under a three-cornered hat, drew up his company of 70 men on the Green,farmers and mechanics like himself; only one is left now $(185 \mathrm{I}$ ), the boy who played the men to the spot. (It was Jonathan Harrington the fifer.) 'They wheeled into line to wait for the Regulars. The captain ordered every man to load his piece with powder and ball. 'Don't fire,' were his words, 'unless fired upon; but if they want a war, let it begin here.' The Regulars came on. Some Americans offered to run away from their post. Captain Parker said, 'I will order the first man shot dead that leaves his place.' 'The English commander cried out, 'Disperse, you rebels! lay down your arms and disperse!' Not a man stirred. 'Disperse, you damned rebels!' shouted he again. Not a man stirred. He ordered the vanguard to fire; they did so, but over the heads of our fathers. Then the whole main body levelled their pieces, and there was need of ten new graves in Lexington. A few Americans returned the shot. British blood stained the early grass which waved in the wind. 'Disperse and take care of yourselves !' was the captain's last command. There lay the dead, and there stood the soldiers; there was a battle-field between England and America-never to be forgot, never to be covered over. 'The 'Mother-country' of the morning was the 'enemy' at sunrise. 'Oh, what a glorious morning is this!' said Samuel Adams."

Seven men had been killed on the spot, 
nine wounded,- - a quarter-part of all who had stood in arms on the Green, under the eyes of Hancock and Adams.

One of the Lexington Munroes, Ensign Robert, was the first man killed by Pitcairn's volley; he was sixty-four years old, and had been color-bearer in the capture of Louisburg by assault in 1745 . Two of his sons and two sons-in-law were in his company on Lexington Green, and eleven of the Munroe clan were in arms that day. Captain Parker did not long survive the battle, dying the next September; but when the Civil War came on, his grandson Theodore had bequeathed to Massachusetts, and Governer Andrew had placed in her Senate Chamber, beside the trophies sent by Stark from Bennington,

"two fire-arms, formerly the property of my honored grandfather,- - to wit, the large musket or King's arm, which was by him captured from the British in the battle of Lexington, and which is the first fire-arm taken from the enemy in the war for Independence ; and also the smaller musket used by him in that battle."

Theodore Parker had died in May, I 860.

Pitcairn and his redcoats, delayed only half an hour by this bloody overture to Washington's grand career, marched on towards Con- 
cord, little knowing what would meet them there. As they climbed the hills in Lexington and lincoln, they could surmise, however, that the country was rising, for the churchbells were ringing an alarm of fire. Pierpont,

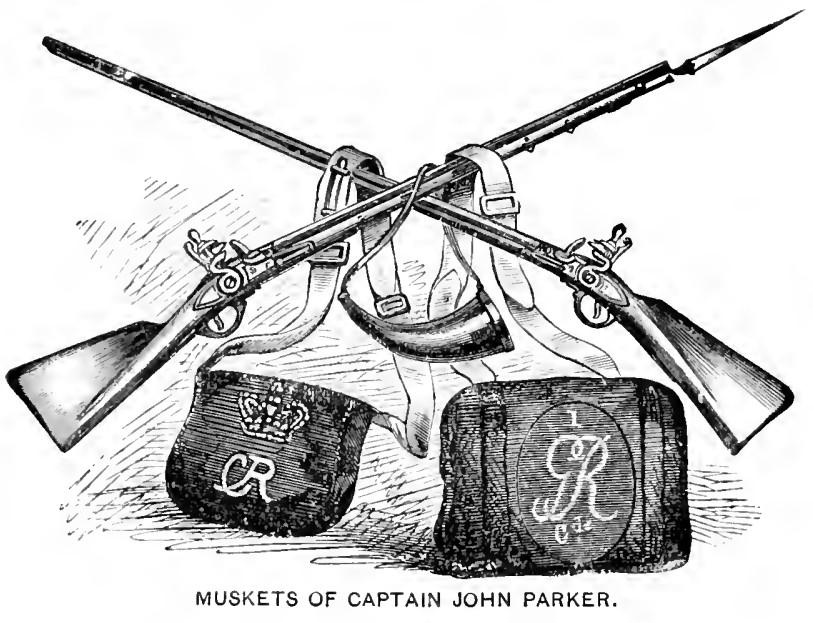

at Acton, overlooking the neighboring towns named by him, gave the greography of this rising in spirited couplets:

"Now Concord's bell, resounding many a mile, Is heard by Lincoln, Lincoln's by Carlisle, Carlisle's by Chelmsford,--and from Chelmsford's swell Peals the loud clangor of th' alarum bell, Till it o'er Bedford, Acton, Westford spreads, Startling the morning dreamers from their beds." 


\section{Concord}

These are the small towns lying along the Concord and Merrimac rivers, and their tributaries, which sent forth the minute-men to fight at Concord Bridge.

Prescott had done his warning work well; and as Emerson said in 1835 :

"In these peaceful fields, for the first time since a hundred years (King Philip's War), the drum and alarm-gun were heard, and the farmers snatched down their rusty firelocks from the kitchen walls, to make good the resolute words of their town debates. These poor farmers acted from the simplest instincts; they did not know it was a deed of fame they were doing."

It was Emerson's grandfather, the town minister, who met them on Concord Green, before his church, and who entered that night in his almanac the events he had witnessed, as soon to be quoted.

By the $i$ th of June, Massachusetts had an army; but when the Concord farmers made their appeal to arms, two months earlier, it was the spontaneous uprising of an armed people to maintain their own votes and defend their threatened homes. This it is, and not their military achievement, striking as that was, which gives their town a place in martial history. The unregenerate imagination of man- 
kind still delights, after so many centuries of barbarous warfare, in the recital of deeds of battle and the conquering march of great soldiers; Alexander and Cæsar-even Hannibal and Bonaparte-continue to receive admiration for their victories; but the purer fame of Washington rests on the accomplishment of that for which the men of Middlesex rushed to arms on the igth of April, I 775. As Emerson, our Washington in the field of literature, said, "If ever men in arms had a spotless cause, they had."

" Behold our river bank, Whither the angry farmers came In sloven dress and broken rank,Nor thought of fame:

Their deed of blood All mankind praise ;

Even the serene Reason says

'It was well done.'"

War had been the normal state of Europe; and from the hour when Bulkeley and Willard made here their honest bargain with the red landlords of these game preserves, cornfields, and fishing-places, down to the Franco-German campaigns of $1870,-235$ years, - there had been scarcely a period of twenty peaceful 


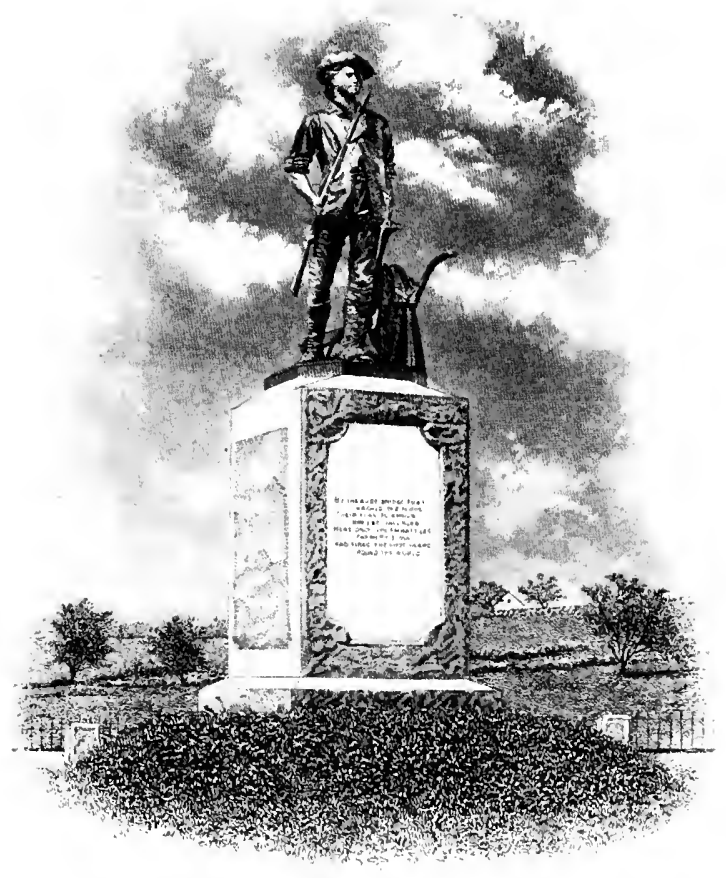

THE MINUTE-MAN.

FRENCH'S FIRST STATUE. 
years in that hemisphere. With us it was different; but for the strife between France and England, in which the colonies were more or less entangled, Nassachusetts had seen no warfare in her borders for nearly a century, when the insolence of the mothercountry forced independence upon us against our will. Yet the fight at the North Bridge was no impromptu affair, as the utterances of our Concord yeomen show. They had declared they would fight for King George or against him, as His Majesty might elect; and when he had made his foolish choice they did not hesitate,-much as they had reason to dread the ordeal by combat. And here again came in the spirit of Calvinism, rallying to the Old Testament, rather than to the New with its gospel of peace and love,--its amnistic gincralc, as poor Trilby says. The grandfather of Emerson (who was also the great-greatgreat-grandson of Peter Bulkeley) was parish minister of Concord; he had been chaplain to the Provincial Congress, and he died in Vermont, as chaplain in the Revolutionary army of General Gates. Five weeks before the invasion of his parish by the redcoats, he had preached to the militia companies gathered in 
this town for review, a famous sermon from the text, "And behold, God Himself is with us for our Captain, and His priests with sounding trumpets to cry alarm against you." He was as good as his word, for he was one of the first to take his musket and join the minute-men in the early morning of the I 9 th of April ; and returning to the Old Manse (then the new manse, for it was built for him and his bride a few years earlier) to protect his family, he saw the brief fight at the bridge from his study window, and wrote of the day's doings this brief chronicle of an eye-witness. His grandson found it in a page or two of his family almanac, where, at the end of April, he wrote, "This month remarkable for the greatest events of the present age."

"This morning, between $\mathrm{I}$ and 2 o'clock, we were alarmed by the ringing of the bell, and upon examination found that the troops, to the number of 800 , had stole their march from Boston, in boats and barges, from the bottom of the Common over to a point in Cambridge, near to Inman's Farm, and were at Lexington Meetinghouse, half an hour before sunrise, where they fired upon a body of our men, and (as we afterward heard) had killed several. This intelligence was brought us first by Dr. Samuel Prescott, who narrowly escaped the guard that were sent before on horses, purposely to prevent all posts 
and messengers from giving us timely information. He, by the help of a very fleet horse, crossing several walls and fences, arrived at Concord at the time above mentioned; when several posts were immediately despatched, that returning confirmed the account of the regulars' arrival at Lexington, and that they were on their way to Concord. Upon this, a number of our minute-men belonging to this town, and Acton, and Lincoln, with several others that were in readiness, marched out to meet them ; while the alarm company were preparing to receive them in the town. Capt. Minot, who commanded them, thought it proper to take possession of the hill above the Meeting-house, as the most advantageous situation. No sooner had our men gained it, than we were met by the companies that were sent out to meet the troops, who informed us that they were just upon us, and that we must retreat, as their number was more than treble ours. We then retreated from the hill near the Liberty Pole, and took a new post back of the town upon an eminence, where we formed into two battalions, and waited the arrival of the enemy.

"Scarcely had we formed, before we saw the British troops at the distance of a quarter of a mile, glittering in arms, advancing towards us with the greatest celerity. Some were for making a stand, notwithstanding the superiority of their number; but others, more prudent, thought best to retreat till our strength should be equal to the enemy's, by recruits from the neighboring towns that were continually coming in to our assistance. Accordingly we retreated over the bridge; when the troops came into the town, set fire to several carriages for the artillery, destroyed 60 bbls. flour, rifled several houses, 
took possession of the Town-house, destroyed $500 \mathrm{lb}$. of balls, set a guard of roo men at the North Bridge, and sent a party to the house of Col. Barrett, where they were in expectation of finding a quantity of warlike stores. But these were happily secured just before their arrival, by transportation into the woods and other by-places.

"In the meantime the guard set by the enemy to secure the pass at the North Bridge were alarmed by the approach of our people; who had retreated as before mentioned, and were now advancing, with special orders not to fire upon the troops unless fired upon. These orders were so punctually observed that we received the fire of the enemy in three several and separate discharges of their pieces, before it was returned by our commanding officer; the firing then became general for several minutes; in which skirmish two were killed on each side, and several of the enemy wounded. (It may here be observed by the way, that we were the more cautious to prevent beginning a rupture with the King's troops, as we were then uncertain what had happened at Lexington, and knew not that they had begun the quarrel there by first firing upon our people, and killing eight men upon the spot.) The three companies of troops soon quitted their post at the bridge, and retreated in the greatest disorder and confusion to the main body, who were soon upon their march to meet them.

"For half an hour the enemy, by their marches and countermarches, discovered great fickleness and inconstancy of mind,- - sometimes advancing, sometimes returning to their former posts; till at length they quitted the town and retreated by the way they came. In the meantime, a party of our men ( 150 ), took the back way through 
the Great Fields into the East Quarter, and had placed themselves to advantage, lying in ambush behind walls, fences and buildings, ready to fire upon the enemy on their retreat."

'This account differs slighty from others, and omits many particulars; it is the most valuable

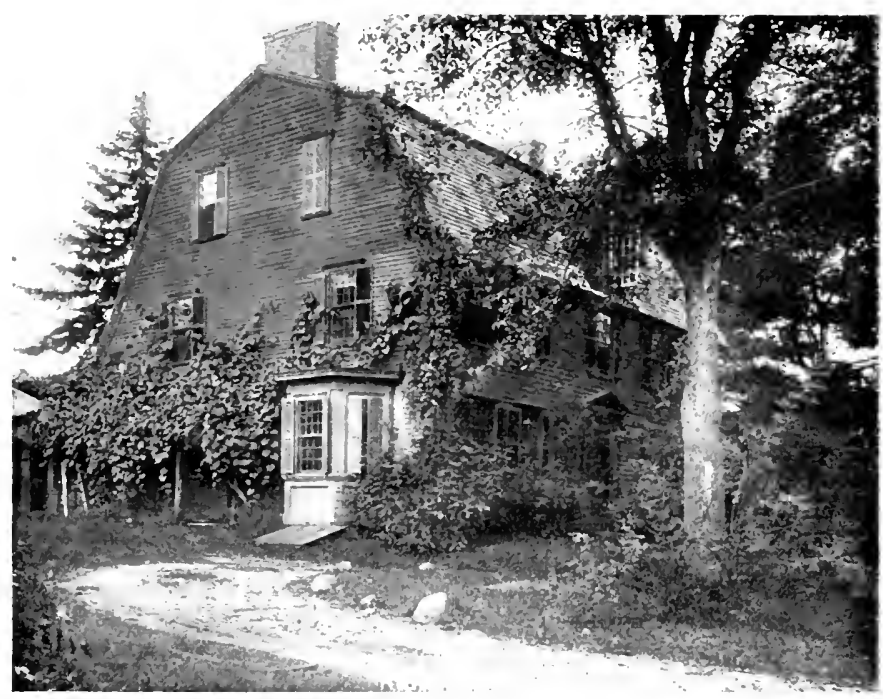

HAWTHORNE'S OLD MANSE.

single version of the memorable skirmish at the Bridge,-in itself trifling, but momentous in its results. Parson Emerson was himself one of those who wished to meet the troops near his 
own meeting-house, but was wisely overruled. He says that two British soldiers were killed at the Bridge-Shattuck, the town historian, says three; the difference is accounted for by a dismal tale which Hawthorne was perhaps the first to print. He derived it, he says, from Lowell, the poet, who had picked it up, no doubt, in his short residence at Concord in the spring of $1_{3} 8$, when "rusticated" here from Harvard College. It may be read in the Mosses from an Old Manse, wherein is found one of the best pictures of our peaceful scenery, - so far removed from thought of bloodshed.

"A youth," says Hawthorne, "in the service of the clergyman [Parson Emerson], happened to be chopping wood, that April morning, at the back door of the Manse; and when the noise of battle rang from side to side of the Bridge, he left his task and hurried to the battle-field, with the axe still in his hand. The British had by this time retreated, the Americans were in pursuit ; and the late scene of strife was thus deserted by both parties. Two soldiers lay on the ground-one was a corpse-but, as the young New Englander drew nigh, the other Briton raised himself painfully upon his hands and knees, and gave a ghastly stare in his face. The boy-it must have been a nervous impulse, without purpose-uplifted his axe, and dealt the wounded soldier a fierce and fatal blow upon the head." 
To a certain extent, Bancroft, in his account of the fight, confirms this tale, saying:

"The Americans acted from impulse, and stood astonished at what they had done. They made no (immediate) pursuit, and did no further harm,-except that one wounded soldier, rising as if to escape, was struck on the head by a young man with a hatchet. The party at Col. Barrett's might have been cut off, but was not molested."

It is traditional that when this party, which had been sent to destroy the military stores at Colonel James Barrett's, two miles to the westward, came back to the Bridge, alarmed by the firing, and saw their countrymen lying dead there, one of them with his head laid open, they were struck with fear and ran on to the main body in the village, telling of what they had seen. And it was this single incident, very likely, which led the English officers, and Lord Percy himself, to report "that the rebels scalped and cut off the ears of some of the wounded who fell into their hands." Bancroft indignantly denies this, saying, "The falsehood brings dishonor on its voucher; the people whom Percy reviled were among the mildest and most compassionate of their race," —which is true.

It is no wonder that the British troops on 


\section{Concord}

their flight back to Boston that day, pursued and ambuscaded by hundreds and thousands of the aroused militia of Middlesex and Essex counties, should themselves have committed some barbarities,- - for their defeat and humilia-

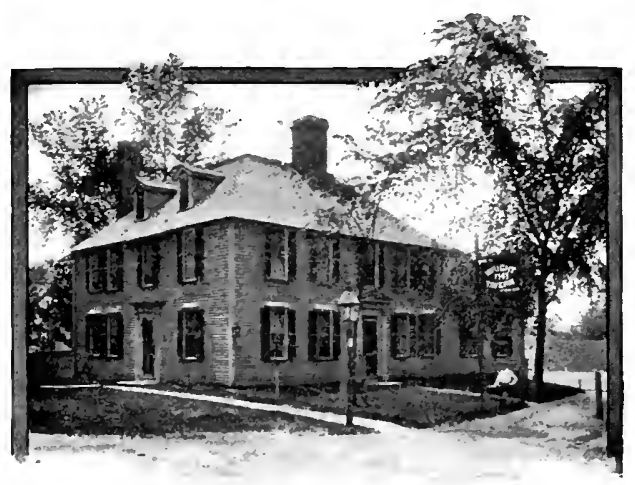

REVOLUTIONARY INN.

tion were great. They lost in course of the day 273 men and officers,--more than had fallen on that glorious day-sixteen years before, when Wolfe died in the arms of victory at Quebec. The loss of the yeomanry was only ninety-one-a third of the British loss,--while all the trophies and circumstances of victory were on the American side. From that day, the Revolution was begun,- - to end only with 
the creation of a new republic. Concord, as President Dwight said, "prefaced the history of a nation, the beginning of an empire." "Man," he added, "from the events that have occurred here, will in some respects assume a new character ; and experience a new destiny." Hence the interest with which the world, from that day forward, began to look on this little town.

Yet the prominence of Concord in the revolutionary century that followed her skirmish at the Bridge and along the Lexington road was in part accidental; for Boston and Virginia were the two foci of the American revolt, and Concord became famous chiefly because it was near Boston. It was otherwise with the literary revolution that began sixty years later, with Emerson for its Washington,- and with results that seem as permanent, and in some sort as important, as those which Washington secured to his countrymen. In 1835 , when Emerson's literary career may be said to have fairly begun, America had maintained her political independence, but had lost much of her political principle: she was powerful without moral progress, and without either a profound philosophy or an original literature. 
The beginnings of poetry and art were visible, but they were more in promise than in performance. Our political writings, though disparaged by Jeremy Bentham, were coming to be recognized as among the foremost; but we had little else that Europe cared to read,- - a few sketches by Irving, a dozen novels by Cooper, two or three sermons and as many essays by Channing.

Into the stagnation of this shallow pool of American letters, Emerson, in I 836, cast the smooth stone of his philosophical first book, - Nature. It made little immediate stir; the denizens of the pool paid small heed to it, and few of them guessed what it meant. It was written in Concord, and chiefly at the Old Manse, where Emerson dwelt with his mother and kindred before his second marriage in ${ } 8_{35}$, and where Hawthorne afterward made the house and himself widely known. The fixing of his own residence in this town by Emerson was due in part to ancestry, and still more to a perception of the fitness of the region for the abode of a poet and sage. The same perception, by Hawthorne, Alcott, Ellery Channing and others,-together with the important fact that it 
was Emerson's chosen retreat,--brought those literary men here. Thoreau, the most original and peculiar genius of the whole group, was born here, and never had much inclination to

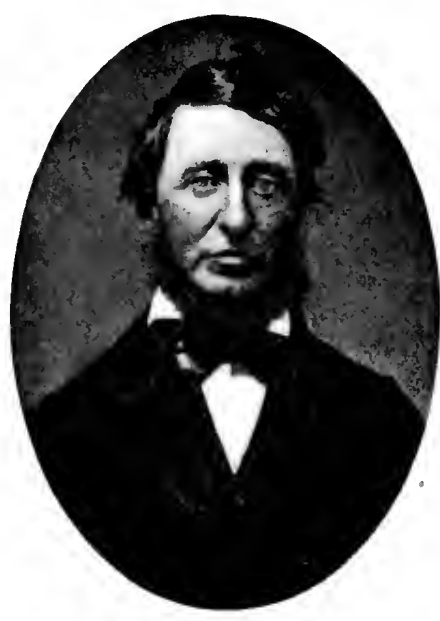

HENRY THOREAU. (1857.) leave Concord, although in youth he talked of adventuring to the wild West, - Kentucky and Illinois at that time,-whither his friend, Ellery Channing, afterward did in fact go. Around Emerson, this circle, with many who only lived here temporarily (like Margaret Fuller and George William Curtis), or not at all, gathered as friends and brothers, or else as disciples,- -and thus the name of Concord became associated, and justly, with a special and remarkable school of thought and literature. Thousands now visit the graves of these worthies, to which, and to their haunts in life-their walks and seats and sylvan places of resort, - an increasing host of pilgrims come year by year. 
The Arabs have a proverb,- “ Though a hundred deserts separate the heart of the Faithful from the Kaaba of Mecca, yet there opens a window from its sanctuary into thy soul." For those who have the true inward illumination, therefore, pilgrimage is not needful; yet to all it is agreeable, and it has been the practice of mankind for ages, and will be, so long as we remain ourselves but pilgrims and wayfarers on this earth. Nasar, the son of Khosrou, who wrote in the time of Haroun Al-Rashid, and called his book The Traveller's Wallct, was not the first, nor Bunyan, with his Pilgrim's Progress, the last, to look on life as a journey ; but let us hear what that Persian says of it :

"Man, endowed with intellect, must search into the origin of his existence,- -whence he came, and whither he shall go,-reflecting that in this world he is making a toilsome journey, without stop or stay, - not even for the twinkling of an eye,- - until he has traversed the measure of that line which marks the time allotted for his existence. For that we are but pilgrims here on earth, God has mysteriously declared."

The attraction of Emerson and the rest of the Concord authors, whose homes or tombs so many pilgrims visit, comes chiefly from the recognition by them of this search by mankind 
after the Infinite,- - their insight into the nature and worth of this pilgrimage of life which all are making. Man loves and seeks amusement to beguile his toilsome or monotonous journey, - and hence the pleasure so many take in the lighter and more graceful or laughable forms of literature. But sooner or later, and in many persons at all times, what Tennyson calls "the ridclle of the painful earth" is before us all for consideration, if not for solution. We see that the universe is moral,-even if we cannot read the moral aright,--and we seek those who can give us "the word of the enigma," as the French say. Emerson gave it in his manner, Hawthorne in his, Thoreau in still another way; and these three Concord authors not only had much vogue in their lifetime, but are yet more widely read since their death. Others, like Ellery Channing, found little audience in youth, and time has not yet essentially enlarged the circle of their readers. With the same moral view of life which his more successful friends took, Channing, the poet (who must always be distinguished from Dr. Channing, the divine, his uncle), had in his style something of that distraction which Montaigne declares is needful to poets. 


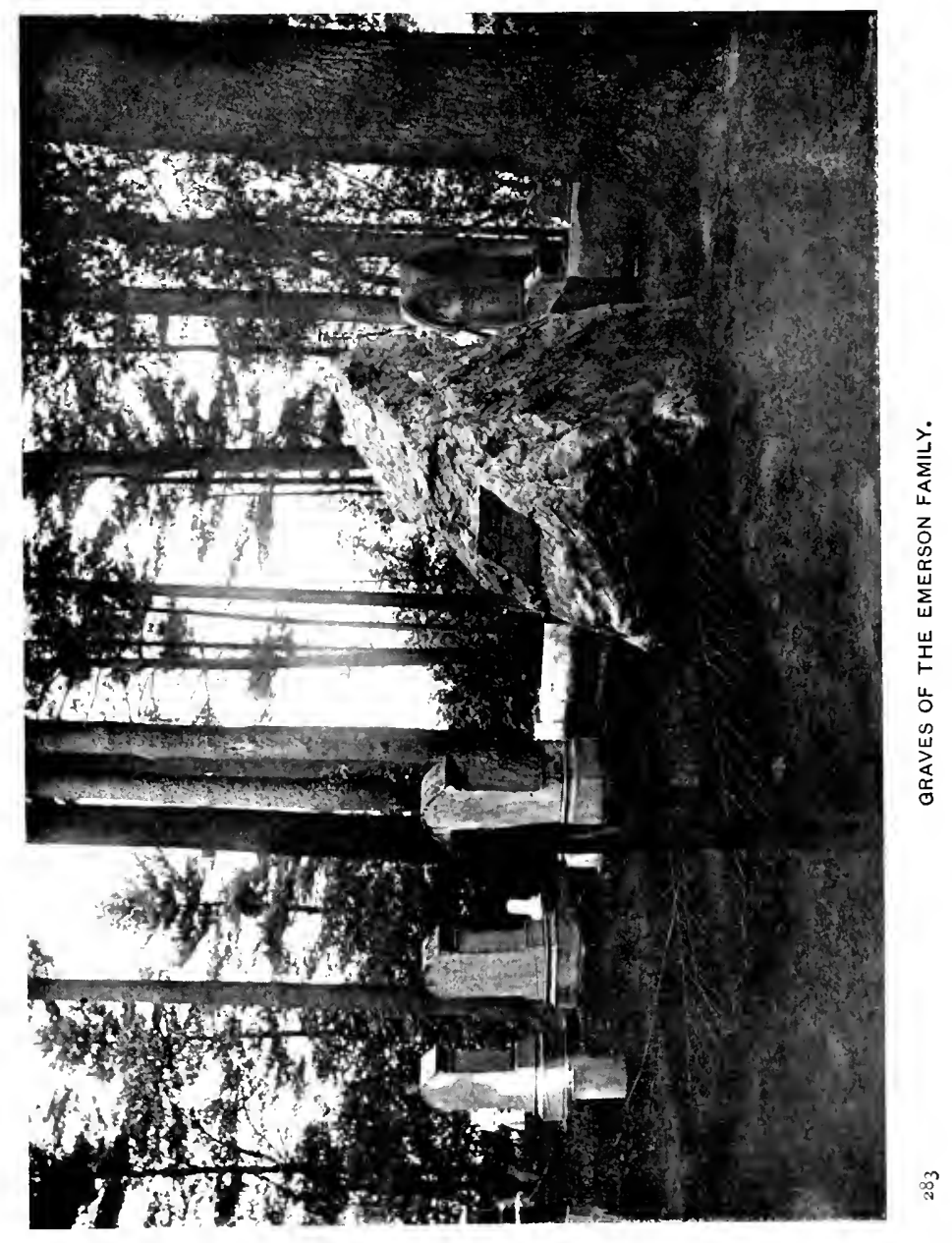


"The precepts of the masters," says this eccentric Gascon, "and still more their example, tell us that we must have a little insanity, if we would avoid even more stupidity. A thousand poets drawl and languish in prose; but the best ancient prose (and 'tis the same with verse) glows throughout with the vigor and daring of poesy, and takes on an air of inspiration. The poet, says Plato" (and here Montaigne gives his own quaint form to the familiar passage in Plato's Laws), "sitting on the Muses' tripod, pours out like mad all that comes into his mouth, as if it were the spout of a fountain ; without digesting or weighing it. So things escape him of various colors, of opposite natures, and with intermittent flow. Plato himself is wholly poetic ; the old theology, say the scholars, is all poetry ; and the First Philosophy is the original language of the gods."

To this wild rule more than one of the Concord philosophers conforms ; there is a perceptible lack of method, even when their meaning is fairly clear. Hawthorne incurs less of this censure than the rest; but he confessed that he did not always comprehend his own allegories, nor know exactly the moral he would insinuate. Emerson goes more directly to his mark; a Frenchman (Chantavoine) has said of him, "In his Essays he is first of all a philosophic moralist, never quite forgetting that he was once a preacher." But, in contrasting him with French writers, Chantavoine admits that 
Emerson has something which the light and brilliant Parisian essayists lack :

"We are afraid, I suppose, of losing touch with things, if we rise much above them; we do not soar high, content to skim the surface; we distrust those generalities, however eloquent or edifying, which might lead us too far aside. Yet, should we borrow something of Emerson's manner, French criticism, both historical and literary, would gain by it ; there might possibly be less ease, less lightness of touch, less glancing wit in our essays; but in return there would be more earnestness and depth in our judgments on men and affairs."

Emerson was a reader and admirer of French prose; he did not find much poetry in French verse. The glancing of his wit was as quick and searching as that of Paris; but he belongs more to the literature of the world than most of the French prose authors since Montaigne and Pascal. In American literature he is unique; so, in his very different way, is Thoreau; so is Hawthorne; and no American, not even one of these three, can be compared with any of them on terms of similarity. There is that in their best writing which puts us upon our best thinking, and leads us along the upper levels of life. Particularly is this true of Emerson; Virtue, radiant, serene and sover- 
eign, sways the realm where Emerson abides, and to which he welcomes his readers, who become his friends. It was said of Socrates, in a dubious compliment, that he "brought philosophy down from heaven to earth"; it might as truly be said of Emerson that he raises earth to the level of divine philosophy. His method in this is purely poetic; therefore, while in verse he lacks what is usually called creative power, he brings with him the atmosphere of poesymore constantly than any modern poet; nor, since Milton, Spenser, and Shakespeare, has any English poet excelled him in this. To this quality, as well as to his courage of opinion and his penetrating insight, do we owe it that he first proclaimed our intellectual independence of the mother-country, as Franklin, Washington and Jefferson declared our political independence. There is, indeed, a certain resemblance between Washington and Emerson which might escape the notice of those who look chiefly at the totally different work each had to do, and the diversity of life and opinion which contrasted Virginia and New England so sharply:

It must be confessed that, in 1732 . Concord was hardly so constituted as naturally 


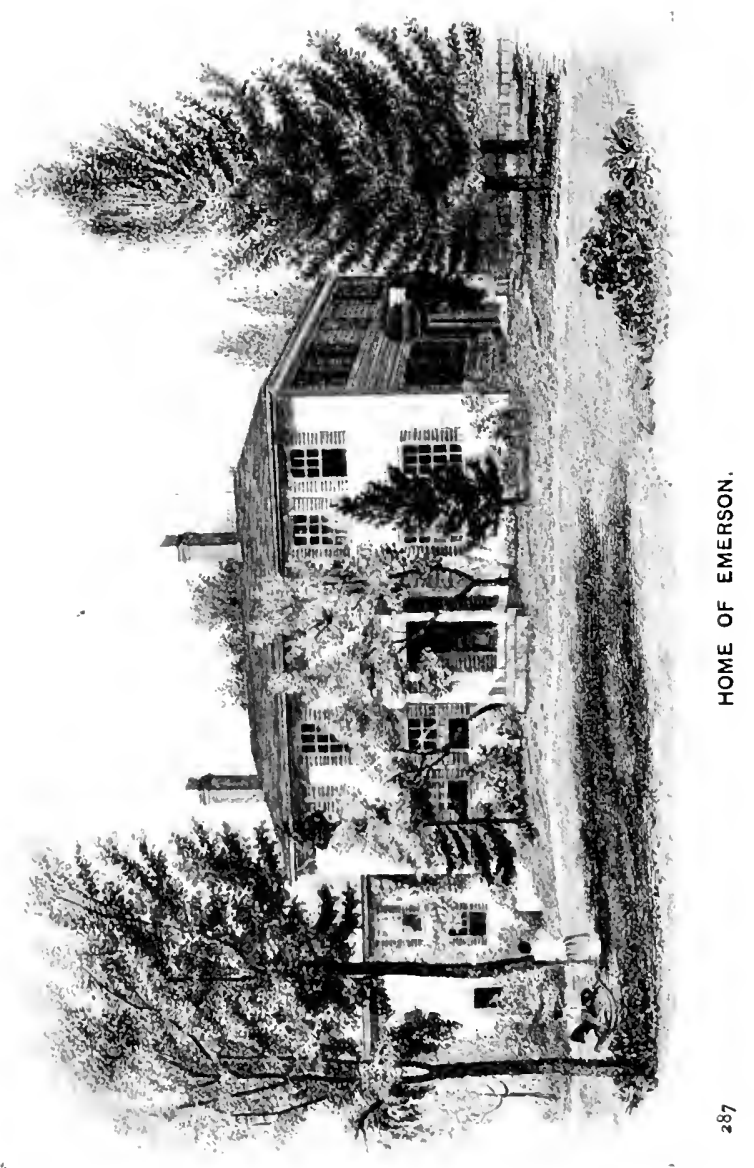


to give birth to Washingtons; indeed, Virginia produced but this one, amid all her great men. The extreme narrowness of Puritan opinion, even when modified by Baptists and Quakers, was not favorable to the rise of men like the great Virginians of the eighteenth century. A milder intellectual climate, a temper less given to disputes about faith and works, election and reprobation, was needful to produce characters so broad, so moderate, and yet so firm, as Washington's. New England did give birth to Franklin, in the very midst of Mathers and Sewalls; but he had to slip away to Philadelphia, in order to grow into his full stature as philanthropist and philosopher. The intolerance of New England deprived us, for more than a century, of the opportunity to produce genius and the gentler forms of heroism. We had the Adamses to set the Revolution on foot, the soldiers of New Hampshire and rural New England to fight its battles; but its noblest leader must come to us from the Potomac, and take us back there, when the long fight was won, to establish our government beside its waters, in sight of his own broad domain. It was not till this century, now declining, that Concord could 


\section{Concord}

show an intellectual Washington; and Emerson must be born in Boston, less provincial than our meadowy village, our "rural Venice," as Thoreau called it in times of river-freshet.

Naturally, when men appear on earth of Washington's or of Emerson's stamp, there has been a long preparation for their advent. They are not found among Hottentots or corn-crackers, 'longshoremen or cowboys; but in some long-tilled garden of the human species, where certain qualities have been inbred by descent and betterment for many generations. Poverty may be their birthright, as in the case of that greatest of Washington's successors, Abraham Lincoln, but the experiences that are transmuted by descent into greatness are quite as often those of poverty as of wealth. Self-reliance, veracity, courage, and the gift of command are essentials in the founders and preservers of nations; these are fostered in all new colonies, and therefore were common qualities in New England, as in Kentucky and Virginia, in their early years. But among the planters of Virginia there grew up a form of society, now forever extinct there, in which these high qualities, together with courtesy and breadth of view, were cultivated 
and flourished to an extent which the Cal. vinistic rigors and enforced economies of $\mathrm{New}$ England never knew. That petty system of inquiring into creeds and points of doctrine which our ancestors brought with them from the Puritan parishes of England, and which was increased here by infusions from Scotland, and the tyranny of ecclesiastical control in Massachusetts and Connecticut, was not wholly unknown in Virginia; but its ill effects were dissipated by the customs of large landholding, outdoor sports, and certain traditions of honor and breeding which the best of the Virginians brought with them from England, and kept up by their habit of frequent intercourse with the mother-country.

It was no $\sin$ in Virginia to dance and play the fiddle; the Anglican Church, while prescribing a formal creed, did not concern itself to inquire every Sunday, or every Thursday, into all the dogmatic abstractions of the Westminster Assembly's Catechism, longer or shorter; men's minds were left to take the course most natural to them. But in New England, along with much acute speculation (the best type of which is Jonathan Edwards), there went a morbid conscien- 
tiousness, turning its eyes upon inward and even petty matters, and leading to numberless quarrels about Original Sin, Half-way Covenants, Justification by Faith, etc. Concord was less infested by this carping, persecuting, quarrelsome spirit than most of New England; yet the church records, and the collections of old Dr. Ripley, show there was much of it. Emerson declares, and justly, that good sense has marked our town annals: "I find no ridiculous laws, no eaves-dropping legislators, no hanging of witches, no ghosts, no whipping of Quakers, no unnatural crimes." But the spirit which led to these mischiefs in other regions of Massachusetts and Connecticut was all about us; and it narrowed the minds and the opportunities of Concord before the Revolution. It was chiefly in New Hampshire, Maine and Vermont, where ecclesiastical domination was less rigid, that mental freedom manifested itself. In the other colonies of the North, wealth and culture were apt to be on the side of England, when our troubles began; in Virginia and the Carolinas, and to some extent in New Hampshire and Maine, wealth took the colonial side.

We may call the imaginative force and 
breadth of the Concord authors "Shakespearian" for lack of a better word; but there was a man of singular mental penetration sometimes visiting here,- Jones Very, of Salem,-who once made a wider generalization-whether wisely or not. When Very was asked to discriminate betwixt Wisdom and Genius, he said, "Wisdom is of God; Genius is the decay of Wisdom"; adding in explanation, "To the pre-existent Shakespeare, wisdom was offered; he did not accept it, and so he died away into genius." We had a superior sage here (Bronson A l c ot t), who had little of the Shakespearian genius, but much of that mystic wisdom which A. BRonson alcott. (1875.) Very thought older and nobler than genius. Religion was his native air,- - the religion of identity, not 
of variety; he could not be polytheistic, as many Christians are, even while fancying themselves the most orthodox worshippers of the One God. He had that intense application of the soul to one side of this sphere of life, which led him to neglect the exercise of intellectual powers that were amply his. $\mathrm{H}$ is gift it was, not to expand our life into multiplicity, - which was the tendency of Emerson, as of Goethe and Shakespeare,-but to concentrate multiplicity in unity, seeking ever the ONE source whence flow these myriad manifestations. His friends used to call him, in sport, the "Vortical philosopher," because his speculations all moved vortically toward a centre, or were occupied with repeating one truth in many forms. He was a votary of the higher Reason; not without certain foibles of the saint; but belonging unmistakably to the saintly order. Of course he was the mock of the market-place, as all but the belligerent saints are; but he was a profound, vivifying influence in the lives of the few who recognized his inward light.

From Alcott, in his old age,- -he was in his eightieth year when the experiment began,came the impulse to that later manifestation 
of the same spirit which had led Emerson and his youthful friends to the heights and depths of Transcendentalism. I speak of the Concord School of Philosophy, which, in the last years of Emerson and Alcott, and with the co-operation of clisciples of other philosophic opinion, gave to the town a celebrity in some degree commensurate with its earlier reputation. It began in the library of Alcott's Orchard House, where his genial daughter, Louisa, had written several of her charming books; it was continued in a chapel, built for the purpose, under the lee of Alcott's pineclad hill, and amid his orchard and vineyard. It brought to reside in Concord that first of American philosophers, Dr. IV. T. Harris; and it gathered hundreds of eager or curious hearers to attend the lectures and debates on grave subjects which a learned body of teachers gave forth. It continued in existence from the summer of I 879 to that of I 888 , when its lessons were fitly closed with a memorial service for Bronson Alcott, its founder, who had died in March, 1888. As was said by the Boston wit of the fight on the I 9 th of April," The Battle of Lexingrton; Concord furnished the ground, and Acton the men,"-so it might. 


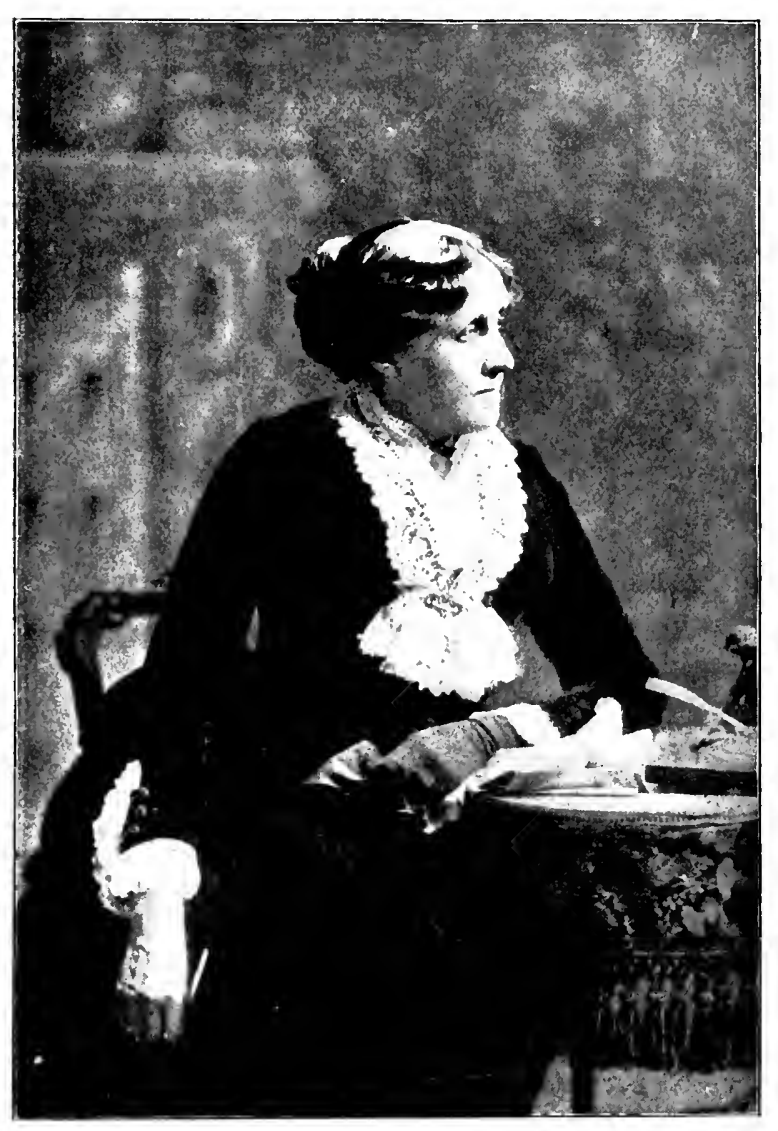

2. M. Ale coll.

295 
be said of this summer university, that Concord provided chiefly the place in which $\mathrm{St}$. Louis and Illinois, New York and Boston, Harvard and Yale, held converse on high topics. Yet Concord gave the school hospitality, and several of its famous authors took part in the exercises,-- sometimes posthumously, by the reading of their manuscripts, as in the case of Thoreau.

Along with the events and the literature that have given our town a name throughout the world, there has flowed quietly the stream of civil society, local self-government and domestic life; broadened at critical times by manifestations of political energy, in which families like those of Hoar, Heywood, Barrett, Whiting, Robinson, Gourgas, etc., have distinguished themselves. Benefactors like Nunroe, who built the Public Library, Dr. Ripley, who for half a century filled the pulpit and took pastoral care, and John Tileston, who brought the public schools to their present useful form; soldiers of the Civil War, like Colonel Prescott and Lieutenant Ripley, and hundreds of unnamed soldiers in the battle of life,--women no less than men,have given their innumerable touch of vigor 
and grace to the ever-building structure of Concord life. Painters of our own have added color, and sculptors like French, Elwell and Ricketson have adorned the town with art. And so we pass on into the new century, with no conscious loss of vital power,-yet with a keen regret for the great men who have gone from among us.

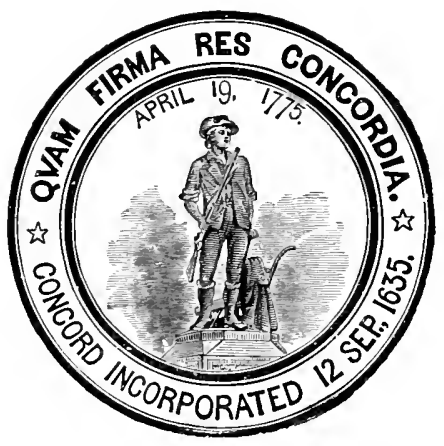





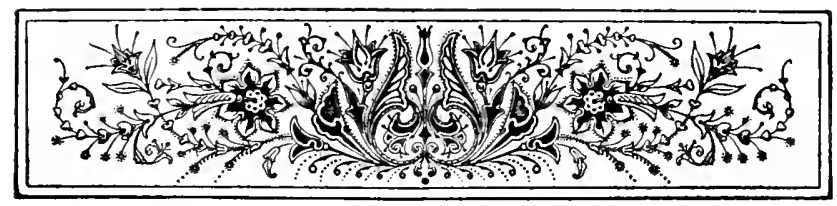

\title{
PLYMOUTH
}

\section{THE PILGRIM TOWN}

\author{
BY ELLEN WATSON
}

"Glory of Virtue, to fight, to struggle, to right the wrong;-

Nay, but she aimed not at glory, no lover of glory she ; Give her the glory of going on, and still to be." Tennyson's Wages.

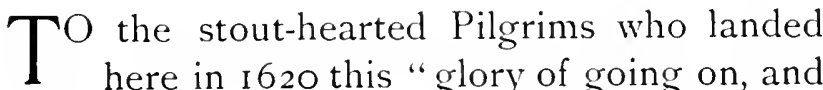
still to be" has been meted in lavish measure. For nearly three hundred years the fire first kindled in far-away Scrooby in the hearts of John Robinson, Elder Brewster, Richard Clyfton, the youthful William Bradford and their devoted followers has burned with a clear flame; the torch of truth there lit by them has been handed on from generation to generation.

For the many latter-day pilgrims who visit the shrines of New England, the gray boulder 
on Clarke's Island where the weary voyagers rested after their stormy cruise in the shallop; the humble rock on our shore where they at length found shelter; our noble statue of "cleareyed Faith" and the not far distant monument on Bunker Hill, will ever bear like testimony to the courage of that little band of independent thinkers. Meeting in secret in the ManorHouse of Scrooby, these far-sighted heroes, when they "shooke of the yoake of antichristian bondage" of the Church of England, made possible for their descendants a later Declaration of Independence!

And every year, with the new knowledge it brings, adds to the pathos of that early endeavor after religious and civil liberty. Many English scholars, generously overlooking the Separation of 1776 , have traced on the mother soil of Old England the very beginnings of the Separatist movement, and thanks to their careful study of musty records and yellow parchments we now have a satisfactory, though still incomplete, record of those few eventful lives to which we proudly owe our present freedom.

One enthusiast even finds the earliest evidences of this movement in the concerted action of certain rebellious weavers of the twelfth 


\section{(1): whirotí plantation}

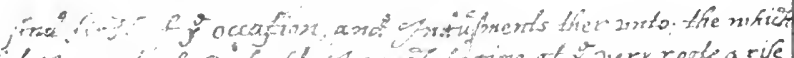

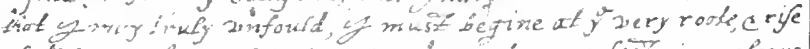

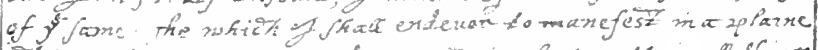

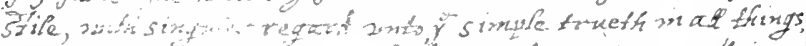

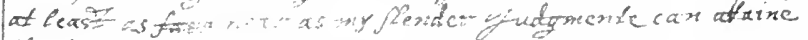
the famb

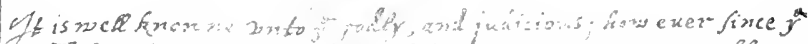

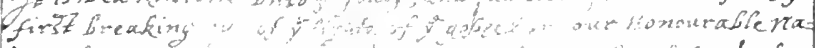

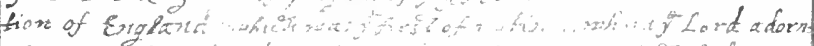

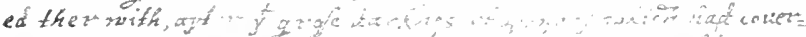

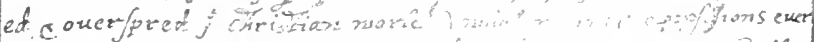

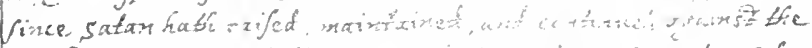

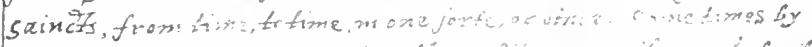

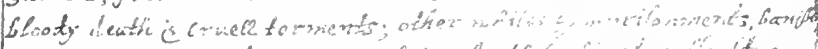

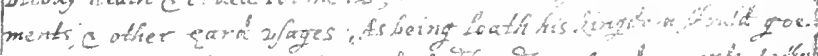

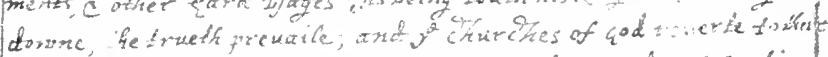

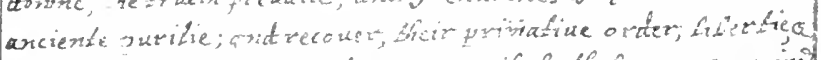

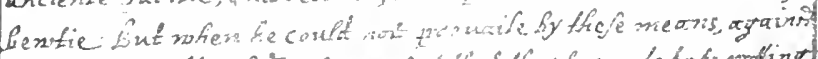

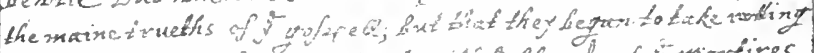

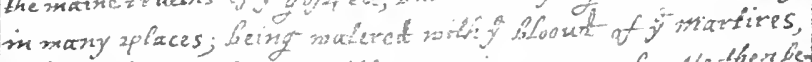

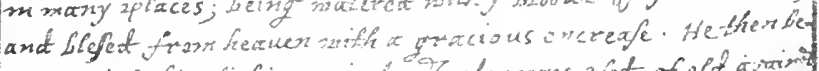

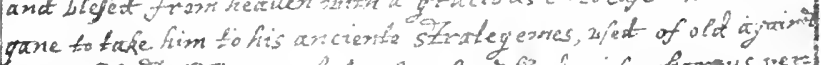

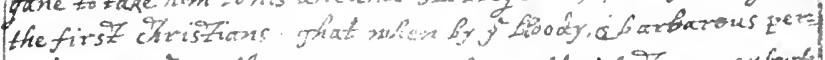

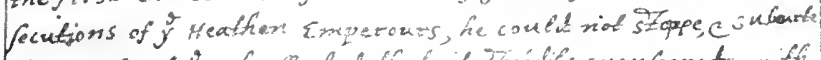

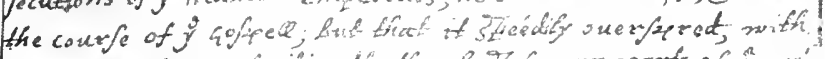
a woundenfule Celeritic, the then besz frown parts of y wow

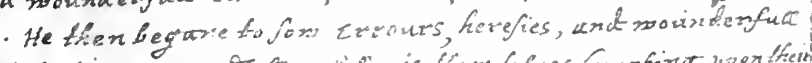
difentions amongst y zroysgours thim felues (norking wporthern

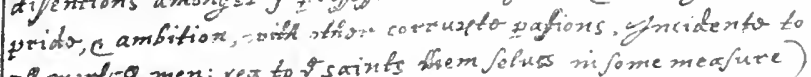

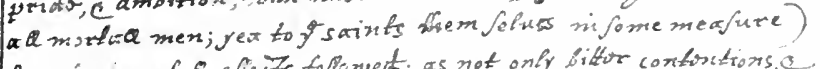

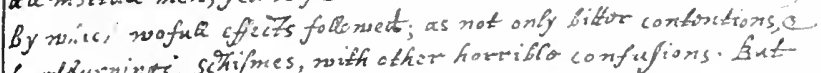
hartsurrings, schipmes, with othir how iblo confufions. But

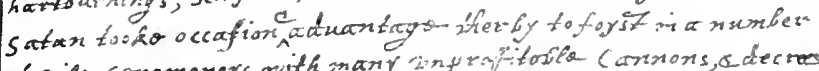

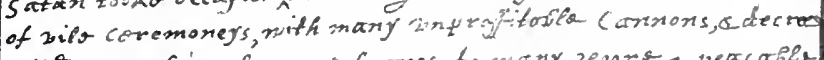

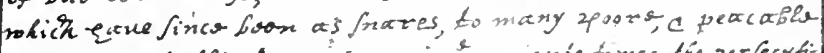

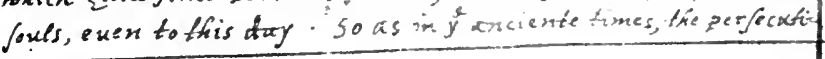


century - thirty weavers of the diocese of Worcester-who were summoned before the Council of Oxford to answer a charge of making light of the sacraments and of priestly power. Though they answered that they were Christians and reverenced the teachings of the

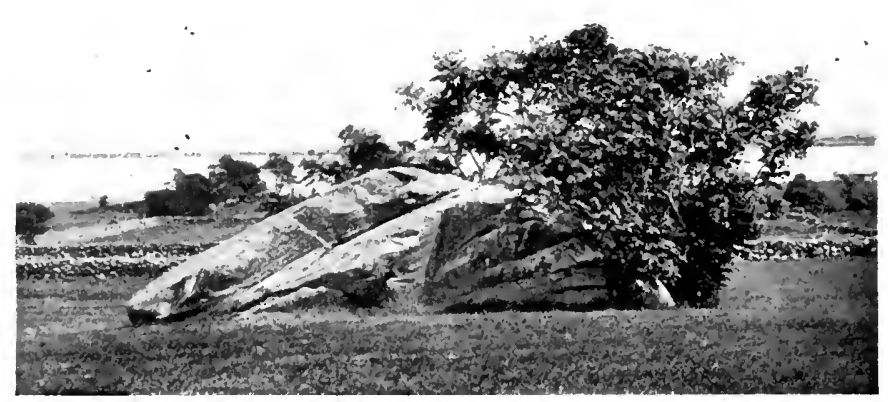

Copyright, r893, by A. S. Burbank.

PULPIT ROCK, CLARKE'S ISLAND.

apostles, they were driven from the country as heretics, to perish of cold. This "pious firmness" on the part of the council, writes the short-sighted chronicler, not only cleansed the realm of England from the pestilence which had crept in, but also prevented it from creeping in again. But the pestilence did creep in 


\section{Plymouth}

again and again and the weeds grew apace, for which thanks are chiefly due to John Wyclif and his followers.

Even before the Reformation Foxe tells of "secret multitudes who tasted and followed the sweetness of God's Holy Word, and whose fervent zeal may appear by their sitting up all night in reading and hearing." But we must be content to trace our ancestry and our love of liberty to the early years of the seventeenth century, at which time, as we may now all read in the clear lettering of Bradford's own pen,

"truly their affliction was not smale; which notwithstanding they bore sundrie years with much patience, till they were occasioned to see further into things by the light $\mathrm{oi}^{\text {i }}$ $\mathrm{y}^{\mathrm{e}}$ word of God. How not only these base and beggerly ceremonies were unlawfull, but also that $\mathrm{y}^{\mathrm{e}}$ lordly \& tiranous power of $y^{e}$ prelats ought not to be submitted unto; which thus, contrary to the freedome of the gospell, would load \& burden mens consciences, and by their compulsive power make a prophane mixture of persons and things in the worship of God. And that their offices \& calings, courts and cannons \&c. were unlawfull and antichristian; being such as have no warrante in $y^{e}$ word of God; but the same that were used in poperie \& still retained."

So these brave men, whose hearts the Lord had touched with heavenly zeal for His truth, 
" as $y^{e}$ Lords free people joined them selves into a church estate, in $y^{e}$ felowship of $y^{e}$ gospell, to walke in all his wares, made known, or to be made known unto them, according to their best endearours, whatsoever it should cost them, the Lord assisting them. And that it cost them something this ensewing historie will declare."

The charming scene of these secret meetings is now well known. In the little village of Scrooby, where the three shires of Nottingham, York and Lincoln join their borders, then stood a stately manor-house, once the favorite hunting-seat of the archbishops of York. Under this hospitable but already somewhat crumbling roof William Brewster, who had been appointed "Post" of Scrooby in I590, welcomed these sufferers for conscience sake. Hither they stole through the green country lanes, from far around to listen to the "illuminating ministry" of Richard Clyfton,

"a grave \& reverêd preacher who under God had been a means of $y^{e}$ conversion of many. And also that famous and worthy man, Mr. John Robinson, who afterwards was their pastor for many years till $y^{e}$ Lord tooke him away by death."

Here, too, from the neighboring hamlet of Austerfield, came the lad William Bradford, already eager for spiritual guidance. Walk- 


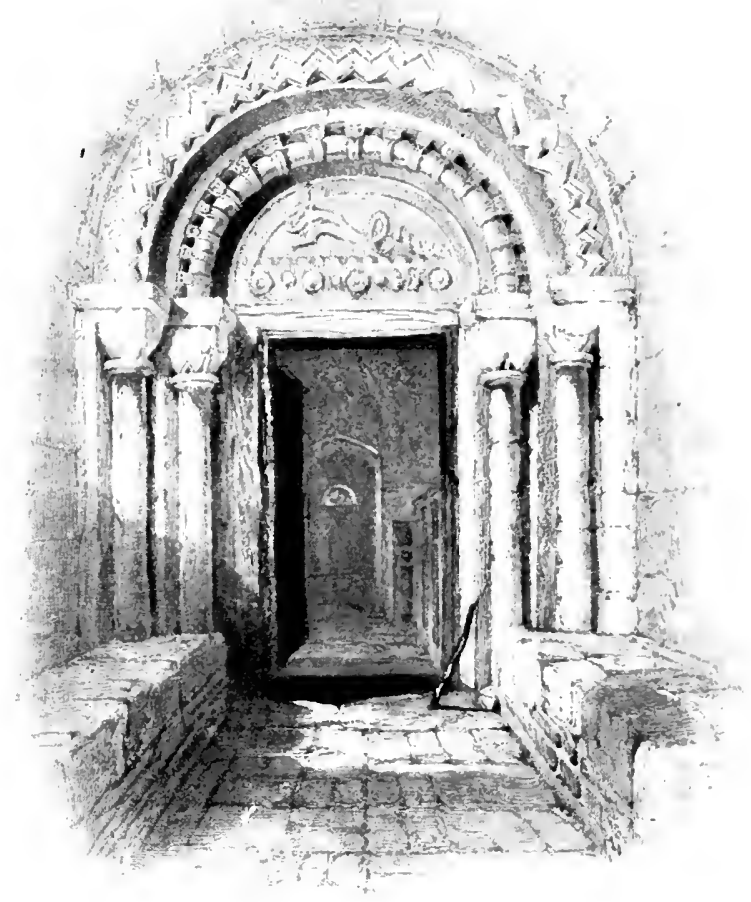

THE EARLY NORMAN DOORWAY AT AUSTERFIELD CHURCH. 
ing under the elm-trees of the highroad, and through the yellow gorse, across green meadows and by the banks of the placid Idle, he stopped perhaps to admire the mulberry-tree planted there by the world-weary Cardinal Wolsey. That arch-enemy of the Reformation little thought that a branch of this tree would one day cross the Atlantic, to be preserved with Pilgrim relics by friends of that " new, pernicious sect of Lutherans," against which he warned the king!

Near Bradford's birthplace in Austerfield now stands, completely restored, the twelfthcentury parish church where he was baptized in 1590 , and from which he "seceded" when about seventeen years old. Did the quaint old bell-cote with the two small bells, the beautiful Norman arch of the southern doorway with its rich zigzag ornament and beak-headed moulding, the wicked-looking dragon on the tympanum, with the tongue of flame-did this perfect picture of Old-World beauty flash across his memory when, some thirty years later, he helped build the rude fort on our Burial Hill, which served as the first "MeetingHouse" in New England?

We like to believe that Bradford belonged 


\section{Plymouth}

to the honest yeoman class, that he "was used to a plaine country life $\&$ the innocente trade of husbandrey" ; we know that he had a natural love of study which led him, despite the many difficulties he met, to master the Dutch

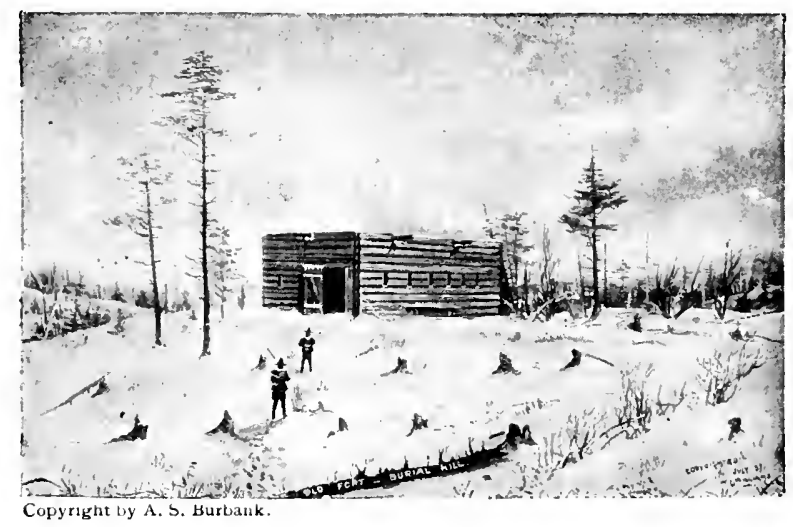

THE OLD FORT AND FIRST MEETING-HOUSE, ON BURIAL HILL, 1621.

tongue as well as French, Latin, Greek and Hebrew, which latter tongue he studied the more, "that he might see with his own eyes the ancient oracles of God in all their native beauty."

Associated as teacher here with the venerable Richard Clyfton, "the minister with the long white beard," and succeeding him as pastor, we have found the eloquent John Rob- 
inson, that winner of all men's hearts, that helper of all men's souls. A youthful student at Cambridge, living in an age and in an atmosphere of religious questioning, he was deeply troubled with scruples concerning conformity. He tells us "had not the truth been in my heart as a burning fire shut up in my bones, I had never broken those bonds of flesh and blood wherein I was so straitly tied, but had suffered the light of God to have been put out in mine unthankful heart by other men's darkness." Happy in finding congenial spirits in the new community at Scrooby, Bradford tells us he soon became

"every way as a commone father unto them." "Yea, such was $y^{e}$ mutuall love and reciprocall respecte that this worthy man had to his flocke and his flocke to him that it might be said of them as it once was of that famouse Emperour, Marcus Aurelious and $y^{e}$ people of Rome, that it was hard to judge wheather he delighted more in haveing such a people, or they in haveing such a pastor. His love was greate towards them, and his care was all ways bente for their best good, both for soul $\&$ body."

Under his inspiring guidance, and with William Brewster as their especial stay and help, they were mercifully enabled to "wade through 
things." Some twenty-three years older than Bradford, we learn from that modest chronicler, who wrote "in a plaine stile, with singuler regard unto $\mathrm{y}^{\mathrm{e}}$ simple trueth in all things," that Brewster had also a wider experience of the world.

"After he had attained some learning, viz., the knowledge of the Latin tongue and some insight into the Greek, and spent some small time at Cambridge, and then being first seasoned with the seeds of grace and virtue, he went to the Court, and served that religious and godly gentleman, Mr. Davison, divers years, when he was Secretary of State, who found him so discreet and faithful, as he trusted him above all others that were about him, and only employed him in matters of greatest trust and secrecy."

After the innocent Davison was committed to the Tower by the treacherous "Good Queen Bess," Brewster retired to Scrooby, where he greatly promoted and furthered their good cause: "he himself most commonly deepest in the charge, and sometimes above his ability, and in this estate he continued many years, doing the best he could, and walking according to the light he saw, until the Lord revealed further unto him."

But these assemblies, however humble and 
secret, could not long escape the vigilant eye of the law. They were now

" hunted and persecuted on every side, so as their former afflictions were but as flea-bitings in comparison of these which now came upon them. For some were taken and clapt up in prison, others had their houses besett $\&$ watcht night and day, \& hardly escaped their hands; and $y^{\mathbf{e}}$ most were faine to flie and leave their howses and habitations, and the means of their livelihood." "Seeing them selves so molested, and that ther was no hope of their continuance ther, by a joynte consente they resolved to goe into the Low-Countries, wher they heard was freedome of Religion for all men."

This quitting their native soil, their dear friends and their happy homes to earn their living, they knew not how, in a foreign country, was indeed considered by many of them to be "an adventure almost desperate, a case intolerable, \& a misserie worse than death." But after many betrayals, many delays, many hardships by land and sea, they finally weathered all opposing storms. At Amsterdam, that friendly city of the Netherlands Republic, whose Declaration of Independence dates from July $26, I_{5} 8$ I, they met together again, with no small rejoicing.

But in the midst of the wealth of this fair city they soon saw " the grime and grisly face of 
povertie coming upon them like an armed man, with whom they must bukle and incounter, and from whom they could not flye." For this reason, and to avoid religious contentions already rife there, in a year's time they decided to remove to Leyden, "a fair and bewtifull citie, \& of a sweete situation." Here the story of the long siege of Leyden, bravely sustained in 1573 , must have excited their ready sympathy, and the city's choice of a university, offered by William of Orange, instead of the exemption the city could have had from certain imposts, must have won the admiration of these scholarly men.

The stay of the English exiles here of some twelve years-the period of the truce between Holland and Spain-was, though trying, no doubt a good preparation for the greater hardships they were to endure. While Bradford wove fustian and his fellow-workers carded wool, made hats and built houses, Brewster printed "heretical" books, and taught English "after $y^{e}$ Latin manner." The harmony of their peaceful and industrious lives attracted many friends, until some three hundred kindred spirits joined John Robinson in his prayers for "more light." 
One who soon proved himself to be an invaluable member of the community was Edward Winslow, a highly educated gentleman from Worcestershire. His energy; his diplomacy and practical experience of the world, his influence with Cromwell and other powerful friends in high places, removed many difficulties in the way of the struggling colony that was to be. Four times he was their chosen agent in England, and was thrice elected governor.

Here John Carver, a trusted adviser, who later became the first governor of New Plymouth, was chosen deacon of their church.

Serving in the troops sent over by Elizabeth to aid the Dutch in maintaining the Protestant religion against the Spaniards was the valiant soldier, Myles Standish, of the Dokesbury branch of the Standishes of Lancashire, who date from the Conquest. There the beautiful Standish church still bears on its buttresses the family shield - three standing dishes argent on a field azure-and Standish Hall is still hung with portraits of warriors in armor, beruffed lawyers with pointed beards, and gay courtiers of the Queen-the Roman Catholic ancestors of our plain fighter! Luckily for us all, he 


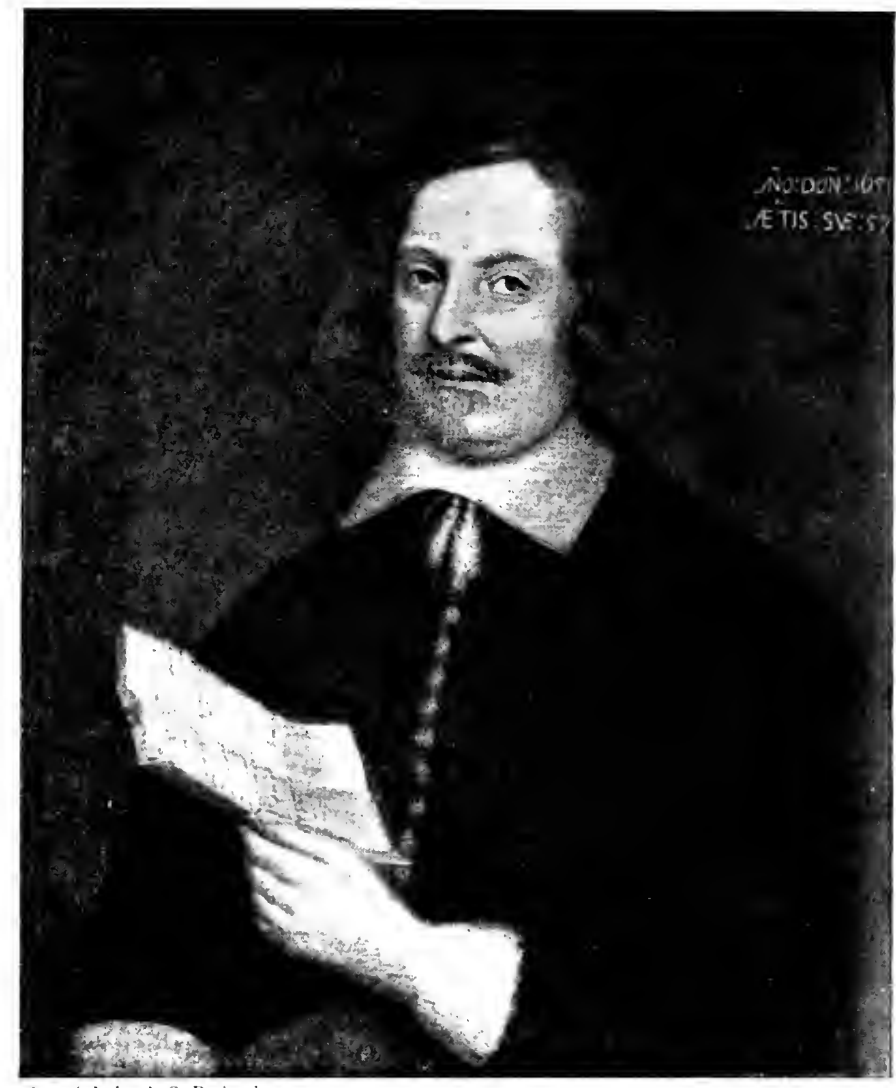

Copyright by A. S. Burtrank.

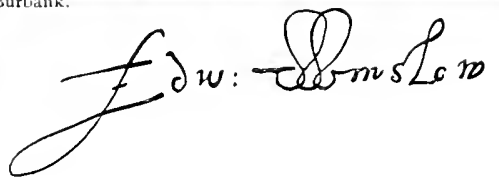


cast in his lot with the plucky workers he met in Leyden, and his cheery presence and courage must have been of great service in planning the perilous voyage on which they were about to embark.

For, as the truce with Spain drew to a close. and as the older among them began to consider the uncertain future that lay before their children, they longed to take refuge on some freer soil, however far away. As Bradford writes, with a courage at once humble and sublime:

"Lastly (and which was not least) a great hope and inward zeall they had of laying some good foundation, or at least to make some way thereunto, for $\mathrm{y}^{\mathrm{e}}$ propagating and advancing $y^{e}$ gospell of $y^{e}$ kingdom of Christ in those remote parts of $y^{e}$ world : yea, though they should be but even as stepping-stones unto others for $y^{\mathbf{e}}$ performing of so great a work."

So, " not out of newfangledness, or other such like giddie humor, but for sundrie weightie and solicl reasons," the voyage was determined upon, and the King's consent to their emigration to America sought.

Winslow tells us, in his Bricfe Narrative of the Truc Grounds for the First Planting of New England, that when their plans were laid before King James he remarked that "it was 
a good and honest notion," and asking further what profits might arise, he was answered, "fishing." "So God have my soul," he said, "so God have my soul, 't is an honest trade; 't was the apostles' own calling!" And we may state here, notwithstanding Bradford's statement that in the beginning "we did lack small hooks," New England, before 1650, annually sent to Europe $£ \mathrm{I}$ oo, 000 worth of dried codfish.

After many weary negotiations, a patent was at length obtained, but the future colonists were refused a formal grant of freedom in religious worship under the King's broad seal. A loan was made by some seventy " Merchant Adventurers" in England, and late in July, I620, we find our future colonists on the quay at Delfthaven, ready to embark on the Speedwell. They are surrounded by their tearful friends, for whom, Winslow says, "they felt such love as is seldom found on earth."

Many of their number are to stay at Leyden under the faithful care of John Robinson, whose touching farewell words Winslow has preserved for us :

" he charged us before God and his blessed angels to follow him no further than he followed Christ ; and if 
God should reveal anything to us by any other instrument of his, to be as ready to receive it as ever we were to receive any truth by his ministry; for he was very confident the Lord had more truth and light yet to break forth out of his holy word."

This sad scene must have been still vivid in Bradford's memory when he wrote some ten years later in Plymouth:

" truly dolfull was $y^{\mathrm{e}}$ sight of that sade and mournfull parting; to see what sighs and sobbs and praires did sound amongst them, what tears did gush from every eye, \& pithy speeches peirst each harte"; "but they knewe they were pilgrimes, and looked not much on those things, but lift up their eyes to $y^{\mathrm{e}}$ heavens, their dearest cuntrie, and quieted their spirits."

After a good run with a prosperous wind they found the Mayflower at Southampton, but as the Speedwcll proved unseaworthy they were again delayed, and after putting in for repairs to Dartmouth and Plymouth, the Mayflower finally, on September i6th, sailed alone from Plymouth. Observe the group of brave voyagers setting forth on an unknown "sea of troubles," trustful wives and children, manly youths and blooming maidens, as they wave a last good-by to dear Old England from the deck of the Mayflower. Their leaders form 


\section{Plymouth}

a notable band: Brewster, Carver, Bradford, Winslow, Standish, the soul, the heart, the head, the good right hand, the flashing sword, well-chosen instruments to unlock the frozen heart of New England, and to found there

"Empire such as Spaniard never knew."

Perhaps George Herbert, prince of poets, referred to this sailing when he wrote in his Church Militant:

" Religion stands on tiptoe in our land, Ready to pass to the American strand."

Of the terrible discomforts and dangers of that perilous voyage of sixty-seven days who has not read the pitiful story? Have we not, all of us, "come over in the Mayflower," and rejoiced with these patient souls when at length, one clear morning in November, the shores of Cape Cod lay fair before their expectant eyes?

Determining to put in to Cape Cod harbor, and so to land on a territory where their patent could confer no rights, the leaders of the expedition, after consulting together in the cabin of the Mayflower, there drew up and signed the historic "Compact" which was to convert the hundred voyagers into the founders of a 
commonwealth. There they solemnly and mutually, in the presence of God and of one another, combined themselves into a civil body politic, to frame and enact such just and equal laws from time to time as should be thought most meet and convenient for the general good of the colony, unto which they promised all due submission and obedience.

While their sloop-rigg shallop of some fifteen tons was made ready for exploration by sea, those who went at once far into the forest came back with reports of fine growths of oak, pine, sassafras, juniper, birch and holly, abundant grape-vines and red cedar, which like sandalwood

"Sheds its perfume on the axe that slays it."

They found excellent springs, many deer and wild-fowl, and what proved to be their salvation in the wilderness, "divers faire Indian baskets filled with corn, which seemed to them a goodly sight." For this precious seed-corn the Indian owners were conscientiously paid double price some six months later.

The weakness and illness natural after the discomforts of such a voyage now made themselves felt in an alarming manner, and an ex- 


\section{Plymouth}

ploring party was hastily organized to select the spot for their final settlement. Setting forth in the frail shallop, a party of eighteen picked men, after a successful "First Encounter" with the Indians, were driven by a furious gale to take shelter in the lee of a little island lying in a friendly harbor to the west of their starting-point. After thawing out over a good cedar-wood fire and resting for a night, they explored the island and repaired their boat. Of this island, afterward named for John Clarke, mate of the Mayflower, Bradford writes :

"But though this had been a day and night of much trouble \& danger unto them, yet God gave them a morning of comforte \& refreshing (as usually he doth to his children), for $y^{\mathbf{e}}$ next day was a faire sunshining day, and they found them sellys to be on an iland secure from the Indeans, wher they might drie their stufe, fixe their peeces, \& rest them selves, and gave God thanks for his mercies, in their manifould deliverances. And this being the last day of $y^{\mathbf{e}}$ weeke, they prepared ther to keepe $\mathrm{y}^{\mathrm{e}}$ Sabath. On Munday they sounded the harbor, and founde it fitt for shipping; and marched into $y^{e}$ land and found diverse cornfeilds and litle runing brooks, a place (as they supposed) fitt for situation ; at least it was $\mathrm{y}^{\mathrm{e}}$ best they could find, and $\mathrm{y}^{\mathrm{e}}$ season \& their presente necessitie made them glad to accepte of it." 
So, on the 2 Ist day of December, I620, was made the now world-famous landing at Plymouth, of which these few words are the humble record.

After a week of anxious waiting their return must have been hailed with delight on board the Mayflower, and their good tidings warmly welcomed. As with all sails set the good ship made her way into the harbor, eager eyes doubtless watched with joy the high hills of Manomet, the wooded bluffs, the shining, protecting beaches, the fair island, the low friendly stretch of the mainland sloping back to the picturesque hillsides, which make Plymouth harbor at all times and seasons a goodly sight to look upon. And here at length lay safely at anchor the

“. . . simple Mayflower of the salt-sea mead !"

And now, "Courteous Reader," as writes that most faithful secretary of the Pilgrims, Nathaniel Morton, in his New England Memorial (1669), "that I may not hold thee too long in the porch," even in such goodly company, I bid you welcome to the Plymouth of to-day. For in the harbor, the sand-dunes, the green hillsides and the fresh valleys and 


$$
14
$$


meadows, in the blue streams and ponds, the past is inseparably blended with the present. A small theatre it is, and the actors were but few who played such important rôles in the building up of a nation, but the few memorials in which that early struggle for existence is recorded are here lovingly preserved.

From the Rock where they landed we may follow their weary footsteps up the steep ascent of the first street, now named for Leyden, their city of refuge, and which may well be called the Via Sacra of Plymouth. Running back from the waterside to the foot of Burial Hill, and parallel to the Town Brook, it formed the centre of their daily toil, the scene of their early joys and sorrows. Here on either hand were staked out the homesteads for the nineteen first families; here with sturdy courage and endless labor they dragged the trees felled outside the clearing, and built their rude houses, thatching them with swamp-grass.

The site of their first or "Common-House" is now marked, and near the lot assigned to Elder Brewster still we may stop to drink from the Pilgrim Spring: the "delicate water" is fresh and sweet now as when our thirsty forefathers delighted in it. 


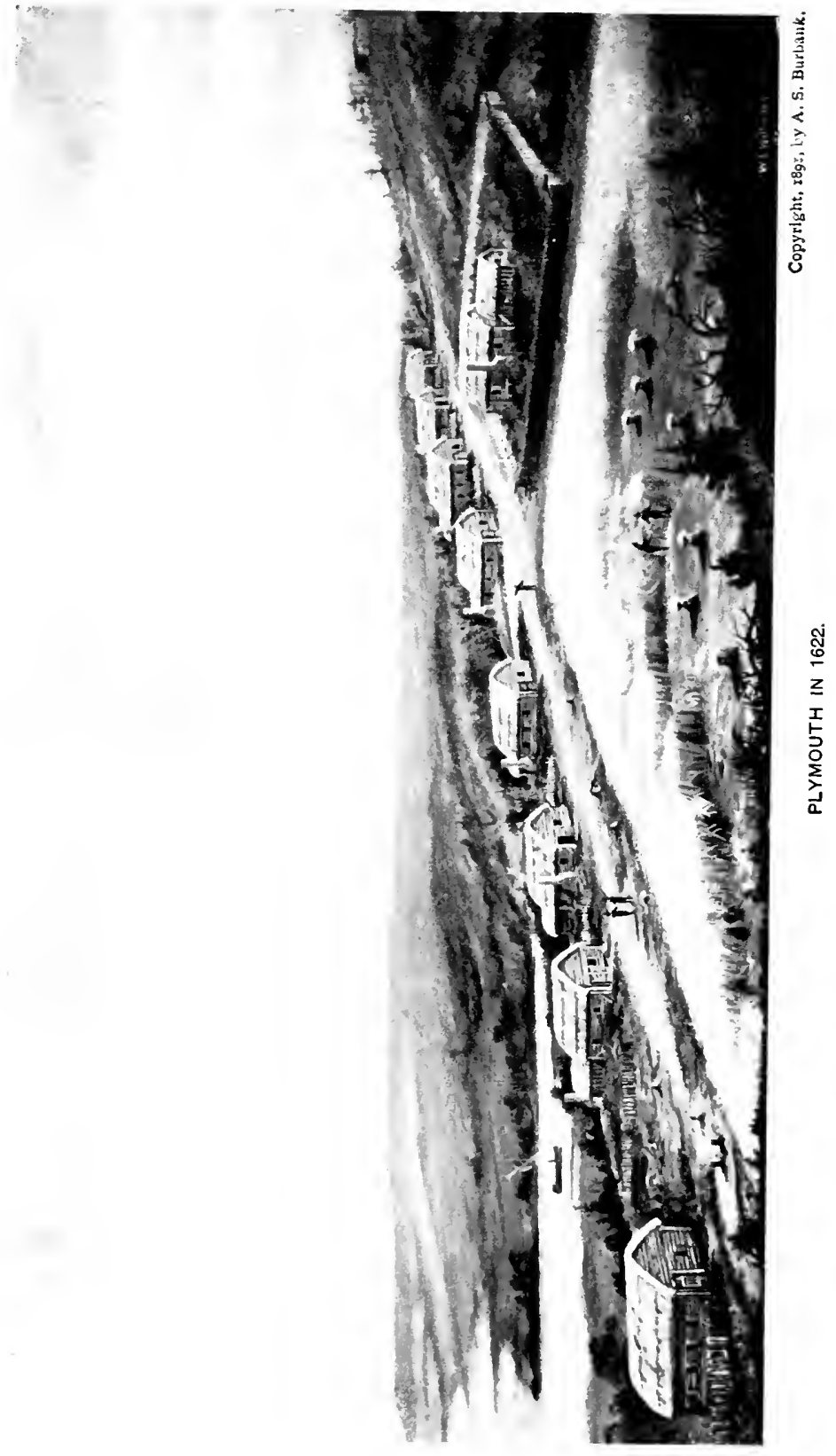


Crossing Main Street, once the King's highway, we find ourselves in Town Square, under the shade of beautiful old elm-trees, planted more than a hundred years ago. To the north was William Bradford's homestead. Here came all those who sought advice and help in their sore need, and here in $6_{3} 0$ were begun those "scribbled writings" which, "peeced up at times of leasure afterward," are now printed in letters of gold in many a faithful memory! Here, perhaps, or in the vicinity of the Common House, was concluded their first treaty with a foreign power for mutual aid and protection, when the noble chief Massasoit, with his sixty Indian braves, was led thither by Samoset, the friendly sachem, whose English welcome had surprised the anxious colonists. Through Samoset they learned that some four years before a pest had devastated that region, called by them Patuxet. With him came Tisquantum, who became a valued friend and interpreter, teaching them to plant their corn when the oak-leaves were the size of a mouse's ear, and to place three herring in each hill with the seed-corn, which novel practice awakened serious doubts in English minds.

In the autumn of $162 \mathrm{I}$, this was the scene 
of the first Thanksgiving held in New England, when, their houses built, their crops garnered from some thirty fertile acres, their furs and lumber safely stored, they made merry for three days, with Massasoit and ninety Indians as guests. Even with fish, wild-fowl and deer in plenty, the good housewives must have spent a lively week of preparation for such a feast!

Farther up the slope was built, in 1637 , their first meeting-house, and at the head of the Square now stands the lately completed stone church of the first parish. In the belfry hangs the old town bell, cast by Paul Revere, which for nearly a century has had a voice in the affairs of the town.

Following the now steep incline, we stop to take breath on the brow of the hill, the spot so wisely chosen by Captain Myles Standish for the building of the solid timber fort, whereon he promptly placed his cannon.

"Unable to speak for himself was he, But his guns spoke for him right valiantly!"

And most persuasive did their voices prove, inspiring awe in the hearts of the "salvages" for many miles around!

Here in the shelter of the fort they met 
for worship; here their hymns of praise and prayers for guidance arose in the still air of the wilderness. In four short months one half of these brave souls had been laid to rest on Cole's Hill by the waterside. And yet, when one April morning those who were left to mourn them stood here watching the May'flower weigh anchor, to flit with her white sails over the blue sea which parted them from Old England, not one soul faltered, not one went back!

The sad loss of their good Governor Carver, whose responsible place was taken by William Bradford, and the daily trials and hardships of that first long year, shook not their sturdy faith. Each day brought its absorbing task, and when, one morning in November, the sentry at the fort shouted, "Sail, ho!" and the Fortune came sailing in by the Gurnet Nose, bringing the first news from the other side, they were ready with a return load of lumber, furs and sassafras for the Merchant Adventurers. Of this load, valued at $£ 500$, Edward Winslow modestly writes in his letter to England: "Though it be not much, yet it will witness for us that we have not been idle, considering the smallness of our numbers this summer." 


\section{Plymouth}

Two years later, after a trying season of drought and famine, when, their corn exhausted, "ground-nuts, clams and eels" were their only food, they still gave thanks to God that He had given them of "the abundance of the seas, and of the treasures hid in the sand." When even the strongest men among them had grown weak for want of food, and their eyes were wearied with watching for a friendly sail, the good ship Anne was sighted in the offing. Dear relatives and friends brought them timely succor and new courage; a season of rejoicing followed, and many happy weddings were celebrated.

In the Anne, perhaps, came the Old Colony record-book, in which was made the early registration of births, marriages and deaths. The first of the laws therein enacted, dating from December 27,1623 , established trial by jury, as may still be seen in the quaint handwriting of these hard-working heroes. This book, together with the Charter of 1629 , curious old papers concerning the division of cattle brought over in the Charity in 1624 , ancient deeds signed by the Indians, the original owners of this our goodly heritage, and many another time-stained treasure, is now carefully 
preserved and gladly shown in the Regristry of Deeds in the Court House.

Looking to the north, beyond the town of Kingston, lying, with its sweet rose-gardens, on the pretty winding river named for that arch betrayer, Captain Jones, of the Mayflower, we see Duxbury and the green slopes of Captain's Hill, so named in honor of Myles Standish, who from the top of his gray stone monument still guards us in effigy. Lingering near the fort and the guns he loved so well, he must often have looked this way, and admired the fine position this hill offered for a homestead. And as with years the colony grew larger, as children came to him and Barbara, and when his first Company of Standish Guards were in perfect training and could be relied upon to defend the colony at need, he bought out Winslow's share in the famous red cow, and led the way to the new fields he longed to conquer. There he was soon followed by John Alden and Priscilla, the Brewsters and other families, and at Marshfield, near by, the Winslows became their neighbors. So some eleven years after the landing came the first separation, which though not a wide one was a sore grief to their tender-hearted governor. 


\section{Plymouth}

Among the now rare gravestones of the seventeenth century on Burial Hill, we look in vain for the most familiar names: Elder Brewster died in $\mathbf{1} 644$, lamented by all the colony; Edward Winslow died at sea in 1655 , and in the two years following this sad loss Myles Standish and Governor Bradford ended their labors. So closed the lives of these leaders of men. Descendants, brave, wise and strong like themselves, continued worthily the work they had nobly begun.

From i630, Plymouth held friendly intercourse with the Boston Bay Colony. The terrors of the war with Philip, treacherous son of the friendly Massasoit, had united her with the neighboring colonies against a common foe, and at length, after seventy-one years of nearly independent existence, we find her, in 1692 , absorbed, with some regret, into the royal province of Massachusetts, but still ready to take her part in public affairs.

That the rôle played by her was a worthy one, the tablets about us testify. Heroes of the expedition against Louisbourg, in $17+5$, lie here; more than a score of Plymouth patriots who served in the Revolution, and many a brave soldier who won his laurels in the IVar 
of I86I. Under this stone, with its quaint urn and willow-branch, rests the famous naval hero of the Revolutionary war, Captain Simeon Sampson, whose cousin Deborah spun, dyed, and wove the cloth for the suit in which she left home to serve as a soldier. Their story, and that of many another hero and heroine now lying here, have been well told by Mrs. Jane Goodwin Austin.

Beneath his symbolic scallop-shell we read the name of Elder Faunce, who knew the Pilgrims, and, living for ninety-nine years, formed an important link between two centuries. The stone consecrated to the memory of the Rev. Chandler Robbins, who for nearly twoscore years toward the close of the last century gave his faithful services to the first parish, reminds us that at one time the town fathers found it advisable to request him " not to have more horses grazing on Burial Hill than shall be really necessary!"

Here, in old times, could be had a grand view of the shipping, come from the West Indies and all parts of the world; from here the news of many fatal shipwrecks had been spread through the town, to rouse willing help for suffering sailors; here, too, no doubt, men's 
souls were often tempted to incur the fine of twenty shillings, the cost of "telling a lie about seeing a whale," in those strict days when a plain lie, if "pernicious," was taxed at half that price!

Old Father Time with his scythe and hourglass-symbols of his power-rules here over seven generations; but lingering while the setting sun illumines the harbor and the surrounding hills with the same radiance that rejoiced the first comers, while Manomet glows with a deeper purple, and the twin lights of the Gurnet shine out, we may still feel in very deed that

"The Pilgrim spirit has not fled."

Turning from the story of Plymouth, as written on the lichen-covered headstones on Burial Hill, let us wend our way under the shady elms of Court Street to Pilgrim Hall, built in 1824 by the Pilgrim Society, instituted four years earlier. Here we may trace, in the many treasured reminders of their daily lives. the annals of those brave souls in whom

\footnotetext{
“. . . persuasion and belief

Had ripened into faith, and faith become

A passionate intuition."
} 
On broad canvases are portrayed the tearful embarkation from Delfthaven, the landing on this cheerless, frozen shore. Here are hung charming pencil sketches of Scrooby and Austerfield, and many interesting portraits: Dr. Thatcher, the venerable secretary of the Pilgrim Society, and author of a charming history of Plymouth; the Rev. James Kendall, for nearly threescore years the beloved minister of the First Church; Gov. Edward Winslow and his son Josiah; Gen. John Winslow, who by royal command in 1755 helped to drive from their homes the French Acadians; Deacon Ephraim Spooner, whose "lining out" of the old hymns formed an impressive part of "Anniversary Day"; Daniel Webster, who lived in Marshfield, and whose glowing oration of 1820 , in honor of the two hundredth anniversary ${ }^{1}$ of the landing of the Pilgrims, was epoch-making in Plymouth annals.

Among the many priceless books and documents here we find the lately acquired Speculum Europa (1605) by Sir Edwin Sandys, the active friend of our Separatists in England,

1 The illustration shown on page 335 is from a pen-and-ink copy of a quaint old painting on glass from China, probably in 1520 . In that country a set of china with this design as decoration was made for this Plymouth celebration. 


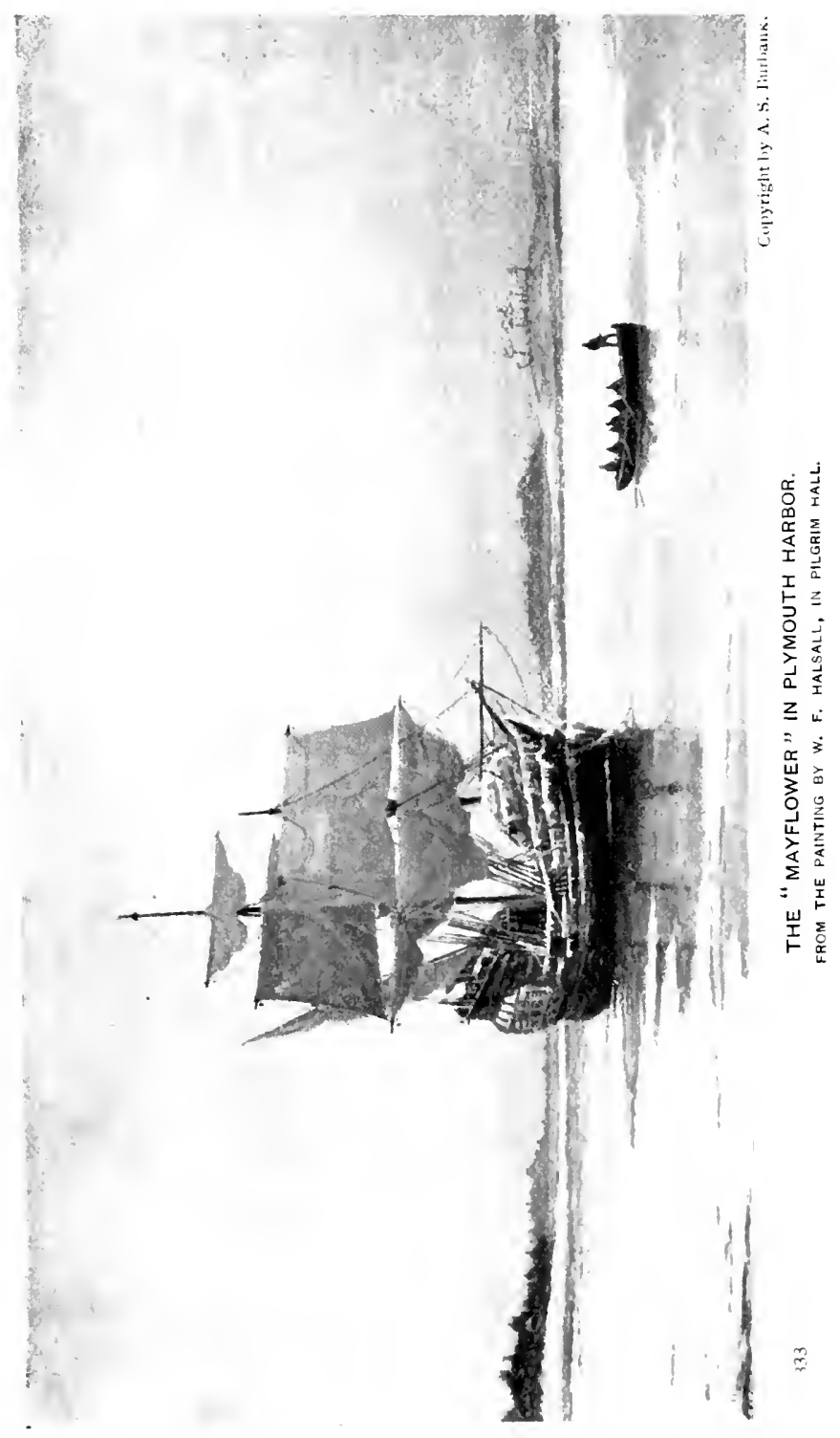


two autographs of John Robinson render this volume of special interest. A facsimile of the Bradford manuscript also is here, and a Confutation of the Rhemists Translation, printed by Brewster in Leyden, in I6I8. Among the old Bibles worn by hands seeking for guidance and comfort is one belonging to John Alden, dated 1620. Here also are a copy of Robert Cushman's memorable sermon on "The Danger of Self-love," delivered by him in Plymouth in I62I; one of the seven precious original copies of Mourt's Relation the journal written by Bradford and Winslow in $1620-2 \mathrm{I}$, and so promptly printed in London in 1622 ; one of the four copies of Eliot's Indian Bible (1685); the Patent of $162 \mathrm{I}$, granted our colonists by the New England Company, and the oldest state paper in the United States.

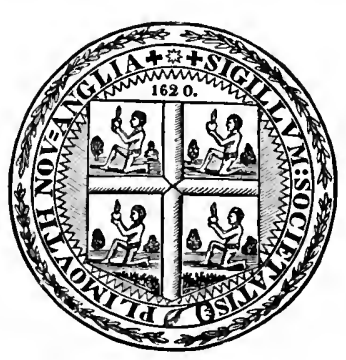

THE OLD COLONY SEAL.

A large copy of the seal of the colony, in handsomely carved oak, reminds us that the original seal was stolen in the days of Andros. Its appropriate motto, "Patrum pietate ortum, filiorum virtute servandum," may be found 


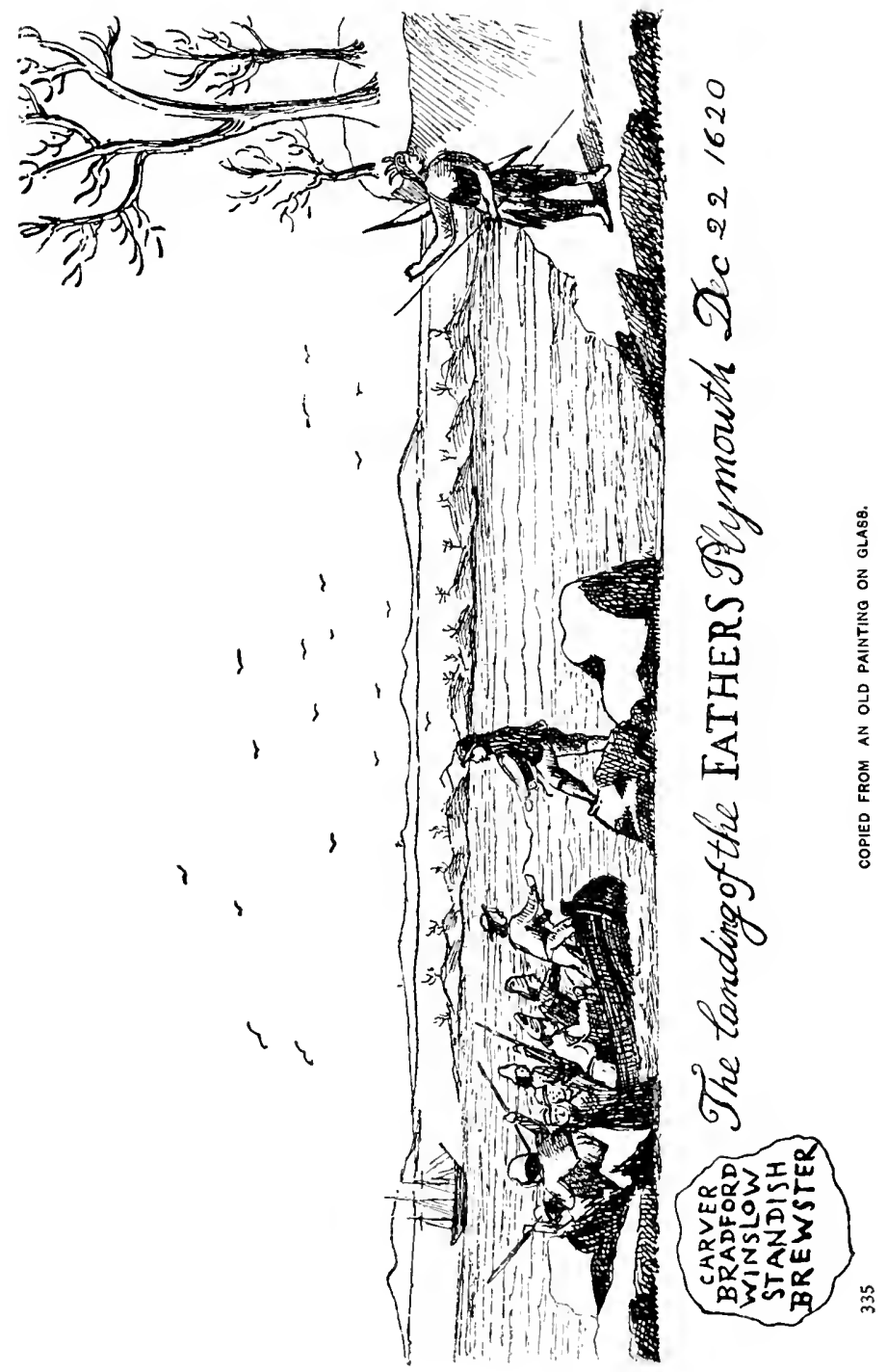


used as a heading of the first Plymouth Four nal, published by Nathaniel Coverly in 1785 , of which one file is preserved in the library of rare old books. Here are the Original Records of the Old Colony Club, founded in 1769 , but dissolved four years later when party feeling ran high between the Whigs and Tories. Its worthy members first instituted the celebration of "Forefathers' Day," and here we may read the bill of fare of their first dinner, "dressed in the plainest manner," beginning with "a large baked Indian whortleberry pudding," "a dish of Succotash," "Clamms," etc. The Indian dishes, succotash and nokake, and the five parched corns which recall the time when their last pint of corn was divided among them, still form part of the "twenty-second" dinner of every faithful descendant !

Here the sword of the truculent Myles Standish lies at rest, and beside it, in lighter vein, a bit of the quilt that belonged to his wife Rose, and a sampler skilfully embroidered by his daughter Lora. Between the ample armchairs in which Governor Carver and EIder Brewster must have pondered over many a weighty problem of government for the people and by the people, is the closely woven little Dutch cradle 
in which Peregrine White, that most youthful of voyagers, was rocked to sleep. The large hole worn in the foot of the cradle suggests pleasantly that the rosy toes of the sturdy baby colonists made early for freedom! Perhaps

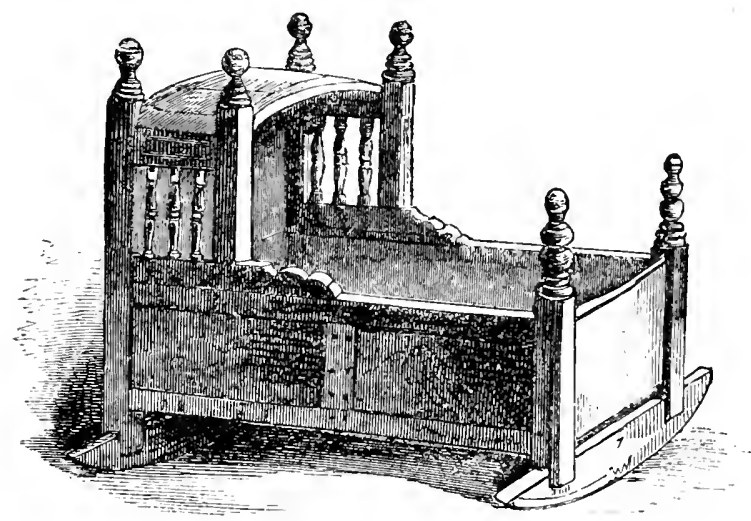

THE FULLER CRADLE.

the tiny leathern ankle-ties, hardly four inches in length, which belonged to Josiah Winslow - this was long before they thought of making him governor-had a hand, or rather a foot, in that bombardment! Near the shoes is a dainty salt-cellar of blue and white enamel, delicately painted with pink and yellow roses, suggestive of fine linen and pleasant hospitality. Here too are 
"The wheels where they spun

In the pleasant light of the sun,"

those anxious, lonely housewives, waiting for their good men to return from dangerous ex-

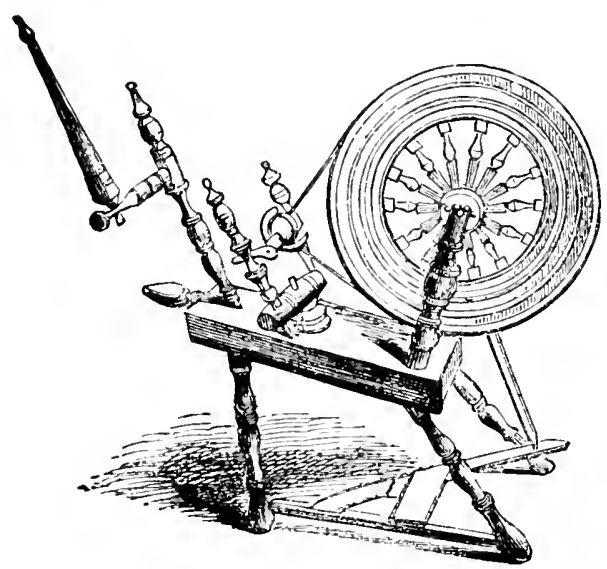

AN OLD ENGLISH SPINNING-WHEEL. peditions in the forest or on the sea. Thus varied was the freight of the Mayflower.

As we walk through the lively main street of the town, we must stop to admire the fine gambrel roof of the old house where lived James Warren, that active patriot, who became president of the Provincial Congress, and whose wife, Mercy Otis Warren, wrote the "rousing word" which kindled many a heart in Revolutionary days. The line of fine lindens just beyond, as they rustle in the cool seabreeze, could whisper many a charming tale of lovely dames and stately men, of scarlet cloaks and powdered wigs they have watched pass by under their shading branches, of treasures of 


\section{Plymouth}

old china and old silver, of blue tiles and clawfooted furniture, of Copley portraits now packed off to the great city, and of many changes come about since they came here as young trees from Nova Scotia, in a raisin-box.

Overlooking the blue water stands the old Winslow house, the solid frame of which came from England in I 754. Under its spreading lindens, through the fine colonial doorway so

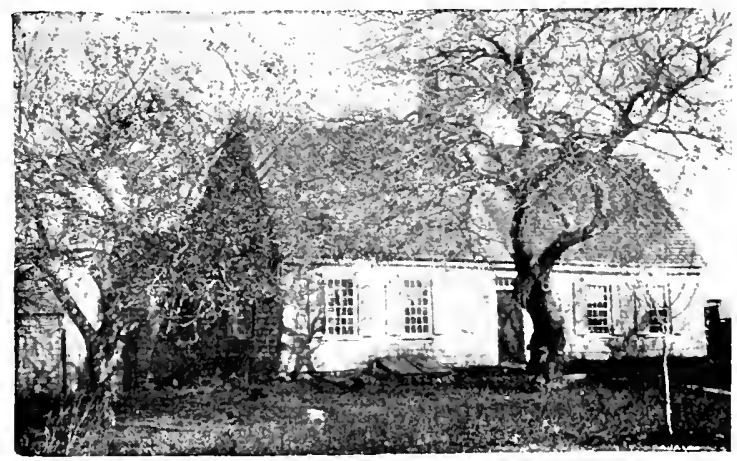

Copyright by A. S. Burbant.

THE DOTEN HOUSE, 1660.

THE OLDEST HOUSE IN PLYMOUTH.

beautifully carved, many distinguished guests have passed, and here Ralph Waldo Emerson was married to Lydia Jackson, who was born in the picturesque house just beyond, ahmost hidden in trees and vines. 
A drive toward the south will take us by some of the oldest houses. From the one with a dyke in front, Adoniram Judson, the famous Baptist missionary, took his departure for Burmah. His devoted sister then vowed that no one should cross the threshold until his return, and the door-step was taken away. Grass grew over the pathway, and the front door remained closed, for he died at sea, in 1850 .

As we pass the handsome new building of the High School, it is good to remember, in this Plymouth of eight thousand inhabitants, paying thirty-four thousand dollars for last year's "schooling," that in 1672 it was decided that Plymouth's school, supported by the rents of her southerly common-lands, was entitled to E33, the fishing excise from the Cape, offered to any town which would keep a free colonial school, classical as well as elementary. And in that free school began an early struggle of the three R's against Latin and Greek. From Plymouth went Nathaniel Brewster, a graduate of Harvard's first class of 1642 , and the first of a long line of Plymouth students to enter Harvard.

Past the blue Eel River, flowing gently through shining green meadows to the sea, we 
may drive along quiet roads in Plymouth Woods, under sweet pines and sturdy oaks, by the shore of many a calm pond, sparkling in its setting of white beach sand. We cross old Indian trails, perhaps, and skirt acre after acre of level cranberry-bogs, pink and white, like a sheet of delicate sprig-muslin, when in bloom, and bright with the crimson fruit in early autumn. In these woods in their season bloom sweet mayflowers, the rare rhodora, the sabbatia, sundew and corema, and there many another treasure may be found by those who know how to seek!

When these forests were first explored, an enterprising member of the Mayflower's crew, climbing a high tree to see how the land lay, saw shining before him a blue sheet of water which he took to be the ocean, and this was called after him "Billington's Sea." Following the shore of this lake, through the leafy paths of Morton's Park, we come upon the source of the famous Town Brook, which with its honorable record of two centuries' supply of alewives has always played an important part in the town's annals, helping to grind the Pilgrims' first grists in 1636 , and now lending its busy aid in turning complicated machinery. 
In the fields on either side-the huntinggrounds of the banished race who once rejoiced in their possession-are still found the beautifully worked Indian arrow-heads and hatchets; here the smoke arose from their wig-

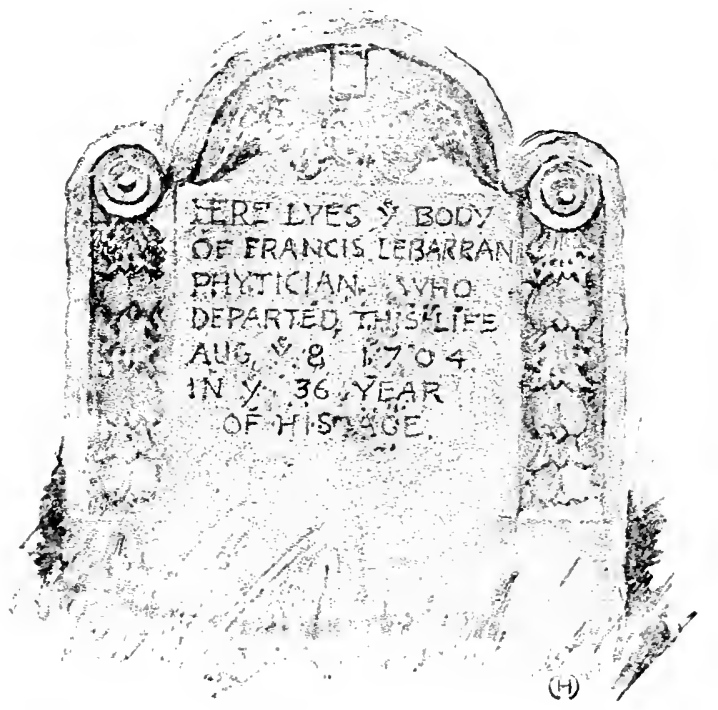

THE GRAVE OF DR. FRANCIS LE BARRAN, THE NAMELESS NOBLEMAN.

wams; here they often paddled past in their swift canoes, and here, perhaps, were shot the five deer that formed their offering in the first New England Thanksgiving.

But the manifold charms of Plymouth and 
Plymouth Woods must be seen and felt on the soil whence they sprung! So in the hope that the "Courteous Reader" to whom they are still unfamiliar may care to verify this truthful statement, we leave in brief and imperfect outline this story of the Old Colony, whither "they wente weeping and carried precious seeds; but they shall returne with joye and bring their sheaves."

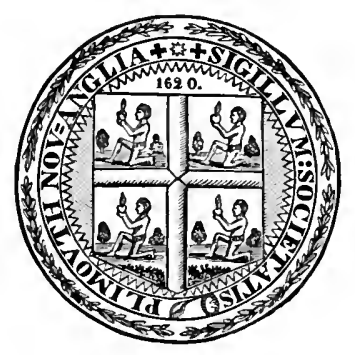





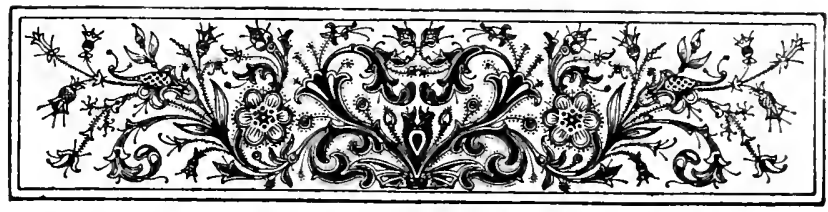

\title{
CAPE COD TOWNS
}

\section{FROM PROVINCETOWN TO FALMOUTH}

\author{
BY KATHARINE LEE BATES
}

" A APE COD," wrote Thoreau, "is the bared and bended arm of Massachusetts; the shoulder is at Buzzard's Bay; the elbow, or crazy-bone, at Cape Mallebarre; the wrist at Truro; and the sandy fist at Provincetown-behind which the State stands on her guard."

This sandy fist curls toward the wrist in such fashion as to form a semicircular harbor, famous as the New World haven which first gave shelter to the Mayflower and her seaworn company. On the 2 ist of Norember (by our modern reckoning), i620, the Pilgrims, after their two bleak months of ocean, cast anchor here, rejoicing in the sight and smell of "oaks, pines, juniper, sassafras and other sweet wood." Here they signed their mem- 
orable compact, forming themselves into a "civil body politic" and covenanting with one another, as honest Englishmen, to "submit to such government and governors as we should by common consent agree to make and choose." Upon the adoption of this simple and significant constitution, the Pilgrim Fathers, still on board the Mayflower in Provincetown harbor, proceeded to set in motion the machinery of their little republic, for "after this," wrote Bradford, "they chose, or rather confirmed, Mr. John Carver (a man godly and well approved amongst them) their Governor for one year." That same day a scouting party went ashore and brought back a fragrant boatload of red cedar for firewocd, with a goodly report of the place.

These stout-hearted Pilgrims were not the first Europeans to set foot on Cape Cod. Legends of the Vikings which drift about the low white dunes are as uncertain as the shifting sands themselves, and the French and Florentine navigators who sailed along the North American coast in the first half of the sixteenth century may have done no more than sight this sickle of land between sea and bay, but there are numerous records of $\mathrm{Fng}$ - 


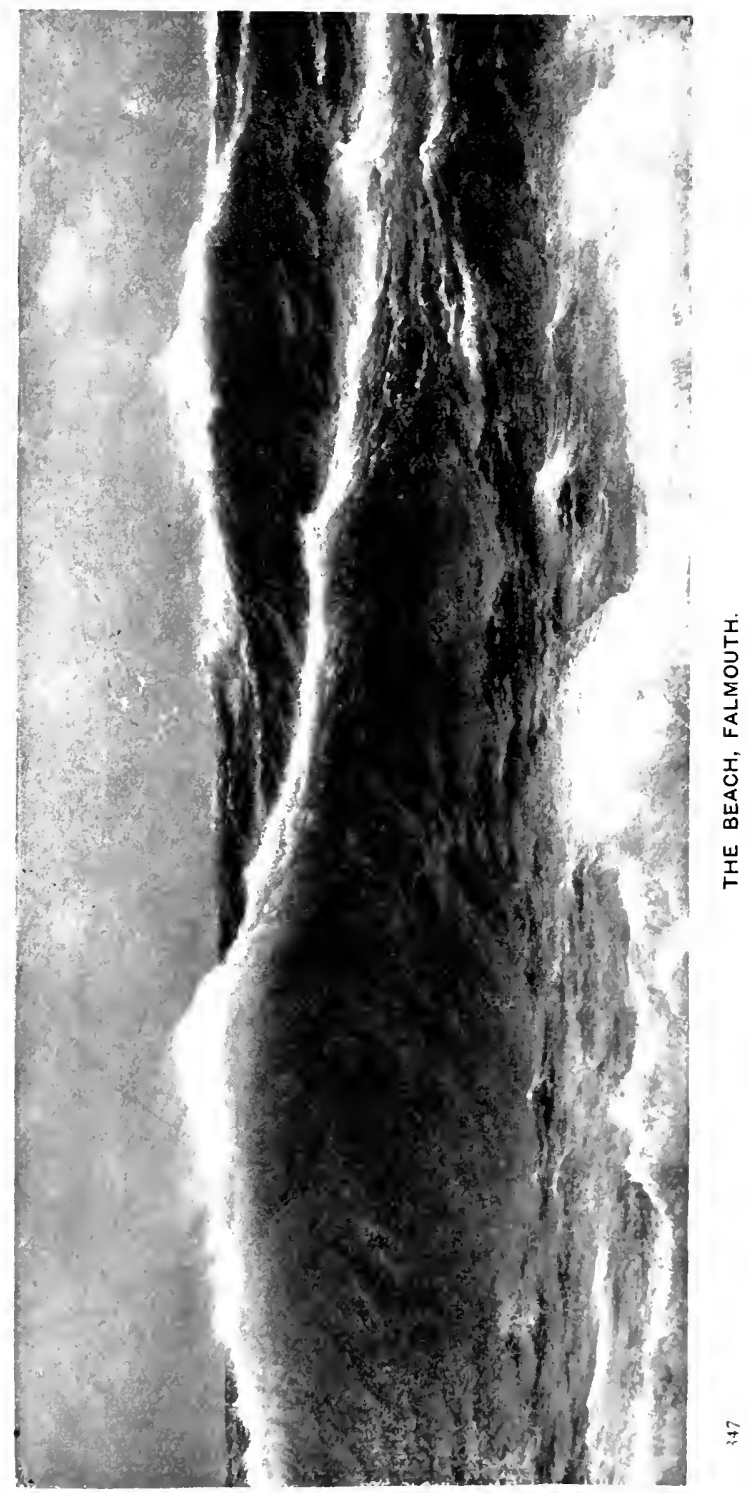


lish, French and Dutch visits within the lasi twenty years before the coming of the May flower. It may be that no less a mariner than Sir Francis Drake was the first of the English to tread these shores, but that distinction is generally allowed to Captain Bartholomew Gosnold, who made harbor here in 1602 and was "so pestered with codfish" that he gave the Cape the name, "which," said Cotton Mather, "it will never lose till shoals of codfish be seen swimming upon the tops of its highest hills." Gosnold traded with the Indians for furs and sassafras root, and was followed the next year by Martin Pring, seeking a cargo of this latter commodity, then held precious in pharmacy. Within the next four years three French explorers touched at the Cape, and a French colony was projected, but came to nothing. The visit of Henry Hudson, too, left no traces. In I6I that rover of land and sea, Captain John Smith, took a look at Cape Cod, which impressed him only as a "headland of hills of sand, overgrown with scrubby pines, hurts [huckleberries] and such trash, but an excellent harbor for all weathers." After Smith's departure, Hunt, his second in command, enticed a group of Nauset Indians on 
shipboard, carried them off, and sold them into slavery at Malaga, Spain, for twenty pounds a man. As a consequence of this crime, the Indians grew suspicious and revengeful, but nevertheless an irregular trade was maintained with them by passing vessels, until the pestilence that raged among the red men of the region from 1616 to 1619 interrupted communication.

The Pilgrims tarried in Provincetown harbor nearly a month. The compact had been signed, anchor dropped and the reconnoissance made on a Saturday. The Sunday following, the first Pilgrim Sabbath in America, was devoutly kept with prayer and praise on board the Mayflower, but the next morning secular activities began. The men carried ashore the shallop which had been brought over in sections between-decks and proceeded to put it together, while the women bundled up the soiled linen of the voyage and inaugurated the first New England Monday by a grand washing on the beach. On Wednesday, Myles Standish mustered a little army of sixteen men, each armed with musket, sword and corselet, and led them gallantly up the wooded cape, "thorou boughes and bushes," nearly as 
far as the present town of Wellfleet. After two days the explorers returned with no worse injury than briar-scratched armor, bringing word of game and water-springs, ploughed land and burial-mounds. William Bradford showed the noose of the deer-trap, a "very pretie devise," that had caught him by the leg, and two of the sturdiest Pilgrims bore, slung on a staff across their shoulders, a kettle of corn. As the few natives whom the party had met fled from them, the corn had been taken on credit from a buried hoard. The following year that debt was scrupulously paid, but a custom had been established which still prevails with certain summer residents on the Cape, who are said to make a practice of leaving their grocery bills over until the next seasnn.

As soon as the shallop could be doated, a larger expedition was sent by water along the south coast to seek a permanent settlement. Through wind and snow the Pilgrim Fathers made their way up to Pamet River, in Truro, the limit of the earlier journey. They did not succeed in agreeing upon a fit site for the colony, but they sought out the corn deposit and, breaking the frozen ground with their swords, secured ten bushels more of priceless 
seed for the springtime. On the return of the second expedition there was anxious discussion about the best course to pursue. Some were for settling on the Cape and living by the fisheries, pointing out, to emphasize their arguments, the whales that sported every day about the anchored ship; but the Pilgrims were of agricultural habit and tradition and had reason enough just then to be weary of the sea. The situation was critical. "The heart of winter and unseasonable weather," wrote Bradford, "was come upon us." The gradual slope of the beach made it always necessary to "wade a bow-shoot or two" in going ashore from the May'fower, and these icy foot-baths were largely responsible for the "vehement coughs" from which hardly one of the company was exempt.

Once more, on the i6th of December, the shallop started forth to find a home for the Pilgrims. Ten colonists, including Carver, Bradford and Standish, together with a few men of the ship's crew, volunteered for this service. It was so cold that the sleety spray glazed doublet and jerkin "and made them many times like coats of iron." The voyagers landed within the present limits of Eastham or Orleans, where, hard by the shore, a camp was 
roughly barricaded. One day passed safely in exploration, but at dawn of the second, when, "after prayer," the English sat about their camp-fire at breakfast, "a great and strange cry " cut the mist, and on the instant Indian arrows, headed with deer-horn and eagles' claws, whizzed about their heads. But little Captain Standish was not to be caught napping. "Having a snaphance ready," he fired in direction of the war-whoop. His comrades supported him manfully, their friends in the shallop, themselves beset, shouted encouragement, and the savages, gliding back among the trees, melted into "the dark of the morning." After this taste of Cape Cod courtesy, the Pilgrim Fathers can hardly be blamed for taking to their shallop again and plunging on, in a stiff gale, through the toppling waves, until, with broken rudder and mast split in three, they reached a refuge in the harbor of Plymouth.

When the adventurers returned to the Mayflower with glad tidings that a resting-place was found at last, the historian of the party. William Bradford, had to learn that during his absence his wife had fallen from the vessel's side and perished in those December 
waters. Three more of the colonists died in that first haven, and there little Peregrine White began his earthly peregrinations. In view of all these occurrences, - the signing of the compact in Provincetown harbor, the first landing of the Pilgrims on the tip of Cape Cod, the explorations, the first deaths and the first birth,-it would seem that Provincetown is fairly entitled to a share of those historic honors which are lavished, none too freely, but, perhaps, too exclusively, upon Plymouth.

When the May'fower sailed away, carrying William Bradford and his tablets, the beautiful harbor and its circling shores were left to a long period of obscurity. Fishers, traders and adventurers of many nations came and went on their several errands, but these visits left little trace. The Plymouth colonists, meanwhile, did not forget their first landing-point, but returned sometimes, in the fishing season, for cod, bass and mackerel, always claiming full rights of ownership. This claim rested not only on their original brief occupation, but on formal purchase from the Indians, in I 654, or earlier, the payment being " 2 brasse kettles six coates twelve houes I 2 axes I 2 knives and a box." In process of time, as the 


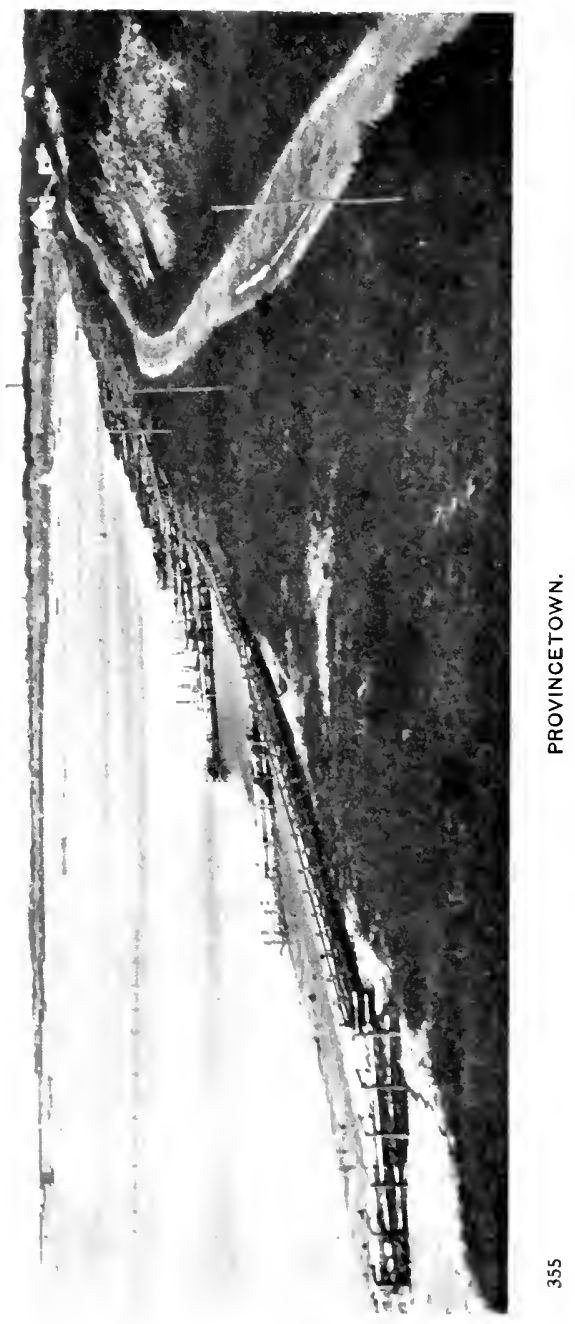


English settlers gradually pushed down the Cape, a few hovels and curing-sheds rose on the harbor shore, but the land was owned by Plymouth Colony until Massachusetts succeeded to the title. These Province Lands were made a district, in the charge of Truro, in 1714 , but in 1727 the "Precinct of Cape Cod" was set off from Truro, and established, under the name of Provincetown, as a separate township. It was even then merely a fishing-hamlet, with a fluctuating population, which by $175^{\circ}$ had almost dwindled away. In Revolutionary times, it had only a score of dwelling-houses, and its two hundred inhabitants were defenseless before the British, whose men-of-war rode proudly in the harbor. One of these, the Somerset, while chased by a French fleet on the Back Side, as the Atlantic coast of the Cape is called, struck on Peaked Hill bars, and the waves, taking part with the rebels, flung the helpless hulk far up the beach. Stripped by "a plundering gang" from Provincetown and Truro, the frigate lay at the mercy of the sands, and they gradually hid her even from memory; but the strong gales and high tides of I $\$ 86$ tore that burial-sheet aside, and brought the blackened timbers again to 


\section{Cape Cod Towns}

the light of day. The grim old ship, tormented by relic-hunters, peered out over the sea, looking from masthead to masthead for the Union Jack, and, disgusted with what she saw, dived once more under her sandy cover, where the beach-grass now grows over her.

Since the Revolution, Provincetown has steadily progressed in numbers and prosperity, until to-day, with over four thousand five hundred inhabitants, it is the banner town of the Cape. During this period of development, the Province Lands, several thousand acres in extent, naturally became a subject of dispute. Old residents had fallen into a way of buying and selling the sites on which they had built homes and stores, as if the land were theirs in legal ownership. Five years ago, however, the General Court virtually limited State ownership to the waste tracts in the north and west of the township, leaving the squatters in possession of the harbor-front. "The released portion of the said lands," stated the Harbor and Land Commissioners in their report of $\mathbf{I} 893$, " is about 955 acres and includes the whole inhabited part of the town of Provincetown."

The present Provincetown is well worth a 
journey. From High Pole Hill, a bluff seventy feet high in the rear of the populated district, one gazes far out over blue waters, crossed with cloud-shadows and flecked with fishingcraft. Old sea-captains gather here with spyglasses to make out the shipping; bronzed sailor-boys lie in the sun and troll snatches of song; young mothers of dark complexion and gay-colored dress croon lullabies, known in Lisbon and Fayal, over sick babies brought to the hilltop for the breezy air ; the very parrot that a black-eyed urchin guards in a group of admiring playmates talks "Portugee." Leaning over the railing, one looks down the bushy slope of the bluff to the curious huddle of houses at its base. Out from the horseshoe bend of shore, run thin tongues of wharf and jetty. Front Street follows the waterline, a seaport variety of outfitting stores and shops, mingled with hotels, fish-flakes, shipyards and the like, backing on the beach, with the dwelling-houses opposite facing the harborview. Back Street copies the curve of Front, and the two are joined by queer, irregular little crossways, that take the abashed wayfarer close under people's windows and along the very borders of their gardens and poultry- 
yards. Although nearly all of the buildings stand on one or the other of these main streets, there are bunches and knots of houses in sheltered places, looking as if the blast had blown them into accidental nooks. In general

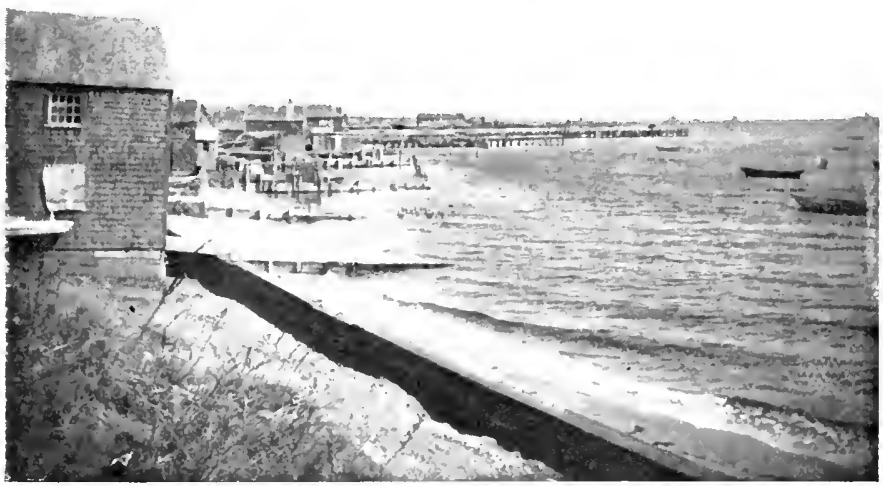

WHARVES AT PROVINCETOWN.

these houses are built close and low, tucked in under one another's elbows, but here and there an independent cottage thrusts its sharproofed defiance into the very face of the weather.

Up and down the sandy knolls behind the 
streets straggle populous graveyards, where one may read the fortunes of Provincetown more impressively, if less precisely, than in the census reports. Where the groodly old Nathaniels and Shubaels and Abrahams and Jerushas rest, a certain decorum of green sockding and white headstone is maintained, despite the irreligious riot of the winds. The Catholic burial-ground, too, is not uncared for in its Irish portion. Marble and granite monuments implore "Lord have mercy on the soul" of some Burke or Ryan or McCarty, but the Portuguese, wanderers from the Cape Verde Islands and the Azores, sleep the sleep of strangers, with no touch of tenderness or beauty about their dreary lodging. Only here and there a little Jacinto or Manuel or Antone has his short mound set about with fragments of clam-shell, as if in children's play. Some lots are enclosed, the black posts with rounded tops looking like monastic sentries, and a few headboards, with the painted name already rain-washed out of recognition, lean away from the wind. In the centre of this gaunt graveyard, where the roaring Atlantic storms tear up even the coarse tufts of beach-grass, a great gray cross of wood, set in a hill of sand, 


\section{Cape Cod Towns}

spreads weather-beaten arms. The guardianship of the Church and the fellowship of the sea these Portuguese fisherfolk brought with them, and as yet America has given them nothing dearer.

The Portuguese constitute a large proportion of the foreign element in Barnstable County, where nearly nine tenths of the people are of English descent. The protruding tip of Cape Cod easily catches such ocean drift as these Western Islanders, and they have made their way as far up the Cape as Falmouth, where they watch their chance to buy old homesteads at low rates. They are natural farmers and even in Harwich and Truro divide their labors between sea and land. But it is in Provincetown that these swart-faced strangers most do congregate, gardening wherever a garden is possible, tending the fish-weirs, working, when herring are plenty, in the camning factories, and almost monopolizing the fresh fishing industry. Even those who are most thrifty, building homes and buying vessels, wear the look of aliens, and some, when their more active years are over, wather up their savings and return to the Azores; but the raven-haired girls are becrinning to listen to l'ankee wooers, 
and the next century may see the process of amalgamation well under way. Already these new Pilgrims have tasted so much of the air of freedom as to wax a little restive under the authority of their fiery, devoted young priest, who upbraids them with his last expletive for their shortcomings as energetically as he aids them with his last dollar in their distress.

In the general aspect of the port, it is as true to-day as when, in 1808 , the townspeople petitioned for a suspension of the embargo, that their interest is "almost totally in fish and vessels." A substantial citizen keeps his boat as naturally as an inlander would keep his carriage. Any loiterer on the street can lend a hand with sweep-seine or jibstay, but the harnessing of a horse is a mystery known to few. In I I I 9 , there was but one horse owned in Provincetown, and that "an old, white one with one eye." In point of fact, however, the fortunes of Provincetown seem to demand, at present, some further support than the fisheries. It is believed that, by dint of capital, labor and irrigation, more could be gained from the soil, and that the advantages of the place as a summer resort might be developed. The whaling business has greatly declined 
since the discovery of petroleum, the mackerel have forsaken their old haunts, and even codfishing, in which Provincetown long stood second to Gloucester, is on the wane. Wharves and marine railways are falling into ruin, and the natives of the old Cape seek a subsistence

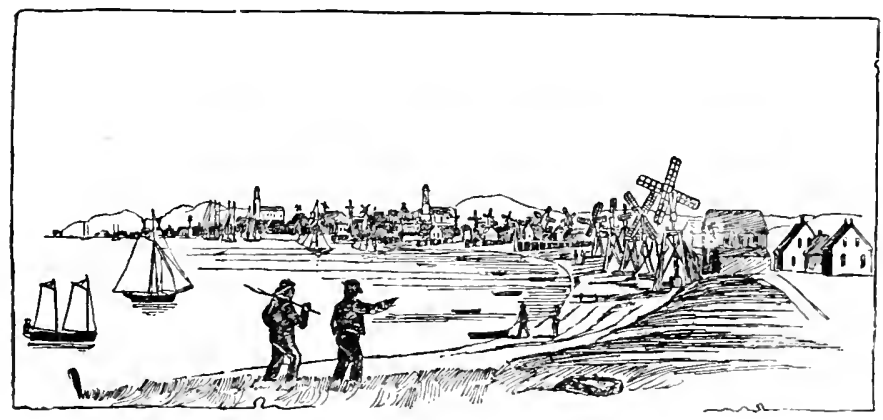

PROVINCETOWN IN 1839.

FROM AN OLD DRAWING.

in Western ranches and crowded cities, leaving their diminished home industries to the immigrants. Still twoscore or so of vessels go to the Grand Banks, and as many more engage in the fresh fishing. Emulous tales do these fishermen tell of quick trips and large catches, for example the clipper Fulia Costa, under a Portuguese skipper, which set sail at six in the morning for fishing-grounds about fifteen miles 
northeast of Highland Light, took fifteen thousand pounds of cod, and arrived at her Boston moorings an hour before midnight. But the "fish-stories" told in Provincetown are more often legends of the past, before the heroic days of whaling went out with the invention of the explosive bomb lance,-legends of fortunes made in oil and ambergris, of hair-breadth escapes from the infuriated monsters, and especially of Moby Dick, the veteran whale who, off the coast of Chili, defied mankind until the whale-gun rolled him over at last, with twentythree old harpoons rusted in his body.

The foreign element in Provincetown is not all Portuguese. There is a sprinkling of many nationalities, especially Irish, and, more numerous yet, English and Scotch from the British provinces, while sailor-feet from all over the globe tread the long plank-walk of Front Street. This famous walk was built, after much wrangling, from the town's share of the Surplus Revenue distributed by Andrew Jackson, and the story goes that the more stiffnecked opponents of this extravagance refused their lifetimes long to step upon the planks, and plodded indignantly through the sandy middle of the road. Upon this chief thorough- 
fare stand several churches, looking seaward. Sailors in these waters used to steer by the meeting-house steeples, which are frequent all along the Cape. Some of those early churches now struggle on with meagre congregations, and a few are abandoned, the wind whistling through the empty belfries. Provincetown has a record of ancient strife between the Orthodox and the Methodists. The established sect resented the intrusion of the new doctrine to such a degree that they made a bonfire of the timber designed for the Methodist building. The heretics effectively retaliated by securing the key to the Orthodox meeting-house, locking out the astonished owners, and taking permanent possession, triumphantly singing Methodist hymns to the Orthodox bass-viol. It was thirty-two years before the discomfited Orthodox rallied sufficiently to build themselves another church.

Journeying from Provincetown, "perched out on a crest of alluvial sand," up the wrist of the Cape, one sees the land a-making. At first the loose sand drifts like snow. Then the coarse marsh-grasses begin to bind and hold it, low bushes mat their roots about it, and planted tracts of pitch-pine give the shifting 
waste a real stability. The Pilgrims found, they said,--but perhaps there was a Canaan dazzle in their eyes,- - their landing-place well wooded and the soil "a spit's depth, excellent black earth." But now all sods and gardenground must be brought from a distance, and a mulberry or a sycamore, even the most stunted apple-tree that squats and cowers from the wind, is a proud possession. When President Dwight of Yale rode through Truro into Provincetown a century ago, he was amazed at the sterility and bleak desolation of the landscape, half hidden as it was by "the tempestuous tossing of the clouds of sand." He was told that the inhabitants were required by law to plant every April bunches of beach-grass to keep the sand from blowing. The national government, stirred by the danger to the harbor, afterwards took the matter in hand. Between I 826 and I 838 , twenty-eight thousand dollars were expended in an attempt to strengthen the harbor shores by beach-grass. Of late Massachusetts has become aroused to the desolate condition of her Province Lands, and is making a determined effort to redeem them by the planting of trees and by other restorative measures. These blowing sand-dunes have, 


\section{Cape Cod Towns}

however, a strange beauty of their own, and the color effects in autumn, given by the low and ragged brush, are of the warmest.

"It was like the richest rug imaginable," wrote Thoreau, "spread over an uneven surface; no damask nor velvet, nor Tyrian dye or stuffs, nor the work of any loom, could ever match it. There was the incredibly bright red of the Huckleberry, and the reddish brown of the Bayberry, mingled with the bright and living green of small Pitch-Pines, and also the duller green of the Bayberry, Boxberry and Plum, the yellowish green of the Shrub Oaks, and the various golden and yellow and fawn-colored tints of the Birch and Maple and Aspen,each making its own figure, and, in the midst, the few yellow sand-slides on the sides of the hills looked like the white floor seen through rents in the rug."

The sand has dealt most unkindly of all with Truro, choking up her harbor, from which a fine fleet of mackerel vessels used to sail. No longer is her rollicking fishing-song, apparently an inheritance from Old England, lifted on the morning breeze :

"Up jumped the mackerel,

With his striped back-

Says he, reef in the mains'l, and haul on the tack,

For it 's windy weather,

It 's stormy weather,

And when the wind blows pipe all hands togetherFor, upon my word, it 's windy weather. 


\section{Cape Cod Towns}

" $\mathrm{UP}_{\mathrm{p}}$ jumped the cod,

With his chuckle head-

And jumped into the main chains to heave at the lead,For it 's windy weather," etc.

This town, the Indian Pamet, was formally settled in I 709 by a few English purchasers from Eastham, having been occupied earlier only by irresponsible fishermen and traders. The new planters took hold with energy, waging war against blackbirds and crows, wolves and foxes, for the protection of their little wealth in corn and cattle, while none the less they dug clams, fished by line and net and watched from their lookouts for offshore whales. The Cape plumes itself not a little upon its early proficiency in whaling. In 1690 , one Ichabod Paddock, whose name might so easily have been Haddock, went from Yarmouth to Nantucket "to instruct the people in the art of killing whales in boats from the shore." And when the sea-monster, thus maltreated, withdrew from its New England haunts, the daring whalemen built ships and followed, cruising the Atlantic and Pacific, even the Arctic and Antarctic oceans. But the Revolution put a check on all our maritime enterprises. The Truro fishermen, like the rest, laid by 
their harpoons, and melted up their mackerel leads for bullets. From one village of twentythree houses, twenty-eight men gave up their lives for liberty. In religion, too, Truro had the courage of ner convictions, building the first Methodist meeting-house on the Cape, the second in New England. The cardinal temptation of Cape Cod is Sunday fishing, and Truro righteousness was never put more sharply to the pinch than in 1834 , when a prodigious school of blackfish appeared off Great Hollow one autumnal Sabbath morning. A number of Truro fishermen, from the Grand Banks and elsewhere, were on their way home in boats from Provincetown, when the shining shoulders of hundreds of the great fish were seen moving through the waves. With fortunes in full view, a goodly number of these men shifted into boats which rowed soberly for their destination, while the rest, with eager outcry, rounded up the school, and drove the frightened creatures, with shouts and blows from the oars, like sheep upon the beach. Church-members who took part in the wild chase were brought to trial, but a lurking sympathy in the hearts of their judges saved them from actual expulsion. 
This befell within the period of Truro's highest prosperity. From I 8 jo to 1855 the wharves were crowded with sloops and schooners, a shipyard was kept busy, and salt was made all along the shore. At the middle of the century, the town had over two thousand inhabitants, but the number has now fallen off by some three fifths. The "turtle-like sheds of the salt-works," which Thoreau noted, have been long since broken up and sold for lumber. There is weir-fishing still, supplying fresh fish for market and bait for the fishing-fleets of Provincetown and Gloucester. Rods of the black netting may be seen spread over the poverty-grass to dry.

Although the sand of Cape Cod is in some places three hundred feet deep, there is believed to be a backbone of diluvian rock. There is a clay vein, too, which slants across the Cape and crops out at Truro in the so-called Clay Pounds, now crowned by Highland Light. shining two hundred feet above the ocean. This hill of clay thus renders a sovereign service to that dangerous stretch of navigation. It must be borne in mind that Cape Cod runs out straight into the Atlantic for twoscore miles, by the south measurement, and then, 


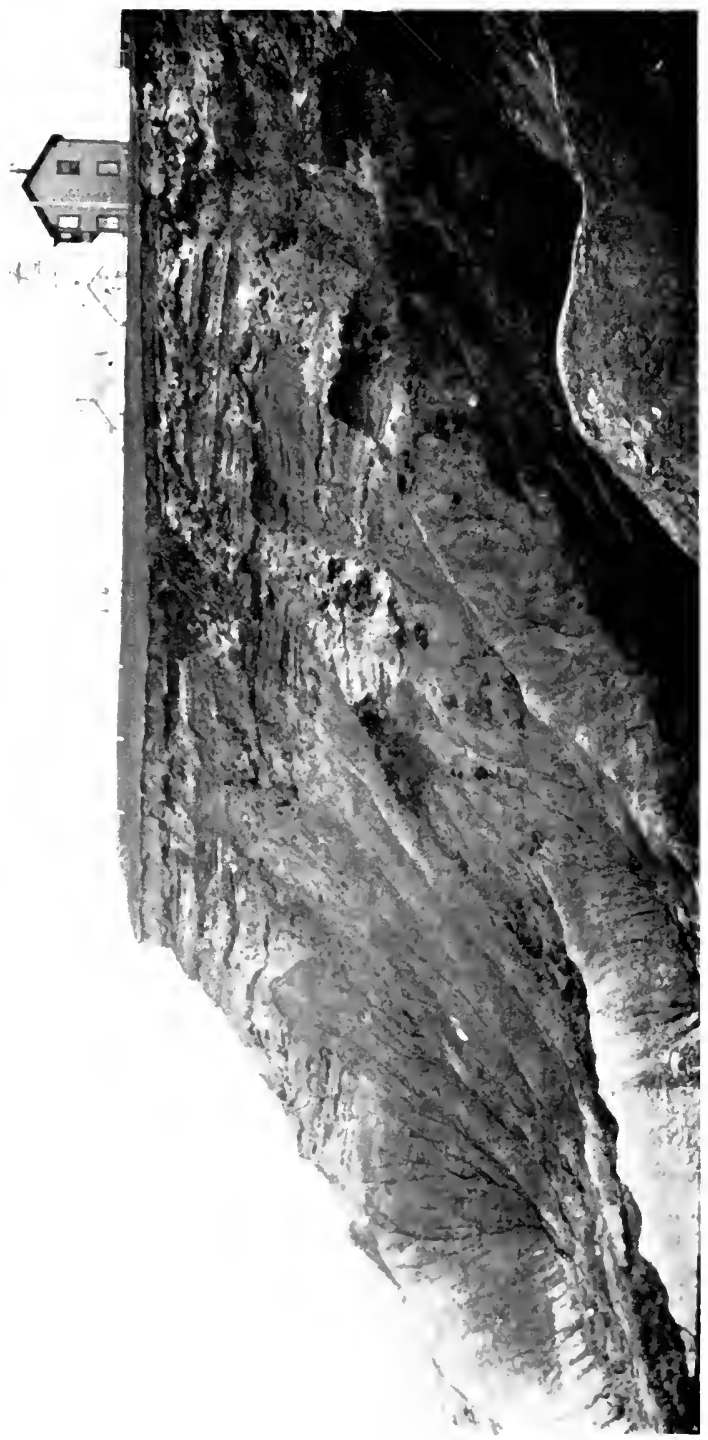

$\stackrel{5}{I}$
$\frac{0}{J}$
0
$\frac{a}{a}$
$\frac{J}{T}$
$\frac{0}{I}$

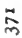


abruptly turning, juts up another forty to the north. The shifty sand-bars of the Back Side have caught, twisted and broken the hulls of innumerable craft. One gale of wind wrecked eighteen ressels between Race Point, at the extremity of the Cape, and Highland Light. The average width of our crooked peninsula is six miles, but at Truro it narrows to half that distance. Across this strip the storms whirl the flinty sand, until the humblest cottage may boast of ground-glass window-panes. The coast outline is ever changing and the restless dunes show the fantastic carvings of the wind. The houses cuddle down into the wavy hollows, with driftwood stacked at their back doors for fuel, and with worn-out fishnets stretched about the chicken-yards. Here and there a pine-tree abandons all attempt at keeping up appearances and lies flat before the blast. The ploughed fields are as white with sand as so many squares of beach, and the sea-tang is strong in the air. Accustomed, before their harbor failed them, to depend chiefly upon the sea for subsistence, the people of Truro now find it no easy matter to wrest a living from what they have of land. Everything is turned to account, from turnips to 


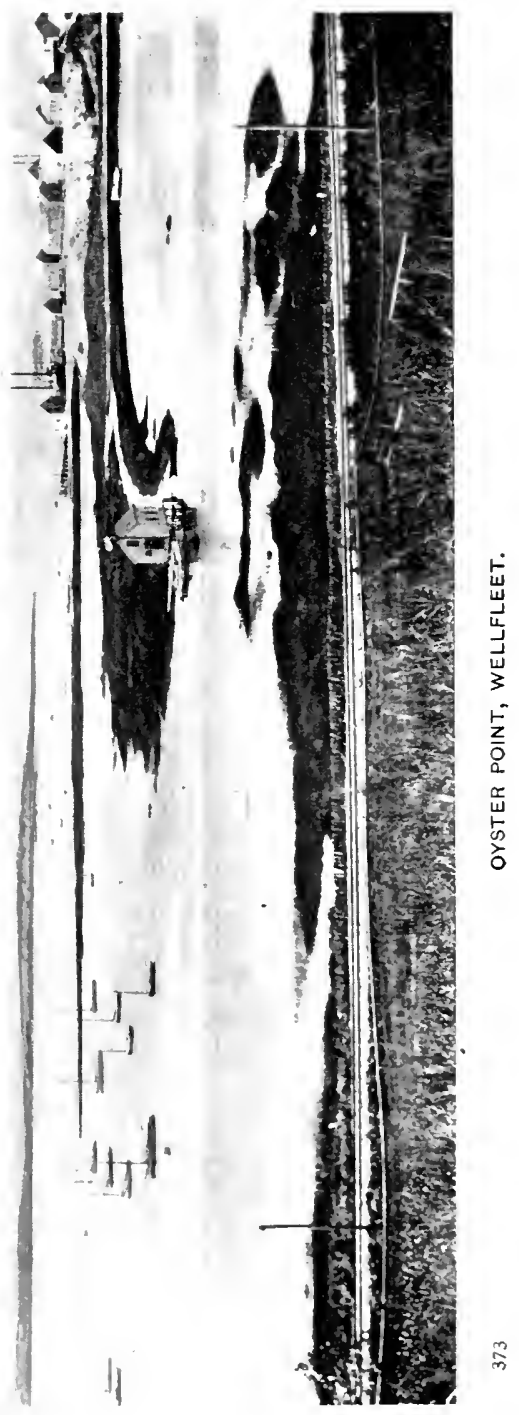


mayflowers. Along those sand-pits of roads, bordered with thick beds of pink-belled bearberries, or where the dwarfish pines, their wizened branches hung with gray tags of moss, yellow the knolls, are gathered large quantities of sweetest, pinkest arbutus for the Boston market.

Wellfleet, which drew off from Eastham in ${ }_{1} 76_{3}$, has also fallen on evil days. Perhaps the fishermen have overreached themselves with the greedy seines. There is high controversy on this point between line-fishers and weir-fishers, but the fact stands that fish are growing scarce. Wellfleet had once her hundred vessels at the Banks, her whaling-schooners, built in her own yards from her own timber, and beds of oysters much prized by city palates. There was a time when forty or fifty sail were busy every season transporting Wellfleet shell-fish to Boston. "As happy as a clam" might then have been the device of Wellheet heraldry. But suddenly the oyster died and, although the beds have been planted anew, the ancient fame has not been fully regained. A town, too, many of whose citizens spent more than half their lives on shipboard, was sure to suffer from our wars, peculiarly 
disastrous to seafaring pursuits. Early in the Revolution, Wellfleet was constrained to petition for an abatement of her war-tax, stating that her whale-fishery, by which nine tenths of her people lived, was entirely shut off by British gunboats, and that the shell-fish industries, on which the remaining tenth depended, was equally at a standstill. In this distress, as again in the Civil War, Cape Cod sailors took to privateering and made a memorable record. Wellfleet, like Truro, has lessened more than one half in population since 1850 , but her shell roads are better than the sandruts of her neighbor, and bicyclists and other summer visitors are beginning to find her out. She has her own melancholy charm of barrenness and desolation quite as truly as she has her characteristic dainties of quahaug pie and fried-quahaug cakes. The place abounds in dim old stories, from the colonial legend of the minister's deformed child, done to death by a dose from its father's hand, that child whose misshapen little ghost still flits, on moonlight nights, about a certain rosebush, to the manyversioned tale of the buccaneer, ever and anon seen prowling about that point on the Back Side where Sam Bellamy's pirate-ship was cast 
away, and stooping to gather the coins flung up to him by the skeleton hands of his drowned shipmates. A volume would not suffice for the stories of these Cape towns. Their very calendar is kept by storms : as the Magee storm of December, I 778, when the government brig Gencral Amold, commanded by Captain James

Magee, went down ;

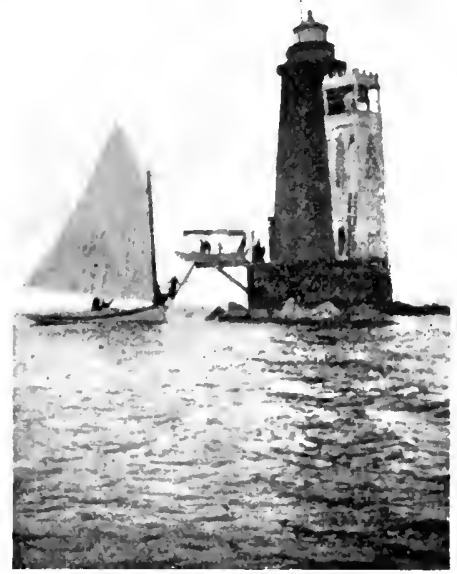

BISHOP AND CLERK LIGHT, HYANNIS. or the Mason and Slidell storm of I 862 , when the Southern emissaries were brought from Fort WVarren to Provincetown, and there, amidst the protest of the elements, yielded up to the British steamer Rinaldo; or the pitiless October gale of ${ }_{1} S_{4}$, when from Truro alone forty-seven men were swallowed by the sea.

The quiet little town of Eastham, originally "Nawsett," settled in I646, only seven years after the three pioneers, Barnstable. Sandwich 


\section{Cape Cod Towns}

and Yarmouth, has shared the hard fortunes of the lower Cape. With a remnant of less than five hundred inhabitants, it finds, under the present stress, a resource in asparagus, shipping a carload or two to Boston every morning in the season. To this land industry the ocean consents to contribute, the soil being dressed for "sparrowgrass" with seaweed and shells. But no hardship can deprive Eastham of its history. After the encounter between the Pilgrims and Indians here in 1620 , the place was not visited again until the following July, when Governor Bradford sent from Plymouth a boatload of ten men to recover that young scapegrace, John Billington. This boy, whose father, ten years after, was hanged by the colonists for murder, had come near blowing up the Mayflower, in Provincetown harbor, by shooting off a fowling-piece in her cabin, close by an open keg of powder, and, later, must needs lose himself in Plymouth woods. He had wandered into the territory of the Nausets, who, although this was the tribe which had suffered from Hunt's perfidy, restored the lad unharmed to the English. The Nausets further proved their friendliness by supplying the Pilgrims, in the starving time of 1622 , with 
stores of corn and beans. But the following year, suspecting an Indian plot against the colonists, Myles Standish, that "little chimney soon on fire," appeared upon the Cape in full panoply of war, executed certain of the alleged conspirators and so

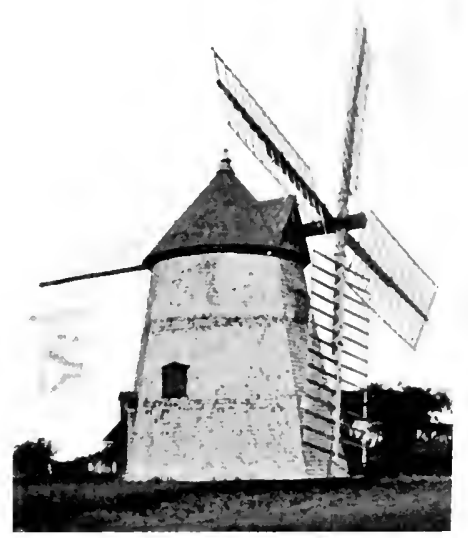

OLD WINDMILL, EASTHAM. terrified the rest that many fled to the marshes and miserably perished.

The traveller up the Cape notices still that Eastham has more of a land look than the lower towns. The soil is darker, small stones appear, and the trees, although still twisted to left and right, as if to dodge a blow, are larger. The Indians had maize-fields there and the site seemed so promising to the Pilgrims that talk sprang up in the early forties of transferring the Plymouth colony thither. As a compromise, several of the old-comers obtained a grant of the Nauset land, and established a branch settlement, soon incorporated as a town- 
ship. Promptly arose their meeting-house, twenty feet square, with port-holes and a thatch. They secured a full congregation by absence penalties of ten shillings, a flogging or the stocks. One of these sturdy fathers in the faith, Deacon Doane, is said to have lived to the patriarchal age of one hundred and ten, rounding life's circle so completely that at the end, as at the beginning, he was helplessly rocked in a cradle.

Thoreau was amused over a provision made by the town of Eastham in 1662 , that " a part of every whale cast on shore be appropriated for the support of the ministry," and drew a fancy-picture of the old parsons sitting on the sand-hills in the storms, anxiously watching for their salaries to be rolled ashore over the bars of the Back Side. One of these worthies, Rev. Samuel Treat, whose oratory outroared the stormy surf, shares with Richard Bourne, of Sandwich, the memory of a true pastoral care for the Cape Indians. He was, in return, so well beloved, that, on his death, his wild converts dug a long passage through the remarkably deep snowfall of the time, and bore him on their shoulders down this white archway to his grave. The Revolutionary $\mathrm{I}$ ar 
was a heavy drain on the resources of the staunch little town, but, with the restoration of peace, whaling and all kinds of deep-sea fishing were resumed, and a tide of prosperity set in. Salt-works were established, and presently Eastham was able to afford such luxuries as a pulpit cushion and a singing-school.

Orleans, set off in 1797 from the southerly portion of Eastham, has an old-fashioned quaintness that is better than business prosperity. Sand has partially closed the harbors, and the population has been dwindling for the past half-century, but the ocean still serves old neighbors as it can with quahaugs and the seaweed, now collected for paper-making. The distinction of being the terminus of the French Atlantic Cable from Brest is in keeping with the name Orleans-a unique instance of a foreign title among these old Cape towns. The early settlers put by the melodious Indian words, Succanessett, Mattacheeset, and the rest, and substituted the dear home names from Devon, Cornwall, Norfolk and Kent. The christening of Brewster, Bourne and Dennis honored severally the Pilgrim elder, the Sandwich friend of the Indians and a Yarmouth pastor; but these are of comparatively recent date. As Well- 
fleet and Orleans have been cut, on north and south, out of the original Eastham, so were Harwich, Chatham, Dennis, Brewster, once "within the liberties of Yarmoutl."

The history of Yarmouth, too, is so closely allied to the histories of Barnstable and of Sandwich, with her daughter Bourne, that the story of all these may be told as one.

These three initial settlements on the Cape were recognized as townships in 1639 . From the outset, the difference in their locations imposed upon them different tasks. Yarmouth, the elbow town of the Cape, bore the brunt of wind and wave; Sandwich kept the border, notably in King Philip's War, when she guarded the faithful Cape Indians from temptation and received for safe harboragre English refugees from the ravaged districts; and Barnstable, the aristocratic sister of the group, made traditions, set examples and produced the Otis family. With Old Yarmouth, the Cape widens. No longer do householders, as at Truro, own land in strips from shore to shore. The soil, too, deepens, and the cows need not with hungry noses brush away the drifted sand to find the grass. On the Back Side is no marked change in aspect. Still pine grove after pine grove 
adds flavor to the salt air, and where the carpet of needles is trodden through, gleam patches of white sand. The strange reappearance of the Somerset is out-miracled in Old Ship Harbor, where, in I863, long after the significance of the name had been forgotten, the hull of the Sparrow-Hawk, wrecked there in 1626 , on her way from London to Virginia, rose again to view. This portion of the Cape is in excellent repute with pleasureseekers, and the seaside cottage is ubiquitous, especially in beautiful Chatham, whose everchanging shore takes the wildest raging of the surf. Harwich, which has gone through the regular stages of whaling, codding, mackerelfishing and salt-making, cultivates in turn the summer boarder, but somewhat quizzically. Retired sea-captains are not easily overawed even by golf-sticks, and retired sea-captains, in Harwich, are as thick as cranberries. Snuffing the brine, they pace their porches like so many quarter-decks and delight their auditors and themselves with marvellous recitals. The Cape has not proved friendly to manufactures in general. Salt-works and glass-works have come to naught,--but the spinning of seayarns is a perennial industry. 


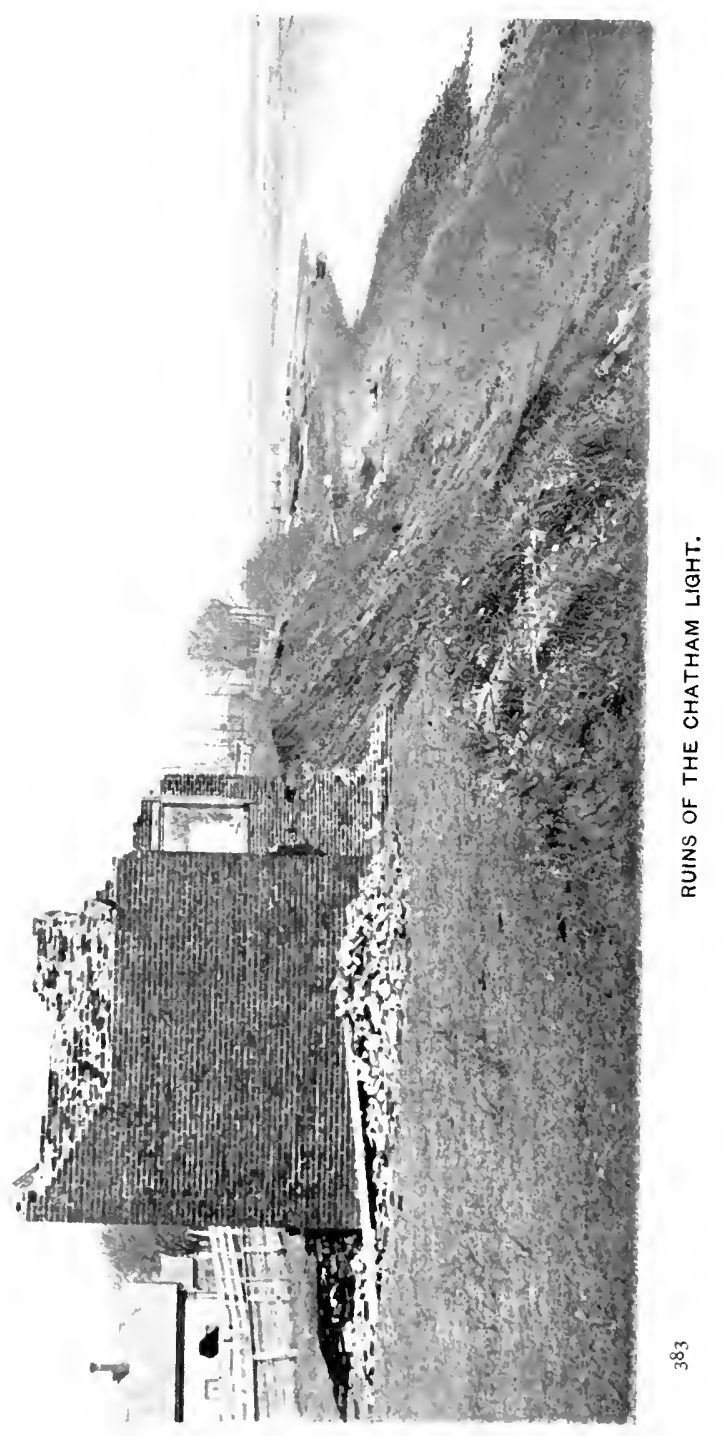


Many of the summer guests prefer the north side of the Cape, where fogs are less frequent, or where, in ancient Indian parlance, old Maushope smokes his pipe less often. Such find in Brewster and Dennis no less delightful colonies of ancient ship-masters, living easily off their sea-hoards. In I 837 that little town of Dennis claimed no fewer than one hundred and fifty skippers sailing from various American ports, and in 1850 it was said that more sea-captains went on foreign royages from Brewster than from any other place in the United States. Often their wives sailed with them and had thereafter something wider than village gossip to bring to the quilting- and the sewing-circle. It was a great day for the chilchen in the village when a sea-captain came home. From door to door went his frank sailor-gifts, jars of Chinese sweetmeats, shimmering Indian stuffs, tamarinds, cocoanuts, parrots, fans of gay feather, boxes of spicy wood, glowing corals, and such great, whispering shells as Cape Cod beaches never knew. It was a hospitable and merry time, given to savory suppers, picnic clambakes, and all manner of neighborly good-cheer. Even the common dread made for a closer sympathy. Any 
woman, going softly to her neighbor to break the news of the husband lost in Arctic ice, might in some dark hour drop her head upon that neighbor's shoulder in hearing of a son drowned off the Banks or slain by South Sea Islanders.

The old town of Yarmouth, dozing thus among children already gray, has many a thing to dream about, when the surf is loud. She remembers the terrible gale of 1635 , in which the Thacher family were wrecked upon the island that since has borne their name, the March snow-storm that destroyed the three East Indiamen from Salem, the stranding of the English Fason, and many a tragedy more. Along that treacherous Back Side, lighthouse towers are now closely set, and well-equipped, well-manned life-saving stations have succeeded the rude Charity Houses, the fireplace, wood and matches, straw pallet, and signal-pole which used to give what succor they might to hapless mariners. The old volunteer coastguard, which rarely failed to pace the beach in storms, is now replaced by a regular patrol, carrying lanterns and red hand-lights and thoroughly drilled in the use of shot-line and breeches-buoy. But still the fierce-blowing 
sand cuts their faces to bleeding and still the furious surf makes playthings of their lifeboats, so that manhood has no less heroic opportunity than in the earlier days. The crew at one of these stations, after an exposure of twelve hours on the wintry beach, failed

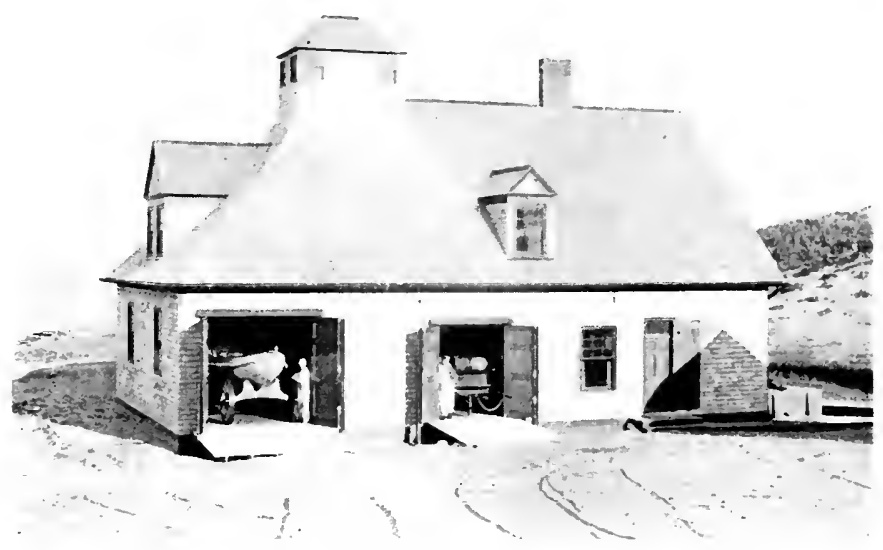

LIFE-SAVING STATION AT WELLFLEET.

in every effort to launch the surf-boat and had to see the rescue they should have made effected by a crew of fishermen volunteers. The keeper brooded over his disgrace and the following winter wiped out what is known upon the Cape as the "goading slur" by a 


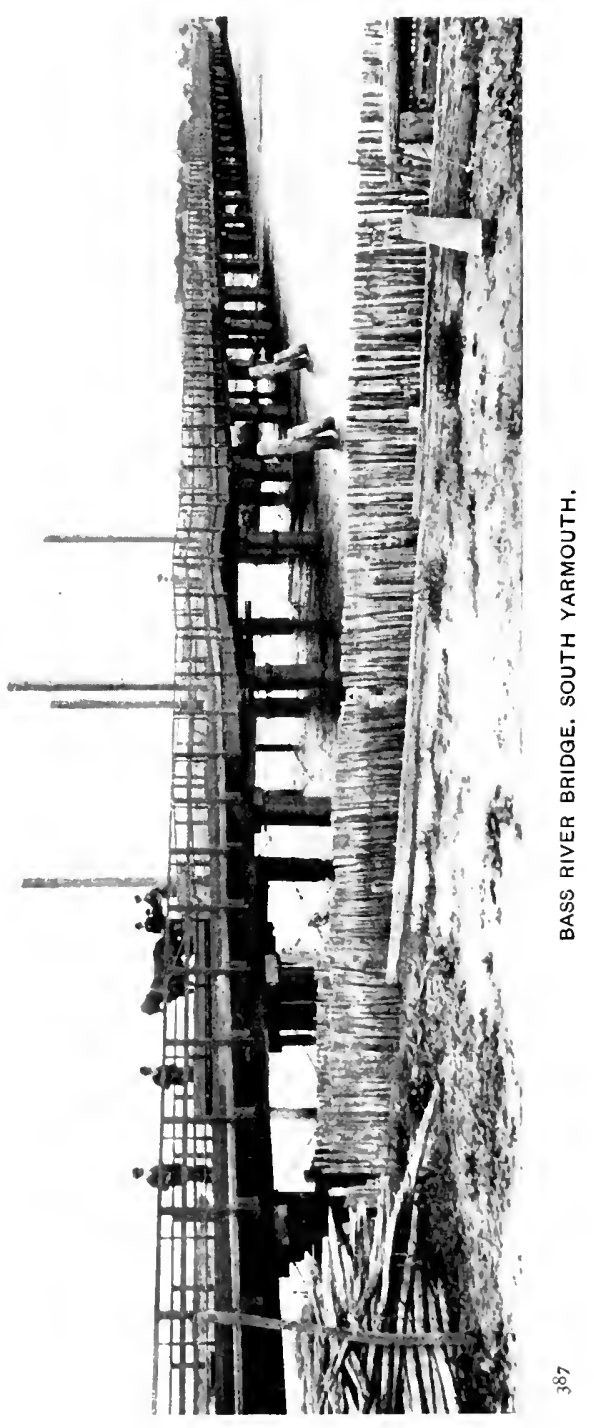


desperate launching in a surf that beat the life from his body.

Ever since the day of the Pilgrims, who made the suggestion, and of George Washington, who furthered the project, there has been talk of a Cape Cod canal to expedite traffic and avert disaster. A channel between Eastham and Orleans was once forced by the sea, and various routes through Yarmouth, Barnstable and Sandwich have been surveyed, and charters granted, but ships still round Race Point. The railroad, however, which was built by slow stages down the Cape and reached Provincetown only a quarter of a century since, has facilitated travel, doing away both with the red-and-yellow mail-coach, which used, a hundred years ago, to clatter through to Boston in two glorious days, and with the packet service of jolly memory. Yarmouth and Barnstable were sharp rivals in these packet trips, Barnstable putting her victories into verse:

"The Commodore Hull she sails so dull

She makes her crew look sour;

The Eagle Flight she is out of sight

Less than a half an hour.

But the bold old Emerald takes delight

To beat the Commodore and the Flight." 
Barnstable has pursued from the outset a course of modest prosperity. She does not ask too much of fortune. If her census-roll has gained only five in the last decade, that is better than losing, as most of the Cape towns have done, and, even so, her numbers rank next to Provincetown. How humble were the beginnings of this sedate and gracious county

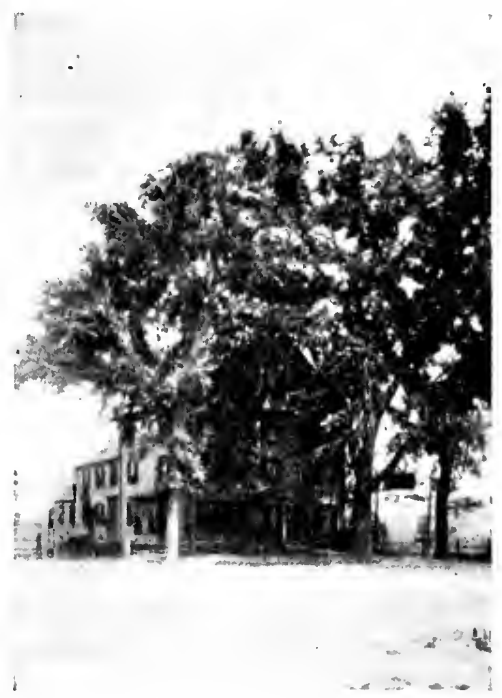

BARNSTABLE INN.

seat may be learned from the letter of an early' citizen, declining Governor Winslow's appointment to lead an expedition against the Dutch. This quiet colonist, who commanded the Plymouth forces in King Philip's War, pleads his domestic cares :

"My wife, as is well known to the whole town, is not only a weak woman, and has leen so all along, but now, 
by reason of age, being sixty-seven years and upwards, and nature decaying, so her illness grows more strongly upon her. Never a day passes but she is forced to rise at break of day, or before. She cannot lie for want of breath. And when she is up, she cannot light a pipe of tobacco, but it must be lighted for her. And she has never a maid. That day your letter came to my hands, my maid's year being out, she went away, and I cannot get or hear of another. And then in regard of my occasions abroad, for the tending and looking after all my creatures, the fetching home my hay, that is yet at the place where it grew, getting of wood, going to mill, and for the performing all other family occasions, I have now but a small Indian boy about thirteen years of age, to help me. Sir, I can truly say that I do not in the least waive the business out of an effeminate or dastardly spirit, but am as freely willing to serve my King and my country as any man whatsoever, in what I am capable and fitted for, but do not understand that a man is so called to serve his country with the inevitable ruin and destruction of his own family."

An "effeminate or dastardly spirit" would indeed be a novelty in the birthplace of James Otis. But it was not only in face of the Indian and the redcoat that these three old towns showed firm courage. To their glory be it remembered that they withstood the persecutor and bluntly refused to enforce the laws against heresy, so that a special officer had to be sent by Plymouth Court to hunt out and oppress 


\section{Cape Cod Towns}

the Quakers. Under his petty tyrannies, the faith of the Friends gained many converts, and Quakerism became permanently established on the Cape.

These upper towns have never depended on the sea as exclusively as those below, and hence the decline of the fisheries has been less disastrous to them. They need industries to hold their young people at home, but the marine manufacture of salt by solar evaporation, the discovery of a Dennis sea-captain, has had its day, and the once famous Sandwich glassworks are now idle. Sheep-raising and cattleraising were long since abandoned, but while the New England Thanksgiving lasts, cranberry culture bids fair to yield an honest profit. As early as 1677 , Massachusetts presented Charles II. (put out of humor by the pinetree shilling) with three thousand codfish, two hogsheads of samp and ten barrels of cranberries. These last are still good enough for a better king than the Merry Monarch, and cranberry-picking is one of the most picturesque sights on the modern Cape. Hundreds of pickers, gathering by hand or with the newly invented machines, move over a bog in ordered companies. The "summer 
folks" flock to the fun, and Portuguese, Italians, Swedes, Poles, Finns, Russians, troop down from Boston and over from New Bedford for the brief cranberry season, or they may come earlier to join the blueberry-pickers that dot the August hills. The bogs are easily made from the wastes of swamp, which are drained, sanded, planted and given three years to grow a solid mat of vines. The crop from a few acres brings dollars enough to carry the thrifty Cape Codder through the year. Rents are of the lowest, and the shrewd old seaman who tends his own garden, salts his own pork, raises his own chickens, milks his own cow and occasionally "goes a-fishin"," while his wife cooks and sews, and "ties tags" for pin-money, has no heavy bills to meet. There is so little actual poverty in these towns that the poorhouse is often rented.

Even Mashpee, once the Indian reservation, but now a little township peopled by halfbreeds, mulattoes and a sprinkling of whites, grows tidier and more capable every year. The aborigines of Cape Cod have left slight traces save the melodious names that cling to bay and creek. Arrow-heads are scattered about, and now and then the plough turns up one of 


\section{Cape Cod Towns}

the clam-shell hoes with which the Nausets used to till their maize-fields. The Praying Indians of the Cape deserve our memory, - for they were always faithful to their English neighbors. When the first regiment was raised in Barnstable County for the Revolutionary War, twenty-two Mashpees enlisted, of whom but one came home. A Praying Indian of Yarmouth has won a place in New England song,- Nauhaught the Deacon, who, hungerpinched, restored the tempting purse of gold to the Wellfleet skipper and received a tithe "as an honest man."

The beauty of the upper Cape, culminating in the lovely town of Falmouth, is largely rural and sylvan. A system of dyking has, within the last fifty years, converted much of the salt marsh to good, fresh meadow, and, from Orleans up, the look of the country is more and more agricultural. Portions of Yarmouth are well wooded, and in Barnstable, Sandwich and Falmouth are depths of forest where the fox and the deer run wild. The wolf alone has been exterminated, and that with no small trouble, the Cape finally proposing, after grisly heads had been nailed on all her meetinghouses, to build a high fence along her upper 
border and shut the wolves out. But Plymouth and Wareham objected, from their side of the question, to having the wolves shut in, and this ingenious scheme had to be abandoned. These woodlands are dotted in profusion with silvery ponds, which the Fish Commission at Wood's Holl keeps well stocked. Often the north side, as in Sandwich, is skirted by long stretches of unreclaimed marsh, over which the heron flaps, with the distinguished air of an old resident, and from which the sweet whistle of the marsh quail answers the "Bob White" of the woods. There is plenty of rock in this landscape, the backbone of the Cape jutting through. Barnstable proudly exhibits four hundred feet of wall, two feet in width, wrought from a single mass of granite found within her limits. Falmouth arbutus grows pinkest about the base of a big boulder known as City Rock, and a field of tumbled stones upon her Quisset road is accounted for on the hypothesis that here the Devil, flying with his burden over to Nantucket, "broke his apron-string." The trees, too, are of goodly size and stand erect. Elms, silver-leaf poplars, balm of Gileads, great sycamores, spotted with iron-rust lichen, 


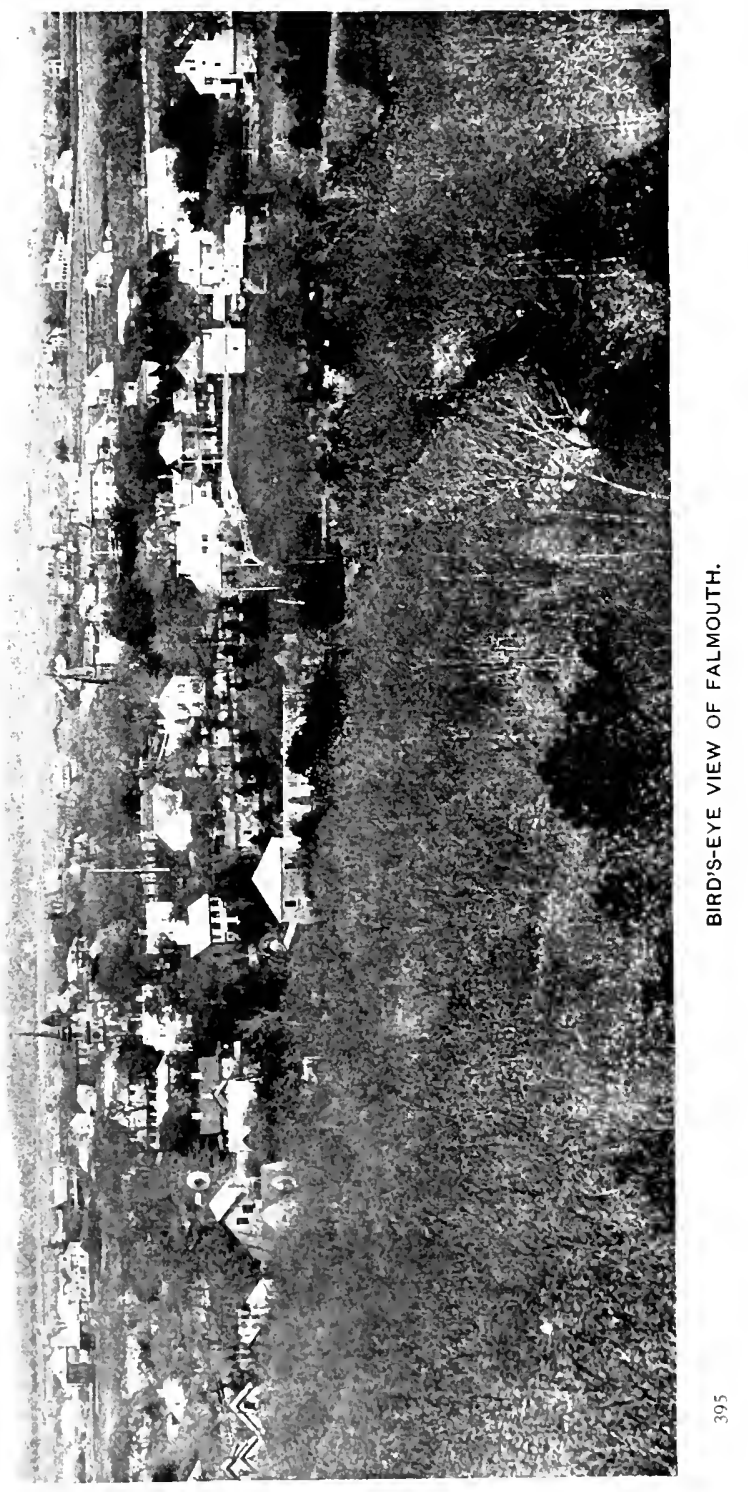


and willows, lemon yellow in the sun, shade the waysides. Golden-winged woodpeckers and red-shouldered blackbirds dart to and fro, while the abundance of jaunty martin-houses shows that Cape Cod hospitality is not limited to the human.

The quiet, white homesteads, with green blinds, broad porches and sometimes a cupola for the sea-view, stand in a sweet tranquillity and dignity that should abash the showy summer residence. But these old-fashioned homes keep up with the times. Against the wellsweep leans the bicycle. The dooryards are blue with myrtle, or pink with rose-bushes, or gay with waving daffodils. Old age is in fashion on the Cape. When twilight fades, the passer-by sees gathered about the early evening lamp the white heads of those whose "chores" are done. And though death comes at last, the cemeteries are so tenderly kept that the grave is robbed of half its dread. Even in the oldest burial-grounds, where the worn, scarred stones lean with the privilege of age, the staring death's-heads are cozily muffled in moss, and "Patience, wife of Experience," sleeps under a coverlet of heartsease.

All the way from Provincetown to Falmouth 


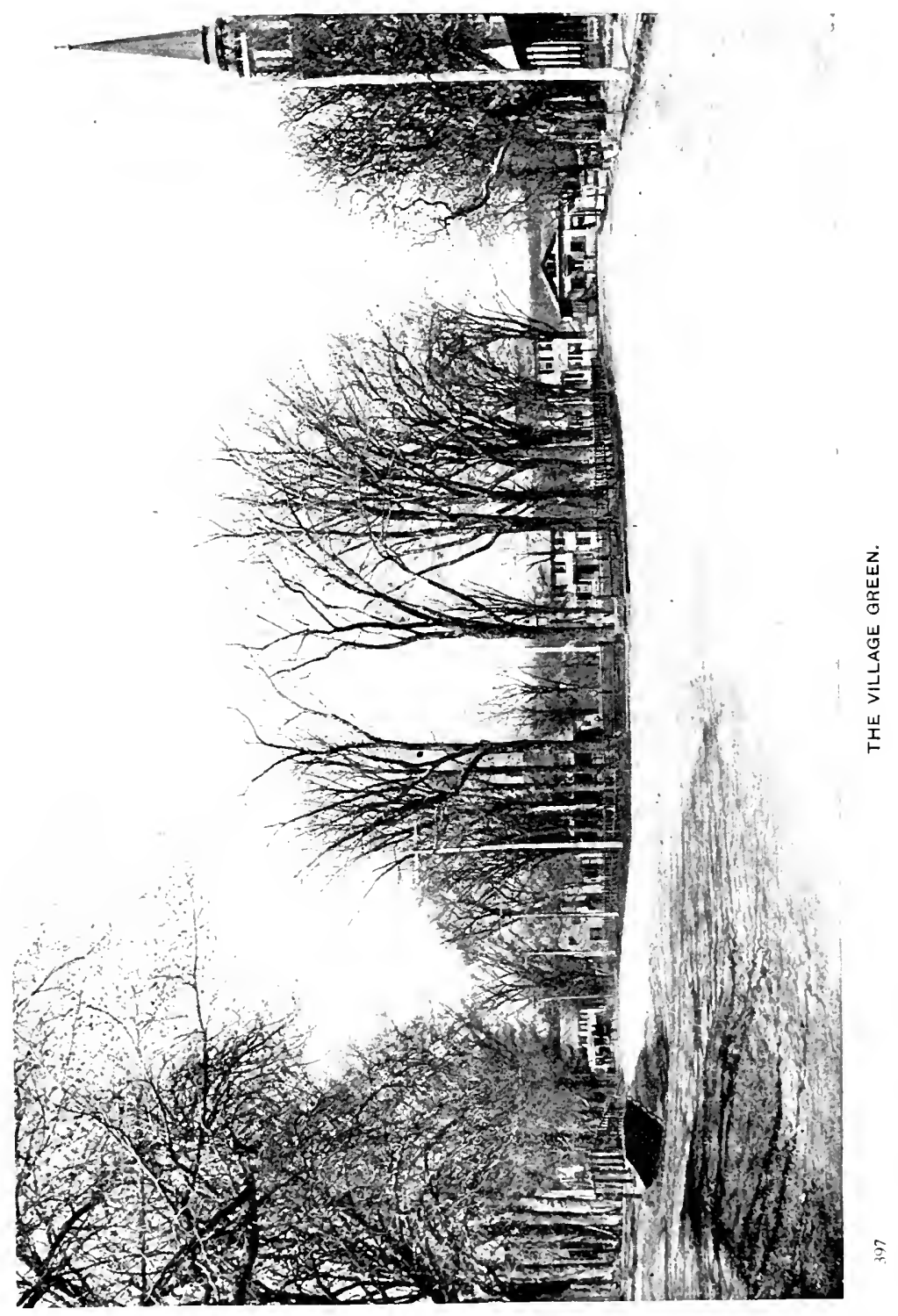


are certain briny signals, - a ship's figurehead, marble steps whose stone was washed ashore as wreckage, lobster-pots, herring-nets, conch-shells set on lintels, a discontented polar bear pacing a stout-paled yard, ruffling cockatoos, boats converted into flower-boxes, whales' vertebre displayed for ornament, garden-beds marked out with scallop-shells, everywhere the ship-shape look, the sailor's handy rig, and everywhere the codfish used for weathercocks. In Barnstable court-house a mammoth cod is suspended from the ceiling. Vistas of ocean outlook, too, from under arches of green branches, flash upon the eye, the salty flavor is not lost in woodland fragrances, and the rolling hills and wavy pastures take their model from the sea.

Of the old-timey features of the Cape, no one is more impressive than the witch-like windmill with its peaked cap, outspread arms and slanting broomstick, reminding us that the Pilgrims came from Holland. Some of these antique mills have been bought by summer residents and moved to their estates for curiosities, but the one at Orleans was in use as late as 1892 , taking its profitable toll of two quarts out of the bushel. 


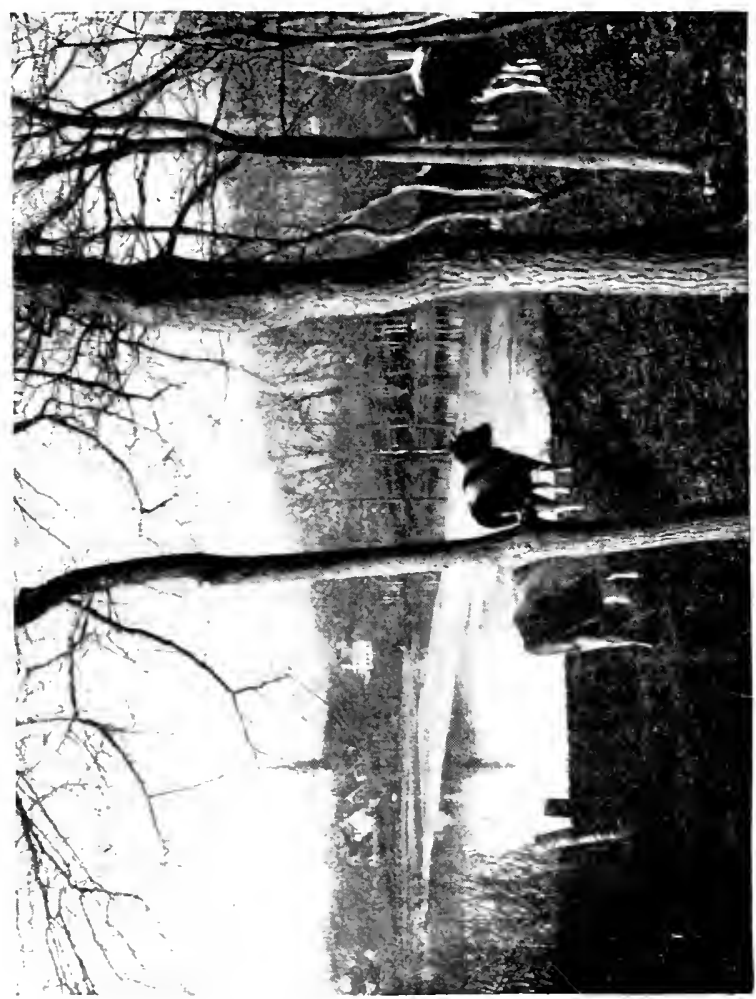

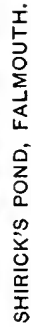

疋 
The general history of Falmouth but repeats the story of her sister towns. The first settlers are believed to have come in boats from Barnstable, in 1660 . They encamped for the night among the flags of Consider Hatch's Pond, where a child was born and, in recognition of the rushes that sang his earliest lullaby, named Moses. The town was duly incorporated in I686, next after Eastham, and has steadfastly stood for piety, wisdom and patriotism. She admitted the Quakers, and if one of her deacons held a negro slave, as colonial deacons often did, poor Cuffee was at least brought to the communion table. It is Truro that contains "Pomp's Lot," where the stolen African, with loaf of bread and jug of water at his feet for sustenance on his new journey, escaped slavery by hanging. As for learning, it was Sandwich Academy which the Cape towns held in awe, but our Falmouth men, like the rest, half sailor, half farmer and all theologian, had a genuine culture, born of keen-eyed voyaging and of lonely thought, that kept the air about them tingling with intelligence. When it comes to war stories, if Provincetown, from her end of the Cape, can tell of her boy in blue that went down with the Cumberland, 


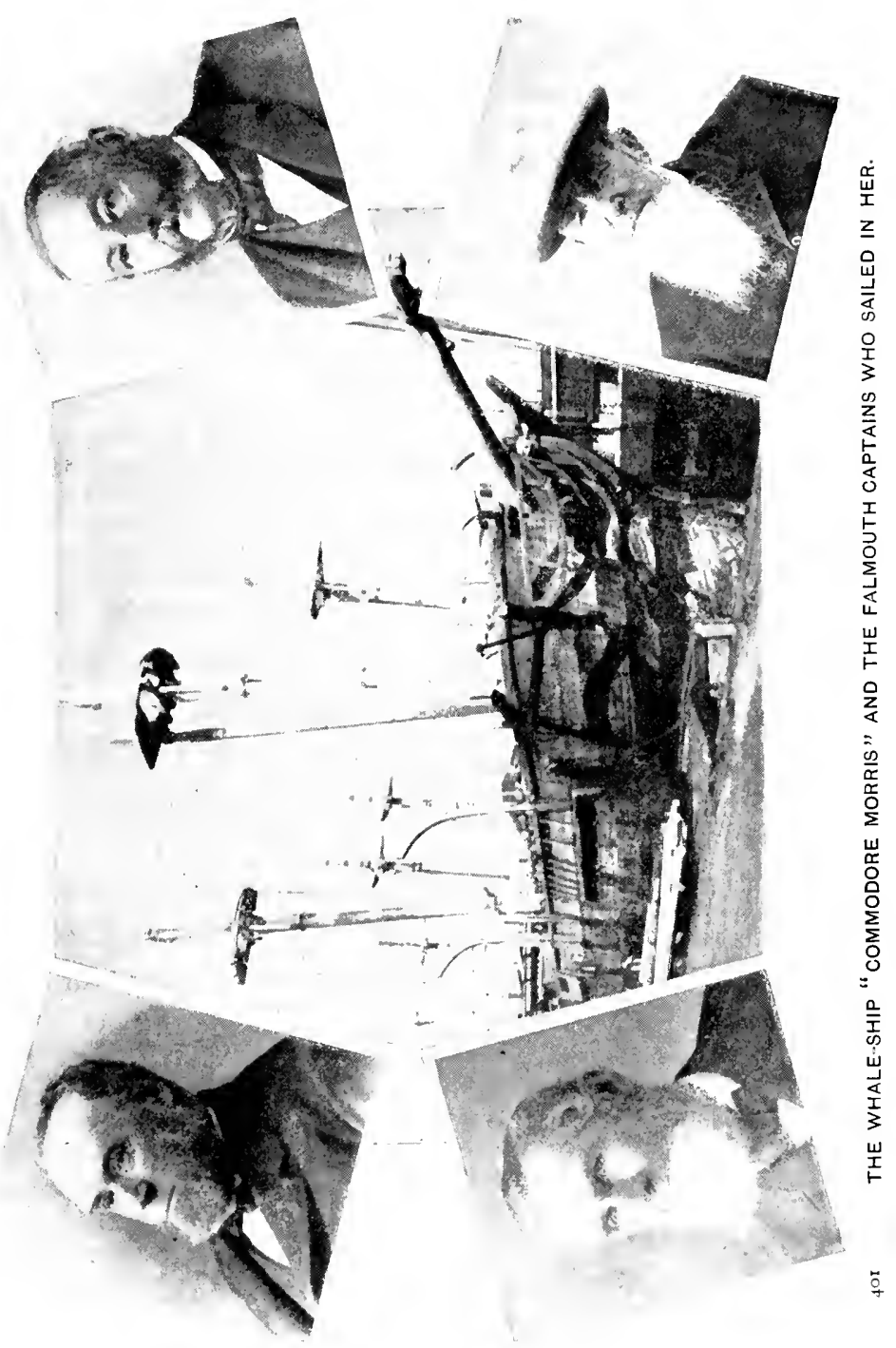


and her naval captain at Manila, Falmouth can recall that twice she was bombarded by the British and twice defended by the valor of her sons, and when the Civil War broke out, with the larger share of her able-bodied men at sea, she yet sent more than her quota of soldiers to the front.

Within the last quarter-century, Falmouth has entered on new activities, largely due to the increasing fame of Buzzard's Bay as a summer resort. The story goes that the town had all gone to sleep, but somebody woke one day and painted his front fence, and forthwith his neighbors, not to be outdone, painted theirs, and their houses too, and the new era came in with a rush. But whatever good fortune the future has in store, Paul Revere's bell, that sounds from her central steeple, will hold Falmouth true to her traditions; for these Cape towns, simple as their record is, have worked out on unconsciously heroic lines the essential principles of a God-fearing, self-respecting democracy. 


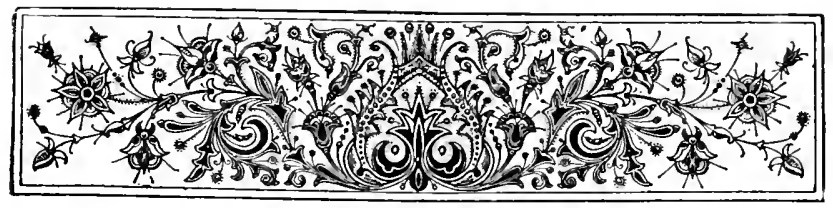

\section{DEERFIELD}

\section{OLD POCUMTUCK VALLEY}

By GEORGE SHELDON

O every one familiar with the history of the
old Bay State, the name of Deerfield naturally brings to mind two diverse pictures: one, the giant trees of the primeval forest under whose sombre shade the white-haired Eliot prayed, and the sluggish stream beside whose banks he gathered its roving denizens for a test of civilization; the other, that scene of woe and desolation, when, under a wintry sky, the glare of burning houses lighted up a wide expanse of snow, shaded by dark columns of wavering smoke, and splashed here and there with red. The first picture suggests possibilities, the second results. The connecting link between the two is the fact that out of the labors of Eliot on the river Charles 
grew directly the settlement of the English on the Pocumtuck.

Back of all was the interest in the newly discovered heathen, which sent currents of gold from England across the seas to the Indian missions. Of all these that of the Apostle Eliot was the head and front. His first attempt, at Newton, was a failure, from its proximity to a Christian town. On his petition, the General Court granted him a tract in the wilderness where he and the uncontaminated native could come face to face with the God of Nature. This tract was claimed by the town of Dedham, and, after a successfut legal contest, the General Court gave the claimant in lieu of it the right to select eight thousand acres in any unoccupied part of the colony. After wide search this grant was laid out on Pocumtuck River, and the selection was ratified by the Court, October is, 1665.

This power, however, was only leave to purchase of the native owners. The laws recognized the rights of the Indians to the soil, and no Englishman was allowed to buy or even receive as a gift any land from an Indian without leave of the General Court. The oft-repeated slander that the fair purchase of land from the 


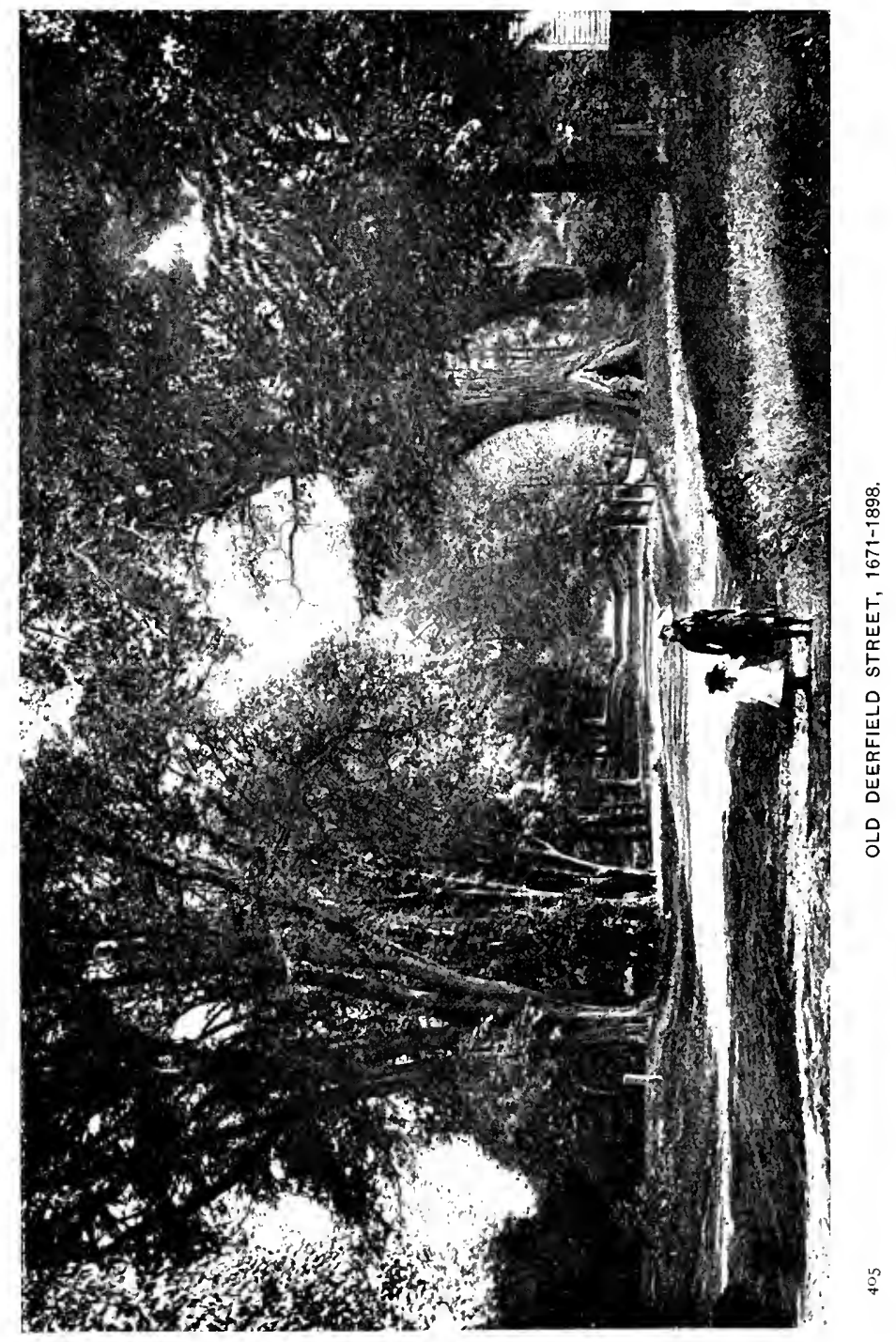


Indians was peculiar to William Penn, can be refuted in general by a study of our early statute books, and in particular by an examination of the original deeds from the Indians, now in our Memorial Hall.

It will be seen by these deeds that the Indians reserved the right of hunting, fishing and gathering nuts-all, in fact, that was of any real value to them. The critic says that in such trades the price was nominal and that the Indian was outrageously cheated. Fortunately, in this case existing evidence proves that Dedham paid the natives more than the English market price, in hard cash, and besides gave one acre at Natick for every four here.

The money to pay for the eight thousand acres was raised by a tax on the landholders of Dedham, the owners paying in proportion to the number of shares or "cow commons" held; and their ownership of the new territory was in the same proportion. There were five hundred and twenty-two shares in all, held in common, covering the whole of Dedham.

In 1671 a committee from Dedham laid out highways, set apart tracts for the support of the ministry, laid out a "Town Plott," and large sections of plow-land and of mow-land. 
In each of these sections individuals were assigned by lot their respective number of cow commons. Later the woodlands were divided in the same manner. For generations this land was bought and sold, not by the acre, but by the cow common, fractions thereof being sheep or goat commons, five of these being a unit.

The "Town Plott," laid out in $167 \mathrm{I}$, is the Old Deerfield Street of to-day.

The first settlers at Pocumtuck were not, as generally supposed, the original Dedham owners. The shares of the latter had been for years on the market, and many had passed to outsiders. But only picked men were allowed to become proprietors. This fact is illustrated by votes like the following:

"Dec. 4, I671. John Plimpton is allowed to purchase land of John Bacon at Pawcumtucke provided that the said John Plimpton doe settle thereupon in his owne person." On the same day the request of Daniel Weld for leave to purchase was refused. No reason was assigned, and Mr. Weld was admitted soon after.

"Feb. I6, I671-2. Lieft. Fisher is alowed libertie to sell 6 cow common rights and one 
sheepe common right at Paucomtuck to Nathaniel Suttlife of Medfield."

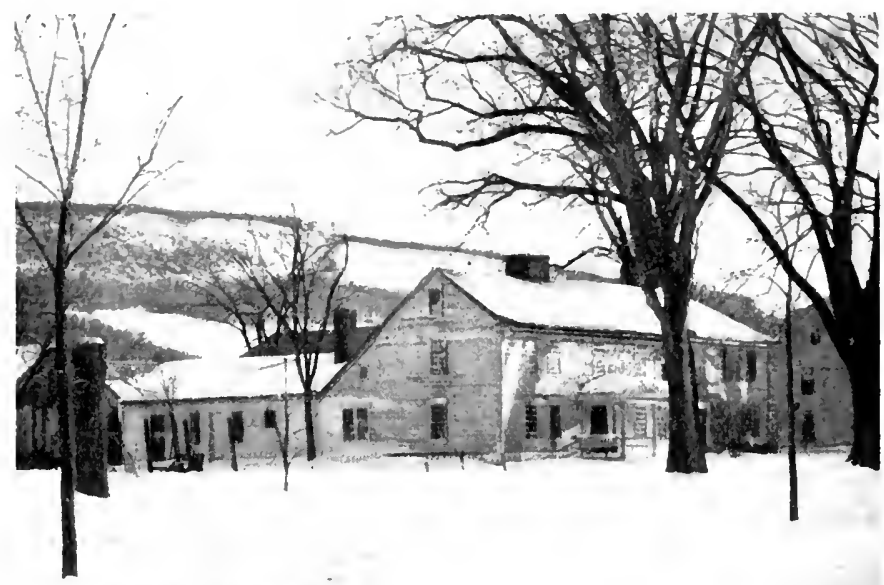

FRARY HOUSE, 1698. OLDEST IN THE COUNTY.

The pioneer settler here was Samuel Hinsdell, of Medford. He had bought shares, and, impatient of delay in making the division, he became a squatter, and in 1669 turned the first furrow in the virgin soil of Pocumtuck. Samson Frary was a close second, if not a contemporary; "Samson Frary's cellar" is mentioned in the report of the Committee, May, 1671 . 


\section{Deerfield}

The settlers increased rapidly. May 7 , I673, the General Court gave them "Liberty of a Towneship," which is Deerfield's only "Act of Incorporation." Soon after, a rude meeting-house was built, and Samuel Mather served as a minister among them.

A loose sheet of paper has been found dated Nov. 7, 1673, with a record of a town-meeting. This was signed by the following, who must be called the earliest settlers:

Richard Weler

John Plympton

Joshua Carter

Samson Frary

Quinten Stockwell

Joseph Gillet

Barnabas Hinsdell

Robert Hinsdell

John Allen

Daniel Weld

Samuel Hinsdell
John Barnard

John Weler

Samuel Herenton

John Hinsdell

Ephraim Hinsdell

Moses Crafts

Nathaniel Sutley

John Farrington

Thomas Hastings

Francis Barnard

Samuel Daniel

Experience Hinsdell James Tufts.

The action of this meeting was chiefly on the division of land, but it was voted that "all charges respecting the ministers sallerye or maintenance bee leuied and raised on lands for the present." Another page shows a meet- 
ing November 17,1674 , when the plantation was called Deerfield. We have no clue as to why or by what authority it was so called.

The newcomers found the meadows free from trees, with a rich soil which soon yielded abundantly of wheat, rye, peas, oats, beans, flax, grass and Indian corn. The meadows were enclosed with a common fence to keep out the common stock, which roamed at will on the common land outside.

The war of 1675 is called "Philip's War" because Philip was able to incite the tribes to hostilities against the whites, rather than because it was carried on under his direction. A seer and a patriot Philip may have been, but he was not a warrior. It is not known that he was ever in a single conflict.

When the first blood was shed at far-away Swanzey, in June, 1675 , the men of Pocumtuck were not disquieted. With the Indians about them they had lived for years in perfect harmony. But when the blow fell on Captains Beers and Lothrop under the shadow of their own Wequamps, war became a reality. As a measure of defense two or three houses were slightly fortified, and none too soon. The village was marked for destruction. On the 
morning of September I, 1675, the Indians gathered in the adjoining woods, awaiting the hour when the men, scattered about the meadows at their work could be shot down one by one, leaving the women and children to the mercy of the Indians. This plan was frustrated. The Indians were discovered early in the morning by James Eggleston, while looking for his horse. Eggleston was shot and the alarm given. The people fled to the forts. These were easily defended by the men, but beyond the range of their muskets ruin and devastation held sway.

Deerfield was the first town in the Connecticut Valley to be assaulted, and the alarm was general. The news reached Hadley the same day while the inhabitants were gathered in the meeting-house observing a fast ; "and," says Mather, "they were driven from the holy service they were attending by a most sudden and violent alarm which routed them the whole day after." Their alarm and rout were needless ; no enemy appeared. Yet these words of the historian are the narrow foundation on which Stiles and others gradually built up the romantic myth of Goffe, as the guardian and deliverer of Hadley. 
September 2, the tactics at Deerfield were successfully repeated by the Indians at Northfield. Eight men were killed in the meadows, but enough were left in the village to hold the stockade. September 4, Captain Richard Beers with his company who were marching to their relief, were surprised, and himself and twenty men were slain. September 5, Major Robert Treat, with a superior force, brought off the beleaguered survivors.

Sunday, September I2, another blow fell upon Deerfield. The place had now a garrison under Captain Samuel Appleton. The Indians could see from the hills the soldiers gathering in one of the forts for public worship. They laid an ambush to waylay the soldiers and people returning after service to the north fort, but all escaped their fire save one, who was wounded. Nathaniel Cornbury, left to sentinel the north fort, was captured, and never again heard from. Appleton rallied his men, and the marauders, after inflicting much loss on the settlers, drew off to Pine Hill.

But a sadder blow was to fall upon the dwellers in this little vale. The accumulated result of their industry and toil was to disappear in flame and ashes. In their wanton destruction 
the Indians had spared the wheat in the field for their own future supply; " 3000 bushels standing in stacks," says Mather. This wheat was needed at headquarters to feed the gathering troops, and Colonel Pynchon, the Commander-in-Chief, gave orders to have it threshed and sent to Hadley. Captain Thomas Lothrop, with his company, was sent to convoy the teams transporting it.

September I 8,1675 , "that most fatal day, the saddest that ever befel New England," says a contemporary, "Captain Lothrop, with his choice company of young men, the very flower of the county of Essex," marched boldly down the street, across South Meadows, up Long Hill, into the woods stretching away to Hatfield Meadows. Confident in his strength, scorning the enemy, Captain Lothrop pushed on through the narrow path, with not a flanker or vanguard thrown out. Extending along his left lay a swampy thicket through which crept a nameless brook. Gradually, the swamp narrowed, and turned to the right across the line of march. At this spot the combined force of the enemy lay in ambush, and into this trap marched Lothrop and his men. While the teams were slowly dragging their loads through 
the mire, it is said the soldiers laid down their guns to pluck and eat the grapes which grew in abundance by the way. Be this true or not, at this spot they were surprised and stunned by the fierce war-whoop, the flash and roar of muskets with their bolts of death. Captain Lothrop and many of his command fell at the first fire. The men of Pocumtuck sank, the "Flower of Essex" wilted before the blast, and-

"Sanguinetto tells ye where the dead

Made the earth wet, and turn'd the unwilling waters red."

The sluggish stream was baptized for aye, "Bloody Brook."

Captain Samuel Moseley, who was searching the woods for Indians, hearing the firing, was soon on the ground. Too late to save, he did his best to avenge ; he charged repeatedly, scattering the enemy, who swarmed as often as dispersed. But he defied all their efforts to surround him. His men exhausted with their long efforts, Moseley was about to retire, when just in the nick of time Major Treat appeared, with a force of English and Mohegans. The enemy were driven westward and were pursued until nightfall. The united 
force then marched to Deerfield, bearing their wounded, and leaving the dead where they fell.

Mather says, "this was a black and fatal day wherein there was eight persons made widows and six and twenty children made orphans, all in one little Plantation." That plantation was Deerfield, and these were the heavy tidings which the worn-out soldiers carried to the stricken survivors of the hamlet. Of the seventeen fathers and brothers who left them in the morning, not one returned to tell the tale. The next morning, Treat and Moseley marched to Bloody Brook and buried the slain-" 64 men in one dreadful grave." The names of sixtythree are known, and also of seven wounded. John Stebbins, ancestor of the Deerfield tribe of that name, is the only man in Lothrop's command known to have escaped unhurt.

The reported force of the enemy was a thousand warriors, and their loss ninety-six. This must be taken with a grain of allowance.

Deerfield was now considered untenable, and the poor remnant of her people were scattered in the towns below.

October 5, Springfield was attacked. The Indians laid the same plan as at Deerfield and Northfield. Only notice given by a friendly 
Indian during the night before saved the town from total destruction. The assailants were Indians who had lived for generations neighbors and friends of the Springfield people. On the $4^{\text {th }}$ they had made earnest protestations of friendship, on the strength of which the garrison had marched to Hadley. This deliberate treachery was probably planned by Philip.

October I9, a large party made an attack on Hatfield, but was repulsed.

As the spring of 1676 advanced, a large body of Indians collected at Peskeompskut for the purpose of catching a year's stock of shad and salmon. Parties from thence occasionally harassed the settlers below, who knew that when the fishing season was over, the enemy would constantly infest the valley, and watch every chance to kill the unprotected. They therefore determined to take the initiative, and at nightfall of May i 8, a party of about a hundred and fifty men under Captain William Turner made a night march, surprised the camp at daylight the next morning and destroyed many of the enemy.

The homeward march was delayed so long that Indians from neighboring camps began to appear. A released captive reported that 
Philip with a thousand warriors was at hand, and as the enemy swarmed on rear and flank, the retreat became almost a panic. The straggling and the wounded were cut off. Captain Turner was shot while crossing Green River, about a mile from the battle-field, and the party, under Captain Samuel Holyoke, reached Hatfield with the loss of forty-two men.

The warring Indians never recovered from the blow at Peskeompskut. Besides their slain, they lost their year's stock of fish, and the hundreds of acres of Indian corn they had planted with the assurance of a permanent abode in that region. The broken, disheartened clans drifted aimlessly eastward. They quarrelled among themselves. Philip, with a few followers, skulked back to Pokanoket, where he fell, August I 2, 1676. The war ended soon after.

In the spring of 1677 , some of the old settlers came back and planted their deserted fields; preparations for building were well advanced by some of the more venturesome, when, September I9, they were surprised by Ashpelon with a party of Indians from Canada, and all were either killed or captured.

In 1679 the General Court passed an act regulating the resettlement of deserted towns, 
requiring the consent of certain authorities who should prescribe

"In what form, way \& manner, such townes shallbe settled \& erected, wherein they are required to haue a principal respect to neerness and conveniency of habitation for securitie against enemyes \& more comfort for Xtian comunion \& enjoyment of God's worship \& education of children in schools \& civility."

By virtue of this act a committee was appointed under whose direction a resettlement of the town began in the spring of 1682 . Induced by grants of land, new settlers appeared, and the plantation progressed rapidly. In I686, sixty Proprietors are named. This year, young John Williams appears on the scene as candidate for the ministry; and, September 21 , he received a "call." He was married July 20, I687, to Eunice, daughter of Rev. Eleazer Mather, of Northampton. October is, i68s, he was ordained, and the First Church was organized.

The second meeting-house was built in 1684 , the third in 1695 , the fourth, a very elaborate one, in 1729 , the fifth, the present brick structure, in 1824 , and it is still occupied by the First Church. In all these, save the last, the worshippers were "seated" by authority. 
In 1688 , on the news of the Revolution in England, the seizure of Andros in Boston and the call for the election of representatives to organize a new government for the Colony, the

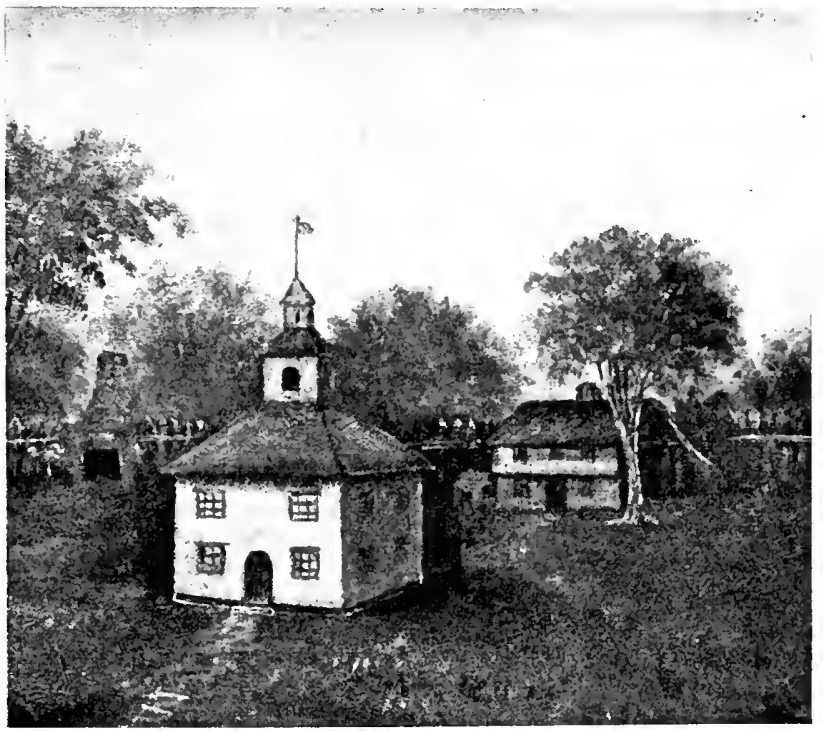

THIRD MEETINQ-HOUSE, 1695-1729.

(OLD INDIAN HOUSE ON THE RIGHT.)

men of Deerfield acted promptly. Lieutenant Thomas Wells, a commissioned officer under Andros, was selected to represent the town, and the selectmen sent to Boston a certificate to that effect. These men were fully aware 
that in the case of a failure of the movement, the vindictive Andros would wreak his vengeance upon all concerned. Shrewd men were at the fore, and Randolph himself might search the town records in vain for any trace of these proceedings or other treasonable action.

During King William's War, the town was harassed by the enemy; drought and insects ruined the crops, and a fatal distemper prevailed. There was question of deserting the place, but bolder counsels controlled. Baron Castine with an army from Canada attempted a surprise of the town, September I 5, 1694 , but he was discovered just in time to close the gates, and was driven back with small loss to the defenders. Another army organized in Canada for the same purpose turned back on being discovered by scouts. During this trial Deerfield suffered great losses, but pluck carried her through.

Queen Anne's War broke out in 1702. The population here was about three hundred souls. The fortifications on Meeting-house Hill were strengthened, and the house of the commander, Captain Wells, about forty rods south, was palisaded. In May, г 703 , Lord Cornbury, Governor of New York, sent word that he had 


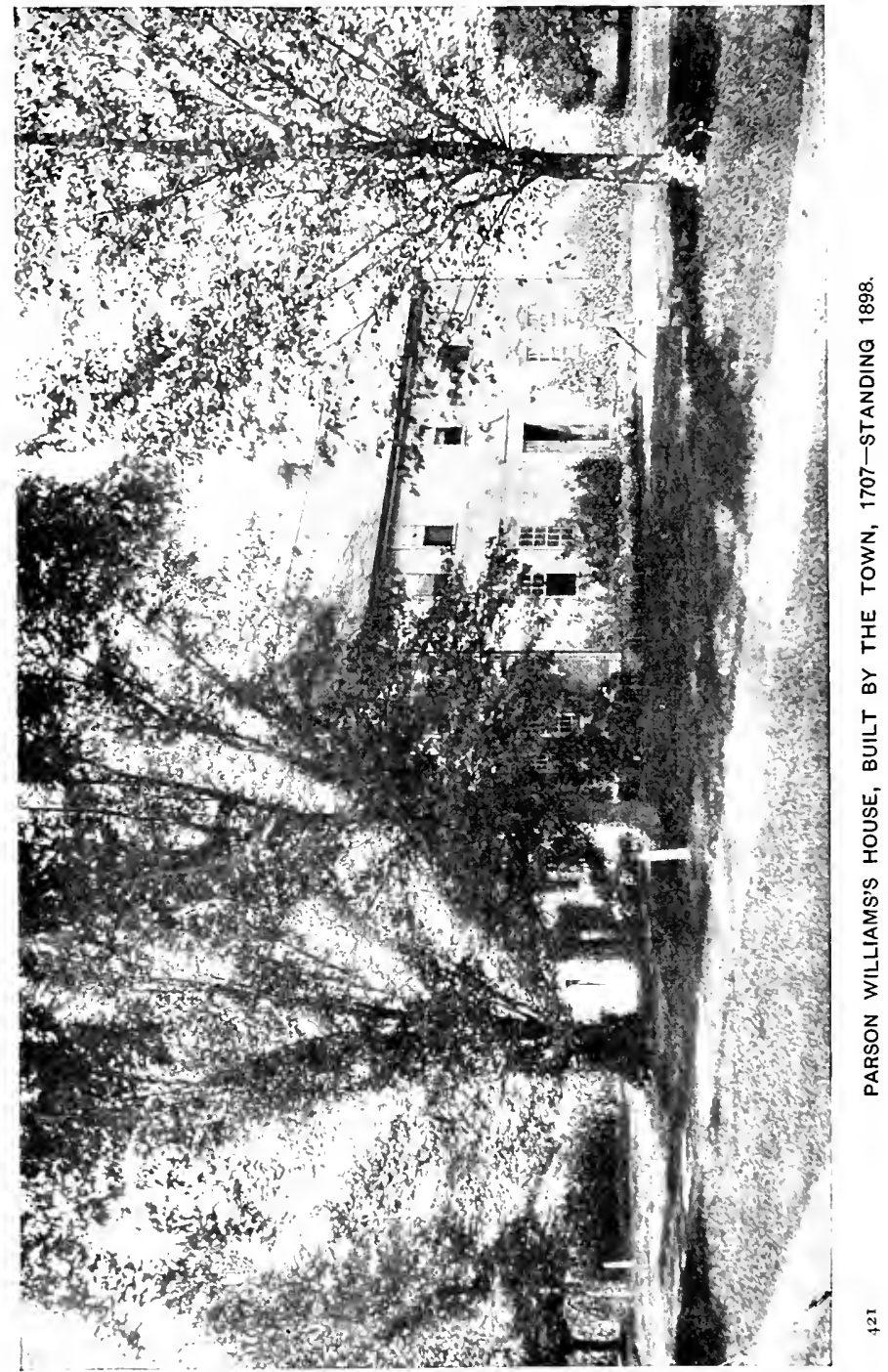


learned through his spies of an expedition fitting out against Deerfield. Soon after, Major Peter Schuyler sent a similar warning to Rev. John Williams. These warnings were emphasized in July by news that the Eastern Indians had made a simultaneous attack on all the settlements in Maine, only six weeks after signing a treaty of peace with the most solemn declarations of eternal friendship. Twenty soldiers were sent here to reinforce the home guard, and all were on the alert; two men, however, were captured October 8 , and were carried to Canada. On the alarm which followed sixteen more men were sent here. October 2 I, Rev. John Williams writes, on behalf of the town, to Governor Dudley :

". . We have been driven from our houses \& home lots into the fort. (there are but ro houselots in the fort); some a mile, some two miles, whereby we have suffered much loss. We have in the alarms several times been wholly taken off from any business, the whole town kept in, our children of $\mathbf{1} 2$ or $\mathbf{I} 3$ years and under we have been afraid to improve in the field for fear of the enemy. . . We have been crowded togather into houses to the preventing of indoor affairs being carryd on to any advantage, . . . several say they would freely leave all they have $\&$ go away were it not that it would be disobedience to authority $\&$ a discouraging 


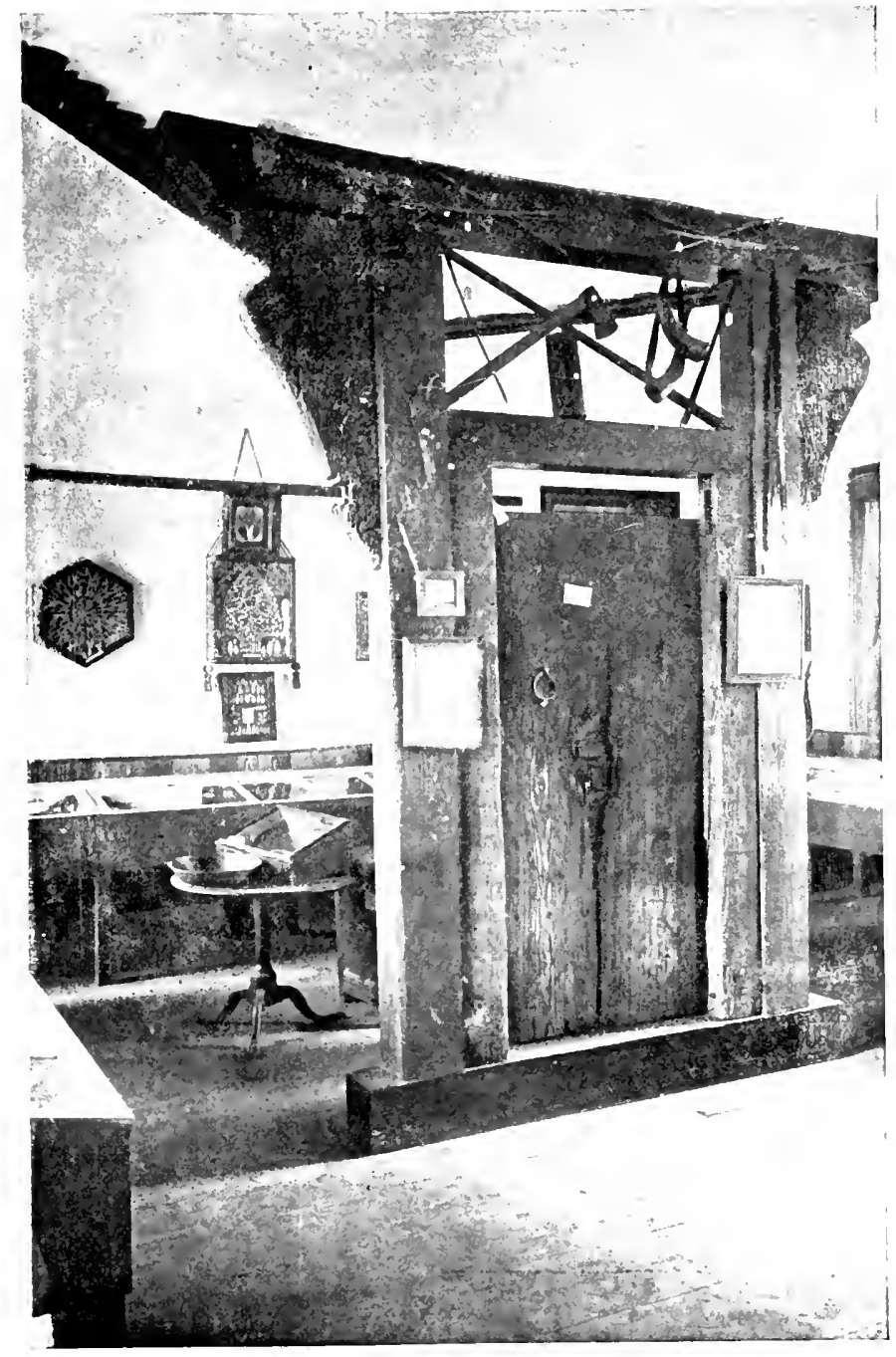

DOOR OF "OLD INDIAN HOUSE" HACKED BY INDIANS.

NOW IN MEMORIAL HALL. 
their bretheren. The frontier difficulties of a place so remote from others \& so exposed as ours, are more than can be known, if not felt.

Nothing can add to this simple and pathetic statement.

The months dragged slowly on, and no enemy. The deep winter snows seemed a safe barrier against invasion. The people, breathing more freely, gradually resumed their wonted ways ; but dark clouds loomed up, all unseen, just beyond the northern horizon. In the early morning of February 29, I703-4, like a thunderbolt from a clear sky, an army of French and Indians under Hertel de Rouville burst upon the sleeping town, and killed or captured nearly all of the garrison and inhabitants within the fort. Through criminal carelessness the snow had been allowed to drift against the palisades, until, being covered with a hard crust, it afforded an easy and noiseless entrance, so that the enemy were dispersed among the houses before they were discovered.

The captives were collected in the house of Ensign John Sheldon, which, being fired by the enemy only on their retreat, was easily saved, and stood until i 848 . It was popularly considered the only one not burned, and has gone 


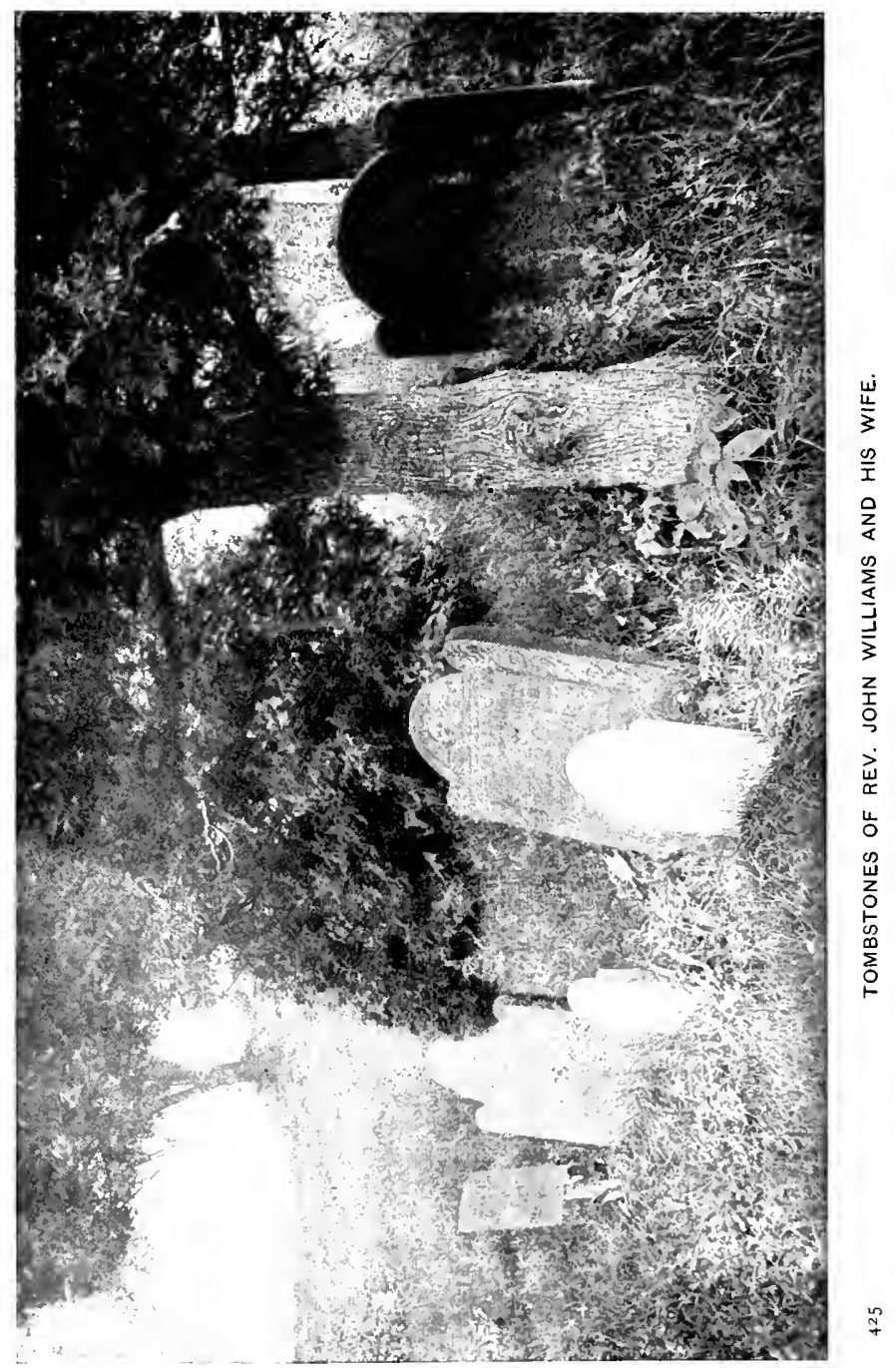


into history as the "Old Indian House." Its front door, hacked by the Indians, is now preserved in Memorial Hall. By sunrise the torch and tomahawk had done their work. The blood of forty-nine murdered men, women and children reddened the snow. Twenty-nine men, twenty-four women and fifty-eight children were made captive, and in a few hours the spoil-encumbered enemy were on their three-hundred miles' march over the desolate snows to Canada. Twenty of the captives were murdered on the route, one of them Eunice IVilliams, wife of the minister. The spot where she fell is marked by a monument of enduring granite.

The desolated town was at once made a military post, and strongly garrisoned. Of the survivors, the men were impressed into the service, and the non-combatants sent to the towns below. Persistent efforts were made to recover the captives. Ensign Sheldon was sent three times to Canada on this errand. One by one, and against great odds, most of the surviving men and women were recovered; but a large proportion of the children remained in Canada. Many of their descendants have been traced by Miss Baker, author of True Stories 
of New England Captives, among them some of the most distinguished men and women of Canadian history.

The inhabitants of Deerfield gradually returned to their desolate hearthstones and abandoned fields, and held their own during the war, but not without severe suffering and a considerable loss of life. Peace was established by the Treaty of Utrecht in $17 \mathrm{r} 3$.

Nine years of quiet followed, in which the town prospered. The Indians mingled freely with the people, bartering the products of their hunting for English goods. A permanent peace was hoped for, but this hope was blasted on the outbreak of the Eastern Indians in 1722. Incited by the Canadians, the northern tribes joined in the war; and Father Rasle's war brought the usual frontier scenes of fire and carnage; the trading Indians being the most effective leaders or guides for marauding parties. Many Deerfield men were in the service, notably as scouts. Inured to hardship, skilled in woodcraft, they were more than a match for the savage in his own haunts and in his own methods of warfare.

In 1729 , before the new meeting-house was finished, the people were called to mourn the 
death of their loved and revered pastor, Rev. John Williams, so widely known as "The Redeemed Captive." His successor was Rev. Jonathan Ashley, who was ordained in 1732 and died in 1780 .

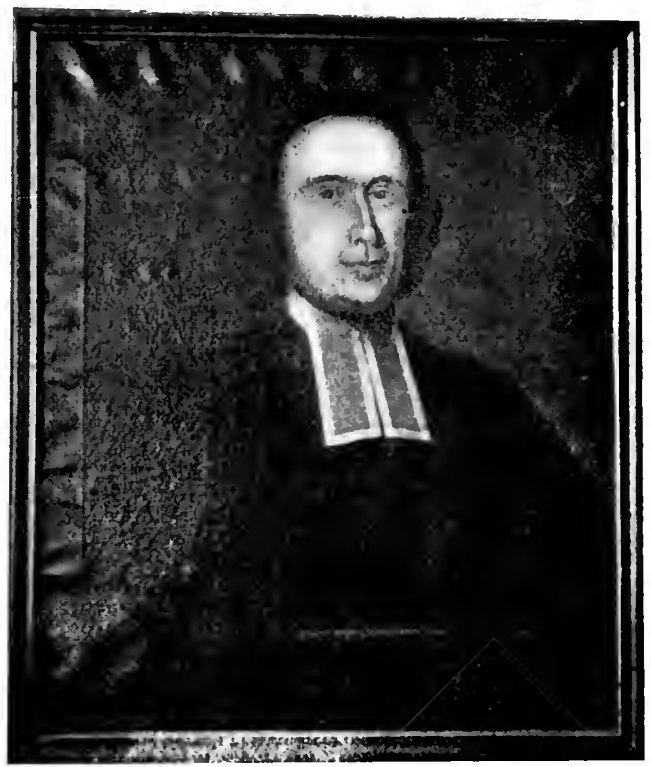

STEPHEN WILLIAMS, 1693-1782.

A CAPTIVE OF FEBRUARY 29, 1703-4.

Rev. Stephen Williams, a son of Rev. John Williams, the first pastor, was born in Deerfield in 1693 , taken captive to Canada in 1704 , 
redeemed in 1705 , graduated at Harvard in I 7 I3, settled as minister at Longmeadow in 1 716 , dying there in 7882 ; he was Chaplain in the Louisburg expedition in $\mathrm{I} 745$, and in the regiment of Col. Ephraim Williams in his fatal campaign in 1755 , and again in the Canadian campaign of 1756 . His portrait, reproduced on page 428 , was painted about I 748 ; it is now in the Memorial Hall of the Pocumtuck Valley Memorial Association, within fourscore rods of the spot where the original was born, and whence he was carried into captivity.

On the closing of Father Rasle's war the settlement expanded; trade and home manufactures flourished. Deerfield remained no longer the frontier town of the valley, and the brunt of the next border war (of I 743) was felt by the outlying settlements. The one sad blow upon this town fell at a little hamlet called The Bars. August 25, I746, the families of Samuel Allen and John Amsden, while working in a hay-field on Stebbins Meadow, with a small guard, were surprised by a party of Indians from Canada, and five men were killed, one girl wounded and one boy captured. This followed close on the fall of Fort Massachusetts, and danger of French invasion was 
felt to be imminent. Active measures were taken for defense; the forts were repaired and the woods filled with scouts.

The closing war with France found Deerfield more strongly bulwarked, and still less exposed to attack. No blood was shed within her narrowed bounds. Her citizens held prominent positions, and did their part in the campaigns which resulted in the conquest of Canada and the consequent immunity from savage depredations. The nest destroyed, the sting of the hornets was no longer felt or feared. The last raid on Massachusetts soil is described in the following mutilated despatch to the military authorities in Deerfield:

“ Colraln, March ye 2I, 1759.

"SIR:-These are to inform you that yesterday as Jo" Mckoon [Kowen] \& his wife were coming from Daniel Donitsons \& had got so far as where Morrison's house was burned this day year, they was fired upon by the enemy about sunset. I have been down this morning on the spot and find no Blood Shed, but see where they led off Both the above mentioned; they had their little child with them. I believe they are gone home. I think their number small, for there was about 10 or $\mathbf{2} 2$ came [torn off]"

The most important civil events of this 
period were the divisions of the township. In I 753 the Green River District, which included what is now Greenfield and Gill, was made a distinct municipality. The next year the construction of a bridge over the Pocumtuck River at Cheapside was a prominent issue ; the discussion ended in establishing a ferry at the north end of Pine Hill in I 758. That year the people in the vicinity of Sugar Loaf petitioned the General Court-but without success-for liberty to form a ministerial and educational connection with the town of Sunderland, and to be exempted from paying certain town taxes in consequence. In 1767 the inhabitants of Deerfield-Southwest were set off into a town named Conway; and Deerfield-Northwest became the town of Shelburne in I 768. The same year Bloody Brook people caught the division fever, but it did not carry them off.

A permanent peace being settled and an unstable currency fixed on a firm cash basis, business projects multiplied, and Deerfield became the centre of exchange and supply for a large territory. The mechanics, or "tradesmen" as they were called, and their apprentices, rivalled in numbers the agricultural population. Here were found the gunsmith, blacksmith, 
nailer and silversmith, the maker of snowshoes and moccasins, the tanner, currier, shoemaker and saddler, the pillion, knapsack and wallet-maker, the carpenter and joiner, the clapboard and shingle-maker, the makers of wooden shovels, corn-fans, flax-brakes, hackels, looms and spinning-wheels, cart-ropes and bed-lines, and pewter buttons, the tailor, hatter, furrier, feltmaker, barber and wigmaker, the cartwright, millwright, cabinet-maker, watchmaker, the brickmaker and mason, the miller, the carder, clothier, fuller, spinner, weaver of duck and common fabrics, the potter, the gravestone-cutter, the cooper, the potash-maker, the skilled forger who turned out loom and plow irons, farm and kitchen utensils. There were doctors and lawyers, the judge and the sheriff; storekeepers were many, and tavern-keepers galore. To all these the old account-books in Memorial Hall bear testimony.

Many leading men held commissions from the King in both civil and military service. These were rather a distinctive class, holding their heads quite high, and when the Revolution broke out they were generally loyal to the King, making heavy odds against the Whigs. But new leaders came to the front, who, so far 
as they had character and force, held their own after the war, and the old Tory leaders were relegated to the rear.

At the opening of the Revolutionary War the parties were nearly equal in numbers; on one yea and nay test vote there was a tie. Excitement ran high. In r 774 the "Sons of Liberty" erected a Liberty Pole, and at the same time a "Tory Pole," whatever that might be. The mob spirit was rampant. Through it the fires of patriotism found vent; but it was always under the control of the leaders, and its most common office was to "humble the Tories," and compel them to sign obnoxious declarations of neutrality, or of submission to the will of the Committees of Safety and Correspondence. A Tory of this period wrote: "Oh Tempora, all nature seems to be in confusion; every person in fear of what his Neighbor may do to him. Such times never was seen in New England."

In October, I 774, a company of minute-men was organized here as part of a regiment under the Provincial Congress. November I4, staff-officers were chosen. David Field, colonel, and David Dickinson, major, were both of Deerfield. December 5, the town raised 
money to buy ammunition by selling lumber from its woodland. January 5, I 775, an emissary from General Gage was here, advising the Tories to go to Boston. "The standard will be set up in March," he said, "and those who do not go in and lay down their arms may meet with bad luck." He was discovered, but had the good luck to escape a mob; another agent who came a few days later was not so fortunate.

But the culmination of all the secret machinations and open preparations was at hand. April 20, at a town-meeting, votes were passed to pay wages to the minute-men for what they had done; "to encourage them in perfecting themselves in the Military Art," provision was made for "practicing one half-day in each week."

The voters could hardly have left the meeting-house, when the sound of a galloping horse was heard, and the hoarse call, "To arms! To arms!" broke upon the air. The horse bloody with spurring and the rider covered with dust brought the news of Concord and Lexington. The half-day drills had done their work. Before the clock in the meeting-house steeple struck the midnight hour, fifty minute-men, 
under Captain Jonas Locke, Lieutenant Thomas Bardwell and Lieutenant Joseph Stebbins, were on the march to Cambridge. This company was soon broken up; Captain Locke entered the Commissary Department, while Lieutenant Stebbins enlisted a new company, with which he assisted General Putnam in constructing the redoubt on Bunker Hill, and in its defense the next day, the ever-glorious I 7 th of June. One Deerfield man was killed and several were wounded.

Independence Day should be celebrated, in Deerfield, June 26, for on that day in 1776 the town

" Voted that this Town will (if $y^{e}$ Honorable Congress shall for $y^{e}$ safety of $y^{e}$ United Colonies declare them INDEPENDENT of $y^{e}$ Kingdom of Great Britain) Solemnly Engage with their LIVES and FORTUNES to Support them in $y^{t}$ Measure, and that $\mathrm{y}^{\mathrm{e}}$ Clerk be directed to make an attested copy of this Vote and forward $\mathrm{y}^{\mathrm{e}}$ same to Mr. Saxton, Representative for this town, to be laid before the General Court for their Information."

Here was treason proclaimed and recorded, and every voter was exposed to its penalty. Ten days later the Continental Congress issued the world-stirring Declaration of Independence. 
On Burgoyne's invasion in I 777 a company under Captain Joseph Stebbins and Lieutenant John Bardwell marched for Bennington. They were too late for the battle at Walloomsack, and found the meeting-house filled with Stark's Hessian prisoners. But they had their share in the work and glory of rounding up and capturing the proud soldiers of Burgoyne.

Deerfield had statesmen as well as soldiers. May I, i 7 So, the town met to consider the new Constitution of Massachusetts; the clerk read the instrument " paragraph by paragraph with pauses between." After due discussion, a committee was chosen to "peruse the Constitution . . . and make such objections to it as they think ought to be made." Three town-meetings were held, the committee reported, and finally a vote was passed " not to accept the third Article in the Declaration of Rights," and that a candidate for governor must "Declare himself of the Protestant Religion" instead of "Christian Religion." The term of eight years instead of fifteen was voted as the time when the Constitution should be revised. With these changes, our civic wisdom approved of this important State paper.

Deerfield did her full duty in furnishing her 
quota of men and supplies through the war. Occasionally, in the later years of the struggle,

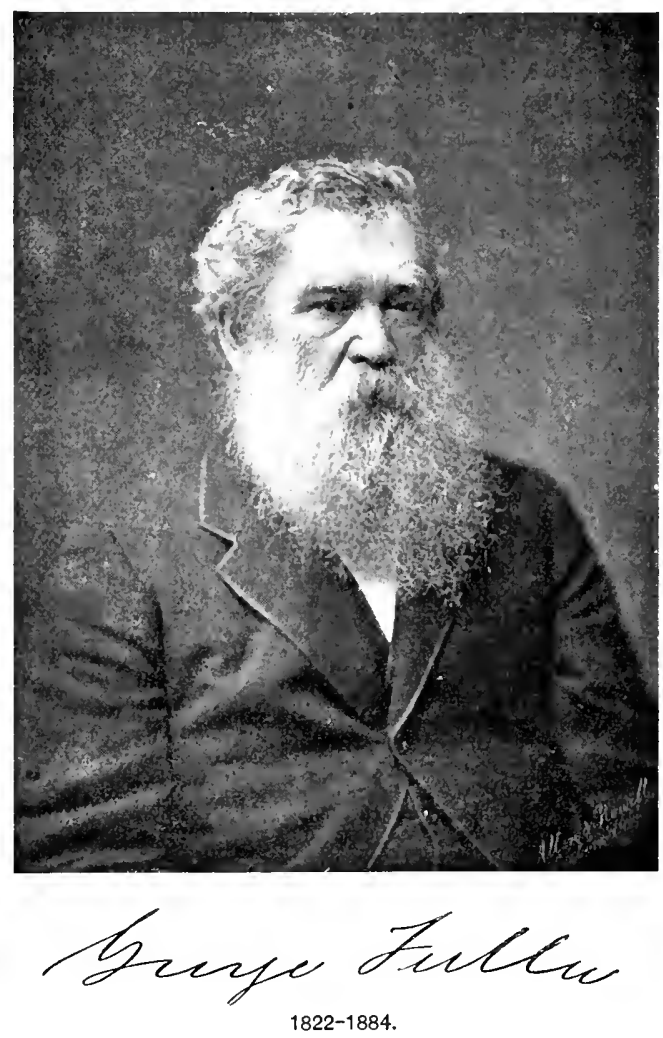

the Tories temporarily obstructed the necessary town legislation. Some of these soon found 
themselves behind the bars, and others in enforced silence under penalty of like restraint. The minister, Mr. Ashley, who had been firm in his loyalty, died in 1780 , and the Tories lost one of their strongest supports. Not until I 787 could the town unite upon his successor, when Rev. John Taylor was ordained. The uprising called Shays' Rebellion did much to harmonize the warring factions, as all united to put it down. Three companies, under Captains Joseph Stebbins, Samuel Childs and Thomas W. Dickinson, were sent to the field of action.

From this time, harmony prevailed, and the career of the town was that of an industrious, hard-working, prosperous, intellectual people. Libraries and literary societies were established, which are still flourishing. Deerfield Academy was founded in I 797, and endowed largely through the liberality of the citizens. Its influence was felt for generations, as its pupils from far and wide were scions of leading families. Among its faculty and graduates may be named men of national reputation, in the scientific, the historical, the ecclesiastical, the military, the artistic and the industrial world.

Failing health obliged Mr. Taylor to resign ; 


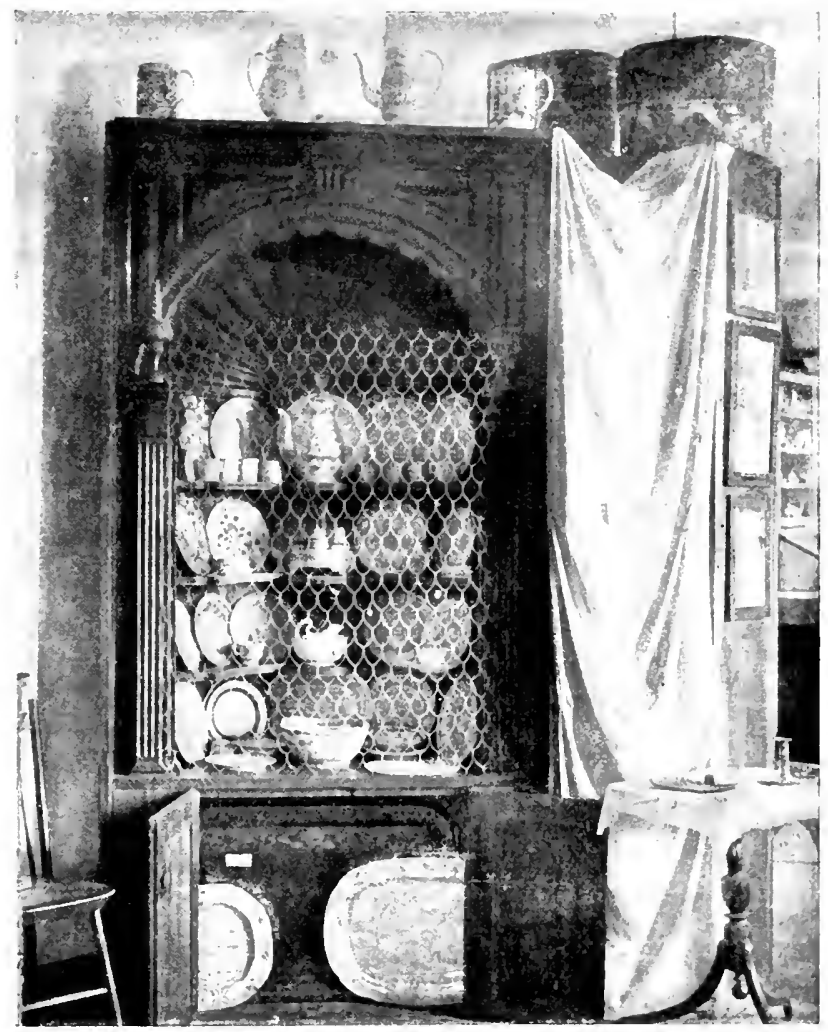

BUFFET FROM PARSON WILLIAMS'S HOUSE.

NOW IN MEMORIAL HALL. 
and in ISo7 the Rev. Samuel Willard succeeded him in the ministry, when, in the separation of the Congregational churches, Deerfield led the van on the liberal side.

The political storms of the first two decades of the century raged here with strength and vigor. In the War of I8I 2 a "Professor of the Art of War" was added to the faculty of the Deerfield Academy, and a Peace Party circulated their protesting publications.

Deerfield was early at the front in the antislavery agitation, and in the war lost some of her best blood. The names of her dead in that righteous war are carved on a fitting monument pointing aloft from the midst of her ancient training-field.

One great attraction in the old town is the Pocumtuck Valley Memorial Association, chartered in 1870 . It owns and occupies the old academy building, which it secured when the new Free Dickinson Academy was established in 1878 . Its museum occupies the entire structure, and contains an exhaustive, characteristic collection of the implements, utensils and general household belongings of the colonial days; and also of the original lords of the valley, the Pocumtuck Indians. 
In the ante-railroad days, Cheapside, at the head of Pocumtuck River navigation, was a thriving business village, with large imports of foreign wet and dry goods, and large exports of lumber, woodenware and brooms; Deerfield was long famous for its stall-fed beef, as many a New York and Boston epicure did testify ; but the advent of the iron horse soon brought about the departure of the fall boat, and the passing of the stall-fed ox. The old town is no longer a centre of political power, or of trade and manufactures. The generous additions of territory to her original Grant have been bestowed upon the children of her loins, now flourishing towns about her. The advent of factories has absorbed one by one her multifarious mechanical industries. Her young men and maidens are seeking elsewhere spheres of action in fields till now undreamed of.

But Old Deerfield still retains much of her best. Still, as of old, she is an intellectual centre. Still beautifully situated, she lies in the embrace of the broad green meadows, with here and there a gleam of silver from the sinuous Pocumtuck. Her ancient houses, shadowed by towering elms, hoary with age, her charm- 
ing wooded heights, her romantic gorges and tumbling brooks, her restful quiet, her famous past, all in harmony with the thought and feeling of her inhabitants, still attract alike men and women of letters, the artist and the historical student. 


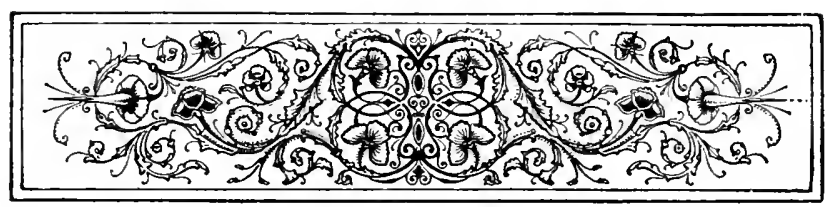

\section{NEWPORT}

\section{THE ISLE OF PEACE}

\section{BY SUSAN COOLIDGE}

HE Isle of Peace lies cradled in the wide
arms of a noble bay. Fifteen miles long and from four to five miles in width, its shape is not unlike that of an heraldic dragon, laid at ease in the blue waters, with head pointed to the southwest. From this head to the jutting cape which does duty as the left claw of the beast, the shore is a succession of bold cliffs, broken by coves and stretches of rocky shingle, and in two places by magnificent curving beaches, upon which a perpetual surf foams and thunders. Parallel ridges of low hills run back from the sea. Between these lie ferny valleys, where wild roses grow in thickets, and such shy flowers as love solitude and a sheltered situation spread a carpet for the spring and early summer. On the farther 
uplands are thrifty farms, set amid orchards of wind-blown trees. Ravines, each with its thread of brook, cut their way from these higher levels to the water-line. Fleets of lilies whiten the ponds, of which there are many on the island; and over all the scene, softening every outline, tingeing and changing the sunlight, and creating a thousand beautiful effects forever unexpected and forever renewed, hangs a thin veil of shifting mist. This the seawind, as it journeys to and fro, lifts and drops, and lifts again, as one raises a curtain to look in at the slumber of a child, and, having looked, noiselessly lets it fall.

The Indians, with that fine occasional instinct which is in such odd contrast to other of their characteristics, gave the place its pretty name. Aquidneck, the Isle of Peace, they called it. To modern men it is known as the island of Rhode Island, made famous the land over by the town built on its seaward extremity-the town of Newport.

It is an old town, and its history dates back to the early days of the New England colony: City, it calls itself, but one loves better to think of it as a town, just as the word "avenue," now so popular, is in some minds 


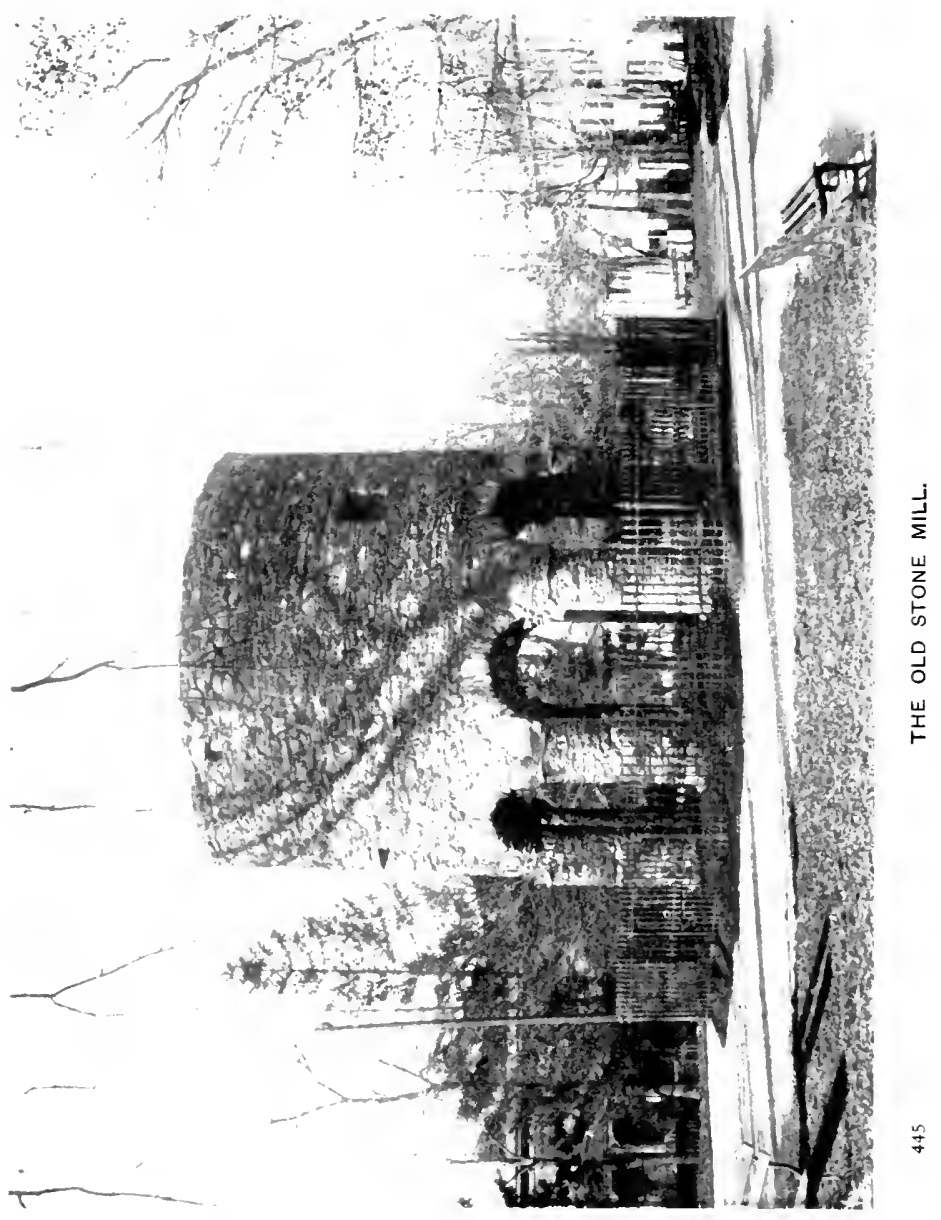


forever translated into the simpler equivalent, "street." As the veiling mists gather and shift, and then, caught by the outgoing breeze, float seaward again, we catch glimpses, framed, as it were, between the centuries, quaint, oddly differing from each other, but full of interest. The earliest of these glimpses dates back to an April morning in 1524 . There is the cliffline, the surf, the grassy capes tinged with sun, and in the sheltered bay a strange little ressel is dropping her anchor. It is the caravel of Vezzerano, pioneer of French explorers in these northern waters, and first of that great tide of "summer visitors" which has since followed in his wake. How he was received, and by whom, Mr. Parkman tells us :

"Following the shores of Long Island, they came first to Block Island, and thence to the harbor of Newport. Here they stayed fifteen days, most courteously received by the inhabitants. Among others, appeared two chiefs, gorgeously arrayed in painted deer-skins ; kings, as Vezzerano calls them, with attendant gentlemen: while a party of squaws in a canoe, kept by their jealous lords at a safe distance, figure in the narrative as the queen and her maids. The Indian wardrobe had been taxed to its utmost to do the strangers honor,-coffee bracelets and wampum collars, lynx-skins, raccoon-skins, and faces bedaubed with gaudy colors. 


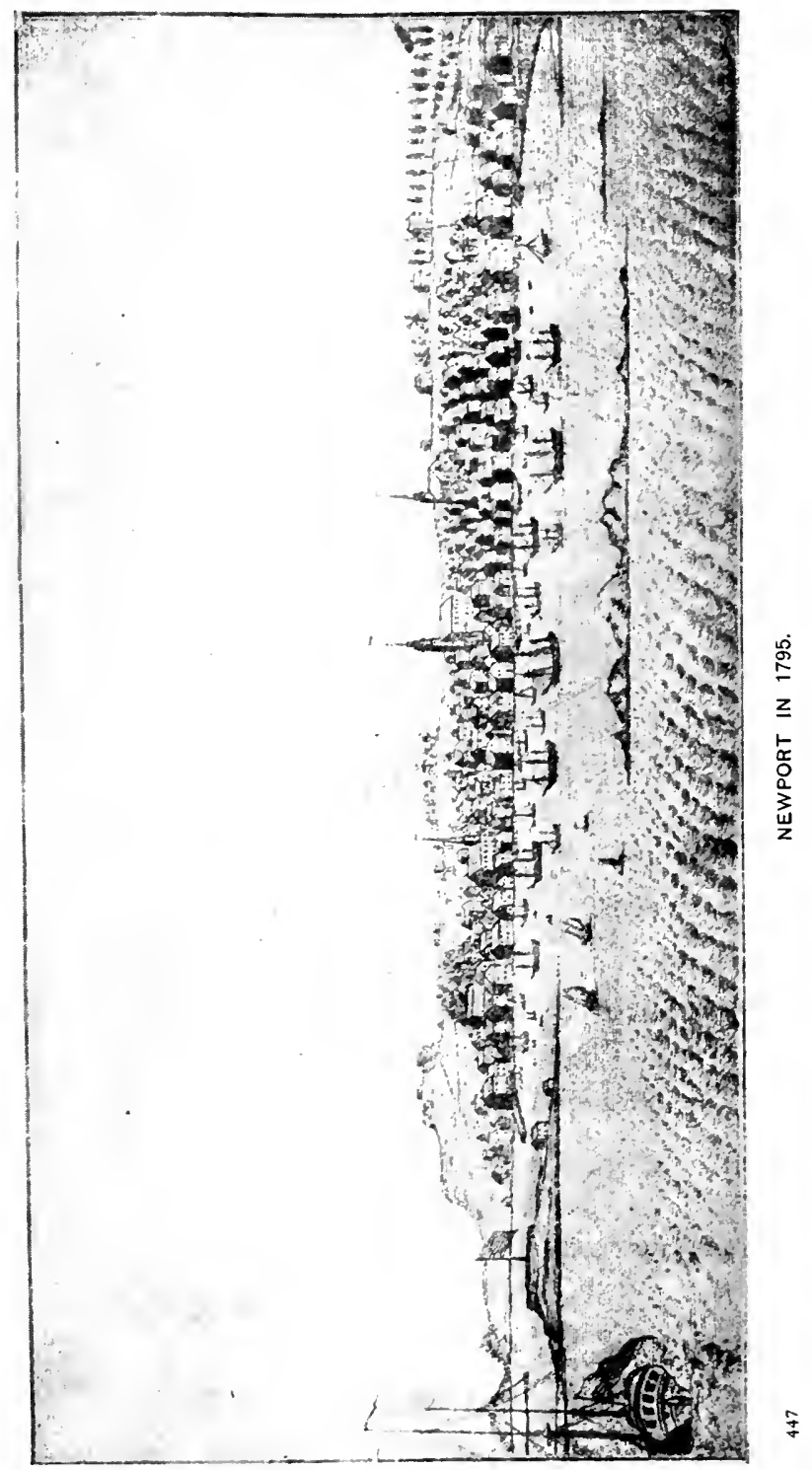


"Again they spread their sails, and on the fifth of May bade farewell to the primitive hospitalities of Newport.". "

IV ampum and coffee bracelets are gone out of fashion since then, the application of "gaudy colors" to faces, though not altogether done away with, is differently practised and to better effect, and squaws are no longer relegated by their jealous lords to separate and distant canoes: but the reputation for hospitality, so early won, Newport still retains, as many a traveller since Vezzerano has had occasion to testify. And still, when the early summertide announces the approach of strangers, her inhabitants, decking themselves in their best and bravest, go forth to welcome and to " courteously entreat" all new arrivals.

Again the mist lifts and reveals another picture. 'Two centuries have passed. The sachems and their squaws have vanished, and on the hill-slope where once their lodges stood a town has sprung up. Warehouses line the shores and wharves, at which lie whalers and merchantmen loading and discharging their cargoes. A large proportion of black faces appears among the passers-by in the streets,

1 Pionecrs of France in the New Woria. 
and many straight-skirted coats, broad-brimmed hats, gowns of sober hue and poke-bonnets of drab. Friends abound as well as negroes, not to mention Jews, Moravians, Presbyterians and "Six-Principle" and "Seven-Principle" Baptists; for, under the mild fostering of Roger Williams, Newport has become a city of refuge to religious malcontents of every persuasion. All the population, however, is not of like sobriety. A "rage of finery" distinguishes the aristocracy of the island, and silk-stockinged gentlemen, with scarlet coats and swords, silver-buckled shoes and lace ruffles, may be seen in abundance, exchanging stately greetings with ladies in brocades and hoops, as they pass to and fro between the decorous gambrel-roofed houses or lift the brazen knockers of the street-doors. It is a Saint's-Day, and on the hill above, in a quaint edifice of white-painted wood, with Queen Anne's royal crown and a gilded pennon on its spire, the Rev. Mr. Honeyman, missionary of the English Society for the Propagation of the Gospel, is conducting the service in Trinity Church. The sermon begins, but is interrupted by a messenger who hurries in with a letter which he hands to the divine in the pul- 
pit. The clergyman reads it aloud to his audience, pronounces a rapid benediction, and "wardens, vestry, church and congregation" crowd to the ferry-wharf, off which lies a "pretty large ship," just come to anchor. A boat rows to the shore, from which alights a gentleman of " middle stature, and an agreeable, pleasant and erect aspect," wearing the canonicals of an English dean. He leads by the hand a lady; three other gentlemen follow in their company. The new arrival is George Berkeley, Dean of Derry, philosopher and scholar, who, on his way to Bermuda with the project of there planting an ideally perfect university, "for the instruction of the youth of America" (!), has chosen Rhode Island as a suitable vantage-point from which to organize and direct the new undertaking. His companions are his newly married wife and three "learned and elegant friends," Sir John James, Richard Dalton and the artist Smibert. Not every Saint's-Day brings such voyagers to Newport from over the sea. No wonder that Trinity Church services are interrupted, and that preacher and congregation crowd to the wharf to do the strangers honor!

The Berkeley party spent the first few 
months of their stay in the town of Newport, whence the Dean made short excursions to what Mrs. Berkeley terms "the Continent," meaning the mainland opposite. Toward the close of their first summer, James, Dalton and Smibert removed to Boston, and the Berkeley family to a farm in the interior of the island, which the Dean had purchased and on which he had built a house. The house still exists, and is still known by the name of Whitehall, given it by its loyal owner in remembrance of the ancient palace of the kings of England.

The estate, which comprised less than a

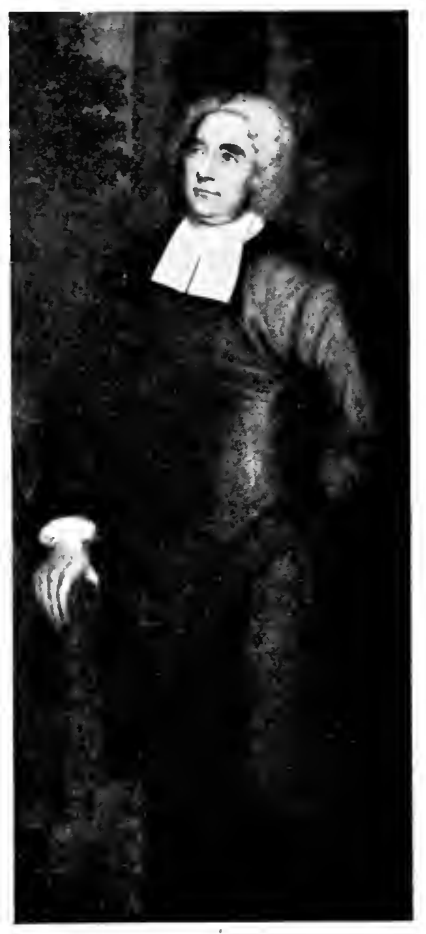

GEORGE BERKELEY, DEAN OF DERRY. hundred acres, lies in a grassy valley to the south of Honeyman's Hill, and about two miles back 
from what is now known as the "Second Beach." It commands no "view" whatever. Dean Berkeley, when asked why he did not choose a site from which more could be seen, is said to have replied that "if a prospect were continually in view it would lose its charm." His favorite walk was toward the sea, and he is supposed to have made an outdoor study of a rocky shelf, overhung by a cliff cornice, on the face of a hill-riclge fronting the beach, which shelf is still known as "Bishop Berkeley's Rock."

Three years the peaceful life of Whitehall continued. Two children were born to the Bishop, one of whom died in infancy. The house was a place of meeting for all the missionaries of the island, as well as for the more thoughtful and cultivated of the Newport society. At last, in the winter of 1730 , came the crisis of the Bermuda scheme. Land had been purchased, the grant of money half promised by the English Government was due. But the persuasive charm of the founder of the enterprise was no longer at hand to influence those who had the power to make or mar the project; and Sir Robert Walpole, with that sturdy indifference to pledge, or to other 


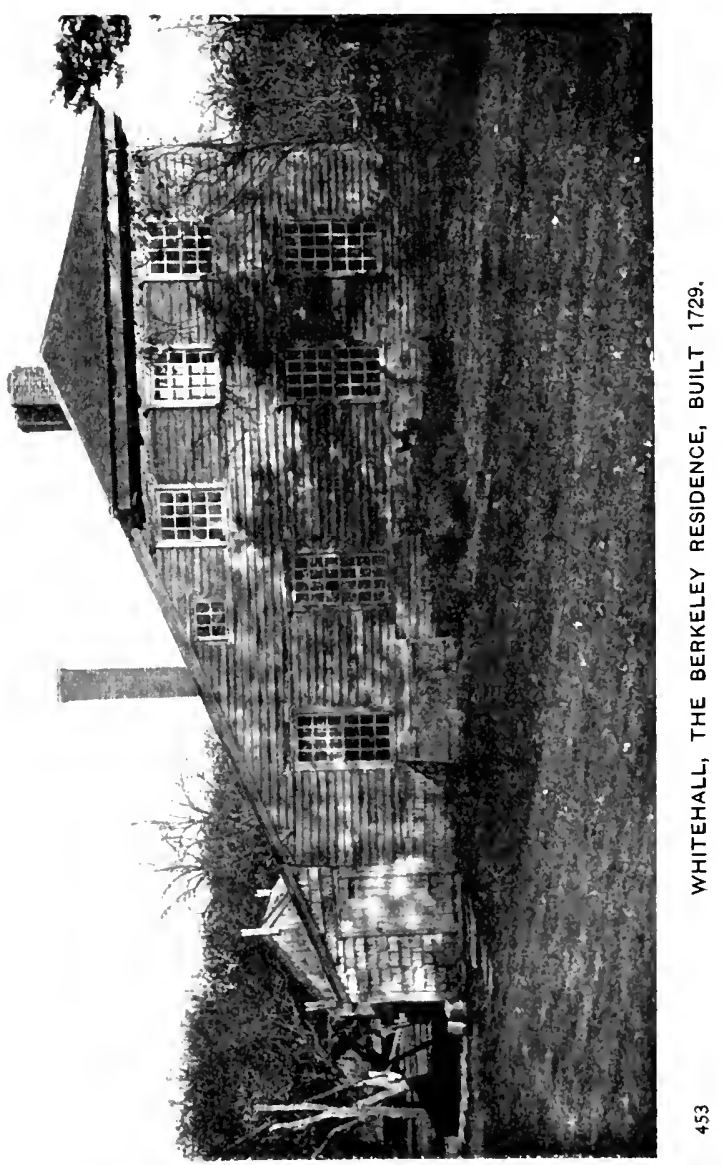


people's convenience, which distinguished him, intimated with fatal clearness of meaning, that if Dean Berkeley was waiting in Rhode Island for twenty thousand pounds of the public money to be got out of his exchequer, he might as well return to Europe without further loss of time. The bubble was indeed broken, and Berkeley, brave still and resolutely patient under this heavy blow, prepared for departure. His books he left as a gift to the library of Yale College, and his farm of Whitehall was made over to the same institution, to found three scholarships for the encouragement of Greek and Latin study. These bequests arranged, his wife and their one remaining child sailed for Ireland. There, a bishopric, and twenty years of useful and honorable labor, awaited him, and the brief dream of Rhode Island must soon have seemed a dream indeed. Few vestiges remain now of his sojourn,- the shabby farmhouse once his home, the chair in which he sat to write, a few books and papers, the organ presented by him to Trinity Church, a big family portrait by Smibert, and, appealing more strongly to the imagination than these, the memory of his clistinguished name as a friend of American letters, still preserved 
by scholarship or foundation in many institutions of learning-and the little grave in Trinity churchyard, where, on the south side of the Kay Monument, sleeps "Lucia Berkeley, daughter of Dean Berkeley, obiit the fifth of September, I 73I."

The traveller who to-day is desirous of visiting Whitehall may reach it by the delightful way of the beaches. Rounding the long curve of the First Beach, with its dressing-houses and tents, its crowd of carriages and swarms of gayly clad bathers, and climbing the hill at the far end, he will find himself directly above the lonely but far more beautiful Second Beach. Immediately before him, to the left, he will see Bishop Berkeley's Rock, with its cliff-hung shelf, and beyond, the soft outlines of Sachuest Point, the narrow blue of the East Passage, and a strip of sunlit mainland. The breezy perch where Alciphron was written is on the sea-face of one of the parallel rockformations which, with their intervening valleys, make up the region known as "Paradise Rocks." Near by, in the line of low cliffs which bounds the beach to the southward, is the chasm called "Purgatory," a vertical fissure some fifty feet in depth, into which, under cer- 
tain conditions of wind and tide, the water rushes with great force and is sucked out with a hollow boom, which is sufficiently frightful to explain the name selected for the spot. The rocks which make up the cliffs are in great part conglomerate, of soft shades of purple and reddish gray. Beyond, the white beach glistens in the sun. And to the left, the road curves on past farmhouses and "cottages of gentility." Away on the valley slope, the slow sails of a windmill revolve and flash, casting a flying shadow over the grass. A mile farther, and the road, making a turn, is joined to the right by what seems to be a farm-lane shut off by gates. This is the entrance to Whitehall. The house can be dimly made out from the road-a low, square building with a lean-to and a long, steep pitch of roof, fronting on a small garden overgrown with fruittrees. The present owner holds it from the college under what may truly be called a long lease, as it has still some eight hundred and odd years to run. He has built a house near by, for his own occupation, and, alas! has removed thither the last bit that remained of the decorative art of the old Whitehall, namely, the band of quaint Dutch tiles which once sur- 


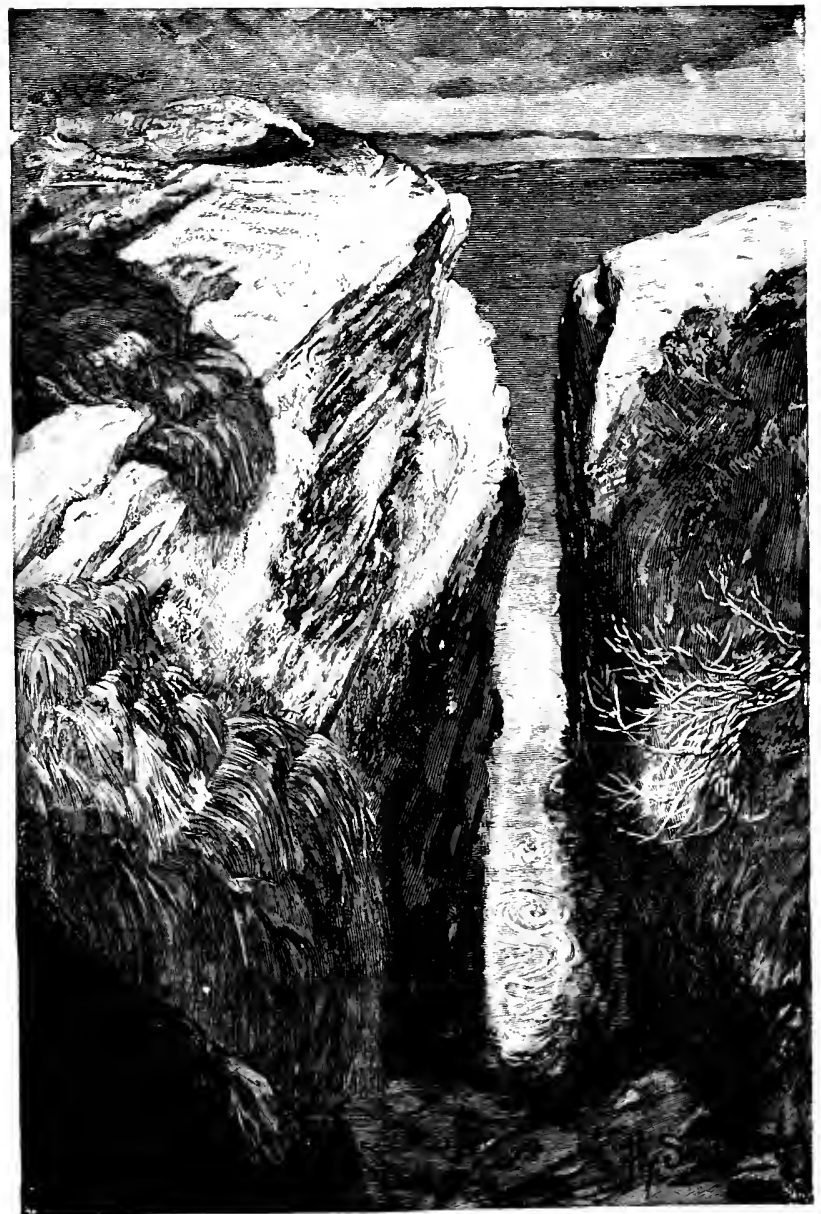


rounded the chimney-piece of the parlor. But the parlor remains unchanged, with its low ceiling and uneven floor; the old staircase is there, the old trees, and, in spite of the tooth of time and the worse spoliation of man, enough is left to hint at the days of its early repute and to make the place worth a visit.

One more glimpse through the mist before we come to the new times of this our Isle of Peace. It is just half a century since Berkeley, his baffled scheme heavy at his heart, set sail for Ireland. The fog is unusually thick, and lies like a fleece of wool over the sea. Absolutely nothing can be seen, but strange sounds come, borne on the wind from the direction of Block Island-dull reports as of cannon signals; and the inhabitants of Newport prick up their ears and strain their eyes with a mixture of hope and terror; for the French fleet is looked for; English cruisers have been seen or suspected hovering round the coast, and who knows but a naval engagement is taking place at that very moment. By and by the fog lifts, with that fantastic deliberation which distinguishes its movements, and presently stately shapes whiten the blue, and, gradually nearing, reveal themselves as 
the frigates Surveillante, Amazone and Gueppe, The Duke of Burgundy, and The Neptune, "doubly sheathed with copper"; The Conquerant, The Provence, The Eveille, also "doubly sheathed with copper"; The Lazon and The Ardent, convoying a host of transports and store-ships; with General Rocham-

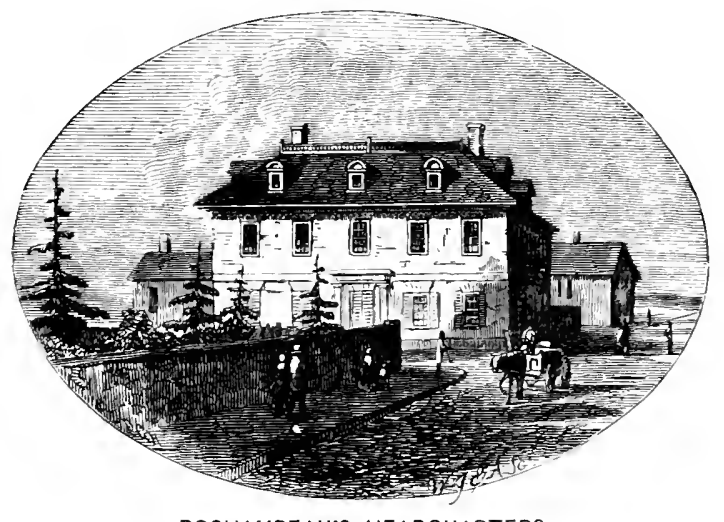

ROCHAMBEAU'S HEADQUARTERS.

beau and his officers on board, besides the regiments of Bourbonnais, Soissonais, Saintonge and Royal Deux Ponts, five hundred artillerists and six hundred of Lauzan's Legion, all come to aid the infant United States, then in the fourth year of their struggle for independence. Never was reinforcement more timely or more ardently desired. We 
may be sure that all Newport ran out to greet the new arrivals. Among the other officers who landed on that eventful inth of July, was Claude Blanchard, commissary-in-chief of the French forces-an important man enough to the expedition, but of very little importance now, except for the lucky fact that he kept a journal,-which journal, recently published, gives a better and more detailed account of affairs at that time and place than any one else has afforded us.

It is from Blanchard that we learn of the three months' voyage; of sighting now and again the vessels of the English squadron; of the Chevalier de Fernay's refusal to engage them, he being intent on the safe-conduct of his convoy; of the consequent heart-burnings and reproaches of his captains, which, together with the stings of his own wounded pride, resulted in a fever, and subsequently in his death, recorded on the tablet which now adorns the vestibule of Trinity Church. The town was illuminated in honor of the fleet. "A small but handsome town," says Blanchard, "and the houses, though mostly of wood, are of an agreeable shape."

The first work of the newly arrived allies 
was to restore the redoubts which the English had dismantled and in great part destroyed. It was at this time that the first fort on the Dumplings, and the original Fort Adams, on Brenton's Reef, were built. The excellent Blanchard meanwhile continues his observations on climate, society and local customs.

One of his criticisms on the national characteristics strikes us oddly now, yet has its interest as denoting the natural drift and result of the employment of a debased currency.

"The Americans are slow, and do not decide promptly in matters of business," he observes. "It is not easy for us to rely upon their promises. They love money, and hard money; it is thus they designate specie to distinguish it from paper money, which loses prodigiously. This loss varies according to circumstances and according to the provinces."

Later we hear of dinners and diners :

"They do not eat soups, and do not serve up ragouts at their dinners, but boiled and roast, and much vegetables. They drink nothing but cider and Madeira wine with water. 'The dessert is composed of preserved quinces and pickled sorrel. The Americans eat the latter with the meat. They do not take coffee immediately after dinner, but it is served three or four hours afterward with tea; this coffee is weak, and four or five cups are 
not equal to one of ours: so that they take many of them. The tea, on the contrary, is very strong. Breakfast is an important affair with them. Besides tea and coffee, they put on table roasted meats, with butter, pies and ham; nevertheless they sup, and in the afternoon they again take tea. Thus the Americans are almost always at table ; and as they have little to occupy them, as they go out little in winter, and spend whole days alongside their fireside and their wives, without reading and without doing anything, going to table is a relief and a preventive of ennui. Yet they are not great eaters."

On the $5^{\text {th }}$ of March, I 78 I, General Washington arrived in Newport. Blanchard thus records his first impressions of the commanderin-chief: "His face is handsome, noble and mild. He is tall-at the least, five feet eight inches (French measure). In the evening I was at supper with him. I mark, as a fortunate day, that in which I have been able to behold a man so truly great."

After the war came a period of great business depression, in which Newport heavily shared. The British, during their occupation of the town, had done much to injure it. Nearly a thousand buildings were destroyed by them on the island ; fruit-and shadetrees were cut down, the churches were used 


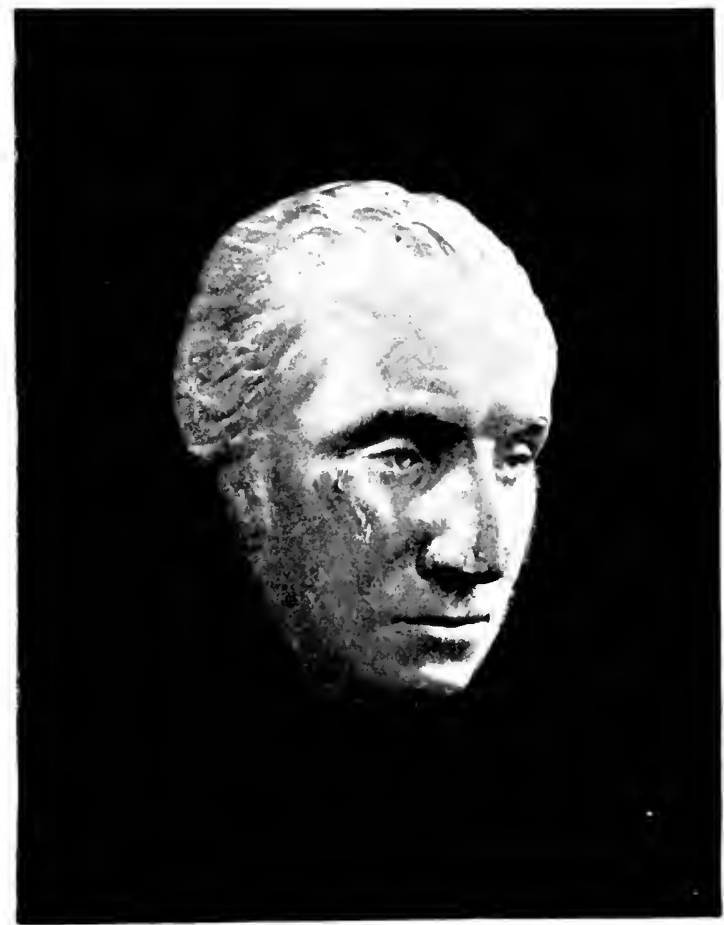

LIFE MASK OF WASHINGTON.

MADE BY HOUDON IN 1785. 
as barracks, and the Redwood Library was despoiled of its more valuable books. Commerce was dead; the suppression of the slave-trade reduced many to porerty, and the curse of paper money - to which Rhode Island clung after other States had abandoned it_poisoned the very springs of public credit. Brissot de Warrille, in the record of his journey "performed" through the United States in I 788 , draws this melancholy picture of Newport at that time:

"Since the peace, everything is changed. The reign of solitude is only interrupted by groups of idle men standing, with folded arms, at the corners of the streets; houses falling to ruin; miserable shops, which present nothing but a few coarse stuffs, or baskets of apples, and other articles of little value; grass growing in the public stuluare, in front of the court of justice; rags stuffed in the windows, or hung upon hideous women and lean, unquiet children."

Count Rochefoucauld-Liancourt, writing ten years later, calls the place "cette ville triste ot bassc," and further ventures on this remarkable criticism of its salubrity:

"The healthfulness of the city of Newport and its environs is doubtless the result of the brilliancy and coolness of its climate, but this coolness proves fatal to its 
younger inhabitants, and the number of young men, and, above all, of young women, who die yearly of consumption is considerable. It is noteworthy that the inscriptions on the tombstones in the cemetery indicate in almost all cases that the person interred is either very young or very oid-either less than twenty years of age or more than seventy."

Whether this statement of Count Rochefoucauld's bears the test of examination would be impossible now to determine, for the century since his visit has made changes in the city of the dead as marked as those effected in the city of the living. But the "cool and brilliant" air with which he finds fault has since been proved by many invalids to be full of health-giving properties. Consumptives are more often sent to Newport for cure, nowadays, than away from it. Asthma, diseases of the chest and throat, nervous disorders, insomnia, excitability of brain, are in many cases sensibly benefited by the island climate, which, however, is less "brilliant" than sedative. This is attributed to the relaxing effects of the Gulf Stream, which is popularly supposed to make an opportune curve toward the shore and to produce a quality of air quite different from that of other New England seaside cli- 
mates. Whatever may be the truth as to the bend of this obliging current, it is certain that something has given to the place an exceptional climate, pure, free from malaria and exempt equally from the fiercer heats of summer and the severer colds of winter.

It was not till about the year i 830 that the

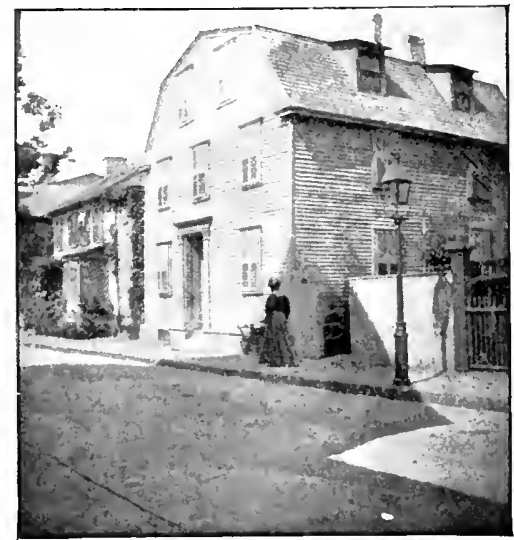

THE PARSONAGE OF MRS. STOWE'S

"MINISTER'S WOOING." true source of Newport's prosperity was realized to be her climate. Since then she has become more and more the Mecca of pilgrims from all parts of the country. Year by year, the town has spread and broadened, stretching out wide arms to include distant coigns of vantage, until now the summer city covers some miles in extent, and land, unsalable in the early part of the century, and but twenty years ago commanding little more than the price of a Western homestead, is now valued at from 
ten to fourteen thousand dollars an acre! Every year adds to the number of cottages and villas and to the provision made for the accommodation of strangers. The census, which in winter counts up to less than twenty thousand, is during the four months of "the season " swelled by the addition of thousands of strangers, many of whom are in a manner residents of the place, owning their own houses and preserving their domestic privacy.

A walk in the older and more thickly settled parts of the town is not without its rewards. There are to be found well-known objects of interest, - the Jewish burial-ground, with its luxurious screen of carefully tended flowers; the Redwood Library, rich in old books and the possession of the finest cut-leaved beech on the island; and the old Stone Mill, on which so much speculative reasoning in prose and verse has been lavished. Some years ago, those ruthless civic hands which know neither taste nor mercy, despoiled the mill of the vines which made it picturesque, but even thus denuded, it is an interesting object. There is old Trinity, with its square pews and burial tablets, and a last-century " three-decker" pulpit, with clerk's desk, reading-desk and preach- 
ing-desk, all overhung by a conical soundingboard of extinguisher pattern-a sounding-

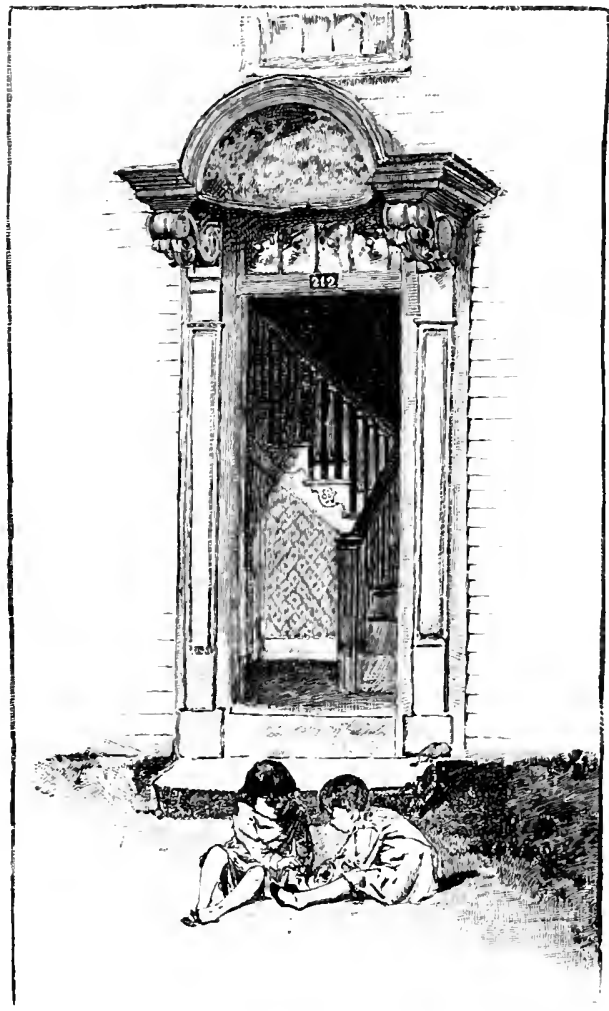

DOORWAY OF OLD HOUSE ON THAMES STREET.

board on which whole generations of little boys have fixed fascinated eyes, wondering in case 
of fall what would become of the clergyman underneath it. And, besides these, each westward-leading street gives pretty glimpses of bay and islands and shipping, and there is always the chance of lighting on a bit of the past,- - some quaint roof or wall or doorway, left over from Revolutionary times and holding up a protesting face from among more modern buildings.

Winter or summer, the charm which most endears Newport to the imaginative mind is, and must continue to be, the odd mingling of old and new which meets you on every hand. A large portion of the place belongs and can belong to no other day but our own, but touching it everywhere, apart from it but of it, is the past. It meets you at every turn, in legend or relic or quaint traditionary custom still kept up and observed. Many farm-hands and servants on the island still date and renew their contracts of service from "Lady-Day." The "nine-o'clock bell," which seems derived in some dim way from the ancient curfew, is regularly rung. The election parade, dear to little boys and peanut-venders, has continued to be a chief event every spring, with its procession, its drums, its crowd of country visitors, 
and small booths for the sale of edibles and non-edibles pitched on either side the StateHouse Square, which, in honor of this yearly observance, is called familiarly, "The Parade." One of the oldest militia companies in New England is the Newport Artillery, and The Mercury, established in 1758 by a brother of Benjamin Franklin, is the oldest surviving newspaper in the United States. Newport also possesses a town-crier. He may be met with any day, tinkling his bell at street corners and rehearsing, in a loud, melancholy chant, facts regarding auction-sales, or town-meetings, or lost property. And, turning aside from the polo-play or the Avenue crowded with brilliant equipages, a few rods carries you to the quiet loneliness of a secluded burial-place, with the name of an ancient family carved on its locked gate, in which, beneath gray headstones and long, flowering grasses, repose the hushed secrets of a century ago. Or, fresh from the buzz and chatter, the gay interchange of the day, you may chance on an old salt spinning yarns of pirates and privateers, phantom ships or buried treasure, or an antiquary full of wellremembered stories whose actors belong to the far-gone past,- -stories of the extinct glories of 


\section{Newport}

the place, of family romance and family tragedy, or tragedy just escaped. What could be finer contrast than tales like these, told on a street-corner where, just before, perhaps, the question $\mathrm{h}$ ad been about Wall Street or Santiago, if the French frigate were still in the bay, or when would be the next meeting of the Town and Country Club! Indeed, it is not so many years since visitors to $\mathrm{New}$ port might have held speech with a dear old

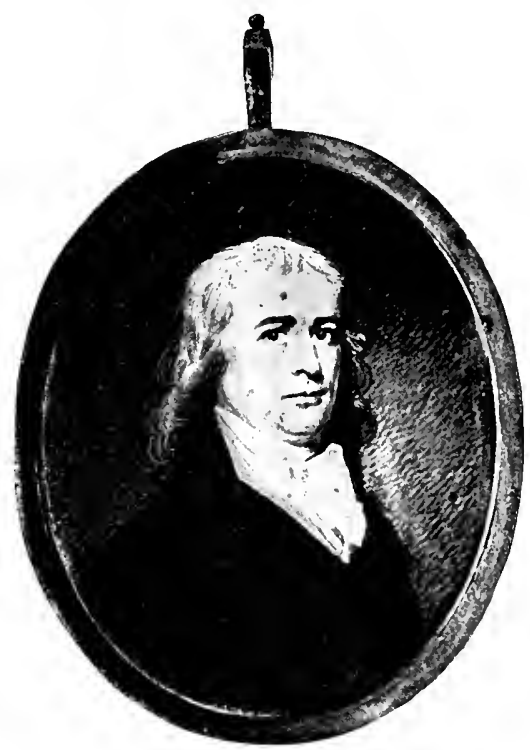

GENERAL NATHANAEL GREENE.

FROM ONE OF MALBONE'S BEST MINIATURES.

lady whose memory carried her back clearly and distinctly to the day when, a child six years old, she sat on Washington's knee. The little girl had a sweet voice. She sang a song to the great man, in recompense for which he honored her 
with a salute. "It was here, my dear, and here, that General Washington kissed me," she would say to her grandchildren, touching first one and then the other wrinkled cheek; and to the end of her life, no other lips were suffered to profane with a touch the spots thus made sacred.

In a country whose charm and whose reproach alike is its newness, and to a society whose roots are forever being uprooted and freshly planted to be again uprooted, there is real education and advantage in the tangible neighborhood of the past; and the Newport past is neither an unlovely nor a reproachful shape. There is dignity in her calm mien; she looks on stately and untroubled, and compares and measures. The dazzle and glitter of modern luxury do not daunt her: she has seen splendor before in a different generation and different forms, she has shared it, she has watched it fade and fail. Out of her mute, critical regard, a voice seems to sound in tones like the rustle of falling leaves in an autumn day, and to utter that ancient and melancholy trutn, Vanitas vanitatum! "The fashion of this world passeth away." We listen, awed for a moment, and then we smile again,_- for bright- 
ness near at hand has a more potent spell than melancholy gone by, - and turning to our modern lives with their movement and sunshine, their hope and growth, we are content to accept and enjoy such brief day as is granted us, nor "prate nor hint of change till change shall come."

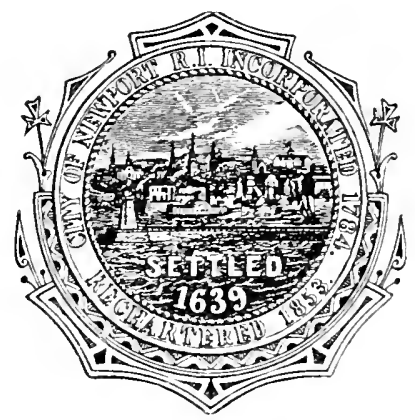




$$
\text { . }
$$




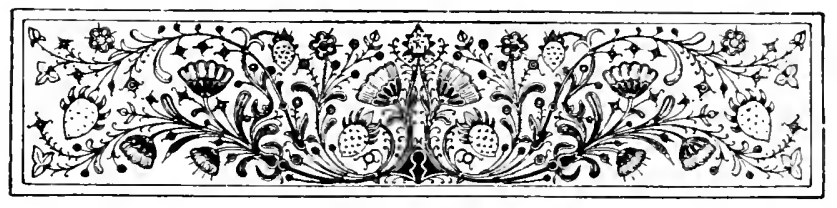

\title{
PROVIDENCE
}

\section{THE COLONY OF HOPE}

\author{
BY WILLIAM B. WEEDEN
}

$\mathrm{HE}$ capital of Rhode Island, the second
city of New England,-an agricultural village in the seventeenth, a commercial port in the eighteenth, and a centre of manufacturing in the nineteenth century, - lies at the head of Narragansett Bay. The mainland of the State westward to Connecticut, according to Shaler, rests on very old rocks of the Laurentian and Lower Cambrian series. The greater part of the bay and the land near Providence is upon rocks belonging to the Coal measures. These rocks, softer than the older ones, have been cut away and afford the inlets of the bay. The surface of the State and the sloping hills of Providence have been profoundly affected by the wearing course of the glaciers.

The original village skirted along the west475 
ern sicle of the ridge, by which ran the little Moshassuck and Woons-asquetucket Rivers. Eastward the ridge stretched in a plateau to the larger Seekonk, which cut off the peninsula. On the eastern side of the Seekonk, Roger Williams had settled and planted, when Plymouth Colony significantly advised him to move on. In June, I 636 , with five companions, he crossed the Seckonk and landed on the rock, since raised to the grade of Ives and Williams streets. Here, as the tradition runs, Indians greeted him cordially, "What Cheer, Netop! What Cheer!" He had arranged with the Narragansett sachems, Canonicus and Miantinomi, for deeds of the lands about these rivers and the Pawtuxet, with certain undefined rights extending westward and northward.

The canoe kept away from What Cheer or Slate rock, south and westward around Tockwotton and Fox Point, up the Providence River, to land near where St. John's Church stands. The spring of water attracting the pioneer and kept as public property is in the basement of a house on the northwest corner of North Main Street and Allen's Lane. North Main was the "Towne Streete," occupied by 


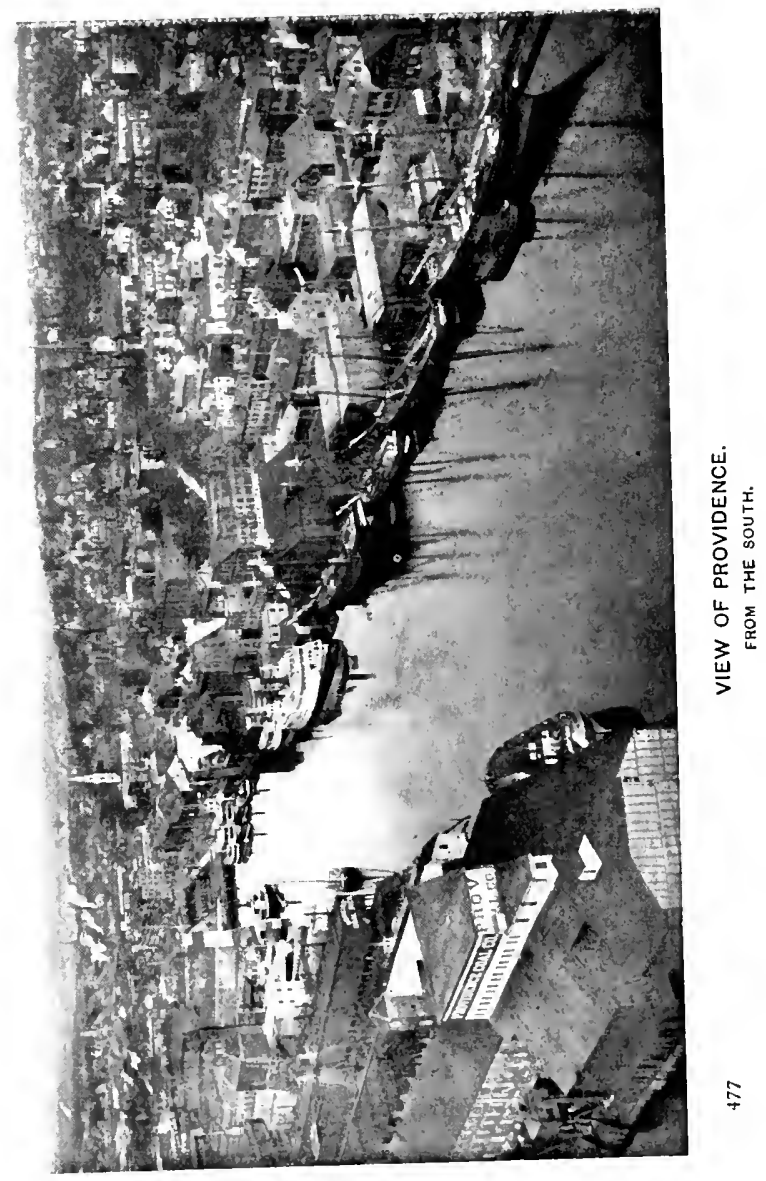


the little band of settlers. Williams's "homelot" stretched easterly, including the land of the Dorr Estate, at the corner of Benefit and Bowen Streets. A stone in the rear of the buildings marks the spot where Roger Williams was buried.

In this man was the germ of Providence, the adumbration of the little commonwealth of Rhode Island. Whatever drove him from Massachusetts, however the Puritans enforced their narrow political scheme, the result was a free State founded on new principles of government. In the words of Thomas Durfee:

"Absolute sincerity is the key to his character, as it was always the mainspring of his conduct. . . . He had the defect of his qualities; - an inordinate confidence in his own judgment. He had also the defects of his race; - the hot Welsh temper, passionate and resentful under provocation, and the moody. Welsh fancy."

The "Plantations of Providence" began in these "home-lots," reaching eastward from the "Towne Streete." It was intended to give each settler five acres. Some had, moreover, meadow-lands, and there were common rights, as in all the plantations of New England. Chad Brown, John Throckmorton, and Gregory Dexter were the committee who made 


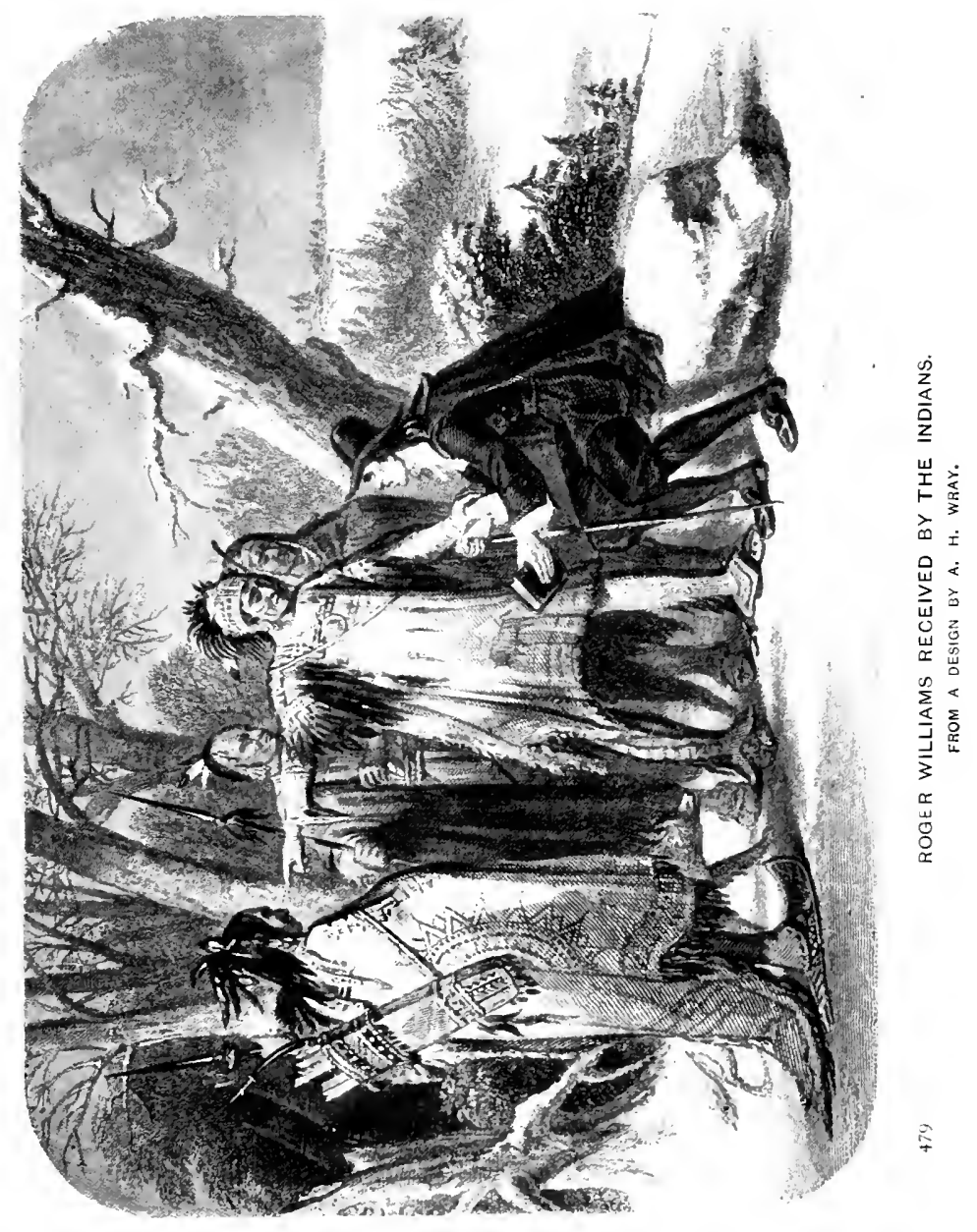


the first allotment. The land had been conveyed from the Indian sachems, and Williams gave it by "initial deed" to his twelve companions, making thirteen original proprietors.

"Probably in the autumn of 1638 , and certainly prior to the i6th of March, I639," the settlers formed the first Baptist church in America. Williams was pastor for about four months, with Holyman as colleague. Chad Brown was ordained in 1642 with William Wickenden. The latter was succeeded by Gregory Dexter. The present church, adapted by James Sumner from designs of James Gibbs, architect, was built in 1775 . Earlier than this, though the date is not fixed, the proprietors had made the following agreement, the importance of which can hardly be overestimated:

"IVe whose names are hereunder, desirous to inhabit in the town of Providence, do promise to subject ourselves in active or passive obedience, to all such orders or agreements as shall be made for public good of the body, in an orderly way, by the major assent of the present inhabitants, masters of families, incorporated together into a town-fellowship, and such others whom they shall admit unto them only in civil things."

Here was laid the foundation of soul liberty. Let us refer to Diman: "Thus, for the first

${ }^{1}$ Arnold, Rhode' Island, i., ro7. 
time in history, a form of government was adopted which drew a clear and unmistakable line between the temporal and spiritual power, and a community came into being which was an anomaly among the nations." It was a pure democracy, controlling the admission of its members.

They soon found that some delegation of power was needed for civil administration, and in 1640 they elaborated their system somewhat, and established rudimentary courts. They perceived that they could not remain safely between the unfriendly colonies of Massachusetts on one side, and the alien Dutch of New York on the other. They sent Williams to England, whence he returned in 1644 , bringing a parliamentary charter. Under this, the towns of Providence, Portsmouth and Newport were united, with the name "The Incorporation of Providence Plantations in the Narragansett Bay in New England." In I645 there were, according to Holmes, IOI men in Providence capable of bearing arms. Staples thinks this estimate includes the population of Shawonet or Warwick. In I663 John Clarke of Newport obtained the royal charter, which was adopted by the freemen of the towns, and the 
commonwealth was entitled the "Colony of Rhode Island and Providence Plantations." The oldest tax or rate bill extant dates from I650, when Roger Williams was assessed $£$ I.I3.4. In 1663 the whole tax was $£ 36$. assessed in "Country pay," which performed such important functions in the currencies of New England, viz., wheat at $4 s .6 d$., peas, $3 s .6 d$., butter, $6 d$.

An important factor in the daily life of Providence has always been in the crossing of the main stream which limited the early village on the west. Mr. Fred. A. Arnold's careful investigation ${ }^{1}$ shows that a bridge at Weybosset, "formerly Wapwayset," or "at the narrow passage," was built before i66o. It was repaired and renewed at various times. In $166 \frac{7}{8}$ Roger Williams undertook, in a most interesting document, to maintain it by co-operative labor from the townsmen and tolls from strangers. It was enlarged until, in the middle of our century, tradition claimed it to be the widest bridge in the world. Other bridges spanned the river, and in the present year the old Weybosset is being replaced by an elaborate steel structure laid on piers of granite.

${ }^{1}$ Proc. R. I. H. S., July, 1895 


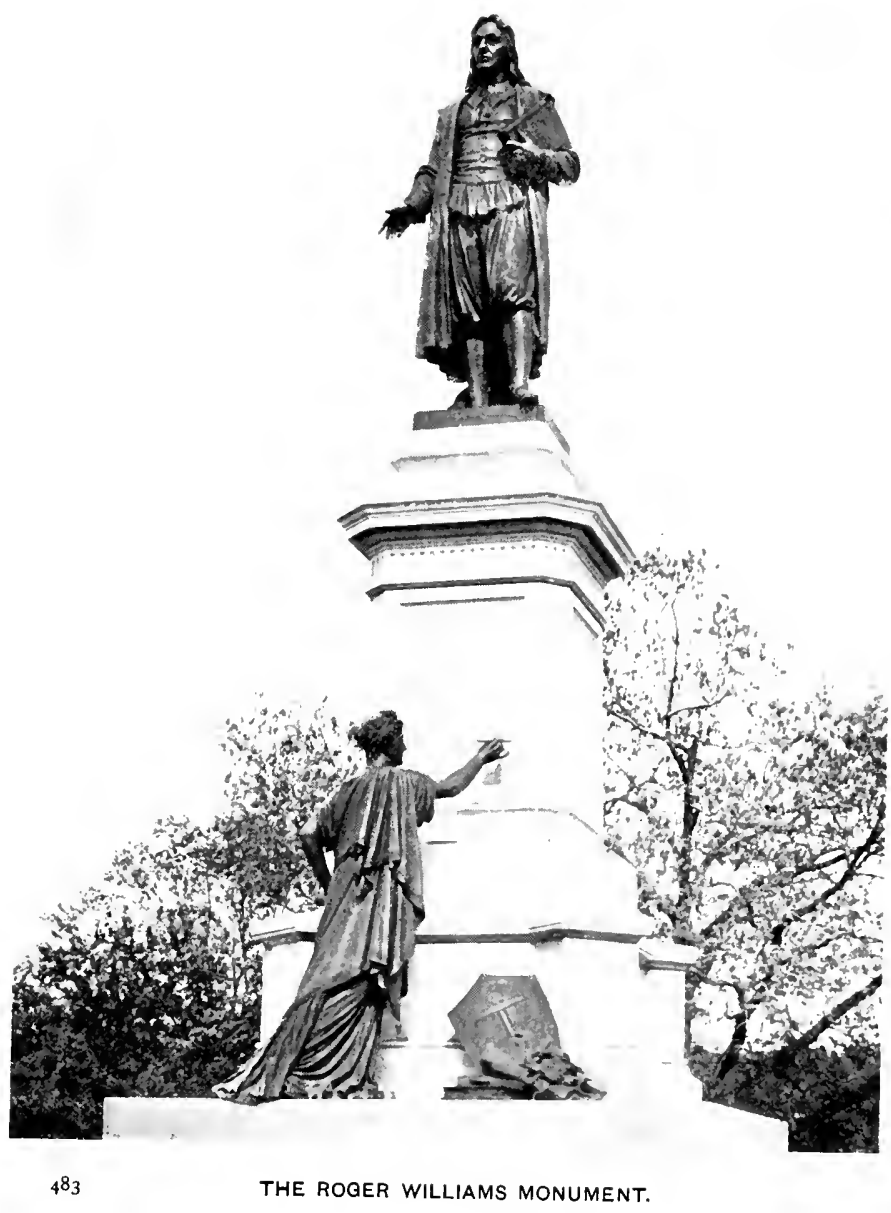


In 1675-1676 King Philip's War, in which the Narragansetts joined, raged through southern New England, and our little plantation was devastated. The women and children generally, with the greater part of the men, sought safety in Newport, Long Island or elsewhere. Thirty houses were burned, chiefly in the north part of the town. After the Indians were beaten, the village was slowly rebuilt. At this time the administration of the settlement was in the hands of the Friends. Their influence was second only to that of the Baptists, until after the Revolution. The only original house standing is the interesting Roger Nowry ${ }^{1}$ tavern, built in 1653 or earlier, called also the Whipple or Abbott house. Guarded by a large elm, it stands on Abbott Street, which runs eastward from North Main. The town council met there, and tradition says Williams conducted prayer-meetings in it.

Some of the sites of the early planters are interesting. Richard Scott, a Quaker and antagonist of Williams, lived on the lot next north of St. John's churchyard. Mary Dyre went from here to be hanged on Boston Common. Near Dexter's (afterward Olney's) lane lived

${ }^{1}$ Isham \& Brown, Houses, p. 21. 
Gregory Dexter. Chad Brown, the ancestor of so many men of mark, lived on land now occupied by College Street. The purpose of the original allotment was to give fronts upon the "Towne Streete" and river, and equal shares of farm-lands. According to Dorr ${ }^{1}$ :

"This attempt at democratic equality only created a multitude of small estates widely separated, and in some instances nearly or quite a mile apart. Besides his homelot of five acres, each proprietor had a 'six-acre lot,' at a distance from his abode; and in a few years one or more 'stated common lots,' which he acquired by purchase from the Proprietary, or by their occasional land dividends among themselves."

The chief holdings were on "Providence Neck," but they gradually extended into "Weybosset Neck."

The latter years of Roger Williams were largely occupied by controversies with his neighbors, including his especial opponent, William Harris. The germs of a new State, rendered indestructible by the complete separation of church and state, if slumbering, yet lived in spite of the petty social stagnation of an agricultural community.

Early in the eighteenth century, the planta-

1 Planting of Providence, p. 43. 
tion took a new departure. Nathaniel Browne, a shipwright, had been driven out from Massachusetts, because he had become "a convert to the Church of England." In i7 I the town granted him one half-acre on "Waybosset Neck on salt water," and again another half-acre for building vessels. His vessels were among the first to sail from Providence for the IVest Indies. Horse-carts and vehicles had been used before I 700 by the wealthy, but Madame Knight's journey to New York from Boston in 1704 shows that the saddle and pillion were the common conveyance along the bridle-paths. Galloping on the Town Street was prohibited in I68I. Through Pawtucket, the Bostonians came by the present North Burying Ground into the Town Street, then crossed Weybosset Bridge on their way toward the southwest. In the wider part of Weybosset thoroughfare, there stood a knoll, which has been levelled away. The road swept around and created the bulging lines of the street. Travel went on through Apponaug and North Kingstown, over Tower Hill and by the Narragansett shore, over the Pequot path toward New York. At this period, the road was opened toward Hartford, and im- 
proved communications were made with the surrounding towns. It was not until 1820 that a direct turnpike was opened from Providence to New London.

Of more importance even was the way into the world outward, through the bay. Pardon Tillinghast had been granted land twenty feet square for a storehouse and wharf "over against his dwelling-place," in I679-80, at the foot of the present Transit Street. There was struggle and competition for "lands by the sea-side," or " forty-foot lots, called warehouse lots," throughout this time, and complete division of the shore privileges was not effected until i 749. All these restless movements showed that the town was waking up and sending its commerce abroad into foreign countries. The first effectual street regulations were in 1736 .

The next church organized after the First Baptist followed the faith of the Six-Principle Baptists. The Friends, as they were expelled from Massachusetts, settled in various towns of Rhode Island. Mention has been made of Richard Scott. In 1672 George Fox visited Newport, and he held a meeting "in a great barn" at Providence. Here was a con- 
testant worthy of our doughty champion, Williams. They disputed with voice and pen, recording their angelic moods in these argumentative titles: The Fox Digged out of his Burrowes begged one side of the question; this was answered with equal logic in $A N c w$ England Fircbrand Qucnchad. The Friends built a meeting-house about I 704 .

The First Congregational Pedobaptist (now Unitarian) Society was formed about 1720 . They built a house for worship in 1723 , at the corner of College and Benefit Streets, where the Court House now stands. This building became the "Old Town House," when the society moved to its present location at the corner of Benerolent and Benefit Streets. Meanwhile the adherents of the Church of England, yet to become the Protestant Episcopal Church of the United States, were gathering in our town. There is some dispute as to the first movements, but Dr. McSparran of Narragansett affirmed that he "was the first Episcopal minister that ever preached at Providence." The society thus formed finally took the name of "St. John's Church, in Providence." The church was raised in 1722 , on the spot where the present building succeeded 
it in 18 Io. It will be observed that these new ecclesiastical developments moved along with the broader commercial life which was animatting the community.

Any historical student should examine Rhode Island for what it is, and even more for what it is not. Roger Williams and his fellows tried a "lively experiment" as daring as it was fruitful. They severed church and state, cutting off thereby the help of an educated clergy. They founded a political democracy, tempering it with the best aristocracy to be obtained, without the ordinary facilities of education derived through such help. Neither the Williams Independents nor the Quakers followed the common formulas of education, which were generally in the hands of Anglicans or Presbyterians. This does not prove that societies can safely drop scholastic education. Many communities have failed for lack of such education. It does prove that the Anglo-American stock engaged in political and economical development will educate itself. At first sight, it was hardly to be expected that isolated and unlettered Providence would be prominent in resisting England, or in forming a new government. But 
she did this, in full share, and the embodiment of her citizenship, the type of her republican character, was in one man, Stephen Hopkins-" great not only in capacity and force of mind, but also-what is much rarerin originative faculty."

Born a farmer in $170 \%$, removing to Providence in $173 \mathrm{I}$, a member of the General

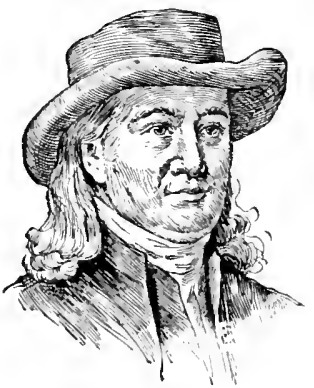
Assembly in 1732 , Chief Justice in I739, one of the committee to form Franklin's plan of colonial union at Albany in I 754 , a signer of the Declaration in 1776 -we have here the full measure of a republican citi-
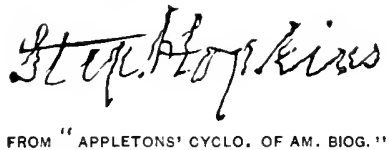
COPYRIGHT, 1887 , BY D. APPLETON \& CO. zen, whether by the standard of Cato, or by the later models of Franklin and Washington. "A clear and convincing speaker, he used his influence in Congress in favor of decisive measures."

In 1758 the first postmaster was appointed by Dr. Franklin. The State House on North Main Street was erected in 1759 ; the Fire 
Department began in $176_{3}$; a "vigorous effort" was made for free schools in 1767 .

A great change was wrought about $i_{7} 6_{3}$ by the opening of Westminster Street. A town named for Mr. Fox's political district had been projected on the west side. It was strangled by the influence of the southern counties. Finally the way across the marsh was laid out. As late as I77I, there were only four houses on the southern and one on the northern side of Westminster Street.

Joseph and William Russell, Clark and Nightingale, with James Brown, the father of the four brothers mentioned below, were among the prominent merchants before the Revolution.

Next to the political change of colony into State, the greatest monument of the larger Rhode Island is the University. Rhode Island College, to become Brown University in I804, was located under President Manning at Warren in $\mathrm{I} 766 . \mathrm{By}$ the "resolute spirits of the Browns and some other men of Providence," University Hall was built in I 770. A government stable and barrack during the Revolution, it has been a beacon-light ever since. 
We said not much might have been expected of little Rhody, by common rules of historic proportion, but the overt acts of the American Revolution began right here in 1772 . The oppressive colonial administration, begun by Grenville, was especially vexatious in Narragansett Bay. The British cruiser Gaspee, attempting an illegal seizure, ran aground on Namquit, since known as Gaspee Point. The news ran like lightning through the town, that the Hawk was fettered on our shore. Four brothers, Nicholas, Joseph, John and Moses, descended from Chad Brown, were all prominent merchants. John was a man of the time. Afterward, his powder, seized in a raid in the British West Indies, arrived in time to be issued in the retreat from Bunker Hill. Brown planned a daring attack on His Majesty's vessel in James Sabin's inn. The historic room has been transferred bodily by the Talbots to their home at 209 Williams Street. Eight long-boats were provided by Brown and moved under the command of Abraham Whipple, afterward a commodore in the Revolutionary navy. A boat from Bristol joined the party. Lieutenant Duddingston answered the hail of the patriot raiders and was severely wounded, 


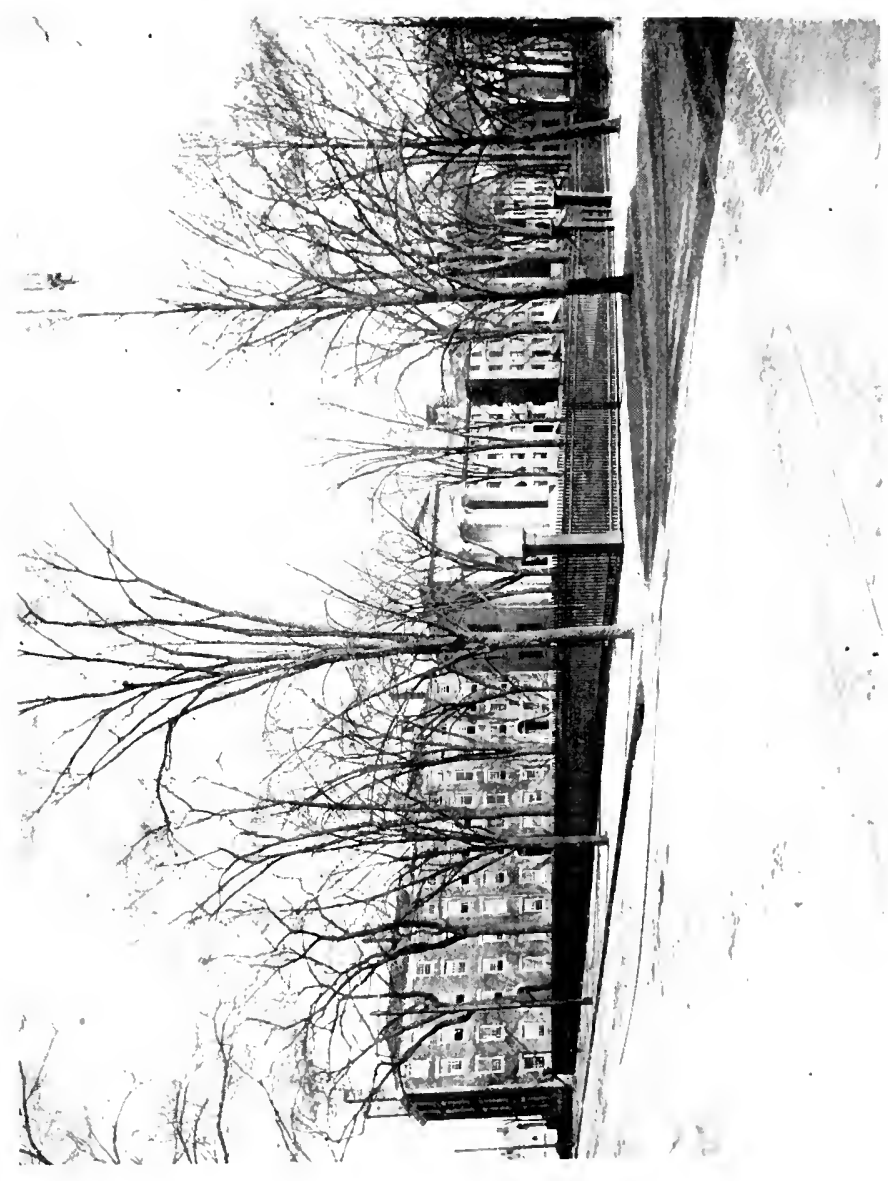

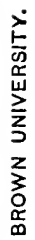


shedding the first British blood in the War of Independence. Whipple's men boarded the cruiser, drove the crew below, took them off prisoners, then fired and destroyed the vessel. It shows the firm temper and new American loyalty prevailing in the town, that large rewards brought out no information which would effectively prosecute Brown and Whipple or their fellow offenders. Brown was arrested and imprisoned during the occupation of Boston, but for want of sufficient proof he was discharged.

Providence contributed its full share to the Revolution. Stephen Hopkins signed the Declaration of Independence with a tremulous hand, but a firm heart. Troops were freely furnished and privateers brought wealth to the town. The second division of the French contingent passed the winter of $\mathrm{I} 782$ in encampment on Harrington's Lane. The street is now known as Rochambeau Avenue. Newport, hitherto the more important port, lost her commerce through the British occupation. The natural drift of commerce to the farthest inland waters available was precipitated by these political changes. Newport never recovered her lost prestige, and Providence developed 
rapidly after the peace. Voyages, which had been mostly to the West Indies with an occasional trip to Bilbao and the Mediterranean, soon stretched around the world to harvest the teeming wealth of the Chinese and Indian seas. The General Washington, the first vessel from Providence in that trade, sailed in 1787. Edward Carrington sent out and received the last vessels in $184 \mathrm{I}$. In the early years of the nineteenth century, the profits of the Oriental trade were very great.

The manufacture of cotton was attempted by several parties, but it was not established in Providence. Samuel Slater located in Pawtucket in I 790. He was induced to come to our State through the sagacity, enterprise and abundant capital of Moses Brown. After about a year, a glut of yarns occurred, and Almy, Brown and Slater had accumulated nearly six thousand pounds. Brown said: "Samuel, if thee goes on, thee will spin up all our farms." The manufacture extended rapidly and became the chief source of the prosperity of the State. It absorbed the capital, which was gradually withdrawn from commerce and shipping.

An important element in the development of our city has been the free banking system. 
The first institution in our State and the second in New England was the Providence Bank, chartered in $179 \mathrm{I}$.

Newspapers only slightly affected the life of the eighteenth century. They began, in a humble way, the great part they were to play in later, modern development. The Providence Gazctte and Country Journal was first published in 1762 by William Goddard. The Manufacturer's and Farmer's Journal, still continuing its prosperous career, appeared in I 820. The Gazette was enlivened by advertisements in verse, of which this is a specimen, from the year 1796 :

"A bunch of Grapes is Thurber's sign, A shoe and boot is made on nine, My shop doth stand in Bowen's Lane, And Jonathan Cady is my name."

Housekeepers in our day consider the servant-girl question a hard problem, but hear the complaint a century ago. There had been taken away

"from the servant girls in this town, all inclination to do any kind of work, and left in lieu thereof, an impudent appearance, a strong and continued thirst for high wages, a gossiping disposition for every sort of amusement, a leering and hankering after persons of the other sex, a 


\section{Providence}

desire of finery and fashion, a never-ceasing trot after new places more advantageous for stealing, with a number of contingent accomplishments, that do not suit the wearers. Now if any person or persons will restore that degree of honesty and industry, which has been for some time missing,"

then this rugged censor offers $\$ 500$ reward.

In 1767 the first regular stage-coach was advertised to Boston. In 1793 Hatch's stages ran to Boston and charged the passengers a fare of one dollar, the same sum which the railway charges to-day. In 1796 a navigable canal was projected to Worcester, John Brown being an active promoter. The project was not carried through until I 828 , when the packet-boat Lady Carrington passed through the Blackstone Canal. The enterprise had poor success. John Brown built Washington Bridge across the lower Seekonk, connecting the eastern shore to India Point, where the wealth of Ormus and of Ind was discharged from the aromatic ships. In this period the first steamboat came from New York around Point Judith and connected with stages to Boston.

The international disputes concerning the embargo and non-intercourse with Great Britain, which led up to the War of I8I2, found 
Providence opposed in opinion to the Executive of the United States. But the opposition was loyal and the government received proper support. Peace was very welcome when it was proclaimed in I8 I5. This year, a tremendous gale swept the ocean into the bay and the bay into the river, carrying ruin in their path. The waters were higher by some seven feet than had ever been known. The fierce winds carried the salt of the seas as far inland as Worcester. Thirty or forty vessels were dashed through the Weybosset Bridge into the cove above. Others were swept from their moorings and stranded among the wharves. Shops were smashed or damaged and the whole devastation cost nearly one million of dollars-a great sum in those days. It was a radical measure of improvement. New streets were opened and better stores rose amid the ruins. South Water and South West Water Streets date hence, and Canal Street was opened soon after.

In $8_{32}$ the city government was organized, with Samuel W. Bridgham for mayor. A serious riot occurring the previous year had shown that the old town government was outgrown. The railways to Boston and Stonington 
changed the course of transportation. In I 848 the Worcester connection, the first intersecting or cross line in New England, gave direct intercourse with the West.

We sent out Henry Wheaton, one of the masters of international law, and we adopted Francis Wayland,a citizen of the world,-who set an enduring mark on Rhode Island. President of Brown University, I $827-$ I 855, his work in the American educational system has not yet yielded its full fruit. He brought teacher and pupil into closer contact by the liv-

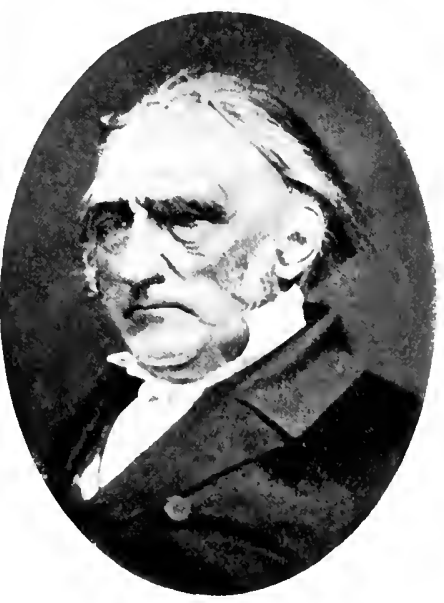

FRANCIS WAYLAND. ing voice. He projected a practical method for elective studies and put it in operation at Brown University in I 850 . Started too soon, and with insufficient means, it opened the way to success, when the larger universities inaugurated similar methods after the Civil War. 
Nine hundred and forty-six students now attend where Manning and Wayland taught.

An armed though bloodless insurrection in 1842 brought our State to the verge of revolution. The old charter of ${ }_{1} 66_{3}$ limited suffrage to freeholders and their oldest sons. Thomas Wilson Dorr was the champion of people's suffrage. His party elected him governor with a legislature, by irregular and illegitimate voting. They mustered in arms and tried to seize the State arsenals in our city. Dorr had a strong intellect; he was a sincere and unselfish patriot, though perverse and foolish in his conduct of affairs. The suffrage was widened by a new constitution in 1843 , which has just been revised by a constitutional commission.

The early cotton manufacture was fostered by the well-distributed water-power of Rhode Island. The glacial grinding of the land had left numerous ponds and minor streams, - - admirable reservoirs of water-power,-just the facilities needed for weak pioneers. As the century advanced, greater force was needed. About i 847 George H. Corliss bent his talents and energies to extend the power of the high-pressure steam-engine. He adapted and developed better cut-off valves, which preserved 


\section{Providence}

the whole expansive force of the steam, stopped off before it filled the cylinder. It was a new lever of Archimedes, and Corliss's machines went over the whole world. This new mastery of force stimulated all industries.

Our little community showed its customary military spirit in $\mathrm{I} 86 \mathrm{I}$. Governor William Sprague mustered troops with great energy. After the famous Massachusetts 6th, the Rhode Island ist Militia with its Ist Battery were the first reinforcements which arrived at Washington. In field artillery, our volunteers were especially proficient.

The growth of the population of Providence is shown in the following table:

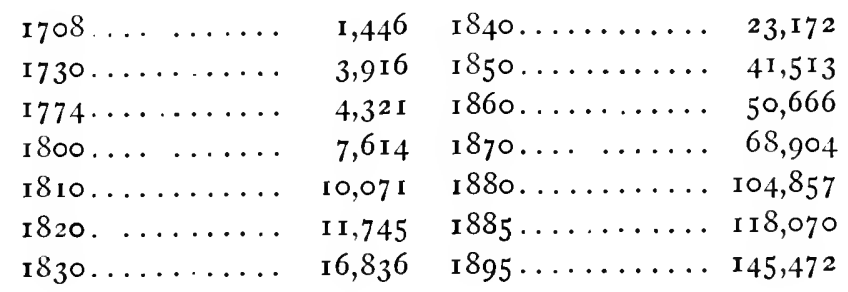

We could not notice all parts of Providence in this cursory survey. Small as well as large implements of iron, jewelry and silver, the invention and immense production of wood- 
screws, india-rubber, worsted,-all these complicated industries have built up an extending and encroaching city, until now three hundred thousand people dwell within a radius of ten miles from our City Hall.

Old Providence, the home of Williams and the Quakers, is fading away. The "Towne Streete," its meandering curves gradually straightening, will hardly be recognized a century hence. The Mowry house, the homes of Stephen and Esek Hopkins, are small, when compared with the mansions of John Brown, Thomas P. Ives, Sullivan Dorr and Edward Carrington; while the solid comfort prevailing in the eighteenth century, as embodied in these houses, is surpassed, though it may not be bettered, by the more pretentious domestic architecture of our day. The Independent worshipers in the First Baptist and First Congregational churches would feel strange under the domes of the beautiful Central Congregational. The Anglicans of the first St. John's would be bewildered by the pointed arches of St. Stephen's. The few Catholic immigrants, bringing the Host across the seas with tender care, and resting at St. Peter and St. Paul's, would be amazed by the swarm of 


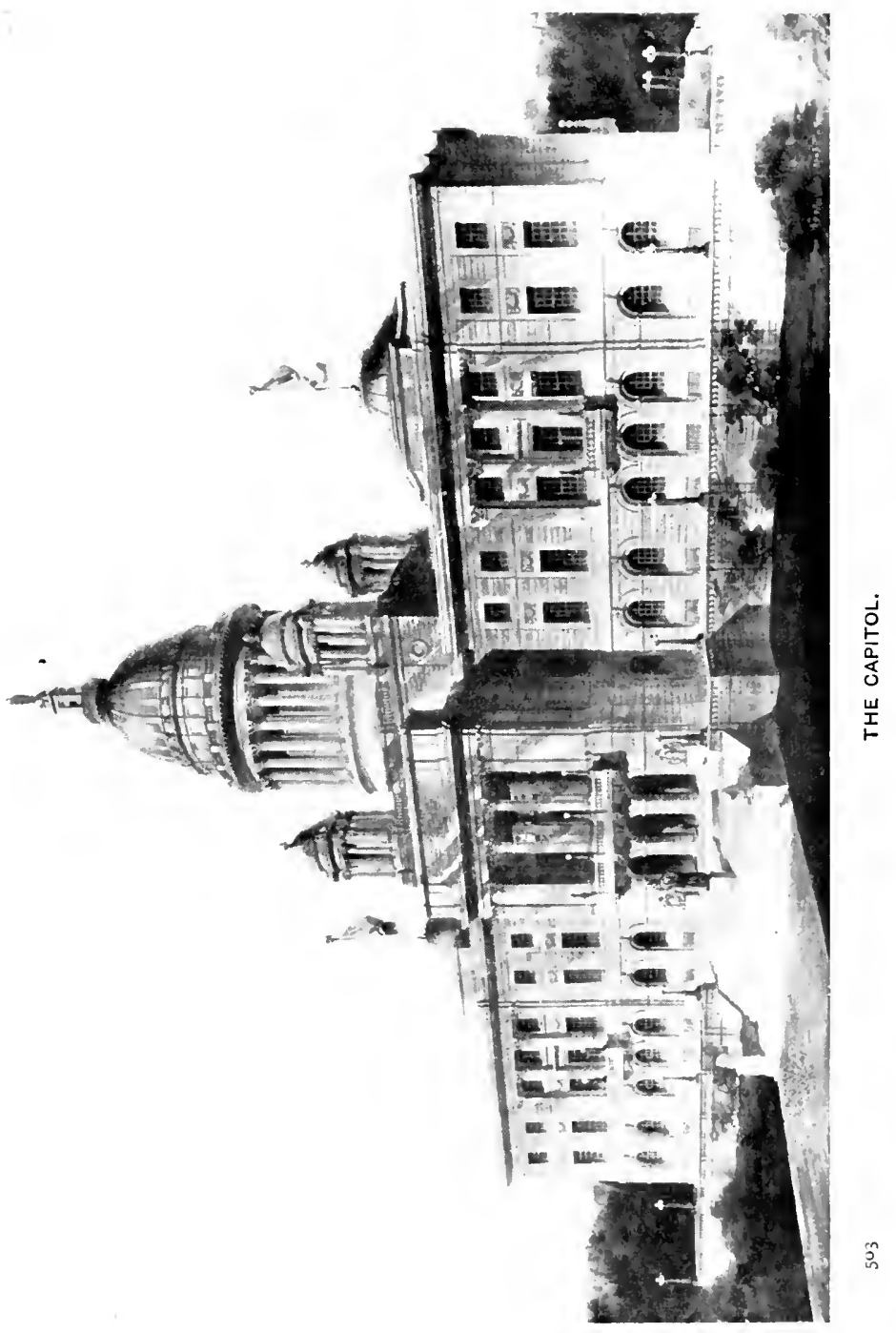


well-to-do citizens clustering beneath the massive towers of the Cathedral.

The industrial and economic evolution is fully as great as the resthetic and architectural. The crazy little organism of Almy, Brown and Slater is replaced by the long, whirling shafts, the spindled acres of the Goddards' Ann and Hope Mill at Lonsdale. The homely security of the market house (present Board of Trade), the Providence Bank and the "Arcade" is overshadowed by the City Hall, the Rhode Island Hospital and Rhode Island Hospital Trust Company. University Hall burgeons into the fair arches of Sayles Hall. No medieval builder worked more reverently than Alpheus C. Morse, as he devotedly wrought at his task, getting the best lines into stone and lime.

Not always does the work of the modern builders tend toward beauty. The masterly brick arcades of Thomas A. Teft kept the city's approaches for a half-century. Swept away by the more convenient passenger station of the New York and New Haven Railway, they will leave behind many regrets. The magnificent marble State House will lift the observer away from and above all the buildings below. 
The growth of Providence runs even with the State's, except in the excrescent luxury of Newport in its summer bloom. We cannot stand still like Holland; we must look outward or decay. The American destiny is reaching out, notwithstanding the caution of the prudent, perhaps of the judicious. The mystic Orient, no longer mysterious, beckons from the West instead of the East. It led the Browns, Iveses, Carringtons, Maurans, and their captains, the Holdens, Ormsbees, Paiges and Comstocks, to opulence. Their descendants, with more abundant capital, ready skill and better organization, ought not to lag in the world's march. Men must be forthcoming:

There has been always a cosmopolitan flavor in the little State, isolated between the restless intellectual energy of Massachusetts and the steady Puritan development of Connecticut. Boston had more trade than Providence and Newport; she was not so truly commercial. The larger Franklin went over to Pennsylvania, but the next man, Stephen Hopkins, stayed in Rhode Island. The seed which Berkeley planted sprouted in Channing, and that influence went throughout New England. The little State has never been without ideas. 


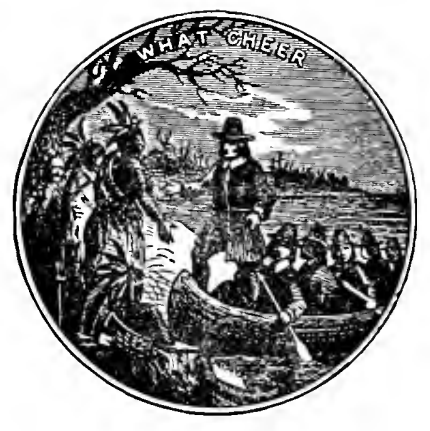

506 


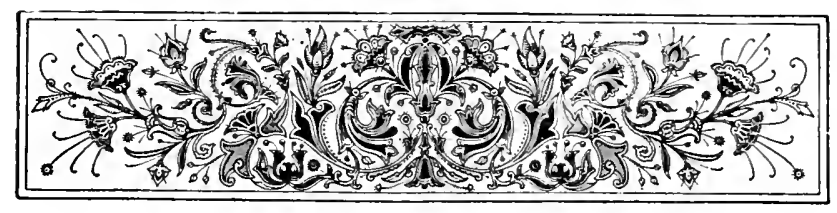

\section{HARTFORD}

"THE BIRTHPLACE OF AMERICAN DEMOCRACY "

BY MARY K. TALCOTT

MONG the historic cities of New Eng-
land, Hartford claims a foremost place. Not only was its settlement of great consequence at the time, but for historical importance and far-reaching results this colony's claims to attention are second only to those of Plymouth and Boston. The foundation of Hartford was a further application and development of the ideas that brought the Puritans to this country, and, to quote the historian, Johnston,-

"Here is the first practical assertion of the right of the people, not only to choose, but to limit the powers of their rulers, an assertion which lies at the foundation of the American system. . . . It is on the banks of the Comnecticut, under the mighty preaching of Thomas Hooker, and in the constitution to which he gave life, if not form, that we draw the first breath of that atmosphere 
which is now so familiar to us. The birthplace of American democracy is Hartford."

This constitution, first promulgated in Hartford, was the first written constitution in history which was adopted by a people and which also organized a government. John Fiske says :

"The compact drawn up in the Mayflower's cabin was not, in the strict sense, a constitution, which is a document defining and limiting the functions of government. Magna Charta partook of the nature of a written constitution as far as it went, but it did not create a government."

On the I $4^{\text {th }}$ of January, 1639 , the freemen of the three towns, Windsor, Hartford, and Wethersfield, assembled at Hartford, and drew up a constitution, consisting of eleven articles, which they called the "Fundamental Orders of Connecticut," and under this law the people of Connecticut lived for nearly two centuries, as the Charter granted by King Charles II., in I662, was simply a royal recognition of the government actually in operation. Another writer says :

"We honor the limitations of despotism which are written in the twelve tables; the repression of monarchical power in Magna Charta, in the Bill of Rights, and 


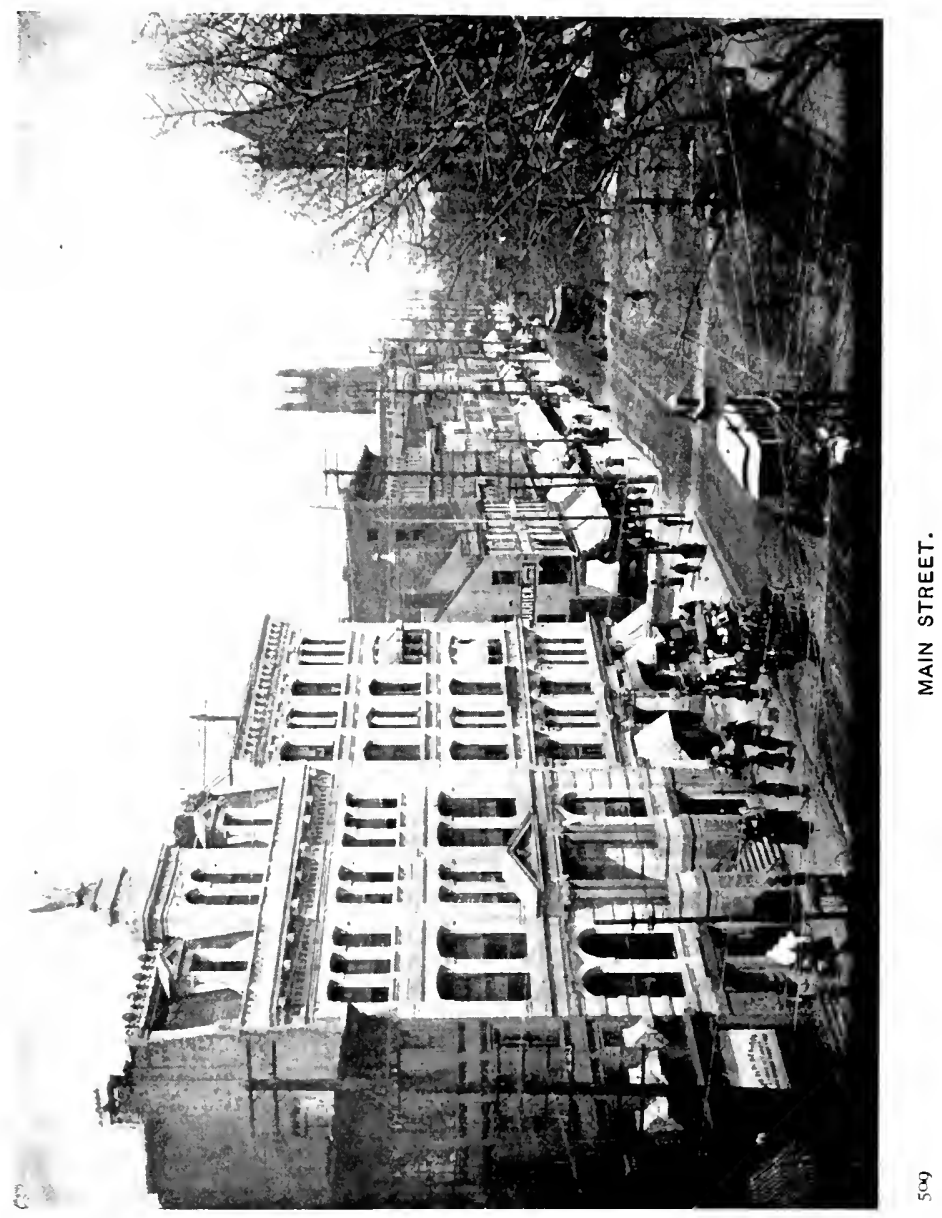


in that whole undefinable creation, as invisible and intangible as the atmosphere but like it full of oxygen and electricity, which we call the British Constitution. But in our Connecticut Constitution we find no limitation upon monarchy, for monarchy is unrecognized; the limitations are upon the legislature, the courts, and executive. It is pure democracy acting through representation, and imposing organic limitations. Even the suffrage qualification of church membership, which was required by our older sister Colony of Massachusetts, was omitted. Here in a New England wilderness a few pilgrims of the pilgrims, alive to the inspirations of the common law and of the British Constitution, so full of Christianity that they felt the great throb of its heart of human brotherhood, and so full of Judaism that they believed themselves in some special sense the people of God, made a written constitution, to be a supreme and organic law for their State."

But for the immediate inspiration of this document we must look to a "lecture," preached by Mr. Hooker on Thursday, May $2 \mathrm{I}, \mathrm{I} 638$, before the legislative body of freemen. Dr. Bacon says of it :

"That sermon, by Thomas Hooker, is the earliest known suggestion of a fundamental law, enacted, not by royal charter nor by concession from any previously existing government, but by the people themselves,-a primary and supreme law by which the government is constituted, and which not only provides for the free 


\section{Hartford}

choice of magistrates by the people, but also sets the bounds and limitations of the power and place to which each magistrate is called."

But we must know something of a people to whom such doctrines were preached--of a people capable of receiving and applying such truths. It is said that three kingdoms were sifted to furnish the men who settled New England, and it may also be said that the Massachusetts Colony was sifted to supply the Connecticut settlers. Three of the eight Massachusetts towns, Dorchester, Watertown, and Newtown (now Cambridge), were not in full agreement with the other five, especially on the fundamental feature of the Massachusetts polity, the limitation of office-holding and the voting privilege to church-members. At first the majority were unwilling to grant the minority "liberty to remove." John Haynes was made Governor of Massachusetts in I6 35 , probably with the hope of retaining his friends in the Colony. But their desire to leave was too strong; small parties of emigrants made their way to the banks of the Connecticut during the year 1635 , but the main body of the colonists did not leave until the spring of 1636. Dr. Benjamin Trumbull, the first 
historian of Connecticut, writing more than one hundred years ago, says:

"About the beginning of June Mr. Hooker, Mr. Stone, and about a hundred men, women, and children took their departure from Cambridge, and travelled more than a hundred miles thro' a hideous and trackless wilderness to Hartford. They had no guide but their compass; made their way over mountains, thro' swamps, thickets, and rivers, which were not passable but with great difficulty. They had no cover but the heavens, nor any lodgings but those which simple natureafforded them. They drove with them a hundred and sixty head of cattle, and by the way subsisted on the milk of their cows. Mrs. Hooker was borne through the wilderness upon a litter. The people generally carried their packs, arms, and some utensils. They were nearly a fortnight on their journey."

Trumbull adds: "This adventure was the more remarkable, as many of this company were persons of figure, who had lived in England in honor, affluence, and delicacy, and were entire strangers to fatigue and danger." When dismissing these colonists Massachusetts sent with them a governing committee, or commissioners, as they were called. At a meeting of these commissioners, held February $2 \mathrm{I}, \mathrm{I} 637$, the plantation, which had been called Newtown, was named Hartford. As Gover- 


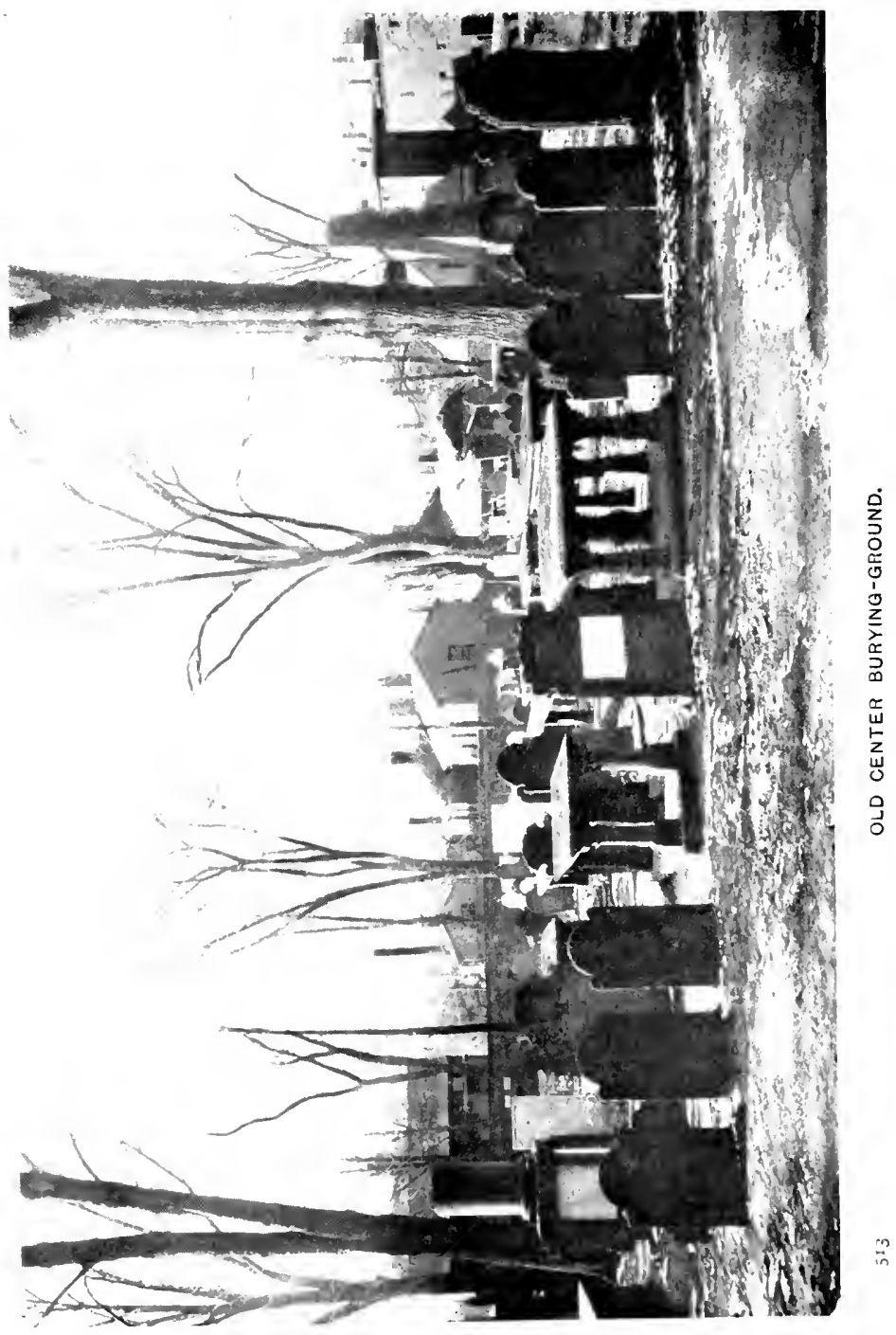


nor Haynes was born in the immediate vicinity of the English Hertford, he probably had much influence in naming the new plantation. On the i th of April, I639, the first general meeting of the freemen under the constitution was held, and John Haynes was elected the first Governor of Connecticut. This selection shows his active sympathy and co-operation with Hooker, and we can entirely agree with Bancroft, when he says: "They who judge of men by their services to the human race will never cease to honor the memory of Hooker, and of Haynes."

But the soil of Hartford has had other occupants; not only the aboriginal owners of the soil, for when the English came they found a Dutch trading-post established on what is yet known as Dutch Point. The English claimed the territory now comprehended in the State of Connecticut by virtue of the discoveries of John and Sebastian Cabot in 1497 , and more especially in 1498 . This territory was included in the grant to the Plymouth Company in 1606 , but that organization undertook no work of colonization. When the settlers of 1635 came they took possession of this portion of the valley of the Connecticut 
under the English flag, and claimed the territory by virtue of patents from the English crown. They paid Sequassen, the Indian chief, who ruled the river Indians, for his lands, and when the Pequots, his over-lords, disputed Sequassen's right to sell, the colonists attacked them, and practically exterminated the tribe. The Dutch settlement originated from discoveries by Adrian Block, who sailed through the Sound in I6I4, and up the Connecticut, or Fresh River, as he called it, in his sloop, The Unrest, as far as the falls, and upon his report to the States-general, a company was formed for trading in the New Netherlands. Only limited privileges were granted to this company, and it was afterwards superseded by the Dutch West India Company, to whom the exclusive governmental and commercial rights for the territory were granted. The Dutch were influenced much more by the desire for a lucrative trade with the natives than by any wish to found a colony, and in 1633 they built a fort on the spot still called Dutch Point, in Hartford, for the purpose of protecting their traffic with the Indians, which they had been carrying on for some ten years. This fort was known as the House of Hope, and when the 
English came they settled all about it, but did not interfere with the Dutch occupation. Naturally, there was friction between the two nationalities, and petty trespasses of various kinds were charged by both parties. Finally, after repeated complaints, the Commissioners of the United Colonies, Massachusetts, Plymouth, Connecticut, and New Haven, met at Hartford, September I I, I650, with Peter Stuyvesant, Director of the New Netherlands, to consult upon the proper boundaries of the Dutch jurisdiction. The matter was referred to arbitrators, and resulted in a transfer to the English of all the territory lying west of the Connecticut except the land in Hartford actually occupied by the Dutch, the New Netherlands taking the country east of the river. But this arrangement did not last long, as, in 1653, war was declared between England and Holland, and the colonies were required by Parliament to treat the Dutch as the declared enemies of the Commonwealth of England. Trumbull says :

"In conformity to this order the General Court was convened, and an act passed sequestering the Dutch house, lands, and property of all kinds at Hartford, for the benefit of the Commonwealth; and the Court also 
prohibited all persons, whatsoever, from improving the premises by virtue of any former claim or title had, made, or given, by any of the Dutch nation, or any other person, without their approbation."

Even after this change of rulers a few of the Dutch traders remained in Hartford, as is shown by references to them on the records, but they all finally returned to the New Netherlands.

During the next thirty years the little settlement on the banks of the Connecticut continued to grow and prosper, having very little to do with the affairs of the outside world. In 1675 and 1676, King Philip's War caused great alarm and anxiety for a time, but after this conflict was concluded by the subjugation of the Indians, peace and quietness again reigned. Soon after the accession of James II., in 1685 , this quiet was however rudely disturbed by the issue of a writ of quo warranto against the Governor and Company of Connecticut, summoning them to appear before his Majesty, and show by what warrant they exercised certain powers. In reply, the Colony pleaded the Charter, granted by the King's royal brother, made strong professions of their loyalty, and begged a continuance of their 
privileges. Two more writs of quo warranto were issued against Connecticut, but she still refused to surrender her Charter, and reelected Robert Treat as Governor. The Charter of Massachusetts had been vacated, and Chalmers, in his History of the American Colonies, says that "Rhode Island and Connecticut were two little republics embosomed in a great empire." Rhode Island, however, submitted to his Majesty, so Connecticut stood alone in refusing to surrender her Charter. In the latter part of 1686 , Sir Edmund Andros arrived in Boston, bearing his royal commission as Governor of New England. After some correspondence with Governor Treat, who still stood firm, he left Boston for Hartford, with several members of his Council and a small troop of horse. When he arrived in Hartford, October 31, 1687, he was escorted by the Hartford County Troop, and met with great courtesy by the Governor and his assistants. Sir Edmund was conducted to the Governor's seat in the council chamber, and at once demanded the Charter. Trumbull says :

"The tradition is that Governor Treat strongly represented the great expense and hardships of the colonists in planting the country, the blood and treasure which 


\section{Hartford}

they had expended in defending it, both against the savages and foreigners; to what hardships and dangers he himself had been exposed for that purpose; and that it was like giving up his life now to surrender the patent and privileges so dearly bought, and so long enjoyed. The important affair was debated and kept in suspense until the evening, when the Charter was brought and laid upon the table, where the Assembly were sitting. By this time great numbers of people were assembled, and men sufficiently bold to enterprise whatever might be necessary, or expedient. The lights were instantly extinguished, and one Captain Wadsworth, of Hartford, in the most silent and secret manner carried off the Charter, and secreted it in a large hollow tree, fronting the house of the Honorable Samuel Wyllys, then .one of the Magistrates of the Colony. The people appeared all peaceable and orderly. The candles were officiously relighted, but the patent was gone, and no discovery could be made of it, or of the person who had conveyed it away."

Sir Edmund was disconcerted, but declared the government of the colony to be in his own hands, annexed Connecticut to Massachusetts and the other New England colonies, appointed officers, and returned to Boston. After the downfall of Andros, in 1689, Governor Treat resumed his position as Governor of Connecticut, and the Charter reappeared from its seclusion, and continued to be the organic law of Connecticut, although in Parlia- 
ment, during the remainder of the colonial period, various attempts were made to have it abrogated. But the Charter Oak, where tradition declared that the document was concealed, continued to be a sacred and venerated object until its fall, August 2 I, I 856 .

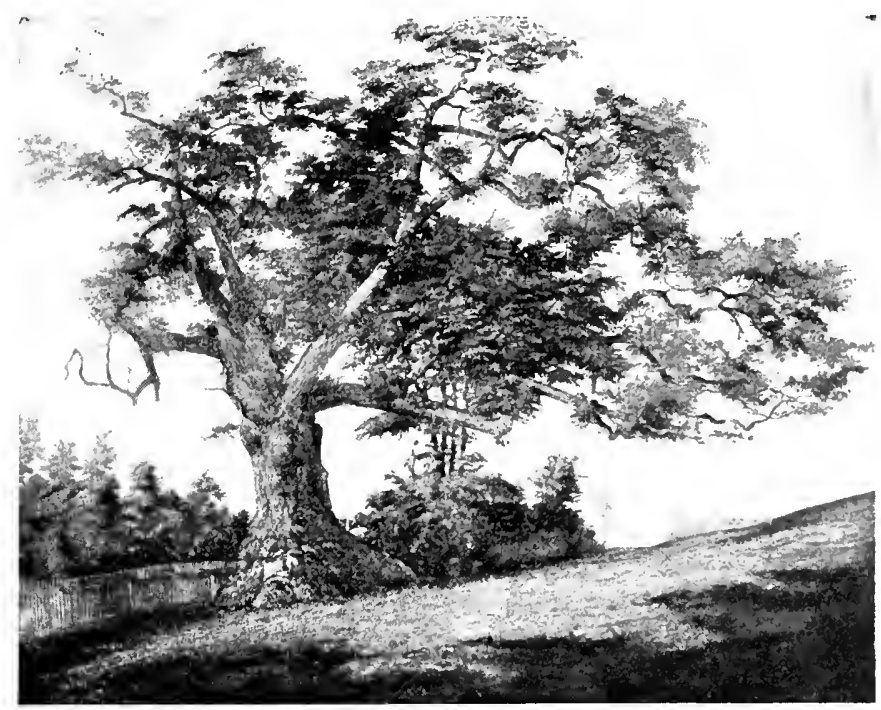

THE CHARTER OAK.

A people that have no history are the happiest, therefore we may assume that Hartford was a happy and flourishing town during the remainder of the colonial period, and even 


\section{Hartford}

during the Revolution there is but little to tell of Hartford. Its situation, so far removed from the seacoast, secured it from the attacks of the British troops, and it was for that very reason a safe and desirable place for the meetings of Generals Washington and Rochambeau, when they wished to arrange the plans for the campaigns that ended with the surrender of Yorktown. The first of these historic meetings took place September I 7 , I78o. Rochambeau came from Newport through Eastern Connecticut, and Washington rode from New Windsor on the Hudson with a guard of twenty-two dragoons. The meeting took place in the public square on the site of the present post-office, and as the two tall, fine-looking commanders-in-chief approached each other bowing, an eye-witness said that it was like the meeting of two nations. The following year another meeting took place at Wethersfield.

During the colonial period there was very little literary production in America, except sermons and theological treatises, and Hartford was no exception to this rule. Her first author was one of her founders, the Rev. Thomas Hooker, "The Light of the Western 
Churches." His writings consisted exclusively of sermons. They were first published in London, and but few have been reprinted in this country. No preacher of great reputation succeeded him, nor any writers whatever. But during the Revolution a star arose on the horizon,-MIcFingal. The first part of the poem appeared as independent verses in the Connecticut Courant in 1775. General Gage had issued a fierce proclamation, threatening to exempt from general pardon some of the Continental leaders, and Trumbull's poem burlesqued the manifesto. It was at once reproduced in the Philadelphia papers, and undoubtedly did a very important work in stimulating the thought and passion of the American Revolution. About ${ }_{7} \delta_{2}$ the whole work was published by Messrs. Hudson \& Goodwin, "near the Great Bridge, Hartford." Tradition states that the scene of the "Town Meeting" refers to the old South Church in this city. Nathaniel Patten, an enterprising, and not over-scrupulous printer in Hartford, issued a second edition of MIcFingal, without the author's consent, and it is an interesting fact that out of this piracy of Trumbull's work here in Hartford grew the national copyright law. 
Trumbull and Noah Webster both exerted themselves strenuously in favor of such a law, and, in $\mathrm{I}_{783}$, the General Assembly of Connecticut passed an "Act for the Encouragement of Literature and Genius," which secured to authors their copyright within the State. The personal exertions of Noah Webster in defense of his spelling-book led to the passage of similar laws by the legislatures of other States, and finally to the passage of a general law by Congress, modelled on the Connecticut act of $\mathrm{I}_{783}$. All the literature of that period in America bears the impress of the golden age of Queen Anne, the Spcctator and the Tatler, Addison and Steele; and McFingal reminds the reader now of Hudibras, now of the Dunciad.

John Trumbull was born in Watertown, Connecticut, then Westbury, April 24, 1750. Both on his father's side and his mother's he was of the pure Brahmin stock of New England, and through his mother he was related to Jonathan Edwards, Timothy Dwight, his fellow-poet, and many other writers of a later time. He exhibited marvellous precocity, and, his father being engaged in preparing a youth of seventeen for examination at Yale, the boy 
of seven was so eager to join in the elder youth's studies that his father allowed him to go through the same course of Greek, Latin, and Mathematics. Both the lads passed, and were admitted members of the college, but the boy of seven was not allowed to proceed with his college course until he was older. He early began writing essays of a satirical nature, and while a tutor at his Alma Mater he wrote The Progress of Dulness, a keen and stinging satire on contemporary life. It also shows, like McFingal, the technical precision of the literary artist. The year 1774 Trumbull, spent in the law-office of John Adams, in Boston, then returned to New Haven, and in I 78 I took up his residence in Hartford, where he remained until I 825 , when he went to Detroit to live with a married daughter, and died there in $183 \mathrm{I}$. In his later life he gave up literature for the law, and was at different times State Attorney for Hartford County, Representative to the State Legislature, Judge of the Superior Court (1801-1819), and Judge of the Supreme Court of Errors (1808-1819).

In the first decade of our independence the "Hartford Wits" made this little provincial capital a brilliant intellectual centre, and an 
important focus of political influence. The original members of the association or club were, Dr. Lemuel Hopkins, John Trumbull, Joel Barlow, and David Humphreys. We may call it remarkable, because, at that time, when Boston was as barren of literary talent as she has since been prolific, this little town of three thousand inhabitants boasted at least four poets who had gained a national reputation. Hopkins was born in Waterbury, Connecticut, in $\mathrm{I} 750$, was a distinguished physician, and one of the founders of the Connecticut Medical Society. He died in Hartford in I801, and his grave may be seen in the old Center burying-ground. No edition of his collected poems has ever been published. They consisted in great part of his contributions to the Anarchiad, the Political Grecnhouse, and the $E c h o$, which were serial satires in verse by the Hartford Wits. The Anarchiad resembled the Rolliad of Frere and Canning, and with the Echo contained a series of social and political satires. Hartford at this time, became and for twenty years thereafter was, the literary headquarters of the Federalist or Conservative party, which favored a strong, general government, and opposed French democracy. 
In consequence, as party feeling ran so high, it became a mark for obloquy and vituperation among the Jeffersonians, which gave it an honorable resemblance to Boston in the antislavery times.

David Humphreys was born in Derby, Connecticut, in I 753, served honorably during the Revolution, and had the distinction of being Washington's aid-de-camp. He also held, after the war, the position of secretary to the commissioners-Franklin, Jefferson, and Adams-appointed to negotiate treaties of commerce with various European powers. Joel Barlow is perhaps the best known of any of the Wits, and but a small portion of his career was passed in Hartford. He took up his residence in our town in $17 S_{2}$, just after leaving the army. He was then engaged in writing his best known poem, the epic I'ision of Columbus, but he did much other literary work, and was also the editor of a weekly newspaper, called The Amorican Mercury, for which he wrote many essays, said to be the precursors of the modern editorial. In 1787 , he completed the Vision of Columbus, and it was published by subscription and dedicated to Louis XVI., King of France. During the 
next year, i 788 , Barlow left Hartford to go abroad; he remained in Europe for seventeen years, and when he returned took up his residence in Washington. Finally, going abroad as Ambassador to France, he died in Poland, while following Napoleon then engaged in his Russian campaign. Richard Alsop and Theodore Dwight, Senior, were admitted into the coterie of the Hartford Wits, and wrote much of the Echo, and a few lines in this series were also contributed by Drs. Mason F. Cogswell and Elihu H. Smith. The Echo was a sort of Yankee Dunciad. It contained many local allusions, as to the Blue Laws, the Windham Frogs, etc., and was also the vehicle of much political satire on the Democrats. Theodore Dwight, one of the Echo poets, was editor of the Connccticut Mirror, and also secretary of the famous Hartford Convention.

No political subject has ever been the theme of more gross misrepresentation or more constant reproach than the assembly of delegates from the New England States which met at Hartford in December, Isi4. After the war of I 8 I 2 had continued two years, our public affairs were in a deplorable condition. The 
army intended for defending the sea-coast had been sent to the borders to attack Canada; a British squadron was lying in the Sound to blockade the harbors on the Connecticut coast, and to intercept our coasting trade; the banks, south of New England, had suspended the payment of specie; our shipping lay in our harbors, embargoed, dismantled, and perishing; the Treasury of the United States was nearly exhausted, and a general disheartenment prevailed throughout the country. In this situation of affairs a number of gentlemen in Massachusetts believed that a convention of prominent men might do good. Many petitions from numerous towns in Massachusetts were received, stating the sufferings of the country in consequence of the embargo and the war, and Governor Strong summoned a special meeting of the Massachusetts Legislature in October, I $S_{1} 4$, when a resolution was passed appointing delegates to a convention to be held in Hartford. The Connecticut Legislature was in session at the same time, and received a communication from the Massachusetts body, requesting them to join in appointing delegates to the convention. This they did, and seven 


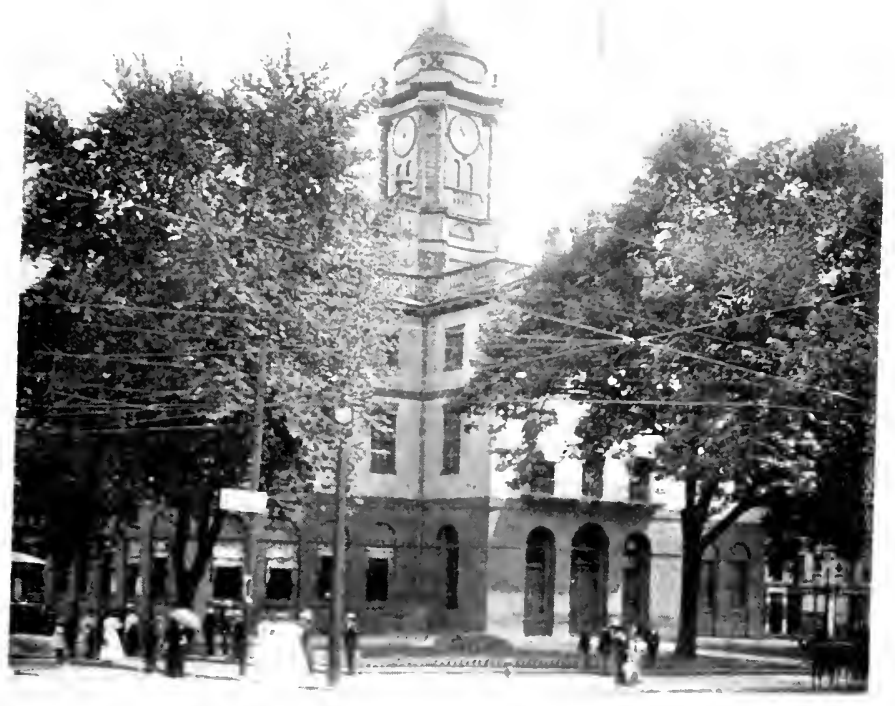

OLD STATE HOUSE, NOW CITY HALL. 
delegates were sent. On December I5, I8I4, the convention, numbering twenty-six delegates, representing Massachusetts, New Hampshire, Connecticut, Rhode Island, and Vermont, met in the council chamber of the State House, now the City Hall of Hartford. Among the delegates were men of such assured position as Harrison Gray Otis, George Cabot, William Prescott, the father of the historian, and Stephen Longfellow, the father of the poet, from Massachusetts; Chauncey Goodrich, Governor John Treadwell, Roger Minot Sherman, and James Hillhouse, of Connecticut. Their deliberations continued for three weeks, and their sittings were held with closed doors, a fact which was brought up against them by their political adversaries as evidence of dark and nefarious designs. During the sessions a small body of recruits for the army, then in Hartford, were paraded in a threatening manner by the officer in command. The proceedings resulted in the adoption of a report and the passage of resolutions recommending amendments to the Constitution of the United States. Among the recommendations was one proposing that representative and direct 


\section{Hartford}

taxation should be apportioned according to the respective numbers of free persons in the States, excluding slaves and Indians. This document was immediately published, and was read with great eagerness. Those who expected to discover sentiments of a seditious and treasonable nature were disappointed. The report expressed an ardent attachment to the integrity of the republic, and its sentiments were liberal and patriotic. A short time after the publication of this document the news of the declaration of peace was received. The people, without waiting to hear the provisions of the treaty, showed their joy by bonfires and illuminations, - a striking commentary upon the character of the war and the general feeling about it. The war being over, the work of the Hartford Convention was no longer needed, and the jarring interests of the State and Federal governments were harmonized.

During the last century the chief business of Hartford was the trade with the IVest Indies. There was also some trafficking with Ireland and with Lisbon, timber being exported to the first named, and fish to the latter. From i 750 to ${ }_{3}{ }_{3} \mathrm{O}$. Hartford not only imported goods from the West Indies, but 
was also a distributing centre for the surrounding country, and for the region that stretches northward to the sources of the Connecticut. During the first thirty years of this century the wharves on the river bank were bustling with traffic and lined with vessels, often three or four rows deep. Large warehouses extended along the banks of the river, where beef and pork were packed for the export trade, great quantities being brought down the river in brine, and inspected and repacked here. The numerous scows and flat-boats in which the up-river trade was carried on, were loaded on their return voyage with sugar, rum, molasses, coffee, salt and other West Indian commodities. S. G. Goodrich, in his Recollections of a Lifetime, describes the city as a centre of the West India trade, and as smelling of rum and molasses. The inland transportation of goods was carried on by lines of freight-wagons running to Westfield, Granby, Monson, Brimfield, Norfolk, Canaan, and the towns in Berkshire County. There were also packet lines running to Boston, New York, Albany, Nantucket, Baltimore, Norfolk, and Richmond. But the building of the Boston and Albany, and of the New York and New 


\section{Hartford}

Haven railroads cut off gradually all the inland and up-river commerce from Hartford, and diverted trade into other directions. This obliged the merchants of Hartford to turn their energies to other lines of business.

One of the most successful of these, and one in which Hartford now holds a unique position, is the insurance business. Nowhere else has the business of fire insurance reached such magnitude as in Hartford. The aggregate capital of the six fire insurance companies in the city is $\$ 10,250,000$, which exceeds one quarter of the capital of all the fire companies in the country. It is supposed that the business began in marine underwriting, as Hartford formerly had such large shipping interests and so many vessels concerned in trade with the West Indies. An insurance office was opened in Wethersfield in 1777 by Barnabas Dean, presumably for shipping. Fire insurance policies were issued in 1794 , and in 1795 a company was formed for the purpose of underwriting on "vessels, stock, merchandize, etc." In I 8 Io the oldest of the present Hartford fire insurance companies was formed,- the Hartford, with a capital of $\$ 150,000$. All the early insurance companies made the mistake 
of dividing profits in periods of prosperity, reserving little or nothing for a day of adversity. But the Hartford met with a severe lesson in December, 1835, when the great fire in New York swept away the capital of the company. All losses were paid in full, and the confidence inspired by this policy increased the business of the company fivefold. In i $87 \mathrm{I}$ the great Chicago fire endangered the existence of the strongest Hartford companies, and five of them were forced to discontinue. But the able management of the four that paid their losses and continued to do business has given the Hartford companies a good reputation. The life insurance business was also early organized in Hartford, which was the earliest place, except the already great cities of New York, Boston, and Philadelphia, to establish this system firmly, and several of the Hartford companies rank among the leading institutions in this business in the country. In Hartford was founded the first accident insurance company organized in America.

Hartford possesses a number of well-known educational and philanthropic institutions,-Trinity College: the Wadsworth Athenæum, containing the Watkinson Library of Refer- 
ence, the Connecticut Historical Society's collections, the picture gallery and public library ; the Theological Seminary, the School for the Deaf, the Retreat for the Insane; all founded in the first half of this century.

First, chronologically, comes "The American Asylum for the Education and Instruction of Deaf and Dumb Persons," the mother-school of all similar institutions in this country. In I $88_{7}$, when the recurring years brought about the one hundredth anniversary of the birth of Thomas Hopkins Gallaudet, the founder of this school for the deaf, the day was celebrated by all deaf-mutes throughout the United States, and commemorated by public services and general festivities. In a building on Main Street, now constituting the southern end of the City Hotel, the American Asylum gathered its first seven pupils, April 15, I8 I7. The starting-point of the enterprise was the eager desire of Dr. Mason F. Cogswell to secure an education for his daughter, Alice, a deaf-mute, whose infirmity was caused by an attack of spotted fever. In I8I5, several prominent gentlemen in Hartford took steps towards the organization of such a school at the instance of Dr. Cogswell, and decided to send the Rev. 
T. H. Gallaudet, then just out of the Andover Theological Seminary, to Europe, for the purpose of acquiring the art of instructing deafmutes. Accordingly, Mr. Gallaudet proceeded to Paris, where he was cordially received by the Abbé Sicard, the Director of the famous Institution for Deaf-Mutes, founded some years earlier by the Abbé de l'Epée. Here every facility was accorded to Mr. Gallaudet, and when he was ready to return to America, one of Sicard's pupils - Laurent Clerc by name,- - offered his services as an instructor in the school to be founded in America, and as he was himself a deaf-mute he was a living demonstration of the fact that a very high degree of education was possible to deaf-mutes. In I 8 I 8 , the number of pupils having increased to sixty, it appeared to the directors that their work was likely to become national, and it seemed proper to invoke the aid of Congress. A petition was accordingly sent to Congress, and was strongly supported by the Connecticut members, by the Speaker, Henry Clay, and by many other influential and philanthropic men. Congress responded by an appropriation of an entire township, comprising 23,000 acres of land. This grant was judiciously 


\section{Hartford}

converted into cash and invested, and the income thus received has enabled the institution to receive pupils at about one half the actual cost of their education. The building now in use was completed in $18_{2} \mathrm{I}$. Since I 825 pupils have been received from the States of Massachusetts, New Hampshire, Maine, Vermont, and Rhode Island, under an arrangement made with the official authorities in those States. While a large proportion of the instructors have always been college graduates, at the same time industrial instruction has, since ${ }_{1} \$_{23}$, been an essential feature in the training, thus rendering the pupils self-supporting members of society.

Another evidence of the philanthropic feeling animating the citizens of Hartford about the same date as the foundation of the Deaf and Dumb Asylum, was the establishment in I824, of the Connecticut Retreat for the Insane. At that time there were only two other institutions in the country for the exclusive care of insane persons, and the importance of restorative treatment was but little understood.

Many citizens of Hartford signed the petition 
requesting the General Assembly to pass an act of incorporation for Washington College, and when the news of its passage was received, May 16, I 823 , their joy was manifested by the lighting of bonfires and the firing of cannon. The people of Hartford surpassed all others in raising money for the new institution. Hore than three fourths of the sum appropriated by the State, \$50,000, was contributed by them, and their city was therefore selected as the seat of the College. A fine site was secured on an eminence overlooking the Little River, the hill now crowned by the beautiful State Capitol, and in I $S_{25}$ two build. ings were ready for occupation. The College was opened under the presidency of the Rt. Rer. Thomas C. Brownell, Bishop of Connecticut, and at all times since its foundation the institution has been administered by men of learning and wisdom. The name was changed in 1844 to Trinity College. In IS 7 I, when the city of Hartford decided to offer to the State a site for the new Capitol, it was proposed to purchase the College campus for that purpose and in February, 1872 , the trustees sold the grounds to the city, reserving the right to use them for five or six years. In 1873 a site of 

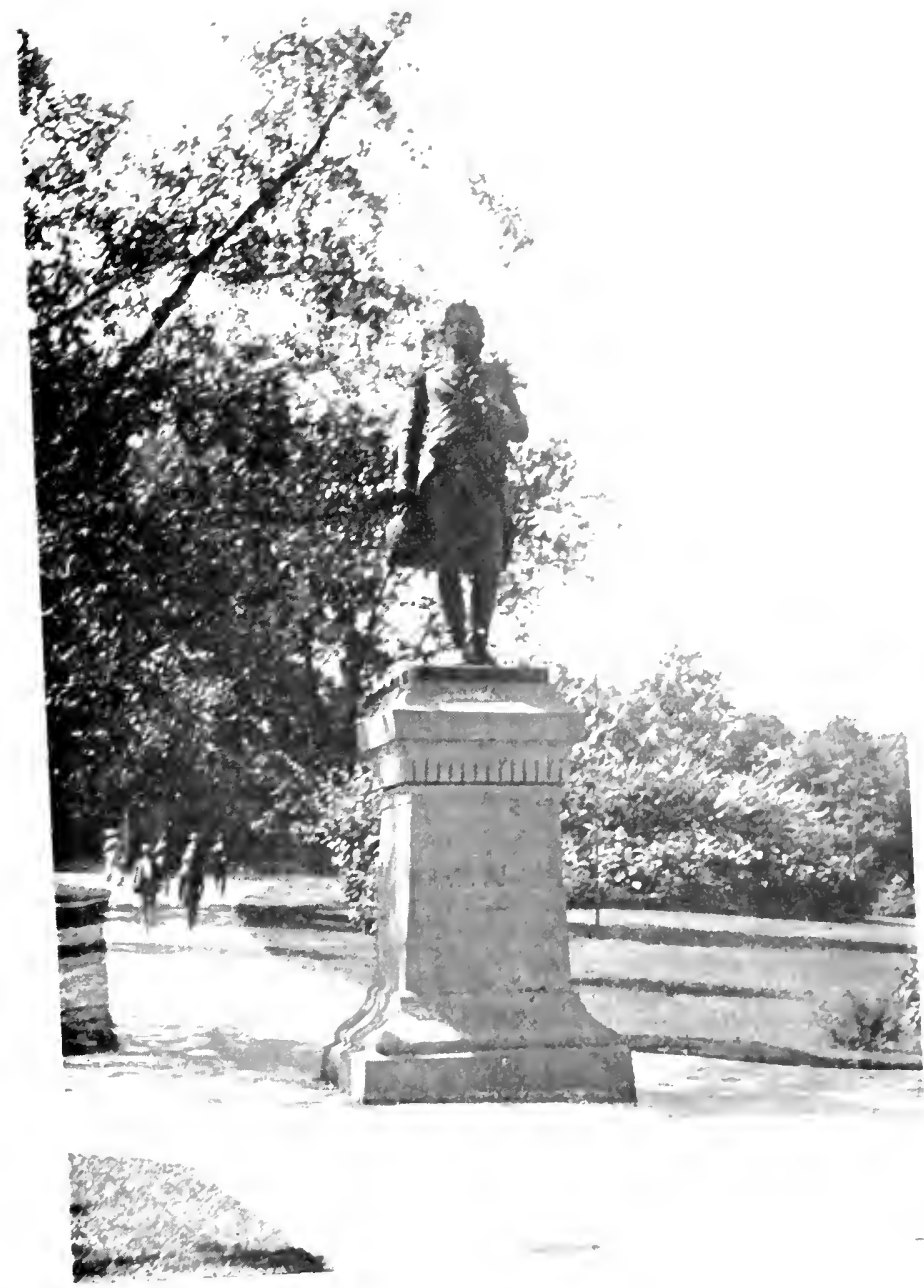

Statue OF ISRAEL PUTNAM.

J. Q. A. WARD, SCULPTOR. 
some eighteen acres on the slope of Rocky Hill, commanding a beautiful view in every direction, was purchased by the College. Ground was broken on Commencement Day, I875, with impressive ceremonies, and two large buildings were ready for occupation in I 878 . The erection of the Northam Gateway, in I $8 S_{1}$, unites the buildings and completes the western side of the proposed quadrangle. The lofty towers have added greatly to the appearance of the structure. The style of architecture is secular Gothic of the early French type.

The buildings of the Theological Seminary on Bioad Street attract attention by their size and dignity. The institution was established in East Windsor in $1_{33}$, and was removed to Hartford in 1865 , occupying the old Wadsworth house and other buildings on Prospect Street. In 1879 , the present structure was occupied, and it has since been enlarged by the addition of the Case Library.

The first great manufacturing enterprise in Hartford, and still perhaps the best known and most important, is the Colt's Patent Fire Arms Manufacturing Company, established by Colonel Samuel Colt in IS48. Colonel Colt 
planned his works on a magnificent scale, and time has proved the wisdom of his plans. To pistols, rifles, and shotguns the company has added, from time to time, the manufacture of gun machinery, Gatling guns, printing-presses, portable steam-engines, and Colt automatic guns. Aside from the output of weapons and machinery, the Colt works have been of great value as an educating force in applied mechanics, and they have turned out many men who have founded large manufacturing establishments. The armory grounds now include two memorial buildings, the Church of the Good Shepherd, built in I 868 by Mrs. Colt, in memory of her husband, and a compan-

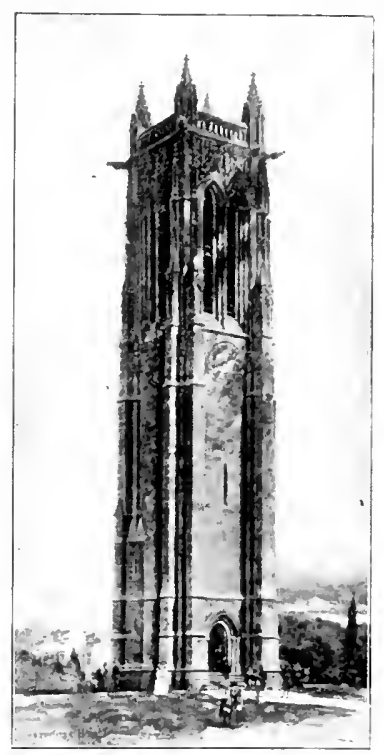

KENEY MEMORIAL TOWER. ion to this, built in 1896 , a parish house, in memory of Commodore Caldwell H. Colt, a structure complete and satisfying in all 
its decorations and appointments. Another memorial structure in the city is just approaching completion,- the Keney Memorial Tower. In this, Hartford will possess an architectural feature unique in American cities, -a Norman bell and clock tower, with fine carvings.

The Messrs. Keney have left another memorial of themselves in the Keney Park, a fine addition to the Hartford park system. The beauty of Hartford and its desirability as a residence have both been much increased by the munificence of individual citizens, and the wise policy of the city government in creating a system of public parks. The first of these, Bushnell Park, the city owes to the wise forethought of Dr. Horace Bushnell, one of her most distinguished citizens. Laid out in I 859, it is, probably, after Central Park in New York, the oldest public city park in the country, and it was obtained in the face of much opposition by a man possessed of great intellect and foresight-for whom it was named in I8;6. The building of the Capitol on the brow of the hill overlooking the Park, and the construction of the Soldiers' Memorial Arch in I 886 , have added much to its beauty and com- 
pleteness. In I 894 , Hartford acquired another park the gift of Col. Albert A. Pope, the head of the Pope Manufacturing Company. This park is situated in the south part of the city.

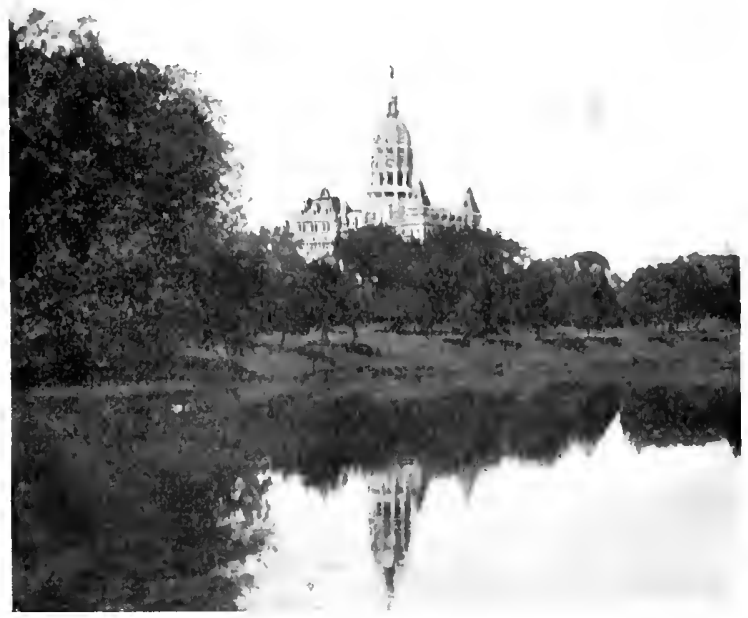

THE CAPITOL.

Very soon afterwards, by the will of Charles M. Pond, the city became possessed of a valuable tract of land on Prospect Hill, the former residence of Mr. Pond. This he desired should be called Elizabeth Park in memory of his wife. Now the Pope, Elizabeth, Keney, and Riverside Parks, the latter on the north mead- 
ows and near the city water-works, make a boulevard around Hartford, which will add much in the future to the beauty of this already beautiful city.

After the brilliant galaxy of the "Hartford Wits" disappeared, a graver class of litererary men took their places: Noah Webster, with his spelling-book and dictionary (he was born in Hartford, West Division, Oct. I6, I 758); Samuel G. Goodrich (Peter Parley); Mrs. Lydia Huntley Sigourney, who obtained the title of "the American Hemans," an almost lifelong resident of Hartford, where her first volume of poems was published in I8I5; George Denison Prentice and John Greenleaf Whittier both lived in Hartford for a time, doing editorial work, when they were yet young and unknown men; Henry Barnard, LL.D., distinguished for his labors in the cause of education, was born in Hartford in I 8 I I, and is still enjoying an honored old age in his native city. But the man of highest genius in Hartford's list of authors during the first half of this century was Horace Bushnell. He came to the city in $8_{33}$, as pastor of the North Church, and remained until his death, in 1876 . His sermons and essays all show 


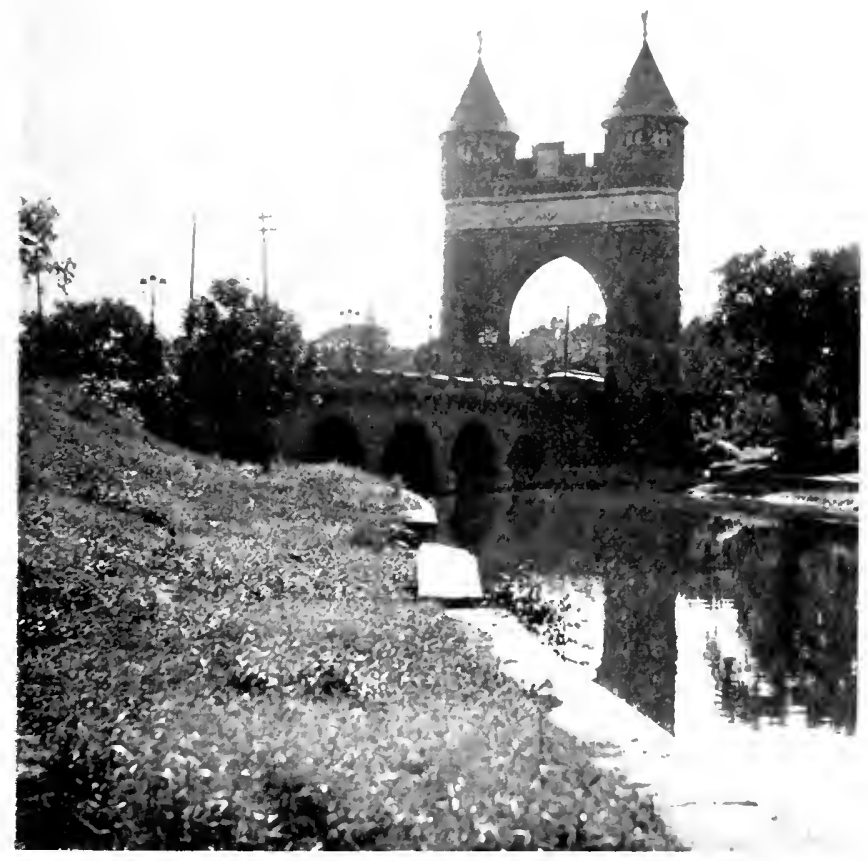

SOLDIERS' MEMORIAL ARCH. 
great imagination and beauty of style, as well as great power of thought. In I864, Mrs. Harriet Beecher Stowe, who had once before

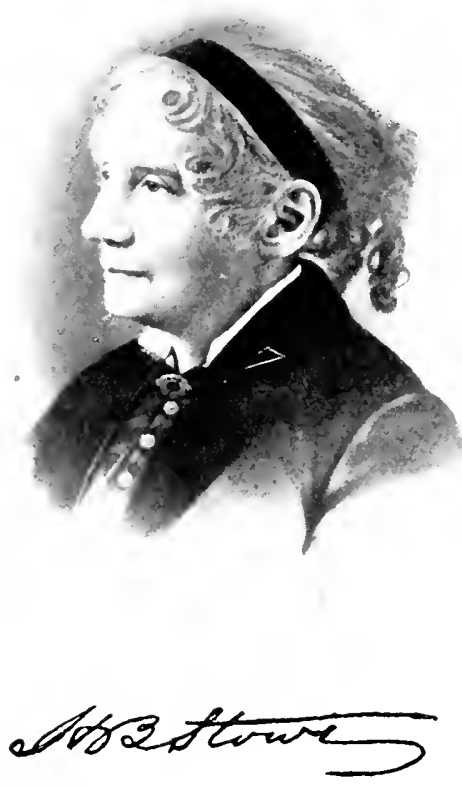

lived in Hartford as a teacher in the famous school of her sister, Miss Catharine Beecher, again took up her residence in the city, and continued to live here until her death, in 1896 . 


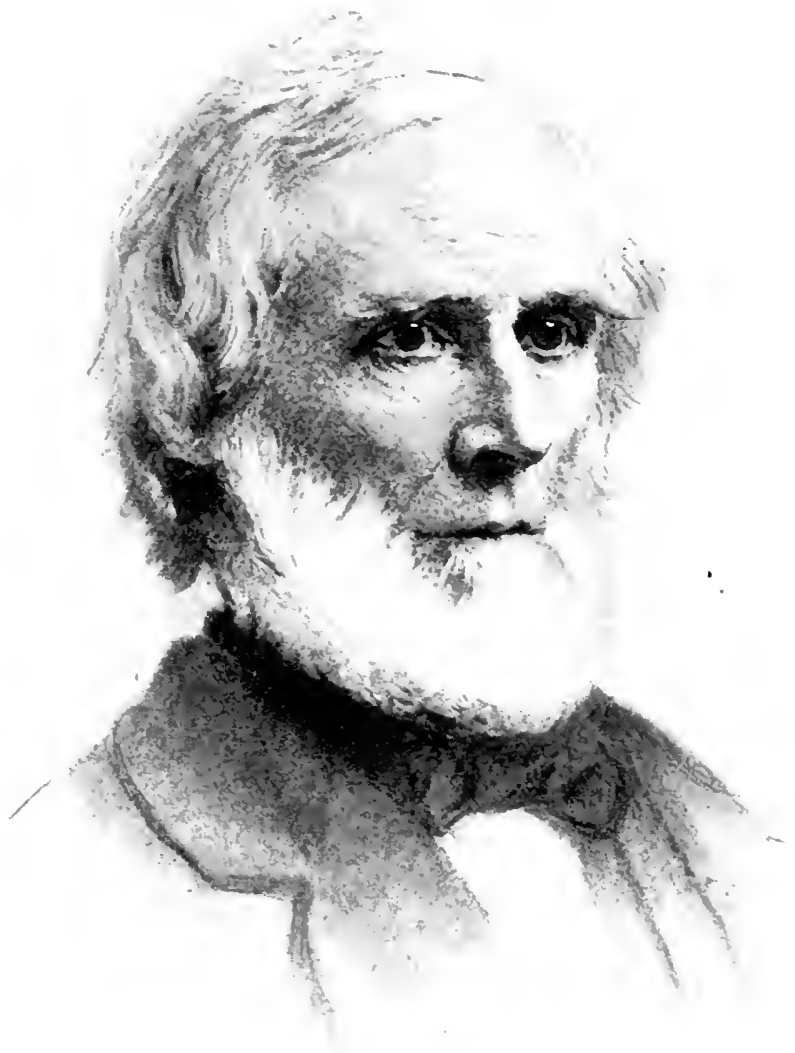

DR. HORACE BUSHNELL.

FROM A CRAYON DRAWING BY S. W. ROWSE. 
During this period a number of her later works were written.

Of living authors, Charles Dudley Warner and Samuel L. Clemens (Mark Twain) have a world-wide reputation. Mr. Warner came to Hartford in I860, as one of the editors of the Press, and subsequently became one of the owners and editors of the Courant, with which paper he is still associated. His Summor in a Garden, which first brought him into notice, appeared in the columns of his newspaper in 1870 , and since that time he has written many essays, novels, and books of travel. Mr. Clemens was born in Florida, Missouri, November 30,1835 , has lived in Hartford since I87I, and all his books which have appeared since 1872 have been written in our city, except his latest, Following the Equator. John Fiske, the historian and essayist, was born in Hartford in 1842 , but he left the city at an early age, and his reputation has been won elsewhere. The same can be said of Edmund Clarence Stedman, the poet and critic, who was born in Hartford in 1833 .

James Hammond Trumbull, LL.D., born in Stonington in $182 \mathrm{I}$, but almost a lifelong resident of Hartford, dying there in 1897 , was 


\section{Hartford}

one of the most distinguished philologists and antiquarians in the country, and his great familiarity with the Indian tongues made him an authority on that subject. Dr. Trumbull's brother, Rev. Henry Clay Trumbull, D.D., of Philadelphia, since is 75 editor of the Sunday' School Times, was a resident of our city from the year I 85 I to 1875 , and during that period he published some of his religious and biographical works. Two other members of the same family, a sister and daughter of Dr. J. H. Trumbull, Mrs. Annie Trumbull Slosson,

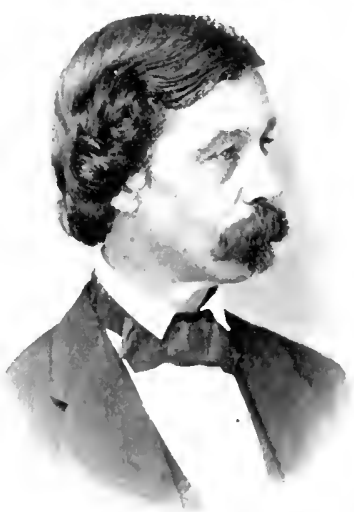

J. HAMMOND TRUMBULL, LL.D. and Miss Annie Eliot Trumbull, have distinguished themselves in literature, by their novels and short stories, some being character studies of New England life. In this line also another Hartford writer excelled, Mrs. Rose Terry Cooke, who was born in Hartford in I 827 , and died in Pittsfield, Mass., in 1892. 
She contributed many graphic stories of rural New England life to the pages of the Atlantic Monthly', Horpers', and other magazines, which stories were afterwards collected and published in book form. Richard Burton, born in Hartford in 1858 , recently appointed Professor of English Literature in the University of Minnesota, has already made a name among the younger men as a poet and critic. Frederick Law Olmsted, born in Hartford, November IO, 1822, now a resident of Brookline, Mass., is well known as one of the foremost landscape-gardeners in this country, and he has also made valuable contributions to the literature of travel and horticulture. Many other persons, either natives or residents of Hartford, have won renown in various fields of authorship. In the art world, Hartford claims Frederick E. Church and IVilliam Gedney Bunce, the painters, E. S. Bartholomew, the sculptor, and William Gillette, the actor and playwright, all natives of the city.

Hartford citizens have borne their part in the councils of the nation. Gideon Welles was Secretary of the Navy under President Lincoln during the Civil War, and until I 869. Isaac Toucey held the same office under Presi- 
dent Buchanan. Hon. John M. Niles was Postmaster-General in I 840 , under Van Buren, and also Senator for a long period. The Hon. Marshall Jewell was appointed by President Grant United States Minister to Russia in I 873 , and in $I 87 t$ he was recalled to enter the Cabinet as Postmaster General. In later years the Hon. James Dixon and General J. R. Hawley have been prominent in the United States Senate.

Hartford has increased largely in population during the last decade, and the numerous trolley lines that have been built, running like the spokes of a wheel into the surrounding country, have contributed much to the prosperity of the city. Many handsome residences have been built, new streets have been laid out, and our city appears to have entered upon a career that promises increased wealth and success.

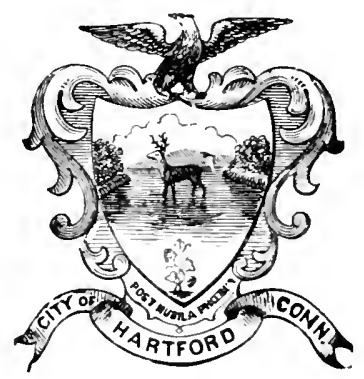


- 


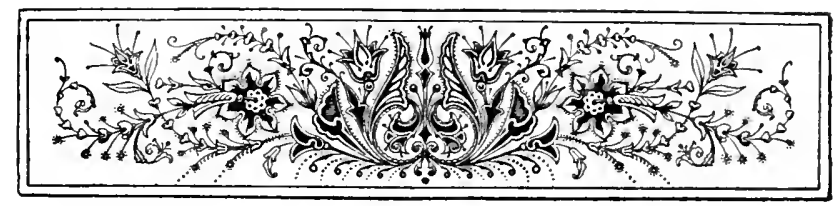

\section{NEW HAVEN}

"THE CITY OF ELMS"

BY FREDERICK HULL COGSWELL

THE main incidents in the history of New original settlement, usually a prosy affair, was brought about by the chance letter of a victorious soldier. On the 26 th of June, 1637 , a company of wealthy English immigrants sailed into Boston harbor, undecided as to its final destination. It was led and directed by Reverend John Davenport, a Non-conformist clergyman of London, and Theophilus Eaton, a retired merchant of the same town, who had once represented the British crown at the court of Denmark. The company had thought to settle near Boston, but a theological controversy that threatened to envelop the whole jurisdiction led to a change of plan, and for several months the party remained at Boston in a state of indecision. 
Meanwhile, the Pequod war was raging along the coast of Long Island Sound, and as the beaten braves were being driven westward toward the valley of the Hudson, their pursuers came upon a spot of surprising beauty. Its charms detained them long enough to note its details. There was a broad wooded plain skirted with green and fertile meadows, bounded on either side by a gently flowing river, and guarded on the north by giant cliffs. Here and there the smoke of Indian camp-fires curled gracefully above the tree-tops, and bark-canoes darted swiftly about in the placid waters of the bay. The place was occupied by friendly natives, anxious for protection against their tribal enemies. Game abounded in the forests; the streams were alive with fish; and the piles of oyster-shells along the shore told of bivalvian riches beneath the glistening waves. The English officers, elated with victory and delighted with the newly discovered land, wrote enthusiastic descriptions to their friends at Boston. As one with an eye to the material advantages expressed it: "It hath a fair river, fit for harboring of ships, and abounds with rich and goodly meadows."

The immigrants at once determined to in- 


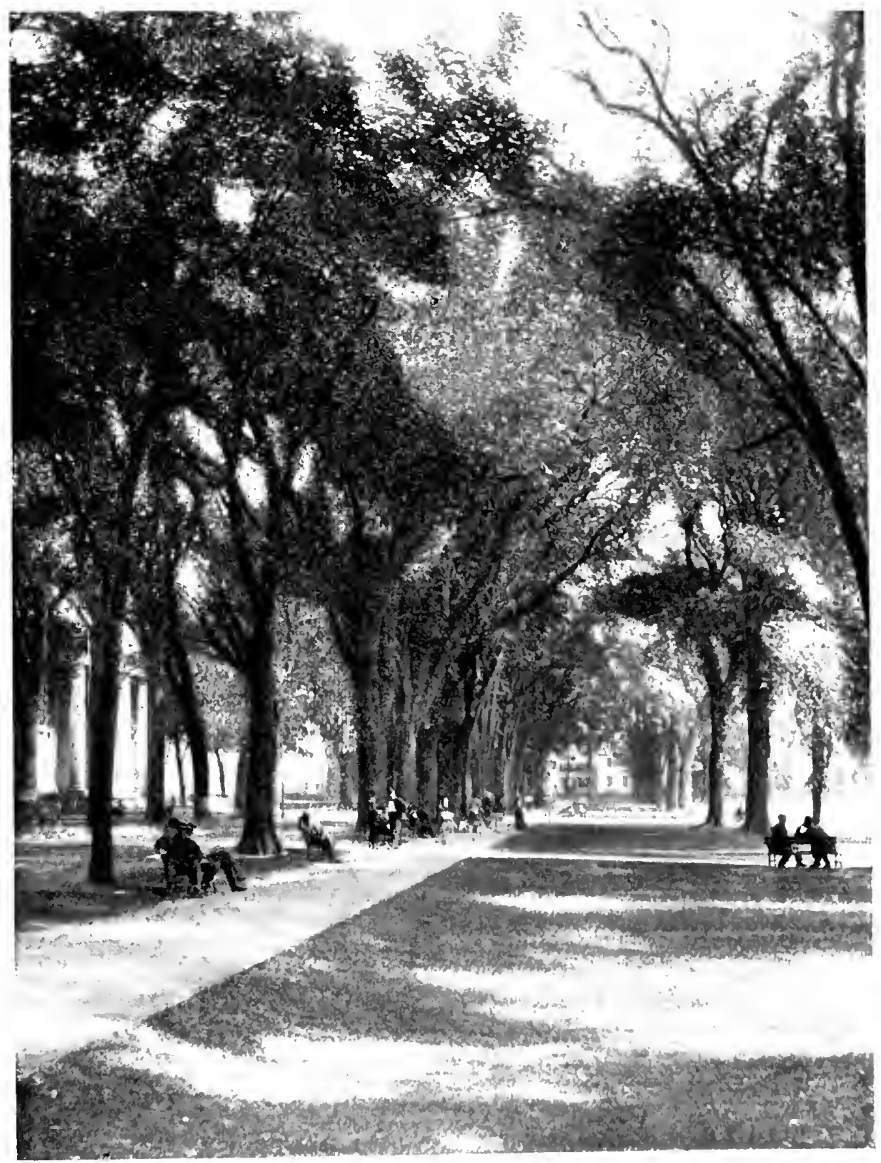

TEMPLE STREET. 
vestigate, and Eaton, taking a small vessel, sailed down the coast and into the harbor of Quinnipiac. He and his companions lost no time in deciding as to their future home. He left seven men to spend the winter with the Indians, and returned to Boston. Those who remained lived in a hut near the shore, and before spring came, one of them died. His name was Beecher, and he has been claimed as the ancestor of the Beecher family in this country. His wife and children came with the main party when the cold weather had passed. A few rods to the west of this first hut stood, in after years, the forge of Lyman Beecher's father.

It is uncertain just what name the Indians applied to the town. The early spelling varied so much that nearly forty different combinations of letters have come down to us, as representing it. It is apparent that the settlers were unable to acquire the aboriginal pronunciation, or to correctly express it in English. They finally adopted "Quinnipiac" as being more euphonious than "Quilillioak " "Quillipiage" and "Queenapiok."

It was with feelings not easily described that the newcomers sailed into the harbor and 
looked upon their future home. There they were to spend the rest of their lives, there they would be laid to rest when their earthly labors were done, and there would dwell their posterity, to represent the principles for which they had sought a new world. In the land of their birth they could not worship as they chose. Unless they followed the rule set down by others, they were not only called heretics and emissaries of the devil, but were imprisoned and fined, and subjected to

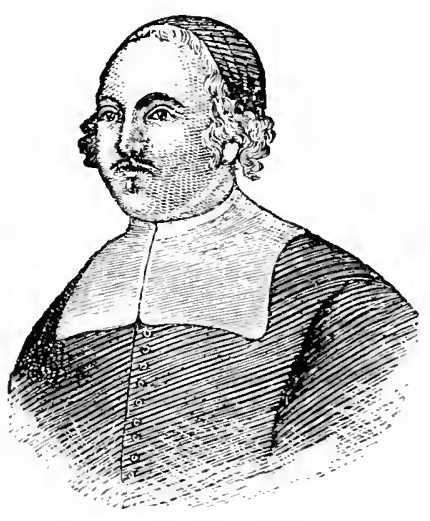

JOHN DAVENPORT.

FROM A PORTRAIT IN POSSESSION OF YALE COLLEGE. great personal indignity. They felt that they were being deprived of a natural right, and despairing of better times at home, came to find a place where they could enjoy uninterrupted the free exercise of conscience.

They were obliged for a time to live on the boat in which the voyage had been made. The first Sunday morning all came ashore to worship under the branches of an oak-tree which 
stood on the bank of a small stream that emptied into the bay. It was in the month of April, I638, and the leaves were not far forth, but under that canopy the first sermon ever heard in that region was preached. This famous tree stood for more than a hundred years after, and when it fell a tablet was placed on a near-by building to show succeeding generations where the forefathers first met for public worship.

A compact was made with the Indians, and the town was laid out by John Brockett, a civil engineer, whose love of a Puritan maiden had led him to abandon brilliant prospects of preferment and cross the seas. First, a large tract was apportioned for a market-place, then the streets were plotted in regular squares surrounding it. The dwellings ranged from mere huts to mansions of grand proportions. Eaton's house contained nineteen fireplaces, and was one of the few houses in the country where sufficient books were found to form a library.

Romance soon gave place to tragedy. An Englishman was found murdered in the neighboring woods, and an Indian so near as to invite suspicion. He was arrested and brought to the market-place. No laws had been framed, 
but an agreement had been made soon after landing, that all disputes should be settled according to Scripture. An inquiry established the Indian's guilt, but there was doubt as to the Scriptural text to apply. The Old Testament rule, "Whoso sheddeth man's blood, by man shall his blood be shed," made the outlook gloomy for the prisoner, while he saw hope in the more recent dispensation, "Go and sin no more." The Puritan forefathers leaned to the conservative view of the case, laid the Indian over a log, chopped off his head, and "pitched it upon a pole in the market-place."

The first public building to be erected, as might have been expected, was a meetinghouse. This was built near the centre of the market-place, and the present edifice stands to-day on nearly the same spot. The meetinghouse was not merely a place for public worship, but town-hall, voting-booth, court-room and forum as well. In summer it was a pleasant place in which to sit, with bird-songs and odor-laden breezes floating in through the open windows, and the long-drawn, monotonous drone of the parson's voice lulling to dreamy drowsiness. But in winter, with the mercury 
twenty degrees below zero; with tingling ears and aching nose ; with shivering frames and feet like cakes of ice, and every man's breath showing white on the frosty air, hell-fire seemed less terrible than the preacher would have it appear.

There were means, however, of getting periodically thawed. Those who lived in town could repair to their homes at the intermission, while the farmers sought their "sabbada-housen" (Sabbath-day houses). These were small huts, each containing a chimney and rude fireplace, and were grouped irregularly about the meeting-house. Here the stiffened limbs were rubbed and toasted, and the creature comforts of pies and cakes and home-brewed ale were enjoyed. Stern times were those, and many a mother saw her tender child laid away in the little burying-ground, chilled to death by the bitter cold of the meeting-house.

While the hearts of these early Puritans beat warmly, their rigid views of life and duty sometimes led to acts of great severity. Public whipping was resorted to, not only as a punishment supposed to be fit for the culprit, but as a warning and a deterrent. It is hard 


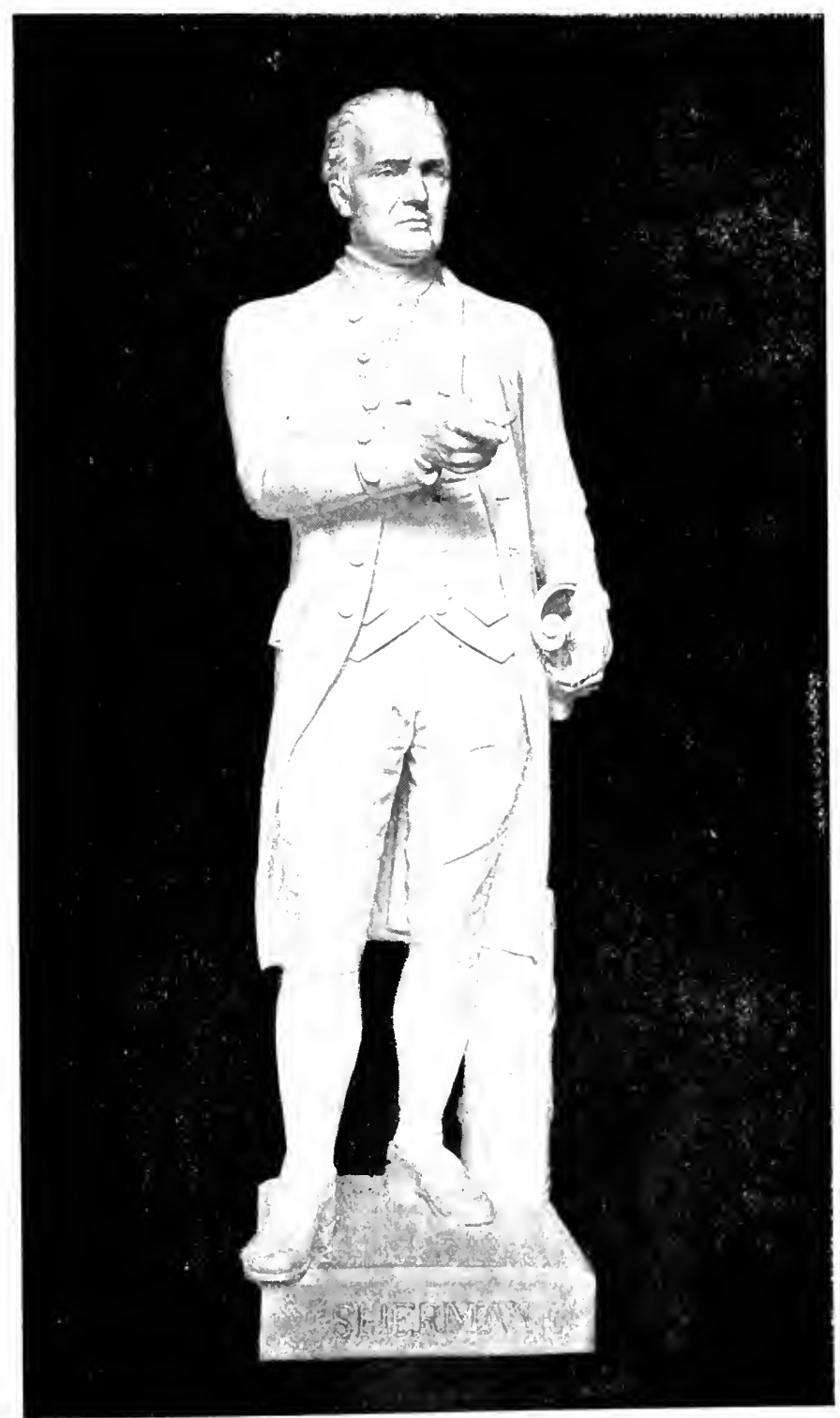

ROGER SHERMAN.

56 $\mathrm{I}$ PHOTOGRAPHED FROM STATUE ON THE EAST FRO, T OF THE CAPITOL AT HAATFORO. 
to imagine a father handing a child over to the courts for public humiliation, yet Richard Malbon, a magistrate, sat at the trial of his daughter Martha, and condemned her to be flogged at the whipping-post. The shameful performance took place on the northwest corner of the market-place, close by the schoolhouse, so that the youthful mind need not fail to understand that the way of the transgressor was hard.

The "Witch Trial" created some excitement in the early days. Elizabeth Godman was the town scold, and kept her neighbors in a state of perpetual worry. Her chief delight was in creating and perpetuating feuds. She had been warned by the magistrates that her way of life was objectionable and might lead to trouble. One day, in spite of the judicial warning, she called at Mistress Hooke's and asked for home-brewed beer. A mug was given her, but she used only part of it. The next day the whole barrel of "beare" was found to be sour. Here were symptoms of witchcraft! Soon after one of Goody Thorpe's chickens died, and when they opened it they found its gizzard full of water and worms! Suspicion began to turn to certainty. This 
led to a quarrel between Elizabeth Godman and Mistress Bishop, and in consequence the latter's baby was born dead. To cap the climax, Mr. Nash's boy had a fit of sickness that puzzled the doctors, and it was thought best, in order to prevent further calamities, to have Elizabeth Godman arrested and tried as a witch. In good old Salem her chances of escape might have been narrow; but while her judges believed in witchcraft and were ready to punish it by death, she was triumphantly acquitted, and wagged her spiteful tongue unmolested the rest of her life.

The most dramatic event in the early history of the colony was the coming of the regicides. Major-Generals Edward Whalley and William Goffe, distinguished leaders in the parliamentary army, had sat on the commission that had condemned Charles I. to the block. Both men stood close to Cromwell during the period of the protectorate, Whalley being Cromwell's cousin, and Goffe a son-in-law of Whalley. Both acted as shire governors and were close personal advisers of the Lord Protector. At Cromwell's death Goffe was consiclered a probable successor, but the monarchy was restored in the person of Charles II., and all who had 
been connected with the trial and execution of the late king were obliged to flee for their lives. Whalley and Goffe sailed for Boston and for a time lived there openly, but a royal warrant for their arrest finally came, and Governor Endicott issued orders for their apprehension. The only men in the country to whom they could look for protection were Mr. Davenport, a known sympathizer and a friend of Cromwell, and William Jones, whose father had been taken as a regicide and executed in London. The hunted men accordingly started for New Haven on horseback, arriving on the 7th of March, I66I. They went to the house of Mr. Davenport and for the next three weeks were concealed there, or across the street by William Jones. On the 27 th, the news of a proclamation for their arrest reached New Haven, and the two generals proposed some military tactics to throw possible pursuers off the scent. They accordingly appeared upon the street the next morning as travellers just arrived from the north, let their identity be known, made various inquiries concerning the town, and asked the way to Manhattan. They departed to the southward and disappeared; but on arriving at Milford, ten miles below, 
they entered the woods and returned quietly to the house of Mr. Davenport. Two weeks later, Kellond and Kirke, two officers commissioned by Governor Endicott, arrived with a warrant and called upon Deputy-Governor Leete at Guilford. There were several men in the Governor's office when the officers presented their credentials. The Governor took the papers and began to read aloud, letting out the whole secret, as he doubtless intended, so that the generals might receive warning and escape. The officers soon found that both the magistrates and the people were inclined to shield the regicides, but made desperate efforts to effect a capture. The fugitives, however, assisted by Davenport, Jones and others, eluded them at every point. Finally, after exhausting their patience and ingenuity, the officers gave up the chase and returned to Massachusetts; but offered large rewards for the apprehension of the regicides. These rewards stimulated the ambition of certain persons, and it was even more dangerous for the hunted men to appear in public, or to let their hiding-place be known. Those who were befriending them were in equal danger; for by aiding and comforting "traitors" they were 
liable to arrest and execution for the crime of high treason.

The regicides remained in the colony about two years, hiding in the houses of their friends; in an old mill just outside the boundaries of the town; in a cave on the side of West Rock; in a pile of rocks on the top; in a Milford cellar; and other places of more or less doubtful identity. The best known of these places is the pile of boulders on the extreme top of West Rock known as "Judges Cave." It is visited every year by thousands of people, who regard it as a connecting link between New Haven and the great tragedy of English history:

About the year i67o a mysterious gentleman about sixty years old, calling himself "James Davids," came to New Haven with the evident intention of spending the rest of his days in the town. He appeared to be wealthy, but no one knew anything of his past. He claimed to be a retired merchant. It is said that one Sunday while Sir Edmund Andros was attending church on the Green, he noticed a tall, soldierly-looking man in a neighboring pew, and inquired who he was. "He is a merchant residing here," was the reply. "I 


\section{New Haven}

know he is not a merchant," said Sir Edmund; "he has filled a more responsible position than that!" Governor Andros had not time to follow up his suspicions, but after the mysteri-

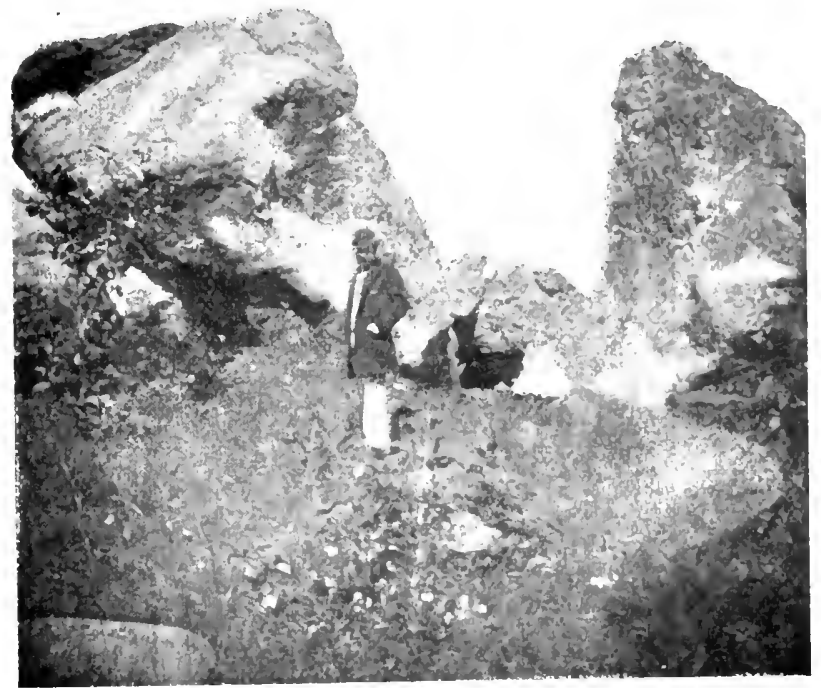

JUDGES CAVE.

ous stranger's death, twenty years later, it came to be known that he was Colonel John Dixwell, another regicide, who had fled from England to escape execution. A century and a half 
afterwards, his descendants erected a monument to his memory behind Center Church on the Green, where it is still an object of interest to visitors.

New Haven received her baptism of fire during the Revolution in the form of an invasion by a detachment of the British army, July 5, I779. The apparent purpose of this act was to cause Washington to weaken his force at West Point in order to defend the Connecticut coast. Washington attacked Stony Point as a counter-irritant, but this did not affect the British until after they were through with New Haven, which was then a village of about eighteen hundred inhabitants. The evening previous (Sunday), arrangements had been maic for a celebration of the third anniversary of the Declaration of Independence, but at ten o'clock the town was startled by the boom of a signal-gun in the harbor. All was confusion during the night, and about five o'clock Monday morning President Stiles, from the steeple of the college chapel, saw, by the aid of a spy-glass, the British fleet embarking at West Haven. A company of students formed and marched to hinder the invaders, while the beacon-fires that had been 
lighted during the night on the neighboring hilltops brought bodies of armed patriots from the surrounding towns. In spite of determined opposition, the enemy, led by General Garth, entered the town at noon and proceeded to plunder and destroy. A pitched battie was fought on the northwest corner of Broadway, but the defenders were overpowered by superior numbers. The intention of the enemy was to burn the town, but it was found that this could not be done without endangering the property of the numerous Tories. An equal number of troops ( 1500 ) landed at Lighthouse Point and approached the town from the east, the intention being to crush all opposition by a junction of the two armies, while Sir George Collier was to bombard the town from his war-ships in the harbor. It having been decided not to apply the torch, those who had entered from the west slept on the Green during the night, and toward morning embarked on the boats at the wharf, after burning much shipping. The eastern division, under General Tryon, captured Rock Fort (afterwards named Fort Hale), but were unable to enter the town. The next day they found the patriots collecting in such numbers that 


\section{0

they decided to withdraw and bestow their attentions upon the little town of Fairfield, which they burned.

A house still standing on the north side of the Green was used by the British as a hospital. Under a tree in front, Whitefield once preached to the multitude, and Jonathan Edwards used to court the daughter of the house.

Colonel Aaron Burr, then twenty-three years old, took an active part in defending the town.

Out on the Allingtown heights, to the southwest of the town, stands a monument to the memory of Adjutant-General Campbell of the British army. This officer showed such a noble spirit of humanity in the discharge of a disagreeable duty, protecting the helpless and preventing needless destruction, that the citizens of New Haven erected this stone to perpetuate his virtues. While on an errand of mercy he was shot by a young man, and on his monument are inscribed the words:

"Blessed are the Merciful."

The Dark Day, immortalized by Whittier, was the igth of May, i 780 . The Legislature was in session in the old State House on the 
Green when a sudden darkness fell. Many believed the Judgment Day was at hand. In the midst of the excitement a motion was made to adjourn, when Colonel Abraham Dav-

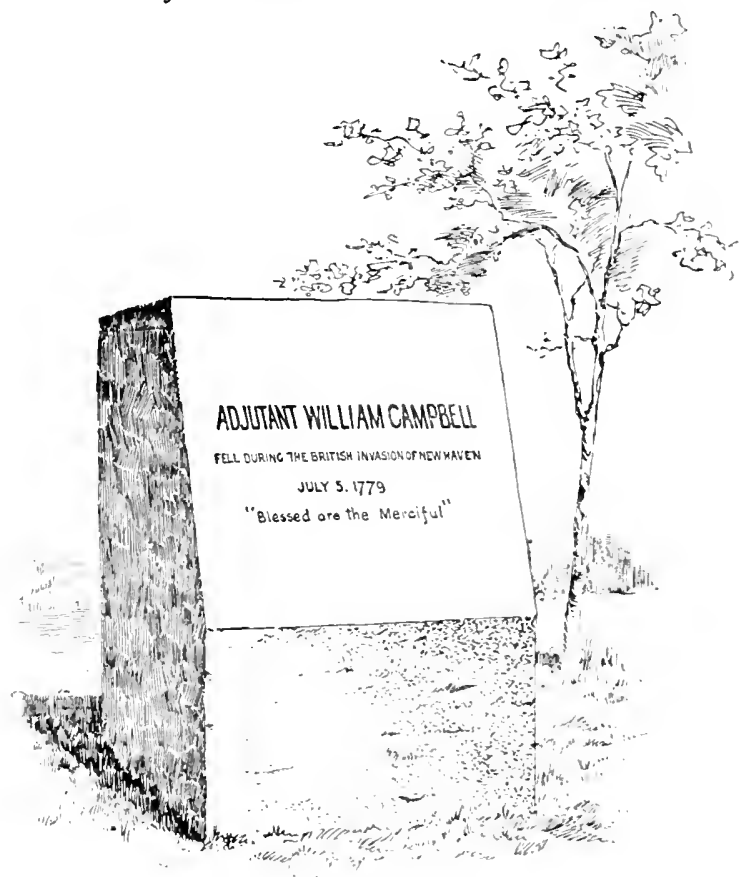

A HUMANE ENEMY.

enport, great-grandson of John Davenport, rose and said: "I am against an adjournment. The Day of Judgment is either approaching, or it is 
not. If it is not, there is no cause for adjournment; if it is, I choose to be found doing my duty. I wish, therefore, that the candles may be brought, and we proceed to business."

"And there he stands in memory this day, Erect, self-poised, a rugged face, half seen Against the background of unnatural dark, A witness to the ages as they pass, That simple duty hath no place for fear."

The foundation of Yale, the "Mother of Collegres," dates back to the colonial period, and was due to the foresight of John Davenport. Within ten years of the settlement of the town, a parcel of land was set aside and known as "college land," and as early as i654 the records of the General Court show "that there was some notion againe on foote concerning the setting vp of a Colledg here at Newhaven, Wch, if attayned, will in all likelyhood prove verey beneficiall to this place." In spite of Davenport's efforts, the project was not carried out during his lifetime, but in I664, the Hopkins Grammar School, named in honor of Governor Hopkins, was organized as a collegiate school. The work of this school being chiefly of a preparatory nature, ten Congregational ministers organized a society for 


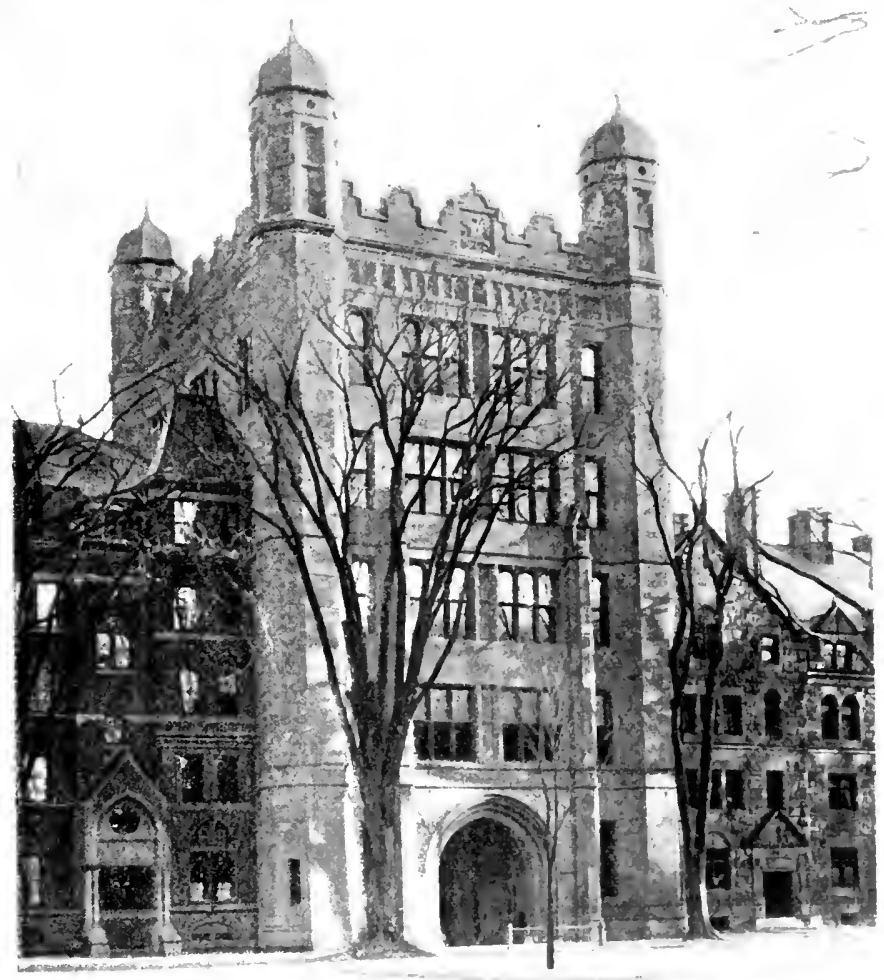

PHELPS HALL. 
the conducting of a college, and, in 1700 , this was chartered as "A Collegiate School in his Majesty's Colony of Connecticut." The first rector, or president, was Reverend Abraham Pierson of Killingworth, and the first student was Jacob Hemingway. For a time the college was settled at Saybrook, but in 1716 it was removed to New Haven. Two years later the name Yale College was adopted in honor of Elihu Yale, at that time its largest benefactor.

The college library had a unique origin. In I 700 , the ten ministers forming the society met at Branford, and each donated a few volumes, saying as he laid them down: "I give these books for the founding of a college in this colony." Forty books were given, forming the nucleus of the great University Library.

The first public commencement occurred in I $7 \mathrm{I}$, the first building having been erected the year previous. For nearly a century and a half the college had to endure a hard struggle for existence, but at the present day, owing to the donations of its graduates and friends, it ranks as one of the richest colleges in the country, and possesses some of the finest and best-equipped buildings in the world. Van- 
derbilt Hall, given by Cornelius Vanderbilt; Phelps Hall, in honor of William Walter Phelps; and Osborn Hall, in memory of Charles J. Osborn, are notable illustrations of combined utility and art. Vanderbilt Hall is not only the costliest but the most complete college dormitory in America.

The rare opportunities now offered at Yale for a wide range of study and original investigation are too well understood to need mention. In I 887, it was resolved that the college had, in view of the establishment of the various departments comprised in a university, attained to that dignity; and since that time it has been known as Yale University.

The Theological Department may be said to have existed from the beginning, theology having been one of the chief studies for a hundred years. It has existed as a separate department since I822, and the Law Department was established the same year. The Medical Department was organized in ISI2. The Scientific Department originated in $1 \delta_{+} 6$ in a professorship in agricultural chemistry and another in analytical chemistry, and since 1859 has occupied separate buildings as a distinct department. 
Yale has always been progressive in respect to the Fine Arts. On receiving the collection of Colonel Trumbull, embracing many pictures of scenes and participators in the Revolutionary War, a building was erected for their exhibition on the campus. Lecture courses were given and interest so far developed that later a large and beautiful building was erected for the purposes of an art school, which has attained great success.

Yale shows that she well deserves her reputation by more than doubling the number of her students within twenty years. The present attendance is upwards of twenty-five hundred, drawn from all parts of the world. The only aristocracy at Yale is that of brains and character, and it is a significant comment on this state of affairs to note that the sons of millionaires frequently do without the luxuries to which they are accustomed, to avoid being classed merely as rich men's sons. The Yale spirit recognizes manliness and industry as paramount qualities, and none stands higher among his fellows than the poor boy who courageously works his way through college, overcoming the obstacles that lie in his way, and maintaining an honorable rank in his class. 


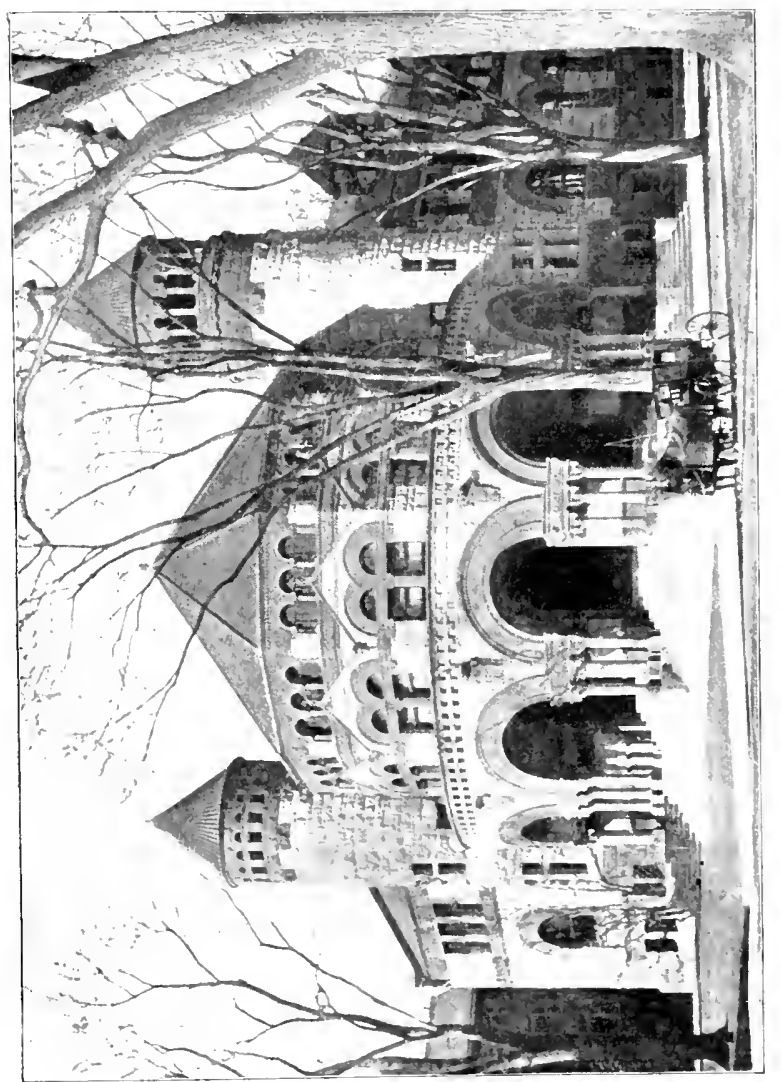

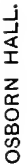


New Haven has sought to preserve memories and mementoes of her historic existence, and the Historical Society building, at the foot of Hillhouse Avenue, never fails to quicken the pulses of the antiquary. Here he finds one of Benjamin Franklin's Leyden jars ; Benedict Arnold's badly punctuated sign, his account-book, medicine chest, mortar and pestle; the table on which Noah Webster wrote the Dictionary; a silver spoon that once belonged to Commodore Isaac Hull (said to have been in his mouth when he was born); and an almost endless collection of relics, rare portraits and books.

Of famous houses, many are still standing: two of Benedict Arnold's; the dwelling of Roger Sherman, signer of the Declaration of Independence, the city's first mayor and a United States Senator; the Trowbridge house, built in 1642 by an original settler; the Noah Web. ster house and others of less interest. One of the "famous spots" is the northwest corner of Union and Fair Streets, where once stood the house of Isaac Allerton, a Pilgrim of the Mayflower. A tablet has been placed on the present building bearing the following inscription :

"Isaac Allerton, a Pilgrim of the Mayflower, and the Father of New England Commerce, lived on this Ground from 1646 till 1659." 


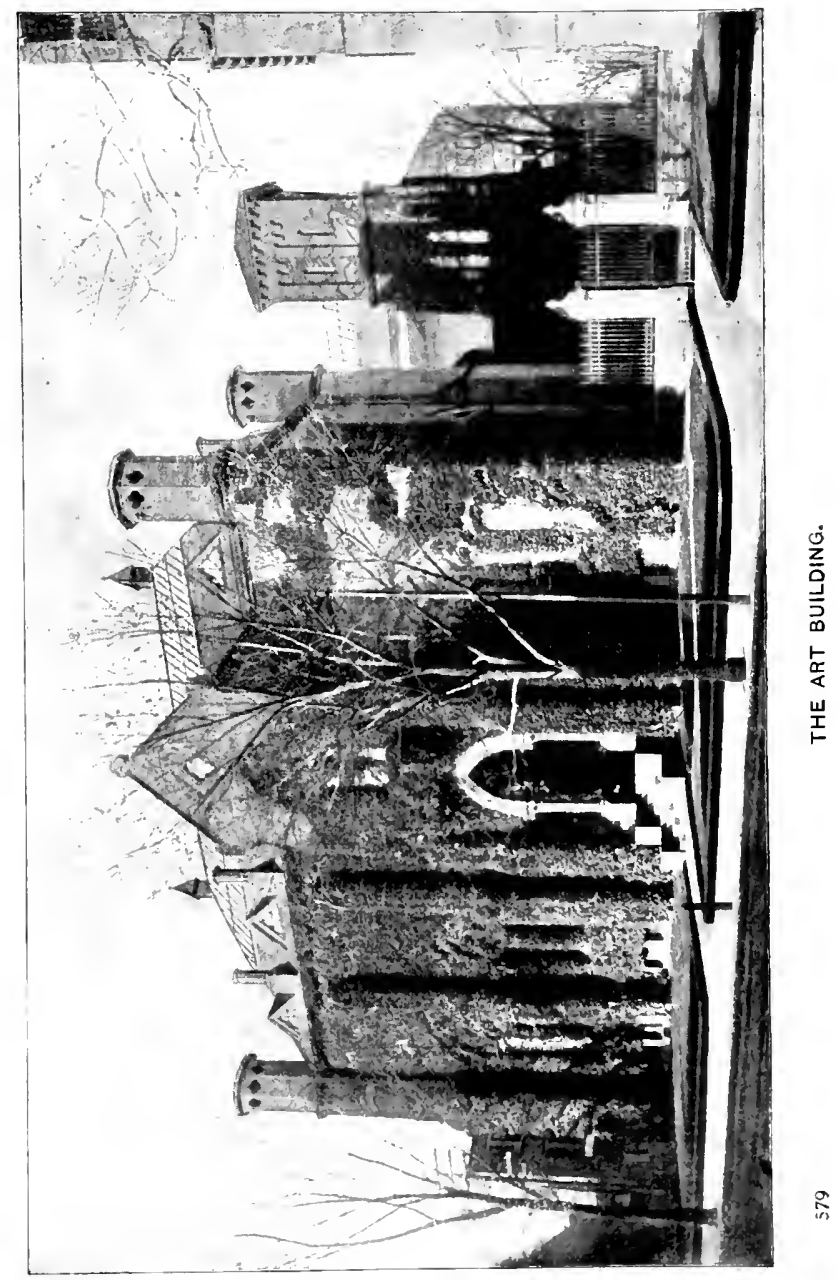


Across the way, on the southeast corner, stands an old house bearing the announcement that this was the birthplace of Andrew Hull Foote, Rear Admiral of the United States Navy.

Center Church, near the centre of the Green on Temple Street, stands over what was formerly a portion of the original burying-ground, and but a few feet from the site of the first meeting-house. From its historic associations it is one of the most interesting churches in the country. Over the principal entrance are these inscriptions:

QUiNNipiaC ChOSEN For SETTLEMENT, A.D. I637.

THE WILDERNESS ANI THE SOLITARY PLACE SHALL BE MAIE GLAD FOR THEM.

O GOD OF HOSTS LOOK DOWN FRON HEAVEN AND BEHOLD AND VISIT THIS VINE.

A.D. I639, A COMPANY OF ENGLISH CHRISTIANS LED BY JOHN DAVENPORT AND THEOPHILUS EATON IVERE THE FOUNDERS OF' THIS CITY. HERE THEIR EARLIEST HOUSE OF WORSHIP WAS BUILT A.D. 1639 .

THE FIRST CHURCH BEGINIING WITH WORSHIP IN THE OPEN AIR APRIL I 5 (O. S.), WAS THE BEGINNING OF NEW HAVEN, AND WAS ORGANIZED AUg. 22 (O. S.), 1639. THIS hOUSE WAS DEDICATED tO THE WORSHIP OF GOD IN CHRIST DEC. 27,1814 . 


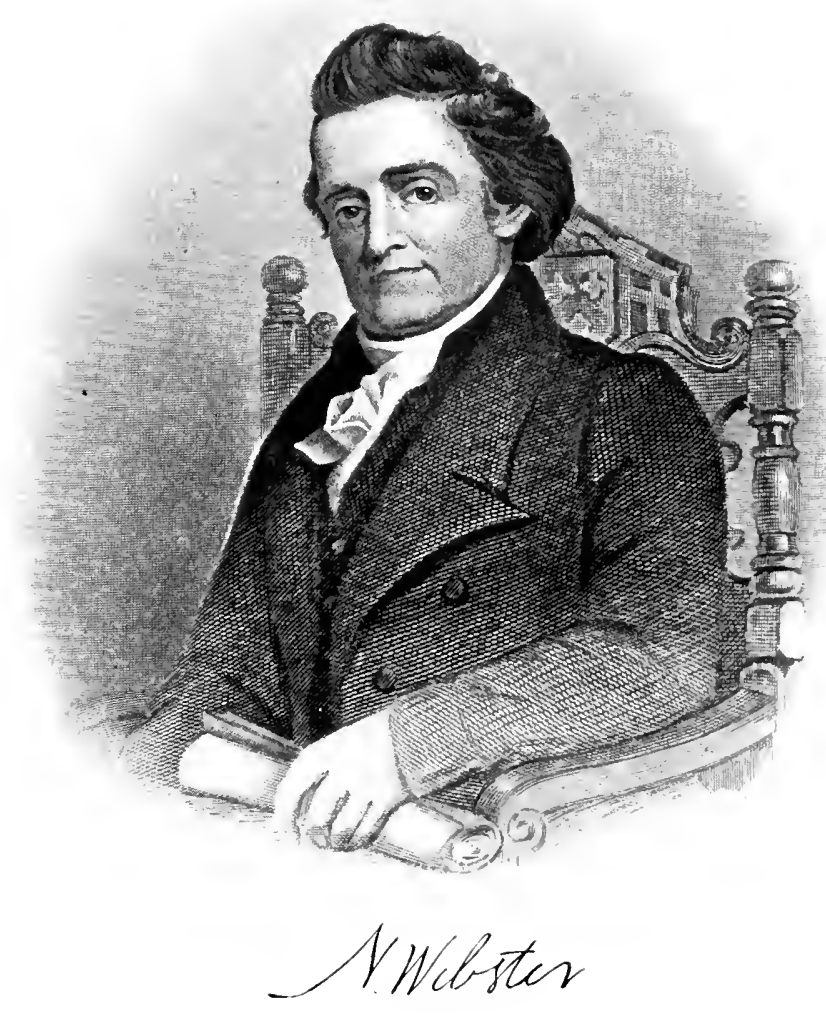

$5^{81}$ 
Dr. Leonard Bacon was for many years pastor of this church. Underneath is a crypt containing the remains and tombstones of many of the Puritan fathers and their families; and here lies the body of Abigail Pierson, sister of the first president of Yale, and wife of John Davenport, Jr.

While around and beneath Center Church " the rude forefathers of the hamlet sleep," the oldest cemetery now existing is that on Grove Street. Many distinguished sons of New Haven are buried there, among them Rear-Admiral Andrew H. Foote, General Amos B. Eaton, Admiral Francis H. Gregory, General Alfred H. Terry, Noah Webster, Lyman Beecher, Benjamin Silliman, Theodore Winthrop, Jedediah Morse (father of American geography), the elder President Dwight and President Day, Colonel David Humphreys, aide on the staff of General Washington, Eli Whitney, inventor of the cotton-gin, Jehudi Ashmun, first colonial agent at Liberia, Governors Ingersoll, Baldwin, Edwards, and many others eminent in business and professional life.

Tottering old men sometimes point to places where Nathan Hale made his great leap, where 


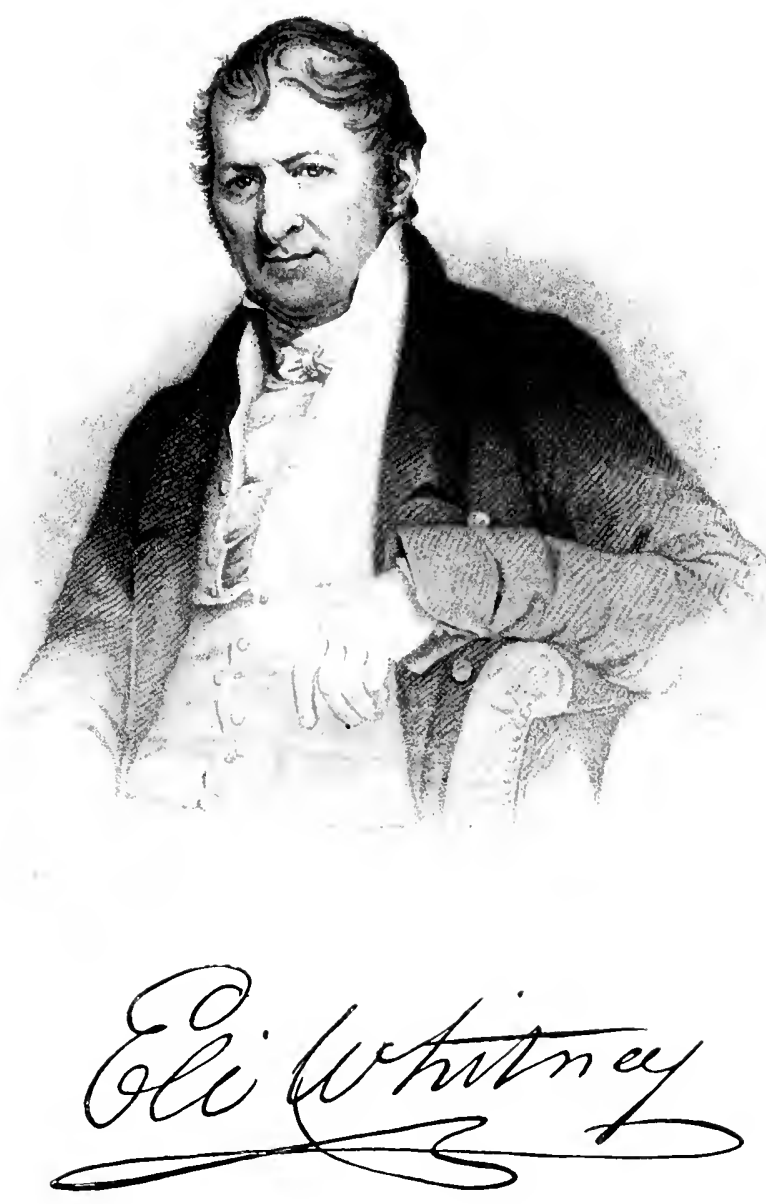

${ }_{5} 83$ 
John C. Calhoun got his boots made, where Joel Barlow ate his hasty pudding, the porch where Commodore Hull liked to sit; and tell no end of stories about visits of Lafayette, James Monroe and "Old Hickory." These are innocent chroniclers, forgetting the present in the glorious past, and we must allow a little for the play of the imagination; but when they aver that Noah Webster, as a lieutenant commanding a company of Yale students, once escorted General Washington through the town and received a compliment therefor, an approving nod is in order, for the great lexicographer recorded the incident in his diary "at the day and time of it."

Visitors frequently refer to the city as an overgrown village. It is hard for a New York man to realize as he strolls through the ample grounds of his New Haven friends, that he is in a city of more than one hundred thousand inhabitants. The value put upon breathingplaces is shown in the large tracts of land devoted to public purposes. One walks hardly ten minutes in any direction without coming upon a square shaded by graceful elms and carpeted by a cleanly shaven lawn; while the margins of the city by river and sound 


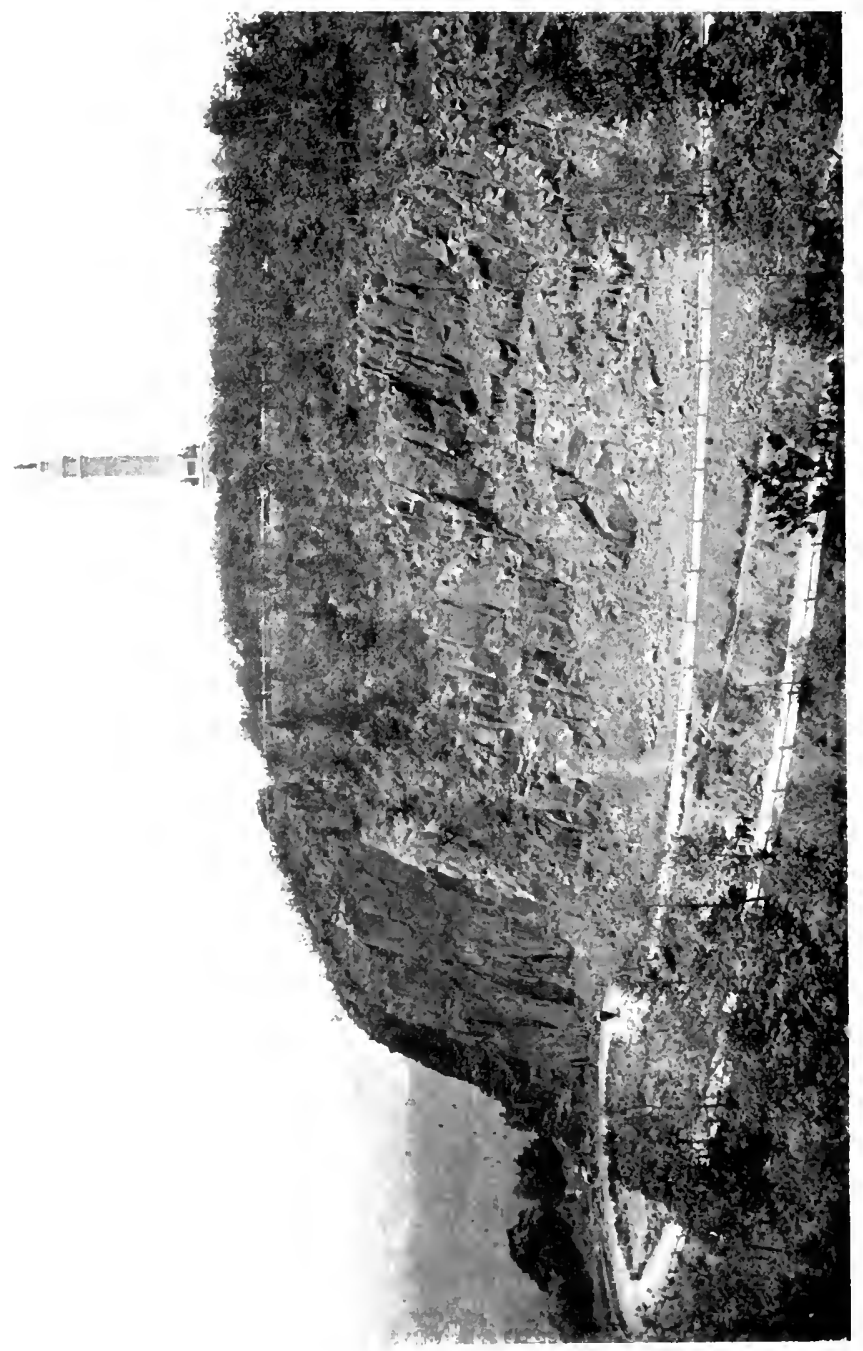

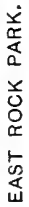


abound in tastefully arranged parks. The transformation of the two great wooded ridges beyond the dwelling-line into well-graded drives, art vying with nature to please the eye and win the soul to beauty, completes the impression sometimes expressed, that New Haven is an immense village encircled by gardens.

But while all this may suggest a condition of dreamy repose, the city is by no means given over to dolce far niente. The University with its manifold departments is a veritable hive of industry; the scales of Justice at the County Court House are tipping endlessly in favor of right against wrong; while the busy hum of the Winchester Arms and a hundred other mills, makes a music that dies not out.

Altogether, historic New Haven is a pleasant place in which to live, and its hospitality is as generous as are its gardens and its parks.

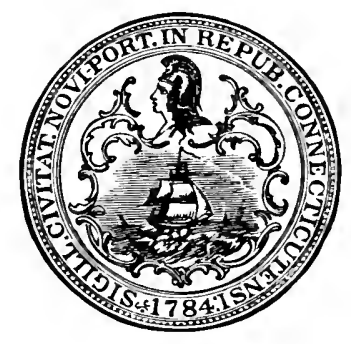




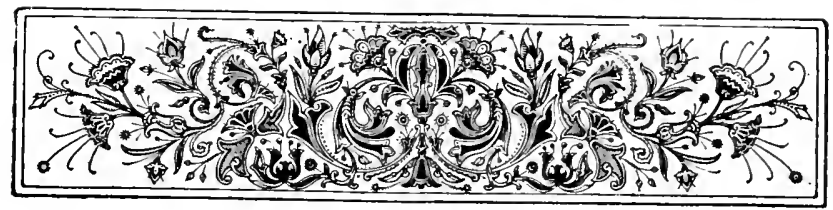

\section{INDEX}

A

Acton, Mass., 262, 266, 272, 294

Adams, John, 49, I87, 228, 524 . 526

Adams, Samuel, 12, ISO, 200, $202,228,259,261,264,265$

Agassiz, Louis, I76, 242

Akers, Paul, 78

Albany, 532

Alcott, A. Bronson, 279, 292, 293, 294

Alcott, Louisa, 294

Alden, John, 328, 334

Alden, Priscilla, 328

Alden, Rear-Admiral, 66

Aldrich, Thomas B., 50, 176

Allen, Samuel, 429

Allerton, Isaac, 578

Allston, Washington, 236

Alsop, Richard, 527

Amherst College, 82

Amsden, John, 429

Amsterdam, 310

Andover, Mass., I44

Andrew, Gov. John, 265

Andros, Sir Edmund, 334, 419, f20,518, 519, 566, 567

Ann, Cape, 126, 127

Anne, Queen, 420, 449, 523

Appleton, Capt. Samuel, 4 I2
Apponaug, R. I., 486

Aquidneck, 447

Arlington, Mass., 2 I9

Arnold, Benedict, 578

Arnold, Fred. A., 206

Arnold, Matthew, 50

Arnold, Thomas, 482

Ashley, Rev. Jonathan, 428, 438

Ashmun, Jehudi, 5\$2

Austerfield, 304, 306, 332

Austin, Jane Goodwin, 50, 330

B

Bacon, Dr. Leonard, 5 IO, 582

Bacon, Francis, 140

Bacon, John, 407

Baker, Miss C. Alice, 426

Baldwin, R. S., 582

Bancroft, George, 50, 89,$2 ; 6,5 \mathrm{I}+$

Bardwell, John, 436

Bardwell, Thomas, 435

Barlow, Joel, 525, 526, 527, $5^{8} 4$

Barnard, Henry, 30, 544

Barnard, Rev, Mr., I5f

Barnstable, Mass., $376,38 \mathrm{I}, 388$, $389,393,394,397,400$

Barnstable County, Mass., 36I, 393

Barre, Mass., 106

Barrett, Col. James, 273, 276 
Bartholomew, E. S., $55^{\circ}$

Bartol, Cyrus, 78

Bates, Katharine Lee, 345

Bedford, Mass., 219, 266

Bedfordshire, 244, 246, 247

Beecher, Catherine, $8,54^{6}$

Beecher, Henry Ward, 8, I I

Beecher, Lyman, \&, 556, 582

Beers, Capt. Richard, 4 IO, 412

Bellingham, Gov. Richard, I4 I

Bemnington, Vt., 265, 436

Bentham, Jereny, 279

Bentzon, Th., 33

Berkeley, George, 450, 45 I, 452, $454,455,458,505$

Berkeley, Lucia, 455

Berkeley, Mrs. George, 45 I

Beverly, Mlass., 92

Billerica, Mass., 2 I9

Billington, John, 377

Blackstone, Sir William, I40

Blaine, James G., 78

Blanchard, Claude, $460,461,462$

Block, Adrian, 5 I 5

Block Island, 446

Borgeaud, Charles, I 7

Boston, 23, 58, 64, 81, 82, 84, 86, $94,96,98$, Iо2, го6, I I I, I I 3 , $141,143,144,149,159,167-$ $210,230,234,248,256,259$, $262,271,277,278,289,294$, $329,364,374,377,388,392$, $419,434,44 I, 45 I, 484,486$, $494,497,498,505,507,518$, $519,524,525,526,532,534$, $553,556,564$

Boston, England, 207, 250

Boston College, i 80

Boston University, I80

Bourne, Mass., 380, $38 \mathrm{I}$

Bourne, Richard, 379

Bowditch, Nathaniel, I 59

Bowdoin College, 76

Brackett, Thomas, 56

Brackett, Mrs. Thomas, 56

Bradford, Gov. IVilliam, 49, I24, I 3 I, I 32, I 34, 299, 303, 304, $306,308,309,311,314,3$ I5,
$316,317,319,324,326,329$, $334,346,351,352,353,354$, 377

Bradley, Rev, Caleb, 75

Bradstreet, Simon, 124, I 25, I40, $216,217,219$

Braintree, Eng., 217, 21 8

Branford, Conn., 574

Brewster, Mlass., 380, 391,384

Brewster, Nathaniel, 340

Brewster, William, 299, 304, 308, $309,311,317,322,328,329$, 334,336

Bridgham, Samuel IV., 498

Brighton, Mass. , 2 I 9

Brimfield, Conn., 532

Brindley, Deborah, I Io

Bristol, R. I., 492

Brockett, John, 558

Brookfield, Mass., 20, I05, I I 7

Brookline, Mass., 204, 550

Brooks, Phillips, Io, I I, 26, I 84

Brown, Alice, 5o

Brown, Chad, $478,480,48_{5}, 492$

Brown, Charles Farrar, 78

Brown, H. B., 79

Brown, James, 49I

Brown, John, 492, 494, 497, 502

Brown, Joseph, 492

Brown, Mloses, 492, 495

Brown, Nicholas, $49^{2}$

Brown University, 49I, 499

Browne, Nathaniel, 486

Browne, Rev. Robert, I13

Brownell, Thomas C., 538

Brunswick, Me., 75

Bryce, James, I 2, I 5, 33

Buchanan, James, $55 \mathrm{I}$

Bucks County, Eng., 247

Bulkeley, Rev. Peter, 243, 244, $246,247,248,249,25$ I, 253 . 268, 270

Bunce, William G., $55^{\circ}$

Bunker Hill, 58, 109, 204, 206, 232, 260, 261, 300, 435, 492

Bunyan, John, 246,28 I

Burgoyne, Gen. John, I12, 210 , $234,238,436$ 


\section{Index}

Burnet, Jacob, 96

Burns, Anthony, 173

Burr, Aaron, I I 2, $57^{\circ}$

Burroughs, Rev. George, 57, I44

Burton, Richard, 550

Bushnell, Dr, Horace, 9, I I, 542, 544

Buzzard's Bay, 345, 402

\section{C}

Cabot, George, 530

Cabot, John, 514

Cabot, Sebastian, 5I4

Cady, Jonathan, 496

Calhoun, John C., 584

Calvin, John, 253

Cambridge, Eng., 220, 308, 309

Cambridge, Mass., I $40,181,204$, 208, 2 II-242, 248, 259, 260, $27 \mathrm{I}, 435,511,512$

Campbell, William, 570

Canaan, Conn., 532

Canning, George, 525

Canonicus, 476

Cape Cod Towns, 345-402

Carlisle, Mass., 266

Carrington, Edward, 495, 502

Carver, John, 312, 317, 326, 336, 346,352

Casco, Me., 56

Casco Bay, 66, 75

Castine, Baron, 420

Chandler, Lucretia, I Io

Channing, Rev. IV. Ellery, 8, I I, 279, 280, 282, 505

Chantavoine, 284

Charles I., 563

Charles II., 39I, 508, 563

Charlestown, Mass., I 36 , I fo, I 4 I, I $68,204,207,215$

Chase, Salmon, 76

Chatham, Mass., 381,382

Chauncy, Rev. Charles, 227

Chelmsford, Mass., 266

Child, Lydia M., I 76

Childs, Samuel, 435

Church, Frederick E., $55^{\circ}$

Church, Major, 57
Clark, Francis E., 8, I I

Clark, Rev. Mr., 26I, 262

Clarke, Captain, 7o

Clarke, John, 319, $48 \mathrm{I}$

Clay, llenry, 536

Cleeves, George, 56, 57

Clemens, Samuel L., 548

Clerc, Laurent, 536

Clifford, Nathan, 76

Clyfton, Richard, 299, 304, 307

Codman, Charles, 79

Cogswell, Alice, 535

Cogswell, F. H., 553

Cogswell, Mason F., 527, 535

Coke, Edward, I 40

Cole, Charles O., 79

Collier, Sir George, 569

Colt, Caldwell H., $5+1$

Colt, Col. Samuel, 540

Colt, Mrs. Samuel, $5+$ I

Conant, Roger, 126, 127

Concord, Mass., 7, 49, 106, 164, 204,2 I $9,232,243-297,434$

Conway, Mass, 431

Cooke, Rose Terry, 50, 549

Coolidge, Susan, ++3

Cooper, J. Fenimore, 279

Copley, John S., 339

Corey, Giles, 144,146

Corey, Martha, I $4+, 145$

Corliss, George H., 500, 501

Cornbury, Lord, 420

Cornbury, Nathaniel, 412

Corwin, Jonathan, 138,142

Cotton, Rev. John, 218, 248, 249,250

Coverly, Nathaniel, 336

Cowper, William, 246, 247

Cromwell, Oliver, 247, 261, 312, 563,564

Crowninslield, Benjamin W. I 58

Crowninshield, George, I 56, I 58

Cumberland County, Me., 76

Curtis, George WV., 49, 280

Cushman, Robert, 334

Cutler, Manasseh, 27, $44,90,92$, 93. 94 , I I 5 
D

Dalton, Richard, 45O, $45^{\mathrm{I}}$

Dana, Richard, 236

Dane, Nathan, 27,87,90, 92

Danvers, 92

Danvers Centre, I 39

D'Anville, Admiral, Igo, I gr, I92, I94, I95

Dartmouth, Eng. . 316

Davenport, Abraham, 57 I

Davenport, John, 553, 564, 565 , $571,572,580$

Davenport, John, Jr., 582

Davenport, Lieutenant, 70

Davison, William, 309

Day, Jeremiah, 582

Daye, Stephen, 24I

Dean, Barnabas, 533

Dedham, Mass., 219, 404, 406, 407

Deerfield, Mass., 84, 403-442

Delfthaven, 3 I 5, 332

Dennis, Mass.. 3 So, 38I, $3^{8} 4$, 391

Derby, Conn., 526

Detroit, 524

Devon, 380

Dexter, Gregory, $478,480,485$

Dickinson, David, 433

Dickinson, Thomas W., 438

Diman, Rev. J. L., 480

Dixon, James, 55 I

Dixwell, Col. John, 567

Doane, Deacon, 379

Dokeshury, Eng., 3I 2

Donitson, Daniel, 430

Dorchester, Mass., 96, I 40, 5 I I

Dorchester Heights, 208

Dorr, Sullivan, 502

Dorr, Thomas IV., 500

Dow, Neal, 64

Dowse, Thomas, I 8 I

Drake, Sir Francis, $34^{8}$

Duddingston, Lieutenant, 492

Dudley, Gov. Thomas, 216, 217 , 219,422

Dunster, Rev. Henry, 227
Durfee, Thomas, 478

Duxbury, Mass., 328

Dwight, Theodore, 527

Dwight, Timothy, $278,366,523$, 582

Dyre, Mary, 484

\section{$\mathrm{E}$}

Eastham, Mass., 352, 368, 374, $376,377,378,379,380,381$, 388,400

Eaton, Amos B., $5^{82}$

Eaton, Theophilus, 553, 556, $55^{8}, 5^{80}$

Edinburgh, I74

Edwards, Governor, 582

Edwards, Jonathan, 7, II, 290, 523,570

Eggleston, James, 4I I

Eliot, C. W., 30

Eliot, John, 334, 403, 404

Eliot, Samuel A., 2 I I

Elizabeth, Cape. 56

Elizabeth, Queen, 309, 312

Elwell, J. D., 297

Emanuel College, 2 I 9, 224

Emerson, Kalph IV., 7, II, 49, I $76,246,250,25 \mathrm{I}, 267,268$, $270,278,279,280,281,282$, $284,285,286,289,29 \mathrm{I}, 293$, 294, 339

Emerson, Rev. Mr., 270, 274, 275

Endicott, John, I23, I 24, I26, I 27, I 28, I 29, I 30, I 3 I, I 32, I4O, I4I, I 52, I $56,216,564$, 565

Essex, Eng., 217

Essex County, Mass., 148, 277 . 413,414

Evans, George, 76

Everett, Edward, r 80, 227, 236

\section{F}

Fairfield, Conn., 570

Falmouth, Nass., 345, 36I, 393, $394,396,400,402$

Falmouth, Me., 56, 57, 58, 60,6I 
Farrar, Charles, 78

Faunce, Elder, 330

Felt, Capt. John, I 54

Felt, Rev. J. B., I 28 , 162

Fern, Fanny, 75

Fernay, Chevalier de, 460

Fessenden, William Pitt, 76

Field, Col. David, 433

Fields, James T., I62, I 76

Fisher, Lieutenant, 407

Fiske, John, 50, 106, 2łI, 508, $54^{\mathrm{S}}$

Foote, Andrew Hull, 58o, 5S2

Fox, George, $4 \mathrm{~S}_{7}$

Foxe, Edward, 303

Franklin, Benjamin, 93. 94, I So, $253,257,256,258,470,490$, $505,526,578$

Frary, Samson, 408

French, Daniel C., 297

Frink, Rev. Thomas, ios

Fuller, Dr., I 32

Fuller, George, +37

Fuller, Margaret, 236, 2 so

\section{G}

Gage, Gen. Thomas, 152, 206, 2 IO, 228, 434, 522

Gallaudet, Thomas H., 535, 536

Garfield, James A., 84, 97

Garrison, IVilliam L., I so

Garth, General, 569

Gates, Gen. Horatio, 270

George III., I 95, 202, 256, 270

Gerry, Elbridge, 23I

Gilibs. James, 480

Gill, Mass., 431

Gillette, William, 550

Gladstone, William E., 253

Gloucester, Mass., 363, 370

Goddard, William, $49^{6}$

Godman, Elizabeth, 562, 563

Goethe, Johann Wolfgang, 293

Goffe, William, +II , 563, 564

Good, Sarah, I 41,143

Goodrich, Chauncey, 530

Goodrich, S. G., 532, 544
Gosnold, Bartholomew, 348

Granby, Conn., 532

Grand Manan, I94

Grant, Ulysses S., 55 I

Gray, I 56

Gray, Asa, 242

Grayson, William, 89

Greele, Alice, 6I, 62

Greene, Nathanael, 214, 47 I

Greenfield, Mass., 43I

Greenleaf, Simon, 76

Gregory, Francis H., 582

Griggs, Dr., I 40

Groton, Mass., $2+6$

Guilford, Conn., 565

\section{H}

Hadley, Mass., $411,413,416$

Hale, Edward Everett, 92, I 17 , I 76,185

Hale, Natthew, I to

Hale, Nathan, 5\$2

Halifax, 195

Halifax Bay, 195

Hamilton, Mass., 92

Hampden, John, 247, $25 \mathrm{~S}$

Hancock, John, I72, 22S, 259. $261,264,265$

Hancock, "Lady," I 72

Hand, Daniel, 29

Hannibal, 265

Harlakenden, Roger, 220

Haroun Al-Rashid, 28I

Harrington, Jonathan, 264

Harris, William, iss

Harris, IV. L., 96

Harris, W. T., 30, 31, 294

Harrold, Eng., 247

Hartford, 9, 92, 140, 219, 456, 507-55 I

Harvard, John, 224, 226

Harvard University, 24, I 06,150 , $222,224,226,228,242,259$, $260,275,340,429$

Harwich, Mass., $361,381,382$

Hatfield, Mass., $413,+16,+17$

Hawkshurst, Eng., 244 
Hawley, J, R., 55 I

Hawthorne, John, I 42

Hawthorne, Nathanie], $7,9,50$, 75, I $25, \mathrm{I} 2 \mathrm{~S}, \mathrm{I} 56, \mathrm{I} 59, \mathrm{I} 60$, I62, 172, 275, 279, 252, 284 . 255

Hayes, Rutherford B., 100

Haynes, Gov. John, 2 I7, 5 II, $5 \mathrm{I} 4$

Hemingway, Jacob, 574

Hendery, fndrew, in

Herbert, (jeorge, $3 \mathrm{I}_{7}$

Hertford, Eng., 514

Hibbins, Ann, IfI

IHigginson, kev. Francis, 132, $133,131,138$

Higginson, Rev. John, I 24

Higginson, Thomas $1 \mathrm{~F}, 32,167$, $23^{6}, 2+1$

IHill, Thomas, 78

Hillhoure. James, 530

Hinsdell, Samuel, 408

Hoar, George F., s6, 58, 89, 93 . $94,96,97,98,100,103,116$, II 7 , IIS

Holden, Mass., I o6

Holmes, John, 236

Holmes, Oliver W., 40, 50, I76, I $75,2 \mathrm{~J}, 227,232,236,24 \mathrm{I}$

Holmes. Rev. Abiel, $4^{\mathrm{S} I}$

Holyman, Rer. Mr., 4 so

Holyoke, Capt. Samuel, 4 I 7

Ioneyman, Rev. Mr., $4+9$

Hooker, Rev. Thomas, 2I 7, 21 8 , $219,507,510,512,514,521$

Hopkins, Dr. Lemuel, 5 25

Hopkins, Dr. Samuel, 8

Hopkins, Esek, 502

Hopkins, Governor, 572

Hopkins, Stepher, 490, 494, 502, 505

Howe, General, I g6, 202, 206

Howe, Julia Ward, I 76

Howells, William D., I76, 2+1

Hubbard, Rev. William, 2 i 8

II ubbardston, Mass., 8:, 106

Hudson, Henry, $34^{8}$

IIudson, J. B., 79
Hull, Isaac, $578,5 s_{4}$

I Iumphreys, David, 525, 526, 582

Iluntingdon, $2+7$

IIutchinson, Anne, 220, 248

Iutchinson, Gov. Thomas, I44, 148

\section{I}

Ingersoll, Governor, $5^{52}$

Ingraham, J. H., is

Ipswich, Mass., 92, 2 I 9

lrving, Washington, 81, 279

Ives, Thomas P., 502

\section{$\mathrm{J}$}

Jackson, Andrew, 364,584

Jackson, Lydia, 339

Jacobs, George, I 24

James, Sir John, $45^{\circ}, 45^{\mathrm{I}}$

James I., 3I 4, 3 I 5

Jefferson, Thomas, 16, 89, 90, $253,257,258,286,526$

Jewell, Marshall, 55I

johnson, Dr. Samuel, I 76

Johnston, Alexander, 507

Jones, Capt., 328

Jones, Rev. John, 246

Jones, William, 564, 565

Judson, Adoniram, 340

Jumel, Betsy, i I 2

Jumel, Stephen, I I 2

\section{$\mathrm{K}$}

Kellogg, Elijah, 7s

Kendal!, Rev. James, 332

Kent, Chancellor, 244, 380

Killingworth, Conn., 574

King, Rufus, 90

Kingston, Mass., 328

Kirkland, Rev. John T., 227

Knowles, Admiral, I96

Knox, Gen. Henry, 214

\section{L}

Lafayette, Marquis de, $158,5^{8} 4$

Lancashire, 3 I 2 
Lancaster, Mass., 105, 246

Langdon, John, 260

Langdon, Rev. Samuel, 232, 259

Larcom, Lucy, 43

Latimer, George D., I 21

Laud, Archbishop, 247

1,ee, Richard Henry, 89

Leete, Deputy Governor, 565

l'Epée, Abbé de, 536

Leslie, Col., I 54

Lexington, Mass., 58, I09, I 74 , 202, 204, $219,238,259,260$, $26 \mathrm{I}, 262,264,265,266,27 \mathrm{I}$, $272,273,278,294,434$

Leyden, 3II, 314, 3I 5, 322, 334

Lincoln, Abraham, I4, 253, 259, 550

Lincoln, Mass., 266, 272

Lincolnshire, 185,304

Lisbon, $53 \mathrm{I}$

Litchfield, Conn., 8

Locke, John, 253, 258

Locke, Jonas, 435

London, I 74, I 76, I78, I 55,334 , $522,553,564$

Londonderry, N. H., 108

Longfellow, Henry W., 50, 66, $68,69,75,78,79$, I 76,214 , $227,234,236,260,262$

Longfellow, Samuel, 73

Longfellow, stephen, 69, 530

Longmeadow, Mass., 429

Lonsdale, R. I., 504

Lossing, B. J., 96

Lothrop, Capt. Thomas, 4 IO, $4 \mathrm{I} 3,+14,4 \mathrm{I} 5$

Louis XV., I 88

Louis XVI., 526

Louisbourg, I $88,202,265,329$, 429

Lowell, James Russell, 32, 50, I $76,214,224,227,231,236$, 239,275

Lowell, Rev. Charles, 23 I

Lynn, Eng., 247

II

Magee, Capt. James, 376
Malbon, Martha, 562

Malbon, Richard, 562

Mann, Horace, 3o, ISo

Manning, Pres. James, 49I, 500

Manomet, 320, $33 \mathrm{I}$

Marcus Aurelius, 305

Marie Antoinette, 90

Marietta, Ohio, 27, $52,34,86,58$, $90,92,97,100, I_{3}, I_{5}, I_{16}$, I 7 , I I 5

Marshfield, Mass., 32S, 332

Mashpee, Mass., 392

Mason, James M., 376

Massasoit, $324,325,329$

Mather, Cotton, I 4 I, I 49,222 , $348,409,4$ I I, 4I 3,415

Mather, Eleazer, 4 I 8

Mather, Eunice, 418, 426

Mayflower, I5, IOO, 316, 3I7, $319,320,326,328,338,34 \mathrm{I}$, $345,346,348,350,352,353$, $354,377,505,578$

Maynard, Sir John, 258

McClanathan, John and Elizabeth, I io

McKoon, Joseph, +30

McSparran, Doctor, 488

Mead, Edwin D., SI

Medfield, Mass., 408

Medford, Mass., 408

Meigs, Return J., 94

Mendon, Mass., I 5

Nerrimac River, 219, 267

Miantinomi, 47ó

Middlesex County, Mass., I05. $258,260,268,277$

Milford, Conn., 564, 566

Milton, John, 222, 286

Minot, Captain, 272

Mobile, 68

Monadnock, 82

Nonroe, James, $5^{84}$

Monson, Conn., 532

Montaigne, $282,284,285$

Montesquieu, 258

Montpellier, I 3

Montreal, 65

Moody, Dwight L., 8, I 
Morrill, Lot M., 76

Morris, G. P., I

Norse, Alpheus C., 504

Morse, Jedediah, $5 \mathrm{~S}_{2}$

Morton, Nathaniel, 320

Moseley, Capt. Samuel, 4I4, 4I5

Motley, John Lothrop, 8I

Mount Wollaston, I2S, 2 I 8

Mowatt, Captain, 60, 61, 62, 72

Mowry, Roger, 484

Munroe, Robert, 265

Murray, Alexander, i Io

Murray, Col. John, Io9, I Io, I I I, I I 5

Musketaquit River, 260

Muskingum, IO2

\section{$\mathrm{N}$}

Nantucket, 368, 394, 532

Narragansett Bay, 8 I, 475,48 I

Narragansett, R. I., 488

Natick, Mass., I04, 406

Nauhaught, Deacon, 393

Naumkeag, 1 26, I 27, I 31, 1 32, I 33

Neal, John, 78

New Bedford, 392

Newburgh, N. Y., 99

Newburyport, I 7 I

New Haven, 24, 487, 524, 532, 553-586

Newport, R. I., 7, I $76,443-473$, $4 \mathrm{SI}, 4 \mathrm{~S}_{4}, 4 \mathrm{~S} 7,494,505,52 \mathrm{I}$

Newton, Mass., 2 I 9, fo4, 5 I I

Newtown, Conn., 5 I 2

Newtowne, Mass., 215, 2I6, 2 I 8 , $219,220,223$

New Windsor, 52 I

New York, 64, 93, 94, I68, I70. I $74,176,44 \mathrm{I}, 486,497,532$, 534,584

Niles, John M., 55 I

Noble, John, I9s

Norfolk, 3 So

Norfolk, Conn., 532

Norfolk, Va., 532

Northampton, Mass., 7,4 I8
Northfield, Mass., 4I2, 4I5

North Kingstown, R. 1., 486

Norton, Charles E., 241

Nottingham, 30.4

Nurse, Rebecca, I44

\section{$\mathrm{O}$}

Oakham, 82, 106

Odell, Eng., 244, 246, 247

Oliver, 'Thomas, 23I, 232

Olmsted, Frederick L., 550

Olney, Eng., 247

Orleans, MIass., 352, 3 So, 38I, $398,393,396$

Osborn, Charles J., 575

Osborn, Goody, I4I, I 43

Osgood, James R., I 76

Otis, Harrison Gray, 530

Otis, James, I $98,22 S, 390$

Ouse River, 246, 247

Oxford, 302

Oxford County, Me., 69

\section{$\mathrm{P}$}

Paddock, Ichabod, 365,

Palfrey, John G., 50, 236

Pamet, 368

Pamet River, $35 \mathrm{I}$

Paris, 178,536

Parker, Capt. John, 261, 264. 265

Parker, Theodore, I76, 261, 262, 265

Parkman, Francis, 50, 8I, 176 , I S I, 446

Parris, Elizabeth, I39

Parris, Rev. Samuel, I39, I 40, I 4 I, I 5 I

Parsons, Samuel IH., 94

Parsons, Theophilus, 76

Pascal, $28_{5}$

['atten, Nathanie], 522

Pawtucket, K. I., 486, 495

Pawtuxet River, 476

Paxton, Charles, 100

Paxton, Mass., 82, I03, 106 
Payson, Edward, 78

Peabody, George, 29, 72

Pelham, Mass., I09

Pemaquid, 58

Penn, William, 406

Pennicook, rot

Percy, Lord, 204, 238, 261, 276

Peskeompskut, 4I6, $4^{\text {I } 7}$

Phelps, William Walter, 575

I'hiladelphia, I 70, 288, 522, 534

Philip, King, $56,81,267,329$, $38 \mathrm{I}, 359,410,416,417,484$, 517

Phillips, Wenctell, 173

Phipps, Sir William, 58, I 46

Pickard, Samuel T.. 53

Pickering. Timothy, 90, I 58

Pierce, Mrs. Anne L., 68

Pierpont, John, 26r, 266

Pierson, Abigail, $5^{\mathrm{Sa}}$

Pierson, Abraham, 574

Pilgrimage, Historical, v, 82

Pitcainn, Major, 265

Pitica n, Simon, Iof

Pittslourgh, $\mathrm{Pa}$., I 00

Pittsfield, Mass., $5+9$

J'lat:o, 7, 284

Plis npton, John, 407

Ply mouth, 1 31, 243, 299, 3+3

$\mathrm{Pl}$;mouth Colony, 57

Plymouth, Eng., 316

Plymouth, Mass., Ioo, 299-3+3, $377,378,390,394,507$

Focumtuck, Mlass., 407, 408, 4 to, $4+4$

Pocumtuck River, 403, 404, 43I, $++\mathrm{I}$

Pokanoket, 416

Pompamamay, Io4

Pond, Charles N., $5+3$

I'ond, Elizabeth, 543

Pool, Maria I., 59

'ope, Albert A., 543

Portland, 8, 53-80

Portsmouth, N. lI., I 7 I

Portsmouth, R. I., 48 I

Powell, Iyman P., xi

Preble, Com. Edward, 60,60
Prentice, George D., 544

Prentiss, Sargent S., 76

Prescott, Col. George, 296

Prescott, Col. William, 204, 206, 232, 260

Prescott, Dr. Samuel, 26I, 267, 271

Prescott, William, 530

Prescott, W. H., I 59

Presumpscot River, 75

Prince, Thomas, 106, 194

Princeton, Mass., 82, 103,106

Pring, Martin, $3+8$

I'rovidence, R. I., 475-506

Provincetown, Mass, $3+5,346$, $350,35 t-365,366,369,370$, $376,377,388,389,396,400$

Pugastion, I04

I'utnam, Ann, I5 I

Putnam, Israel, 96, 97, 435

Putnam, Rufus, 27, 82, 88, 90, $92,93,94,96,97,95,99$, I00, 102, I09, II 1 , I 15 , I I 6,118 , II9

Putnam, W. I., 76

Pym, John, 25s

Pynchon, Colonel, +1 3

Q

Quelsec, 200, 277

(Quincy, Josiah, 227, 236

Quincy, Josiah, Jr., I 74

Quincy, Mass., I2s

Quincy, Mrs. Josiah, 172

Quinnipiac, 556, 580

$\mathrm{R}$

Kasle, Inather, $427,+29$

kaymond. $75,7^{6}$

Reade, lieutenant, jo

Reed, Thomas B., 56, 57.60

Revere, Paul, $174,260,262,325$, 402

Kiedesel, von, liaron. 234

1 iedescl, von, Baroness, 234

kipley, l.ientenant, 296 
Ripley, Rev. Dr., 262, 291, 296

Robbins, Rev. Chandler, 330

Robinson, Rev. John, 299, 304 , 307, 311, 315, 334

Rochambeau, Count, 459, 52 I

Rochefoucauld-Liancourt, Count, 464,465

Rousseau, Jean J., $25^{8}$

Rouville, Hertel de, 424

Rowlandson, Joseph, IO5

Roxbury, 202, 208

Russell, Joseph, 49 I

Russell, William, 491

Russell, William E., 239

Rutland, Eng., 116

Rutland, Mass., 81-II9

\section{$\mathrm{S}$}

Sabin, James, $49^{2}$

St. Edmundsbury, I 13

Salem, 9, 57, 75, 84, I2I-I66, I 7 I, 216, 258, 355, 563

Samoset, 324

Sampson, Deborah, 330

Sampson, Simeon, 330

Sanborn, Frank B., 243

Sandwich, Nass., $376,379,380$, $351,388,391,393,394,400$

Sandys, Sir Edwin, 332

Saratoga, N. Y., I 2

Sassawannow, $\mathrm{IO}_{4}$

Saybrook, Conn., 574

Schuyler, Major Peter, 422

Scott, Richard, 434

Scott, Walter, I6I

Scrooby, Eng., I I9, 299, 300, $304,308,309,332$

Sebago, Lake, 75

Seekonk River, 476, 497

Selden, John, I 40

Sequassen, 5 I 5

Sewall, Samuel, 105, 108, I50, I 5 I

Shakespeare, William, I35, 286, 292, 293

Sharnbrook, Eng., 247

Shaw, Martha, I IO
Shaw, Robert, 173

Shaw mut, 168

Shawonet, R. I., $4^{\text {S }}$

Shays, Daniel, 97, I06, 438

Shelburne, Mass., 431

Sheldon, Ensign John, 424, 426

Sheldon, George, 403

Shepard, Rev. Thomas, 2 I9, 220,222

Sherman, Minot, 530

Sherman, Roger, $57^{8}$

Shirley, Gov. William, 187, 191, I 94

Shirley, Thomas, 174

Shrewsbury, Mass., 106

Sicard, Abbé, 536

Sidney, Algernon, 253, 258

Sigourney, Lydia H., 544

Silliman, Benjamin, 5 है?

Simmons, Franklin, 78, 79

Skelton, Rev. Samuel, I 33, 134

Slater, John F., 29

Slater. Samuel, 495

Slidell, J., 376

Slosson, Annie T., 549

Smibert, John, 450, 45I, 454.

Smith College, 82

Smith, Colonel, 204

Smith, Elihu H., 527

Smith, Elizabeth Oakes, 78

Smith, Capt. John, 56

Smith, John, 348

Smith, Seba, $7 \delta$

Socrates, 286

Somerset, H. M. S., 356

South Boston, I 83

Sparks, Rev. Jared, 227,236

Speedrell, the, 315,316

Spenser, Edmund, $2 \$ 6$

Spooner, Ephraim, 332

Sprague, William, 501

Springfield, Conn., I to

Springfield, Mass., 415,4I6

Standish, Barbara, 328

Standish, Lora, 336

Standish, Myles, 312, 317, 325, $328,329,336,350,352,353$. 378 


\section{Index}

Standish, Rose, 336

Stark, Gen. John, 265, 436

Stebbins, John, 4I5

Stebbins, Lieut. Joseph, 435 , 436,438

Stedman, Edmund C., 548

Stephens, Mrs. Ann S., 78

Stiles, Ezra, 4 I I, 568

Stimson, F. J., 50

Stonington, Conn., 498, 548

Story, Joseph, I 59, 227

Story, William, 236

Stoughton, Lieutenant-Governor, I 49

Stowe, Harriet Beecher, 8, 50, 76,546

Strong, Governor, 528

Stroudwater, 76

Stuyvesant, Peter, 516

Sudbury, 84

Suffolk, England, I 3

Sumner, Charles, I 76

Sumner, James, 480

Sunderland, 43I

Suttlife, Nathaniel, 408

Sutton, Mass., 97

Swanzey, 4 Io

\section{$\mathrm{T}$}

Talcott, Mary K., 507

Taylor, Father, II

Taylor, Rev. John, 438

Teft, Thomas A, 504

Tennyson, Alfred, 282, 299

Terry, Alfred H., 582

Thatcher, Doctor, 332

Thoreau, Henry, 7, 280, 282, 285, $259,296,345,367,370$

Throckmorton, John, 478

Tileston, John, 296

Tillinghast, Pardon, 487

Tilton, J. R., 79

'Tisquantum, 32.4

Tituba, 1 39, I41, 143, I44, I 50

Tocqueville, Alexis de, I

Toucey, Isaac, $55^{\circ}$

Trask, Joseph, Io4
Treadwell, John, 530

Treat, Major Robert, 4I2, 4I4, 415

Treat, Robert, 518, 5 I9

Treat, Rev. Samuel, 379

Trimountain, 168

Trinity College, 534, 538

Tripoli, 69

Trumbull, Annie E., 549

Trumbull, Dr. Benjamin, 5II, $512,516,518$

Trumbull, Colonel, 576

Trumbull, Henry C., 549

Trumbull, James H., 548, 549

Trumbull, John, 522, 523, 524 . 525

Truro, Mass., 345, 351, 356, 361, $366-376,38 \mathrm{I}, 400$

Tryon, General, 569

Tucker, Richard, 56

Tufts College, 180

Turner, Capt. William, 4I6, 4I7

U

Upham, Charles W., I 28, 144. 162

\section{V}

Van Buren, Martin, 55I

Vanderbilt, Cornelius, 575

Vane, Sir Henry, 222, 248, 249

Varnum, J. M., 94

Very, Jones, I 59, 292

Vezzerano, $446,44^{8}$

Voltaire, 258

\section{W}

Wachusett, Mass., 82, I03, IO4, I05, IIf

Wadsworth, Captain, 5 I 9

Wadsworth, Henry, $6 \mathrm{~S}$

Wadsworth, Gen. Peleg, 68, 69

Wales, Prince of, 72

Walker, Gen. Francis A., 117

Walker, Kev. James, 227

Walpole, sir Robert, 452 
Wamassick, 104

Wananapan, IO4

Ward, Gen. Artemas, I06, 204, 207, 208, 232

Ward, Edward, I84

Ware, Ashur, 76

Wareham, Mass., 396

Warner, Charles Dudley, $5+8$

Warren, James, 338

Warren, yoseph, 174, 214,228 , 259,262

Warren, Mercy Otis, 338

Warren, R. I., 49

Warville, Brissot de, 464

Warwick, R. I., 48I

Washington, D. C., 24I, 527

Washington, George, 93, 96, 95, 99, I02, I54, 158, 202, 207, $208,214,232,260,265,268$, $278,256,288,289,388,462$, $47 \mathrm{I}, 472,490,521,526,568$, 582,584

Waterbury, Conn., 525

Waters, Lieutenant, 66

Watertown, Conn., 523

Watertown, Mlass., 2 I 5, 260, 5 I I

Watson, Ellen, 299

Wauchatopick, 105

Wayland, Francis, 499. 500

Webster, Daniel, 49, 87,88 , I 8o, 332

Webster, Noah, 523, 544, 578, $582,5^{\text {st }}$

Weeden, William B., 475

Weld, Daniel, 407

Welles, Gideon, $55^{\circ}$

Wellesley College, I 80

Wellfleet, Mass., 35 I, 374, 375, $376,380,393$

Wells, Captain, 420

Wells, Thomas, 419

Westbury, Conn., 523

Westfield, Conn., 532

Westford, Mass., 266

West Haven, Conn., 568

West Point, 568

Wethersfield, Conn., 508, 521 , 533
Weybosset, R. I., 482,485

Whalley, Edward, 563, 564

Wheaton, Henry, 499

Wheelwright, John, 248, 249

Whipple, Abraham, 492, 494

Whipple, Edwin P., 176

White, Peregrine, 337, 354

Whitefield, George, $57^{\circ}$

Whiting, Rev. John, 253

Whitney, Eli, 582

Whittier, John G., 50, 54, 8I, I $76,54+, 570$

Wickenden. William, 480

Wilkins, Mary E., 50

Willard, Benjamin, I05

Willard, Henry, 105

Willard, Rev. Joseph, I08, 227

Willard, Rev. Samuel, 440

Willard, Simon, 105, $219,243$. 244. 246,268

William the silent, 3 I I

Williams, Abigail, I 40

Williams, Col. Ephraim, 429

Williams, Rev. John, 4I8, 422 , $+28$

Williams, Roger, 9, I I, I 24, I 36 , I $38,152,449,476,478,480$, $48 \mathrm{I}, 482,484,485,486,485$, 489,502

Williams, Rev. Stephen, 428

Willis, N. P., 78, 178

Wilson, Rev. John, 220

Windsor, Conn., 508

Winslow, Edward, 312, 314, 315, $317,326,325,329,332,334$, 389

Winslow, Gen. John, 332

Winslow, Josiah, 332, 337

Winthrop, Gov. John, I36, I40, I68, I80, 214,2 I 6,220 , 248

Winthrop, kobert C., 49

Winthrop, Theodore, 582

Woburn, Mass., 260

Wolfe, Gen. James, 277

Wolsey, Cardinal, 306

Woodhill, 244

Wood's Holl, Mass., 394 
Worcester County, Mass., 97, 103, 105

Worcester, Eng., 302

Worcester, Mass., 82, 103,105, I I I, I I 3, I I 6, I I 7, 498, 499

Worcestershire, 312

Wyclif, John. 303

Wyllys, Samuel, 5 I9

\section{Y}

Yale, Elihu, 574

Yale University, 24, 366, 454, $523,572,574,575,576,582$, 584,586

Yarmouth, Mass., $368,377,380$, $381,385,393$

Yorkshire. 247, 304

Yorktown, 52I

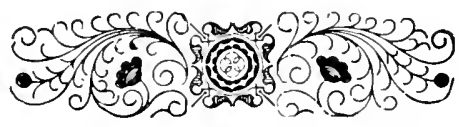




\section{Historic Towns of New England}

Edited by Lyman P. Powell. With introduction by George

P. MORRIS. With 160 illustrations. $8^{\circ}$, gilt top, $\$ 3.5^{\circ}$.

Contents: Portland, by Samuel T. Pickard; Rutland, by Edwin D. Mead; Salem, by George D. Latimer ; Boston, by Thomas Wentworth Higginson and Edward Everett Hale; Cambridge, by Samuel A. Eliot: Concord, by Frank A. Sanborn; Plymouth, by Ellen Watson; Cape Cod Towns, by Katharine Lee Bates; Deerfield, by George Sheldon; Newport, by Susan Coolidge; Providence, by William B. Weeden; Hartford, by Mary K. 'Talcott ; New Haven, by Frederick Hull Cogswell.

\section{Historic Towns of the Middle States}

Edited by Lyman P. Powell. With introduction by Dr. Albert Shaw. With over 150 illustrations. $8^{\circ}$, gilt top, $\$ 3.50$.

Contents: Albany, by W. W. Battershall; Saratoga, by Ellen H. Walworth ; Schenectady, by Judson S. Landon: Newburgh, by Adelaide Skeel: Tarrytown, by H. W. Mabie; Brooklyn, by Harrington Putnam; New York, by J. B. Gilder; Buffalo, by Rowland B. Mahany; Pittsburgh, by $S$. H. Church: Philadelphia, by Talcott Williams; Princeton, by W. M. Sloane; Wilmington, by E. N. Vallandigham.

\section{Some Colonial Homesteads}

And Their Stories. By Marion Harland. Second impression. With 86 illustrations. $8^{\circ}$, gilt top, $\$ 300$.

"A notable book, dealing with early American days. . . . The name of the author is a guarantee not only of the greatest possible accuracy as to facts, but of attractive treatment of themes absorbingly interesting in themselves, . . . the book is of rare elegance in paper, typography, and binding."-Rochester Democrat-Chronicle.

\section{Tlore Colonial Homesteads}

And Their Stories. By Marion Harland. With over 70 illustrations. $8^{\circ}$, gilt top.

\section{Where Ghosts Walk}

The Haunts of Familiar Characters in History and Literature. By Marion Harlanl, althor of "Some Colonial Home. steads," etc. With 33 illustrations. $8^{\circ}$, gilt top, $\$ 2.5^{\circ}$.

"In this volume fascinating pictures are thrown upon the screen so rapidly that we have not time to have done with our admiration for one before the next one is encomtered. . . Travel of this kind does not weary. It fascinates."- lew bork Times.

G. P. PUTNAM'S SONS, NEW YORK AND LONDON 


\section{BELLES=LETTRES}

\section{Browning, Poet and Man}

A Survey. By Elisabeth Luther Cary, author of "Tennyson ; His Homes, His Friends, and His Works." With cover design by MARGaRET ARMSTRONG. IVith 25 illustrations in photogravure and some text illustrations. Large $8^{\circ}$, gilt top (in a box), $\$ 3.75$.

This volume forms a companion work to Miss Cary's book on Tennyson issued last year, and which met with such a cordial reception.

\section{Tennyson}

His Homes, His Friends, and His Work. By Elisabeth Luther Cary. With is illustrations in photogravure and some text illustrations. Second edition. Large $8^{\circ}$, gilt top (in a box), $\$ 3.75$.

"The multitudes of admirers of Tennyson in the United States will mark this beautiful rolume as very satisfactory. The text is clear, terse, and intelligent, and the matter admiralsy arrangerl, while the mechanical work is faultless, with art work especially markej for excellence."-Chicago Inter-Ocean.

\section{Petrarch}

The First Modern Scholar and Man of Letters. A Selection from his Correspondence with Boccaccio and other Friends. Designed to illustrate the Beginnings of the Renaissance. 'Translated from the original Latin together with Historical Introductions and Notes, by JAMES HARver Robinson, Professor of History in Columbia University, with the Collaboration of HeNRY Winchester Rolfe, sometime Professor of Latin in Swarthmore College. Illustrated. $8^{\circ}, \$ 2.00$.

"Petrarch is widely known as a poet of the Italian language whose love for Laura is immortalized in a long series of sonnets. It was an admirable idea for Prof. Robinson to translate for us a selection from the letters of Petrarch, and to intersperse their thoughtful and scholarly, fresh and interesting, notes and comments." $-\lambda$. Y. Times.

\section{Literary Hearthstones}

Studies of the Home Life of Certain Writers and Thinkers. By MARION HARLAND, author of "Some Colonial Homesteads and Their Stories," "Where Ghosts Walk," etc. Put up in sets of two volumes each, in boxes. Fully illustrated. $\quad 16^{\circ}$.

The first issues will be:

Charlotte Brontë.

Hannah More. John Knox.

In this series, Marion Harland presents, not dry biographies, but, as indicated in the sub-title, studies of the home-life of certain writers and thinkers. The volumes will he found as interesting as stories, and, indeed, they have been prepared in the same method as would be pursued in writing a story, that is to say, with a due sense of proportion.

G. P. PUTNAM'S SONS, NEw YORK AND LONDON 



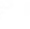







\section{(1)}

(5) (1) Th

(2)

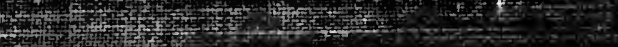

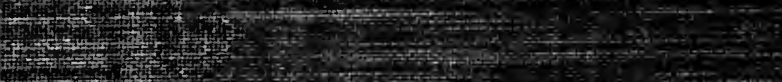

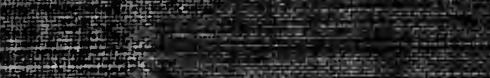

W.

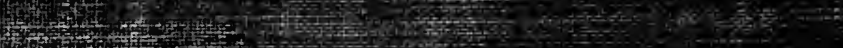

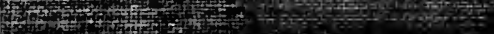

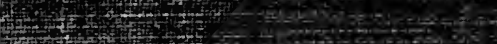

Hor

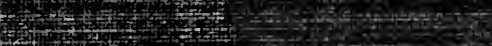

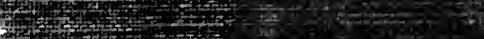

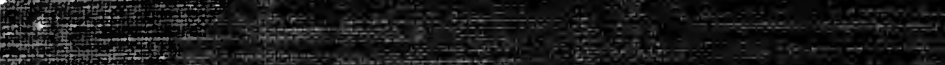

Fr.

at

1.

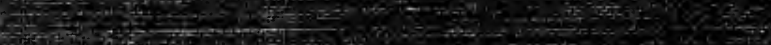

A3

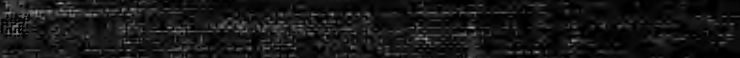

$\lim _{x \rightarrow 0}$

W.

(2)

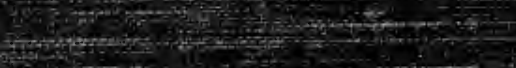

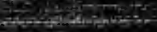

(1)

S" a

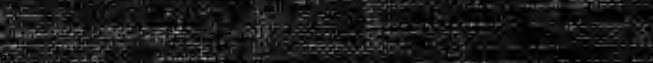

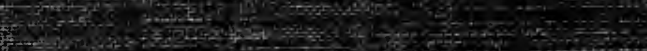

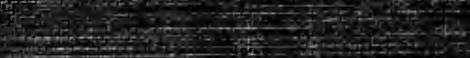

P.

Let

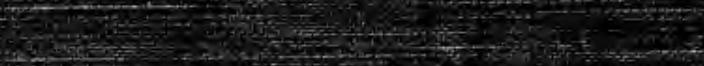

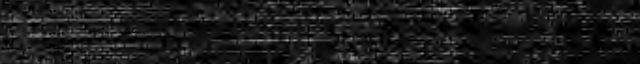

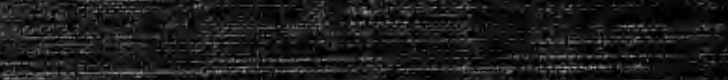

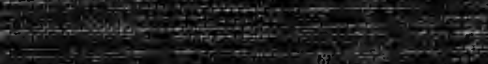

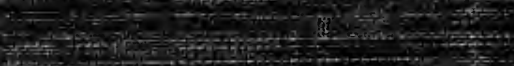

